Universidade de São Paulo Faculdade de Arquitetura e Urbanismo

Departamento de Projeto

Valério Marcos Nogueira Pietraroia

\title{
Do limite à permanência do projeto
}




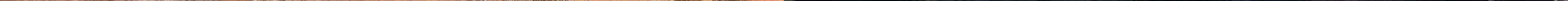




\section{Do limite à permanência do projeto}

Tese apresentada à Faculdade de Arquitetura e Urbanismo

da Universidade de São Paulo para a obtenção do título de Doutor em Arquitetura e Urbanismo.

Área de Concentração: Projeto de Arquitetura

Orientador: Prof. Dr. Francisco Spadoni

São Paulo, março 2019 
Autorizo a reprodução e divulgação total ou parcial deste trabahho, por qualquer melo convencional ou eletrônico, para fins de estudo e pesquisa, desde que citada a fonte.

\section{vpietra@usp.br}

vpietra@npc-arq.com.br

Pietraroia, Valério Marcos Nogueira
Do limite à permanência do projeto / Valério Marcos Nogueira
Pietraroia; orientador Francisco Spadoni. - São Paulo, 2019.
717 p.
Tese (Doutorado) - Faculdade de Arquitetura e Urbanismo da Universi-
dade de São Paulo. Área de concentração: Projeto de Arquitetura.
1. Projeto de arquitetura 2. Equipamento público. 3. Padrão 4. Sistema.
I. Spadoni, Francisco, orient. II. Título.

Nome: PIETRAROIA, Valério Marcos Nogueir

Título: Do limite à permanência do proje

Tese apresentada à Faculdade de Arquitetura e Urbanismo da Universidade de São Paulo para a obtenção do título de Doutor em Arquitetura e Urbanismo.

Aprovado em:

Prof. Dr

Instituição:

Julgamento:

Prof. Dr.

Instituição:

Julgamen

Prof.Dr.

Instituição:

Julgamento:

Prof.Dr.

Instituiç̃ão

Julgamento:

\section{Banca Examinadora}

(2)

(20)




$$
8
$$




\section{Agradecimentos}

Ao Prof. Dr. Francisco Spadoni, pela decisiva orientação.

Ao Prof. Dr. Paulo Júlio Valentino Bruna, que apoiou desde o início minha proposta.

A todos os funcionários da biblioteca da FAU-USP, cuja disponibilidade muito contribuiu nas investigações realizadas em especial à Eliana de Azevedo Marques, à Gisele Ferreir de Brito e ao Cristiano Morais da Trindade.

Aos colegas e aos professores da Pós-Graduação, Luiz Antônio Jorge, Fernanda Fernandes, Maria Cristina Leme, Reginaldo Ronconni e Daniele Pisani pelos importantes ensinamentos.

Aos colegas e Profs. Drs. Milton Braga e Ângelo Bucci, que me receberam nos cursos de graduação e com quem pude partilhar experiências fundamentais de aprendizagem.
Aos Profs. Drs. Alexandre Delidjaikov, Rodrigo Queiroz e Arthur Rozestraten, por informações que orientaram o cam nho desta tese.

Aos fotógrafos Nelson Kon, Pedro Vanucchi e Leonardo Fnotti, que documentam em alto nível nossa arquitetura.

À Fundação Oscar Niemeyer, em especial à Angela Vascon-

À Professora Béatrice Reichen, que muito contribuiu na compreensão do Learning Center - EPFL, em Lausanne.

À Médiathèque da EPFL, Lausanne, em especial a Alain Herzog, pela qualidade do material fornecido.

À Profa. Dra. Marie-José Fourtanier, que me recebeu na Université Toulouse-le-Mirail

À Annie Coutelle, ex-adida linguística do Consulado Geral da França em São Paulo, pelo apoio logístico em minhas pesquisas.
A Haude de Chalendar, dos Archives Municipales de Suresnes, eà Emeline Trion, do MUS - Musée d'Histoire Urbaine et Sociale de Suresnes, que dedicaram tempo significativo para fornecimento de documentos e visita à École en plein air.

À diretora do Collège Karl Marx em Villejuif, Krebis Jamila que me recebeu e testemunhou sobre a realidade do lugar da aprendizagem na França.

À Sylvie Barbier, diretora do Réseau de Création et d'Accompagment Pédagogique, que forneceu documentos audiovisuais importantes para minha pesquisa.

À Clotilde Deschamps, responsável pela documentação digital do Service du Patrimoine et Inventaire d'Ile de France.

À Cité de l'Architecture et du Patrimoine: Archives d'Architec ture du XX $X^{\circ}$ siècle, em Paris, em particular a Alexandre Ragois, que me atendeu prontamente em minhas pesquisas.

À Bibliothèque Kandinsky - MNAM/CCI, do Centre Georges Pompidou em Paris, especialmente à Mica Gherghescu, pelo material que enriqueceu os raciocínios desenvolvidos na minha pesquis
A Associazione Archivio Terragni, à Associazione Made in MAARC e à prefeitura de Como, que forneceram materia ncial e me permitiram conhecer melhor a obra de Terragni.

À Claudia Nucci, que continua entendendo e apoiando meus desafios.

À Patrícia Casadei, pelas versões sempre precisas.

À Dra. Cleyde Casadei, que ainda nos presenteia com inú meras leituras.

A minha mãe, Antonieta, e a meu pai, Rangel, por terem me ensinado a descrever o mundo em palavras e desenhos.

Aos queridos Enrico e Gabriel Pietraroia, cuja dedicação deu vida às páginas aqui apresentadas.

À Cristina Pietraroia, que diariamente constrói nosso percurso.

A John Coltrane, Pat Metheny e Herbie Hancock, pela inspiração e companhia 
Resumo

0 tema desta tese são os projetos elaborados para atender contextos ou programas pouco definidos, especiamente aqueles desenvolvidos como padrão ou sistemas serem implantados.

O objetivo é identificar as estratégias e metodologias de projeto aplicadas nas obras examinadas como contribuição ao entendimento do projeto em situações pouco determinadas ou em constante evolução, como as que vivemos atualmente.

fim de entender projetos de equipamentos púb cos atuais, especialmente aqueles com a missão de apren zagem e de formação, nosso trabalho percorreu um período significativo do século XX e do início do século XXI em que as intensas transformações dos contextos físico e social imprimiram uma permanente evolução programática do tema.
Foi possível observar que a permanência do projeto como meio de enfrentamento da condição social urbana está fundamentalmente baseada no conhecimento dos elementos construtivos como elementos de projeto e não na referência formal como transformadora do lugar. Ao construir um raciocínio e não uma análise das obras, nossa tese responde à hipótese colocada inicialmente. Nela, afirmamos que o projeto deve promover a permanência da arquitetura ao encontrar na realidade as condições de uma ação mais ampla entre os indivíduos. Para isso, o conhecimento acumulado pela arquitetura ganha importância na busca pela interdisciplinaridade necessária.

Palavras-chave: Projeto de arquitetura. Equipamento público. Elementos construtivos. Arquitetura escolar. Padrão. Sistema.
The topic of this thesis is the projects conceived to tisfy demands of not well defined contexts or program especially those conceived as standards or systems to be mplemented.

The objective is to identify project strategies an methodologies used in the architectural works examined as a contribution to understanding projects which are in va guely-determined or continuously-evolving situations like the ones in which we live today.

In order to understand current public building projects, mainly those with learning and educational purposes, our work covered a meaningful period from the $20^{\text {th }}$ centhe early $21^{\text {st }}$ century in which intense transformations of physical and social contexts imprinted a permanent and programmatic evolution of the topic.
It was possible to observe that the continuity of coneiving projects as a way of confronting social urban conditions relies mainly on understanding constructive elements as project elements and not on considering formal references as a transforming agent of the place. By developing a ins of the works, our thesis answers the hypothesis formulated initially in wich we affirm that the project should promote the continuity of architecture by seeking in the reality conditions for broader action among individuals. Therefore, the knowledge accumulated by architecture assumes importance in the search for the necessary interdisciplinarity.

Key words: Architecture project. Public building. Constructive elements. Educational architecture. Standards Systems. 
crítica de arte, na medida em que se caracteriza pela emissão e um juízo, desenvolve-se próxima à teoria, à estética e à historia. Não se deve, contudo, entender tal julgamento apenas em eu sentido mais imediato, de promoção ou negação do estabe cimento de quais obras são melhores, quais são piores. A mis são da crítica vai além, é muito mais complexa, está impregnad de problemas metodológicos e de contradições. Constitui um atividade com amplo sentido cultural. Sua missão é interpretar contextualizar, e pode ser entendida como uma hermenêutica que revela origens, relações, significados e essências. A dificuldade de emissão desse juízo aumenta num período de incerte. zas e de complexidade como o atual. 
Introdução

Cap1. Noções e princípios básicos

ap 2. O contexto e a independência do projeto

2.1 A escola revolucionária de Niemeyer:

CIEP - Centro Integrado de

Educacạoa Pública

2.2 CEU - Centro de Educação Unificaa

Uma possivel genealogia do

Sumário
Cap 3. O programa e a

independência do projeto

3.1 Mies e a independentcia do program

3.2 Um programa em formação:

Learning Center EPFL, Lausanne, SANAA

Cap 4. O tempo e a independência do projeto

Candilis-Josic-W

como pesquisa

4.2 ENSA - École Nationale Supérieure d'Art

LAB.F.AC, Limoges, França

4.3 Senai padrāo modular: modelo ou sistema

Considerações finais

Bibliografia 

"Cópia Fiel" (Copie Conforme, 2010) é um curioso lhar etnográfico de um diretor iraniano para a cultura das imagens ocidental: Abbas Kiarostami vai ao polo irradiador do cânone da ilusão figurat va das imagens (a Itália dos museus, igrejas e arte sacra) para mostrar, paradoxalmente por meio do artifício (um escritor que promove um livro sobre o valor das cópias em relação a obra artística original e que voluntariamente participa de um "role-playing" proposto por sua admiradora), que as imagens são intransitivas, não remetem a nad fora delas mesmas, seja uma suposta natureza dvina ou real. Elas sempre foram meros simulacros. [...] Uma falsificica̧ão poderia ter a mesma validade que a original? Mona Lisa teria um original? Ou o que chamamos de "original" já seria uma falsificação da Gioconda real? 0 que chamamos de arte, nada mais seria [do que] uma percepção human influenciada pelo contexto onde o objeto se encontra como, por exemplo, o museu

FERREIRA, 2013
As considerações ao lado, acerca do filme Cópia Fiel,

No mestrado, foi fundamental, para estudar o projeintroduzen com propriedade um tema de interesse em relação ao culto da imagem na sociedade contemporânea, a saber, o valor de arte assumido pela imagem em função do contexto em que é inserida. Assim a cópia teria um valo mais significativo como obra de arte em relação ao origina no momento em que é instalada num museu. No entanto, teria a obra a capacidade de demonstrar suas qualidades sem que tal operação fosse realizada? Como poderíamos avaliar a arquitetura em situação análoga, ou seja, quando o projeto teria sido desenvolvido sem que seu contexto estivesse definido?

Tais questionamentos foram a base da presente pesquisa, um prolongamento natural do meu trabalho anterio Arquitetura do Espetáculo em Cena ${ }^{1}$. Uma das considerações trazidas pela dissertaç̃o refere-se ao um novo significado para a arquitetura que perdera sua função original, desde que provida de qualidades essenciais. Doravante cabe avaliar como os projetos definidos a partir de um padrão ou de modelos, sem um contexto predefinido, comportam-se adquirem valor relacioná-lo com a cidade como argumento, como roteiro e como personagem. Agora, é o modelo que será avaliado encuanto projeto, na perspectiva de sistema ou do sistem em que se insere ou ainda com o qual se relaciona. 0 fi condutor da pesquisa é a identificação dos valores essenciais capazes de suportar a diversidade de situações em que a obra poderá ser implantada e suas constantes mudanças. Perguntamo-nos como o projeto baseado em un pa programas distintos e como constrói seus fundamentos para permitir sua evolução no tempo? Seriam a padronização do projeto e sua repetição suficientes para onfrentamento de uma realidade cada vez mais difusa?

Ângelo Bucci (2010: 20) aponta-nos caminhos ao indagar: "Como propor projetos numa cidade que parece já ter perdido o sentido?" Ou seja, quando o contexto parece ter perdido o sentido. Em sua tese de doutorado, São Paulo, Razões de Arquitetura, Bucci, preocupado em discutir a pertinência do ato de projetar na metrópole, en especial no centro da cidade de São Paulo, propõe novas 
estratégias ou operaç̃̃es: mirar, transpor, invadir, infiltrar (2010:113). Segundo ele, seriam essas estratégias válidas para enfrentar um momento de incertezas, tal como o que estamos atravessando.

Por outro lado, as dificuldades para compreender o valor da arquitetura, independentemente do seu contexto, mostram-nos a urgência na formação do espírito crítico capaz de orientar o projeto em momentos de franca transformação. Não se trata da busca do projeto baseado na universalidade, como se orientou a Arquitetura Moderna na primeira metade do século XX. A arquitetura, assim como a arte, demanda o entendimento de fundamentos que a sustentem e que devam amparar sua atuação em uma perspectiva mais ampla. ${ }^{2}$ Dessa forma, entendemos que o fortalecimento do projeto é um dos caminhos fundamentais para o enfrentamento da multiplicidade de situações em que a arquitetura deve atuar

Há, na arte, situações que dificultam seu entendimento, como argumenta John Dewey em seu livro Arte como Experiência, o que pode gerar o risco de configurarmos cânones, distantes da experiência humana:

$\overline{2} \quad$ Ver SYKE, 2013.
Quando os objetos artísticos são separados das

condições de origem e funcionamento na exp

riência, constrói-se em torno deles um muro que

quase opacifica sua significacão geral com a qual

lida a teoria estética. A arte é remetida um cam-

po separado, onde é isolada da associação com os

materiais e objetivos de todas as outras formas

de esforço, sujeiçăao e realizaçãa humanosos. Assim

de esforço, sujelção e realização humanos. Assim

iniciativa de escrever sobre a filosofia das belas-

-artes. Essa tarefa é restabelecer a continuidade

entre, de um lado, as formas refinadas e intensi-

ficadas de experiência que são as obras de arte $\mathrm{e}$, de outro, os eventos, atos e sofrimentos do cotidiano universalmente reconhecidos como constitutivos da experiência. (DEWEY, 2010: 60)

Não se trata, portanto, de privar a arquitetura de seu contexto ${ }^{3}$, pois o projeto faria "a ponte" entre forma e experiência, como podemos compreender a partir das considerações de Dewey. 0 caminho de investigação que propomos busca aprofundar o conhecimento dos valores que qualifi-

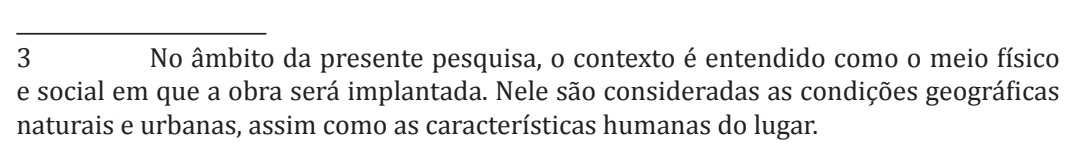

cam a arquitetura sem que, para isso, seja preciso justificá-la pelas condiç̃es do sítio ou pelo momento civilizatório em que se inseriu. Acreditamos, assim, haver maior potencial de sobrevivência do projeto, mesmo em momentos de constante transformação e de intenso questionamento de sua validade.

Sabemos que, em certa medida, a arte baseada en valores universais foi protagonista de parte significativa do século XX. Sua capacidade de transmitir conteúdos nas mais diversas sociedades estabelecidas esteve no centro das preocupações defendidas pela Arquitetura Moderna como força da liberdade criadora.

No entanto, se a crítica a tais valores foi ancorada principalmente na identificação das culturas locais, nas condições do sítio e nas relações sociais estabelecidas em determinado grupo, como a arquitetura poderia atuar no momento em que tais princípios parecem ter perdido o sentido, como indagado por Ângelo Bucci? Acreditamos que a arte permanece quando os valores locais tornam-se veículo do exercício da principal função a ser considerada: a existência humana.

Podemos encontrar um paralelo examinando a universalidade do escritor Graciliano Ramos, sobretudo em seu romance Vidas Secas. Ao se dedicar à essência de seus personagens, ou seja, à sua condição humana, o escritor atinge inúmeras culturas através do mundo, tendo nas $\mathrm{d}$ ficuldades do terreno e da linguagem os agentes de compreensão e disseminação de sua universalidade:

Graciliano não "depende" do Nordeste [...] Estes dois lados da questão - na medida em que o autor não depende do país, ou da região, que constit um dos seus motivos mais visíveis, e na medida ento que oletror está dispensado do con mechenestes dois lados da questão deviam cort prova suficente da autonomia daquele valor constitui a criação liteŕrir com nova vel qude, a qual só sob apectos de to e mesmo assim prudentemente, referi à em que se fundamenta, ou que toma, referi àquela (MONTEIRO 1959, apud GARBUGHO, BOSL FACIOLI, 1987:272)

Visto sob outro ângulo, podemos dizer que o compromisso do poeta é expressar-se. Quem se expressa profundamente a si mesmo, expressa aos outros, ou seja, "quanto mais individual, mais universal" pois os sentimentos descritos estão na base de toda a humanidade, independentemente de fronteiras e de regimes políticos, como afirma Mário Quintana: 
Do individual e do universal

Existe um mundo para cada espécie de bicho. Mas

existe um mundo diferente para cada bicho da es-

pécie humana. Dáí, a minha desconfiança da poe-

sia de equipe, engajada, comprometida. Porque

um poeta, quanto mais individual, mais univers

meio, da época, do folclorismo, dos campes

chados do regionalismo. (QUINTANA, 2009, in

FRANCESCHI, 2009: 72, 73)

No filme Phoenix ${ }^{4}$, a identidade da personagem principal somente é percebida quando ela canta ao final. As transformacõos físicas e as mudanças de comportamen causadas pelos horrores da segunda grande guerra, foram suficientes para que ela não fosse mais reconhecida, mesmo pelo marido, que a considerava morta Mas foi a traves do canto, o principal valor de sua identidade, que sua existência não pôde mais ser negada.

Assim como a literatura e o cinema, a música tanbém revela bons argumentos para o embasamento de no sas questões.

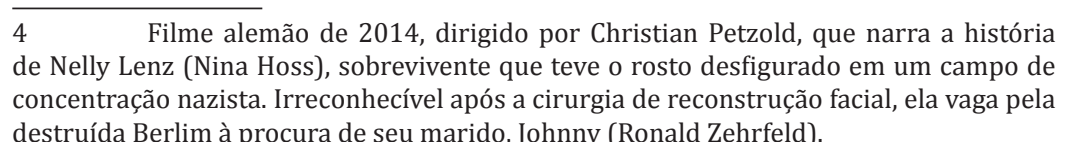

Na área musical vale destacar os standards do jazz que são temas cujo conhecimento universal permite que músicos de origens diversos possom praticar sua liberdace criadora desde o primeiro encontro independente do lugar em que se encontram. São obras recriadas a cada nova execução, não por um novo arranjo, mas por uma nova construção, baseada na repetição do tema. Em outras palavras, não haveria improviso, puro e simples, sem o prosseguimento do tema 0 arranjo musical cria uma nova maneira de executar a melod do grupo de insthentos ou a interpretă a ou específico, ou ainda, para potencializar certas qualidades melódicas. 0 standard do jazz, de maneira distinta, passa a cada repetição por uma nova construção, torna-se uma nova obra, seguindo exaustivamente a referência original à qual pode ser permanentemente identificad.

Podemos entender o standard examinando a formação da palavra: stand + hard, ou seja, aquilo que se mantén de pé por sua capacidade exemplar. Não seria uma obra sen nenhuma característica especial, algo genérico ou comum mas sim uma obra dotada de qualidades consistentes cap-zes de inclú́la em um repertório comuma todos os músicos.
Ao retornarmos para o campo do projeto, podemos observar que a estandardização do mobiliário é tambèn uma estratégia utilizada para que a arte tenha um alcance universal. A produção em massa do objeto industrializado encontra, assim, um caminho para atingir maior número de indivíduos. No entanto, Alvar Aalto nos ensina, através de seus projetos, como determinados standards tornam-se modelos diversos, ainda que repetindo suas soluç̃oes, como evidenciados pelos curadores de recente exposição sobre sua obra:

solução concebida por Aalto se fundamenta no princííio da estandardização flexível, que busca

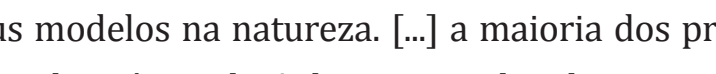

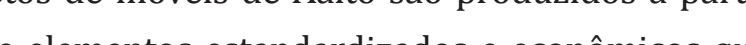
Tem ser ma do difentes non Dariedade de modelos.

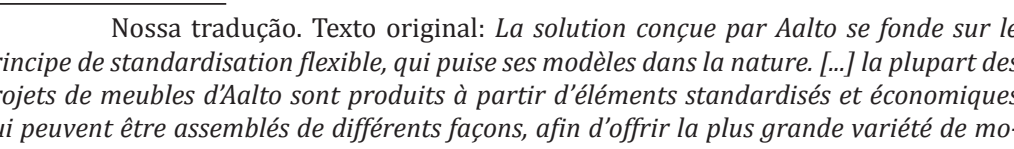

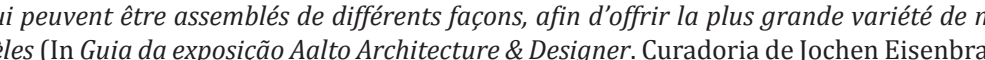

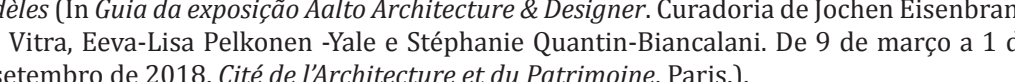

Em outras palavras, o projeto preserva sua capacidade de inovar a cada repetição sem que suas qualidades primordiais sejam abandonadas.

0 número de casos semelhantes que nos fazem refletir sobre o tema é extenso. El Lissitzki, em seu Plano de 1924 para Moscou, propõe a construção de diversos edifícios monumentais, os Prouns Repasse-Nuage, em cruzamentos importantes, indiferente à concentração urbana da cidade. 0 projeto é alheio à noção de lote, de limites, e concentra sua força criativa na forma e na estrutura espetacular para sinalizar a presença da modernidade na metrópole soviética, ou seja, ele independe do contexto.

creditamos que a sobrevivência do projeto deveria ir além das dificuldades de ordem ambiental e social pelas quais a sociedade se depara diariamente. Por isso, do aplicado evolução, em que o tempo deve ser considerado como fundamento. Em outras palavras, a presente pesquisa examina como a arquitetura sobrevive à falta de determinação. 

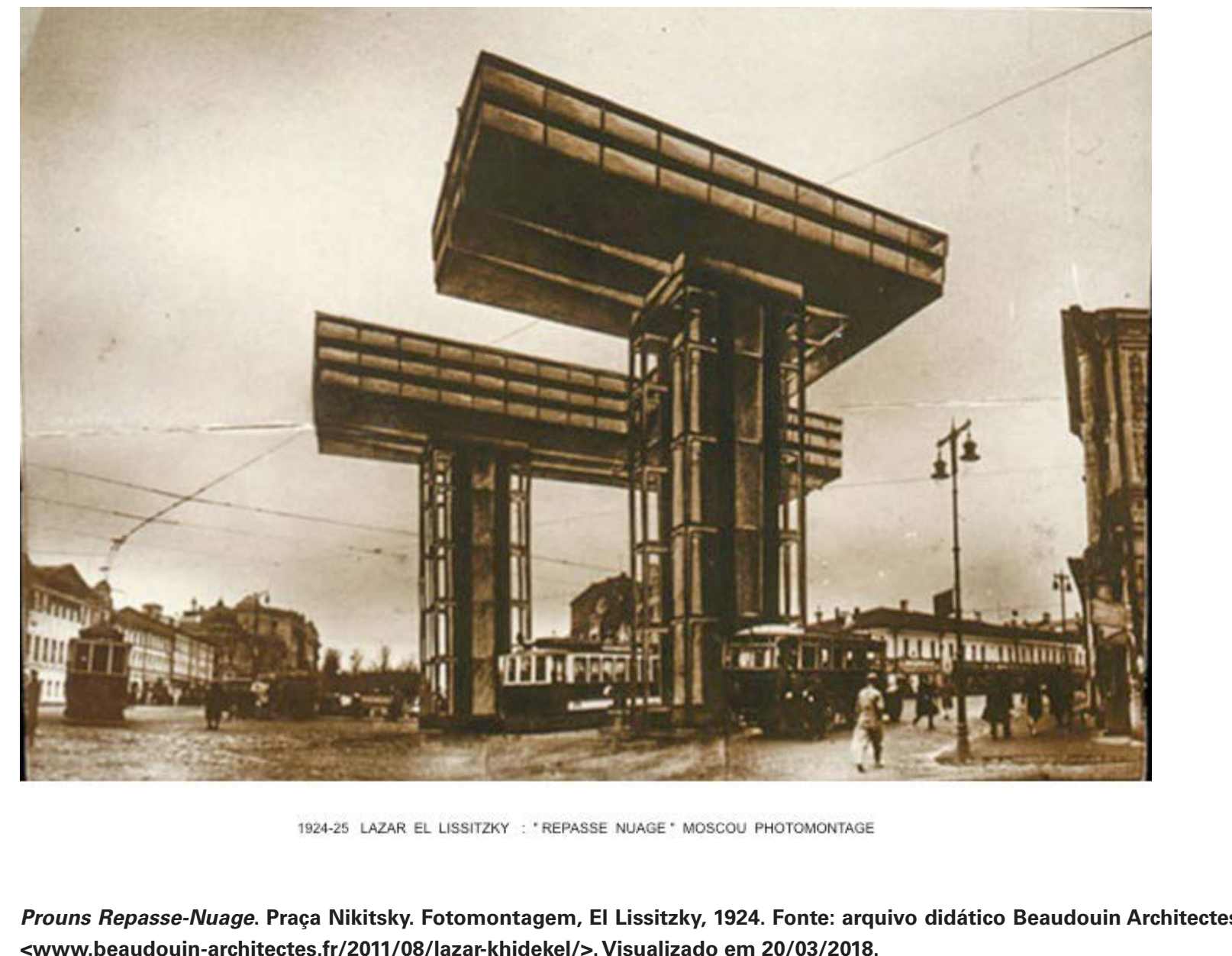
A imagem que abre esta tese mostra a escola da p quena Bento Rodrigues após a passagem do mar de lana que destruiu todo o seu território, resultado do maior desastre ambiental ocorrido no Brasil ${ }^{6}$. Mais do que a grave devastação do ambiente natural que se estendeu por todo o Vale do Rio Doce até sua foz na costa do estado do Espír to Santo, a passagem dos dejetos resultantes das atividades mineradoras na região de Mariana destruiu o meio ambiente construído pelo homem desde o século XVIL periodo que o subdistrito teve papel expressivo no ciclo da mineração colonial.

A foto aérea mostra com clareza o pouco que resto da edificação, com sua organização espacial em "pente" velada por suas paredes manchadas pela lama, como uma escultura emergindo do solo, rodeada por um contexto que não existe ma ahecimento or pujo coção de sua comunidade durante mais de três séculos. Assin poderíamos admitir que a arquitetura como construção resistiu ao desastre, mas não se pode deixar de perceber que ela parece não fazer mais sentido. A imagem se aproxima

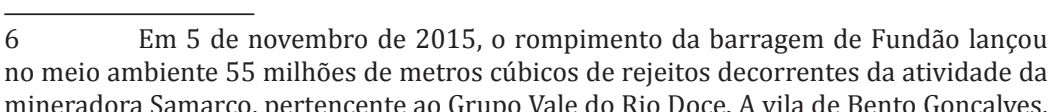

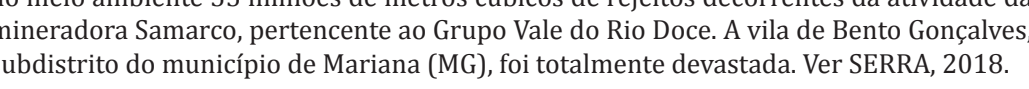

um modelo tridimensional digital que poderia ser aplicado em contexto qualquer, uma verdadeira imagem do mudo virtual.

Apesar de tudo isso, as estruturas internas do equipamento público se mantêm em pé, o que permitiria su recuperação. Entretanto, se o contexto não mais existe, arquitetura deverá buscar outra maneira de se justificar ou outro território para se implantar, como foi a solução oficial pretendida pelas autoridades envolvidas na reconstruč̃o da vila desaparecida.

Tais observações ilustram de maneira preliminar como a arquitetura parece permanecer vinculada ao co texto em que se insere. É certo que a velha Bento Rodrigues pouco evoluiu em três séculos de existência, o que indica um profundo enraizamento da comunidade con ambiente natural e sua relação com 0 ambiente construído. Mas é certo também que o equipamento edificado mantém suas características, que poderiam ser repetidas me uma nova realidade a ser reconstruída. No caso citado, o projeto perdera o sentido por operar em um contexto nexistente. Esta é a questão inicial que orienta nossa pesquisa, a saber, em que medida é possível justificar o projeto quando o contexto é desconhecido. outra imagem presente na capa desta tese reproduz uma obra do artista Lazar Khidekel, originário de VItebsk (Bielorrússia), professor da Escola de Artes de Vitebsk, que funcionou de 1918 a 1922. Dirigida inicialmente por Marc Chagall e posteriormente por Kasimir Malévich essa escola teve atuação fundamental na formação da Vanguarda Russa nos anos pós-revolução, mesmo estando distante das metrópoles soviéticas ${ }^{7}$. A arquitetura visionária proposta por Khidekel pousa no território sem um destino determinado. São formas predefinidas, inseridas na paisagem aquática natural e que apontam para a convivência harmônica entre o ambiente natural e o ambiente construído. Para Khiedekel, a arquitetura poderia se estabelecer em total harmonia com o meio ambiente abrindo caminho para as atividades humanas que surgiriam, portanto, sen um programa totalmente estabelecido a priori.

Assim, nosso trabalho aponta caminhos a partir dos uais a pesquisa se desenvolveu, de maneira a construir un entendimento mais amplo do seu principal objetivo: dentro da perspectiva da arquitetura contemporânea brasileira com enfoque nos equipamentos públicos, investigar estracadas à arquitetura a ser implantada em contextos variados ou não definidos e 7 Ver KHIDEKEL, 2014 L LAMPE, 201 suas relações com os sistemas em que se inserem, considerando a repetição como instrumento de projeto, seja com modelo ou como padrão

Isso significa organizar a pesquisa em três subtemas de investigação:

- o projeto cujo contexto do ponto de vista físico indefinido e cuja repetição pode ser uma condição primordial;

o projeto que deve suportar a indefinicão programa, ou seja, cujo contexto social não está claramente determinado;

- o projeto em que o tempo é o ingrediente fundamental, sendo a evolução, o improviso ou as mudanças de uso alguns de seus pré-requisitos, constituindo-se um atributo para o enfrentamento das indefiniç̃oes do progra do contexto acima citadas.

É com essa estrutura que organizamos os capítulos desenvolvidos a seguir. Antes disso, o primeiro deles define as noções e os princípios fundamentais que utilizamos em nossa pesquisa. 
Enfrentar as incertezas

As ciências permitiram-nos obter muitas certezas,

mas revelaram-nos igualmente inúmeras incerte-

zas durante o século XX. [...] Não se pode mais eli-

minar a incerteza pois não se pode conhecer com

perfeita precisão todas as interações de um sistema,

sobretudo quando esse é muito complexo. Logo, a

imprevisibilildade encontra-se no seio do próprio

determinismo em si. A abordagem por indução ou

deduç̃o, que ao mesmo tempo fundamentam a

ciência clássica e nosso modo ordinário de enten-

do essa ruptura, está hoje consumada, por outro

ainda falta aos cientistas a cultura epistemológica

necessária para conceber uma mudança de para

digma. É verdade que cada um em sua disciplin

procura negociar com a incerteza. [...] Deve-se, por-

tanto, mudar a maneira de se conceber o conheci-

mento científico.

MORIN, 2014

Noções e princípios básicos

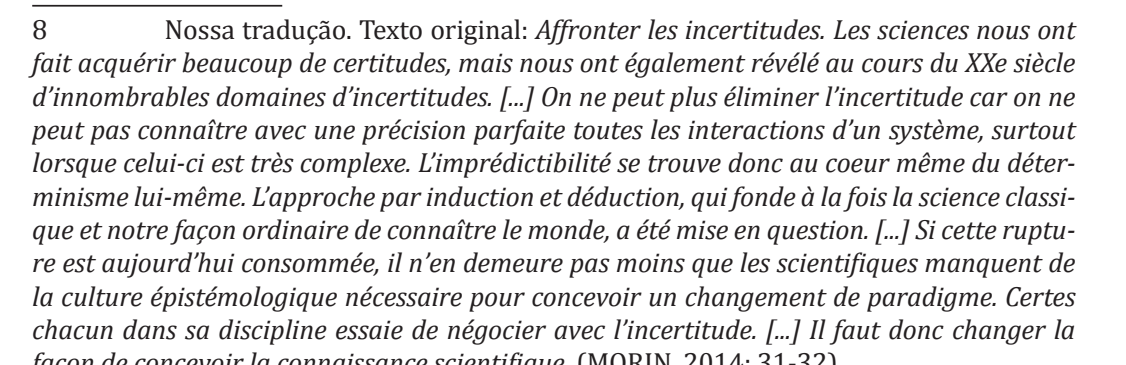

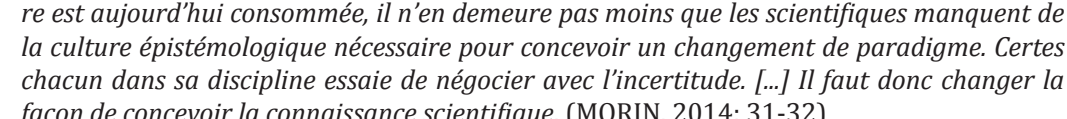

Edgar Morin (2014) deixa claro, na epígrafe ao lado, por que cada vez mais devemos rever os procedimentos de investigação em função da extrema complexidade com que os sistemas atuam sobre a realidade. A resposta determinista decorrente da causa, da ação que levaria a uma reação, não mais se ampara em mecanismos seguros de com preensão da realidade, reflexão que se aplica ao projeto.

A arquitetura passou um período significativo em que o contexto, em grande medida, protagonizou ou, pelo menos, orientou de maneira decisiva o projeto, o que levou a historiografia a dedicar especial atenção à arquitetura adaptada ao lugar9. Em muitas situações, os diagnósticos e os mapas conceituais, baseados na leitura do território, adquiriran importância semelhante ou superior ao próprio projeto

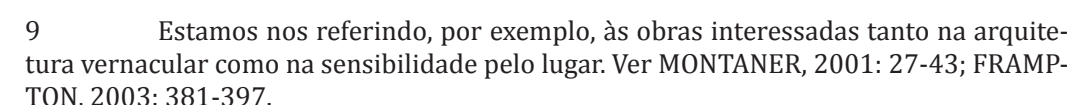

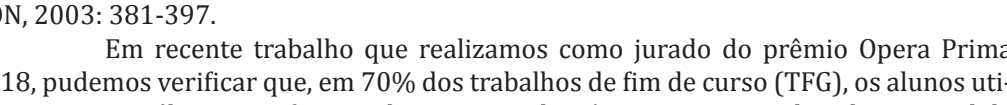

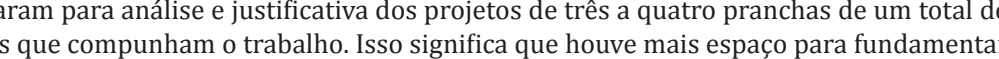

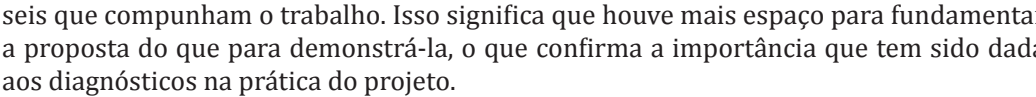


Por outro lado, nos últimos anos, vê-se uma expressiva demanda para a elaboracẵo de projetos sem um contexto definido, ou seja, um projeto padronizado a ser implantado quando necessário, em local a ser escolhido e cuja repetição é uma de suas premissas.

Assim, parece-nos que a dependência do projeto em relação ao contexto poderia limitar a definição das qualdades do próprio projeto. Na medida em que a indefiniç̃a do sítio indicaria uma lacuna para a definição do projeto, seria fundamental direcionarmos nossa investigação para os valores da arquitetura baseados em suas estruturas internas $^{11}$, sem que fosse necessário justificá-la pelo contexto

De modo semelhante a indefinição do sítio à qua nos referimos, não podemos negar que vivemos em um realidade difusa, pouco consolidada, o que dificulta a percepção dos valores e das relações sociais que o projeto deve enfrentar. A velocidade com que as mudanças

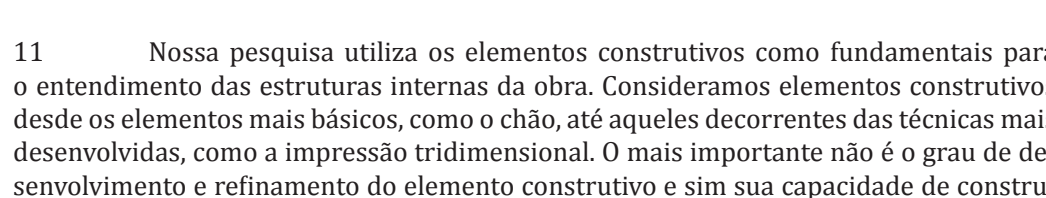
senvolimento e ref
că de uum abra. ocorrem e como novas relações surgem demonstra certa defasagem com o tempo do projeto, ou seja, o tempo necessério para a compreensão da realidade citada e na elboração das respostas.

A fim de que o projeto retome sua atuação como agente de transformação da realidade é necessário que ele seja capaz de criar condições para a antecipação de novas relações ou, pelo menos, de responder com precisão e agilldade às demandas já formuladas.

O contraponto a essas consideraç̃os acima citadas são os projetos que permanecem atendendo a novas redlidades ou novos usos, mesmo que, em sua origem, não tenham sido consideradas tais situações. Haveria um grand interesse em identificar quais foram os fundamentos responsáveis pela permanência de suas qualidades, mesmo quando seu programa já não faz mais sentido ou quando as transformações do contexto não justificam mais as decisões originais de projeto.
Ao final de nossa dissertação de mestrado, Arquitetura do Espetáculo em Cena (2014), pudemos afirmar, baseados no que observamos em nossa pesquisa, q de toda a transfor ão da percepção e da própria representação do projeto, são os princípios constitutivos e o valores essenciais da arquitetura que permanecem reve ladores de qualidades e de consciência estética fundamentais. Uma das respostas para a permanência da arte sobre (a) der as condições que estabelecem os fundamentos da obra e de desvendá-las. Seria esse o esforço de conceber um artefato, dotado de estrutura definida por critérios de forma consciente, como postula Hélio Piñon (2006). 0 autor afirma que, sem levar em considerač̃o a dimensão aut desvinculála de sua genealogia e de su prática, estaríamos incorrendo no mesmo erro dos que tentaram explicá-la através de critérios sociológicos e técnicos.
Ao fazermos uma retrospectiva, observamos que a referida pesquisa mostrou que tais desafios se colocam no momento da escolha dos instrumentos dos se valeré pura tetura do espetáculo que estaria sofrendo para responder adequadamente a esses desafios. Ainda que a complexida de do tema demonstrada em nossa dissertação seja uma prova disso, tais desafios fazem parte da essência da própria natureza da arquitetura.

Observamos que as ideias de Peter Collins (1998) colocam o tema como sendo de especial interesse para compreender a evolução da arquitetura, em especial na Modernidade. 0 autor salienta que

[0] problema de criar inequivocamente uma expressão arquitetônica pode parecer insolúvel por três atitudes mutuamente excludentes. Por exemplo, pode-se declarar que cada program é susceptível de várias soluções (e portanto não cabe pensar em uma única expressão funciona autêntica); pode-se declarar que um edifício mo- 
derno necessita ser o mais adaptável possivel (e portanto que o exterior deve expressar essa "flexibilidade"), ou se pode ter a visão (já exposta respeito dos teatros, hospitais e prisões) de que 作 dronizadas. (COLLINS, 1998: 238)12

Por outro lado, Marina Waissmann (1993) pondera que, mesmo aceitando a existência de valores universais na arquitetura, há a necessidade de afirmação de valores próprios, historicamente esquecidos pela dependência cultural.

Pudemos, então, verificar que a relação com o lugar, assunto significativo das discussões teóricas da arquitetura desde a metade do século XX, ganha importância nas apropriações e ocupações de obras existentes, seja do galpão genérico abandonado ou do edifício exemplar que perdera sua função original.

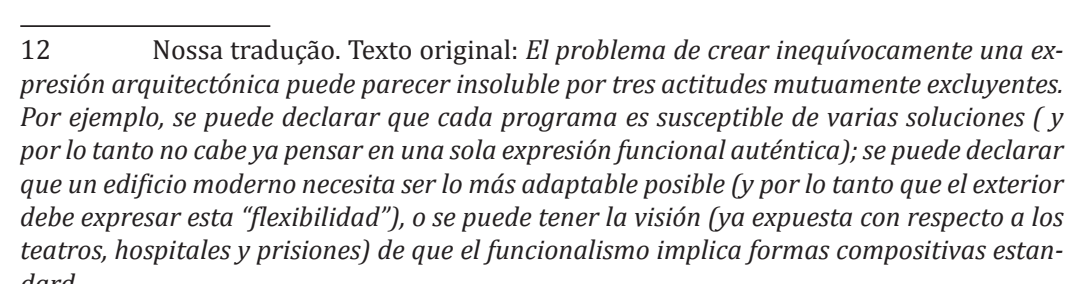

A arquitetura, enquanto artefato, daria sentido ao lugar, participaria de forma decisiva na construção do território, o que consideraria sua preexistência, ainda que não consolidada ou mesmo em processo de transformação, pela própria dinâmica urbana em que se insere.

Dentre os aspectos revelados no referido trabalh (PIETRAROIA, 2014) destacamos aqueles providos de extremo interesse para o projeto enquanto instrumento de aálise, dentro da linha de investigação na qual nos inserimos em nível de doutoramento.

Inicialmente, as qualidades de natureza essencial da obra, como sua estrutura interna, capaz de conferir-lhe identidade concreta, são determinantes para a sua sobrevivência e sobretudo para a sua transformação, muito mais pela permanência de sua estrutura formal arquitetônica, dentro de um quadro de evolução de usos, do que pela conservação integral dos seus aspectos estéticos, como monumento ou como obra de arte. Entretanto, ficou evidente que, nos casos estudados naquele momento, não seria possível o resultado alcançado se a intervenção partisse da edificação desprovida dessas qualidades essenciais, mesmo que a alta tecnologia estivesse a serviço da arquitetura, mesmo se fosse ela a estratégia de projeto.

Há ainda um aspecto referente ao que podemos chamar de "cidade como geradora da forma". Nessa situação, a arquitetura e sua relação com a cidade não resultaria diretamente das condições encontradas em determinado território. Isso significa que cabe ao projeto promover identidade da obra de forma coerente com as condiç̄ões do lugar.

$$
\text { Como bem observa Waissman: }
$$

[...] a arquitetura é uma atividade concreta e pratica, e qualquer tipo de reflexão a que ela se refra conservará uma relaçăo mais ou menos direta com a práxis. É assim que a teoria, definida com sistema de pensamento, pode assumir a form normativa, isto é, um sistenia de leis ou normas que determinam como deve ser a arquitetur (WAISSMAN, 1993: 29) 13. $^{13}$
As afirmações supracitadas (apud PIETRAROIA, 2014) nos permitem retomar, dentro da linha de trabalho que considera o projeto de arquitetura como instrumento de análise e pesquisa, questões que se tornaram recorrentes na historiografia recente ligadas à padronização, à estandardização e à criação de projetos capazes de atender através de sua repetição e da agilidade de sua implantação às carências de infraestrutura de nossas cidades. Este é o ponto inicial da presente pesquisa.

Em um primeiro momento a citada urgência seria motivaç̃o suficiente para que se realize uma pesquisa que busque avaliar experiências significativas da arquitetura brasileira contemporânea que enfrentaram tais desafios Um novo balanço atualizado a respeito dessa produção mostra-se assim obrigatório na medida em que incorpora o enfoque do projeto como instrumento de pesquisa.

Além disso, a universalidade da padronização, tão cara ao Movimento Moderno $0^{14}$, permite-nos afirmar ser

$14 \quad$ Sobre o que é Moderne, ver Bpun 2010:21 
este um tema fundamental para a prática do projeto. Em outras palavras, estamos diante de questões que envolvem aspectos prim forma ou a oposiç̃o entre singularidade e identidade (PFEIFFER, 2002).

ideia da autonomia da arquitetura não é nova. As discussões sobre o tema se intensificaram durante o século $\mathrm{XX}$, influenciadas por reflexões originadas durante o Século das Luzes.

Devemos lembrar que Claude-Nicolas Ledoux, como assinala Emil Kaufman (2002: 61-62), considerou ter a forma uma lei interior capaz não somente de promover sua própria organização interna mas também a de sistemas mais complexos. Observaç̧ões semelhantes, feitas por Josep princípios de autonomia da forma como fundamental para a arquitetura de Durand a Louis Kahn, passando por Le Corbusier. Essas considerações já seriam suficientes para que o tema fosse analisado sob uma perspectiva atualizada: produto da concepção moderna encontra sua legalidade formal ao concluir o processo de concepcão: a ordem é espećf́ica de cada obieto e aparece só ao final do projeto. Tal estrutura, própria de cada artefato, lhe confere uma identidade concreta: lhe faz "ser algo" sem necessidade, portanto, de "parecer-se aloo" [-1 A identificacão do problema, prévia à proposta arquitetônica- de caráter artístico - seria necessariamente racional. mas a arquitetura não baseia seus critérios de concepcão em preconceitos racionais, senão em processos de intelecção visual nos quais a proposta de forma resolve situações de projeto, ao mesmo tempo que revela o caŕáter atíico de sua natureza. (PIÑON, 2008: 50)

0 raciocínio de Piñon não se opõe às dificuldades apontadas por Collins para a concepção do projeto. Ao contrário, explica a arquitetura como disciplina, capaz de construir seu sentido através dos processos que lhe são próprios e não daqueles originários de outros campos.

15 Destaques do autor

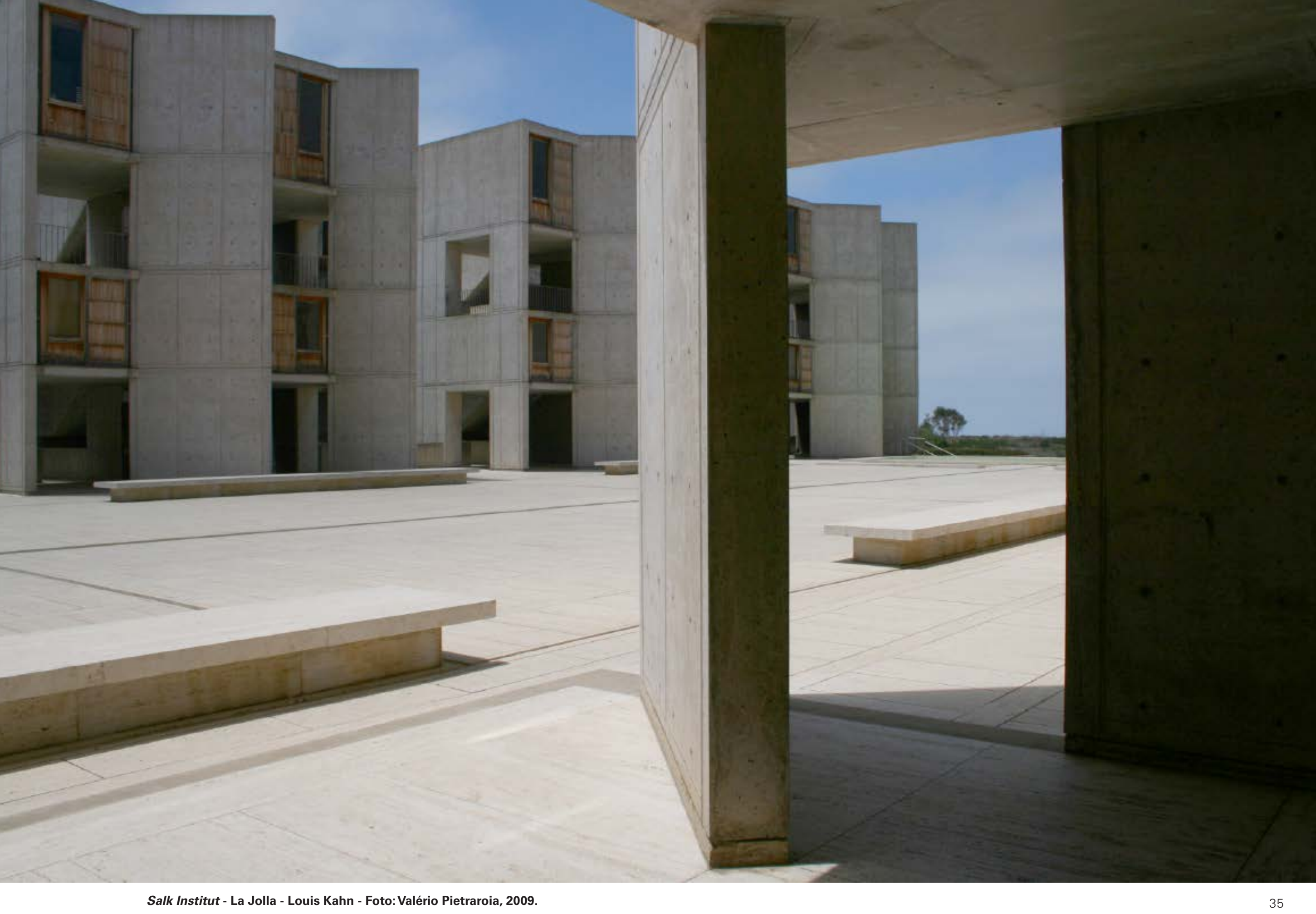


Alan Colquhoun (2004: 99) lembra que o próprio Le Corbusier justificava sua arquitetura como uma disciplina autônoma, não desvinculada da realidade contextual, mas constituindo-se como uma técnica por meio da qual essa realidade é transformada.

Para o enfrentamento de sistemas cada vez mais complexos que caracterizam nossa realidade, Peter Eisenman vem desenvolvendo uma significativa produção teórica e prática baseada na busca pela autonomia da forma, em um primeiro momento, e na construção de um outra realidade, através de mecanismos de certa forma "autra realidade, através de mecanismos de certa forma lugar, como veremos no capítulo 4.

Mais adiante, é verdade que o cenário atual aponta para a intensificação da industrialização da construção apoiada nas amplas possibilidades oferecidas pelas inovaç̃̃es da tecnologia da informaç̃õo. Se por um lado, tal situação abriu caminho para o exerć́cio da singularidade, d originalidade da obra e da espetacularização da arquitetura (PIETRAROIA, 2014), por outro lado permitiu o avanço e a aceleração de experiências de estandardização em que a reprodutibilidade do modelo prevaleceu.

Assim, parece-nos necessária a compreensão como o processo de projeto ocorre nas situaç̃oes citadas. Ou seja, um projeto, cujo contexto não é definido $a$ prion se apoiaria, se fundamentaria apenas no programa para se justificar. Nesta hipótese, seria o programa a chave para enfrentar realidades diversas, tanto do ponto de vista físico como social e econômico. Seria essa uma tentativa de ue as formas abstratas resultantes fossem capazes de servir a todas as situações (VIDLER, 2006).

Dito de outra forma, o projeto seria muito mais o resultado de fundamentos construídos pela própria arquitetura como disciplina, ou seja pelo acúmulo do conhecimenconsiderar que a prática arquitetônica assume maior autonomia dentro de um cenário cuja realidade se apresenta difusa, pouco definida. Seriam essas as bases para o entendimento de novas metodologias de projeto ou seriam, antes disso, as origens e os fundamentos do projeto que estariam estar em pauta?

Essa é uma das perguntas cujas respostas deveriam ser pesquisadas para a compreensão de uma prática profissional cada vez menos independente. Em outras palavras, vivemos em uma realidade pouco definida, em que o projeto é convocado a intervir dentro de amplos e complexos programas de ordem econômica, social e política. Isso significa que as dificuldades e a relevância do atuac̃̃o do arquitetura devem ser mais complexa a resposta que o projeto deve elaborar no atendimento de um determinado programa, mas é necessario que a compreensão dos elementos que o compõem seja estabelecida, o que nos permite prever seus efeitos, mesm antes da experiência pelo simples pensamento e racioćn (HUME, 1973: 154).

Se consideramos que há uma grande dificuldade de reconhecimento do contexto, que a realidade evolui de maneira contínua e cada vez menos previsível, é possível supo que as respostas de projeto tenham que admitir mecanis- mos muito mais amplos do que a conhecida flexibilidade. Isso significa, no nosso entendimento, que estaríamos no momento em que o projeto deve assumir o protagonismo na medida em que seria na compreensão de suas qualidades fundamentais que poderíamos encontrar caminhos para responder à complexidade crescente.

Há uma linha de investigação cujos autores apontam a necessidade da criação da "Inteligênncia do Projeto" (SPEAKS, 2002) como estratégia necessária para tal enfrentamento. Trata-se da constituiç̃o de um acervo de conhecimento de projeto, preestabelecido a partir da experiência acumulada, de maneira a simular cenários diversos com auxílio do conhecimento da tecnologia digital. Nesse sentido, seria oportuno entender e refletir em relação a esses mecanismos, como faremos no capítulo 4.

Não podemos deixar de observar ainda que as incertezas, a dúvida ou a mudança nunca deixaram de fazer parte do universo do projeto. Pode-se admitir que a velocidade e a dinâmica das mudanças têm se intensificado em função da tecnologia, de maneira muitas vezes incontrolável, mas 
écerto também que a arquitetura nunca se beneficiou tanto de dispositivos oferecidos por essa mesma tecnologia para enfrentar suas dificuldades.

Podemos então dizer que, na arquitetura, a forma é resposta à dúvida, à incerteza, à irregularidade. Quando p projeto atua, está resolvendo, solucionando, está compensando ou antecipando uma ausência, uma falha. Nesse sentido, o projeto atua para resolver conflitos entre a forma proposta e o contexto, como um "contra regra".

Entretanto, se o projeto baseia-se no entendimento

prévio do contexto, valendo-se de diagnósticos apurados mparados pelos recursos tecnológicos, que relaciona um número extraordinário de dados, podemos dizer que arquitetura, baseada no programa, estaria segura em suas proposições. Como veremos adiante, nas noç̃es terminologicas, foi o que afirmou Enrico Tedeschi (1960) ao apontar o uso de sofisticados recursos matemáticos para resolver programas cada vez mais complexos, entendidos, nes caso, não apenas como programas de ordem funcional mas também como programas que apresentam as condições sítio em que o projeto será implantado, ou seja, todos os recursos que promovem a elaboração de extensos diagnósticos que inva avelmente pretendem justificar as tomadas de decisãa ${ }^{16}$ Seguindo esse procedimento, o reconhecimento do contexto torna-se primordial.

Parte significativa dos questionamentos críticos da Arquitetura Moderna, em especial na segunda metade do século $\mathrm{XX}^{17}$, baseou-se no excessivo domínio dos valores universais em detrimento dos valores locais, 0 que afastaria a arquitet segundo os autore projeto acerta na medida em que se contextualiza, signific se vincular às condições que atualmente nos parecem frágeis pela rapidez com que se modificam.

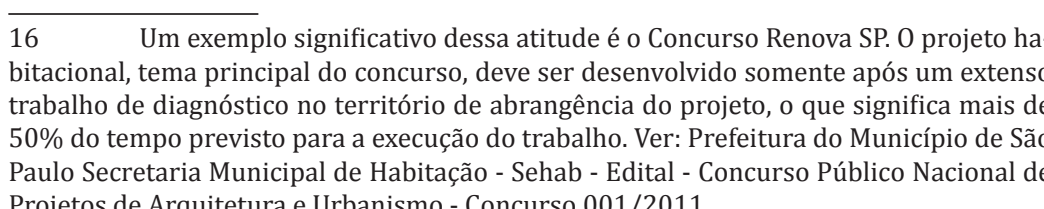

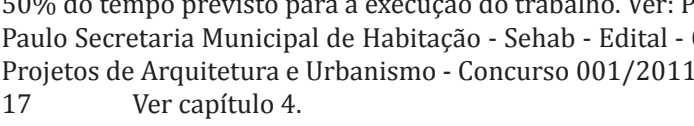

Então, vejamos: o projeto como resultado da proximidade com o objeto preexistente (a arquitetura) ou de un conjunto de objetos (a cida ideias que encontra respaldo nas reflexões de pensados como David $\mathrm{Hume}^{18}$, que acreditava na continuidade das deias, ou seja, na similaridade a partir da qual uma ideia poderia ser gerada. Para Hume, a utilidade do pensamento científico estaria na possibilidade de "controlar e regular os contecimentos futuros por meio das causas", isto é, o recoinento anterior da teal e gerar uma ideia, pois "quando não podemos encontrar nenhuma impressão, podemos estar certos de que não $h$ ideia alguma" (1973: 161). Para a arquitetura, podemos dzer que o projeto seria a ideia gerada pela "impressão" do contexto 0 pensamento de Hume encontra, ainda, na seintera para a produção das ideias, em sua busca por justificá-las a partir desse reconhecimento apurado. $O$ autor completa

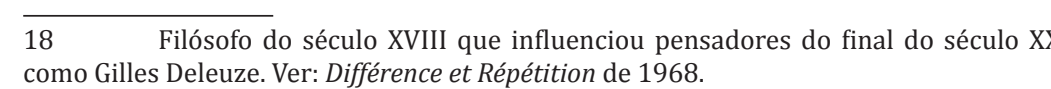

todos os raciocínios abstratos há um ponde vista que, se temos a sorte de acertar com e, nos permite ilustrar melhor o assunto do que m toda a eloquência e a expressão mais copio ste mundo. É esse ponto de vista que devemos a retórica para assuntos (HUME, 1973: 161)

Poderemos, então, apoiados na avaliaç̃o de obras escolhidas, identificar seus mecanismos de projeto, próprios da arquitetura, sem contudo perder a perspectiva en relaç̃o ao quadro urbano e social com o qual elas se relacionam, mas não considerando sua contextualização comø instrumento de projeto, o que nos parece mais apropriado. Como afirma Colquhoun, sobre a Tipologia e Metodologia de Projeto,

m]inha intenção ao sublinhar esse fato [a preexistência de complexos tipológicos para de uma arqutetua que a ceta a tra

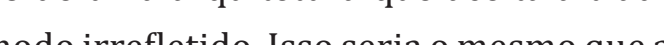


a existência de uma relação fixa e imutável entre formas e significados. A mudança é a característica de nosso tempo, e justamente por isso é preciso investigar o papel que as modificaçôes de soluçoss-tipo desempenham com relaçăo aos pre

Não se pode também deixar de refletir sobre as posiç̃es colocadas por Robert Venturi no prefácio de sua obra Complexidade e Contradição em Arquitetura (2004) que, mesmo tendo sido escrita em 1966, demonstra como há preocupações que fazem parte do universo arquitetốnico de maneira atemporal. Em primeiro lugar, o autor coloca a necessidade de revisão dos meios de expressão da arquitetura para responder às perspectivas ampliadas e à arquitetura para responder às perspectivas ampliadas e à
complexidade de suas metas. A simplificação da forma ou sua complexidade superficial não seriam suficientes para isto. Venturi antecipa o discurso que desenvolveremos mais adiante e completa:
Embora os meios envolvidos num programa 作

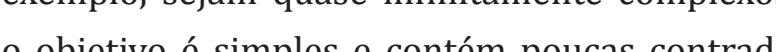
cojest cocs, enbora os melos envolvidos no programa

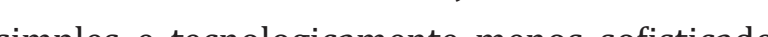
do que quase qualquer oute proje soisticados

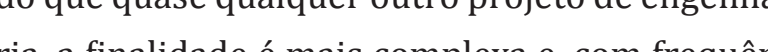

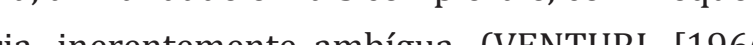
2004:8)

Ao considerarmos as cinco últimas décadas, podemos observar que a complexidade do programa estari ampliada no momento da experiência contemporânea por conta de suas ambiguidades. Naquele momento, Venturi estava preocupado em demonstrar como a ambiguidade é característica da arquitetura o que justifica suas contradições. Para nosso trabalho, seria um componente importante a ser incorporado na discussão dos mecanismos de projeto aqui estudados.
A pesquisa bibliográfica que realizamos no presente trabalho, mesmo não apresentando reflexões objetivas de autores sobre o tema, revelou raciocínios muito significativos para nossa compreensão a seu respeito. Esses autores têm em comum uma preocupação constante en relação ao projeto arquitetônico: a realidade incerta ou a realidade indeterminada.

$$
\text { No nosso entendimento, para que o tema proposto }
$$
possa ser estudado e para que o projeto torne-se instrumento dessa investigacãoo, é prudente organizá-lo pela proximidade de suas preocupações

Nas leituras e pesquisas realizadas encontramos afirmações e preocupações muito semelhantes para justificar ou para contextualizar diversos temas que "orbitaram" o campo da arquitetura, em momentos distintos, mas em particular nos últimos cem anos. A síntese da forma, a abstração, os sistemas, os diagramas e outros conceitos foram usados pelos arquitetos, por teóricos e por críticos d arquitetura para o entendimento de determinada postura assumida pelo projeto.
As semelhanças não se limitam à discussão das decisões próprias da arquitetura, ou melhor, da práxis que demostra o tema, mas insistem nos fatores que or eintensificaram tais preocupações. Em muitas situações as decisões foram amparadas pela necessidade de se enfrentar uma realidade difusa e indeterminada, ou ainda de programas e práticas a serem criados, que são situações de interesse de nossa pesquisa. Os momentos de incerteza tendido como destino, opera com a incerteza, sendo o resultado da dúvida que deve ser solucionada e respondida ao final do processo.

Algumas palavras repetem-se constantemente e demonstram a amplitude do tema: espaço que representa de forma esquemática (ITO, 1996), sistema, modelo, padrão forma simples e reconhecível, abstração, matriz, autonomia, evolução, flexibilidade, flexibilização. 
Nesse sentido, portanto, parece-nos significativo procurar entender ou encontrar um caminho, um fio condutor, que aproxime preocupaçes reconentes dentro do tema proposto.

Definidas as três principais linhas de investigação o corpo teórico que as apoia, nosso trabalho examina projetos significativos, especialmente dentro da produção da arquitetura brasileira contemporânea, tendo como enfoque oequipamentop bico A pesquisa, ino tro to ño selimita o recorte descrito acima pois entendemos ser fundamental que obras do cenário internacional, que enfrentaram situações semelhantes às colocadas aqui como hipótes devam também ser abordadas com o objetivo de compará -las, mesmo que tenham sido realizadas em momentos históricos distintos. Ou seja, consideramos menos relevante a datação das obras escolhidas e muito mais significativa sua contribuição para a resposta às perguntas formuladas. 0 paralelo com a obra consagrada permite construir um lastro teórico baseado na práxis.
Em seu recente artigo, Tratados brasileiros de arquitetura moderna - Aprendendo arquitetura com quem faz - parte 1 e $2^{19}$ Pando Fijita coloca com chreza a necessidade de se ade de se estabelecerem obras de referência a partir do estudo das realizações de arquitetos cuja produção recente permite o entendimento dos mecanismos que são próprios do universo da arquitetura. Numa clara alusão aos Tratados de Arquitetura que historicamente formaram geraç̄õs de arquitetos, o autor destaca como o conhecimento da maneilhidos poden ser una fora a mação das novas gerações de arquitetos.

Assim, estabelecemos para cada um dos capítulos que compõem esta tese um grupo de obras que, ao serem examinadas, trazem subsídios para o entendimento dos problemas colocados.

Tal metodologia pretende identificar ideias sobre as obras, mais do que um discurso sobre as palavras, ainda que o entendimento teórico esteja presente. (PIÑON, 1998: 33)

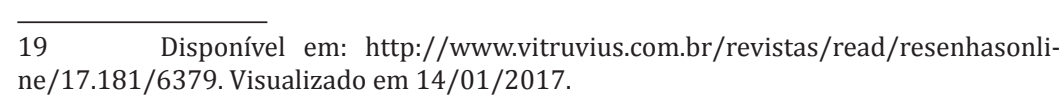

Inicialmente porque esses projetos consideraram

Mas por que, além do objeto de estudo ser definido pelo equipamento público na arquitetura contemporânea brasileira, considerar como referência obras estudadas no mestrado Arquitetura do Espetáculo em cena como o Teatro Necional de Manthim de Mies van der Rohe (1953), Fun Palace, de Cedric Price (1961)? em certa medida, continuam atuais, mesmo que a presente pesquisa não se limite a um tema específico, como o que fo por elese na se th vel verificar como o projeto reservou espaço para a evolução, eocupações manifestadas pela sociedade da época e que 
em Mies, e para o imprevisto, em Price, não pelo discurso conhecido da flexibilidade, mas sim pela construção de mecanismos ou estruturas que permitiram a intervenção na própria edificaç̃ão. Ou seja, as proposições presentes nessas obras não envelheceram, não perderam significado e podemos dizer que foram potencializadas nas primeiras décadas do século XXI. Ao incluíllas como obras a serem examinadas, estabelece-se a aproximação necessária para o entendimento dos mecanismos de concepção e desenvolvimento de projetos que revelaram qualidades exemplares. Devemos reconhecer os elementos construtivos como elementos de proeto através da observação e da comparação entre as obra e não dos discursos que procuraram justificá-las. Assim, a investigação estará direcionada para a construção de un método que contribui para a avaliação crítica e o aprendizado do projeto, baseados no acúmulo do conhecimento um caminho consagrado da pesquisa científica, como muito bem captado por Ezra Pound
O MÉTODO adequado para o estudo da poesia e d literatura é o método dos biologistas contemporâneos, a saber, exame cuidadoso e direto da matér pécime com a outra 20 [-1] “A ciência não consiste pécime com a untra. [.... A A tência não consiste nos abstratas correspondentes a número de corsas que desejamos descobrir", diz um comentalor francês de Einstein. [..] a ciênnia se desenvolven francês de Einstein. [.... a ciência se desenvolve un mais rapidamente depois que Bacon sugeriu exame direto dos fenômenos e depois que Galilieu u e outros cessaram de discutir as coisas em excesso e começaram a olhar realmente para elas e a vê-las melhor. (POUND, 2006: 23 - 26)

Para fundamentar a pesquisa literária, Pound entende que deve haver um paralelo metodológico com as pesquisas realizadas nas ciências biológicas ou nas ciências físicas, por exemplo, sem, no entanto, ser necessária a definição de paradigmas pois "uma afirmação geral é válida somente com REFERÊNCIA a objetos ou fatos conhecidos" (POUND, 2006: 30) ${ }^{21}$

$\begin{array}{ll}20 & \text { Destaques do autor. } \\ 21 & \text { Destaque do autor. }\end{array}$
Entretanto, nas investigações da ciência, mesm sendo um modelo ou padrão aceito, que funciona ao permitir a rep
mente sus mente suscetível de reproducão») É o que afirma Thomas S. Kühn (1978) ao mostrar como o paradigma auxilia a pesquisa científica na antecipação de raciocínios que somente serão demonstrados posteriormente através de aparelhos experimentais. 0 método adequado, segundo Kühn, está

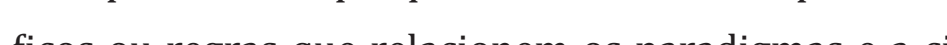

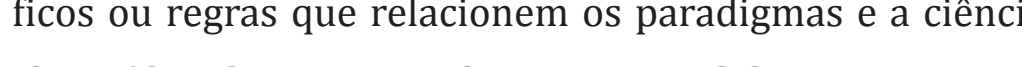
abstraídos de seus paradigmas mais globais, para serem empregados posteriormente em suas pesquisas. Em outras palavras, o paradigma conteria regras e pressupostos sem contudo, ser passível de repetição, como um modelo a ser Pound o paradigm é a refência válida a ser reconhecida e articulada com a teoria. 0 esforço científico de articulação deve ser perseguido até que o paradigma não encontre mais consistência suficiente por anomalias reconhecidas que indiquem a necessidade de serem suplantados por novos paradigmas, o que explica as revoluçōes cientificas (KÜHN) A prioridade está, então, no reconhecimento das referências, como insiste $o$ autor:

investigação histórica cuidadosa de uma determinada espacialidade num determinado momento revela um conjunto de ilustracões recorrentes quase padronizadas de diferentes teorias nas suas aplicaç̃os conceituais, instrumentais e na observacâao. Ao estudá-los e utilizá-los na prática, os membros da comunidade considerada aprendem seu ofício. (KÜHN, 1978: 67)

É certo também que, no interior dos subtemas propostos, não poderemos nos apoiar em mecanismos únicos para o exame e avaliação das obras. Assim como a complexidade é o predicado cada vez mais presente da realidade a diversidade de projetos estudados deverá ser enfrentad considerando-se as particularidades de cada um, o que explica certas diferenças adotadas para o exame de cada obra. A compreensão do projeto através das mesmas analogias ou teorias cumpriria a missão proposta de maneira incompleta. 
As analogias formais ${ }^{22}$, como instrumento privilegiado do conhecimento disciplinar da arquitetura, perm tem generalizar situações particulares para que possamos nos aproximar da realidade, é o que argumenta Mário Júlio Krüger $^{23}$, para quem esse procedimento é valioso por não estabelecer regras ou princípios para a atividade projetual. Ou seja, pode nos ser útil como procedimento sem que haj a expectativa de construção de um manual de projeto ou uma lista de regras, o que nos interessaria muito mais como processo de análise e não de projeto.

Krüger desenvolve seu raciocínio ao apresentar que considera uma forma de tornar explícito o conhecimen to, o que permite à arquitetura estar em uma área disciplnar, mesmo quando há divergências (1986: 52).

Para o autor as teorias de Competência operam por nalogia fort, tantiva que usa modelos existentes para elaborar previsões de novos projetos. Como exemplo, o objeto industrial auto-

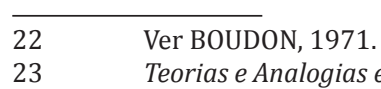

móvel originou um padrão de ocupação espacial que ainda persiste, "a máquina de morar"

Por outro lado, se a andogia substantiva se dá através de teorias de Desempenho, temos a atividade projetual baseada em regras de um sistema de conhecimento. 0 projeto é a resolução formal de subproblemas decorrentes da subdivisão de problemas mais complexos, como agrupamento de soluçõos, o que retoma, em certa medida, os procedimentos compositivos atualizados por uma abordagem analítica. A linguagem originada pelo procedimento pode ser identificada na medida em que há a repetição de elementos, situações e organizações, ou seja, a composição é instrumento da repetição, que é uma parcela do que tratamos no capítulo 2.

Há ainda o que Krüger chama de teoria de Desempenho por analogia formal, que gera, a partir de um protocolo ou de uma matriz, estados intermediários antes de atingir seu estado final. A inexistência de uma situação final, definitiva é a característica do projeto que se materializa com um trabalho de resolução de sistemas de grande comple- xidade pela geração de anagramas técnicos, espaciais e funcionais capazes de produzir significativos resultados ao longo do tempo, como trataremos no capítulo 4.

Assim, completa o autor, ao colocarmos em questão a validade das analogias, podemos justificar o raciocínio por sua incapacidade de estabelecer princípios ou fundamentos para o projeto.

Antes de iniciarmos o exame dos projetos, consideramos ser necessário definirmos terminologias e noç̃es que serão utilizadas no nosso trabalho.
Questões de terminologia

problema com os arquitetos do século XIX residia menos no fato de terem deixado a inovacão para os engenheiros do que em terem ignorado a revolução técnica desenvolvida por outros. Os arquitetos atuais, em sua compulsão visionária para inventar novas técnicas, negligenciam sua obrigaç̃õo de serem especialistas nas convenções existentes. [...] rquiteto seleciona tanto quanto cria.

0 esclarecimento das noções de tipo e modelo, protótipo e sistema para a pesquisa do projeto padrão parece-nos necessário por permitir maior clareza nas escolha do objeto de estudo e na metodologia empregada neste uno que o projeto reconheça experiência acumulada pela disciplina e que opere com as convenções existentes, como na afirmação de Venturi, citada na epígrafe. Nesse sentido, parece-nos importante, num primeiro momento, a discussão de tais noções e quais vínculos poderiam ser estabelecidos com o trabalho empreen- 
dido aqui. Mesmo porque há diversas definições e comparaçōes utilizadas pela historiografia da arquitetura en momentos distintos tais noç̃es, seu entendimento para nosso trabalho.

Isso não significa, entretanto, que temos como obje tivo ou como metodologia o uso do conceito de "tipo" para justificar o projeto como padrão, por exemplo. Tais noç̃oes se encontram de certo modo esgotadas, como poderemo observar, mas seu conhecimento é fundamental para construção do fio condutor de nosso trabalho.
S problemas de arquitetura não permitem soluções únicas, definitivas; por isso, há pouco valor seguir normas categóricas e absolutas. Se evitará assim a il lusão de encontrar a solução de valor geral, que não existe em arquitetura, e o erro do tipo de edifício, tipo que deveria ser igualmente bom em um lugar e em outro, em um clima e em outro, em qualquer forma de sociedade ou comunidade humana.

TEDESCHI, 1965

O pensamento de Enrico Tedeschi, em sua obra Teoria de la Arquitectura, é portador de um desafio constante do processo de propto Segundo ele, não é possiverque uma solução absoluta encontre resultado positivo em qualquer contexto. Não haveria, portanto, como estabelecer um projeto como um padrão, funcionalmente definido, a se implantado indefinidamente, mesmo que fossem estudadas experiências semelhantes bem sucedidas que trataram $\mathrm{d}$ mesmo tema. definição do tempo necessário para que a citada experiência seja capaz de reunir o conhecimento suficiente para construção de um corpo teórico. De fato, ao ria, a arquitetura vem sendo definida por critérios de form baseados no uso de noções técnicas e da razão (COLLINS, apud TEDESCHI, o.p. p. 8)

Ainda que não esteja desenvolvendo um raciocínio para a definição de padrão ou para a validade do conceito, Giulio Carlo Argan, em sua obra Projeto e Destino (2000) faz uma importante constataç̃o que auxilia nosso trabalho. Para Argan, há uma mudança significativa entre a noção de Para Argan, há uma mudança significativa entre a noção de
módulo herdada da tradição da arquitetura clássica e a noção elaborada pela arquitetura moderna. Enquanto na primeira, chamada por ele de módulo-medida, a repetição da dimensão-padrão e das proporç̄es gerad ponsável pelas qualidades estéticas e espaciais da obra, segunda, o módulo-objeto, é concebida como um standar desvinculado do sítio, baseado em funções práticas e capa de proporcionar novos e imprevisíveis horizontes. Assim o standard abre amplas possibilidades no campo da pro- 
dução industrial da arquitetura e na inovação em relação à concepção do espaç̧o, que o autor chama de "espacio-temporal" pois teria a capcida de de produzir ese produzir en direção à principal funç̃o, a da existência humana.

Poderíamos, então, considerar que o standard sera um possível caminho para o processo de síntese do projeto, não como uma operação de redução ou de busca do mínimo, mas sim na procura das estruturas essenciais para que o objeto edificado se qualifique por determinada independência em relação ao sítio, não sendo, portanto, gerado por ele. Nesse caso, o standard atingiria uma determinada autonomia capaz de resistir às mudanças do sítio, ou mesmo a sua indefinição, de maneira a manter sua pertinência ao longo do tempo.

$$
\text { A dificuldade maior, já assinalada por Tedeschi, }
$$

caberia ao projeto na elaboração dessa síntese. Argan ainda exemplifica:
Mas o mesmo Le Corbusier, quando enfrenta polêmica do objeto e $o$ tema do standard (e enfrenta-os, é preciso dizer, com mestria) assume o tom e a gravidade daquele moralista que de fato é: e, se se observa a sua arquitetura, será fácil constatar que ela não nos impõe uma nova teoria constatar que do ancencoso mas uma nova teo estimulante conceppção do objeto arquitetônice. 0 qual, não podendo mais ser definido pelo sítio que ocupa no espaço ou por seu lugar no conterto da natureza, tem na lúcida definicicão da funç̧ão

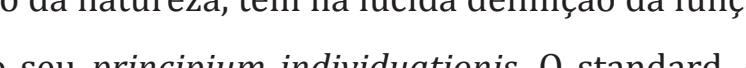

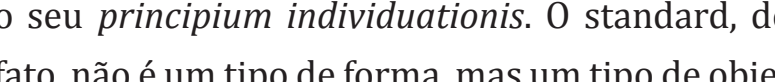

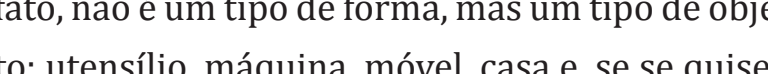
cidade. E como tal toma o lugar a e se quise dulo no processo da projetacão clássica: a nonde se afirmar que a grande descoberta da arquitetura moderna é a substituicão do módulo-medida pelo módulo-objeto. É este o ponto de partda dos novos processos. avaliação da funçãoo edilícia, de uma nova (mas posteriori) concepcão do espaço, tom (món é preciso dizer da industrializač̃o dos processos construtivos. (ARGAN, 2000, p. 100) to de Argan é a Unité d'Habitations projetada por Corbusier e implantada em diversos sítios. Contextos bastante distintos, como o ambiente da grande cidade de Marselha multicultural, mediterrânea, de clima quente e seco, até os bosques temperados da pequena Briey-en-Forêt no norte da França ou ainda a Berlim metropolitana, receberam exemplares da obra, elevada à categoria de equipamento, mais do que simplesmente uma edificação habitaciona por incorporar espaços comerciais e educacionais. 0 objeto arquitetônico, como produto da tecnologia moderna assume a qualidade de objet-type da civilização moderna como observou Colquhoum (2004: 104). E mesmo para se opor a uma ordenação clássica da cidade, este autor assinala como Le Corbusier trabalhou 作 plástico, e completa mais adiante: “Uma vez tendo estabelecido um padrão, ele simplesmente é repetido" (COLQUHOUM, 2004: 115)
[..] a sociedade influi na arquitetura de muitas maneiras, diretas e indiretas, mas principalmente pedindo satisfação edilícia para certos usos que por ser típicos da estrutura social em um momento determinado, produzem tipologias. [...] Desde que estas formas estão finalmente consideradas, no processo histórico, como testemunhos de uma época e de sua cultura, se afirma ssim a relação dialética sociedade-artista, pela qual o artista atua em uma situação social exisente, mas ao mesmo tempo contribui com sua obra a formar essa sociedade e a caracterizá-la. TEDESCHI, 1965

Os tipos da arquitetura do movimento moderno fom responsáveis por sua difusão como ideais a serem "alcançados". Para Anthony Vidler (2008), essa seria a segunda noção de tipo pois os arquitetos iluministas já haviam utilizado em seus projetos o conceito de tipo formulado pelo abade Marc-Antoine Laugier, em sua obra Essai sur 
'Architecture (1755). A arquitetura se basearia, segundo esse conceito, numa ordem racional originada da natureza, o que jus combinação de elementos tipológicos, o que, por sua vez, fundamentaria sua aparência exterior. "Quando a perfeição é atingida, não há senão imitá-la ou decair", firma Laugier (apud AZEVEDO, 2009: 53) lembrando-nos da necessidade de equilíbrio do uso da razão, exigente de ordem, e da imaginação, sedenta de variedade.

Em sua obra, Sobre a Tipologia em Arquitetura (1963), Argan estabeleceu as diferenças entre o tipo 0 modelo ao identificar no primeiro a história como se principal componente. Para Argan, esse fato o diferenciaria fundamentalmente do modelo, uma forma a ser copiada, reproduzida 0 tipo estaria muito mais enraizado uma detern damentais e permaneste incoro como fator de construção de sua identidade, pois depende ria de uma série de construções análogas por seus aspectos formais e funcionais. Nessa nocão de tipo, a arquitetura se espelha em outra "natureza", a do ambiente construído, a cidade, o meio ambiente inventado pela civilização. Com a arquitetura industrial. Portadora de um programa interamente novo, em processo de elaboração, a arquitetura industrial, ao contrário da religiosa historicamente rep tida e copiada, estaria a serviço do desenvolvimento da arquitetura do presente e do futuro, pelo fato de configurar novos tipos.

Segundo Montaner (2001), a necessidade de se estabelecerem critérios de análise crítica foi responsável pel elaboração da noção de tipo, num período de ampla diversidade interpretativa, o que aproximou o campo da arquitetura do estruturalismo filosófico.

Vidler (2006) chamou essa noç̃o de terceira tipologia por representar um crítica direta à fragmentação da cidade moderna, responsável pela suposta incapacidade desta última de configurar cidade. Ao buscar a clareza e coerência da cidade do século XVIII, a terceira tipologia estaria, dentro de um pensamento estruturalista, buscando o aspecto mais concreto da forma: sua estrutura. Como postura crítica à modernidade, muito mais do que propositiva Vidler vê na terce to do ciclo comandado pela produçao e pelo consumo pois há interesse no uso crítico de tal conceito na compreensão da espacialidade baseada nas formas geradas pela cidade em detrimento das questões funcionais e construtivas.

as é na ideia de transformação, de mudança, do surgimento de "novos" tipos a partir de momentos de intensa renovação técnica, estrutural, de uso e de escala, que Rafael Moneo traz considerações mais apropriadas aos interesses de nossa pesquisa. Moneo, em seu artigo Sobre la Noción de Tipo (1978), também resgata as noções de tipo do século XVIII, que haviam, segundo ele, transformado arquitetura em resultado, em produto. Durante a modernidade, o abandono de tais conceitos deu lugar à técnica à ciência como maneira de enfrentar as novas demandas da sociedade industrial. Haveria uma construção capaz de atender a uma necessidade, o que permitiria sua repetição, sua reprodução, o que converteria a obra em protótipo. conclui o autor.
Ao avaliarmos as afirmações em epígrafe de Tedeschi, extraídas de sua obra - Teoria de la Arquitetura - encontramos um entendimento an nãonega a ou invenção da arquitetura em resposta às novas relações de determinadas sociedades

Estaria nesse raciocínio mais uma resposta para definição do projeto como padrão? Como origem das demandas que justifiquem sua reprodução industrial podemos considerar que sim. Entretanto, devemos analisar, através do projeto, se não estaríamos materializando un novo repertório de formas e de espaços após o esgotamento das premissas de ordem tecnológica e de racionalidade. 
Modelo

À mais perfeita reprodução falta sempre algo: $\mathrm{o}$ hic et nunc da obra de arte, a unidade de sua pre

BENIAMIN, 1961

A noç̃o de "modelo" também veio caracterizar uma série de atitudes dos arquitetos paulistas modelo de soluções arquitetônicas, modelos estruturas, até modelos de relações sociais. [..] m São Paulo, Niemeyer foi cultuado pelas ideís e pelas realizações construídas que, passadas por uma releitura, se transformaram noutra arquitetura nas mão dos arquitetos paulistas - sem perder a essência que a originou.

SEGAWA, 1997 presente e a modelizaçăo espacial de uma real oferece, no nivel do imaginario uminstrumento de concepção a priori do espaço edificado, o modelo. [...]

A segunda [metodologia] centralizou o trabalho no tratado e na utopia: dois procedimentos-tipo de concepção do espaço edificado seriam criados a partir do surgimento do projeto instaurado. Um deles, elaborado pelos tratados de arquitetra, consiste na aplicação de principios e de regra 0 outro, decorrente da utopia, consiste na repiodução de modelos. Esses dois procedimentos, regra e modelo, corresponderiam a duas atitudes fundamentalmente diferentes face ao projeto edficante e ao mundo edificado. [...]

Mas, através de derivas, transformações e sincretismos, essas figuras manifestariam uma re sistência insólita à destruição. Triunfantes ou vergonhosas, íntegras ou mutiladas, assim como aquiteturas de pedra que a ruína nos perm estemunhar e que sobrevivem às instituiçōes e as formas do saber das quals foram contemporaeas, as duas arquiteturas discursivas imporiam ma presença irrevogavel que, ao longo do teno, continua a fazer sentido: figuras cuja pre nancia resistiria à usura dos acontecimentos, a sedimentação das mentalidades, às reestrutura cóes do saber, e cujo significado transcenderia significado de seus conteúdos.

segunda imagem, que eu denominaria mode os traços espahais deslocados e reproduziveis, releva, ao contrário, exclusivamente da sombra humana e de m sistema estrito de normas culturals.

HOAY, $1980^{24}$

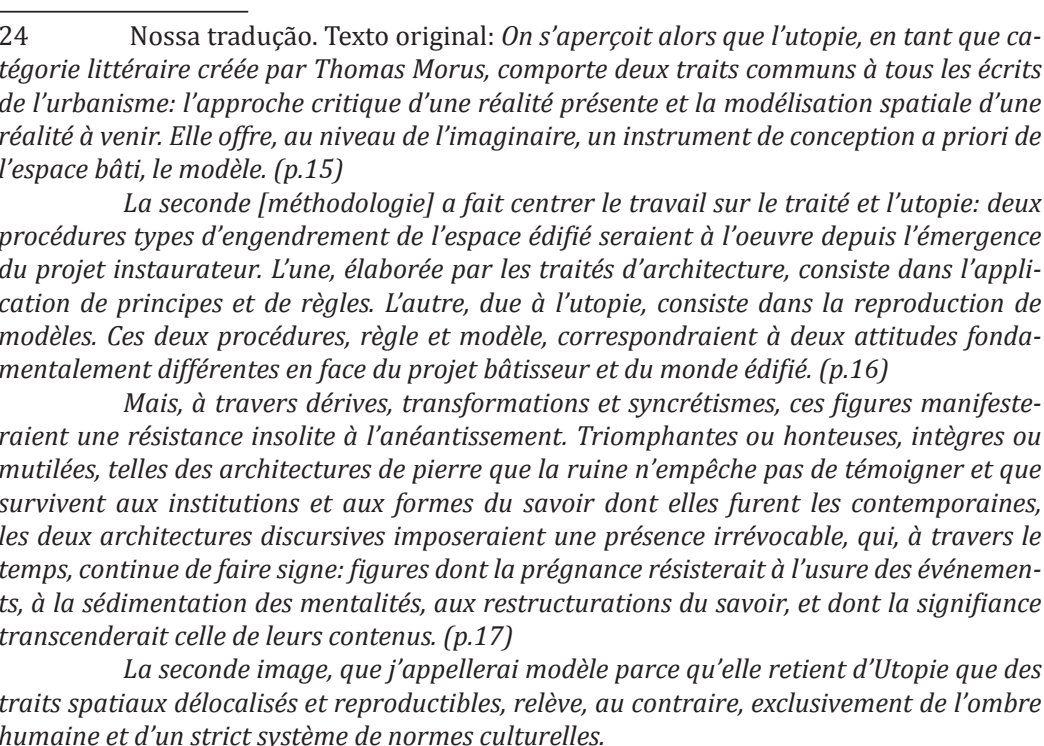

Quando a Casa de Vidro de Philip Johnson em New Canaan foi apresentada, seu autor publicou ao mesmo tempo um texto em que deixa claro que a obra é o resultado da síntese de modelos heterogêneos. Os modelos assumem papel de fonte geradora do projeto, como nos lembra Wilfried Kühn em seu artigo Miesà Bad Karlshafen - la présence réflexive du classique (2002).

Na arte e na arquitetura em particular, modelo é un assunto de extrema complexidade. As citações em epígrafe ilustram algumas das noç̃es de modelo discutidas por importantes autores. É na sua amplitude que o tema, ao atravessar os diversos períodos históricos, assumiu interpretações distintas sem, contudo, deixar de se fazer presente no ideário do projeto. Em outras palavras, é no modelo que a arquitetura vai buscar sua referência ou vai negar determinada tradição, e mesmo a inovação vai apontar para o modelo de outras disciplinas a fim de fundamentar sua pertinência. 
O modelo, como obra a ser imitada, mesmo sendo pela sintese de vários modelos como na Casa de Vidro en New Canaan ou como na obra de Niemeyer, lembrada por Segawa, é a estratégia do projeto e, principalmente, de seu próprio aprendizado. A obra de Rafael torna-se modelo ser imitado e modelo a ser repetido (MIGLIACCIO,2010: 11), sendo a Vila Madana prova disso.

Mas se Françoise Choay vê a persistência dos tracos culturais e humanos - "a sombra humana" - no modelo ços culturais como um aspecto permanente, capaz de garantir sua reprodutibilidade, um outro autor importante, Nuno Portas, revela, por outro lado, a dificuldade de extrair da complex dade do conhecimento o que "deve alimentar a criação de uma arquitetura" (1965: 20). Isto é, a manutenção de atrrbutos capazes de qualificar a obra como modelo, sem a inluência do contexto, seria cada vez mais uma árdua tarefa por depender da capacidade e da sensibilidade do projet em identificar os atributos fundamentais que o definirian Choay, como pesquisadora crítica, está, inicialmente, preocupada em demonstrar historicamente a permanência modelo como instrumento de elaboração de uma teoria da arquitetura e, posteriormente, do urbanismo, em oposiça desde Alberti, construíram um discurso baseado nas normas e nas regras. Portas manifesta-se de maneira distinta pois demonstra sua preocupação em relacão às dificuldades cada vez mais crescentes na busca pel identificação dos valores que representariam no projeto o modelo de sociedade ao qual se refere, ou seja, ele traz a questão de como tornar o projeto autêntico no sentido er portador de estruturas constitutivas fundamentais en uma sociedade em intensa mudança. 0 desafio é colocado ho momento de identificar e avaliar a pertinência de tals qualidades, como observou Mário Carpo: “[...] para imitar um edifício, é necessário tê-lo visto" (2002: 44), ou seja, necessário compreendê-lo para que a cópia se baseie na Canso ins ver através, entender e não apenas de olhar

modelo como espaço seria, para Choay, a perm nência e a projeção de um "projeto instaurador", seguindo a tradiçăo do «texto instaurador» utópico de Thomas Morus. Seguindo essa noç̃ão, o modelo desvincula-se das condições

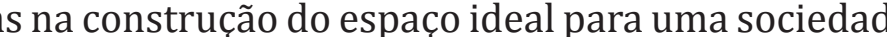
ideal. Nesse sentido, sua reprodutibilidade teria a capacida de de gerar espaços-modelo a partir de cada implantação pois traria consigo a capacidade de edificar ambientes sociais dentro de um ideário desejado. Assim, o modelo apontado por Choay teria no nosso trabalho o papel de criação do lugar na medida em que, através do projeto, as r espaciais, tanto internas quanto externas, seriam capazes de construir situações sociais de alto teor urbano; o modelo carregaria a propriedade de estabelecer mudanças ou, pelo menos, de instaurar caminhos para que tais acontecimentos sejam possíveis.

$$
\text { As considerações acima aproximam o pensamen- }
$$
to de Portas ao de Choay. Portas também acredita que ha projetos utópicos, como a Unité d'Habitation de Le Corbusier (1965: 31), que foram responsáveis pela remodelação das teorias urbanísticas elaboradas pelo arquiteto, ou seja a Unité seria o modelo a ser reproduzido indefinidamente pois "o conteúdo da peça arquitetônica continha o princípio de uma nova cidade". Nesse sentido o modelo torna-se un standard: ao sercapazde interferir nas diversas sithacto que é submetido, ele assume a condição de padrão, por não ser apenas a repetição do mesmo, e sua reprodutibilidad não indica a ausência de um caráter, como observado por Walter Benjamin na citação que abre esta seção. Podemo considerá-lo, dessa forma, um importante tema a ser pes- 


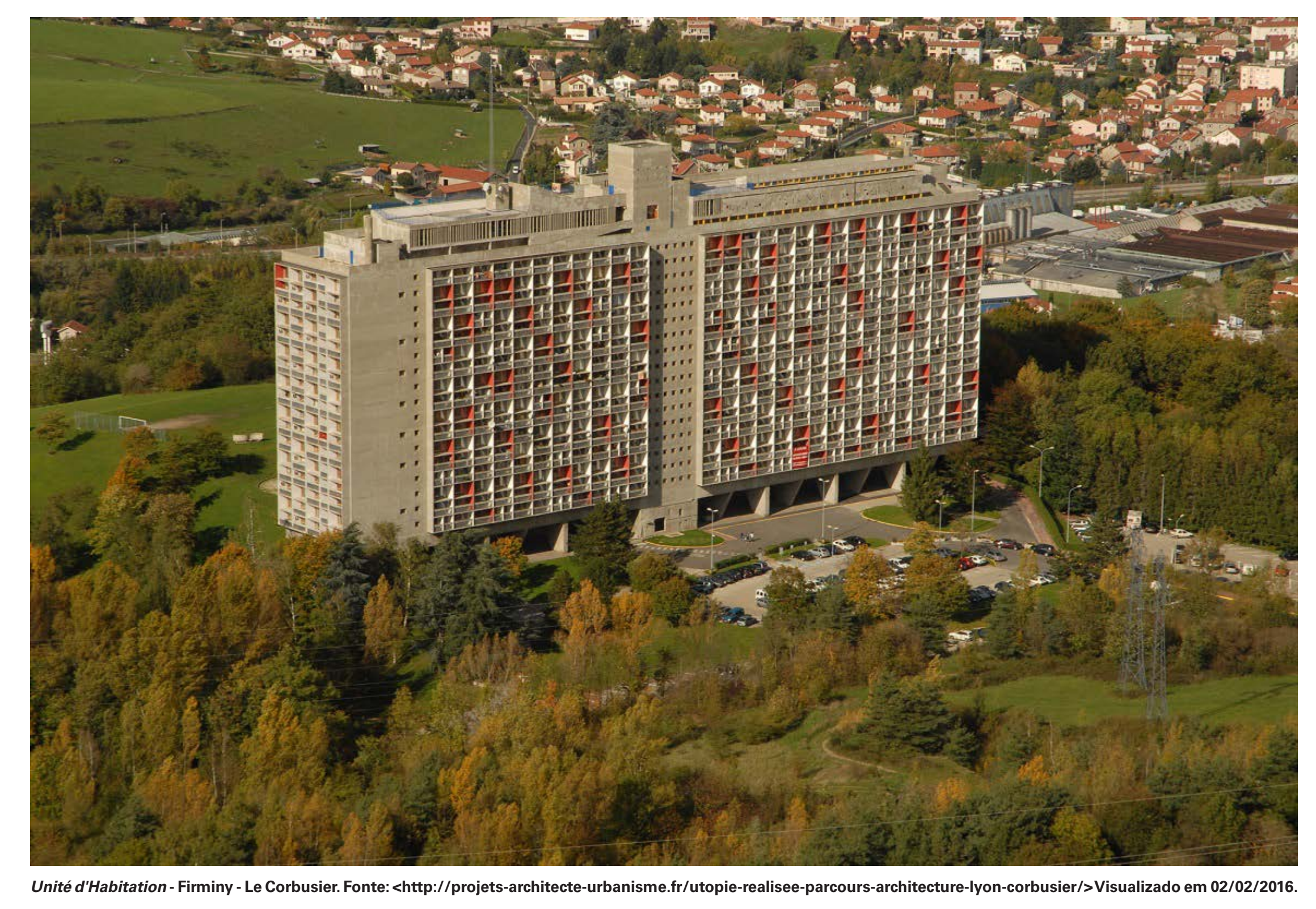
tanto no decorrer como ao final do processo de projeto.

A nocão de protótipo, para nossa pesquisa, está distante do protótipo industrial, ou seja, da primeira materialização de uma ideia de objeto a ser reproduzido indefinidamente através de processos industriais. 0 "proto", do que é anterior, está muito mais próximo da noção de modelo sem, contudo, considerar a presença da imitação no processo de criação.

Os protótipos na arquitetura durante o movimento moderno estão diretamente ligados à noção do objeto arquitetônico como referência à imagem da máquina. Roger Sherwood descreveu em sua obra, Modern Housing Prototypes (1978), o valor de protótipo assumido pelos projetos modernos 0 autor mostra como a resoluça

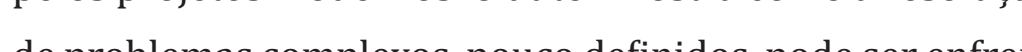
de problemas compers, ponfre tada através da utilizaçăo de projetos conhecidos, testados. como uma solução inicial, traçando um paralelo com a reso lução dos problemas matemáticos (BEZERRA, 2011). À medida que o processo avançaria, o protótipo seria substituído erísticas fundamentais do protótipo utilizado.

Nesse sentido, poderíamos admitir que estamos falando de "protótipos" muito mais do que de um único protótipo. Caberia ao projeto a escolha dos protótipos a serem selecionados e, sobretudo, a metodologia de sua utilização. metodologia de fazer analogias como o emprego de protótipos de modo sistemático, o que facilitaria sua repetição Isso não corresponderia à mesma noção de analogia defendida por Argan, como vimos. Para Sherwood, foi a metodologia a responsável pelo surgimento de edifícios análogos pois estes incorporam e se identificam pelas quest ginadas no processo de projeto e de producão.

Se esse raciocínio de projeto, aplicado principalmente às habitações, obteve grande alcance, em especial durante o período pós Segunda Grande Guerra, impulsionado pelo processo de industrialização da construção, ele 
foi também responsável pelo enfrentamento dos novos programas que surgiram por esse mesmo processo, ainda que isso tenha oco das estaçoes ferrovias que se tran tipos de uma geração de estruturas similares espalhadas pelo globo (BRUNA, 2002).

Sherwood, porém, destaca a dificuldade de se aplicar essa noção de protótipo nos projetos com alta complexidade hospitais por exemplo, por não haver coerência entre cad um desses equipamentos, o que dificultaria sua repetição.

Por essas considerações, o projeto teria a missão de seleção e escolha dos protótipos como referência. Essa capacidade de compreensão e identificação das qualidades a serem apreendidas estaria imbuída do conhecimento padrões arquitetônicos, num primeiro mon seguida, permitir o desenvolvimento natural da obra.

Em Arquitetura do Espetáculo em Cena (PIETRAROIA, 2014: 198), observamos como o Pavilhão Philips, projetado por Le Corbusier em 1958, foi baseado, inicialmente, em axiomas matemáticos, graças à colaboração de Yannis Xe-

. Oproprio músico e matemático viria a assinalar que, a partir de certo momento, foi necessária a intuição para que abra se concretizasse, mas reconhece que proporcionada pelos cálculos matemáticos iniciais.25

É sobre a metodologia de aplicação e não da definição de tipo que Coulquhoun talvez nos traga uma contribução mais próxima de nossa pesquisa. Em Tipologia e Metodologia de Projeto (1967), no nosso entendimento, o auto está preocupado com a aplicação prática da tipologia, o que aproximaria suas consideraçoes muito mais do protótipo do que do tipo baseado nos conteúdos urbanos, da crítica tipológica, definidos por Argan, e que Vidler viria a chamar de Terceira Tipologia. Esse fato nos parece claro quando o autor afirma:

A mudança é característica de nosso tempo e jus tamente por isso é preciso investigar o papel que as modificaçōes de soluçōes tipo desempenham com relação aos problemas e soluč̃os que não têm precedentes em qualquer tradicão. (COULQUHOUN, 2006: 282)
Baseando-nos em considerações como essas, deveemos verificar como seria possivel o uso do protótipo enquanto instrumento de projeto para respon formuladas pela presente pesquisa.

25 Ver COULQUHOOUN, in NESBITT, 2006: 282. 

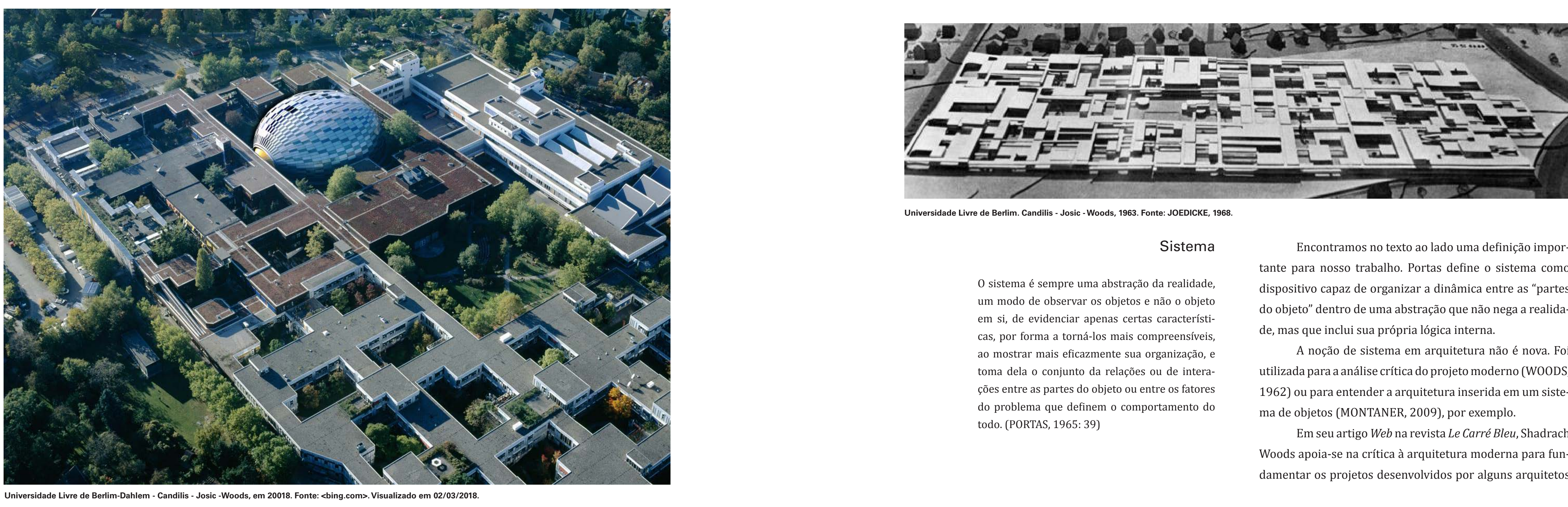

Niversidade Livre de Berlim. Candilis - Josic -Woods, 1963. Fonte: JOEDICKE, 1968

Sistema

Encontramos no texto ao lado uma definição importante para nosso trabalho. Portas define o sistema com dispositivo capaz de organizar a dinâmica entre as "partes

sistema é sempre uma abstraç̃̃o da realida m modo de observar os objetos e não o objet m si, de evidenciar apenas certas característcas, por forma a torna-los mais compreensíveis as mostrar mais eficazmente sua organização, ma dela o conjunto da relações ou de interaçoses entre as partes do objeto ou entre os fatores todo. (PORTAS, 1965: 39) de, mas que inclui sua própria lógica interna. tilizada para a a 1962) ou para entender a arquitetura inserida em um sistema de objetos (MONTANER, 2009), por exemplo.

Em seu artigo Web na revista Le Carré Bleu, Shadrach Woods apoia-se na crítica à arquitetura moderna para fundamentar os projetos desenvolvidos por alguns arquitetos 
que compuseram 0 Team X a partir da década de $1950^{26} .0$ autor admite a contribuiç̃o da arte Moderna, sobretudo na redescoberta da continuidade espacial, mas lembra que o mundo é composto por uma superfície contínua envolvid por um espaço contínuo. 0 espaço total geraria a sociedad universal, apesar de sua independência. Para enfrentar caos estabelecido pela falta de objetivos, seria necessário estabelecimento de sistemas contínuos, capazes de evoluir pois considerar rar a de tempo, como veremos no capítulo 4

Já Montaner, ao aplicar a teoria dos sistemas de Niklas Luhmann, renova o entendimento da arquitetura em sua capacidade de interagir com o território em que se insere. Segundo ele, isto permite evitar o reducionismo presente até aquele momento, responsável pela crise do objeto moderno. 0 autor afirma ser a organização interna, composta por elementos heterogêneos de distintas escalas, responsável pelas mentos heterogêneos de distintas escalas, responsável
estratégias de adaptação à complexidade do contexto. A constituição de um sistema coerente pode ser entendida como necessária para que a arquitetura enfrente desafios cada vez mais indeterminados. Como observa

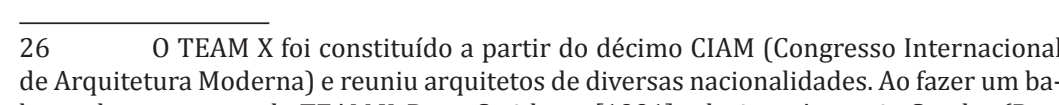

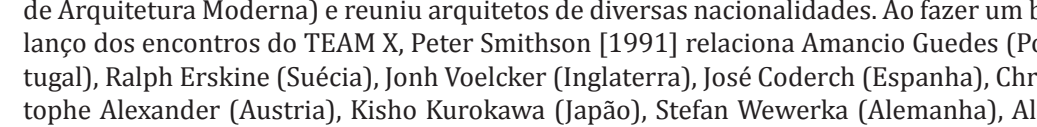

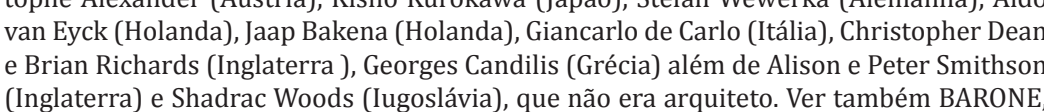

Helio Piñon (2006: 90), a coerência interna dos elementos constitutivos da obra de arte são capazes de sustentar sua existência sem que haja dependência de sua finalidade. Iteração dos usos previstos, a obra se mantém coerente ncorporar de maneira natural suas novas funções. Não há necessidade de explicála a não ser pelos próprios critérios de estrutura interna pelos quais foi concebida. Seguindo um raciocínio da estética kantiana Piñon argumenta que, pra a arquitetura, esta é a condição para que a obra não perca sentido, mesmo quando o uso não é mais justificado.

0 argumento ajuda-nos a entender a sobrevivência da obra no tempo, condição necessária para que, mesm com as mudanças de uso e as transformaç̃̃es do contexto, sua permanência possa ser notada com clareza. Novamente

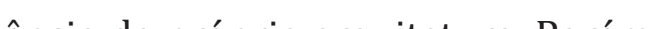
que nos parece importante é entender a arquitetura con um sistema que é o próprio mecanismo de construção da obra, em que não apenas se considera o tempo mas também o improviso: qualidades adaptativas leva a uma das princpais alterações epistemológicas da prática projre (LUHMANN, apud ROCHA, 2009: 110)
(orma para nocao de projeto como

or outro lado, o uso de sistemas para gerar, ordear ou fazer evoluir o projeto arquitetônico é considerado fundamental por alguns autores (MAHFUZ, 2009) para solução de programas de alta complexidade ou de grande escala. 0 sistema poderia assumir um papel abrangente flexível, como apoio à prática projetual, de maneira a orga nizar necessidades e características físicas de ordem quantitativa. Nesse caso, podemos falar da sistematização das informações e dos procedimentos para que o projeto não perca o controle do processo, mais do que da criação de um sistema que substituiria a solução arquitetônica ou, de fato seria o sistema o próprio partido arquitetônico.

que nos parece razoável é considerar a segund

hipótese portadora de interesse, não apenas por explicar uma metodologia de projeto mas, sobretudo, por institur caminhos para o entendimento do projeto como estratégia de enfrentamento das citadas incertezas.
As noções terminológicas discutidas permitem-nos apontar com maior clareza o caminho que deverá assumir presente pesquisa.

0 confronto das considerações de importantes autores, discutidas dentro de uma linha de investigação que pretende definir o objeto de estudo, demonstrou que 0 intenso debate ocorrido, especialmente na segunda metade do século XX, em torno da nocão do tipo, mesmo sendo fundamental para a historiografia da arquitetura, não traz contribuição significativa para nosso trabalho.

Da mesma maneira, os protótipos decorrentes da industrialização da arquitetura, baseados em conceitos da racionalização dos meios produtivos, não foram capazes de estabelecer os padrões que auxiliem as operaç̃oes de projeto. Sua contribuição se mostrou fundamental na padronização dos componentes e na elaboração de metodologias de concepção voltadas para a produção, controle e manutenção da obra, num exercicicio que se aproxima da noção 
de normatização ou de regra, como defendida por Choay (1980). No entanto, ainda que seja fundamental que o projeto se apoie nesse conhecimento, não nos parece suficiente utilizá-lo no enfrentamento dos problemas que trazemos para nossa pesquisa.

Dessa forma, os conceitos em que podemos nos apoiar com maior interesse são, primeiramente, os que definem o objeto arquitetônico por suas qualidades internas, isto é, os modelos entendidos como standards, tal como apontado por Portas (1965) e Argan (2000), e sua capacidade de estabelecer uma identidade com o lugar. Além deles, são também lecer uma identidade com o lugar. Além deles, são também de grande interesse os conceitos que estabelecem estreita terminada realidade, como sistemas capazes de encarar os constantes desafios apresentados pela cidade pós industrial, cujo questionamento e aprendizado crítico da segunda metade do século XX é destacado por Milton Braga:
Talvez pudéssemos sistematizar a imensa gan de novos argumentos urbanisticos introduzic vés da noção de contexto - embora essa categoria hoje esteja sendo cada vez mais suplantad pela noção de sistema. 0 contextualismo foi un estratégia de leitura e ação, em relação à cidad que levou os arquitetos a uma compreensão mu to mais ampla das dinâmicas urbanas. Sobretud quanto ao caráter processual desses organismos quanto ao caráter processual desses organismoš
irredutíveis, nesse viés, a objetos de configuracā̃o irredutiveis, nesse viès, a objetos de configuraçâa GA, 2010: 29)

A decisão de incorporarmos as citadas noções ao corpo teórico da presente pesquisa indica nossa preocup ção em direcionar a investigacão para o conhecimento objeto arquitetônico propriamente dito, isento, de algum forma, de certo determinismo contextualista que domino parte do debate em torno dos valores singulares que a arquitetura deveria assumir em função do caráter do lugar como defendidos por Christian Norberg-Schulz

Ver MONTANER, 2001, pp. 40
Isn't life a series of images that change as they repeat themselves?

WARHO Repetir repetir - até ficar diferente. Repetir é um dom do estilo.

[...] o que foi a arte grega senão uma pura e contínua estandardização!

COSTA, in XAVIER, 198

ste subcapítulo trata do projeto elaborado para ser repetido, ou seja, aquele que é concebido considerando variabilidade de contextos, ainda que atenda a um programa de necessidades preciso, definido, e que deve ser implantado em um território amplo e diverso.

A origem ou a razão dos projetos padronizados é diversa. Em momentos distintos da história, por meio da repetição, a arquitetura foi chamada para demarcar o dominio territorial (Roma Imperial $)^{29}$ ou para atender a una

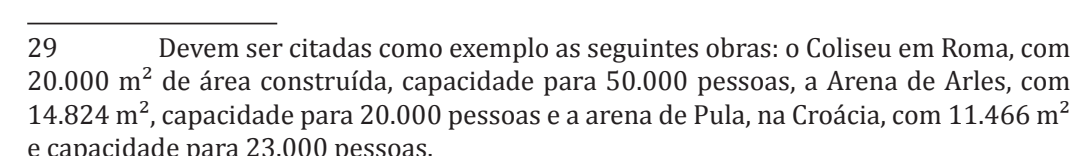

determinada urgência (pós Segunda Grande Guerra) ou, ainda, para responder ao processo de industrialização dos meios de produçãa $0^{30}$. Outro exemplo notável desse procedimento foram as prefeituras implantadas na Inglaterra na segunda metade do século XIX que associavam o serviço segunda metade do século XIX que associavam o serviço
público administrativo, legislativo e judiciário à vida cultural da comunidade, configurando uma nova nova ordem social no interior de um complexo equipamento cívico ${ }^{31}$

Na realidade, a repetič̃o do projeto esteve presente na historiografia da arquitetura como um dos dispositivos para a sistematização da disciplina, da definição das ordens clássicas aos protótipos modernos, passando pelos tratados renascentistas.

A reflexão de Lúcio Costa, supra citada, traduz a visão da arquitetura como a formulação e a repetição de padrões e modelos, numa tentativa de associar, naquele momento histórico, uma tradição disciplinar à ruptura estética representada pelos preceitos da modernidade.

Nesse sentido, Costa não estaria se distanciando de uma metodologia de constituição de um repertório capaz de guiar os camingo

\begin{tabular}{ll}
\hline 30 & Ver BRUNA, 1978.2 \\
31 & Ver PlETRARRIA, 2014.
\end{tabular} 
Migliaccio (2010) lembra-nos que o esforço empreendido por Rafael para descrever com desenhos a Roma antiga decorrera do entendimento da expressão visual como fundamentação da teoria. A compreensão dos princípios e dos procedimentos constituiria um repertório metodológico e não formal, completa $o$ autor.

Dessa forma, a repetição seria a característica primordial do projeto e estaria a serviço muito mais de uma retomada ou de uma nova apropriação do tema do que do eterno retorno do mesmo (FINGERMANN, 2014: 36).

A repetição na arte é uma estratégia de criação. Se tomarmos o teatro, vemos que ele éo lugar em que a criação dá através da repetição: a cada sessão, o espetáculo é recriado muito mais do que simplesmente reapresentado. É o momento em que algo que existia no passado existe novamente, afirma Peter Brook (2015), que in

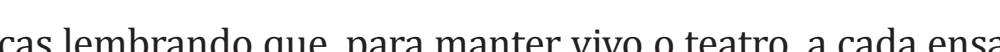
é preciso arriscar-se nas descobertas do dia anterior.

Brook é um pensador teatral que considera um te tro vivo aquele que coloca à prova diariamente novos safios, ainda que sua repetição esteja sempre baseada no texto original, ou seja, em uma ordem sobre a qual o espetaculo deve exercer 26). Nesse tar, re-novar e (re)-(i)novar. detalhadamente descrita em cada partitura. Ela só existe como obra de arte no momento em que é executada, ou seja, quando é repetida a cada concerto. Como na arquitetura antes de existir, a obra musical é totalmente escrita. Reserva, entretanto, determinada variação, fruto do desempenho dos músicos envolvidos e das condições do ambiente em que é executada.

0 jazz ultrapassa esses limites. Osstandards são obras como fundamento a repetição de suas estrut ras como forma de ampliaç̃o do compo criativo dos músicos no momento de sua execução, abrindo amplo caminho para o improviso. Seu valor estaria representado pela capacidade de transmissão de seus conteúdos a cada repetição. esse respeito, vale trazer para a discussão uma afirmação de Gilles Deleuze e algumas análises de sua obra feitas por Luiz Orlandi:

A repetição nada muda no objeto que se repete pespara (Droblema (DELEUZE 1968: 96) 32

mudança só pode ser ligada à repetição, não po A bjetos, mas por efeto da produc̃o parodo

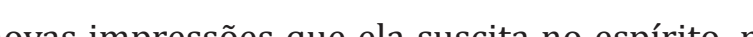

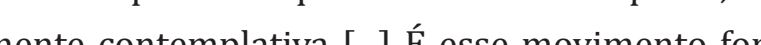
ado pela "diferenç" de impressões "no" espirito pascos Jic Que está acontecendo em minha mente, quando contemplo repetič̃es e sinto uma variaç̃o de

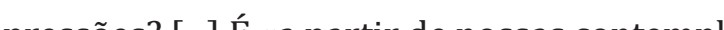
ches, diz Deleuze, «que se defr entrelaçamentos, os presentes e as fadigas que nos compõem». E em vez de submeter a contemplação ao negativo da atividade, Deleuze lembra Wue «contemplar é questionar». (ORLANDL, in FINGERMANN, 2014: 99-101)

Como observamos na introdução da presente pesquisa, a repetição de obras qualificadas como standards (PORTAS, 1965) foi capaz de introduzir conceitos urbanos antes mesmo que fossem totalmente elaborados, caso das Unités d'Habitation que Le Corbusier implantou em contextos europeus diversos.

No momento da concepção, a indefinição do contexto era desejada. Le Corbusier imprime nas Unités d'Habitation a síntese das propostas por ele elaboradas. 0 objetivo estava em demonstrar a capacidade transformadora du a quitetura - o projeto modificando o contexto ou, em outras palavras, o projeto construindo um lugar que não existia. 
Repetir, elaborar novamente João Gilberto é o músico solitário e meticulos que trata a bossa nova com integridade, com música autêntica. [...] Com ele, a arte é ascendid à exatidão, é a regra e a exigência de perfeiçãa do sentido auditivo mais educativo e privilegiad. que repete o mesmo para corrigir e sentir pra zer com julgar e reconhecer a pureza melód. [...] Aceitara a importância da obra desses artistas [como João Gilberto] é admitiri que a repetição uma concepção artística não implica tédio, ou trvialidade, que a arteé sempre diferente, mesmo partir do principio comum, que sua repetiçăo, $c$ letiva ou indindual, deschcadera um processo cundopana constraco da idade que se ressente quando há farta de ing construcộs.

ESPALLARGAS, 2016
A repetição rigorosa da música e das apresentações de João Gilberto, acima assinalada por Luiz Espallargas, traz para a obra não somente a certeza de certeza de sobrevivência za sua busca pela exatidão e pela construç̃o de uma identidade.

Dentro da produção arquitetônica brasileira recente, a padronização e o padrão têm sido utilizados de manera significativa. Podemos citar exemplos conhecidos como o Plano de Ação do Governo Carvalho Pinto $(1959 / 1963)^{33 .}$ que implantou equipamentos públicos, como os Fóruns, nas cidades do estado de São Paulo e cujo projeto foi repetido de maneira exaustiva

Outro exemplo notável foi a construção de mais quinhentos Centros Integrados de Educação Pública (CIEP) no estado do Rio de Janiro na década de 1980, ač̃o condenada pelo sociólogo Darcy Ribeiro, tendo seu modelo pré-fabricado projetado pelos arquitetos Oscar Niemeyer e por João Filgueiras Lima, responsável pela fabricação do componentes. Esse último faria trabalho relevante, até seu

33 Ver CAMARG0, 2016 HADLCH. 2009 recente desaparecimento, com o enfoque na repetição do modelo, baseada na padronização dos componentes do sistema construtivo Bs ca capaz de atender demandas diversas por equipamentos sociais em distintas regiões do país, levando a ideia de reprodução do detalhe a seu ápice.

Trabalho semelhante iniciado na década de 1970 pelo arquiteto João Honório de Melo Filho como coorden dor de projeto da CONESP34 hoje FDE ${ }^{35}$, estabeleceu a pador de proje da droñăa em diversos níveis da produção da obra. Tendo como referência a obra marcante de Richard Neutra, como mostraremos no capítulo 2, o trabalho iniciado por João Honório e equipe vem sendo aprimorado ao longo de quatro décadas. Não é mais a repetição do modelo de partido arquitetônico mas sim o padrão dos ambientes, dos componentes, dos detal ponde às necessidades de racionalização do projeto, de sua construção e manutenção. Experiências recentes ilustram a pertinência do

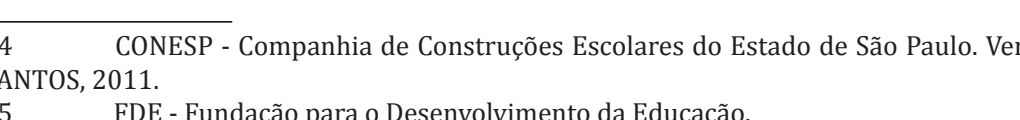

tema: na cidade de São Paulo temos os Centros de Educação Unificada (CEU), que surgiram para responder às carências de equipamentos, mais especialmente no que se refere educaç̃o, e que são fundamentais para nossa pesquisa dad sua continuidade por mais de uma década e meia (2000 2018) e sua abrangência (mais de 50 unidades implantadas ou em construção, totalizando quase 1.000 .000 m²), como veremos a seguir.

Outro exemplo que podemos citar é o projeto de Unidades Territoriaii ${ }^{36}$, desenvolvido para a Secretaria de Segurança Pública do Estado de São Paulo, dentro do programa de reengenharia e de modernização da Polícia Civil nas cidades paulistas e que instituiu o padrão para todas as unidades a serem construídas no estado.

Como se pode notar, a extensão de experiências recentes relativas ao tema e o envolvimento de importantes arquitetos à frente dessas realizações levam-nos a investigar os exemplos que consideramos mais relevantes.

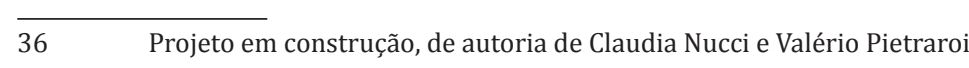


Os centros esportivos e de lazer - como as cas do povo e os clubes opeŕ́rios se multiplicam mas as edificações destinadas ao ensino eram as mats características. Correntes pedagógicas progressistas aliaram-se à experimentacão arquitetônca para produzir um novo tipo de prédio escolr bem iluminado, com espaços abertos e prontos para acolher novas atividades. [ $] 0$ resultado fo algo novo na estrutura urbana - o bairro equipado com edificacōes necessárias à vida comunit COHEN, 2013

Na passagem acima, Jean-Louis Cohen fala das mudanças urbanas decorrentes da valorização da arquitetura como equipamento de transformação social. 0 trecho é extrá́do do capítulo A Arquitetura da Reforma Social - Equi pando as Periferias, de sua obra $O$ Futuro da Arquitetura desde 1889. Nele, Cohen aborda as transformaç̃oes ocorr- das no período entre as duas grandes guerras, em especia nas cidades europeias. Do ponto de vista do projeto, podemos afirmar que se trata de um momento fundamental para introdução do conceito de equipamento público e para avaliação da arquitetura enquanto equipamento de transformação social.

A noção de equipamento público é introduzida com maior significado no período descrito por Cohen. Baseando-se na lógica funcional dos "condensadores sociais" vanguarda soviética ${ }^{37}$, mesmo aos programas estabele dos, como os educacionais, deveria ser atribuída a missão de promover as novas práticas sociais que pudessem rom per com o modo tradicional de relacionamento dos individuos ao mesmo tempo em que intensificariam sua integracão. 0 ordenamento espacial do meio ambiente constrú́ teria virtudes pedagógicas capazes de promover as tran formações sociais em curso, como assinalado por Anatole Kopp (1990:17). Porém, Kopp adverte

$37 \quad$ Sobre "condensadores sociais", ver KopP, 1990: $74-11$.11

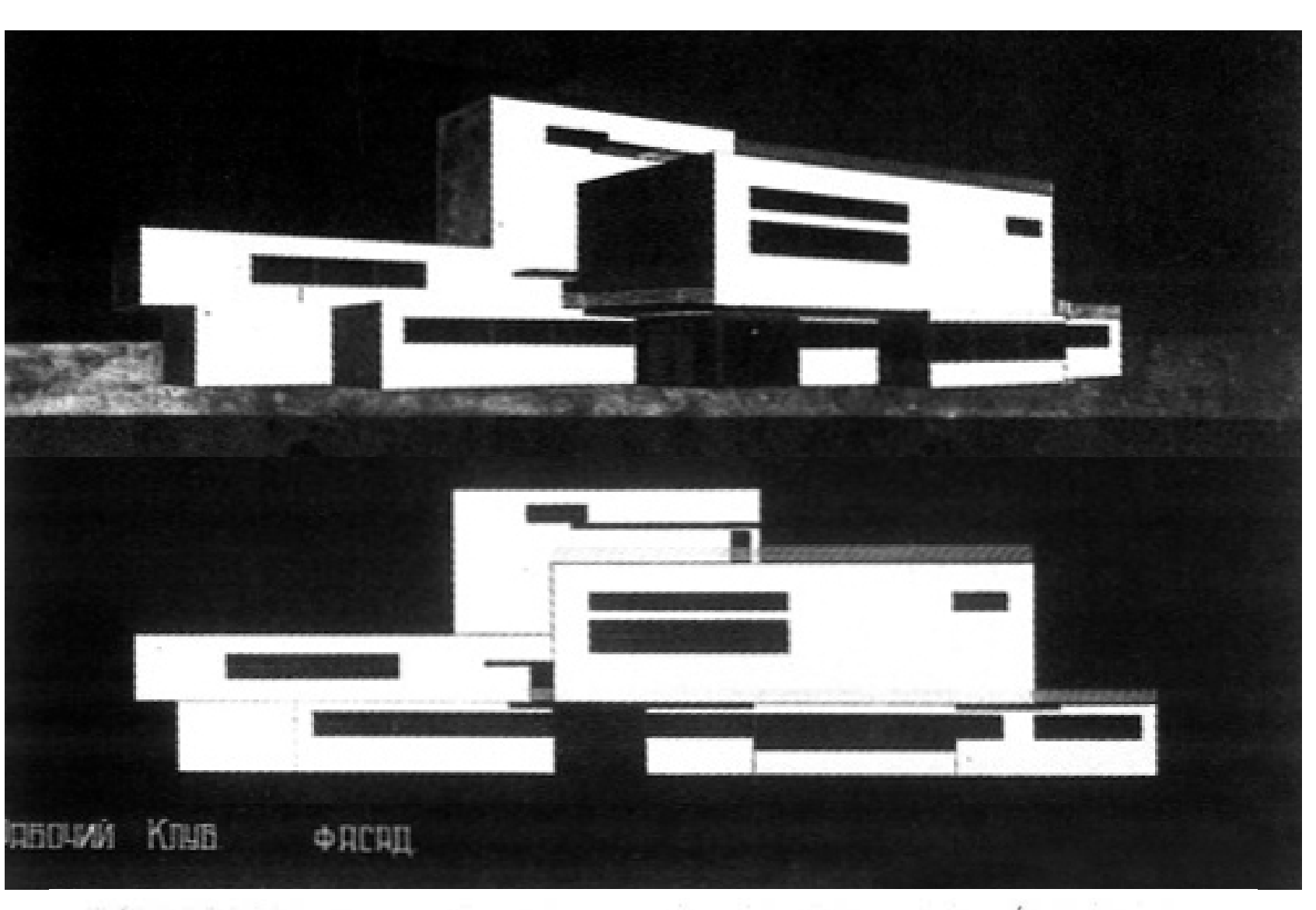

ПЛ国 2 ต苗.

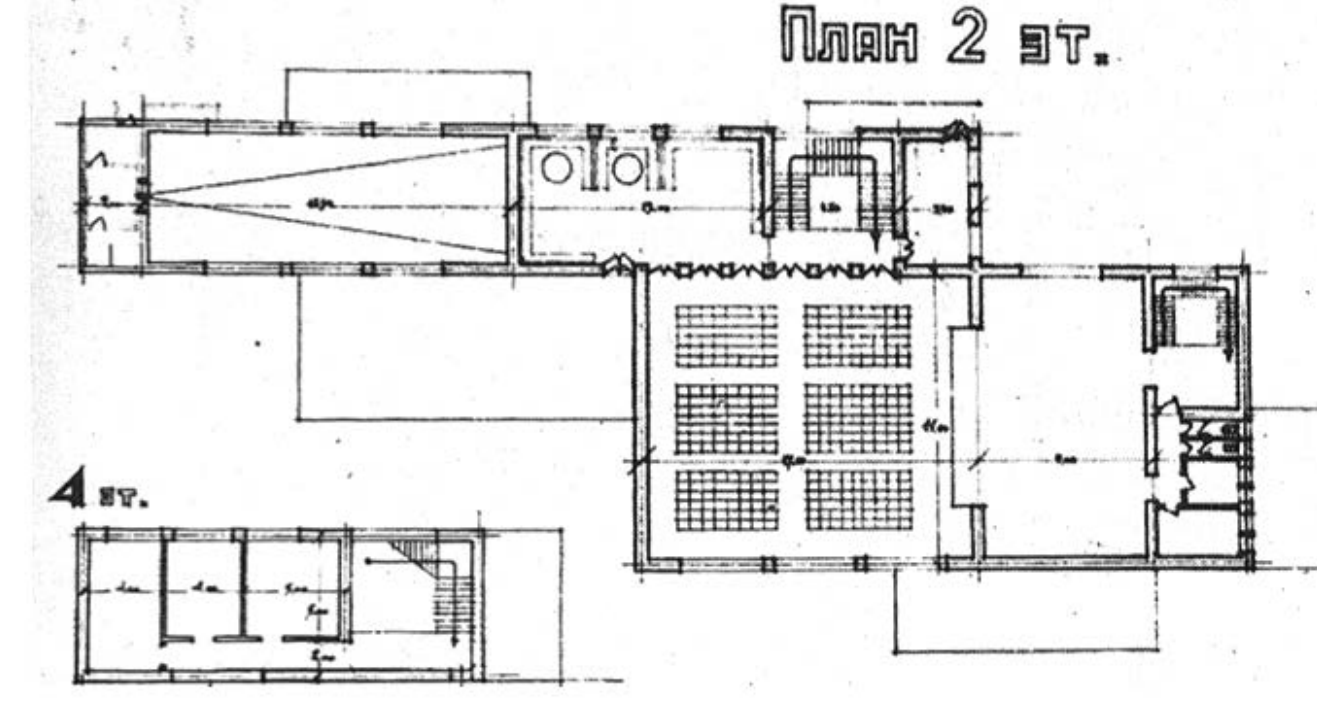


Sempre em busca dos "condensadores sociais" da nova vida, ficou claro que não se tratava de realizá-los um a um, edifício por edifício; todo o a biente humano e que deveria constituir um único "condensador social" ${ }^{38}$

Assim, de certo modo, é também introduzida a no ção de rede de equipamentos de promoção social coletiva integrada ao meio ambiente construído e exercendo certo protagonismo. A urgência na construção ou na reconstrução do ambiente social urbano ocorre pelo advento da Revolução Russa de 1917 e ante aos escombros da Primeira Grande Guerra, como na Alemanha sufocada pelo Tratado de Versalhes ${ }^{39}$. Se por um lado a construção soviética por um nova sociedade fez surgir a arquitetura de novos programas de promočão da coletividade, como o clube do trabahador projeto de Lazar Khidekel mostrado acima, ou as casas do povo, mencionadas por Kopp, por outro lado, o quadro de re construção de parte substancial da Europa, em especial na Alemanha, colocou o arquiteto no papel de construtor de un novo ambiente, não constituído de monumentos ou de obras

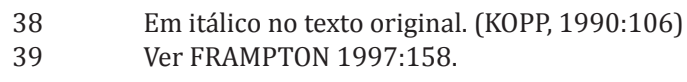

singulares, mas sim de um agrupamento em que a habitação esta envolvida por uma série de equipamentos sociais

Devemos destacar a socialdemocracia alemã - a República de Weimar - do período entre as duas grandes guerras como fundamental para o entendimento dessa experiência. Para Cohen (2013:185), graças à convergência de profissionais em torno do grupo liderado por Ernst May, então responsável pelos programas habita "rankfurt, foi possivel se obter o "ambiente total" em que a paisagem assume parte do programa político-social através da integração das habitações aos equipamentos e ao espaços coletivos. 0 resultado obtido pela equipe de May, entre 1925 e 1930, impressiona e é decorrente da objetivdade com que o projeto foi tratado, alinhando economia e eficiência, completa Frampton (1997:166) ${ }^{4}$

Dessa forma, a Neues Bauen, como foi chamada na Alemanha, demonstrou a capacidade da arquitetura mo-

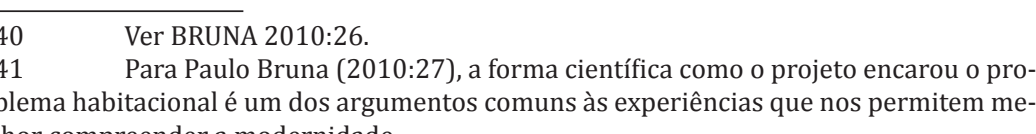

derna de enfrentar os novos desafios decorrentes do processo de industrialização do século XIX. A citada evolução na atuação do Kopp como responsável pelo estabelecimento da Nova Arquitetura, pois como "os problemas do ordenamento espacial $^{42}$ estavam na ordem do dia, a arquitetura, no sentido estrito do termo, estava superada" (1990:106, destaque da edição brasileira). Ou seja, a Nova Arquitetura seria um nova maneira de atuação dos arquitetos perante as novas demandas da sociedade moderna aproximando-os do Sachlichkeit ou Nova Objetividade, como considera ton (1997:157). Para a "nova construção", numa tradução livre, seria necessária uma nova maneira de projetar ou, en outras palavras, seria necessário conceber o projeto como Associado a esse fato, o Neues Baeun não teria obtido o resultado que ainda hoje impressiona sem uma «nova política

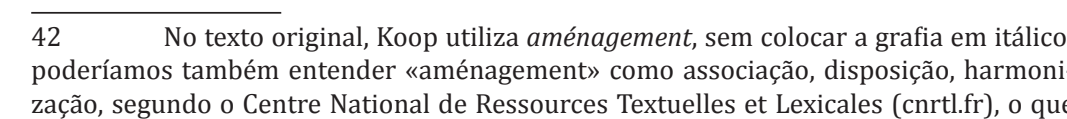

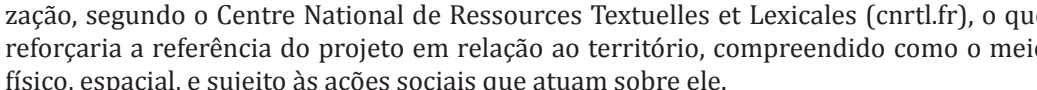

de construção», como prefere traduzir Cohen (2013:191) em que o Estado planeja em larga escala os vastos programas sociais que a sociedade reclama (BRUNA, 2010:88).

Entretanto, apesar dos arquitetos do Neues Baue terem construído milhares de habitaçoes que constituíam esses Siedlungen, ou conjuntos dotados dos equipamento culturais e sociais necessários, a quantidade não seria tudo adverte Kopp, para quem

-.] os arquitetos alemães do “Neues Bauen"33 e os - os arquitetos alemães do "Neues Bauen"33 e os jeto arquitetônico num projeto de sociedau. nesses casos, o projeto não era de sua alcada. Ele emanava de organismos políticos e sindicis, do poder, ele prolongava lutas históricas em favor da mudança, da qual os arquitetos eram an favor

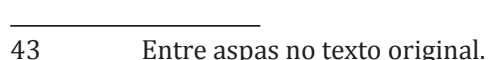




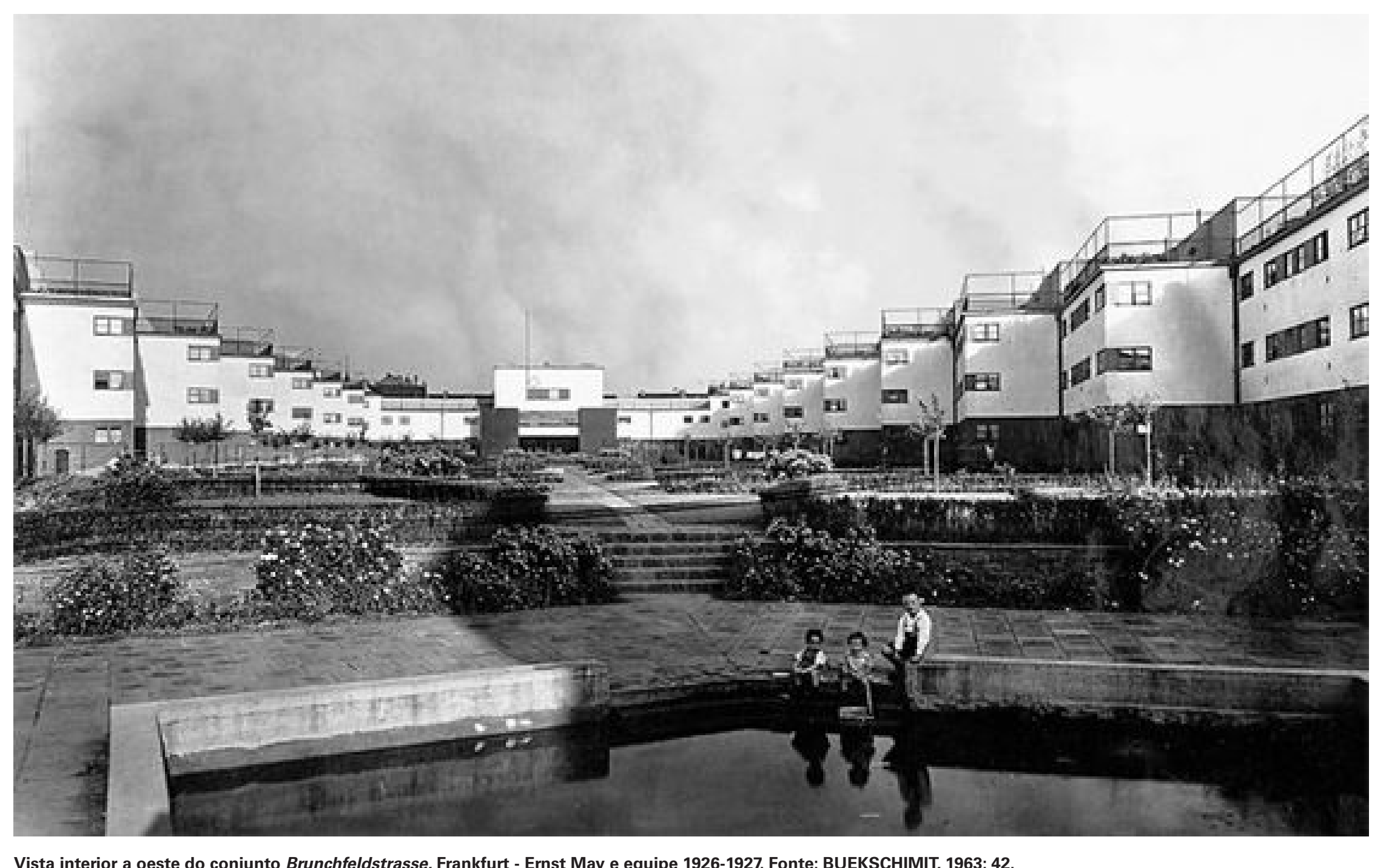
cerca de dois hectares em que a dimensão maior com 210 metros, paralela ao rio Main na direção leste-oeste, prevalece na organização do espaço coletivo no interior do pátio formado. Na extremidade oeste, o acesso é feito por um portal singelo, como pode ser visto na imagem anterior. eixo de simetria, em seguida, estrutura os canteiros semi-públicos usados como jardins e como pequenas hortas, cujo desenho obedece à mesma ordem de orientacão das beresponde à reprodução da parcela de terreno ocupada pela massa construída ou, em outras palavras, o paisagismo interno é a reprodução em negativo da

alas de habitaça tégia, o projeto demonstra de maneira definitiva a importância com que o equipamento público foi tratado.

A edificação do Centro Comunitário é composta por um volume principal retangular com três pavimentos, alisimetria, situação única no conjunto. Sua articulação em re-

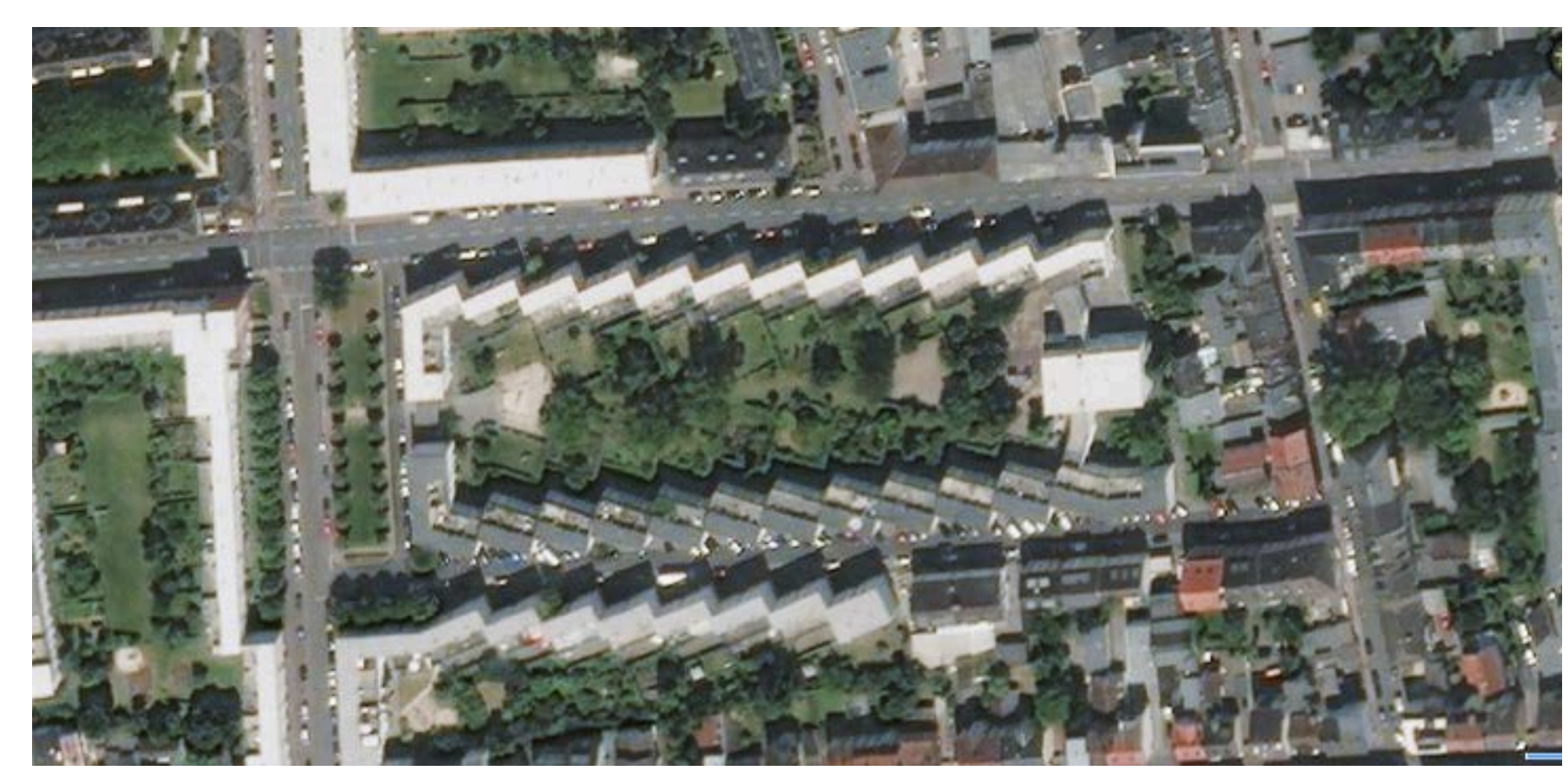


beneficiam as habitações. Todos esses atributos

contribuem para destacar a edificação em relação

ao conjunto. Em certa medida, o resultado tem

sua monumentalidade amparada pela implanta-

ção que se aproxima de uma disposição clássica.

No entanto, o maior interesse na obra se

refere à simultaneidade de usos em sua estrutu-

ra interna, como pode ser observado a seguir. No

pavimento térreo há três acessos independentes.

0 central atende ao jardim da infância, distribuí-

do no volume retangular e nas duas alas de ar-

ticulação com as habitações. Assim, as salas de

tividades e de convivência das criancas são vol-

tadas para dois pátios internos descobertos, be-

neficiando-se da parcela mais protegida do terre-

no. 0 canto norte do volume retangular abriga $o$ acesso ao primeiro pavimento em que estão localizados um posto de saúde e uma sala de leitura.

No canto oposto, ao sul do volume, $\mathrm{o}$ acesso aten-

de segundo pavineth

zada e cujas atividades são ampliadas em direção

aos terraços que fazem a transição com as duas

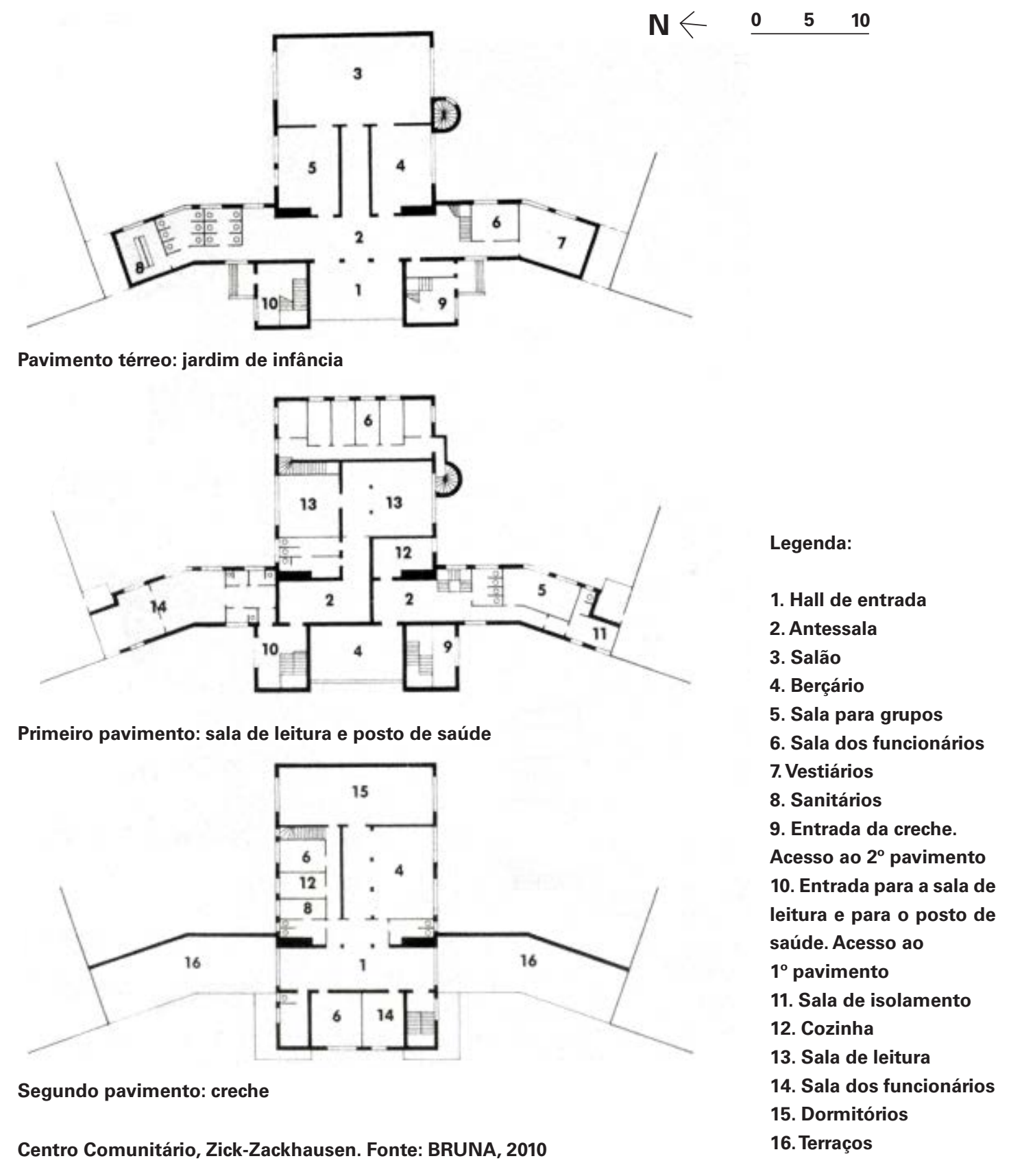

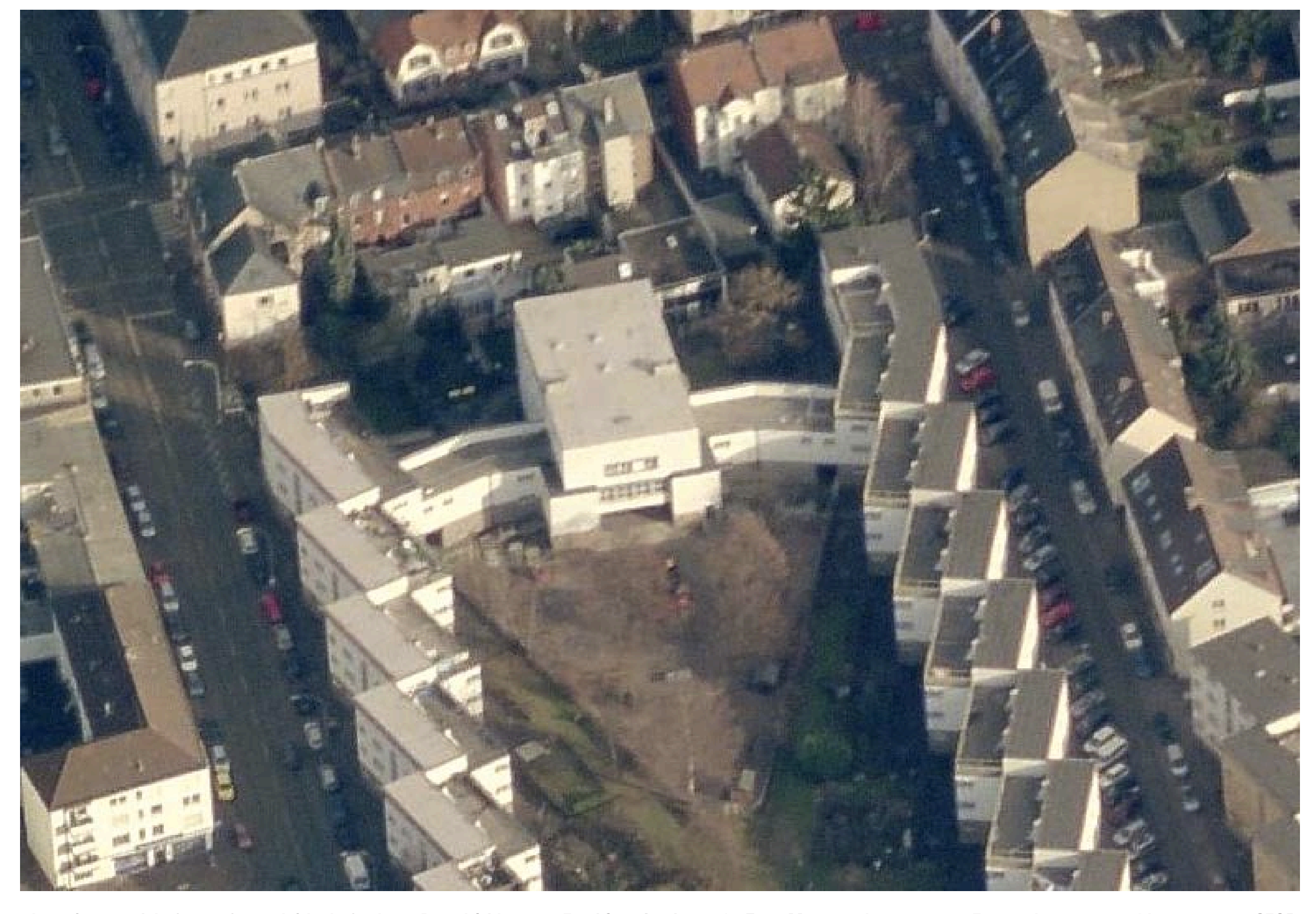

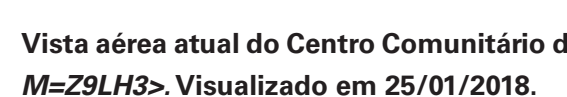


alas habitacionais

Se, por um lado, o projeto do Centro Comunitário se apresenta de uma maneira tradicional e previsível do ponto de vista de sua presença em relação ao conjunto urban formado em Brunchfeldstrasse, sua organização interna, baseada na simultaneidade de usos, e seus espaços de articulação com as alas habitacionais o transformam no artefato principal do projeto de May e equipe.

É certo que, como vimos, as preocupações com a racionalidade extre

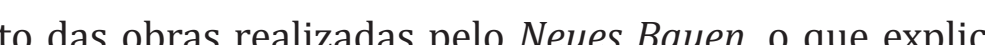
simple simplicidade no tratamento volumétrico das edificações e de seus espaços internos. Isso não representa, no entanto, a ausência do projeto na determinação dos seus elementos construtivos primordinis, capazes de enfrentar a nova condição urbana que se apresentava, ao alterar as relações entre o ambiente construído e o ambiente natural. Suas especificidades abrem caminho para diferentes situações tanto no nível do solo como de sua cobertura, por exemplo. A diversidade programática, ainda que apoiada na escala interna do bairro, é a prova de que o projeto não se limita mais aos aspectos subjetivos, pois sua expressão está fumtos do Neues Bauen (KOPP 1990.50). Em outras palavras, a arquitetura proposta é suficientemente consistente para suportar demandas geradas pelas pesquisas e diagnósticos realizados para apoiar sua concepção, o que não limitou sua natureza inovadora, como pode ser observado nas imagens da época de sua inauguração. do desenvolvimento dos capítulos que apresentam os três subtemas aqui mencionados e que buscam avaliar em que medida a independência do projeto em relação ao programa, ao contexto e ao tempo contribuiria para a sobrevivên-

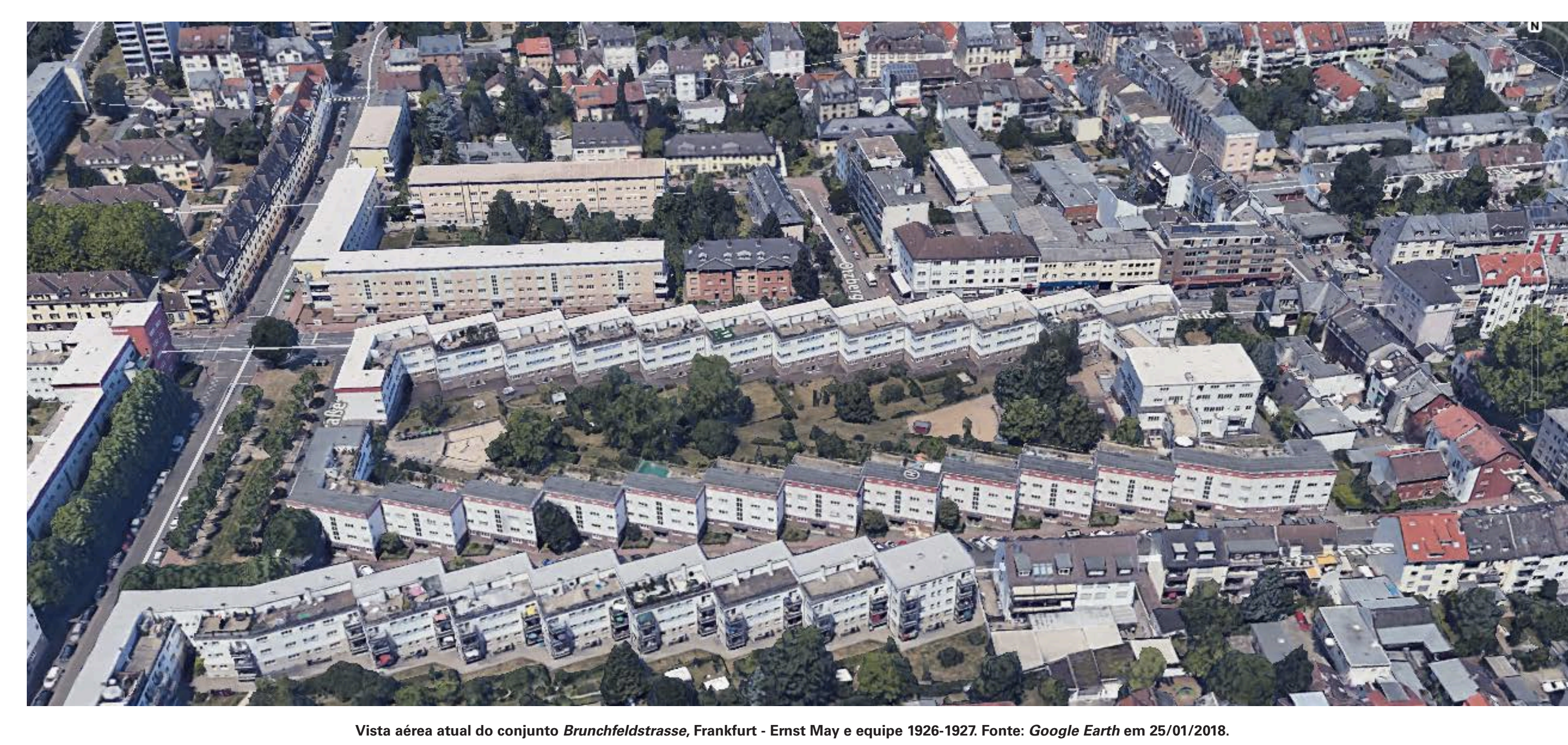


Encontramos nas observações desenvolvidas até aqui, a origem de parte significativa das preocupações que motivaram experiências recentes no Brasil, sobretudo nas grandes cidades. Nessa situação, o projeto de um equipa-

independência do projeto Em nenhum outro lugar do mundo, o positivismo

de Auguste Comte foi levado mais a sério do que no Brasil. [...] Com Auguste Comte e Le Corbusier como padrinhos, a arquitetura nunca foi, no Brasil, uma ciência oculta e especulativa. Ela permanece [...] uma disciplina consciente das questões sociais e atenta ao meio ambiente, um saber prático promovido por uma inteligência otimista e generosa. ${ }^{45}$

O contexto e a mento público de grande porte, capaz de enfrentar os desequilíbrios do vasto território da metrópole, surge como solução duradoura, como nas experiências dos CIEP (Centros Integrados de Educacão Pública - 1983 a 1987 e 1991 a 1995) no Rio de Janeiro e dos CFU (Centro Unificado - 2002 a 2018) em São Paulo. A importância de tais iniciativas pode ser observada, por exemplo, na edição especial sobre o Brasil em 2004, da revista francesa L'Archi-

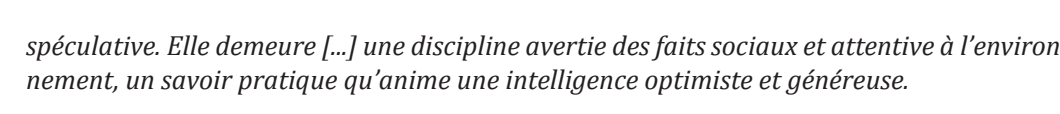


2.1

A escola revolucionária de Niemeyer: CIEP - Centro Integrado de Educação Pública Conceito do Arquiteto

Trata-se de um projeto arquitetônico revolucionário, sob o ponto de vista educacional. Escols que não visam apenas - como as antigas-instrur seus alunos mas, sim dar um apoio efetivo a todas as crianças do bairro. Eisto explica serem, no térreo, para elas abertas aos sábados e domingos: ginásio, gabinete médico, dentário, biblioteç, etc. Daí a dificuldade de utilizar as velhas escohs - vão sendo remodeladas - pois não foram projtadas para esse programa.

O amplo plano de implantaç̃ão do CIEP (Centro Integrados de Educação Pública的), que marcou o primeiro governo eleito no estado do Rio de Janeiro após a re democratização ocorrida no Brasil na década de 1980, é

mossa pesquisa um exemplo notável pelas caracteristicas do projeto desenvolvido e pela abrangência territorial que a Niemeyer ${ }^{4}$, rama arquitet pepsto, o que, segring ele, atesta o caráter revolucionário do projeto. Niemeyer justifica tal qualidade pelo fato de que a arquitetura proposta distancia-se das "velhas escolas" que não haviam sido projetadas para esse fim e nem possuíam possibilidades de mudanças adaptações. Na concepção de Niemeyer, a arquitetura do CIEP estaria a serviço do seu programa pedagógico inovador, ao abrir caminho para os benefícios do ensino em tempo integral e sua complementação com atividades esportivas e culturais. Nesse sentido, o projeto assume total independência em relaç̃o ao contexto em que deverá se inserir. Niemeyer encara a enorme carência educacional do estado do Rio de Janeiro naquele período como problema a

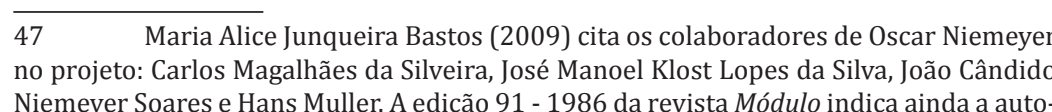

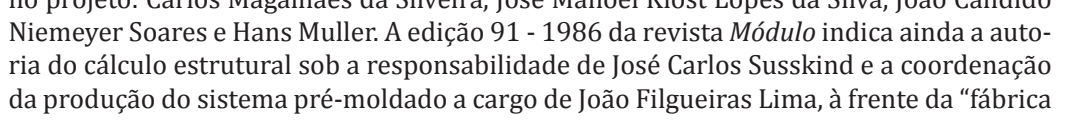

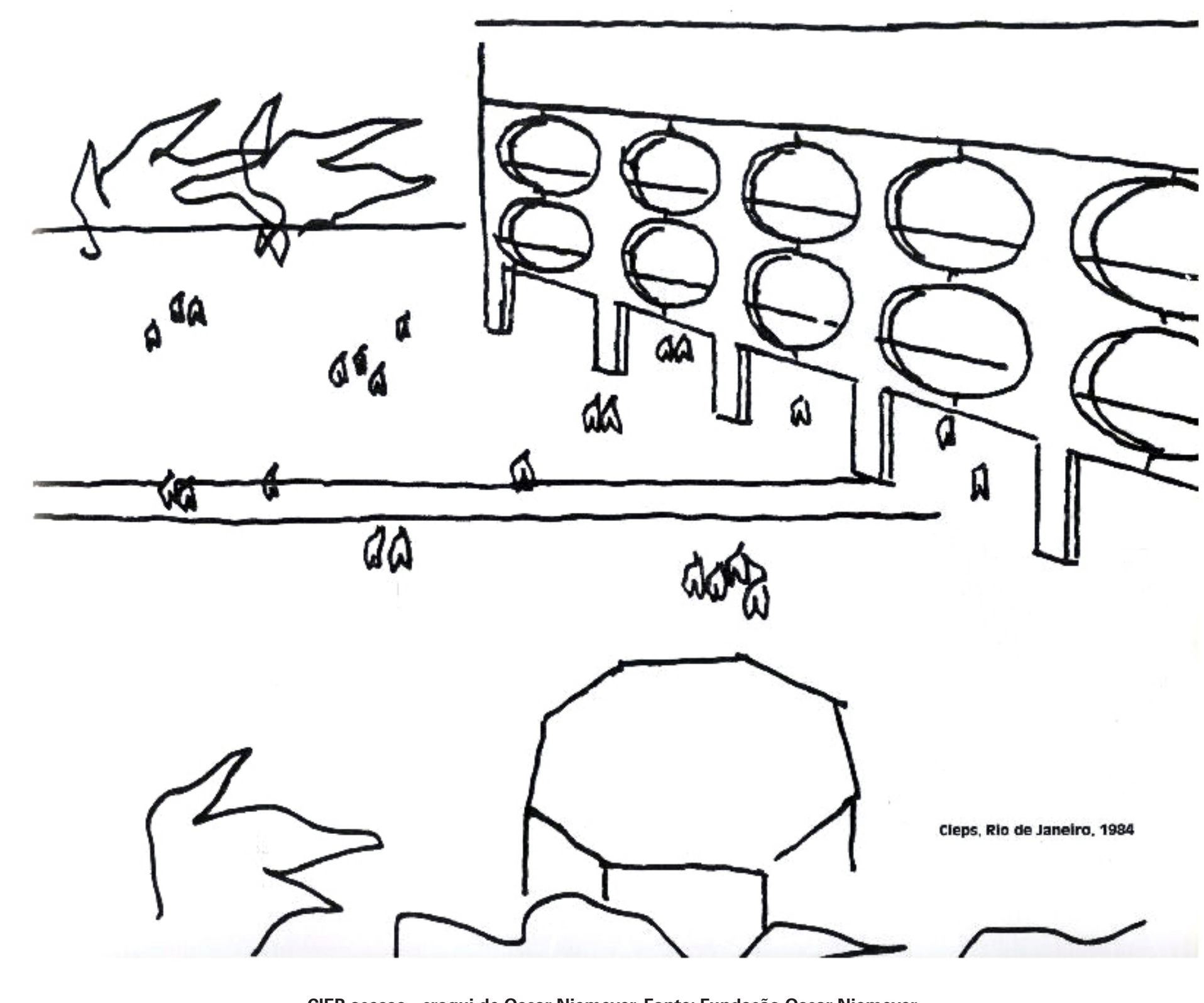

CIEP, acesso - croqui de Oscar Niemerter fo 
ser combatido pela eficiência funcional e pela capacidade de reproduç̃o do modelo arquitetônico por ele concebido. De acordo foram construídos $500 \mathrm{CIEP}$ nas duas gestões do governdor Leonel Brizola $a^{48}$, marca expressiva alcançada graças ao uso da solução estrutural em concreto pré-moldado, o que permitiu a execução dos seus $7.000 \mathrm{~m}^{2}$ de construção en apenas seis meses. Sobre esse importante aspecto, há diferenças entre as diversas afirmações recolhidas pela revista Módulo em sua edição 91, de 1986: para Niemeyer havia uma economia de $30 \%$ nos custos da obra e prazo de quatro meses de construção. Já Teresa Graupner indica a necessidade de oito meses para que um CIEP fosse construído. D qualquer forma, todos esses prazos podem ser consider dos reduzidos em relac̃o ao praticado historicamente pua esse tipo de obra no Brasil, o que seria confirmado por Bastos mais de dez anos depois.

Na extraordinária produção arquitetônica de Oscar Niemeyer, cuja vitalidade atravessou o século XX e persis-

48 1983-1987 e 1991-1995. tiu até a primeira década do século XXI, os CIEP podem ser inseridos dentro do grupo de obras marcantes cujo ápice fora a constur meyer reorganiza os procedimentos e as soluções dos proetos anteriores conforme princííios baseados na concisão e na simplicidade a partir da fusão entre forma e estrutura (QUEIROZ, in BRUNA, 2017 : 237). 0 CIEP, enquanto projeto, está mais próximo dos referidos princípios do que da riqueza compositiva da primeira metade do século $\mathrm{XX}$, que apresentou Niemeyer para o cenário internacional. 0 olhar atento do arquiteto em relação aos princípios fundamentais da arquitetura, imune aos questionamentos estéticos do período, pode ajudar-nos a entender a permanência de sua obra, como detalha Hugo Segawa:

Arquitetura moderna era sinônimo de racion lismo, funcionalismo. 0 mote "forma segue a funcão" foi o axioma do modernismo ortodoxo ao qual Niemeyer jamais foi afeito. Todavia nos anos de vigência da crítica pós-moderna, Niemeyer fo varrido como um "impenitente velho moderno" Se houve algo pertinert moderno foi a denúncia do funcionalismo ortodoxo. Um edifício que é concebido fielmente um programa, a uma função, e se cristaliza nesse arcabouço funcional, está condenado à obsolescência porquanto no mundo contemporâne velocidade das mudanças (das necessidades, das finalidades, dos propósitos, dos significados) tornam a arquitetura uma obra mutante, abe ta. 0 apego de Niemeyer a forma pareceu ser 0 alcanhar de Aquiles de sua arquitetura, razão maior da desconfiança sobre o jovem Niemeye. Mas a sua longevidade the assegurou a reparaçă da afronta. As funçōes desvanecem, os humores ambiam, mas a forma pernanece. O tenpo 1 gitimou multas a aty des do aryiteto bra os pós-modernos - mesmo sem querer - dera iis sentido à prédica e aos desenhos do mo no Niemeyer. (SEGAWA, apud BRUNA, 2017: 164)

Fica claro que a experiência dos CIEP é fundamenta para entender a repeticão do projeto por duas características iniciais, que merecem ser lembradas: primeiramente, por se um projeto de autoria de Oscar Niemeyer e, em seguida, pela escala de abrangência do programa, que permitiu implantar, a partir de um único projeto, mais de 500 equipamentos públicos de educacãa $0^{49} \mathrm{em}$ um prazo relativamente comparado a or a um extenso território do estado do Rio de Janeiro em sua diversas situações geográficas. Como veremos, é importante observar que o projeto se manteve sem alterações durante os doze anos de sua implantação, ainda que o programa pedagógico tenha sido questionado e revisto.

Por essas razões, entendemos que nossa pesquisa deva abordar a experiência dos CIEP por dois caminhos: em primeiro lugar, situar o projeto em relação à obra de Niemeyer. Em segundo lugar, entender os raciocínios de proje-

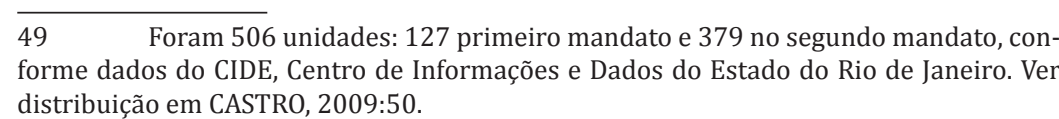


Vale lembrar que o CIEP é antes de mais nada uma escola. Ou seja, mesmo considerando que as qualidades formadoras do programa proposto por Darcy Ribeiro foram responsáveis pela significativa abrangência da experiência CIEP e, portanto, merecedoras de destaque, o que nos interessa entender é o que se refere ao projeto arquitetônico do CIEP enquanto modelo de escola concebido para ser repetido e para viabilizar um programa revolucionário, como petido e para viabilizar um programa revolucionário, como citado por Niemeyer em epígrafe. Em outras palavras, não se trata de desconsiderar a importância do programa pedagógico e social que norteou o CIEP como projeto, mas situá-lo dentro das experiências de implantação de rede de equipamentos públicos baseada na repetição do projeto padronizado transformado em modelo.

A extensa atuação profissional de Oscar Niemeyer apresenta diversas obras em que o tema da escola fora abordado de maneira exemplar e que devem ser objeto de interesse. Dessa forma, não seria prudente se debruçar so-

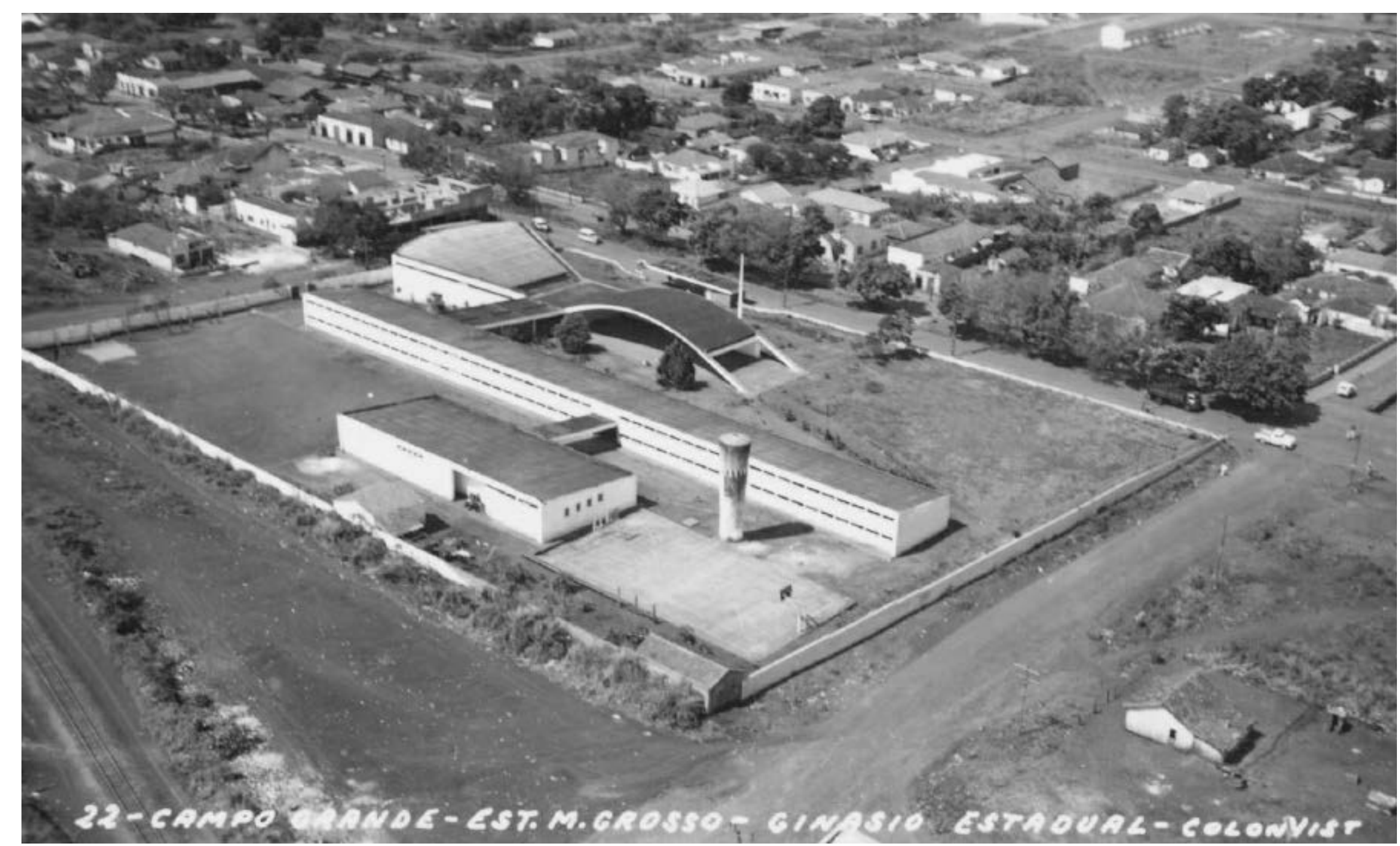

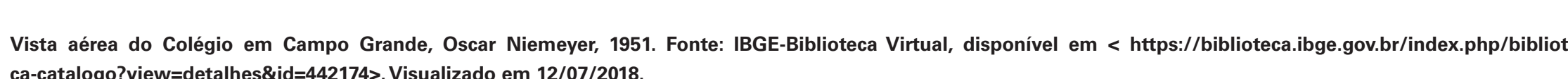

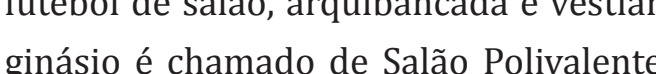
também é utilizado para apresentações teatrais, shows de música, festas etc. No terceiro bloco, de

[...] uma escola que funciona dis 8 tor abrigar 1.000 as da tarde, com capas 8 da três andares, estão as salas de aula, um centro médico, a cozinha e o refeitório, além das áreas de apoio e recreaçăa. No segundo blocc, ha og

O CIEP foi idealizado por Darcy Ribeiro, Secretário hador Leonel Brizola nas décadas de 1980 e de 1990. Seu mplo programa, que associava práticas esportivas edr rais ao ensino formal estabelecido, exigiu um equ pane que pudesse atender ao período escolar em tempo integral. 


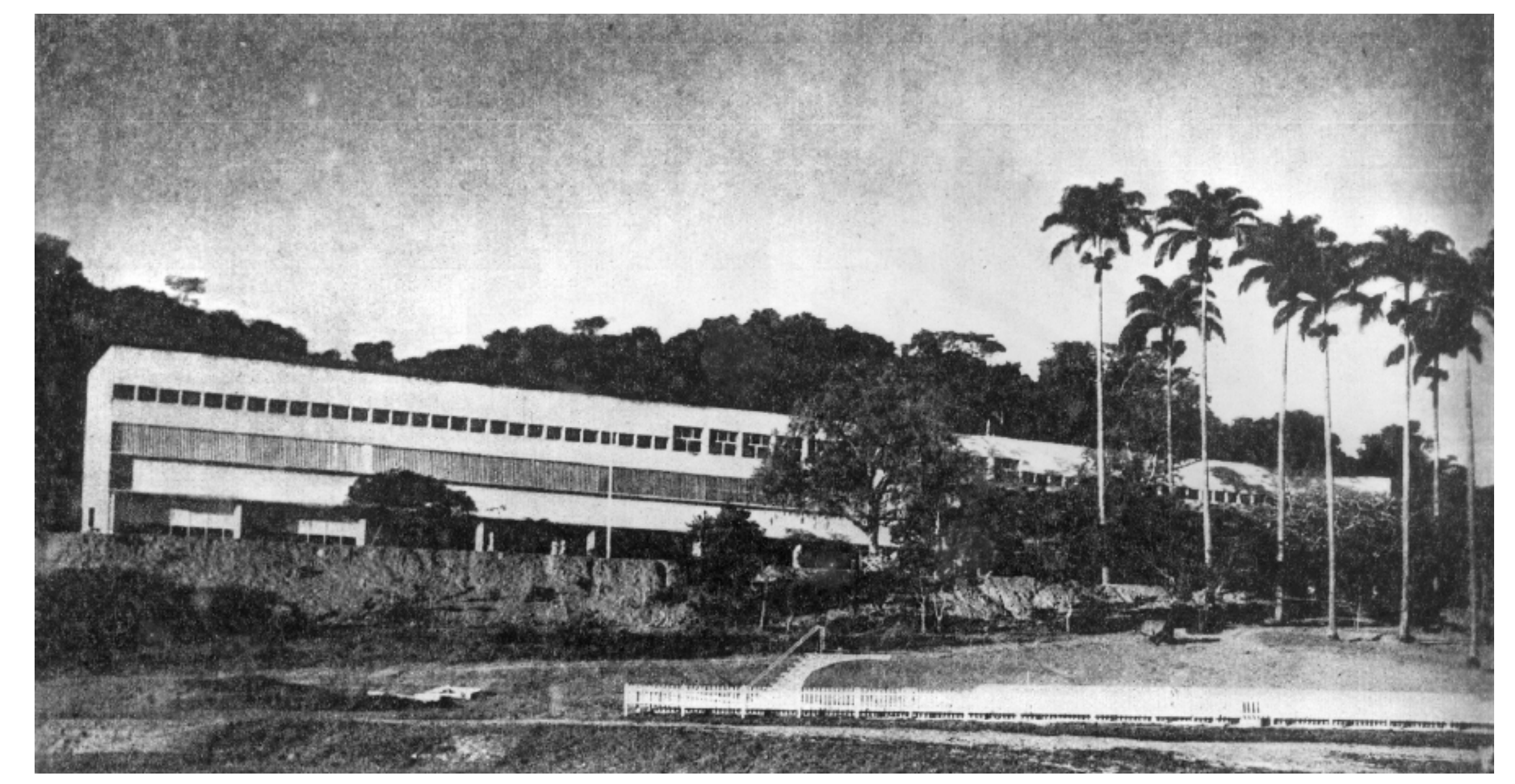
Colegio de Cataguases. Fonte: PAPADAKl, 1950 - cortesia Fundą̧âo Oscar Niemeyer.

bre o projeto do CIEP sem conhecer, através do projeto, a visão de Niemeyer.

Das obras escolares de Niemeyer podemos destacar aquelas projetadas até 1954 , período que se caracteriza primordialmente pelo exercício compositivo do vocabulá- rio criado por ele no projeto do Conjunto da Pampulhas" Nesse grupo de escolas mencionamos cronologicamente Colégio de Cataguazes 51 $^{1}$ 1943-1946) a Escola Júlia Kubitschek em Diamantina (1951), os Colégios Estaduais de Co-

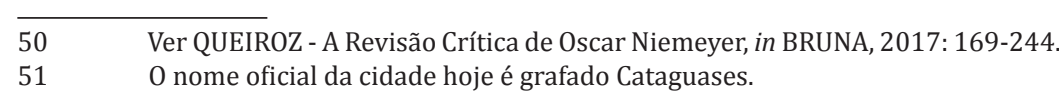

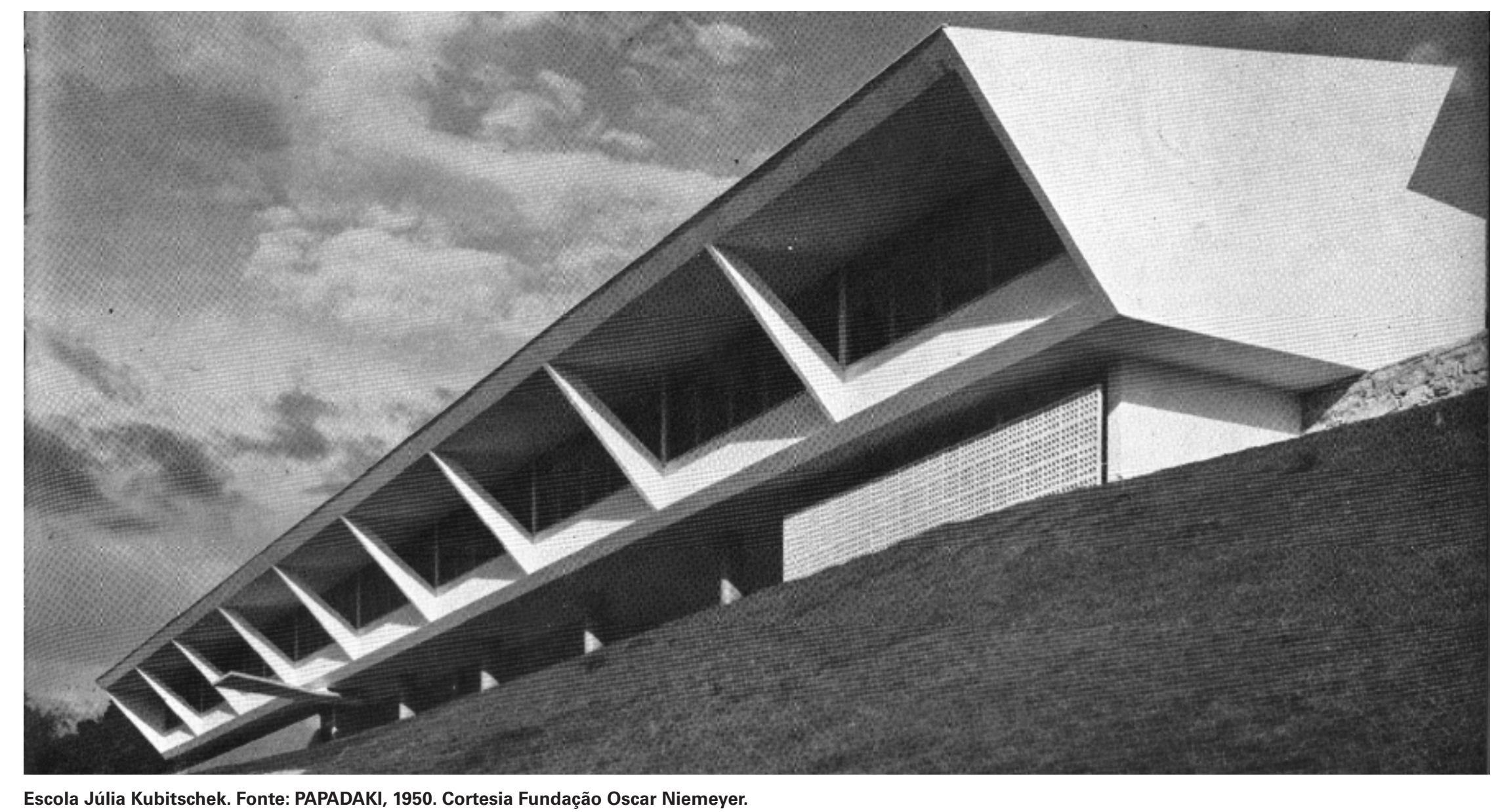

rumbá e de Campo Grande (1952) e, finalmente, o Colégio Estadual Central Milton Campos em Belo Horizonte (1954) Os dois primeiros projetos são o resultado da compreensão do relevo acidentado, típico das Minas Gerais, em

que o projeto é resolvido em corte transversal, ou seja, o longo prisma retangular definido pelo arquiteto é implantado paralelamente às curvas de nível, em um platô criado pela movimentaço do terreno cuidalosamente trabalh 

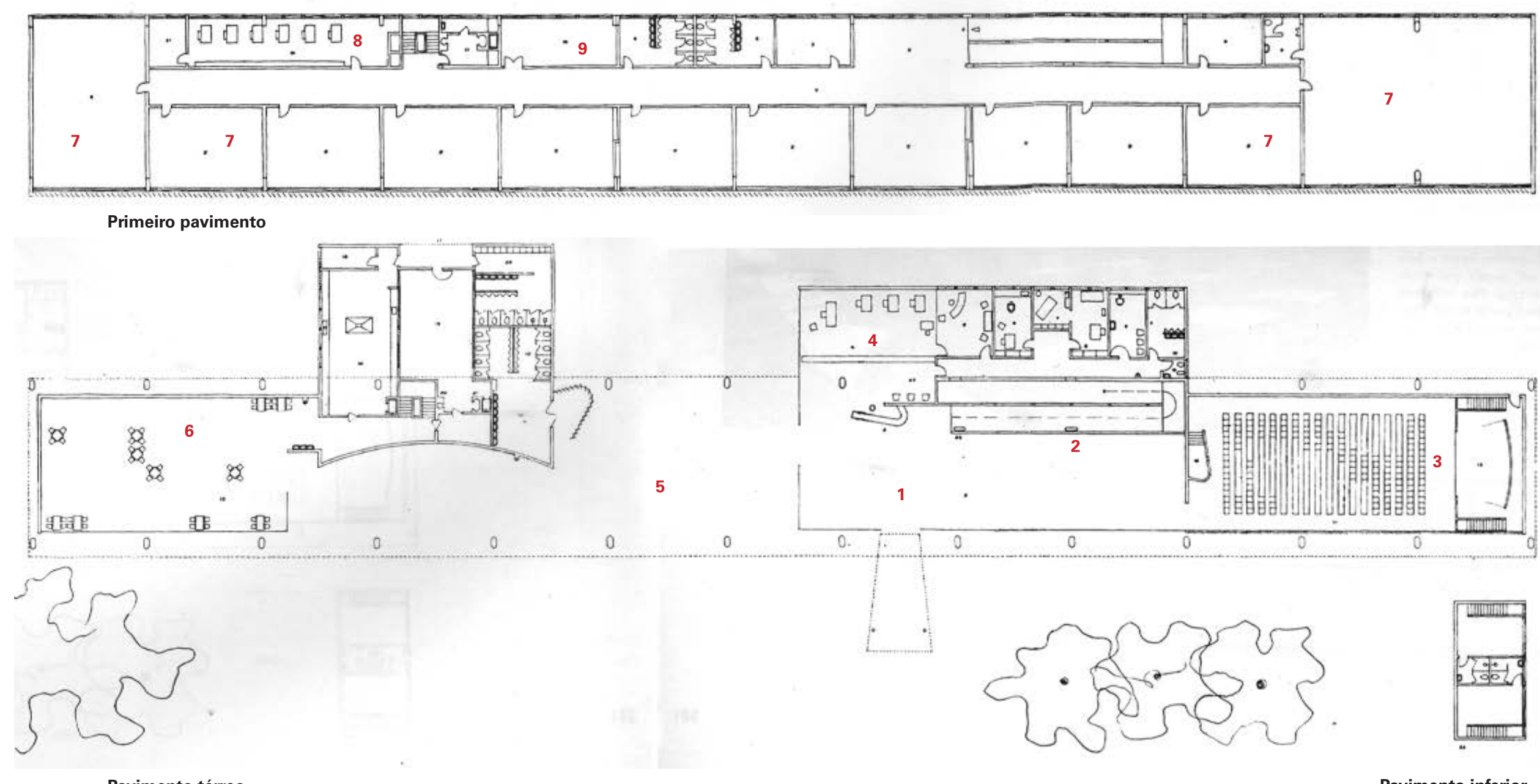

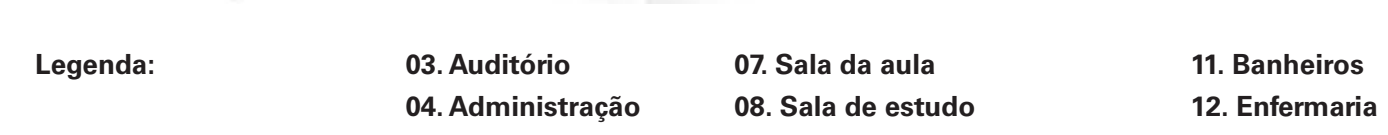

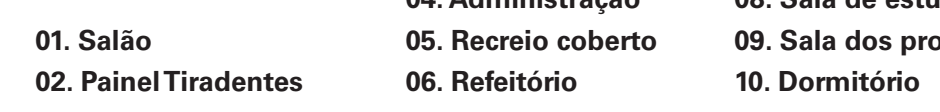
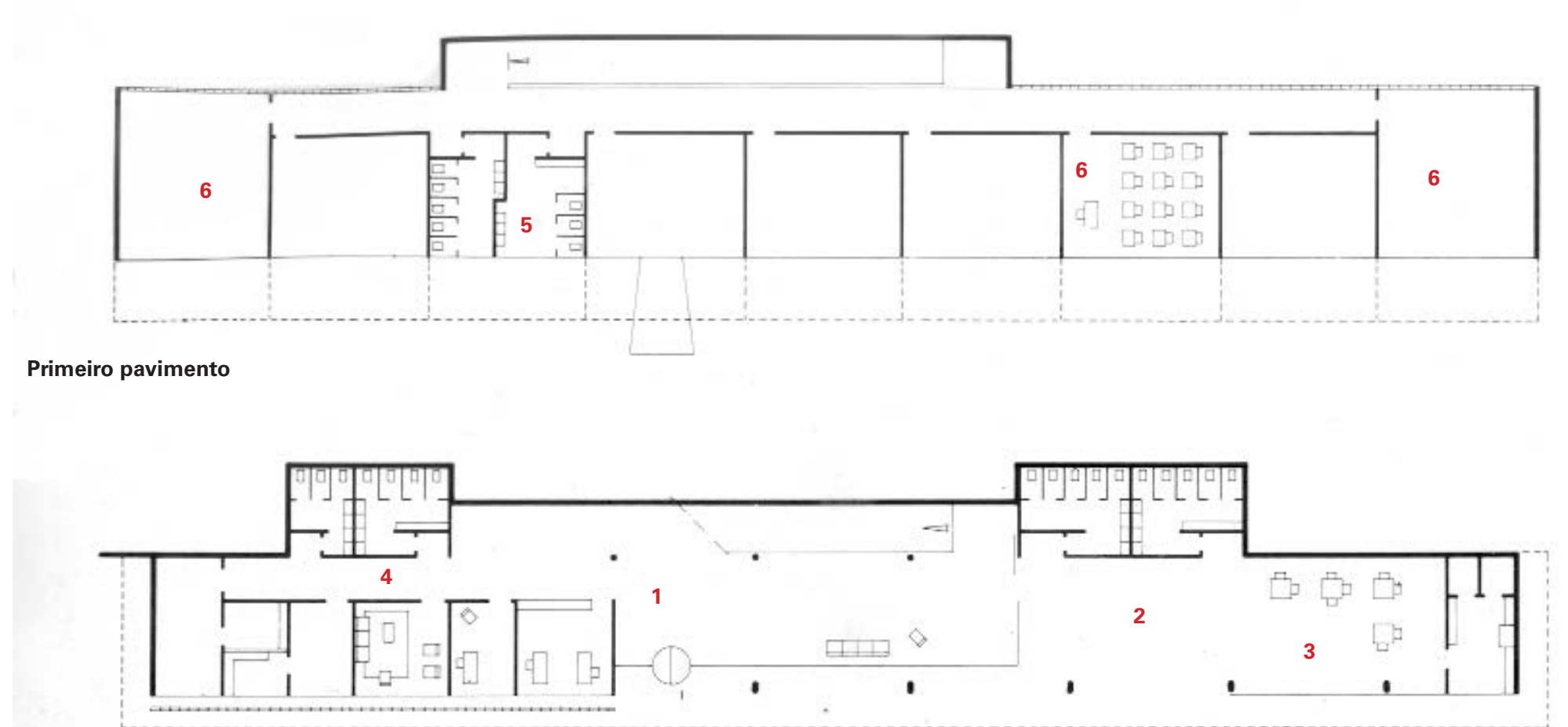

Legenda:
01. Saläo
02. Recreio coberto

03. Refeitório
04.Administraça

04.Administraçăa
05. Sanitários
06. Sala de aula 


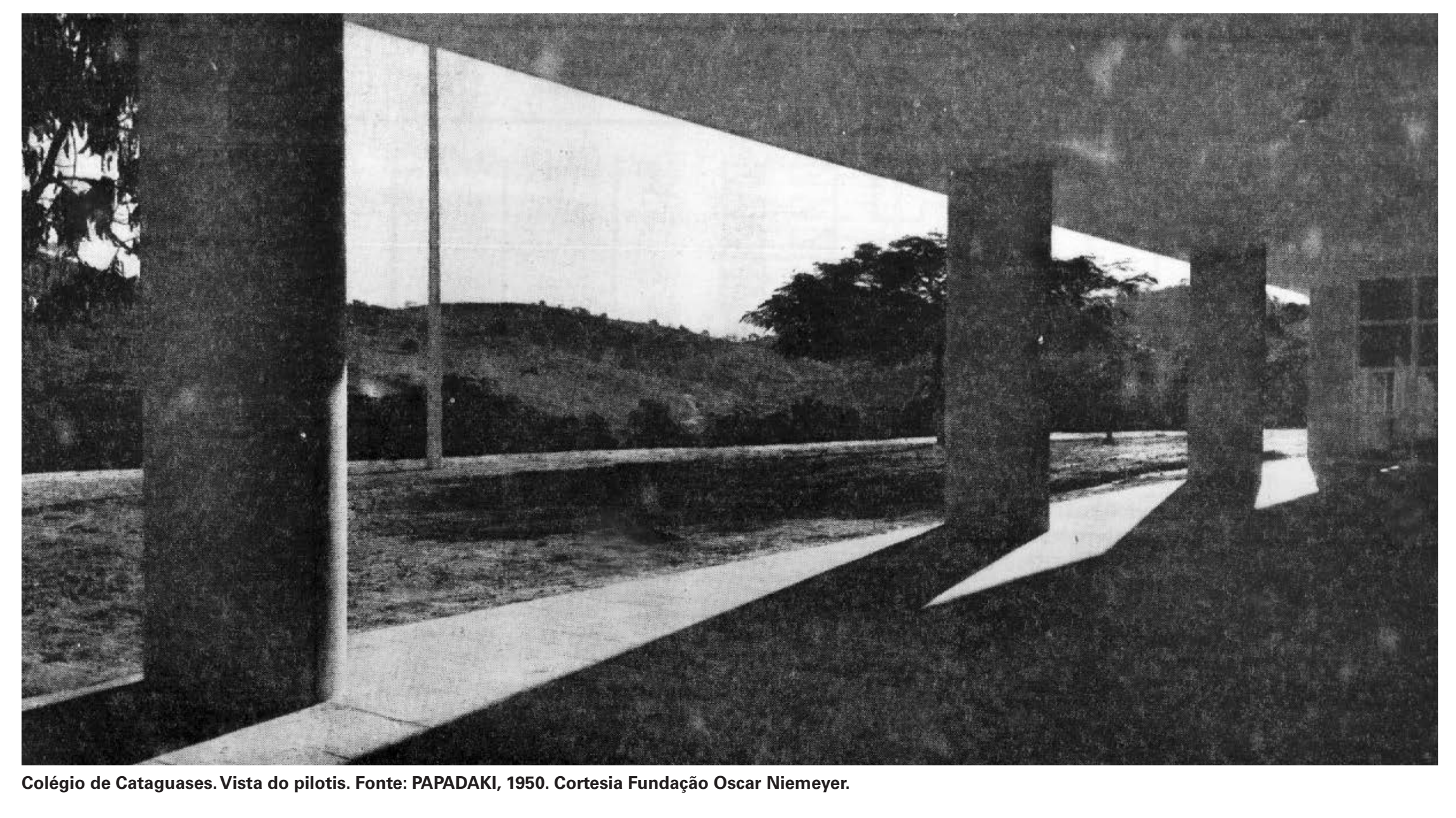

do, constituindo assim uma "modificação mimética da topografia local" (MACEDO, 2008: 273). As diferenças no porte das obras é explicada pelo programa: o de Cataguases é um colégio em regime de internato e semi-internato, com doze salas de aula $a^{52}$ e atendendo até 500 alunos, enquanto o de Diamantina atende a um programa escolar mais modes-

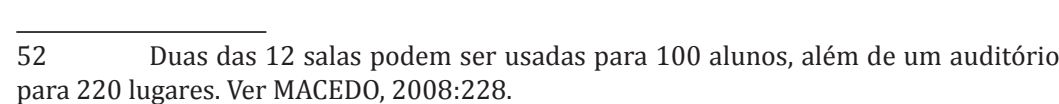

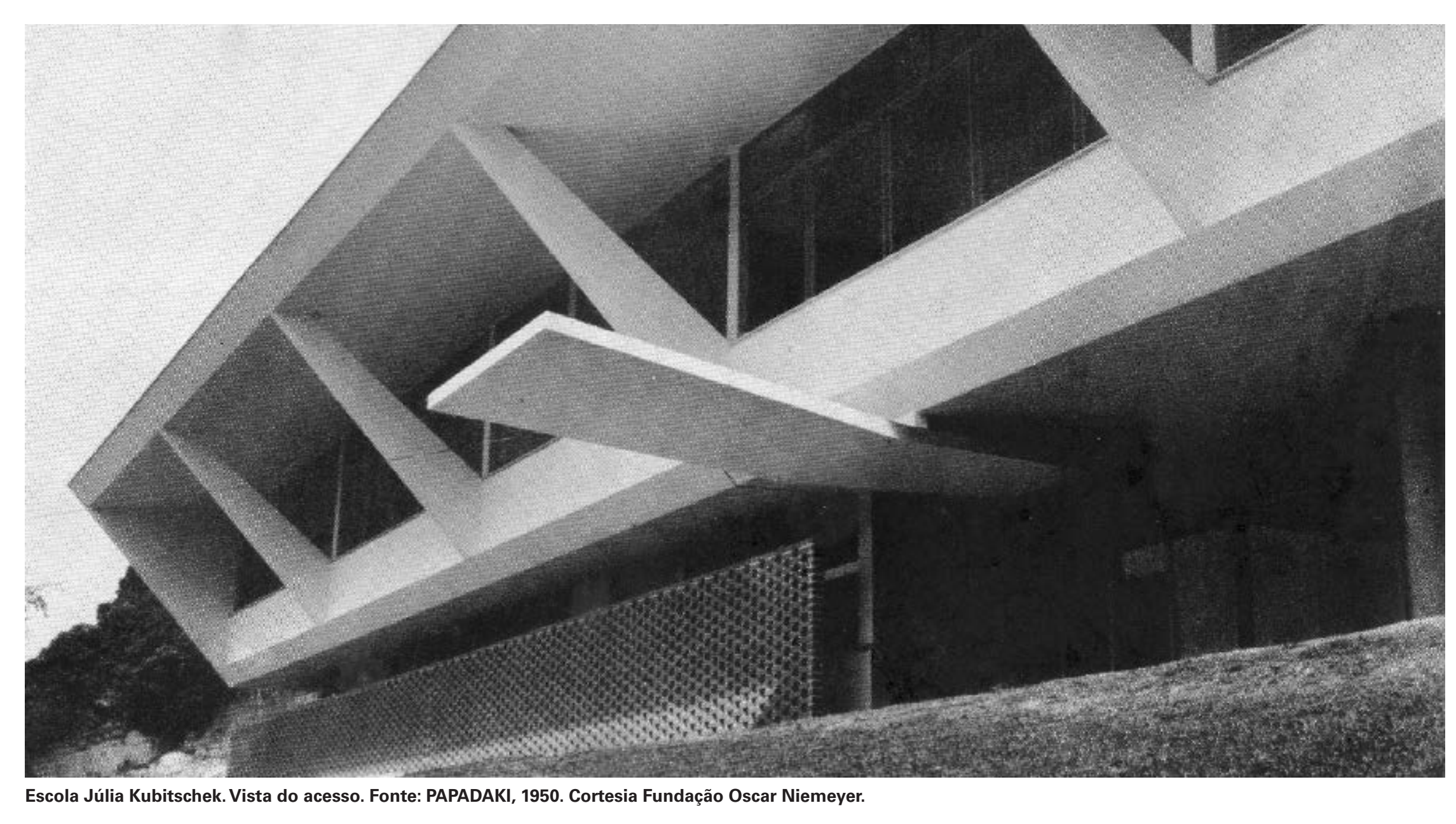

to, com sete salas de aula

Os elementos comuns nos dois projetos são a tipologia do prisma suspenso por pilotis e a circulação longitudinalmente disposta na porção posterior do volume e atendida por rampa. A diferença de orientação entre as sa las de aula das duas escolas explica as distintas soluções de cobertura e de proteção solar. Enquanto para a orientação sudoeste de Cataguses Nien 
puro, graças à cobertura plana, e resolveu a proteção por brise soleil, composto por laminas verticais, para a orientação sudeste tura inclinada formando um grande beiral frontal apoiado em pilares inclinados em concreto. A solução ampliou o pé direito da porção posterior das salas de aula, permitindo a introdução de aberturas altas que promovem a iluminação e a ventilação natural cruzada. 0 mesmo ocorreu em Cataguases no segundo pavimento, destinado aos dormitórios dos internos, hoje transformados em salas de aula: o desnível do teto plano permitiu a introdução de uma segunda faixa de abertura mais alta, porém mantendo a mesma orientação das janelas baixas.

O tratamento aparentemente distinto das duas escolas, quando examinamos os cortes, são, na realidade, variações dos raciocínios compositivos desenvolvidos por Niemeyer no Conjunto da Pampulha, ou seja, integram o grupo de obras geradas segundo os princípios que consagram sua produção no período, como aponta Rodrigo Queiroz:

A maioria dos projetos de Oscar Niemeyer que edem sua experiênncia na Pampulha é identmão do repertório plástico utilizado em cada um dos edifícios localizados ao redor da lagoa artificial em Belo Horizonte [] [RUEIROZ in BRUNA 2017: 173]

Se em Diamantina a plasticidade desejada é garantida pelo importante beiral apoiado em pilares inclinados, em Cataguases a rigidez do longo volume se contrapõe à imponente marquise que marca o acesso principal à escola, cujo pilotis recebe o painel curvo em pastilhas de autoria de Paulo Werneck à esquerda e o monumental painel "Tiradentes", pintado pro Cândido Portinari ${ }^{53}$.

distância de mais de $500 \mathrm{~km}$ entre as duas cidades não foi motivo suficiente para Niemeyer alterar substancialmente sua estratégia compositiva para as escolas citadas, porém pode-se verificar que cada uma das obras assume determinada identidade na paisagem local, muito em função da maneira como cada conjunto é assentado no terreno ${ }^{54}$.

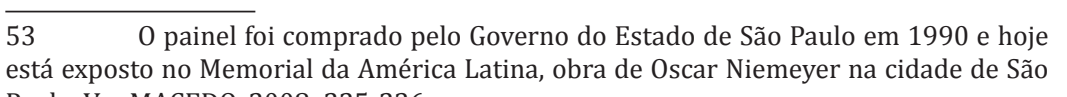

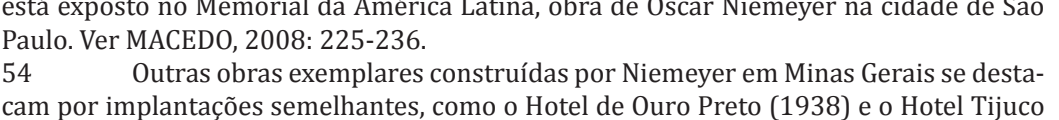
em Diamantina (1951) mesmo não ocorreu entre as cidades de Corumba Campo Grande, no Mato Grosso do Sul, distantes mais de $400 \mathrm{~km}$. Niemeyer projetou a escola para Corumbá a pedido do Governo do Estado em 1951, mas, por reivindicação da população, o mesmo projeto foi repetido em Campo Grande, sem, entretanto, ter havido a participação do arquiteto ou de sua equipe na implantação da obra.

0 fato explica a repetição do mesmo projeto mas com a orientação invertida. 0 clima extremamente quente do Mato Grosso do Sul foi o motivo para Niemeyer orientar em Corumbá todas as salas de aula para o sul, com o objetivo de evitar a insolação direta das fachadas. Situação inversa ocorre em Campo Grande, sem que tenha havido qualquer tipo de modificação do projeto.

$$
\text { Ao contrário de Minas Gerais, as escolas em Mato }
$$
Grosso do Sul se beneficiam dos terrenos relativamente planos, o que permitiu que a composição entre os pavilhões funcionais se desse numa escala bastante generosa, desta que que favorece a aeração dos ambientes, como pode ser observado nas imagens. A amplitude dos terrenos perm tiu que Niemeyer pudesse exercitar sua liberdade criadora dentro do vocabulário compositivo do Conjunto da Pampulha, como citado acima.

Assim, o bloco formado pelo auditório trapezoidal pelo pátio coberto foi resolvido pela cobertura oblíqua invertida do primeiro e pelos arcos em abóboda do segundo, com vão livre de 30 metros, sempre em concreto armado moldado no local. A ligação com o longo bloco didático e deste com o bloco do refeitório é feita por marquises também em concreto, que seguem a leve inclinação do terreno criando uma interessante relação entre as áreas funcionais edificadas transversais e as áreas livres, solução muito próxima da escola projetada por Carlos Frederico Ferreira n conjunto Vila Guiomar, em Santo André $(1940)^{55}$, o que indica claramente sua filiação à arquitetura moderna praticada no Rio de A inversão de orientação ocorrida na repetição do projeto de Corumbá em Campo Grande, apesar de dificultar a proteção das fachadas, como vimos, é justificada pela importância que o projeto reserva ao pavilhão auditório- 


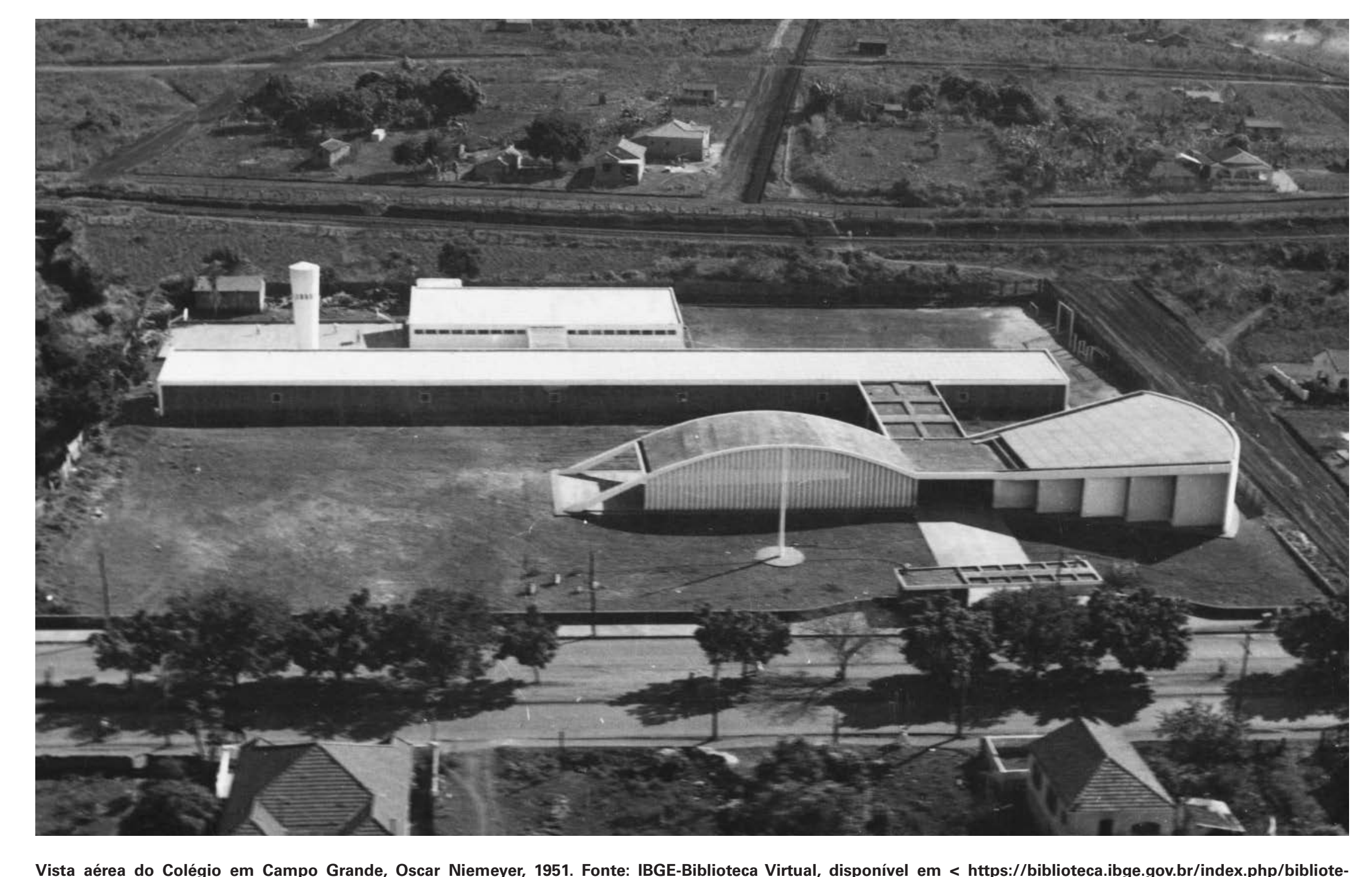

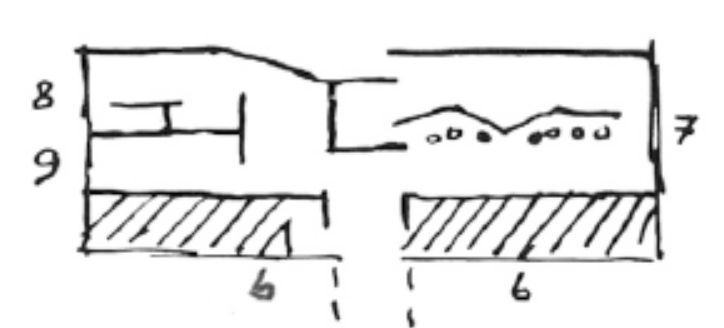

LLII प1 II III

vins

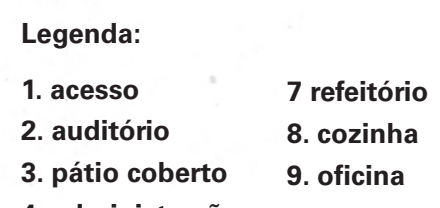

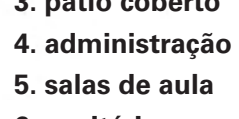

तु?

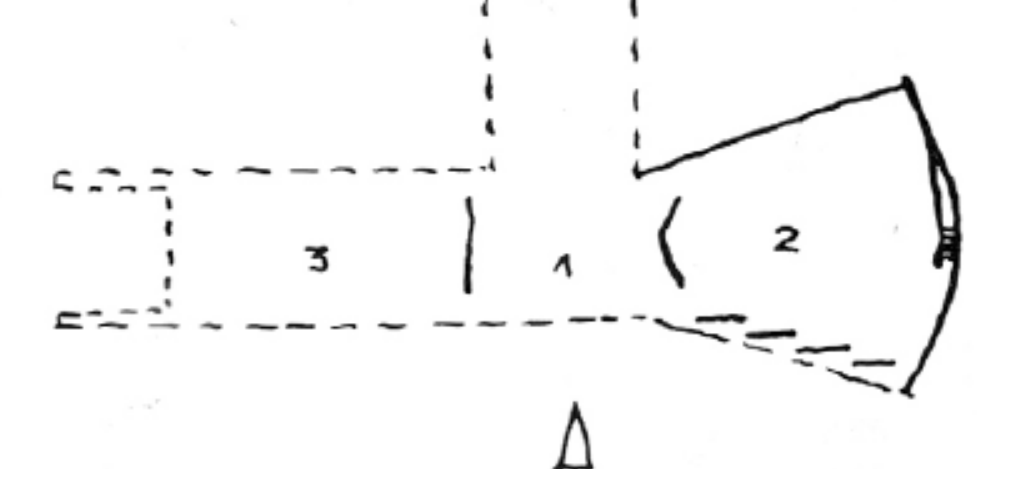



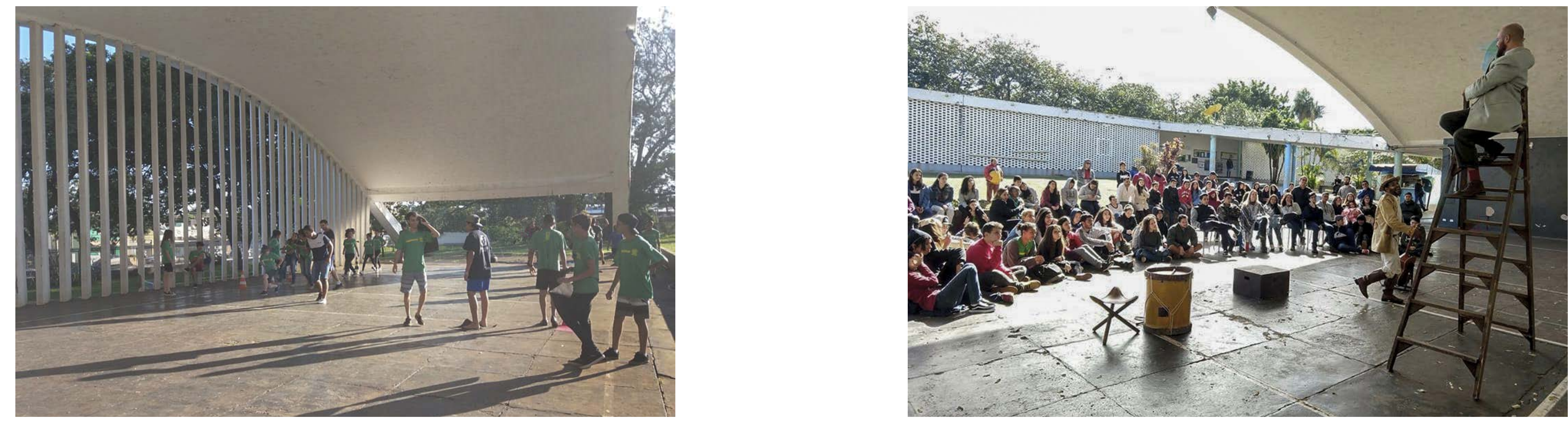

Esportes no pátio do Colégio de Campo Grande, em que pode ser observad
campo\%/20 grande\%200niemeyerzepa=SEARCH_BOX>, visualizado 25.02.18 
-pátio coberto se considerarmos suas qualidades plasticas e sua relação con a comunidade local. É possível verifi que o projeto

seipm desenvolvidas ativida cas gracas cas graças aos elemontos constron citados. Fica difícil, no entanto, justificar em Campo Grande as mesmas proteções solares das galerias das salas de aula e elemento var quadrada e das do pitio cobert do pátio coberto e do auditório, uma reprodução da solução usada por Niemeyer na Igreja São Francisco de Assis na Pampulha.

Há ainda uma ordem estabelecida pelo traçado urbano de Corumbá, cujo exo partindo da estação ferroviária éa re erência que Niemeyer adota para compor seus pavilhões na quadra, reforçando a reação do projeto com a morfologia local,

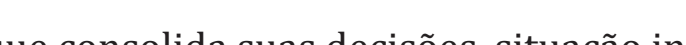
que consolith xistente em Campo Grande e que fragiliza

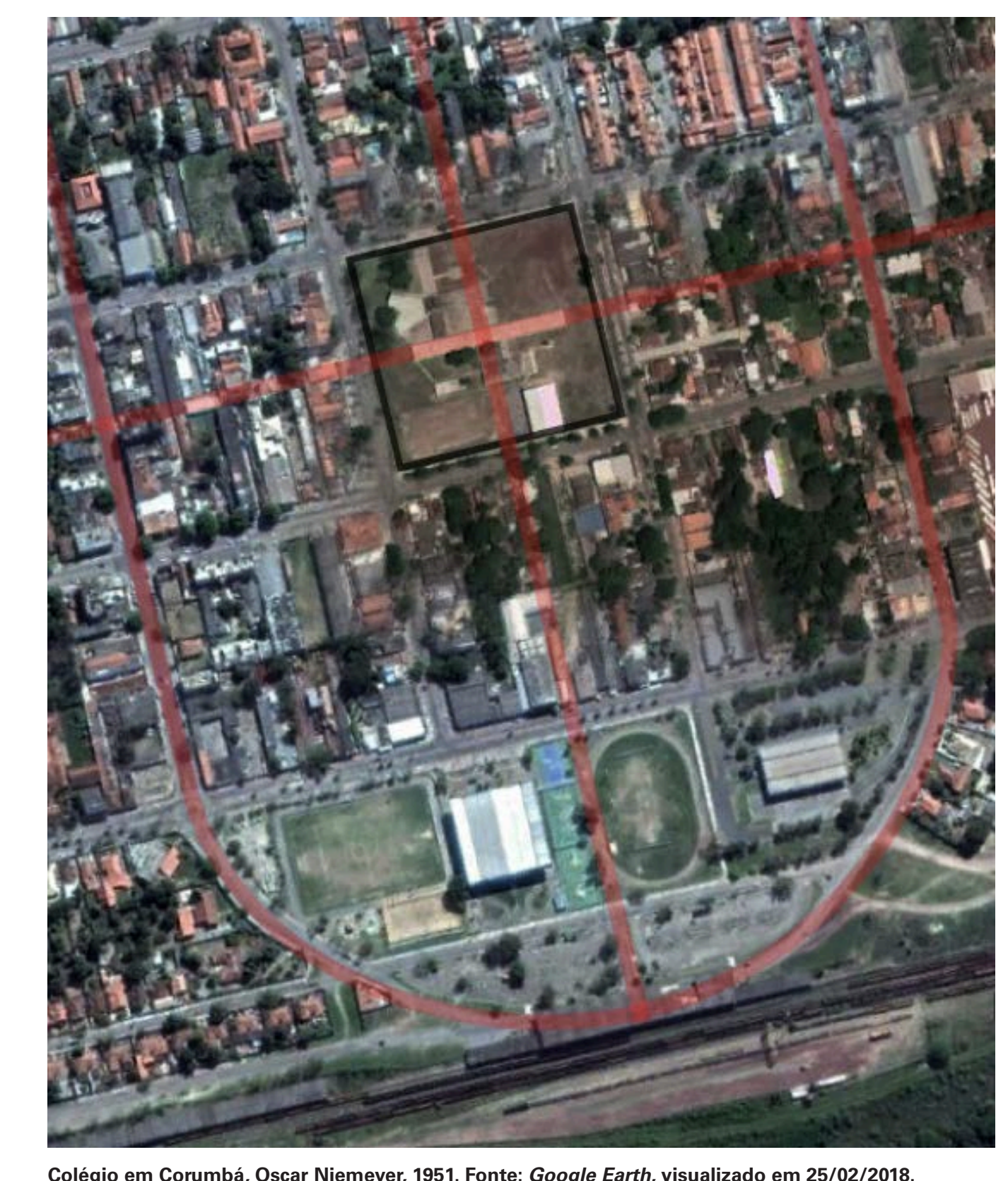

ainda mais a repetição do projeto.

作 e (1954) completa o grupo de escolas projetadas por Niemeyer na primeira metade do século XX, no momento en que sua arquitetura inicia uma trajetória muito mais votada para a síntese da forma, como apontado pela historiografia e assumido pelo próprio arquiteto ${ }^{56}$

Nesse sentido, o Colégio Central, entre os projetos de escola realizados por Niemeyer, pode ser entendido como uma obra de transição que ainda mantém parte da força compositiva criada pelo arquiteto, mas que introduz alguns dos procedimentos que caracterizaram o período cujo ápice foi a construção de Braślia.

Do ponto de vista do assentamento das edificações no terreno, é evidente a constituição de uma plataforma artificial, nivelada com a face superior do quadra que é totalmente ocupada pela escola, mesmo considerando o acentuado de clive em que está situada. Como a obra foi construída após a demolição de antigas edificações existentes (MACEDO 2008: 276), Niemeyer potencializa esta situação criando uma base em pedra nas três outras ruas, como pode ser observado na imagem da maquete.

56
$169-244$. Ver QUEIROZ "A Revisăo Crritica de Oscar Niemeyer" , in BRUNA, 2017.
Os volumes agora estão soltos, sem as marquises de ligação, valendo-se dos vazios intermediários para a compreensão do projeto, ainda mais do que nas implantaçõe em Mato Grosso do Sul, como ressalta Danilo Macedo:

[...] as obras de Oscar Niemeyer evoluem da simples manutenç̃o de uma topografia original rumo a um entendimento e readaptação desta to pografiia atraves da implantaçăo do edifício. Seus projetos continuam dependendo em grande parte dos espaços vazios adjacentes, cujo distanciamento proportonado ao observador permite a

No Colégio Central, a expressão plástica se distancia da Pampulha para uma expressão em que a síntese da forma está caracterizada pela estrutura. Em primeiro lugar, 0 longo prisma que abriga as salas de aula é suspenso não mais por uma malha regular de pilotis mas sim por pórticos rígidos biarticulados, o que fundamenta o desenho obliquo dos apoios A expressiva altura da viga que constitui linhas de sheds que proporcionam ventilação e iluminação 


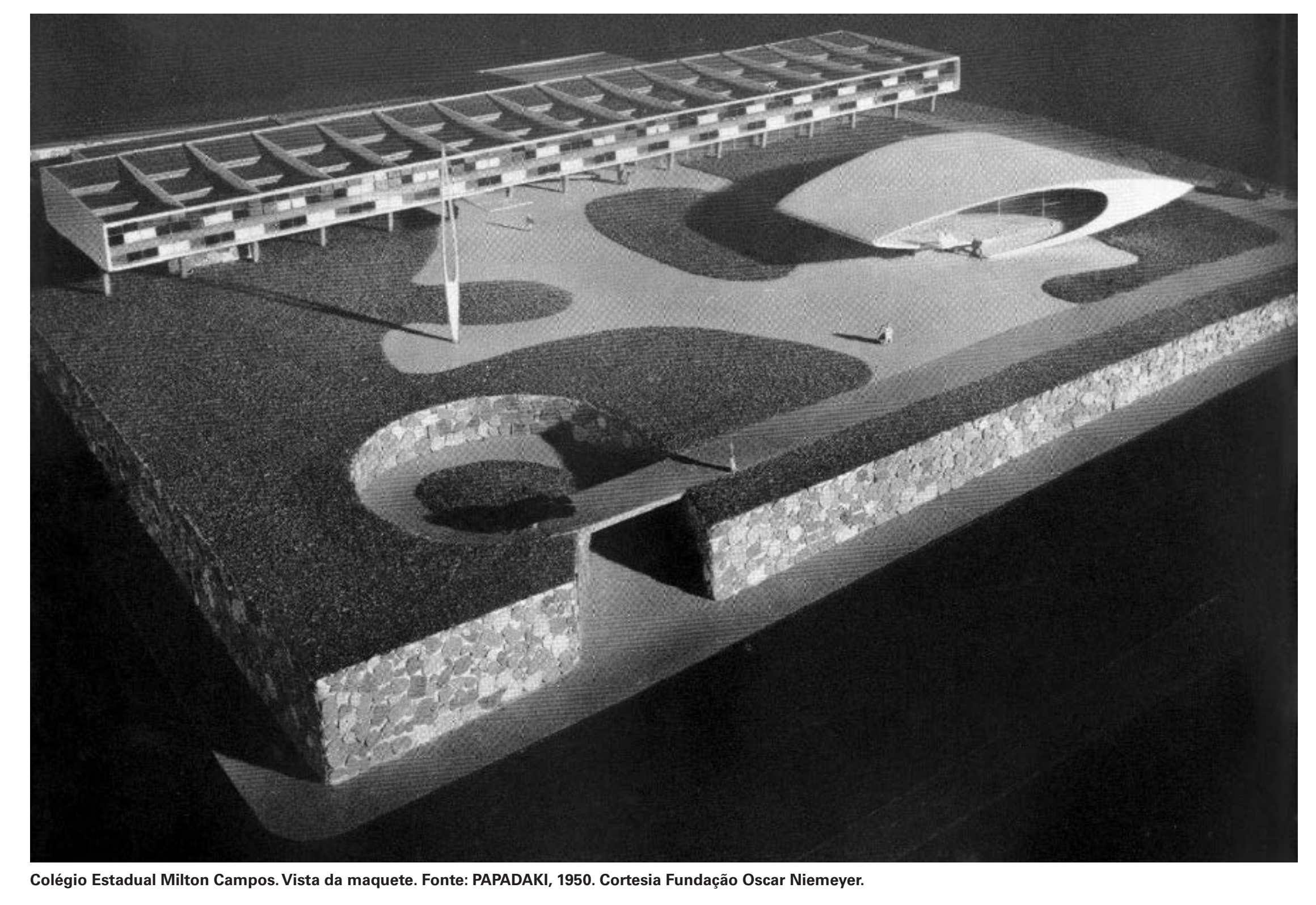

naturais para os ambientes internos, localizados no terço central do pavimento superior. Esse pátio interno suspenso tratado como área de convergência onde estão distribudos a rampa, os sanitários e as salas de apoio.

Ainda que o Colégio Central possa ser considerado uma obra de transiç̃ão e haja significativa distância com as obras consagradas de Niemeyer em Brasília, seu estudo nos auxilia a entender as estratégias de projeto usadas pelo arquiteto trinta anos depois na concepção do CIEP, considerando que [a] experiência projetual dos palácios de Brasília

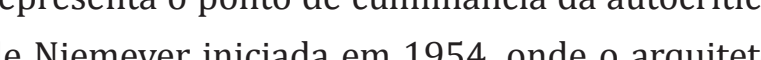
Vevê os procedimentos e as solucios formis de pus projetos anteriores mas nasos abondon

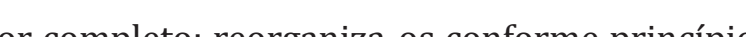
The fuño entre formo estrutura [-] os elementos ( caráter de apêndice e a feicão compositiva, assu- mindo a escala e o perfil da forma em sua totalidconsequência de um traç̧o vigoroso, contínuo e elementar. [QUEIROZ, apud BRUNA 2017: 237]

visita ao Colégio Central foi fundamental para examiarmos o corte transversal do bloco didático e poder, assim relacioná-lo com as pesquisas projetuais da obra de Niemeyer acima citadas. A fusão entre forma e estrutura, apontada po Rodrigo Queiroz como fundamento do período que culminou com a construção de Brasilia, ainda não se manifesta ecom a mesna força dos Pácios da

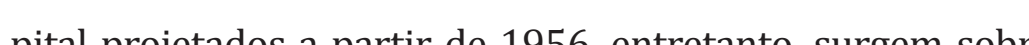
a plataforma formas claras definidas pela estrutura, relacionando-se muito mais entre si do que com a cidade.

A carga simbólica que as formas criadas assumem tem seu ponto mais significativo no auditório, destacado no canporáno em que a plataforma atinge seu nível mais elevado em relação à rua Novamente é possível identificar no corte do volume curvo a expressividade estrutural em que a cobertura em abóboda não repousa no terreno, como na Pampulha. Niemeyer a mantém em balanço nas extremidades, suspensa juntamente com a laje curva da plateia-palco, graças a uma série de pilares em 

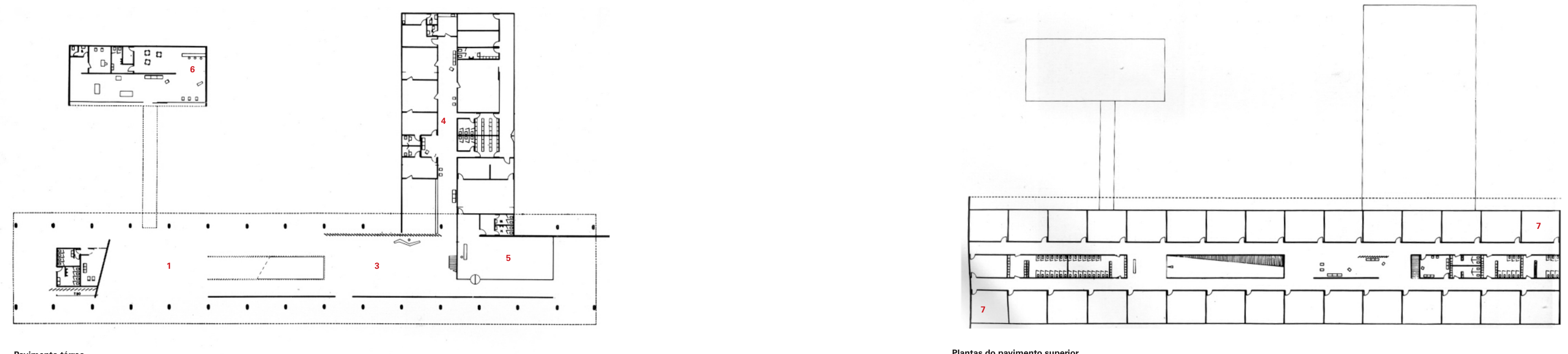

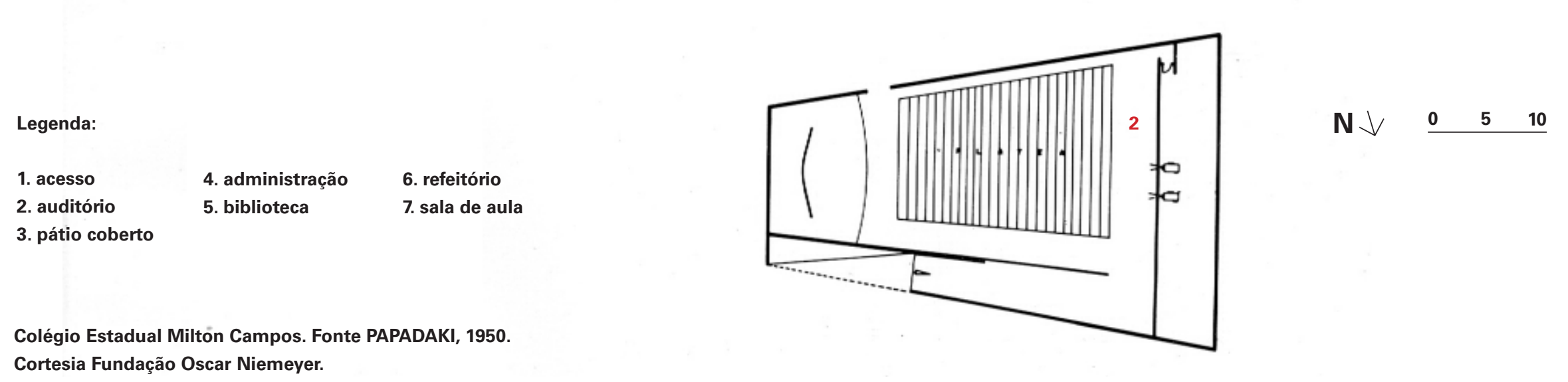



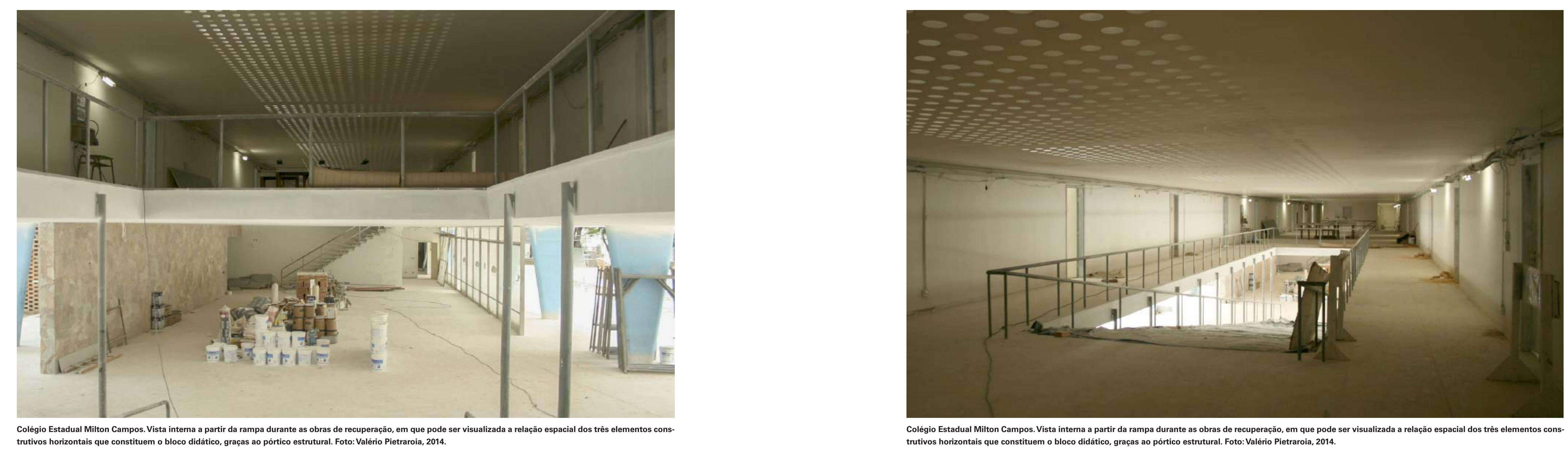

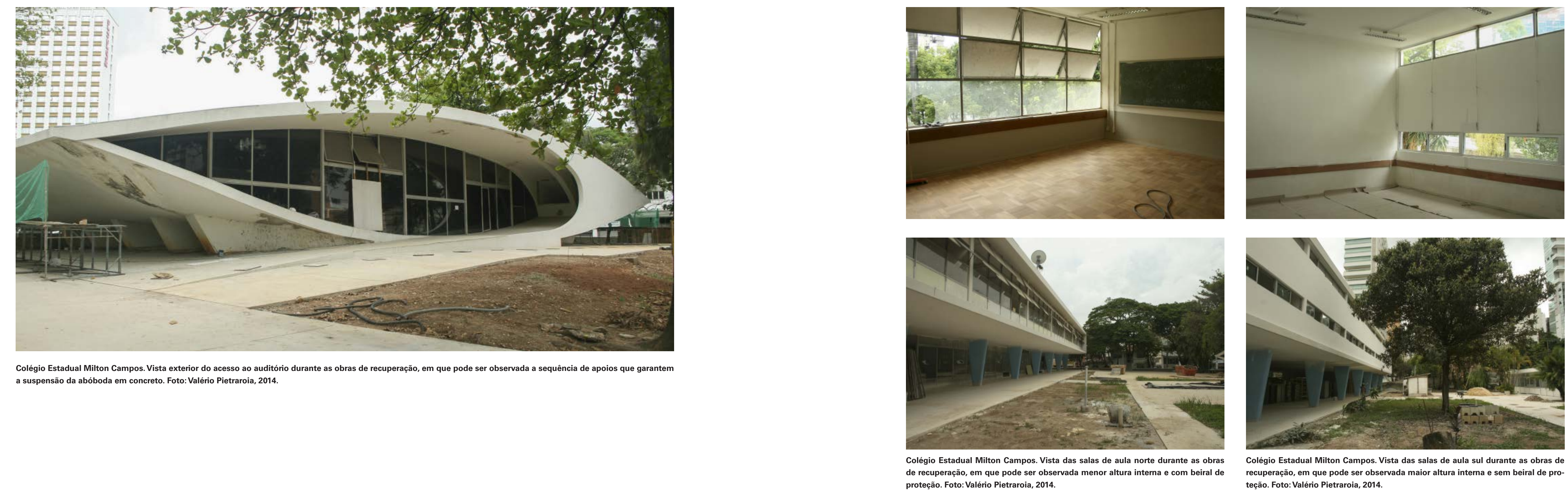


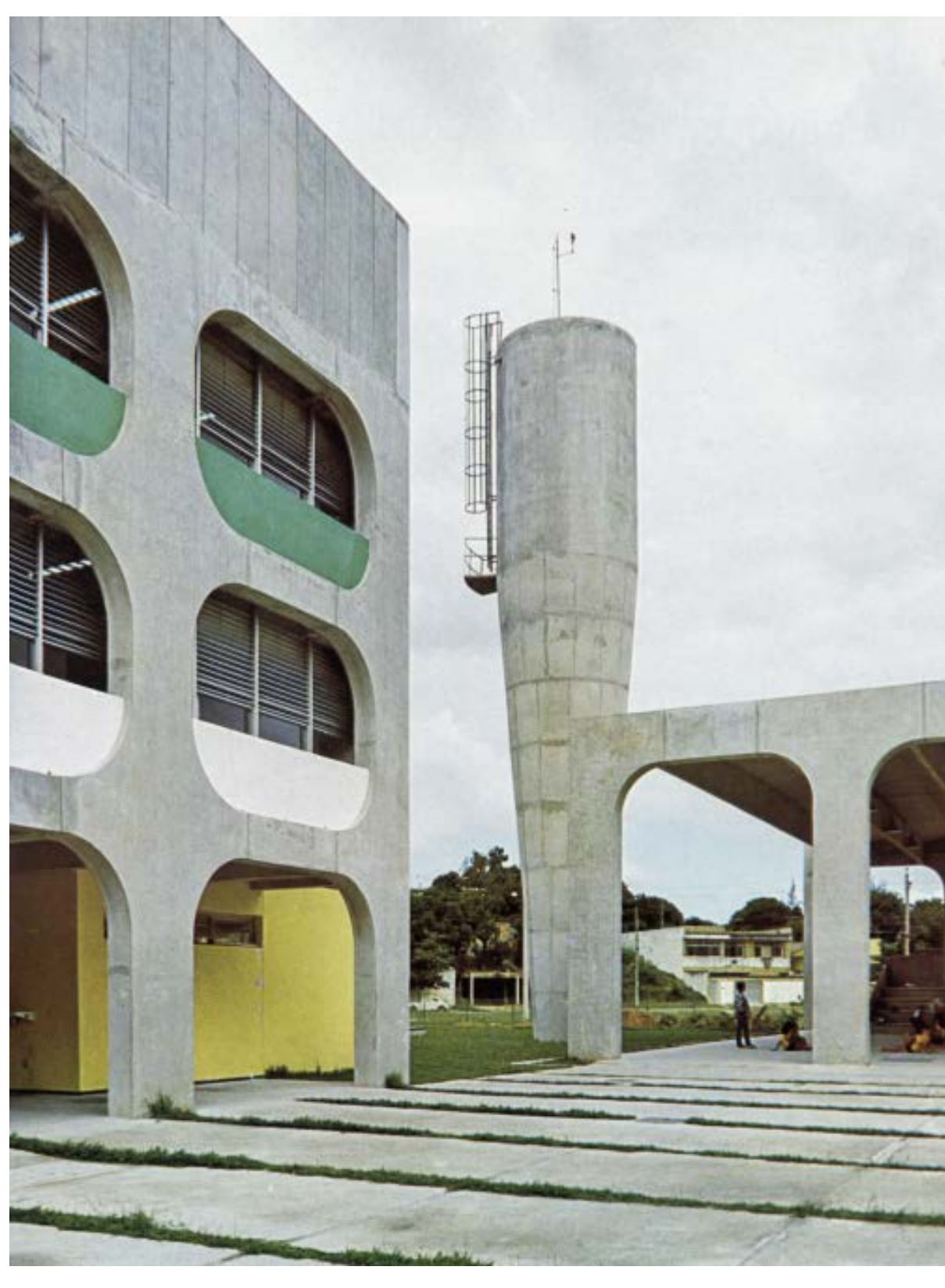

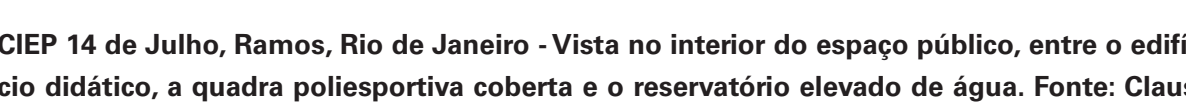

" $Y$ ", estrutura calculada pelo engenheiro Z. Gab-

O Programa Especial de Educação ${ }^{58}$

Após a observação das obras acima examinadas, podemos agora introduzir o projeto do CIEP de maneira mais apropriada, segundo nosso entendimento, por meio dos manuscritos do seu autor:

A solução permite: Maior economia de tempo e dinheiro pois é toda pré-fabricada.

Pré-fabricação radical com apenas 3 elentintos. Colunas superpostas de $3 \times 15$

Utilização de terrenos menores do que peco de tera us a$$
\text { eliminaç̃o dos blocos paralelos que }
$$

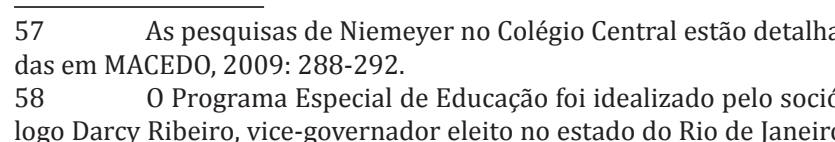

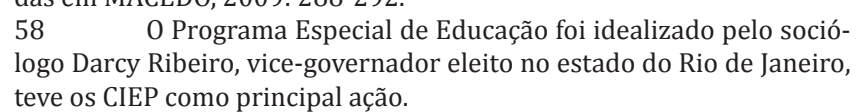

a obrigaria

nclusive maior importância ao empreendiento não se perdendo entre os prédios existenes como ocorreria com uma construcão térrea. Explicação Necessária

0 trabalho a elaborar [...] se reduz a uma adapt

ča lógica e funcional da escola piloto levando

conta a forma do terreno, os acessos existentes

sua conformacão natural. [Niemeyer transcriç̃̃o

de trechos dos manuscritos sobre os CIEP. Fonte

Fundação Oscar Niemeyer; ;rifos do autor]

As três décadas que separam o projeto do Colégio

Central em Belo Horizonte (1954) e o projeto do CIEP no Rio de Janeiro (1984) constituem um período em que o trabalho de Niemeyer, em especial após a construção de Brasilia, alcançou reconhecimento internacional, o que the proporcionou uma extensa produç̃o nos mais variados teOscar Nieneyer expresso en sels no Oscar Niemeyer expresso en sens manuscitos que devemos nos apoiar para o entendimento das intenções do autor no momento da concepção do CIEP. 0 arquiteto sublinha as virtudes do projeto para dar "maior importância ao em- preendimento" e por representar uma síntese lógica e funcional da escola, 0 que limitaria 0 trabalho de implantação e sua conformação natural".

Por esse raciocínio, fica claro que a repetição do projeto piloto vai priorizar as relações preestabelecidas pelo modelo e reservar poucas oportunidades para que o coninterior de

[...] seu desenho original, um esforço concentrado de Estado para levar o social para dentro da escola. Um CIEP conteria nele mesmo, em su dinâmica interna, todos os aspectos de assistênca social. educaçao, sadde, cultura, atendmento miliar [BOMENEY, 2009: 114]

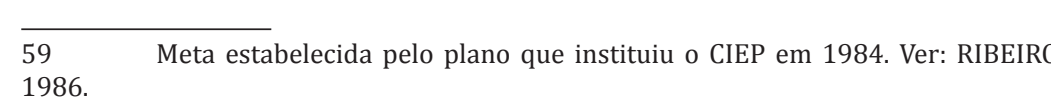


O desenho original citado por Helena Bomeney refere-se ao desafio de ampliar o alcance do equipamento público de educação para além do programa educaciona revolucionário proposto por Darcy Ribeiro e citado por Nie meyer no início do capítulo. Nesse sentido, sua originalida de está associada à construção de uma representação de equipamento público nos possíveis 500 contextos distintos em que deverá ser implantado.

Passamos, então, ao entendimento do referido de senho original, identificando-o em relação à obra de Niemeyer no que se refere à escola

A partir da avaliação do programa proposto, $\mathrm{Nie-}$ meyer organizou o projeto padrão em três edificações, detenha sido a premissa a ser observada para a viabilidade do plano, cada um dos blocos funcionais assumiu uma form que o identifica no conjunt

Assim, o edificio didatico, um bloco retangular com dupla orientação, recebe todas as salas de aula e as áreas no térreo, Niemeyer distribui inug extenidade do o refeitório e, na outra, os serviços médicos e odontológ cos, formando entre eles um amplo pátio coberto conforú por pus pavimentos a mesma organização baseada na localização dos sanitários nas extremidades e a circulacão centralizada a partir da rampa, proporcionando liberdade na definição dos ambientes, dentro da modulação dimensional estabelecida pelos elementos construtivos. A citada liberdade se apresenta ainda na solução diviśrizs a meia altura que limitam as salas de aula e a circulação central. A situação de amplitude e de interação gerou, no entanto, dificuldades de uso, e obrigou a revisão do detalhe durante a segunda fase de implantação do Plano.

Ainda no bloco didático, o arquiteto propõe que a cobertura possa receber atividades, o que viabilizou a inclusão de uma quadra esportiva coberta e o reservatório de água, uma variação do projeto padrão, pois, como observa Maria Alice Junqueira Bastos, o projeto assumia uma

configuração que demandava terrenos de dez mil metros quadrados. A dificuldade de contar cor grandes terrenos nas áreas mais densas levou uma solução mais compacta com a quadra esportiva na cobertura do edifício escolar. [BASTOS,
$2009: 42-45$

A platibanda alta em concreto coroa o volume e protege $\mathrm{o}$ uso das coberturas. Como demonstram os croquis, a frontalidade do volume é potencializada pela série de pilares, cujos consoles curvos serão solidarizados por trecho de vigas a serem moldados no local, conformando uma superfície monolítica contínua, sem a tradicional marcação de juntas da construção pré-fabricada, constituindo a expressão estrutural como arquitetura que trabalho de Niemeyer. Nesse aspecto, o argumento da pré-fabricação perde sua força ao depender da moldagem do concreto no local, sem a qual a estrutura estaria incompleta. Para o arquiteto, entretanto, é na construção desse arcabouço que serão inseridos os peitoris coloridos recuados cujas aberturas arredondadas e protegidas por brise-soleil deverão identificar o CIEP nas possíveis 500 implantações 0 jogo compositivo entre cores primárias aplicadas nos peitoris recuados deverá diferenciar cada CIEP, identificando equipamento público em cada nova situação $0^{60}$

A sombra no térreo é a chave para compreendermos quais as estratégias oferecidas por Niemeyer para as

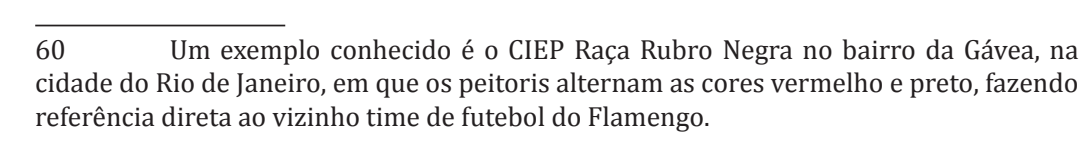

possiveis implantaçoes. Como vimos, ao deslocar para as extremidades os volumes do refeitório e do serviço médiverão seguir uma composição que priorize os vazios entre os blocos funcionais. Em outras palavras, Niemeyer padroniza não somente os blocos funcionais mas também a maneira pela qual irão se relacionar.

Por esse raciocínio, o bloco octogonal que define a biblioteca deverá ser disposto no terreno em contraponto ao bloco esportivo, constituído por uma sequência de pórticos em concreto que definem sua cobertura. Os eixos longitudinais do bloco didático e do bloco esportivo estarão preferencialmente perpendiculares para obedecer orientação mais favorável em relação à incidência solar, enquanto a biblioteca se beneficia da planta octogonal para ser posicionada. A identificação volumétrica do octógono é potencializada por um pavimento superior que receberá a residência de alunos, constituindo parte do programa social estendido, idealizado para o CIEP. Ao recuar duas porções opostas do térreo onde a biblioteca está instalada, Niemeyer cria uma sombra generosa para o ambiente de 


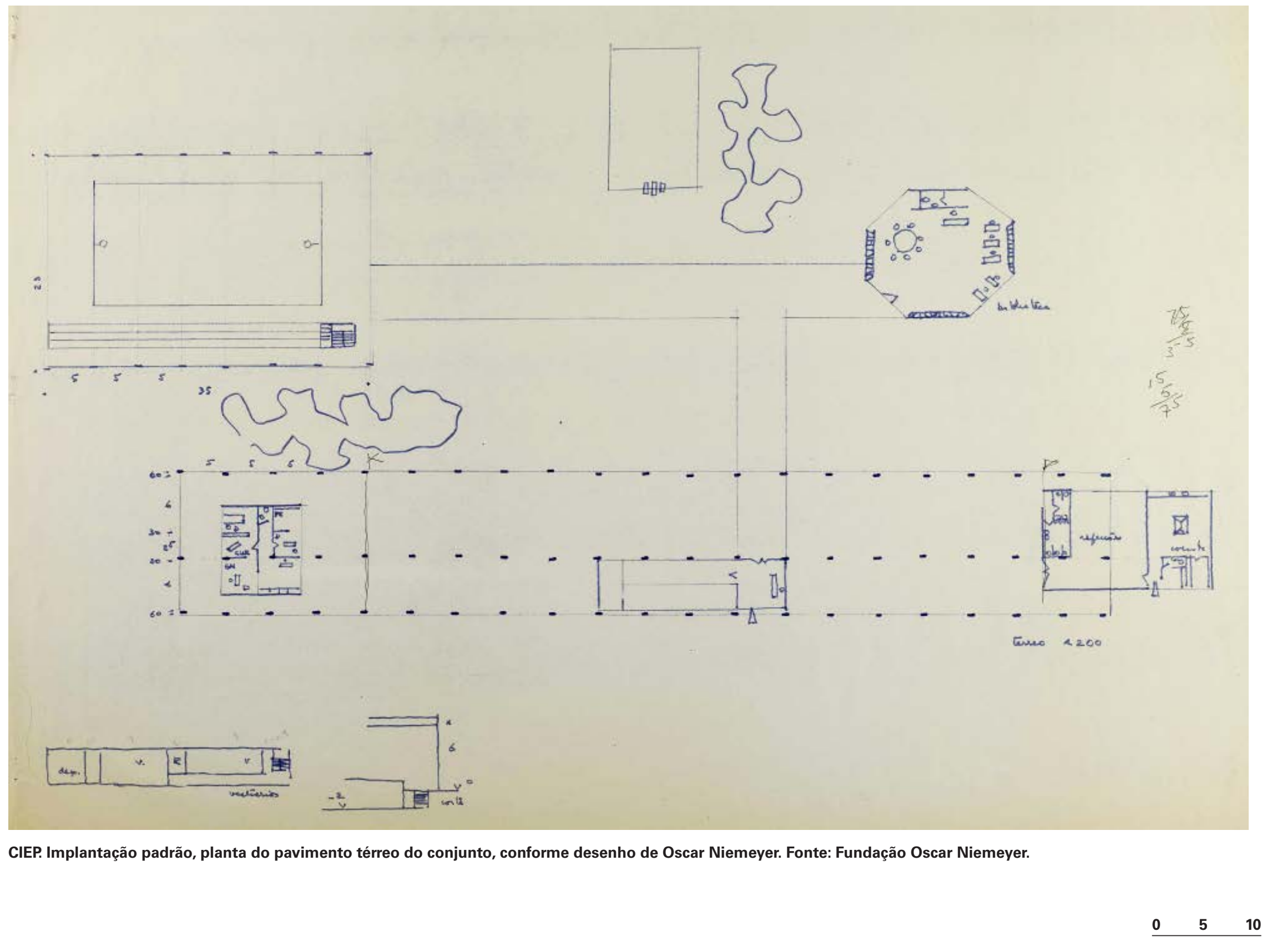

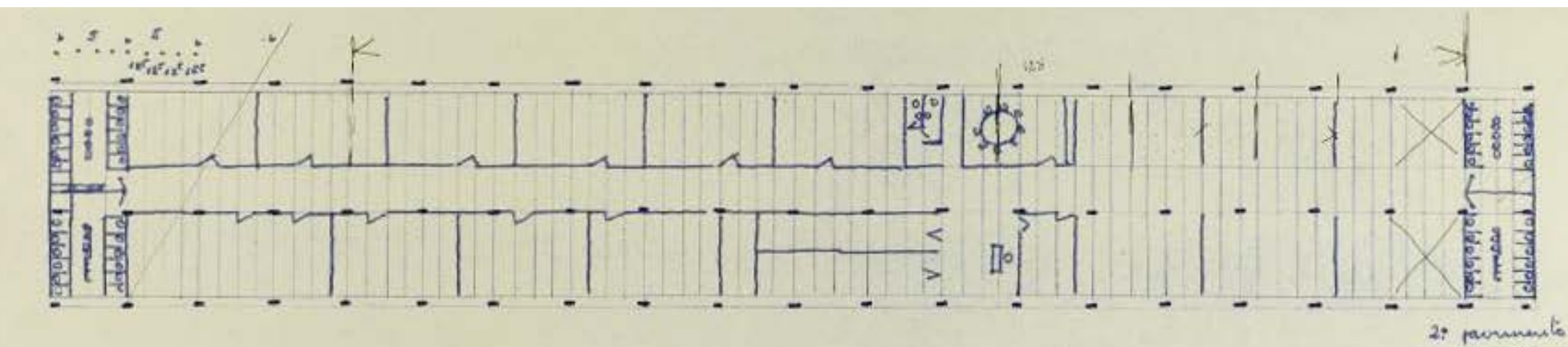

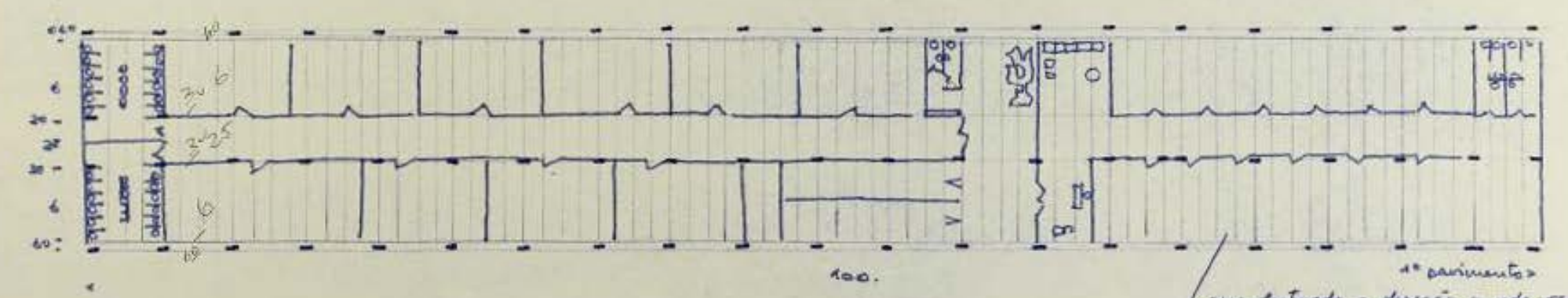

CIEP. Projetto padrão do edificio didatitico, planta do $1^{\circ} \mathrm{e}$ do $2^{\circ}$ pavimento, conforme desenho de Oscar Niemeyer. Fonte: Fundaçäo Oscar Niemever. 

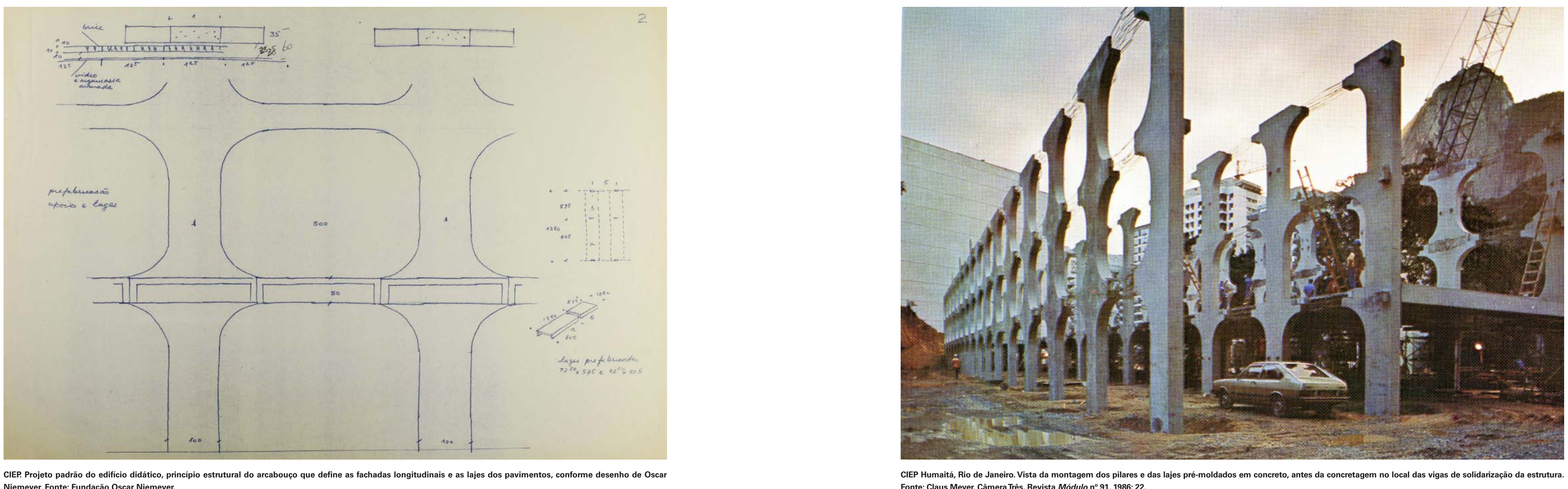
leitura e faz flutuar o volume superior dos dormitórios.

Ao avaliarmos o desenho do autor para a implan-

tação padrão, que seria o assentamento ideal, é possíve identificar uma porç̃̃o quadrada do chão que, de uma certa forma, delimita uma matriz abstrata para a relação entre as formas de cada bloco funcional. Mesmo sendo visível que o programa irá evoluir e partes dos blocos serão modificada ${ }^{61}$, a intenção clara de Niemeyer em determinar a construção do espaço público no interior do conjunto está expressa de maneira indiscutível, independentemente contexto. 0 campo definido pelo desenho é a folha de papel, ou seja, não há um limite físico a ser considerado, pois ele poderá assumir as mais diversas configurações. Fora da porção quadrada que relaciona os volumes há espaços residuais que não deverão ter grande significado perante a

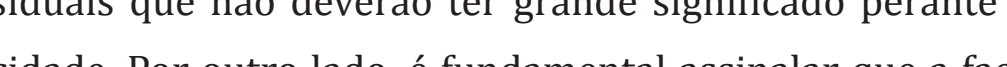
em pilotis do bloco retangular, ao ser a geratriz da porção quadrada, constrói a interface urbana aparentemente desprezada. São aproximadamente setenta e cinco metros frontalmente voltados para a cidade, o que nos remete à escala, até certo ponto monumental, desejada pelo arquiteto.

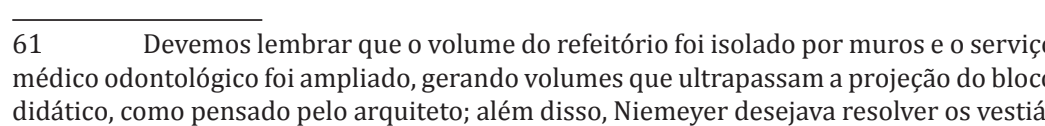

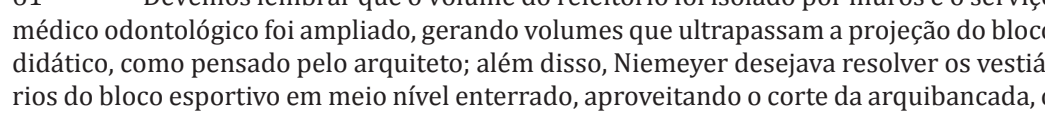

Completa a série de edificações projetadas o rese vatório de água em "taça”," uma reprodução fiel que $\mathrm{Nie}$ meyer já testara em inúmeros outros projetos.

Para Carlos Dunham, o CIEP segue à risca as implantações de Niemeyer em que os objetos arquitetônicos são dispostos numa esplanada, "uma espécie de vazio edificado, preparado para recebê-los" (2009:72). A relação do CIEP com a cidade se dá em função da conformação do contexto, ou seja, os limites e as possibilidades locais poden gerar alguma interação do equipamento com o contexto, no entanto, a força da relação interna entre os objetos é que deverá estar garantida.

Nesse sentido, cabe salientar que o que prevalece enquanto implantação do equipamento público é a dificudade para que o conjunto se relacione com o contert projeto de Niemeyer acerta ao eleger o chão como plataforma de relacionamento entre os objetos arquitetônicos projetados, admitindo certo isolamento, não no sentido de desvinculá-lo da condição urbana, mas por considerá-lo protegido e, até certo ponto, alheio. No entanto, evidencia seus limites ao tentar integrá-lo em áreas urbanas consoldadas como no centro do Rio de Janeiro ou no bairro do Enenho Novo, ou ainda, em Niterói. Nas situaç̃es opostas, na

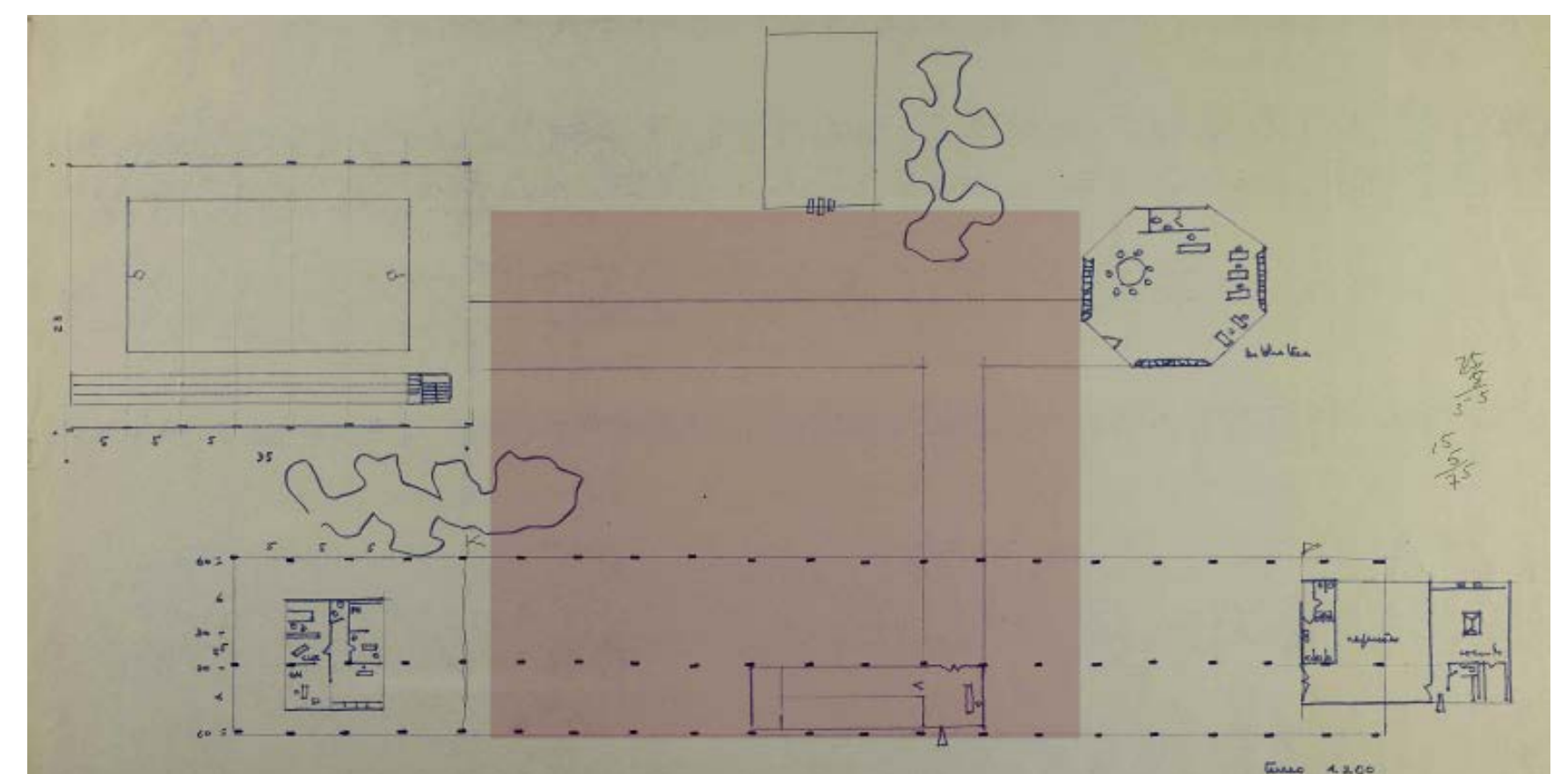

CIER. implantaçăo padrão,
espaço publico no interior do conjunto, conforme desenth
de oscar Niemever. Fonte

ausência da cidade formal como em Curicica ou no Realengo, o equipamento surge como referência, tal como previs

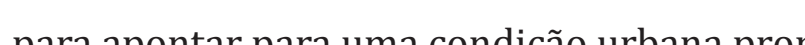
Vale destacar, ainda, que Niemeyer mantém no CIEP características marcantes de sua obra, sobretudo a síntese formal baseada na expressão estrutural monumental preservando em certa medida as relacões de escolcos os as do zonte. Iss significa que o projeto não abre mão de fundamentos que
0 arquiteto considera essenciais para o lugar da aprendizagem, tendo a escala do aluno como referên

Se as dificuldades da condição urbana são enfrentadas de maneira desproporcional, o projeto deve preserva os elementos construtivos capazes de oferecer qualidade a esse desafio. Em outras palavras, a arquitetura do lugar da aprendizagem deve ser portadora de suas condições 


$$
\text { L揹 }
$$

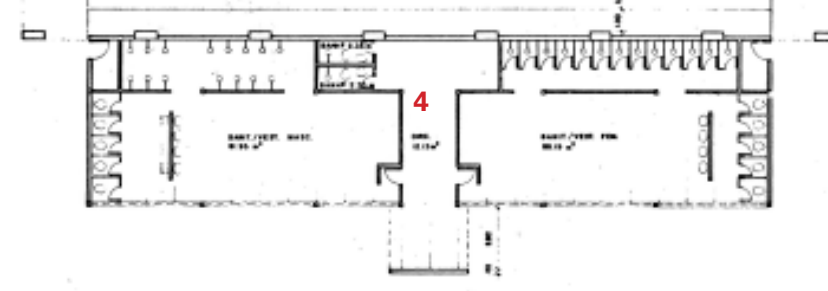

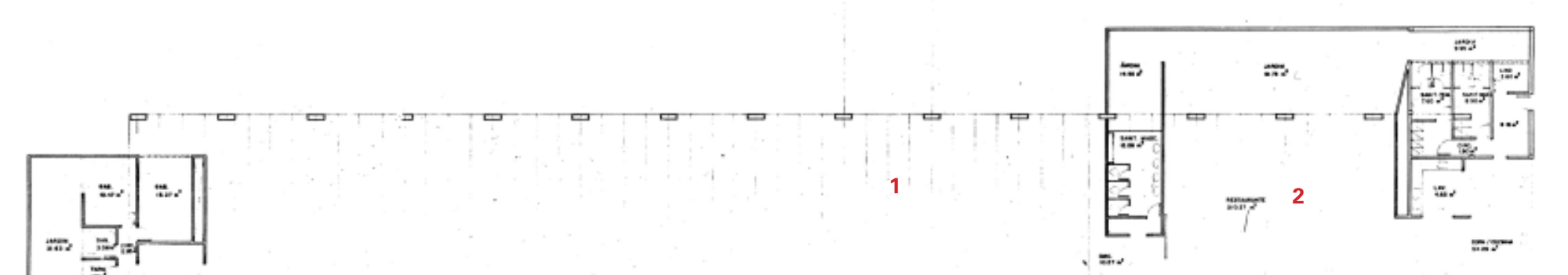

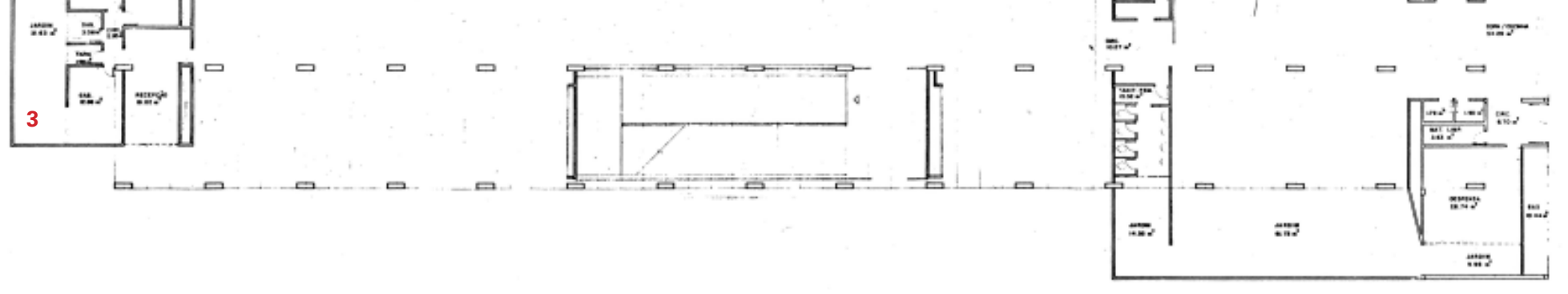

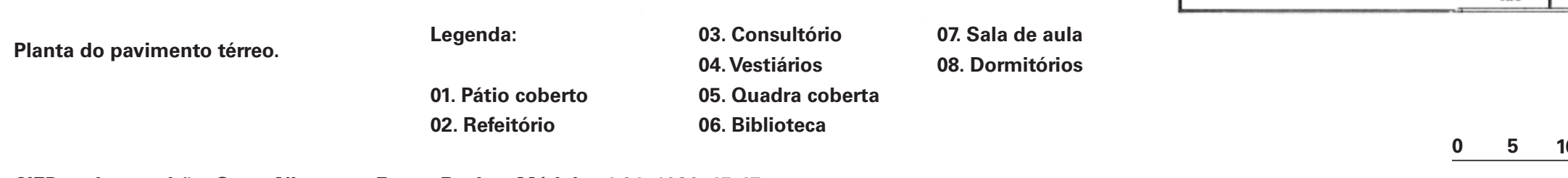
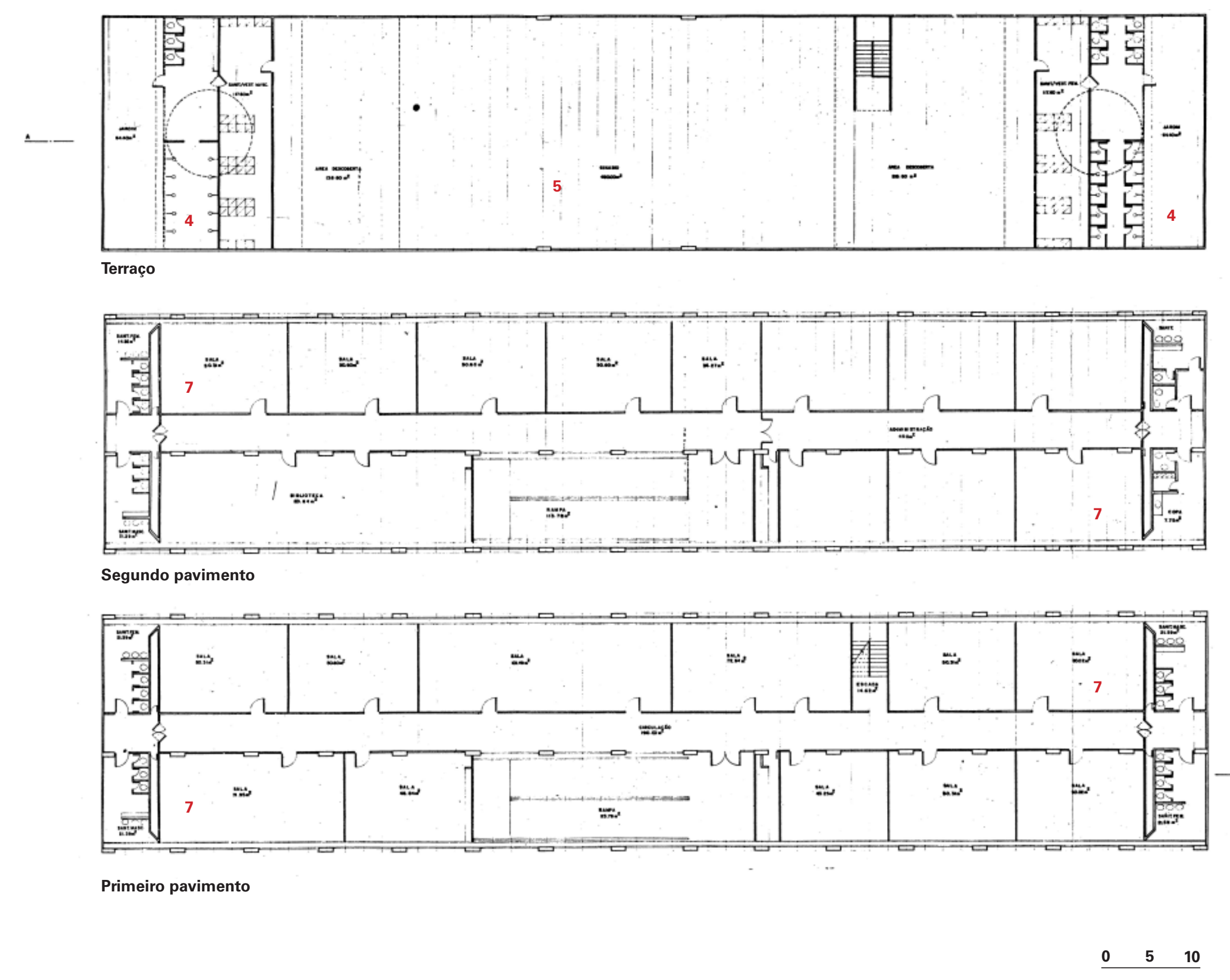


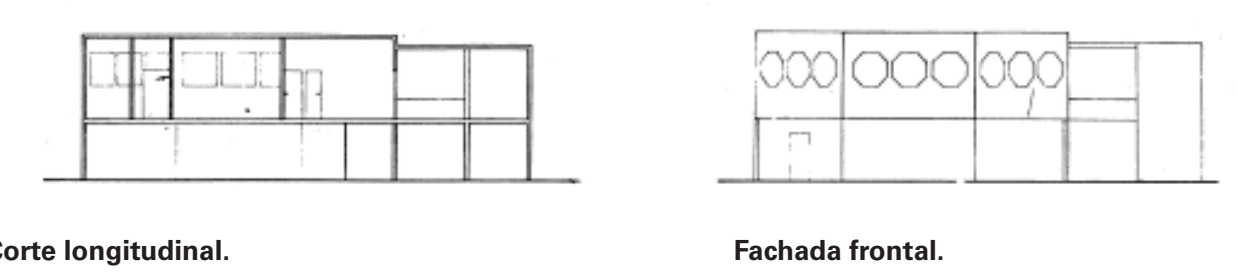

$$
\text { (1) 且 }
$$$$
\text { Primeiro pavimento: bibliotec }
$$$$
\text { Segundo pavimento: dormitorio }
$$

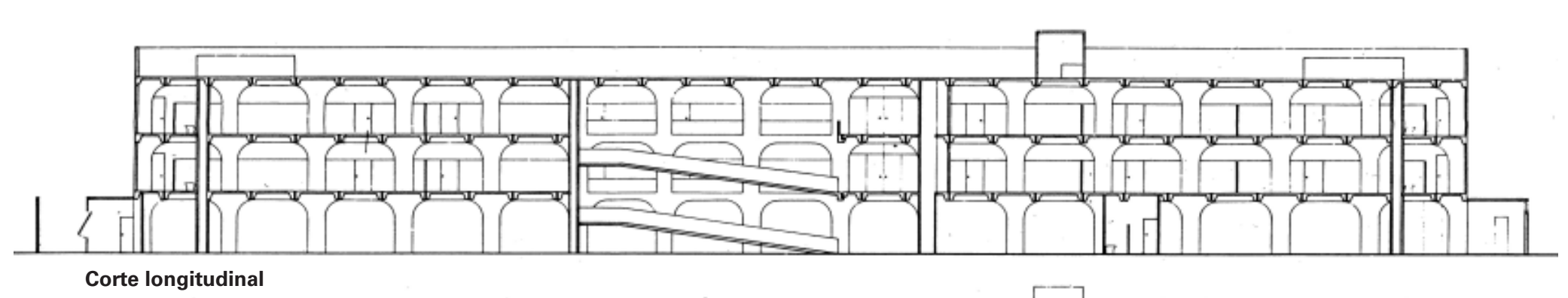

Elevąátrontal Elevacăo frontal
Edificio didático sem o terraço acessivel

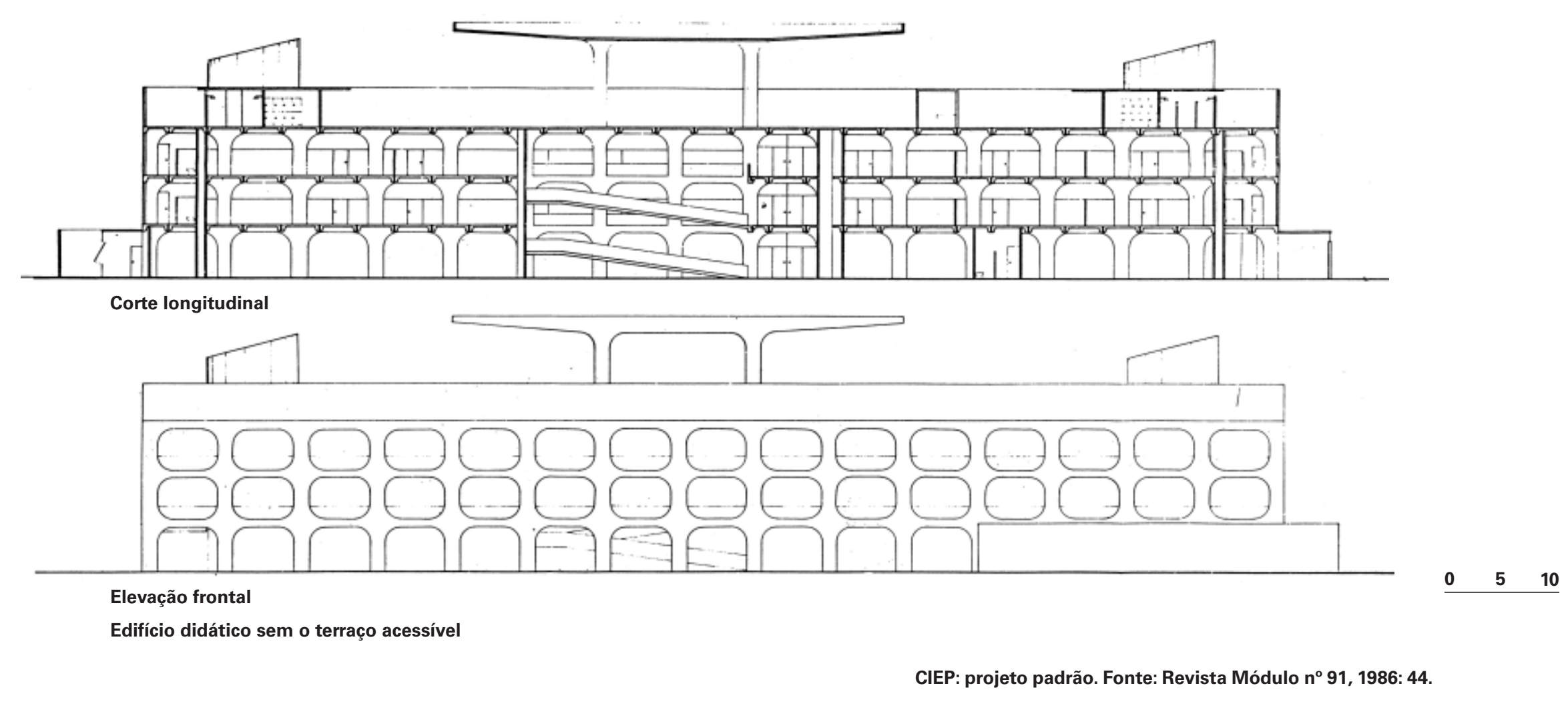



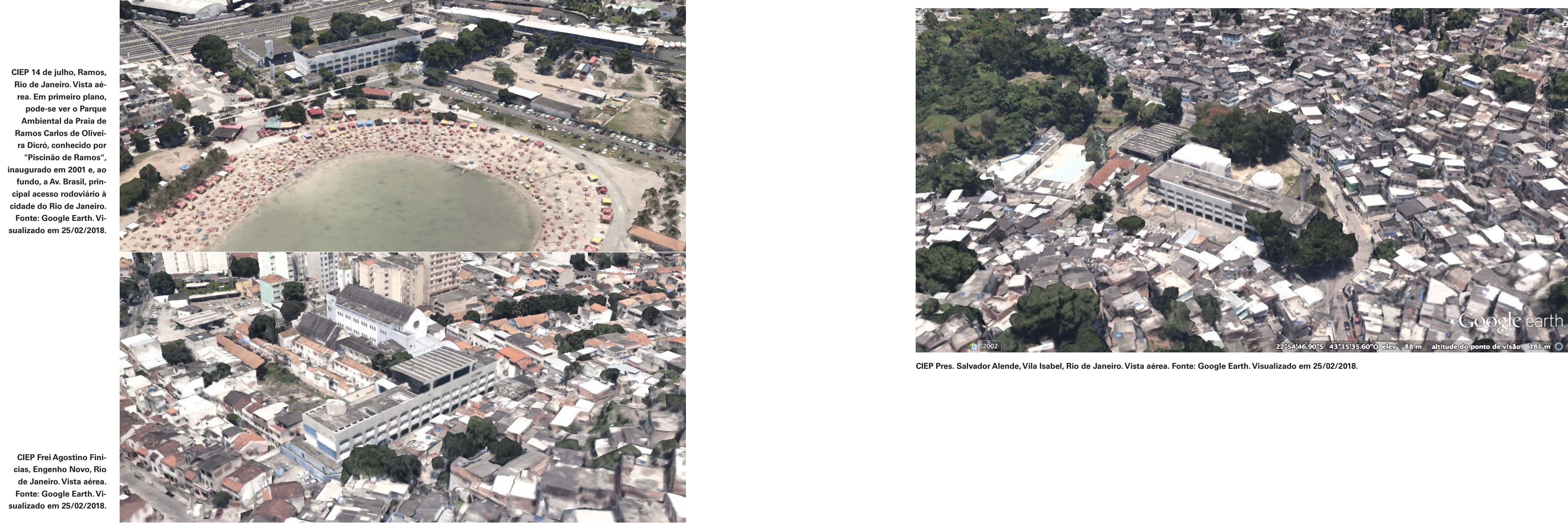

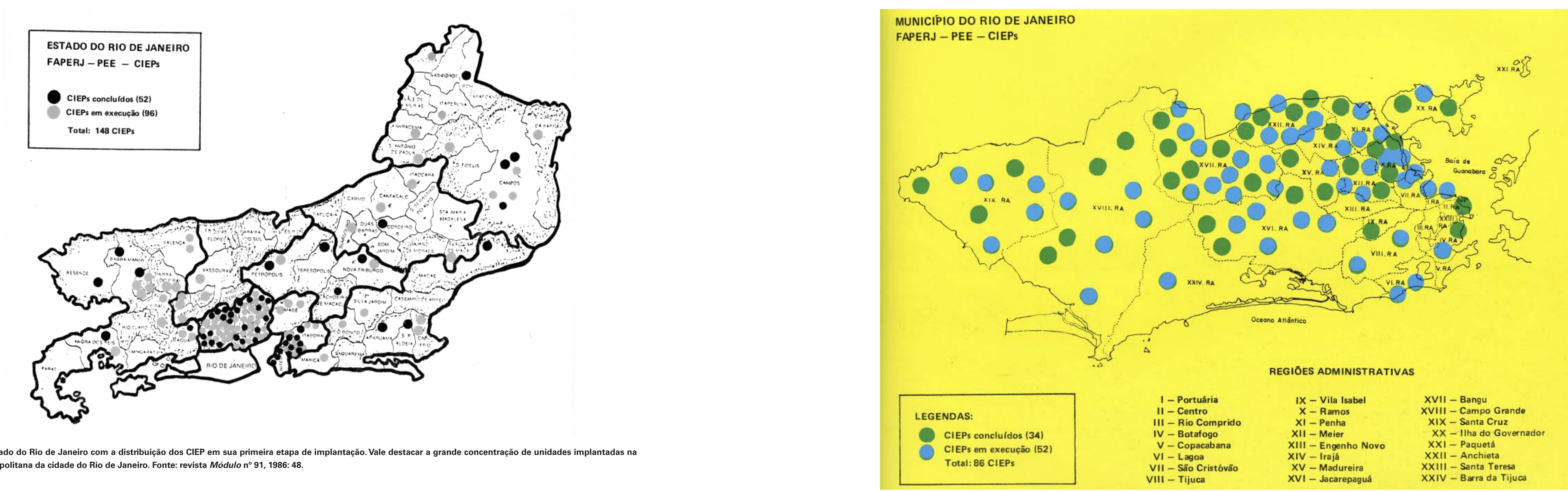
O ano de 1987, que encerra a primeira fase do plano de implantação do CIEP com 127 unidades, também importante para a compreensão do trabalho de Oscar Niemeyer no período pois, no nosso entendimento, ele está vinculado de maneira direta à experiência do CIEP, apesar de aparentes distinç̃oes, como veremos.

Em junho de 1987 a revista francesa L'Architecture d'Aujourd'hui $i^{62}$ publica edição dedicada ao Brasil, após mais de vinte anos da inauguração de Brasília e de um longo eclipse do "sublime compromisso entre arquitetura urbanismo", segundo seu editorial (1987:3). Entretanto, a revista afirma ser um período em que a arquitetura brasileira atravessa a "apologia da diversidade", na qual a permanência da obra de Oscar Niemeyer pode ser comprovad

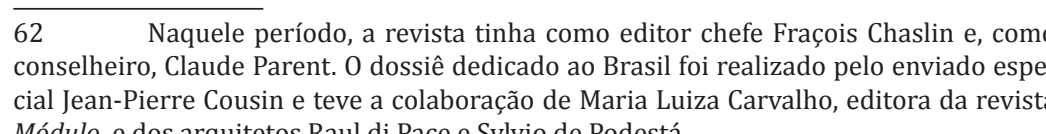

pela construção do Panteão Tancredo Neves, em Brasilia, e pelo programa industrializado dos CIEP no Rio de Janeiro. A primeira, uma obra de "grande atualidade e importante sição dos objetos arquitetônicos que formam a Praça dos Três Poderes, a esplanada mais simbólica da nova Capita. Quanto aos CIEP, afirma-se que "o que é surpreendente é a amplitude como programas de equipamentos escolares socioculturais implantados" (1987: 11-13).

O CIEP é mostrado de maneira simplificada em que as plantas dos blocos são publicadas como "agrupamento típico", destacando apenas o grande esforço de reforma do sistema escolar do Rio de janeiro. Entretanto, chama a atenção uma pequena nota da seção de atualidades (1987: X) em que é apresentada a maquete do projeto de 0scar $\mathrm{N}$ meyer para a futura sede do jornal L'Humanité, porta voz do Partido Comunista francês, a ser construída em Saint-De nis, cidade que faz parte do aglomerado urbano de Paris, e a ser implantada ao lado da Catedral de Saint-Denis, considerada uma das primeiras obras da arquitetura gótica na
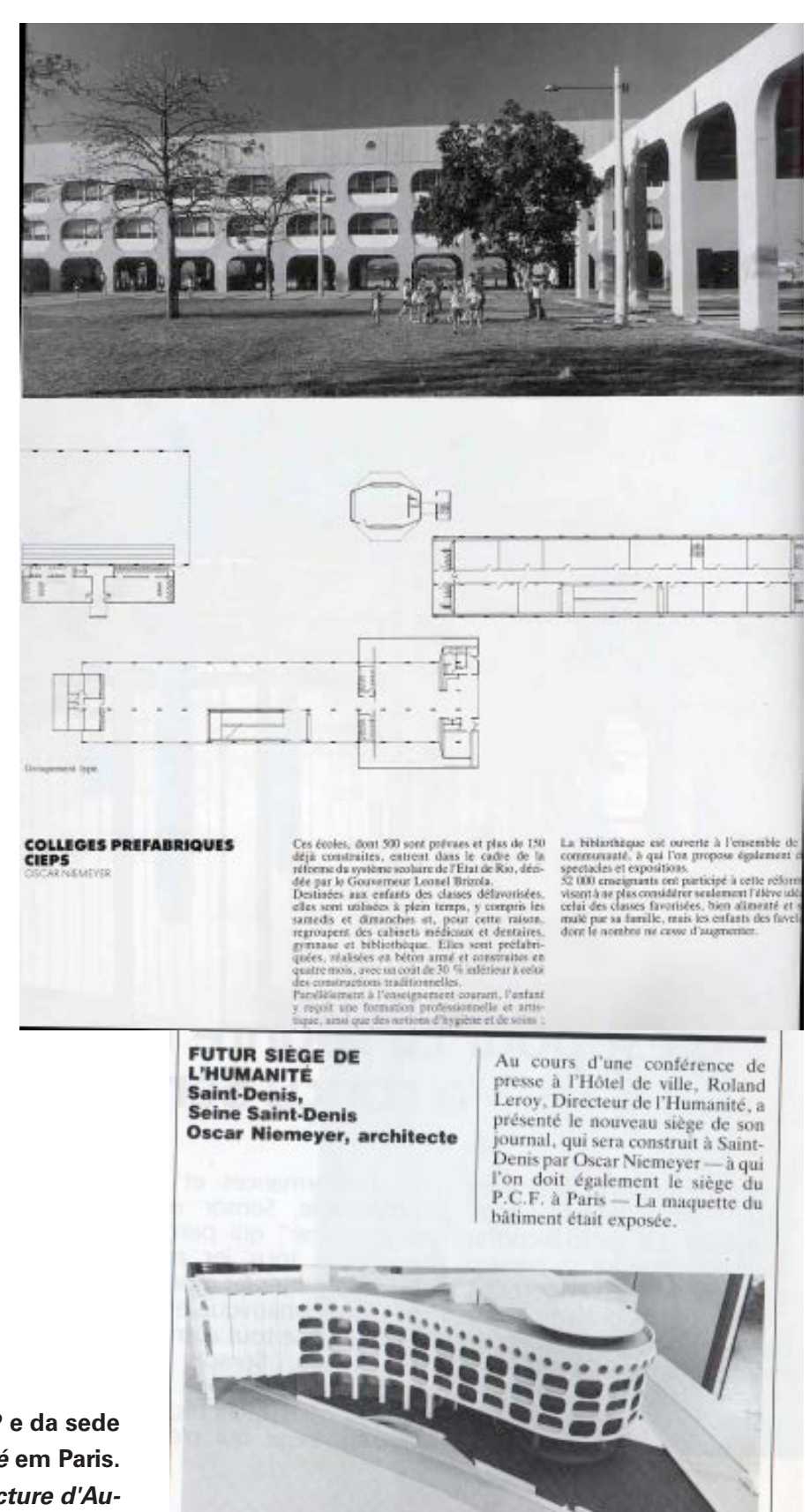

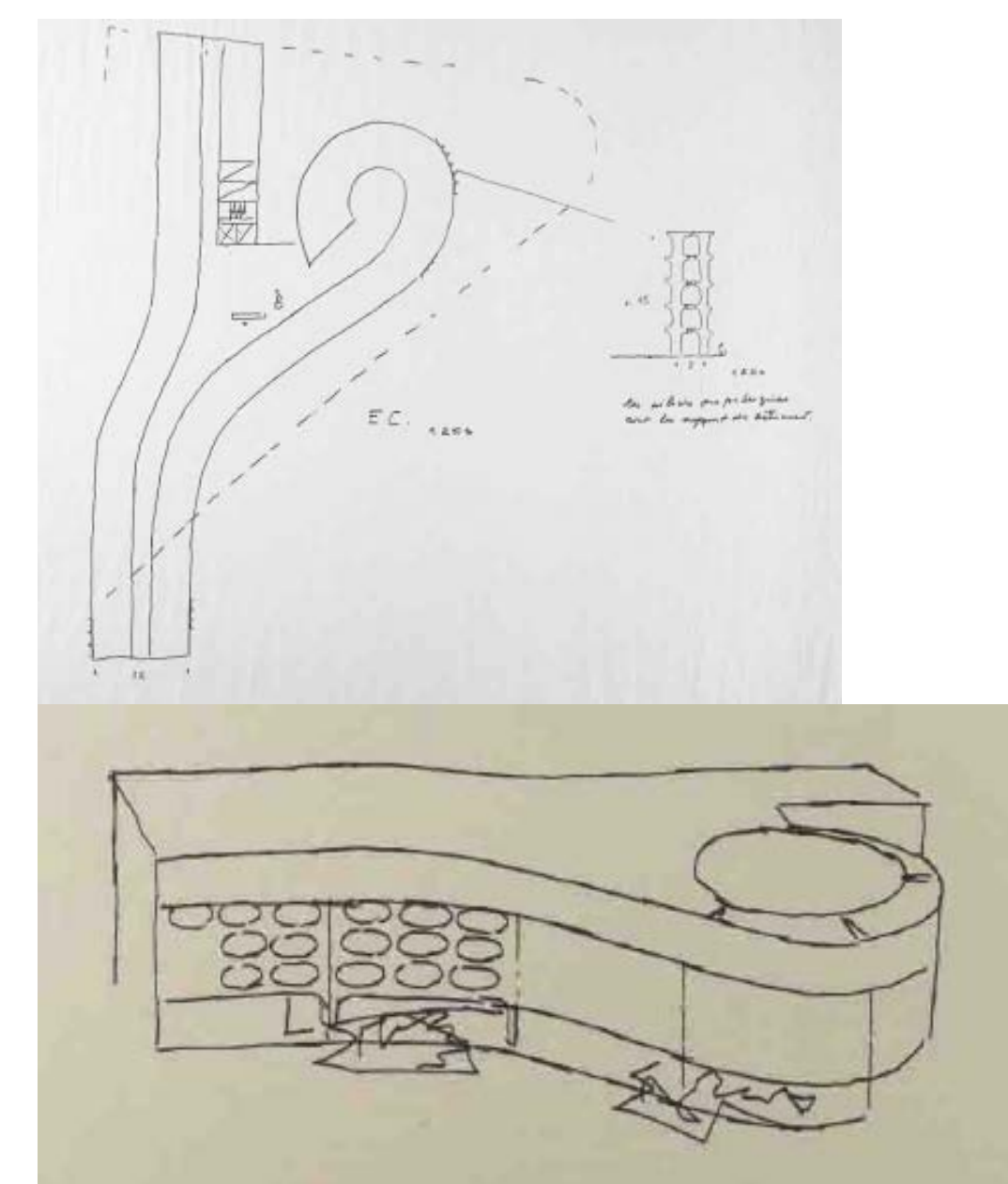

Sede do jormal L'Humanité em Paris, 1987, conforme deserto do Oscer Sede do jomal L'Humanité em Paris,
mever. Fonte: Fundaçąo oscar Niemeyer. 
Europa ${ }^{63}$, e onde estão enterrados os reis da França. 0 que deve ser destacado da imagem da maquete e dos croquis de Niemeyer é a semelhança do projeto com o CIEP no que se refere aos elementos construtivos: os mesmos pórticos que formam o arcabouço do equipamento escolar carioca é empregado em Saint-Denis para realizar uma engenhosa articulação da obra com o histórico contexto urbano. As mesmas intenções construtivas citadas para o CIEP explicam o projeto francês, como afirma o arquiteto en crito: "os pilotis pré-fabricados são os apoios do edifício" Porém, sensível ao contexto histórico, Niemeyer partirá das geometrias sugeridas pela morfologia local como geradora da forma, o que inclui a transposição da rua e o volume cilíndrico junto à esquina. 0 desenvolvimento do projeto trouxe modificações que distanciou a obra dos elementos construtivos iniciais mas aproximou-a do diálogo com o contexto histórico ao optar pelo uso da pele de vidro para definir o volume e refletir a monumentalidade da vizinhança.

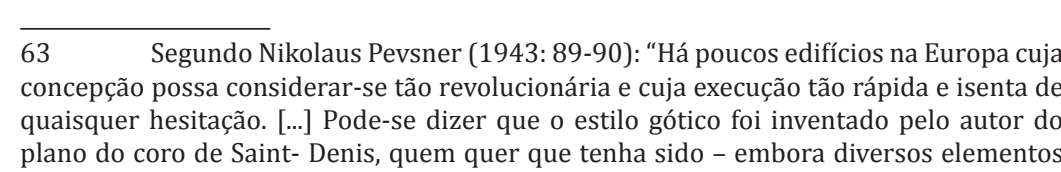

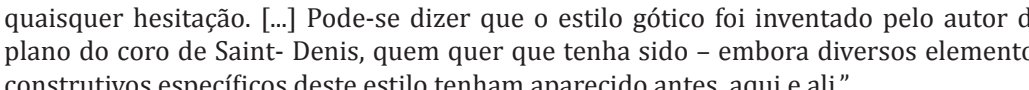
64 Nossa traduscán. Texto original do manuscrito de Niemeyer: Les pilotis pref
Outro fato significativo, que encerra o ano de 1987 e projeto de Oscar Niemeyer para o Memorial da América Latina, 作 como idealizador do programa que pretendeu transforma o amplo terreno remanescente das obras do metrô paulistano em uma praça cívica capaz de enaltecer a integração da América Latina. Niemeyer repete a proposta de objetos arquitetônicos de formas bem definidas, distribuídos en a plataforma mineral, sem que haja qualquer relação com o lugar. A obra foi muito criticada pelos excessos estruturais que a definem e principalmente pela total ausência de integração com o contexto, um desprezo pelo urban enquanto gerador da forma. Ao dar as costas para a cidade, "claramente, perdeu-se uma grande e talvez única oportu-

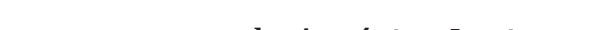
a deterioração

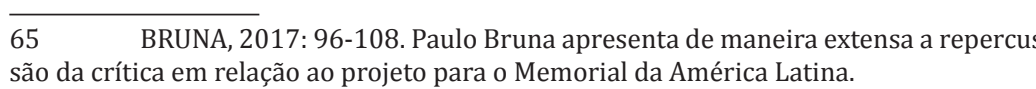

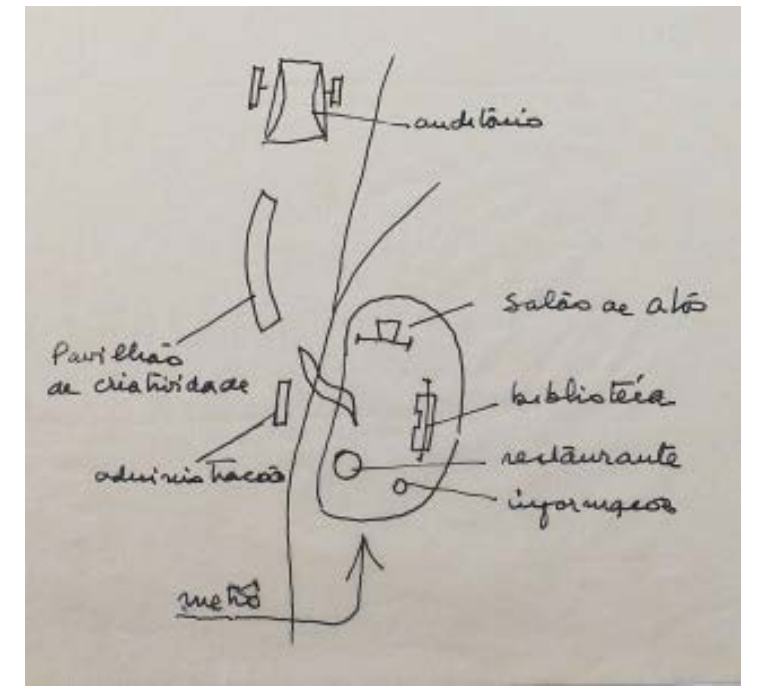

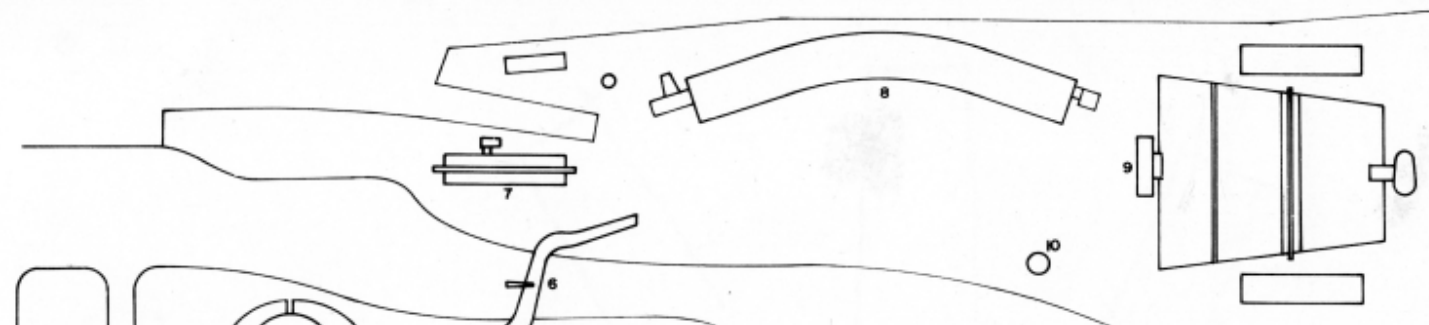

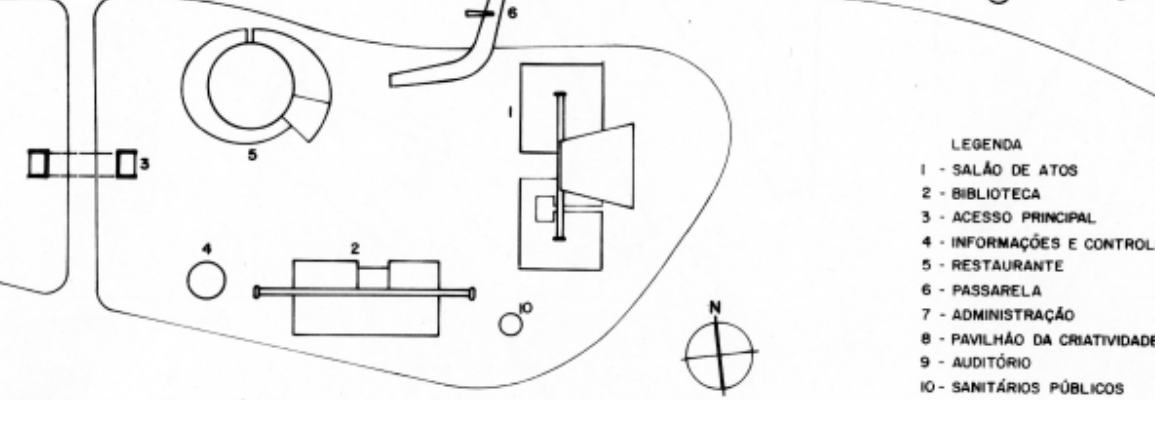

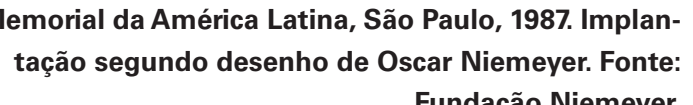

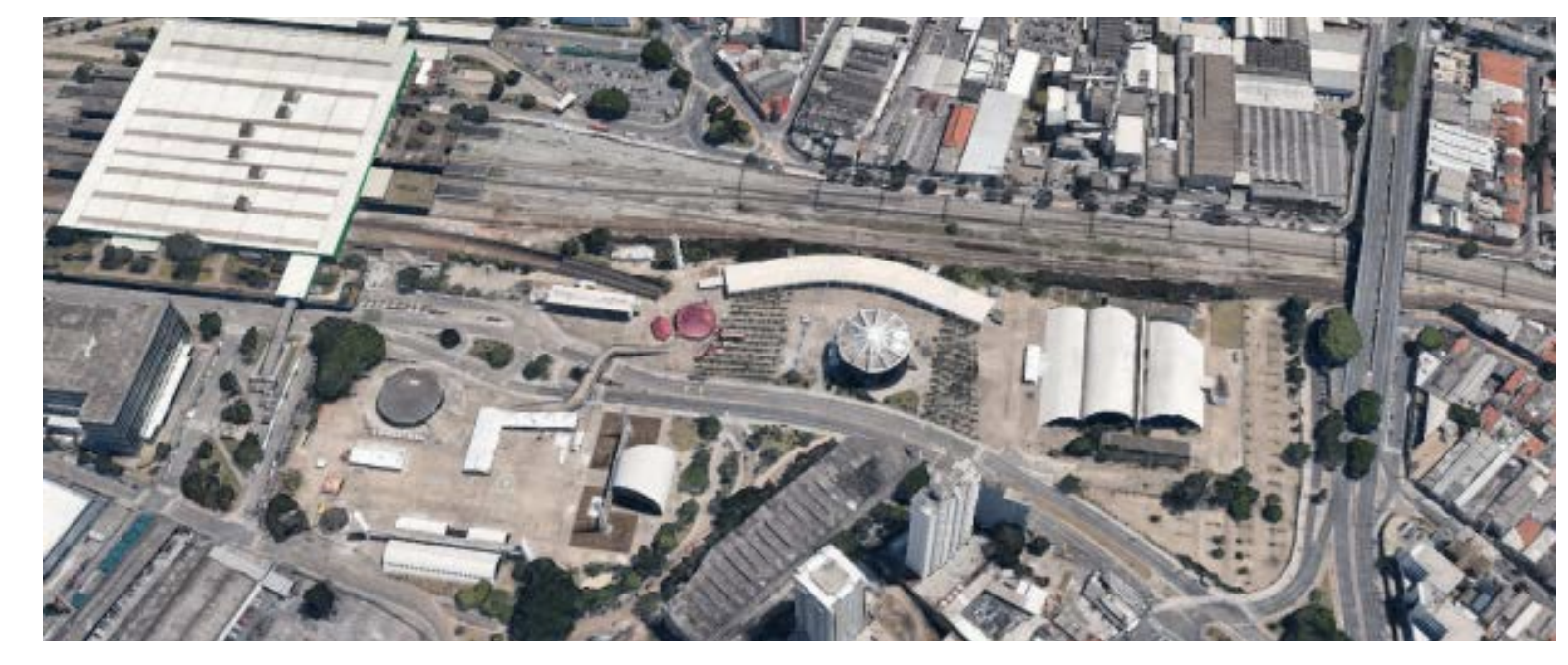


O II Programa Especial de Educação $0^{66}$

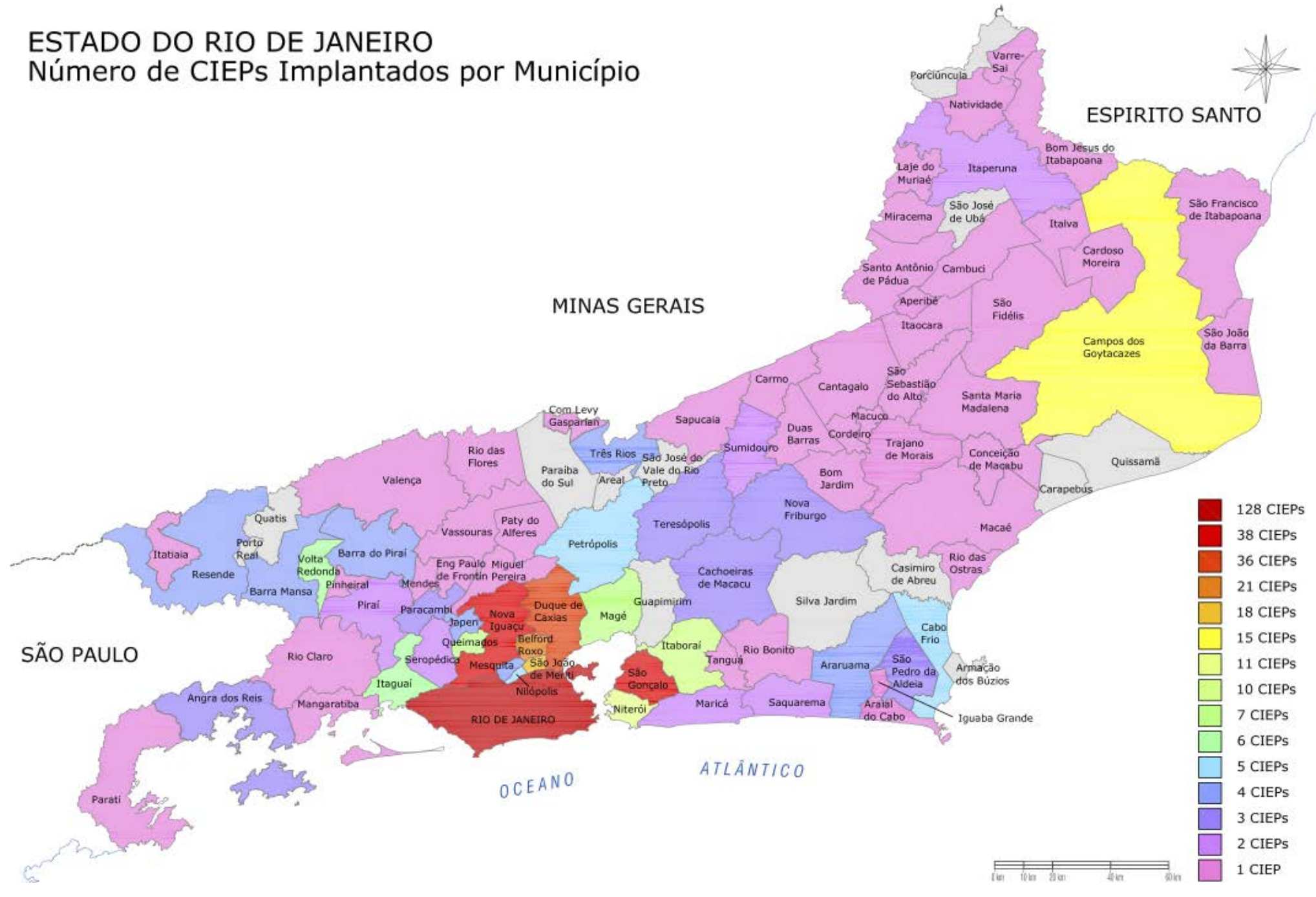

Município do Rio de Janeiro

Localização de CIEPs

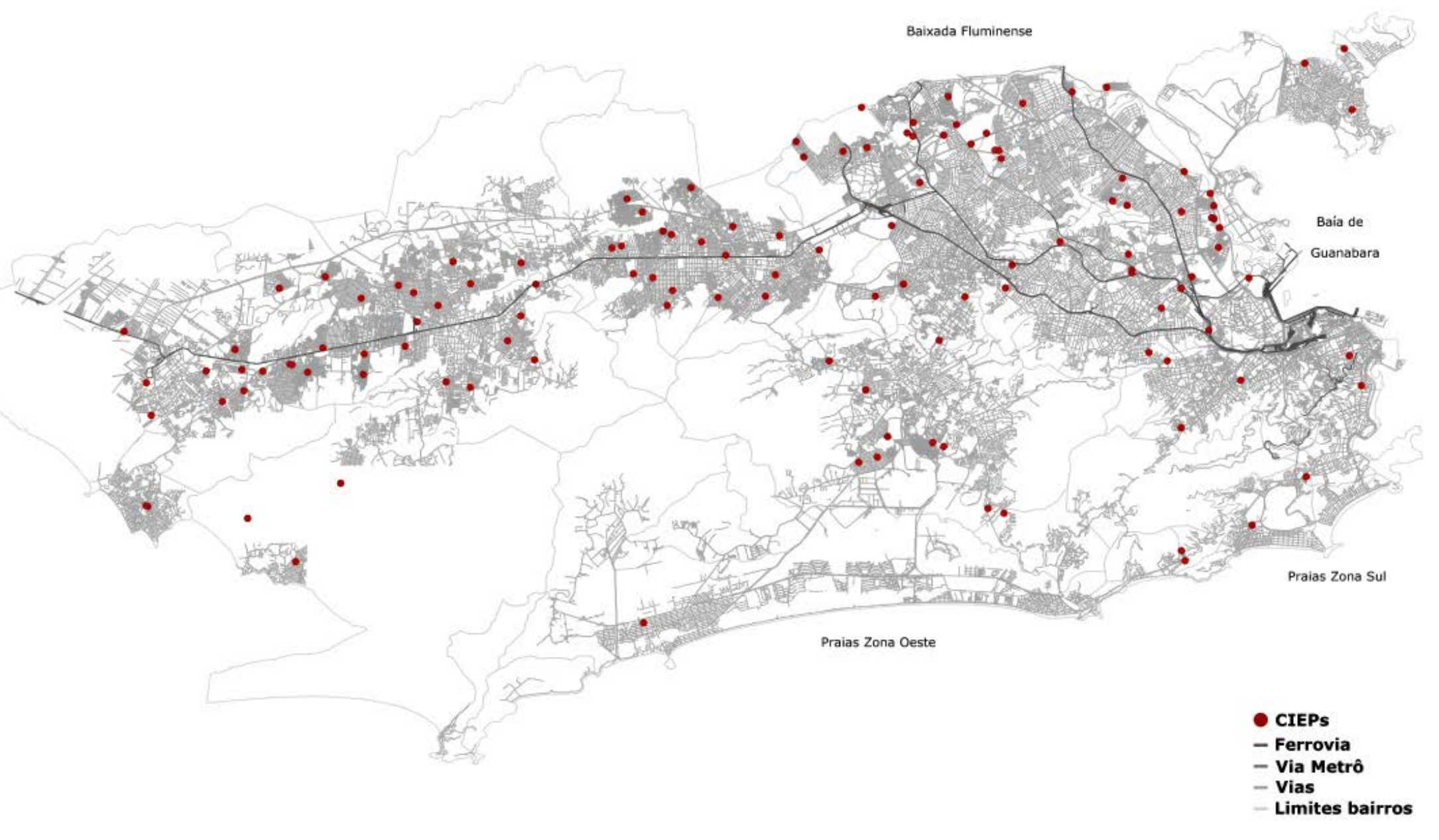


A segunda fase do plano de implantação do CIEP, 1991-1995, foi marcada por um número expressivo de unidades construídas, 379 em todo o estado do Rio de Janeiro, resultado que ultrapassou a meta prevista no plano, totalzando 506 unidades.

Segundo Carlos Dunham (2009: 48), foi também o momento de recuperação dos 127 CIEP construídos durante o primeiro mandato do governador Leonel Brizola que haviam sido descaracterizados pela administração que o sucedeu. Nesse sentido, ficou claro que o programa e a estrutura administrativa responsáveis por ele não foram
( manência fosse garantida independentemente do grupo político o nistraria. A situaç̧ão estaria muito mais relacionada à fragilidade apontada acima do que à solução física materializada pelo projeto de Oscar Niemeyer, como assinala Cândido Alberto Gomes (2010: 60) para quem "a conclusão foi que, no CIEP, o que mais importava não era o prédio ou o tempo integral e, sim, a sua filosofia".

A retomada da implantação dos CIEP foi bastante

eficiente, pois já havia um projeto desenvolvido e testado além de um plano estabelecido, o Programa Especial de
Educação, revisado por Darcy Ribeiro somente em seus as pectos pedagógicos e que representavam sua essência.

Ao confrontarmos as implantações dos CiBP

mais de 30 a do dín do do

meyer podemos também relacionar asper

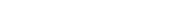

de

tição do padrão se transforma em modelo identificável no

amplo território formado pelo estado do Rio de Janeiro.

Primeiramente, o projeto de Niemeyer, ao ser def-

nido primod

tese da forma, viabilizou sua pré-fabricaç̃ão e consequen- temente sua repetição em prazos relativamente reduzidos,

atingindo a expressiva marca de $3.500 .000 \mathrm{~m}^{2}$ constrú́dos

em doze anos destinados ao equipamento escolar. A in decisivanente para viabilidade do plano limitou, no entanto, as possibilidades de adaptações e de evolução no tempo. Quando o padrão não foi suficiente para atender à demanda local ou ao seu crescimento, a solução encontrada foi repetir o conjunto no mesmo terreno, prejulicando a descentralizaç̃o do equipamento no bairro e gerando maiores dificuldades em sua gestão, situação semelhante enfrentada pela experiência de sistematização da
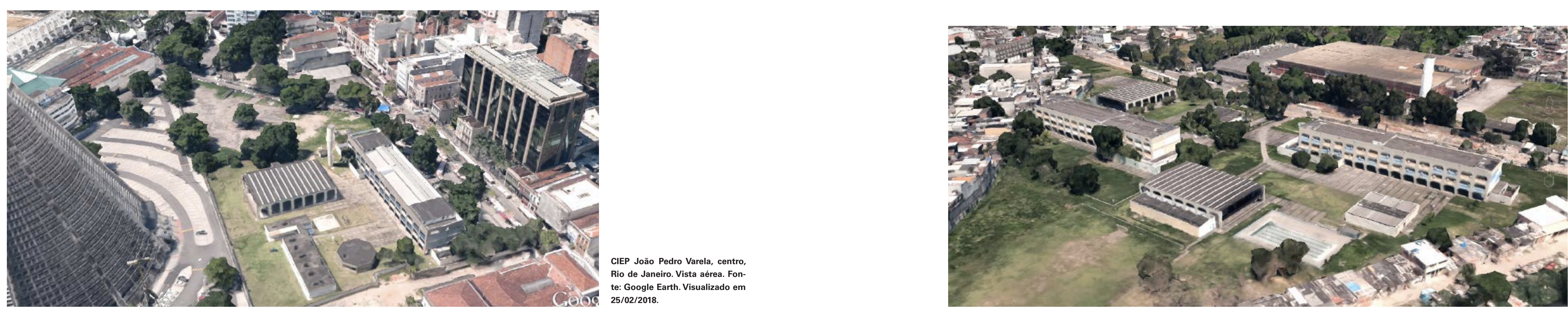

CIEP Maria Wer-
neck de Castro e
CIEP Mario Tamneck de Castro e
CIIPP Mario Tam-
borideguy, Irajá, 
rede escolar idealizada e coordenada por Anísio Teixeira no Rio de Janeiro em 1930, como veremos na segunda parte deste capítulo.

Em seguida, ao serem implantados em 78 municipios, ou seja, em mais de $80 \%$ dos 92 municípios que formam o estado do Rio de Janeiro, o CIEP pode ser identifica do enquanto arquitetura num amplo território de grande diversidade geográfica e que é composto tanto por pequede alta densidade populacional representadas pelas areas metropolitnas da capital. Nesse sentido, o equipamento torna-se referência física na paisagem, sem distinç̃o entre a cidade formal e a cidade informal.

Por outro lado, ao limitar as possibilidades de a ticulação entre os objetos arquitetônicos que compõem CIEP e o contexto, definindo o espaço pubblico materializa-

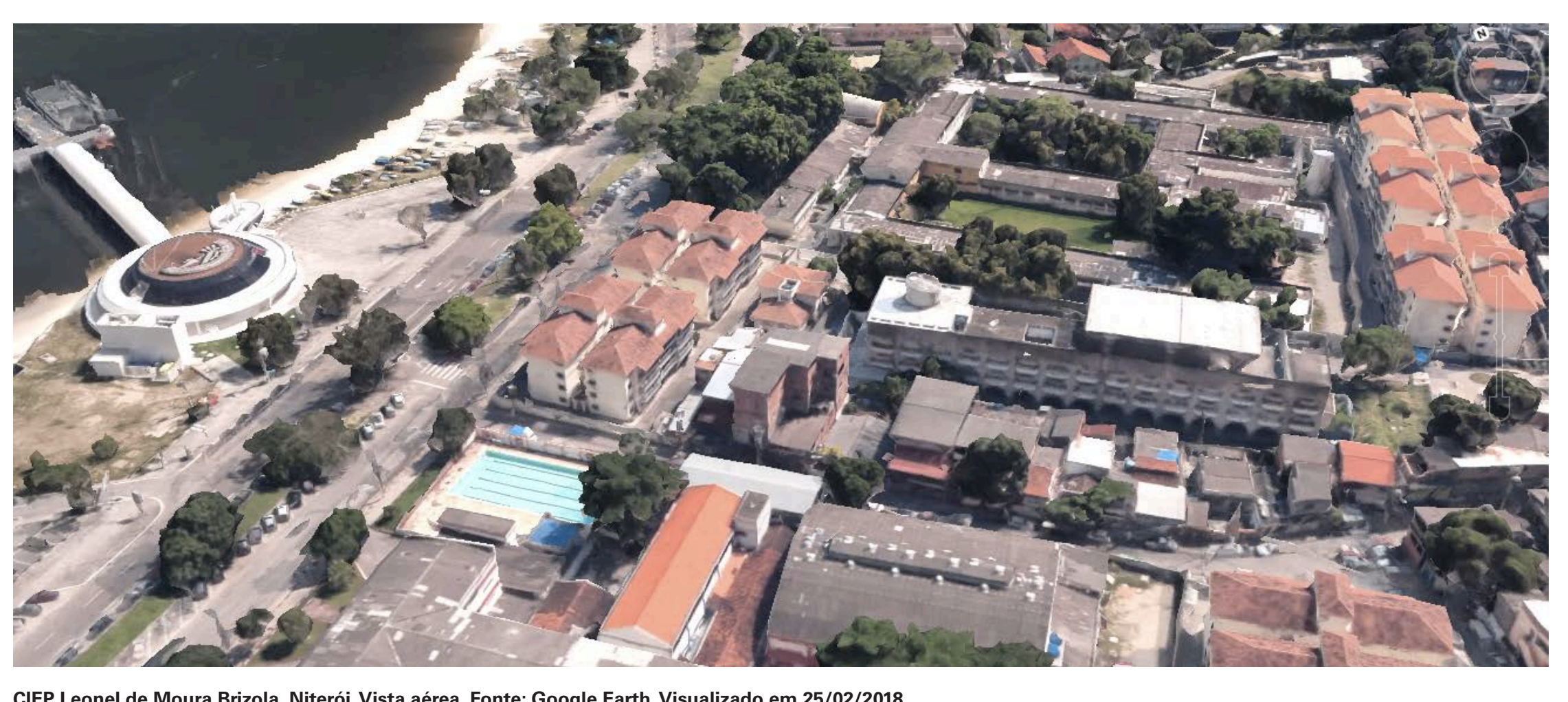

do por uma esplanada no interior do conjunto, o projeto de Niemeyer caminhou, em muitas situacōes, para um sign-

seu projeto para o Memorial da América Latina em São Pau-

lo. Ainda que a escala seja adequada para os terrenos quase

sempre exíguos, a obra surge como definidora do lugar ou

como referência sem, no entanto, poder transformá-lo.
Nesse caso, a repetição cumpre sua missão de redo modelo e da permanência do equipamento na paisagem, mas não promove o que poderíamos chamar de variaç̃o do tema, circunstanciada a cada nova realidade

Ao examinar a situação atual das inúmeras implantações, destacamos que a rede de equipamentos se configura como um arquipélago no revolto oceano urbano, mesmo quando inserido em áreas limites, como pode ser observado em grande parte das implantações apresentadas.

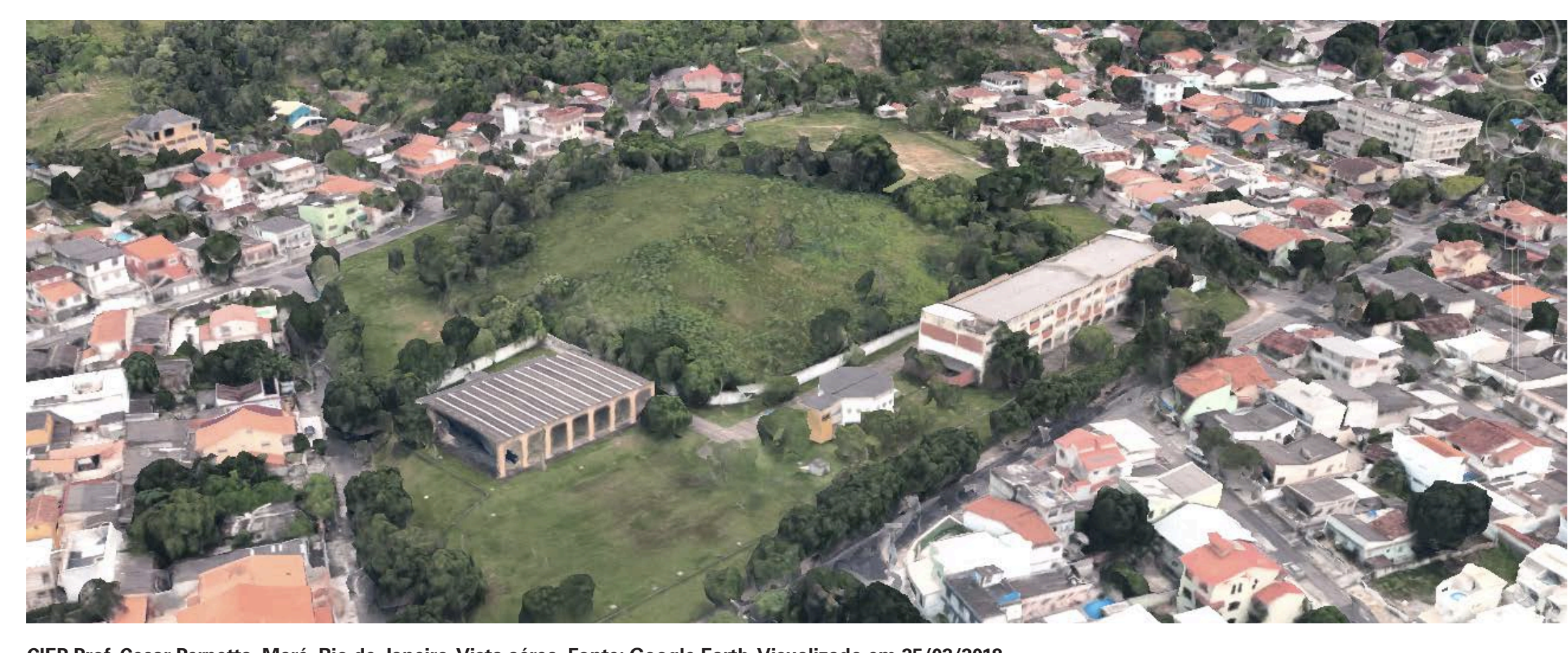



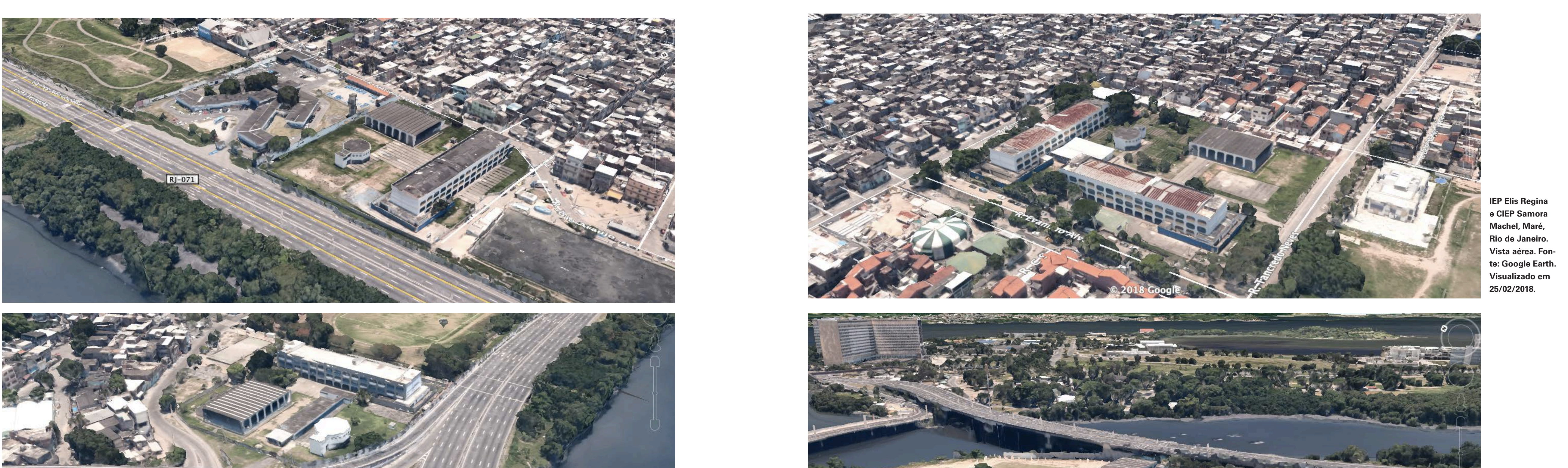
x 5 - 2 

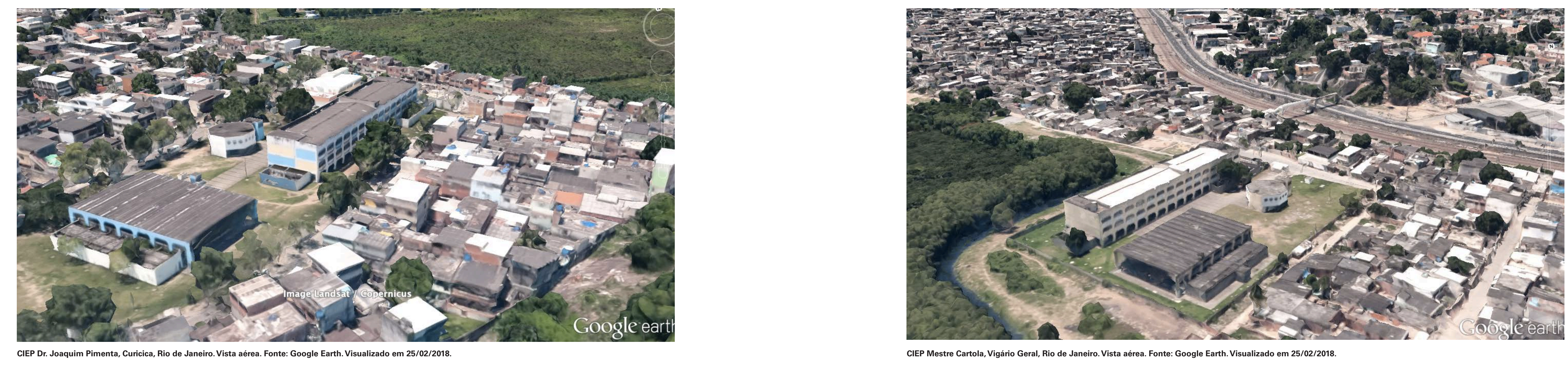


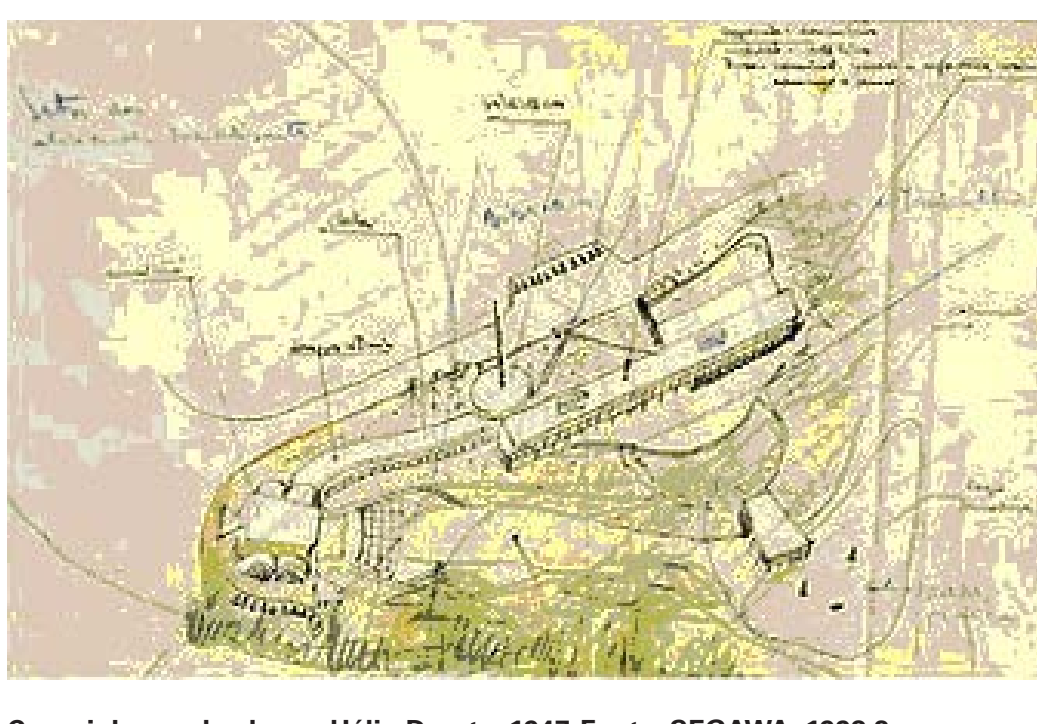

Croqui de escola-classe, Helio Duarte, 1947. Fonte: SEGAWA, 1998:3

lado, o estudo e a compreensão do projeto arquitetônico original e dos projetos dele derivados podem nos oferecer importantes caminos para entender o projeto como mero de enfrentamento da condicãa urbana e social.

Como primeira investigação, cabe-nos examinar origem do projeto arquitetônico, que denominamos CEU Centro Educacional Unificado (CEU I), projeto dos arquitetos Alexandre Delijaicov, André Takiya e Wanderlay Ariza ${ }^{68}$ do Departamento de Edificaç̃es da Secretaria Muni-

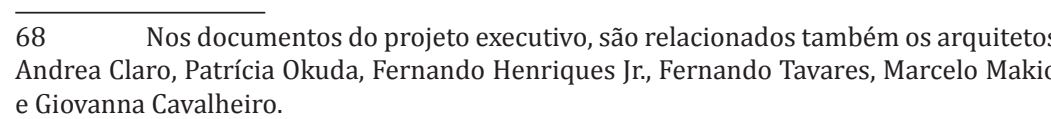

cipal de Infraestrutura Urbana e de Obras da Prefeitura Municipal de São Paulo (EDIF), foi uma iniciativa da administração municipal para responder às carências socioeducacionais da cidade por meio de uma rede de equipamentos públicos de grande porte, distribuídos nas regiões menos atendidas pela nfraestrutura urbana e social do município de São Paulo Essa rede, implantada pela prefeitura entre 2001 e $2004^{\circ}$ resgatou experiências semelhantes, nas quais se inspirou como o progran céca da de 1940 em Salvador promovido pela prefeitura loc e idealizado pelo educador Anísio Teixeira, e o $2^{\circ}$ Convênio Escolar de São Paulo, que na primeira metade da década de 1950 construiu 70 equipamentos socioeducacionais (escolas, bibliotecas, teatros e parques infantis) ${ }^{70}$, projetados pela tor da Comissão Executiva do Convênio.

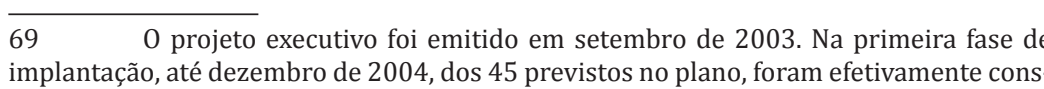

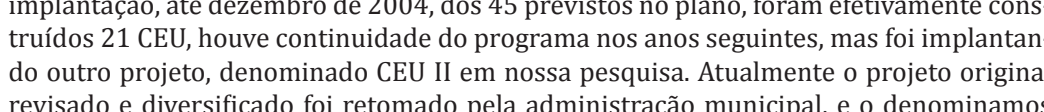

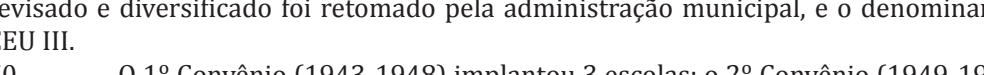

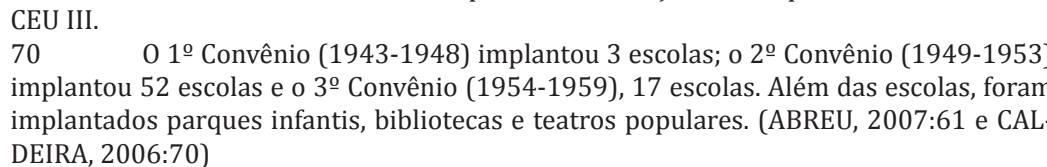

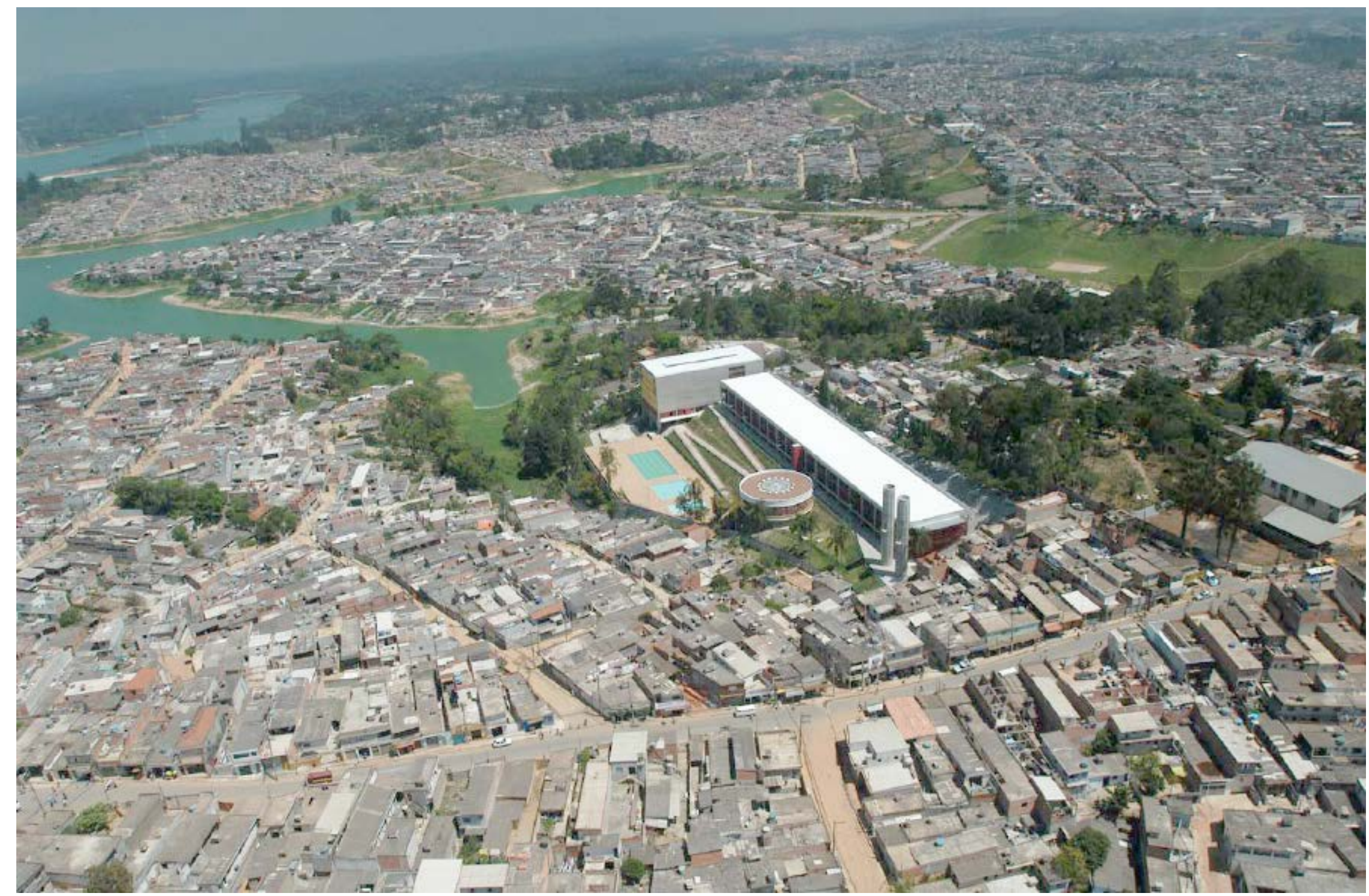

CEU Navegantes, vista aérea Fonte: David Rego Jve Beto Garavello. Fonte: EDIF 
Seguindo a lógica de seus antecessores, mas ampliando de maneira significativa a escala das edificaçõos projetadas, foram construídos, a partir de um único projeto, 21 CEU com aproximadamente $13.500 \mathrm{~m}^{2}$, num sistem pré-fabricado em concreto armado e aço, de um total de 45 conjuntos planejados.

magnitude da primeira fase de implantação dos CEU, proporcional à escala metropolitana da cidade, foi motivo de diversas publicacões especializadas, nacionais e internacion 1 tes para c̃ò s̀ à sua genealogia, aspecto que desenvolvemos a seguir No texto introdutório da revista portuguesa Jornal Arquitectos, de 2004, os autores do projeto indicam a origem dos CEU. Citam ainda como, com a proposta da Praça de Equipamentos, a equipe da EDIF avançou nos conceitos introduzidos no Brasil no final da década de 1940:
CEU como Praça de Equipamento recupera o conceito de escola/parque escola/classe idelizado pelo educador Anísio Teixeira e pelo arquiteto Hélio Duarte no final dos anos 40 dentro du Comissão Executiva do Convênio Escolar (atual EDIF - Departamento de Edificac̃es do Secretria de Servicos e Obras da Prefeitura do Municpio de São Paulo). (DELIIAICOV 2004: 3 em negrito no texto original)

No mesmo ano de 2004, o artigo de Renato Anelli, Centros Educacionais Unificados: Arquitetura e Educação em São Paulo, publicado na Itália e na Sú́ça ${ }^{71}$ confirma as citadas referências de ordem programática e arquitetônica e mostra também como a abrangência do Convênio Escolar foi extremamente significativa para a cidade de São Pa lo

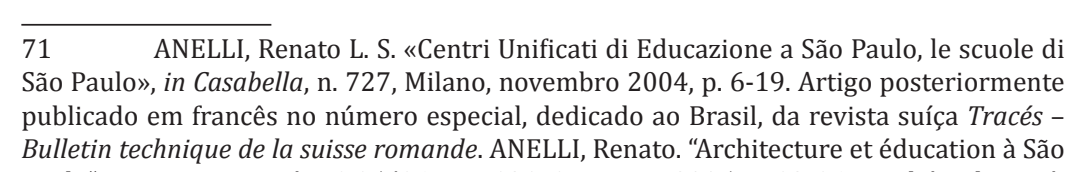

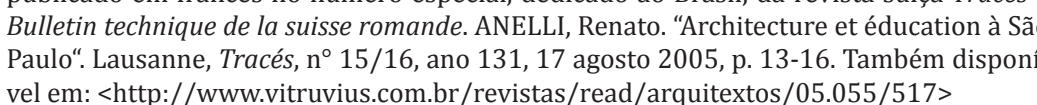

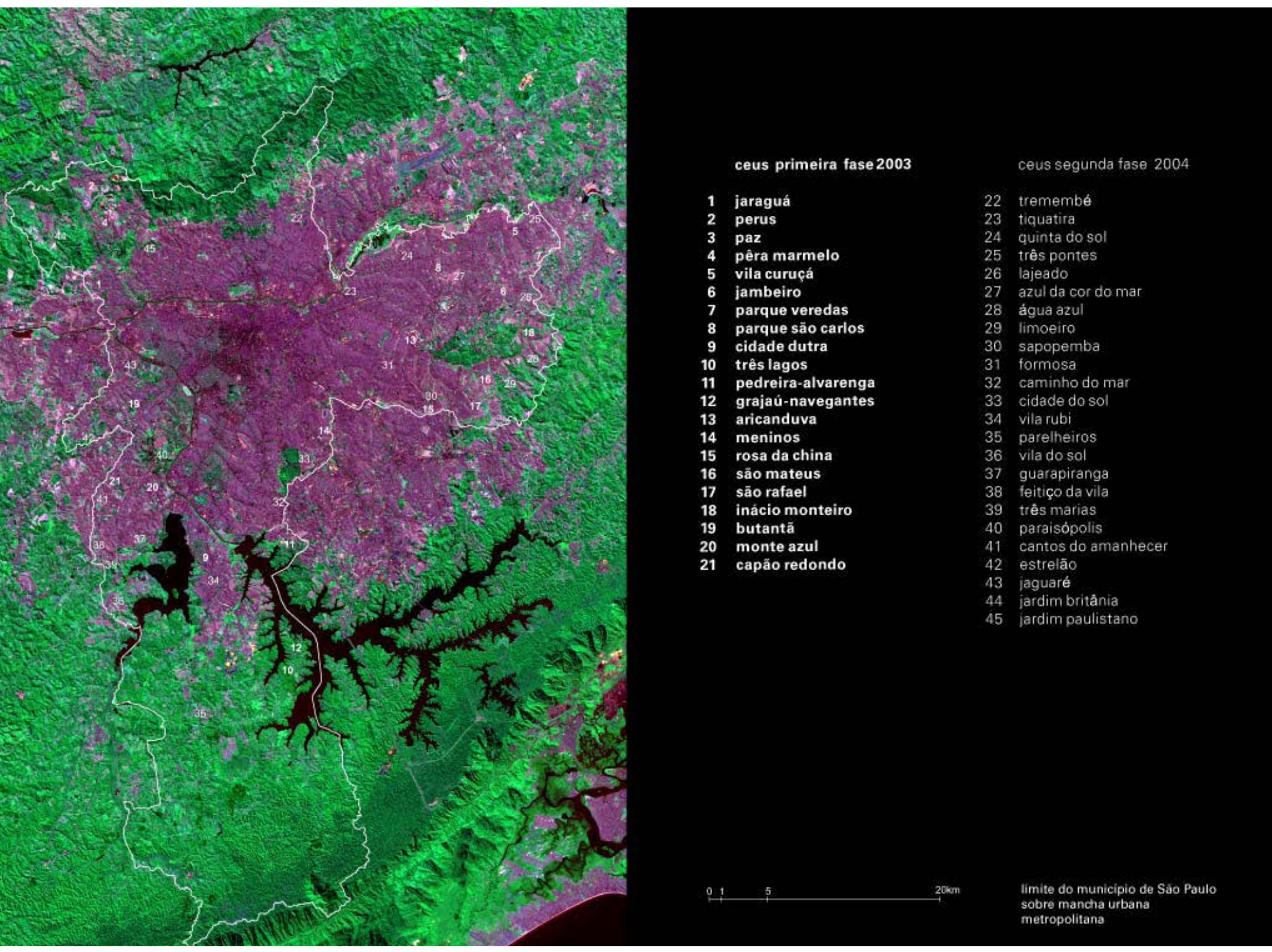




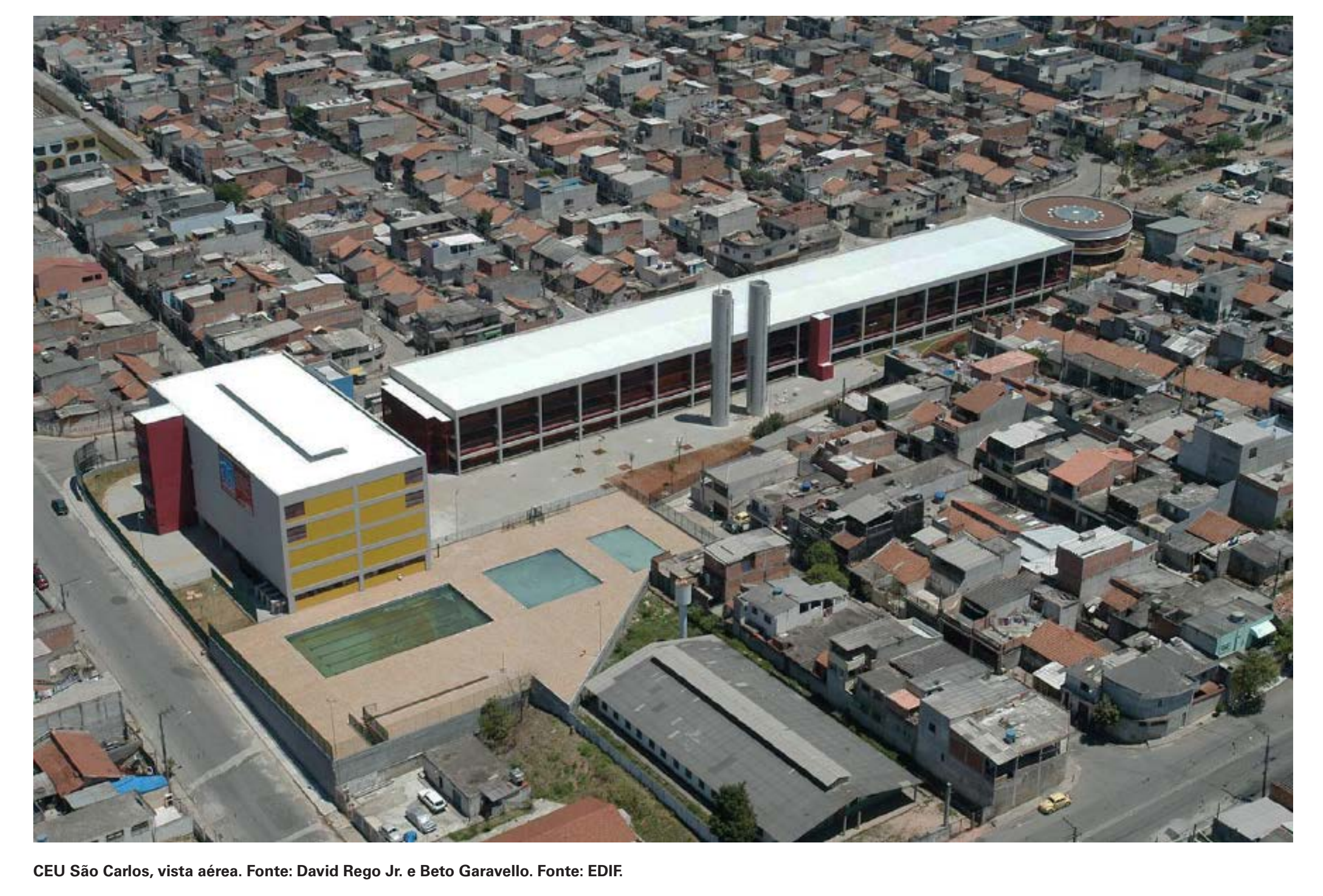

arquitetos conceberam uma escola parque. En

meio a uma grande área verde, a transparência

das salas de aula tornava obsoletos os prédios

escolares da época, até então enclausurados em

suas pesadas alvenarias.

As oscilações da política impediram a continui-

dade dessa experiência em Salvador o que veio

a ocorrer na cidade de São Paulo quando Duarte

assumiu a direç̃o de planejamento da Comissão

Executiva do Convênio Escolar (1948-1952).

rápida expansão urbana de São Paulo na décad

de 1940 havia levado a um monstruoso déficit de

vagas em escolas. Pressionados por movimentos

populares, Prefeitura Municipal e Governo Esta-

dual firmaram um convênio para a construção

e operação em massa de escolas, propondo-se

a construir em 5 anos 100 escolas para atender a 48.000 crianças. Objetivo que seria superado com a construção de 140 unidades entre escolas. parques infantis, bibliotecas e teatros populares. (ANELLI, 2004: 6) s caracteristicas de sua implantação "em uma grande área verde" e de sua salas de aula "transparentes", responsáveis pela qualidade de sua arquitetura comparad aos edifícios "enclausurados" da época. É certo que as duas características associadas a uma mesma obra escolar são portadoras de condições inovadoras, porém seguramente podem encobrir seus verdadeiros atributos arquitetônicos como veremos adiante ${ }^{27}$.

As publicações brasileiras especializadas também relataram as origens do projeto dos CEU após a sua primeira fase de implantação e no momento em que sua continuidade estava baseada em uma modificação do projeto original. 0 artigo de Maria Alice Bastos lembra a importância do equipamento público - "praça ou clube de lazer"- para o atendimento de toda a comunidade

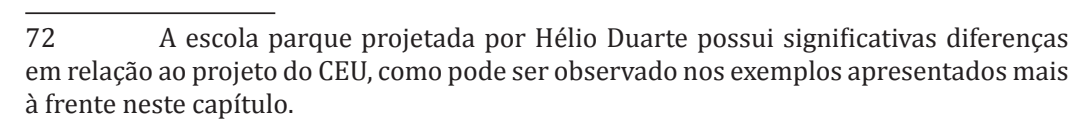

CEU Sāo Carlos, vista aérea. Fonte: David Rego Jr. B Beto Garavello. Fonte: EDIF. 
Os CEUs ocupam áreas nos rincões mais carentes do municíipio e têm a proposta de oferecer um programa educacional amplo, que inclui esportes e áreas artísticas. Além das questões educacionais, seu espaç físico é liberado para uso como praça ou clube de lazer nos finais de semana ara encontro da comunidade. No caso dos CEUs, a inspiraç̃õo na escola-parque de Anísio Teixeira parece ser também arquitetônica. 0 projto faz homenagem ao desenho moderno que Teixeira tanto prezava e e involuntariamente que Teixeira ga simbólica que se mesclou a ele em termos de utopias sociais. (BASTOS, 2009)

A autora ressalta, ainda, o fato de que, em relação à escola-parque, a inspiração do CEU não seria apenas de ordem programática pois considera um "desenho moderno", tão prezado por Anísio Teixeira. Aspecto importante para nossa pesquisa, tal afirmação nos leva à seguinte pergunta: qual seria o "desenho moderno" em que o CEU se inspira? Alexandre Delijaicov, já em 2011, portanto após uma década do início da implantação da rede CEU, menciona um dos fundamentos ainda mais significativos do projeto, $o$ que nos apresenta com maior clareza uma possível genealogia baseada no trabalho da equipe liderada pelo arquiteto Affonso Eduardo Reidy no Rio de Janeiro:
No Rio de Janeiro, surgem alguns intelectuais como o Anísio Teixeira, um grande educador, e Reidy, arquiteto pouco lembirque foi sempre um servidor público que proje de infraestruturas urbanas a arquitetura de equipamentos públicos e a arquitetura da habitação social, integradas.

№ Brasil a promulgã̃o dos direitos humanos 1948 foi um momento muito importante Antsio Teixeira e um grupo de jovens arquitetos, que trabalhavam ou estavam muito ligados às ideias desenvolvidas no Rio de Janeiro, vieram para Sã conceito de redes: a rede de escolas públicas municipais. Em 1948, montou-se, por meio de uma equipe (Comissão Executiva do Convênio Escode São Paulo para que fossem projetadas e consescolas-praça ${ }^{73}$ seriam projetadas nos bairros da periferia daquela época, os bairros operários. (DELIJAICOV, 2011: 1)

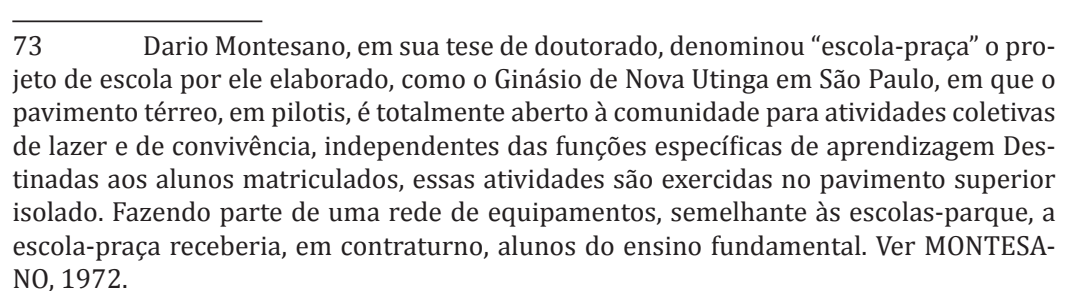

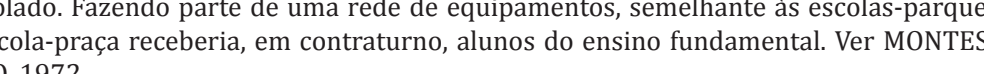
Paulo, junto com Hélio Duarte, para implantar o lar), um convênio entre o Estado e o Município truídas 50 escolas- parque. As escolas-parque

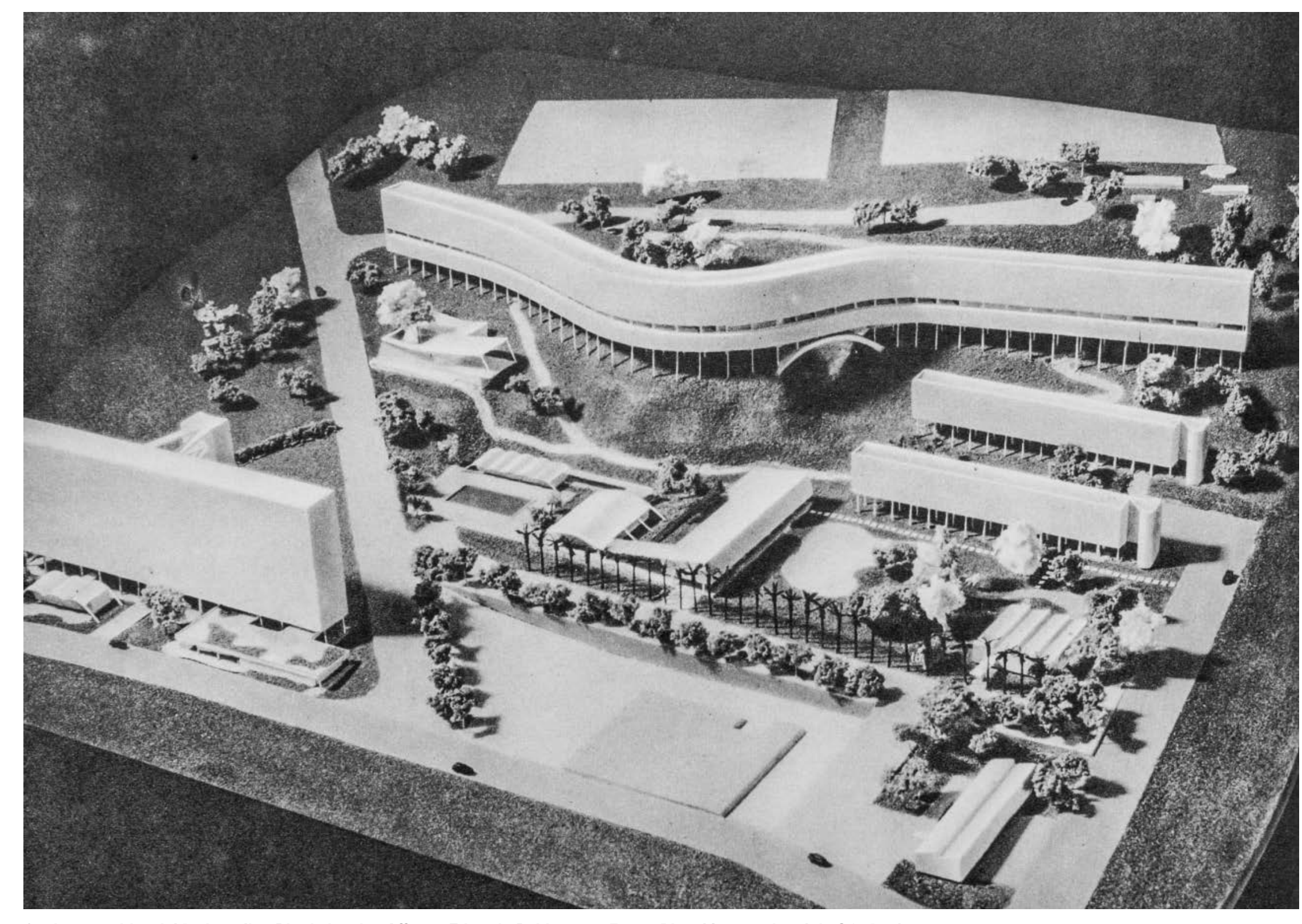


No trecho acima, Delijaicov, além de reafirmar a inspiração na experiência do Convênio Escolar, cita o período carioca de atu presença e a liderança de Affonso Eduardo Reidy nas ideias que nortearam a arquitetura produzida do Rio de Janeiro naquele período, dentro de uma visão de cidade em que infraestrutura, equipamento e habitação estão integrados. Essa condição inovadora deve ser destacada no âmbito da nossa pesquisa.

Nesse sentido, há uma contribuição importante para o entendimento da referida genealogia que havia sido sintetizada anteriormente por Segawa na edição da revista Projeto (1986) dedicada à arquitetura escolar, quase duas décadas antes do projeto do CEU. Nela, Segawa fala das construções escolares desde a Primeira República e destaa "chegada" da arquitetura moderna em São Paulo, incialmente de maneira "sóbria e discreta", após a criação da Comissão Permanente de Ensino e do Código de Educação do Estado em $1934^{74}$ e que vai se expressar com muita força a partir do final da década de 1940, durante a celebração do 2o Convênio Escolar entre a Prefeitura Municipal e 0 Estado de São Paulo:

74 De inspiraçắ carioca. Ver CALDEIRA, 2005: 24.
Convênio Escolar 1949-1954: Comissão Executva instalada em 1949. 68 prédios escolares, projetados por arquitetos como Edurdo Coron Roberto Tibau, Oswaldo C. Goncalves, o prón H. Duarte e o engenheiro Ernest Robert Carvalho Mange. Introduzia-se então, en $S P$ a arquiletra moderna de inspiração carioca em abras oficiais, moderna de inspiração carioca em obras oficiais, sob o traço de arquitetos formados no RJ (Duarte, zadora [...] (SEGAWA, 1986: 64)

Fica claro, portanto, que as profundas transformações do equipamento público escolar em São Paulo podem ser explicadas pela introdução da arquitetura de expressão moderna carioca trazida pelos arquitetos formados no Rio de Janeiro. Essa é uma condição fundamental para a comto do CEU porém não significa ter sido o único caminho percorrido pela arquitetura pública moderna em São Paulo.

Paulo Bruna mostra-nos como, antes do Convênio Escolar, Os Primeiros Arquitetos Modernos projetaram construíram em São Paulo conjuntos habitacionais de gran- de qualidade, cuja arquitetura fora baseada nas noções de modernidade introduzidas na Europa no período entre as duas grandes guerras ${ }^{75}$. Bruna, entretanto, tam sidera que em relação aos projetos dos conjuntos habitacionais, o itinerário do Movimento Moderno até São Paulo passa primordialmente pelo Rio de Janeiro, então Capita Federal ${ }^{76}$. É possível notar que em boa parte dos projetos paulistas a presença do equipamento escolar é marcante mantendo coerência com a arquitetura dos conjuntos. Vale destacar ascola stadualde por Carlos Frederico Ferreira no conjunto Vila Guiomar, en Santo André (1940), a escola do conjunto Várzea do Carm (1942), de Attílio Corrêa Lima, Hélio Uchôa e José Theodulo da Silva e, em especial, a escola maternal e a escola primári do Conjunto Cidade Jardim (1944) de Eduardo Kneese de Mello, que teve Hélio Duarte como colaborador, pouco tempo antes do início de sua atuacão como Diretor Executivo do 20 Convênio Escolar.

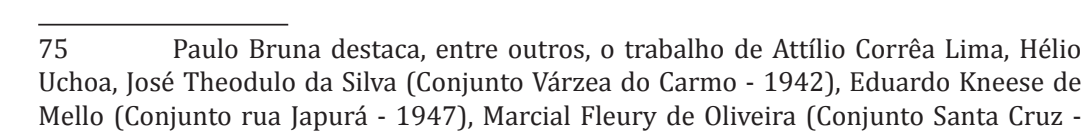

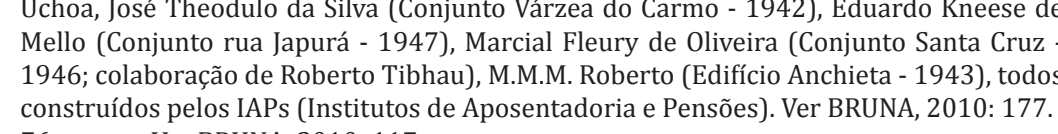

erreira, por exemplo, publicou o projeto da escola em Vila Guiomar (1940) na revista Arquitetura e Engenharia em $1950^{77}$, dedicando parte substancial do artigo para os "critérios de estudo" na concepção da referida obra. Cinco das oito páginas publicadas foram dedicadas aos parâmetros que orientaram o projeto com ênfase na sala de aula apresentando dados comparativos com experiências internacionais, como o Colégio Karl Marx, em Villejuif na França, do arquiteto André Lurçat que estudaremos mais adionte neste capítulo. Carlos Ferreira apresenta uma extensa reflexão das condições ambientais encontradas e como orientaram e fundamentaram o projeto da escola. 0 equipament é tratado, assim, com grande importância para o projeto do Conjunto Residencial de 2.000 moradias.

implantação da escola, em terreno que domin visualmente o bairro, é marcada pela presença de dua edificações paralelas em relação à rua e alternadas entre si, cujos pilotis, que ocupam a quase totalidade do térreo conformam dois ambientes de recreação protegidos, ao "ar

7 Ver revista Arquitetura E Engenharian n 14, 1950: 53:61. 

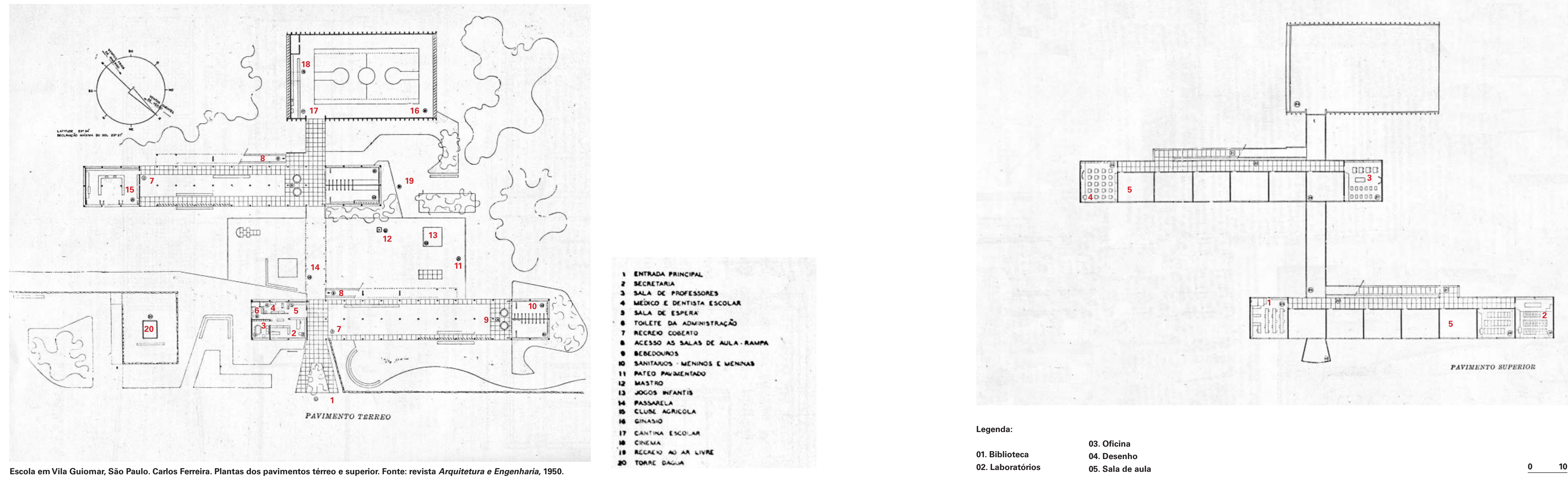

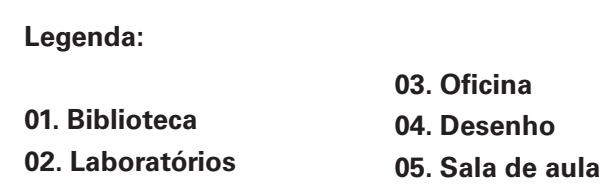


livre", também alternados. Dessa forma, é constituído um eixo de circulação transversal, coberto por uma pequena marquise em concreto armado, que interliga a rua, os blocos didáticos e o gnasio cober sas características confirmam a filiação da obra de Carlos Ferreira à arquitetura moderna praticada no Rio de Janeiro naquele momento $0^{78}$.

O que merece destaque são suas preocupações para fundamentar as escolhas do projeto, sobretudo pelo minucioso trabalho de detalhamento das fachadas das salas de aula do pavimento superior, com acesso por rampa, o que o aproxima das preocupações higienistas e funcionalistas da arquitetura moderna do período entre as duas grandes guerras e antecipa parte significativa da atuaç̃̃o da equipe do 20 Convênio Escolar em São Paulo e do trabalho de Richard Neutra, como veremos adiante.

Podemos então admitir que, no que se refere às transformações da arquitetura escolar, as evidências apontam para os conceitos disseminados por Anísio Teixeira, desde sua atuação como Secretário da Capital Federal, e para a arquitetura carioca praticada por Reidy. Em outras palavras, podemos entender as referidas transformações por duas visões não conflitantes, mas que apontam resultados diferentes, como iremos verifica

Programa como arquitetura: Teixeira e Rio de Janeiro, Capital Federal
A inegável contribuição de Anísio Teixeira, nascido na Bahia, para a renovação do ensino em seus diversos ní veis no Brasil do século XX pode ser comprovada pela extensa bibliografia que trata dos seus aspectos pedagógicos e sociais, o que refletiu diretamente na estrutura física necessária para isso. Do ponto de vista da arquitetura, nosso estudo concentra-se nos períodos que se tornaram referência sobre $o$ assunto.

Em primeiro lugar, sabemos que o trabalho empreendido por Teixeira para a sistematização da rede es colar no Rio de Janeiro na década de 1930 foi baseado n experiência norte-americana conhecida como Escola Platoon, que associava o ensino às práticas esportivas, artísra a amplos programas que, além da sala de aula, deveriam prever ambientes para o esporte (ginásios e campos), para as artes (ateliês e auditórios) e para trabalhos manuais (oficinas), 79 Ver também ABREU (2007: 29-40). 
seriam necessários terrenos extensos, o que dificultou sua implantação na cidade do Rio de Janeiro. Para solucionar tal problema, a rede proposta por Teixeira, inserida no Plano Urbanístico de Alfred Agache para a Capital Federal, foi sistematizada através de dois tipos de escola - escola-classe e escola-parque - em que,

[o] primeiro seria destinado ao ensino tradicional [...], e o segundo, para as atividades especial formativas e complementares de artes, esportes, higiene, biblioteca, atividades manuais e industriais [...]; [em] período integral, aulas alternadas […] (ABREU, 2009: 31)

Com esse princípio, uma escola-parque de grande extensão poderia atender quatro escolas-classe, introduzindo a noç̃̃o de rede de equipamentos escolares que funcionariam em regime de alternância de turnos. Ainda dentro da sistematização proposta, havia seis tipos de edifício padrão, projetados pela Divisão de Predios e Apparelhamentos Escolares, coordenada por Enéas Silva ${ }^{80}$, proporcionais à capacidade de alunos, que compreendiam a Escola Tipo Mínimo (240 alunos - 2 salas de aula e uma sala multiuso)

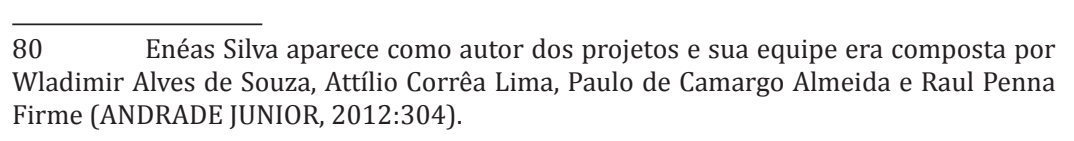

ascola Nuclear (1.100 alunos - 12 salas de aula), a Escolas-Parque e a Escola Platoon com 12, 16 e 24 salas; sendo que a de 24 va da escola-parque, como pode ser observado na próxima página.

Há nessa proposta a inédita sistematização da estrutura física escolar no Brasil, apoiada nas propostas de re novação pedagógica defendidas por Anísio Teixeira. Nesse sentido, a noção de rede de equipamentos escolares, baseada no uso do projeto padronizado é implantada como una aç̃o inserida no planejamento da cidade do Rio de Janeiro representado pelo Plano Agache ${ }^{81}$

Podemos destacar a sensibilidade do projeto par enfrentar o problema em diferentes escalas e não como um único padrão a ser repetido, o que reforça sua aposta em certa diversidade dentro de uma família tipológica. Em oude ao adnir vachaço do projeto en finça do contexto e das necessich locis Fic evidente a rigdez geome (a) geratriz das plantas, o que indica determinada previsão de evolução entre elas. Entretanto, não há uma estratégia clara

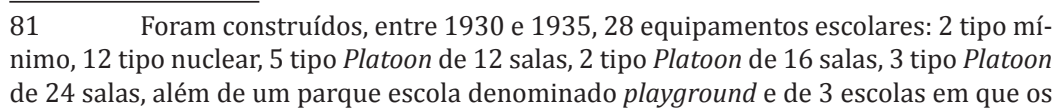

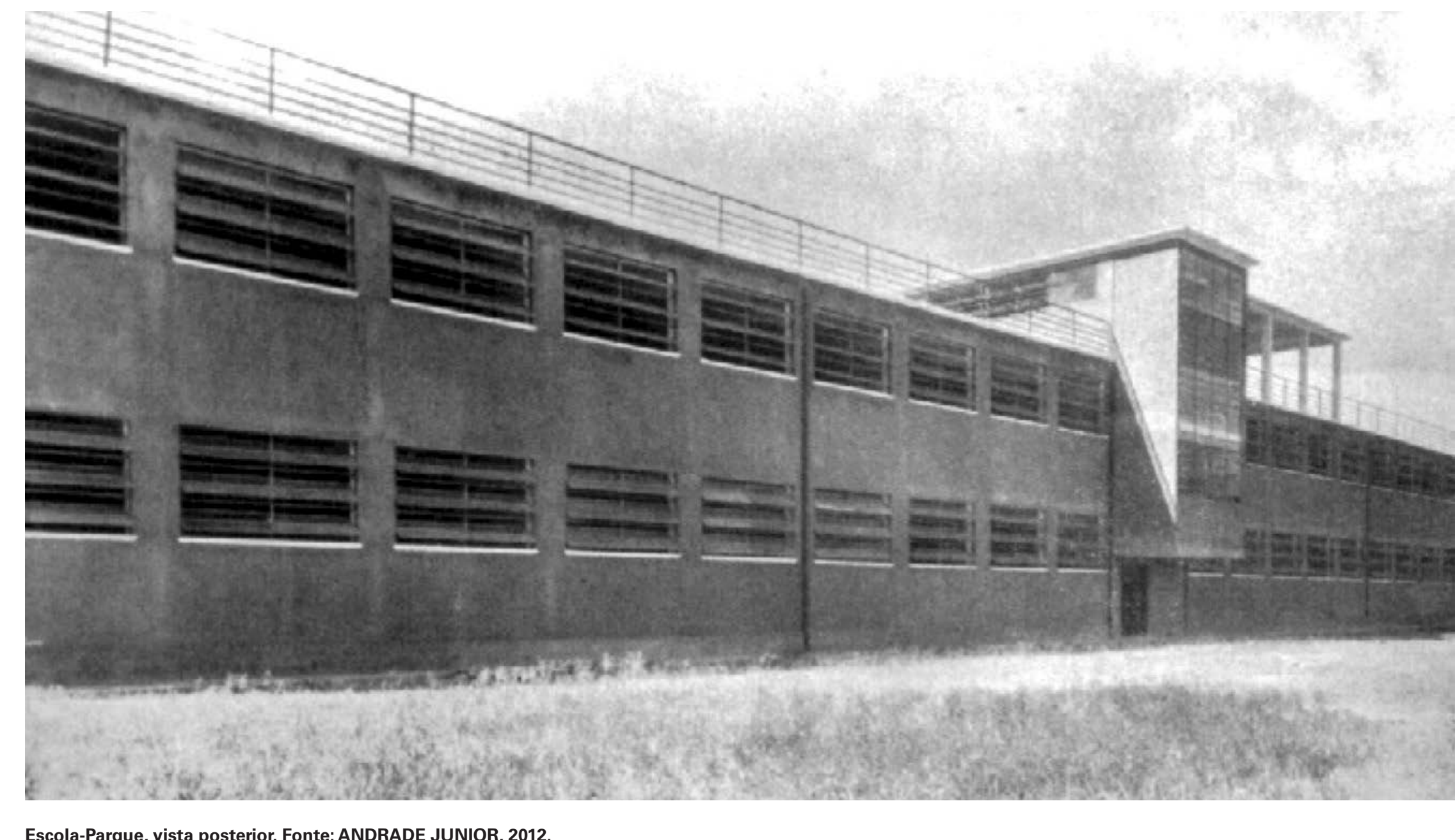

Eseola 


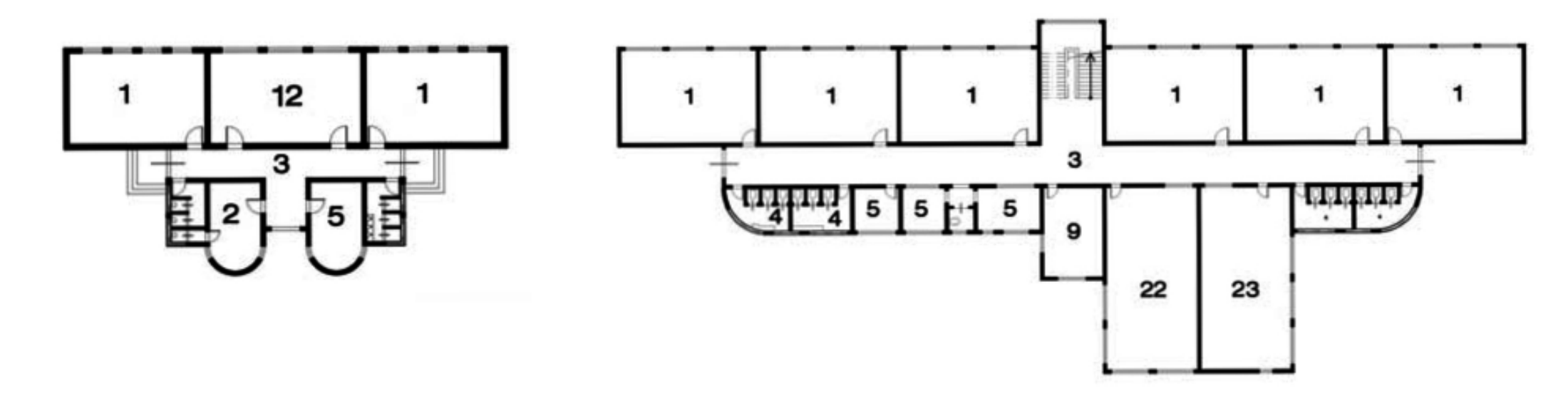

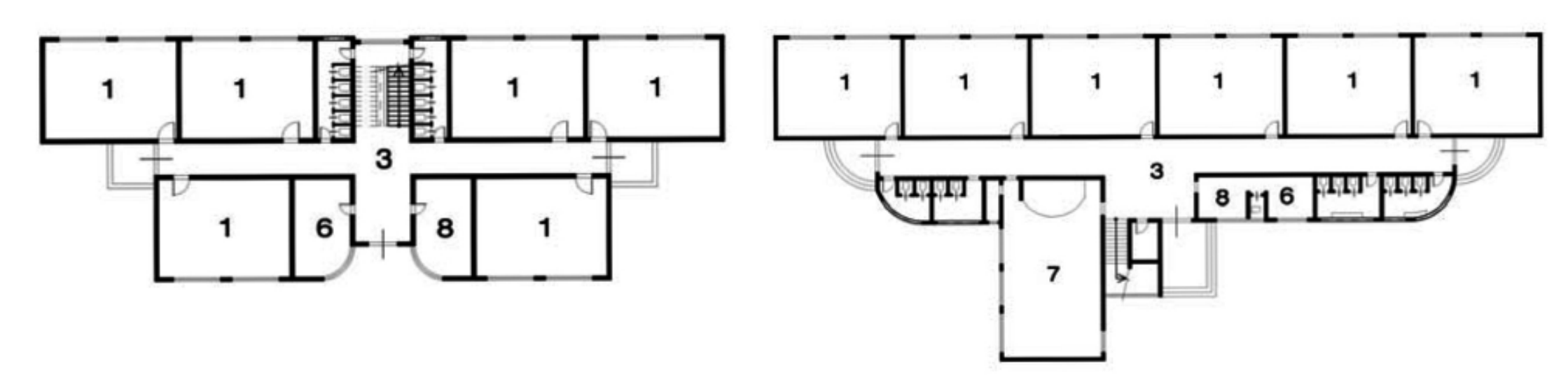

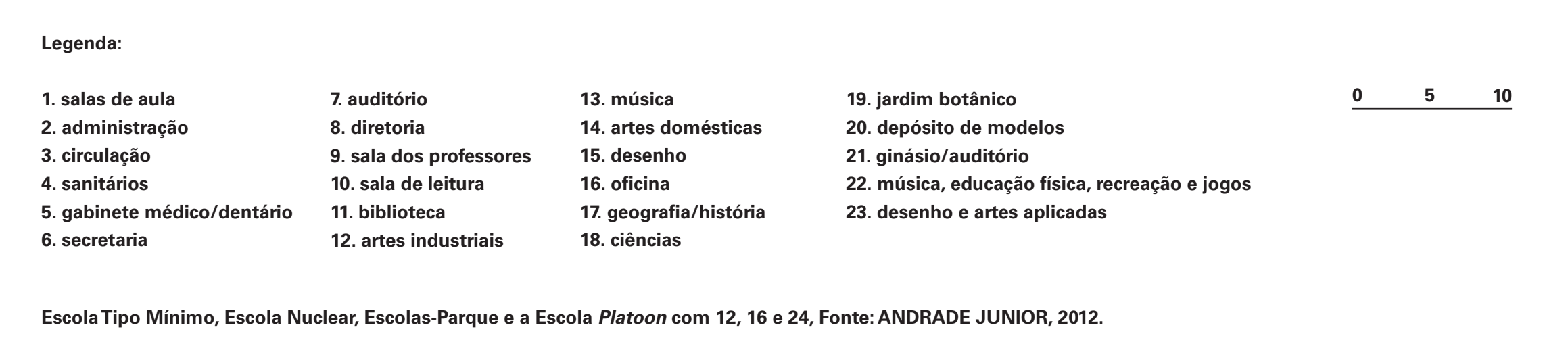

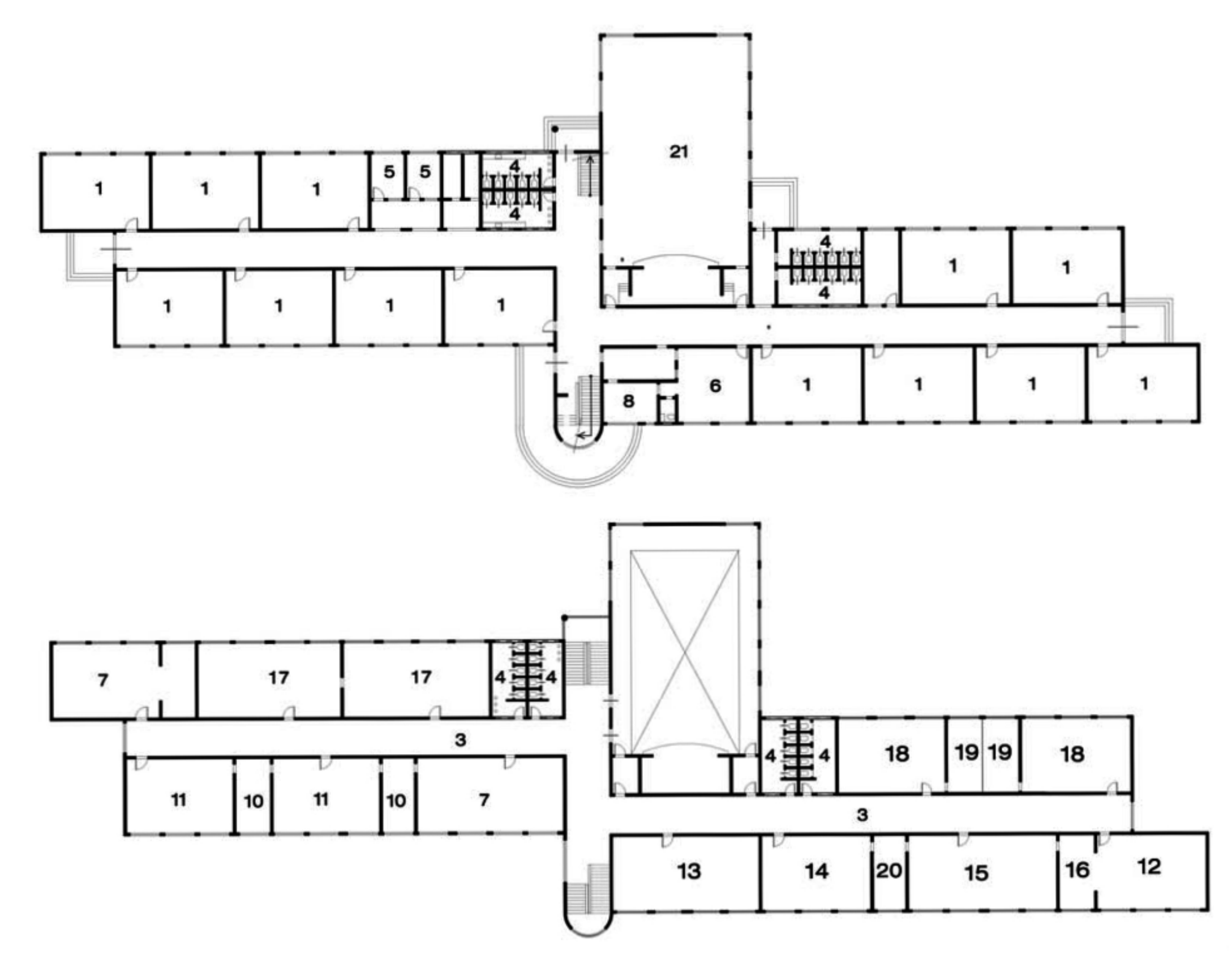


para a ampliação do equipamento escolar, ficando essa tarefa a ser cumprida pela repetição de um outro padrão.

Por outro lado, ao examinarmos os projetos padrão $0^{82}$, nota-se que a arquitetura proposta ainda guard estreita semelhança com os estilos ecléticos da arquitetura pública da Primeira República, em especial pelos volume organizados por um eixo de simetria e pela expressão estética muito próxima do estilo art-déc $0^{83}$. Apesar da ausência do ornamento decorativo das fachadas, não há evidências da expressão

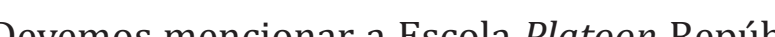
no bairro de Vila Isabel com 24 salas, que segue as características acima citadas, porém se destaca internamente pela expressão estrutural em concreto armado, próprias de Auguste Perret ${ }^{84}$.

Nesse sentido, podemos afirmar que as inovações programáticas introduzidas foram pouco acompanhadas pela renovação da arquitetura escolar, ou seja, pouco

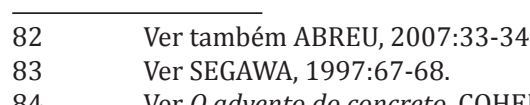

Ver SEGAWA, 1997:67-68.
Ver o advento do concreta. COHEN, 2013: 46-50. contribuiram para alterar o cenário arquitetônico exisente. Há uma rica dinâmica entre os prismas retangulares e curvos, uns casos, o que confere às fachadas uma notável movimentação, muito próxima do trabalho de Mallet Stevens na Françą ${ }^{85}$. No entanto, permanecem distantes as relações francas entre o ambiente construído e o ambiente natural, a integração entre as diversas alas de aprendizagem e dessas em relação às áreas de convivência e a total inexistência do uso dos ambientes, tanto os de conviver das práticas pedagógicas e de socializaç̃o, fundamentos o projeto moderno, como veremos.

Esse aspecto torna-se importante pelo fato de a introdução em São Paulo do Código de Educação em 1933 formaç̃̃o da Comissão Permanente, responsável por s

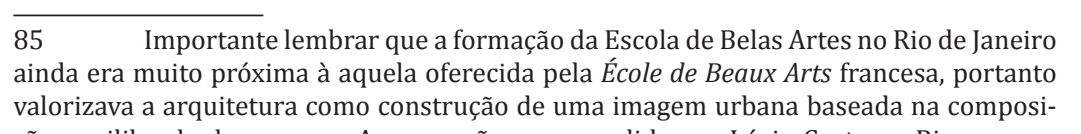

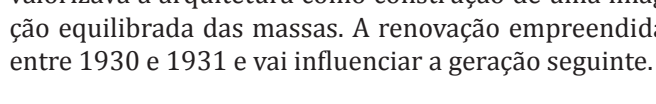

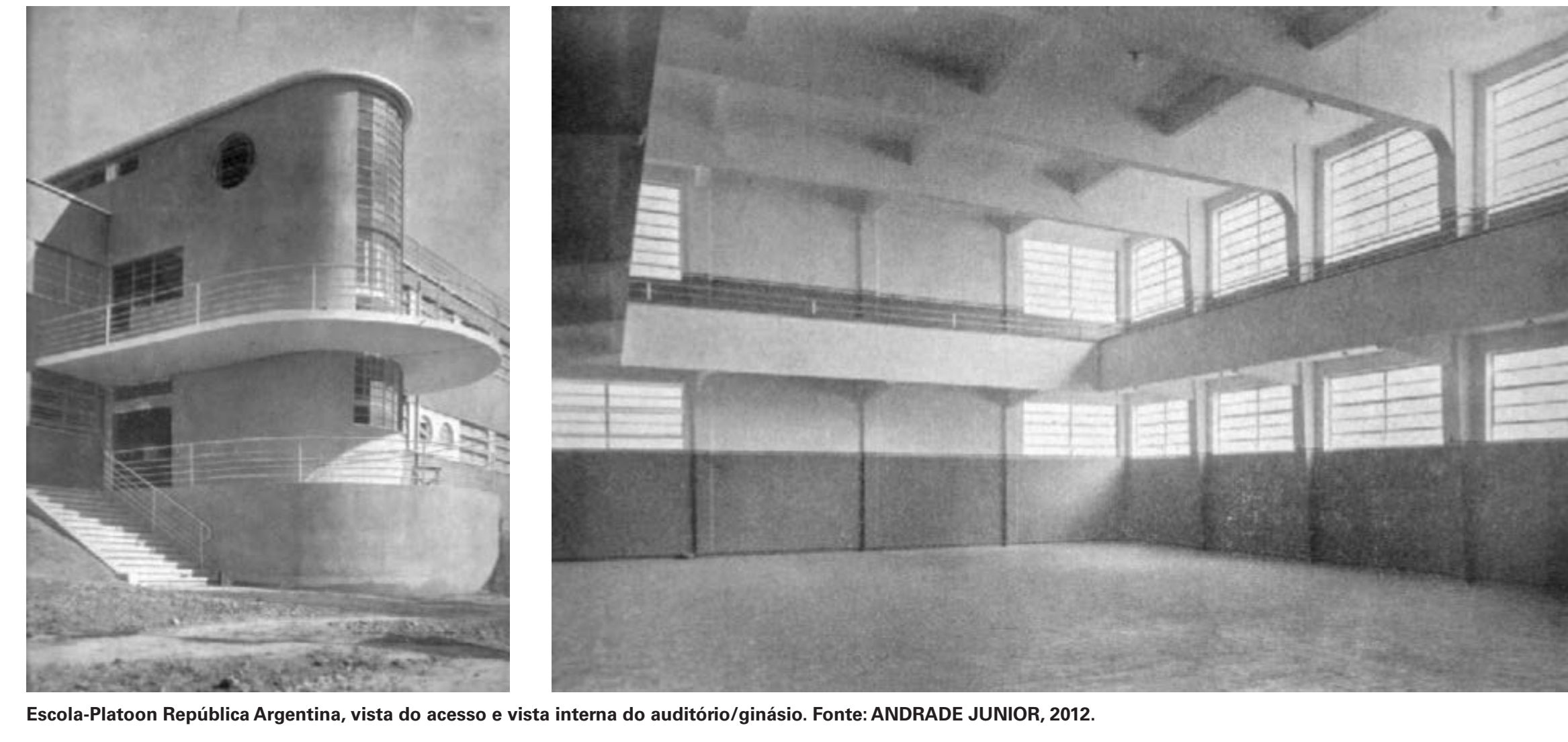




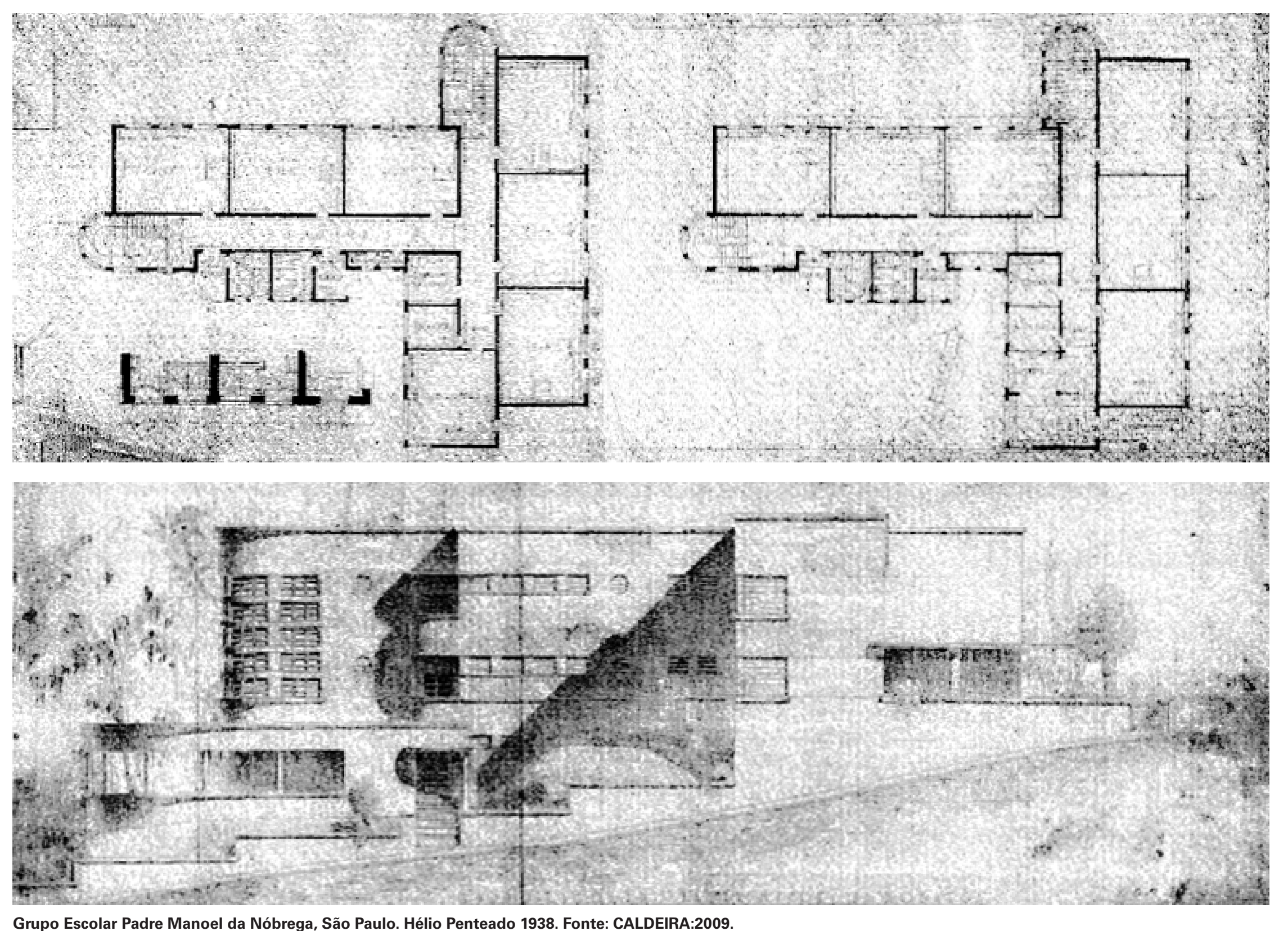

Em São Paulo, no entanto, no que se refere à arquitetura escolar decorrente do Código, o rompimento com a simetria e com a rigidez espacial trouxe modificações nas implantaçeses rer

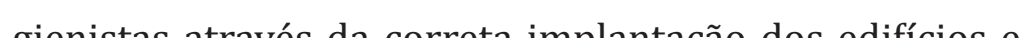

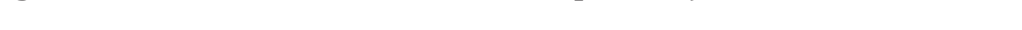
relação à insolação e à ventilação dos ambientes, com implantações em «L, Z, U ou E Е» $\aleph^{86}$ o que seria classificada com a arquitetura moderna "sóbria e discreta", como lembrou Hugo Segawa (1986.64). Além disso, a noção de rede de equipamentos escol

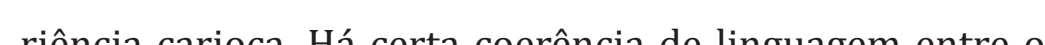
projetos e a insistência na resolução das necessidades de caráter higienista, sempre presentes, sem que haja a repeticão de soluções completas ${ }^{87}$, ou seja, a repetição do projeto.

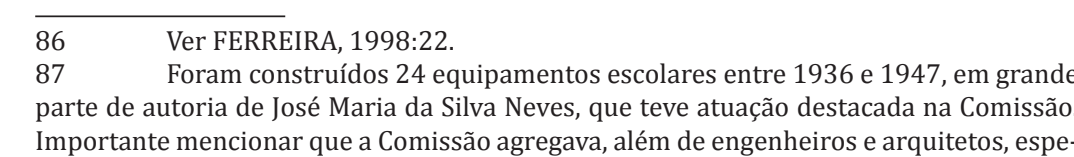

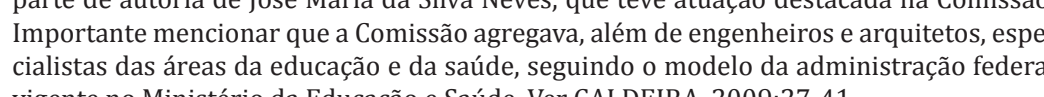

Ao retornarmos à forte influêncis exercida por Anisio Teixeira, devemos observar a rede de equipamentos escolares implantada por ele na Bahia na década de 1940 em particular, a criação dos Centros Educacionais, como o Carneiro Ribeiro em Salvador.

Durante sua atuação como Secretário Municipal de Educação e com a colaboraç̃ão do arquiteto Diógenes Rebouças ${ }^{88}$, foram implantadas setenta edificações escolare no estado da Bahia até 1950, cuja particularidade estava no caráter evolutivo do projeto, chamado de "projeto extensível", mas ainda sem a sistematização de uma rede de equipamentos. Obedecendo à coordenação modular en um único ambiente implantado nas zonas rurais podia ser ampliado para 3, 6 e 12 salas de aula, atingindo sua confi-

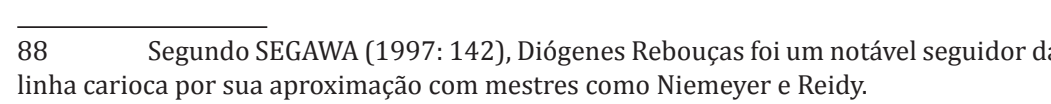




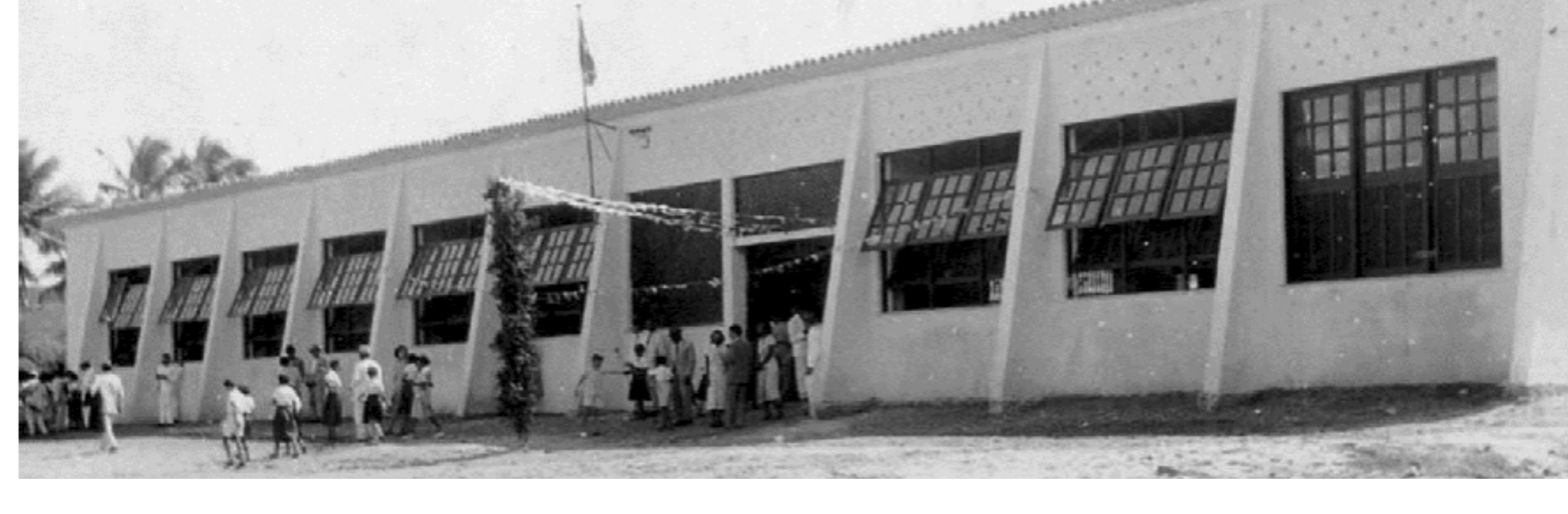

Vista de escola padrão escola nuclear.

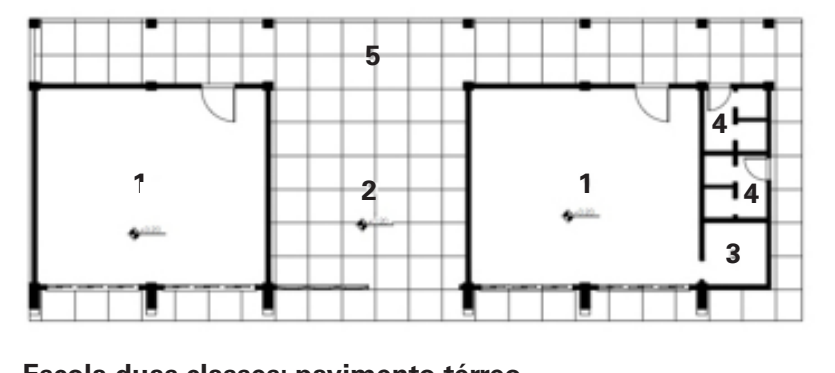

Escola duas classes: pavimento téreo.

Legenda:
1. C. Casse 2. Recreio coberto 3. Depósito
4. Sanitarín 5. Circulaçá

Escola Padrão. Fonte:ANDRADE JUNIIOR, 2012

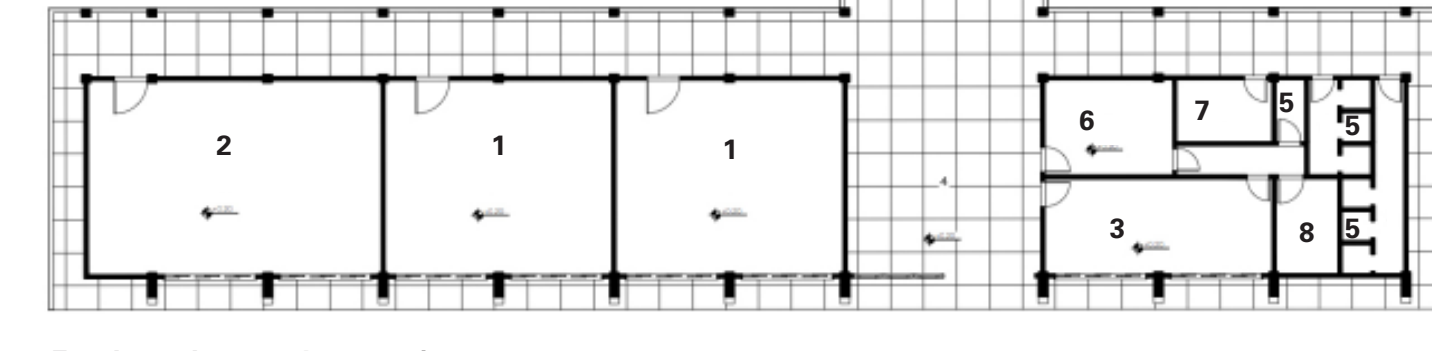

pavimento terreo

Legenda:
1. Classe 2. Classe especial 3. Biblioteca 4. Recreio coberto
5. Sanitárí 6. . Direcáa 7 . Zelador 8 S. Secretaria

05

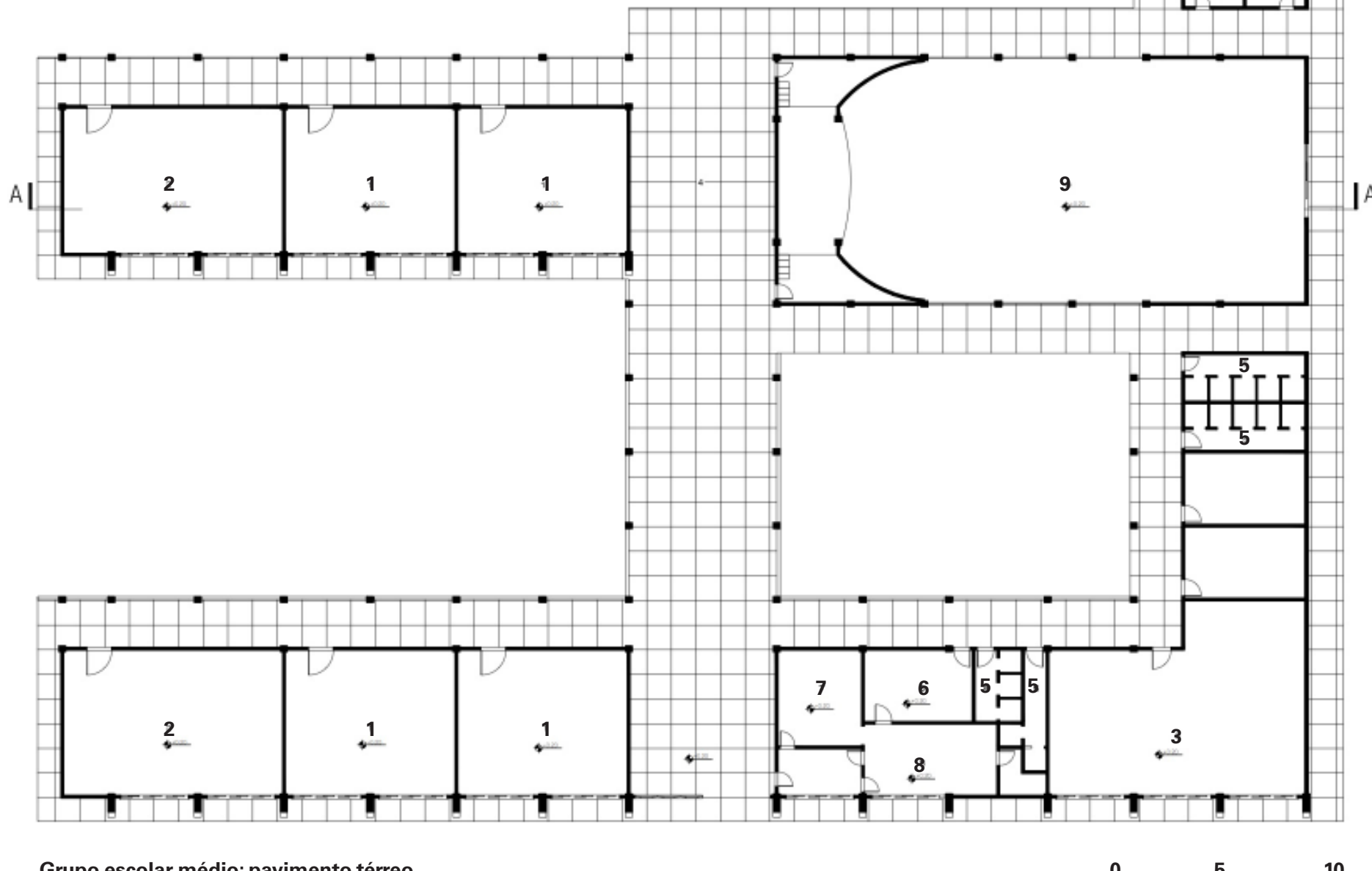

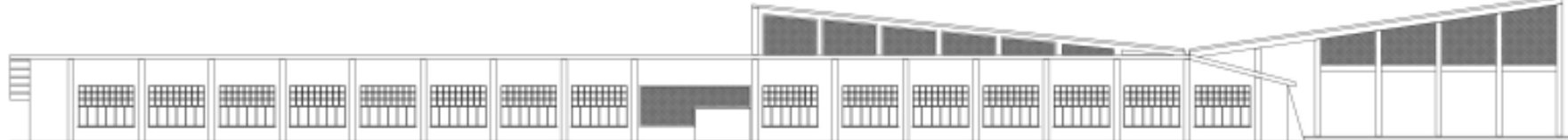
Grupo escolar médio: fachada princip 


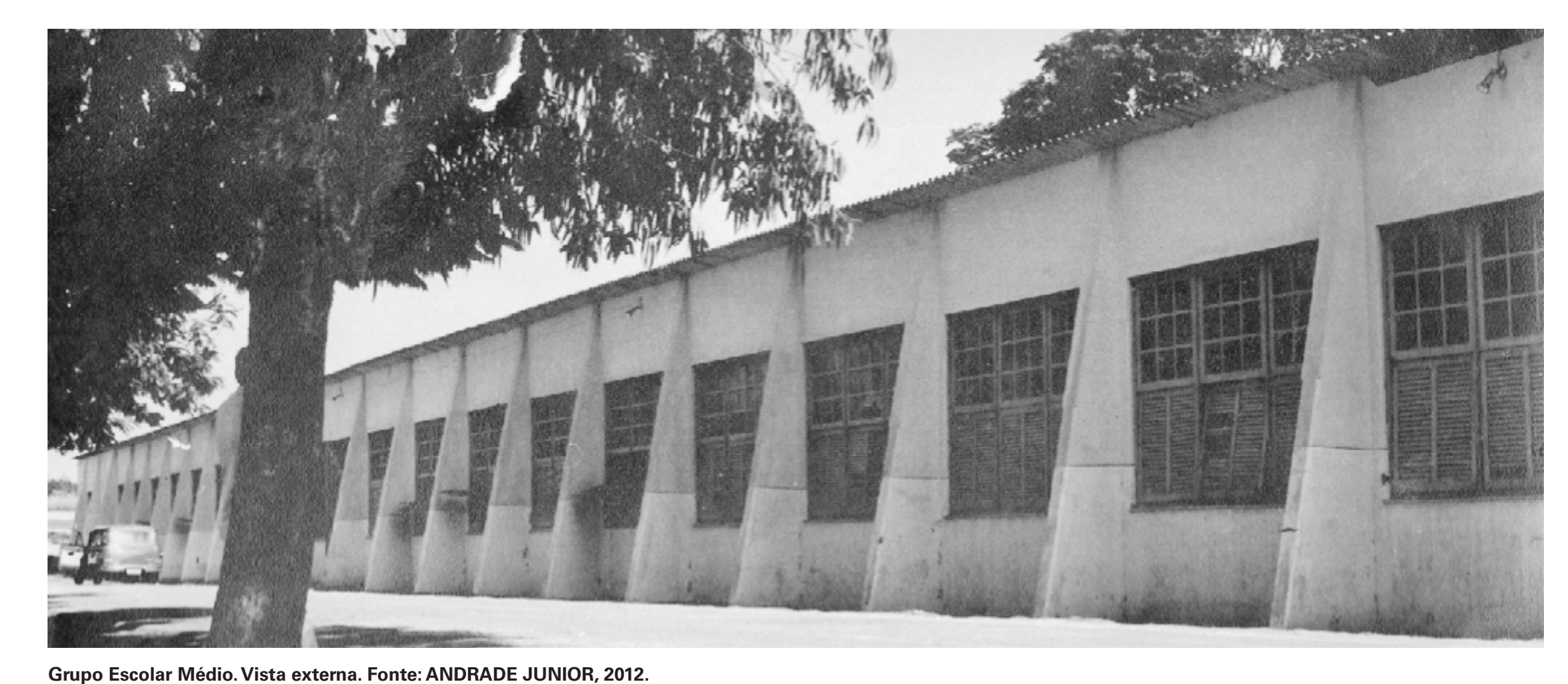

guração completa com a adição de mais 6 salas, jardim de infância, teatro, ginásio, cantina e centro de formação de adultos, transformando-se num centro comunitário. Como demonstra a extensa pesquisa de Nivaldo Andrade Junio (2016:317-324), Rebouças imprime ao projeto características da arquitetura moderna herdadas de sua formação carioca, particularmente na organização pavilhonar das alas e no uso de apoios inclinados em consonância com as coberturas oblíquas, ainda que os materiais e as técnicas construtivas fossem simples e tradicionais.

Foi em Salvador, no entanto, que Teixeira implantou o Centro Educacional Carneiro Ribeiro (1947), obra exemplar em que as inovações arquitetônicas foram reflexo do objetivos programáticos traçados ${ }^{89}$, obedecendo ao conceito de rede

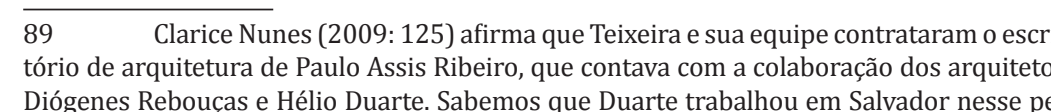

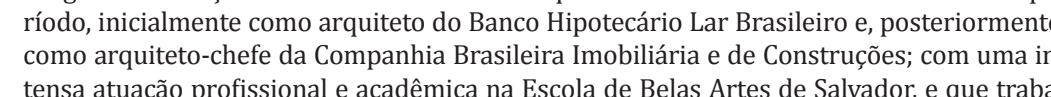

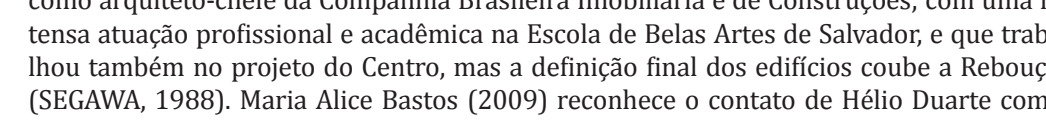

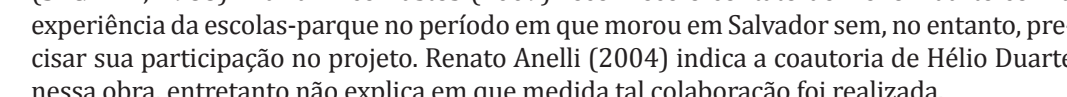

atende quatro escolas-classe. Como escola-parque, o Centro é composto por distintas edificações especializadas ualmente o programa: um auditório de forma cônica, um galpão envidraçado cuja estrutura em arco de madeira lhe confere características industriais, chamado pavilhão de "atividades de trabalho", um ginásio de "atividades de educação física" também em arco de madeira e uma biblioteca octogonal conformam as principais edificações construídas. Organizadas no interior de uma quadra urbana de maneira a configurar um conjunto em torno de uma grande área verde retangular, as edificações são interligadas por caminhos protegidos por singelas coberturas. Encontramos aí a noção de pavilhão ${ }^{90}$, cuja singularidade da forma irá marcar a produção da arquitetura brasileira na década seguinte, em especial no trabalho de Oscar Niemeyer.

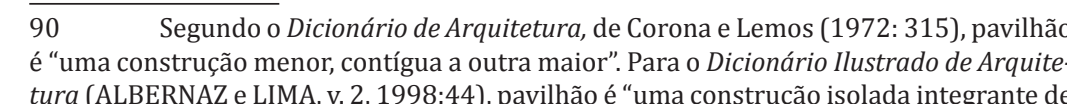



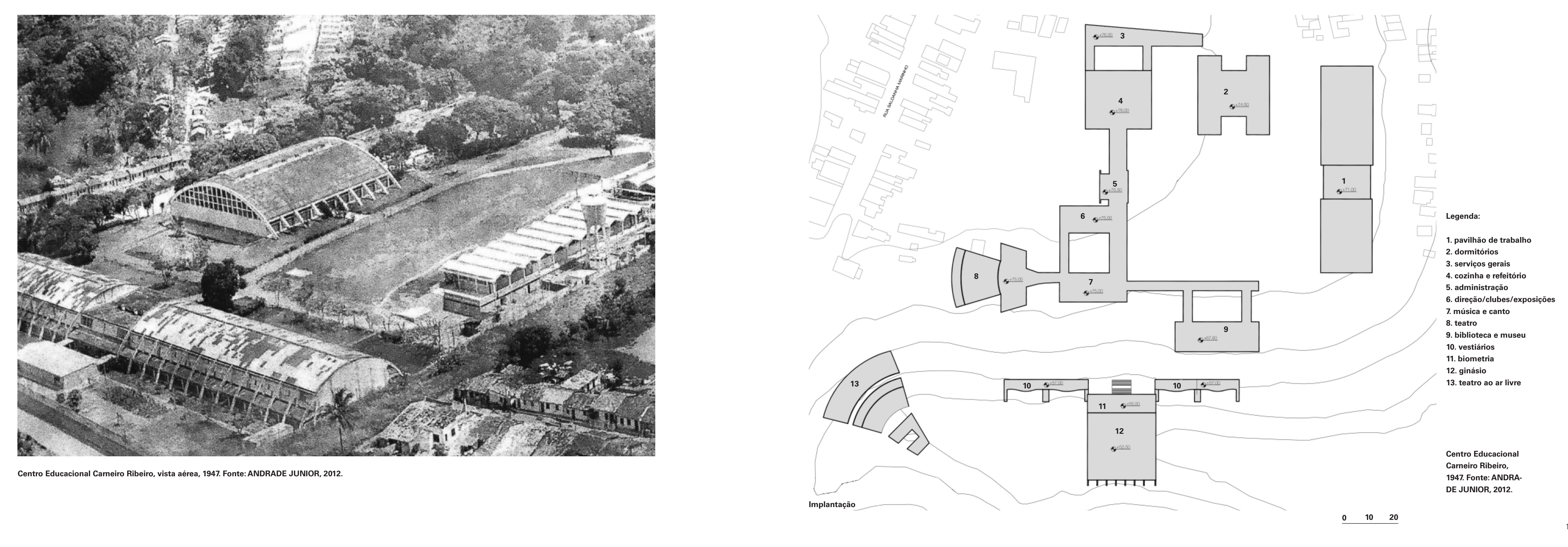

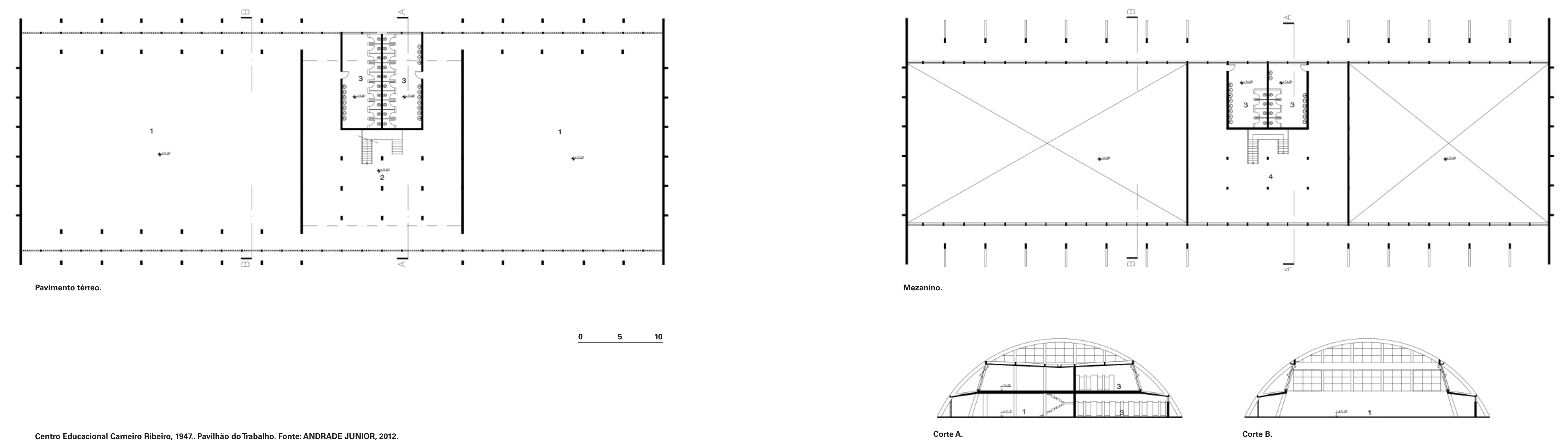

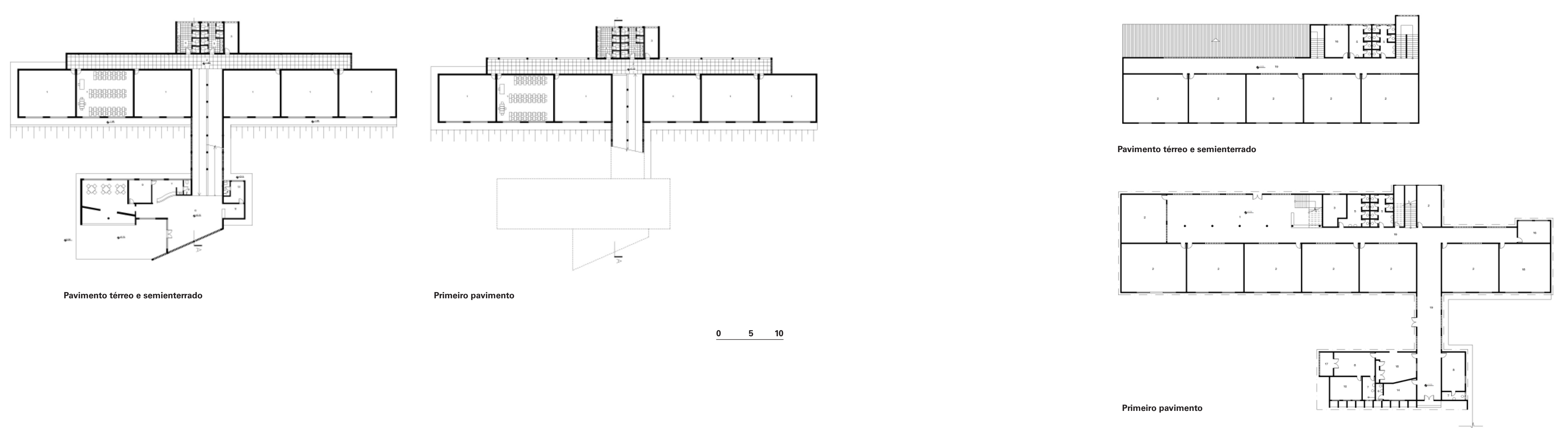
Documentos recolhidos por Andrade Junior mostram Hélio Duarte como autor do projeto inicial de alguns dos pavilhões e de 3 escolas-classe, cada uma com um projeto distinto ${ }^{91}$. Entretanto, a obra construída do Centro Educacional Carneiro Ribeiro corresponde ao projeto de Diógenes Rebouças, desenvolvido e detalhado pelo escritór de Paulo Assis Ribeiro (2012:345-347). Mesmo tendo se tornado obra de referência, a rede de cinco equipamentos escolares não teve continuidade em outros bai ros de, devido a

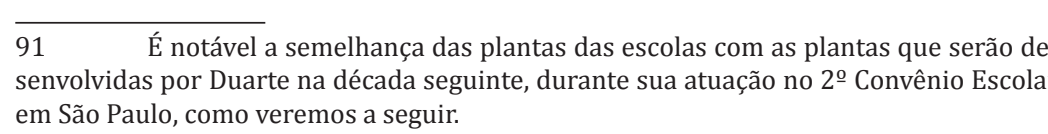

No final da década de 1950 surge novamente a oportunidade de implantação de uma rede de equipamentos de aprendizagem, em que Teixeira vai liderar a elaboração e a implantação do Plano de Construções Escolares de Brasília (1957), em consonância com o projeto de Lúcio Costa para a nova capital. Esse novo momento torna-se oportuno por se tratar de um ambiente phnojdo e constrúdo segundo

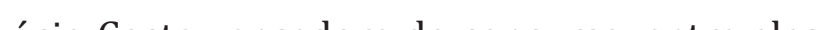
como núcleo da unidade de vizinhança.

No Plano de Construções Escolares de Braśília, Anisio Teixeira exercita de maneira ampla e completa a estruturação teórica de toda a rede física de ensino a ser imph ta na nova Car

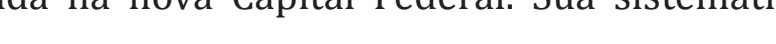
desde a pré-escola, chamada de "jardim de infância", até a universidade. Num certo sentido, destaque deve ser feito à maneira científica e objetiva como o Plano é definido, detalhado e justificado, o que nos leva a entendê-lo como um Programa para

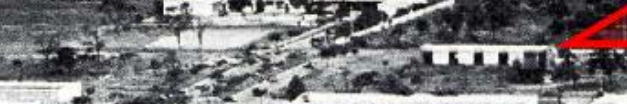

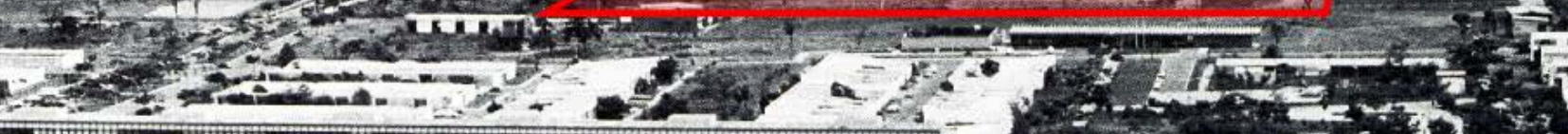

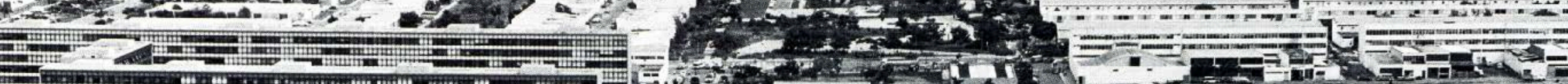

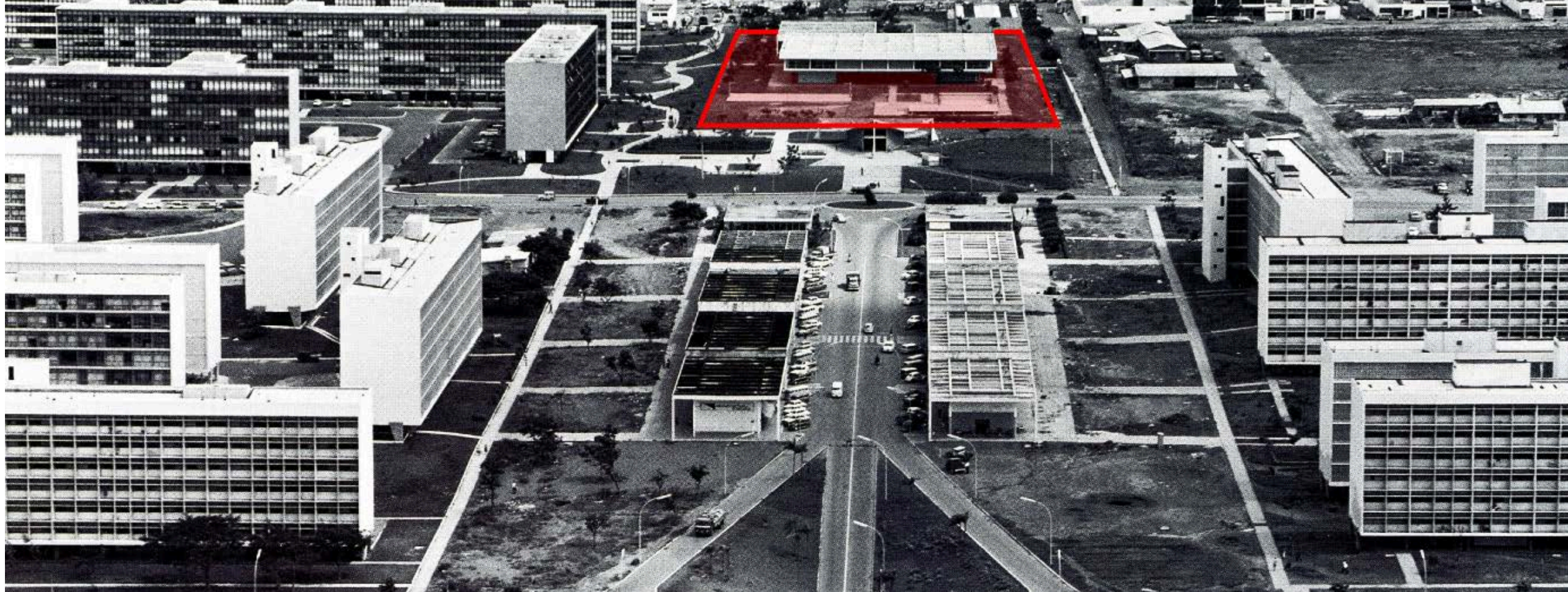
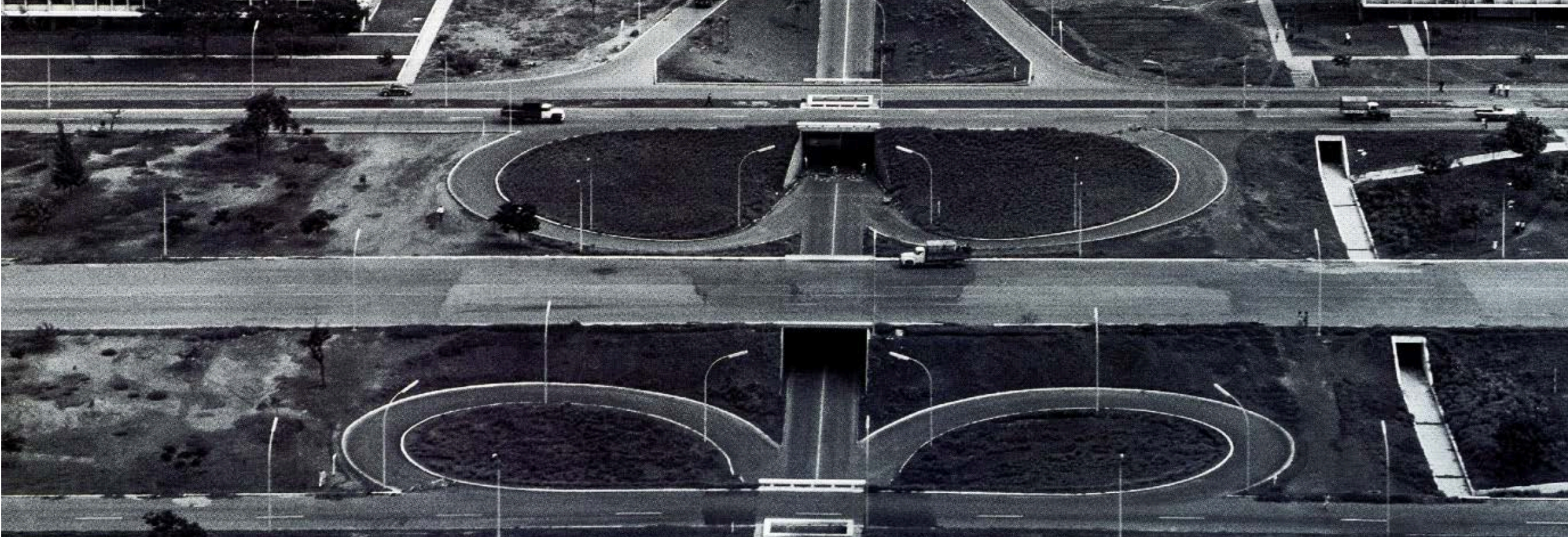
[...] um conjunto de edifícios, com funçōes diversas e considerável variedade de forma e de objetivos, a fim de atender a necessidades específicas de ensino e educação e, além disto, à necessidade

Seguindo a lógica sistematizada pelo projeto de Lúcio Costa para o Plano Piloto, o Plano de Teixeira organiza a rede de equipamentos de aprendizagem, chamados de Centros Educacionais de Brasília, da seguinte maneira:

Cada superquadra, prevista para receber entre 2.500 a 3.000 habitantes, abrigará:

a) 1 jardim da infância, com 4 salas, para, em 2 turnos de funcionamento, atender a 160 crianças (8 turmas de 20 crianças)

b) 1 escola-classe, com 8 salas, para, em 2 turno atender a 480 meninos ( 16 turmas de 30 alunos) (TEIXEIRA, 1961:195)
Referência ${ }^{92}$ pois fundamenta as conformações físicas ropostas apoiadas na metodologia de aprendizagem e organização administrativa preconizadas, como pode ser 1 "escola-parque" - destinada a atender, em 2 se, em atividades de iniclaçăo ao trabalho (para meninos de 7 a 14 anos) nas pequenas "oficinas de artes industriais" (tecelagem, tapeçaria, ençdernação, cerâmica, cartonagem, costura, borddo e trabahlhos em couro, ă, madeira, metal, etc. . além da participação dirigida dos alunos de 7 a 14 anos em atividades artisticas, sociais e de recreção (música, danç̧a, teatro, pintura, exposiçỗe grêmios, educacão física). (TEIXEIRA, 1961:196)

Em seguida, os alunos mais velhos seriam atendidos por um conjunto de edifícios, Centros de Educação Média ou Secundária compreendendo, além da edificačão destinada à educaçăo connpensiva - ncluindo ginásio ou pedagógico e escola agrícola -, outras que abrigariam teatro, biblioteca, exposições e centro de educação física o que completa a rede de equipamentos de aprendizagem que antecede o ensino universitário.

A precisão quantitativa e qualitativa das informacões expressas no Plano o tornaria atualmente um Termo
Escola-Parque de 1.000 crianças de 7 a 14 anos (em cada turno), constituindo os locais adequados às atividades programadas, numa faxxa de terreno de $80 \times 160$

. Condições óbvias: a) Só um piso elevado; b) axa de ocupação do terreno relativamente baixa circundantes, jardins, piscina e esportes.

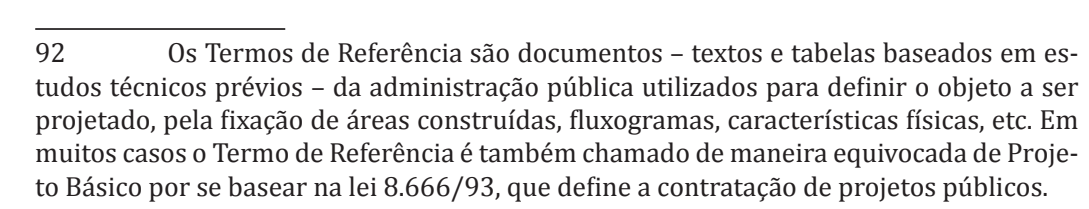

O Problema: Construir área para conter cêrca 

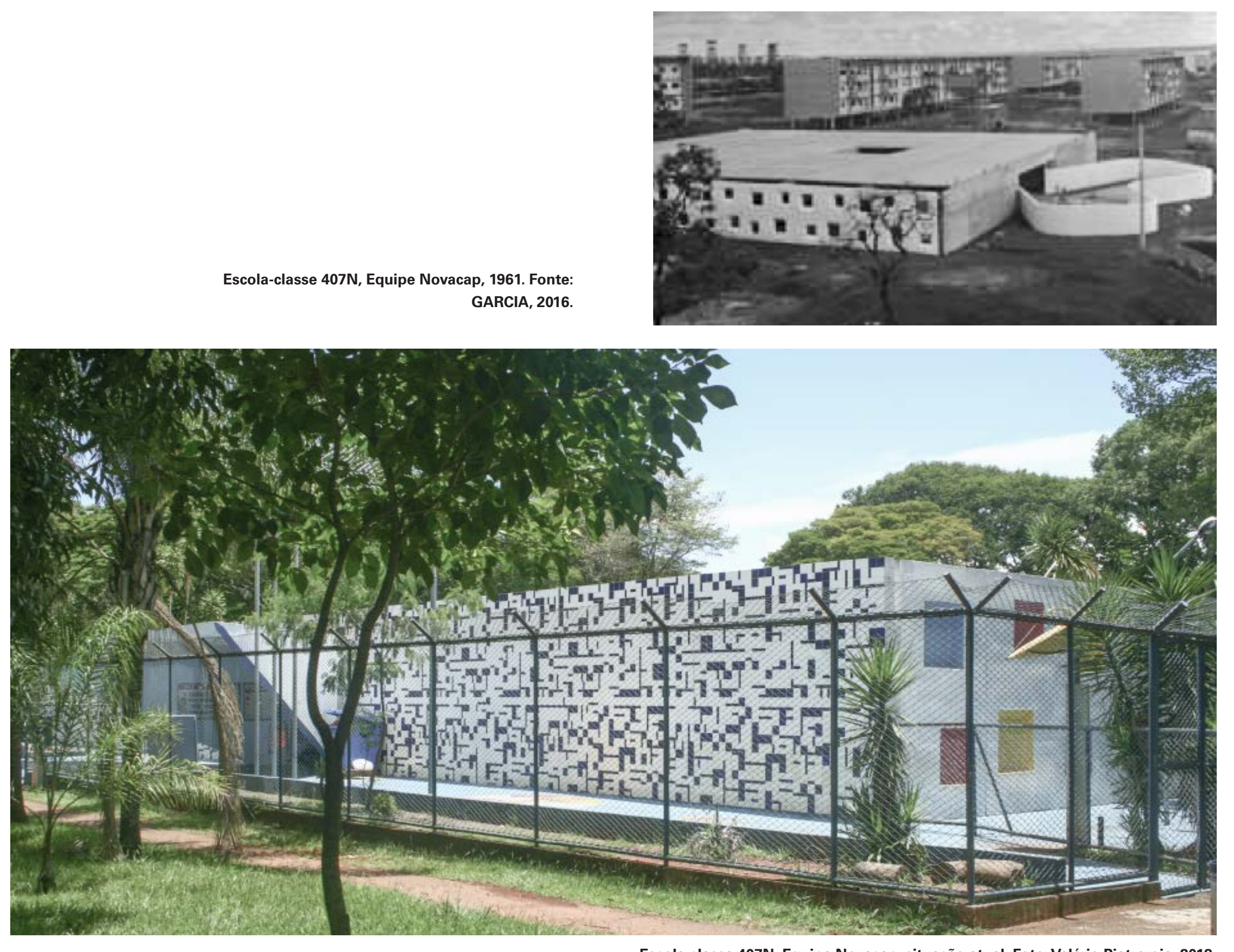

Escolaclasse 114S, Wilson Reis Netto, 1961. Fonte: PERERAA, 2007
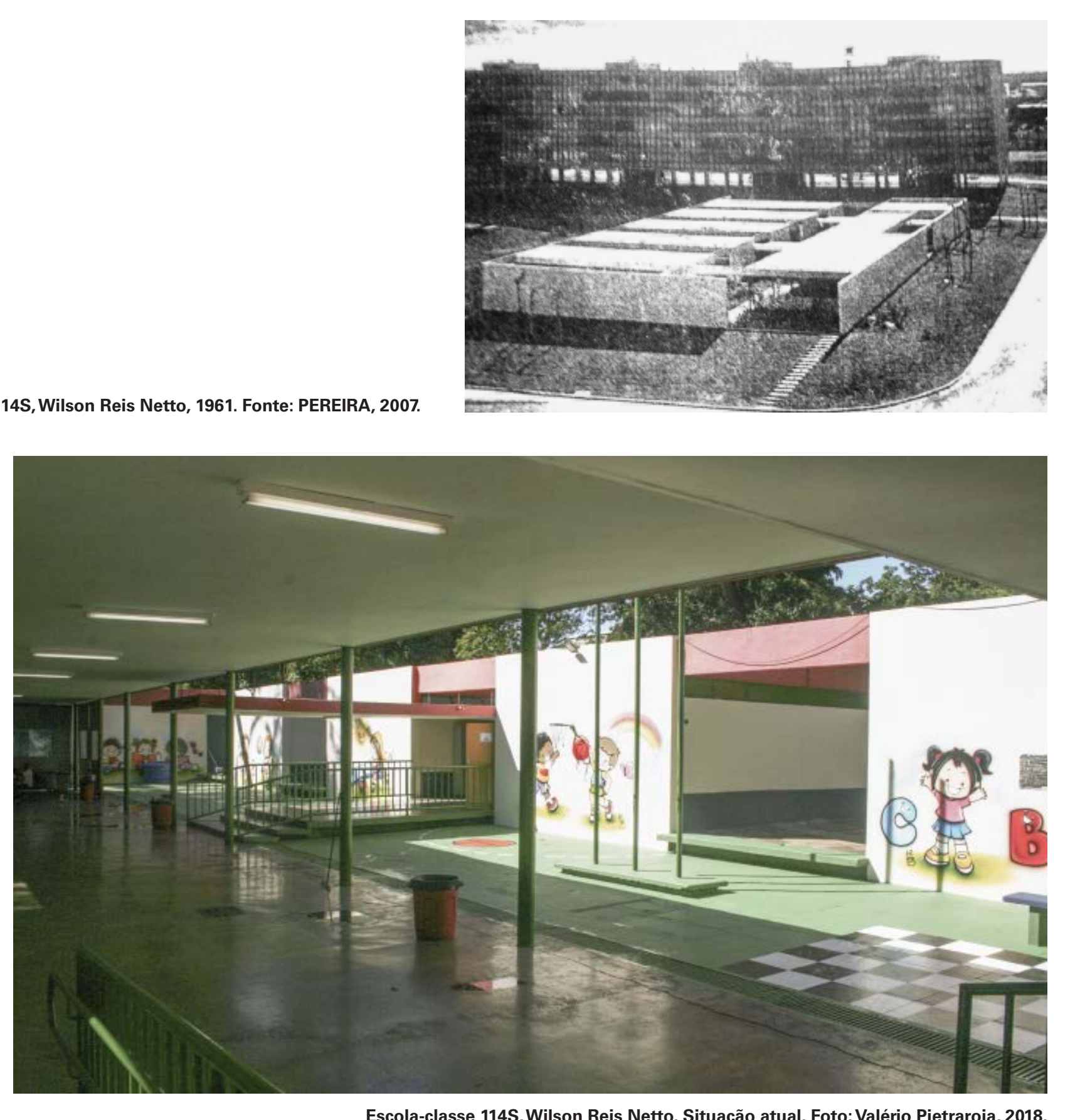
3. Resultante geométrica: Planta condensada máximo - Um Quadrado - 50 x 50 metros - 2.500 metros quadrados - no piso superior. Zonas livres permitindo a continid reo. Fora do quadrado: só o indispensável.

4. Iluminação natural do prisma construtivo: Du-

pla: - Lateral - uniforme com protecão parcia

pla: - Lateral - uniforme com proteção parciał

direção.

5. Disposição da principal área construida: Éco-

com a localizacão de um só tocesso amplo e

bloco de instalaçōes sanitárias na zona centra

Completa maleabilidade da distribuicão do

paço interno, ampliado pela continuidade - Pos-

sibilidade de isolamento total, sem quebra da continuidade, por meio de placas transparentes acima de 2 metros. (TEIXEIRA, 1961:198)
Uma versão do Plano foi publicada na revista Modu$10^{93} \mathrm{e}$ ilustrada pelos projetos de José de Souza, que estudaremos mais adiante.

Nas previsões do Plano, seriam implantados 28 conjuntos de escolas-parque, portanto com 112 escolas-classe, o que pretendia atender 56.000 alunos, aproximadamente. A rede efetivamente implantada atende atualmente 5 conjuntos de escolas-parque e escolas-classe projetadas construídas segundo o Plano de Teiveira e sofreu diverEntretanto, pelo número reduzido de escolas-parque, os conjuntos atendem mais do que quatro escolas-classe, demonstrando certa fragilidade do sistema atual.

Do ponto de vista de nossa pesquisa, destacamos a seguir o Centro Educacional implantado no entrequadras 307 sul e 308 sul.

93 Revista Módul nn 20, 1960: 2-15. 

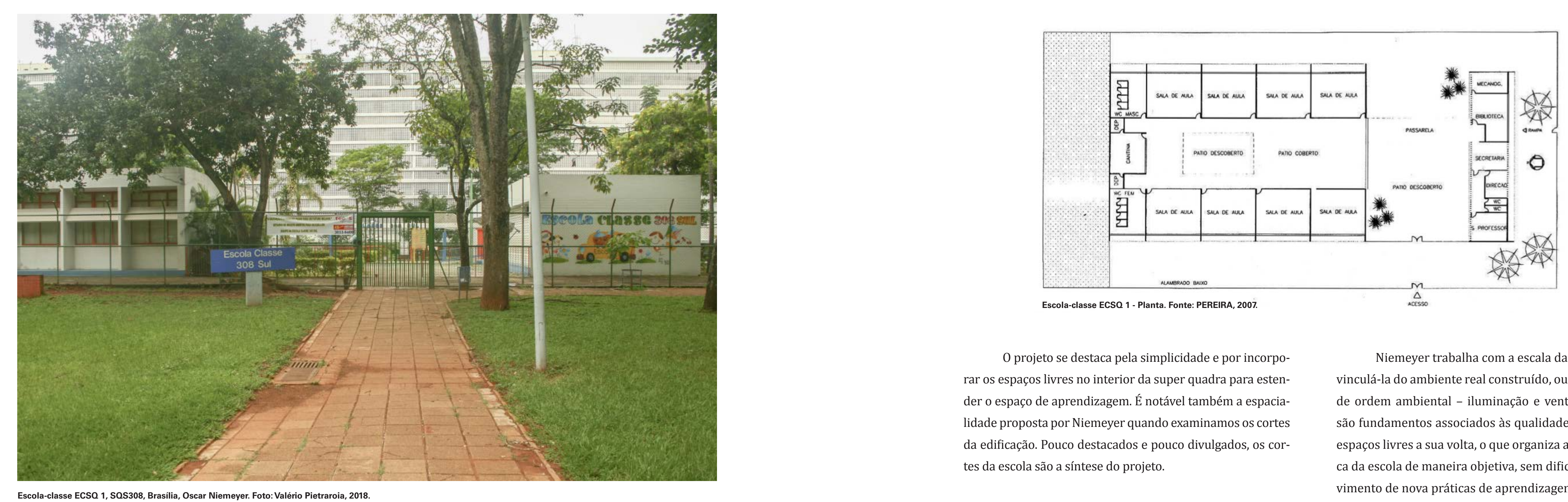

0 projeto se destaca pela simplicidade e por incorporar os espaços livres no interior da super quadra para estender o espaço de aprendizagem. É notável também a espacialidade proposta por Niemeyer quando examinamos os cortes da edificação. Pouco destacados e pouco divulgados, os cortes da escola são a síntese do projeto.

Niemeyer trabalha com a escala da criança sem desvinculá-la do ambiente real construído, ou seja, os atributos de ordem ambiental - iluminação e ventilação naturais são fundamentos associados às qualidades ambientais dos espaços livres a sua volta, o que organiza a rotina pedagógica da escola de maneira objetiva, sem dificultar o desenvolvimento de nova práticas de aprendizagem. 

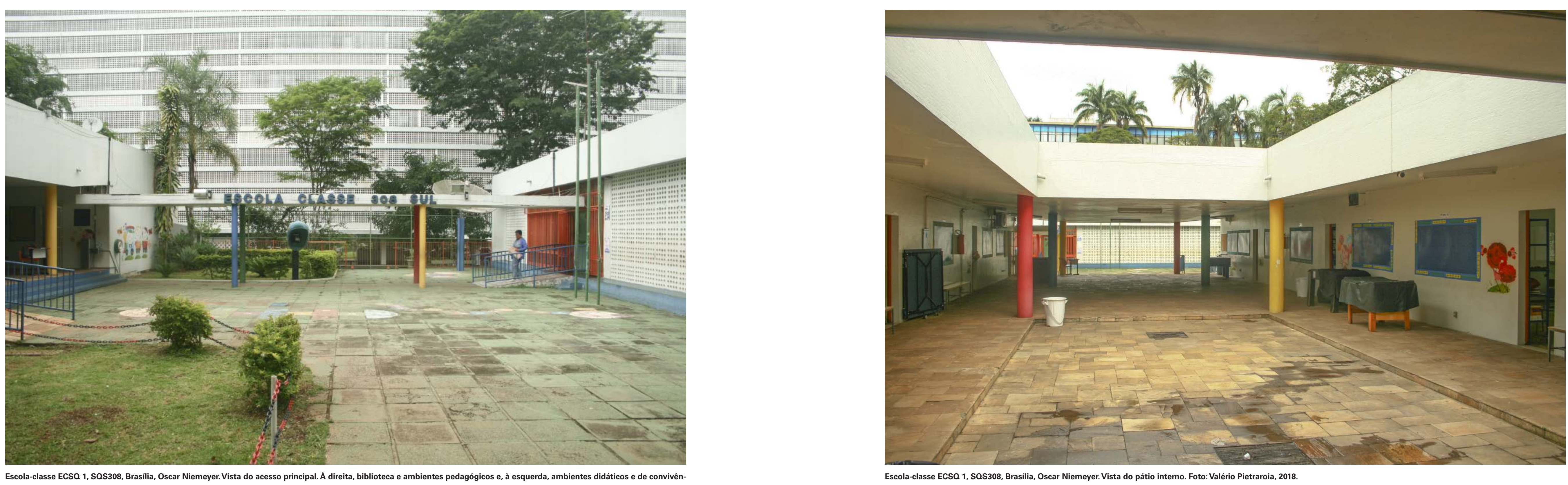
É, no entanto, a escola-parque que revela os maiores atributos para a compreensão do projeto como instrumen-

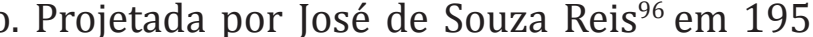
segue as orientações transcritas acima, como pode ser observado:

A implantação de Reis acentua a direção leste-oeste predominante da faixa entrequadras. 0 posicionamento das edificações configura parcelas de áreas livres que assumen dois parmentos, sc m) preconizada por Anísio Teixeira. Centralizada na faixa de $160 \mathrm{~m}$ de extensão, que forma o entrequadras, ela configura uma sombra, tão necessária na aridez da Capital, com seu pilotis formado por pilares triangulares. 0 espaço livre e acohedor criado orgniza as principis atividades a que a escoa-parque fora destinada: a leste os esportes, com as quadras e as piscinas, e a oeste, as oficinas de arte e o auditório. São atividades próprias para serem praticadas em espaços externos (esporte e trabalhos manuais) ou que possuem uma dnâmica de funcionamento específico (auditório).

$96 \quad$ Sobrea obra de losé de Souza Reis em Săo Paulo, ver PIETRAROIA, 2017.

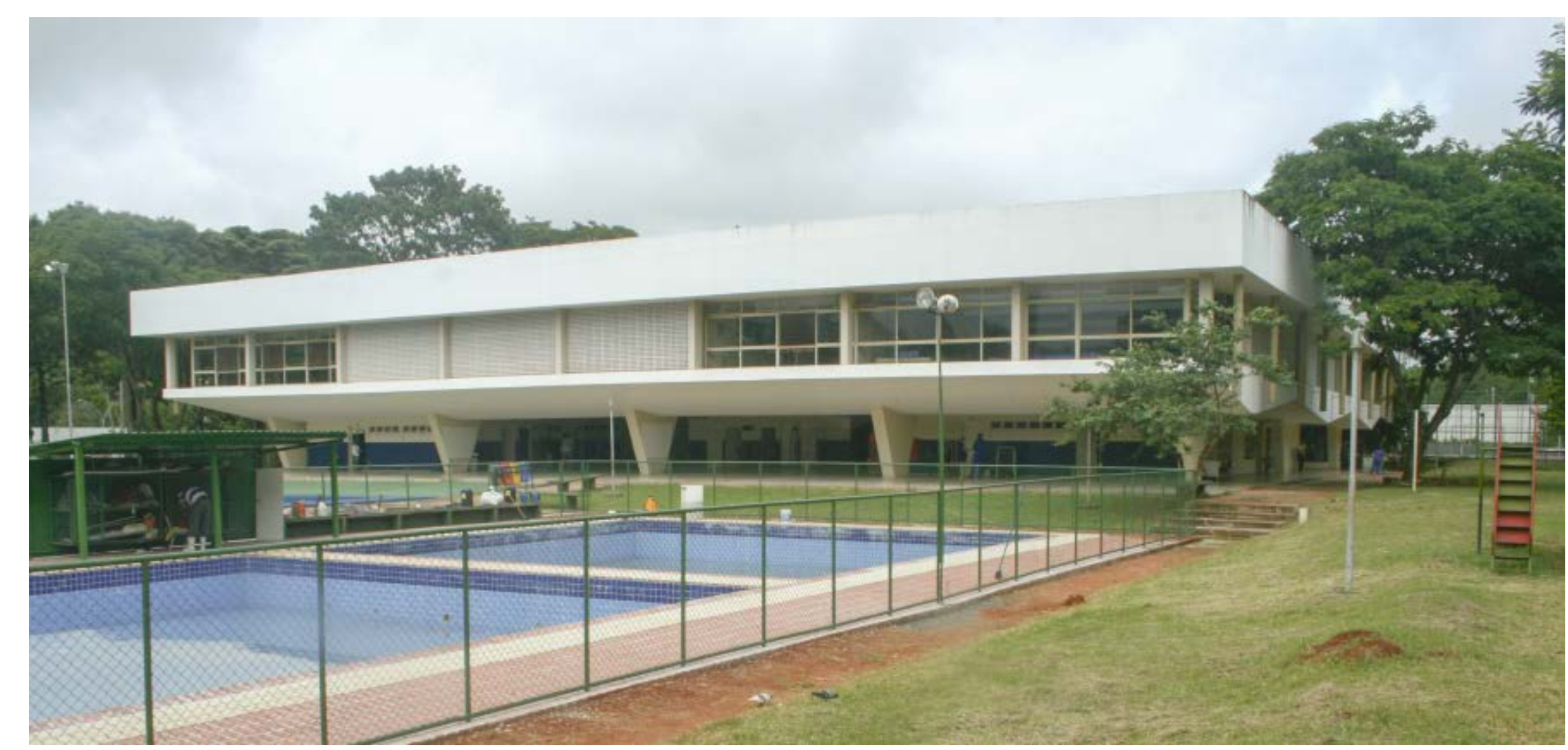

Escola-parque, entrequadras 3075 308S, Brasilia, José de Souza Reis. Bloco central, vista leste junto às áreas esportivas. Foto: Valério Pietraroia, 2018. 

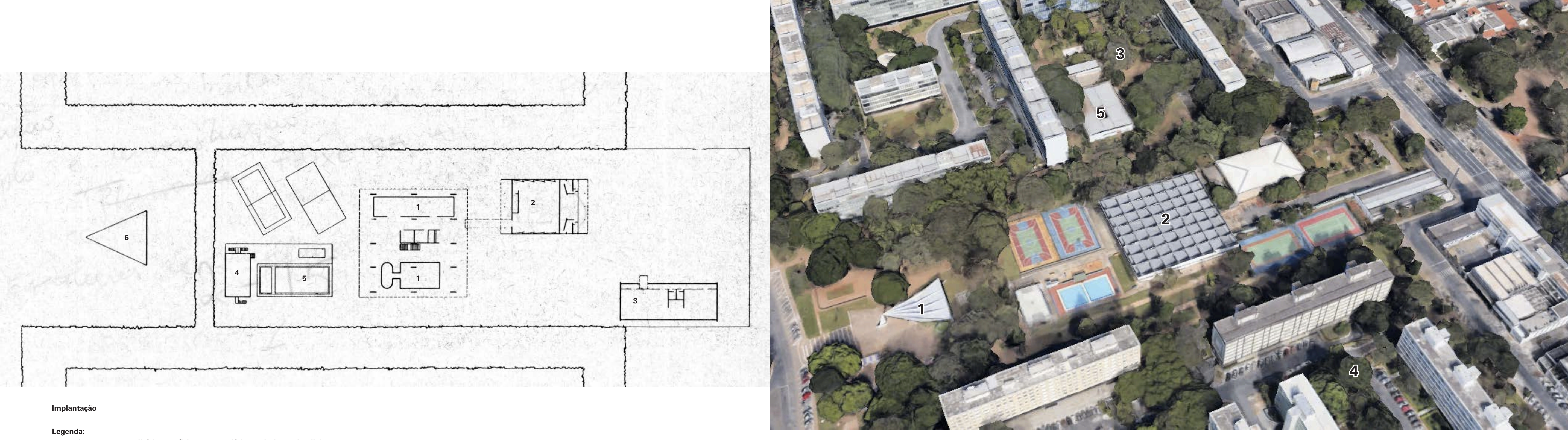

N个 $\quad 0 \quad 1020$

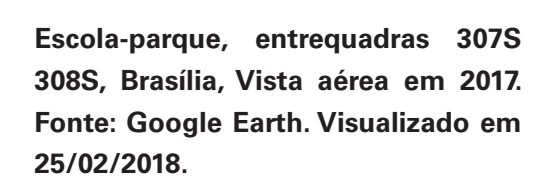

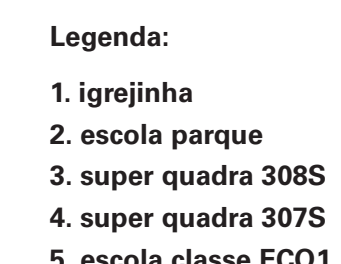




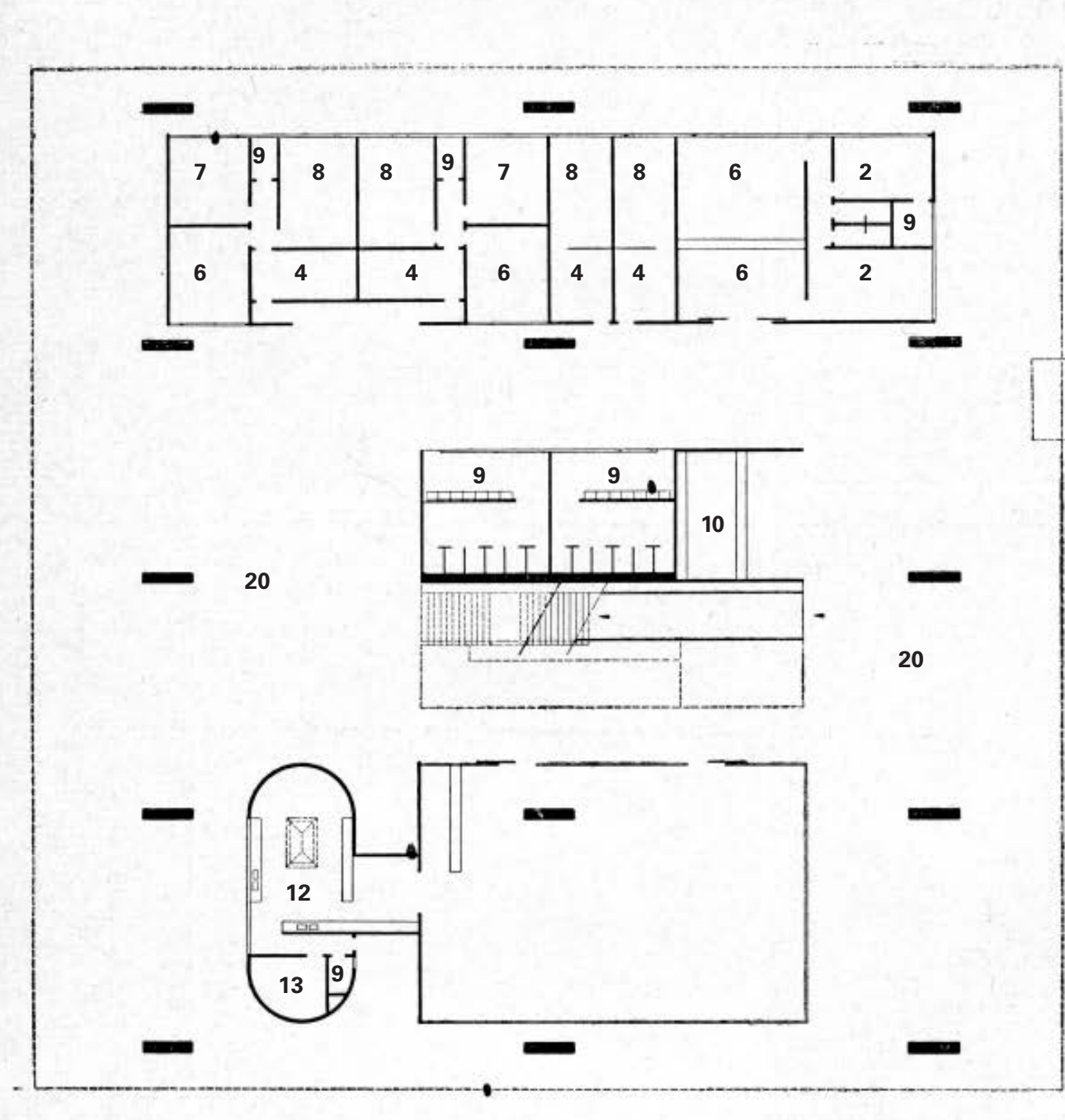

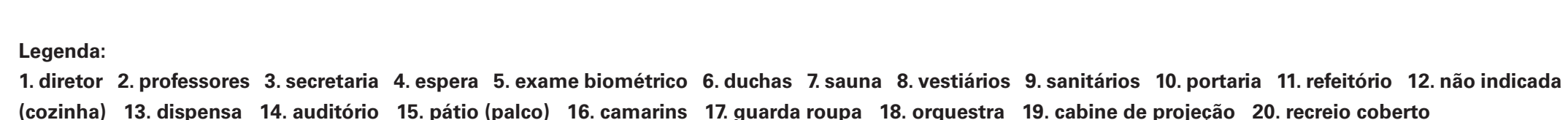
Escola-parque, entrequadras 3075 308S, Brasilia. Fonte: revista Módulo, n² 20, 1961.
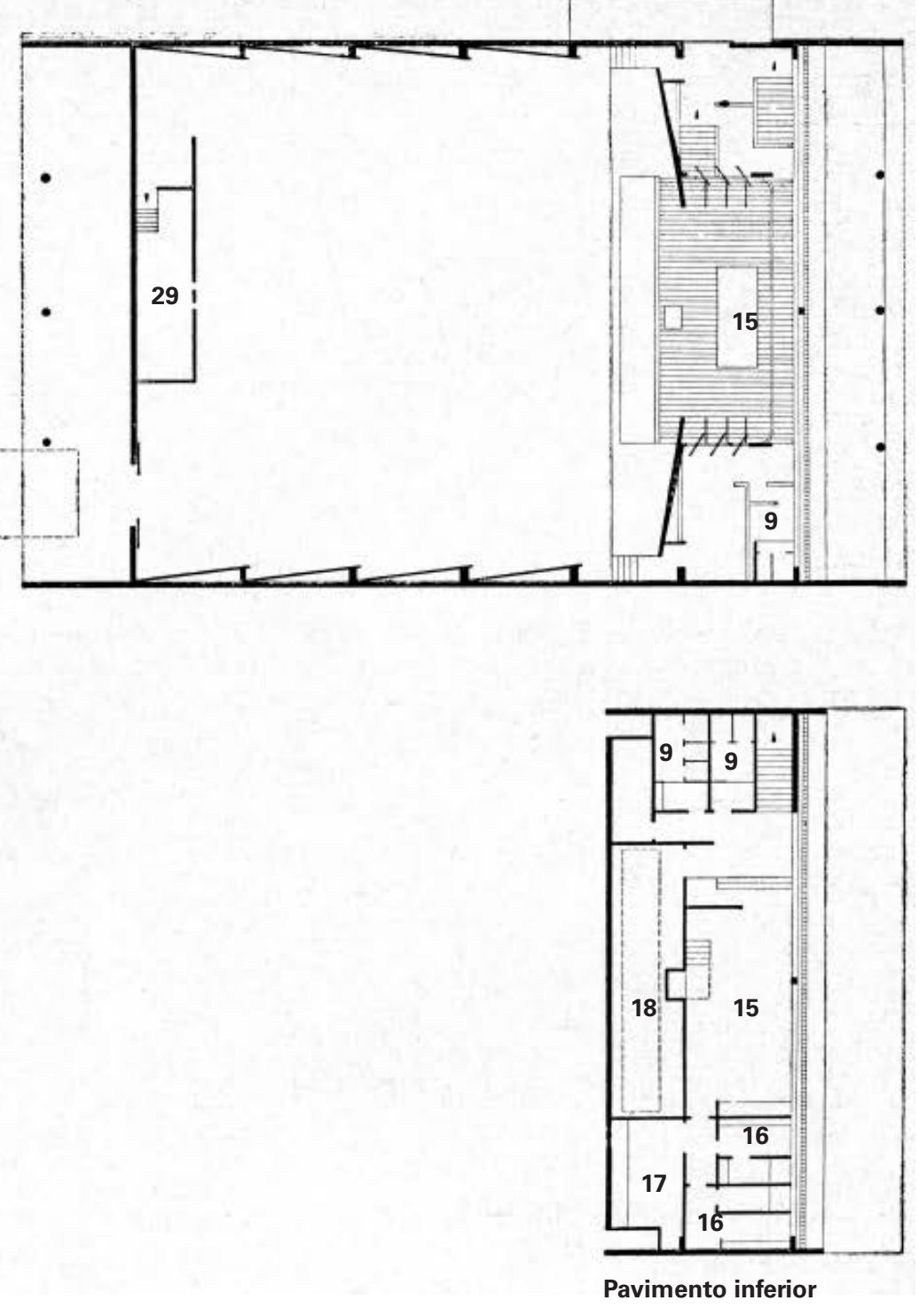

$\mathbf{N} \uparrow \quad \begin{array}{lll}0 & 5 & 10\end{array}$

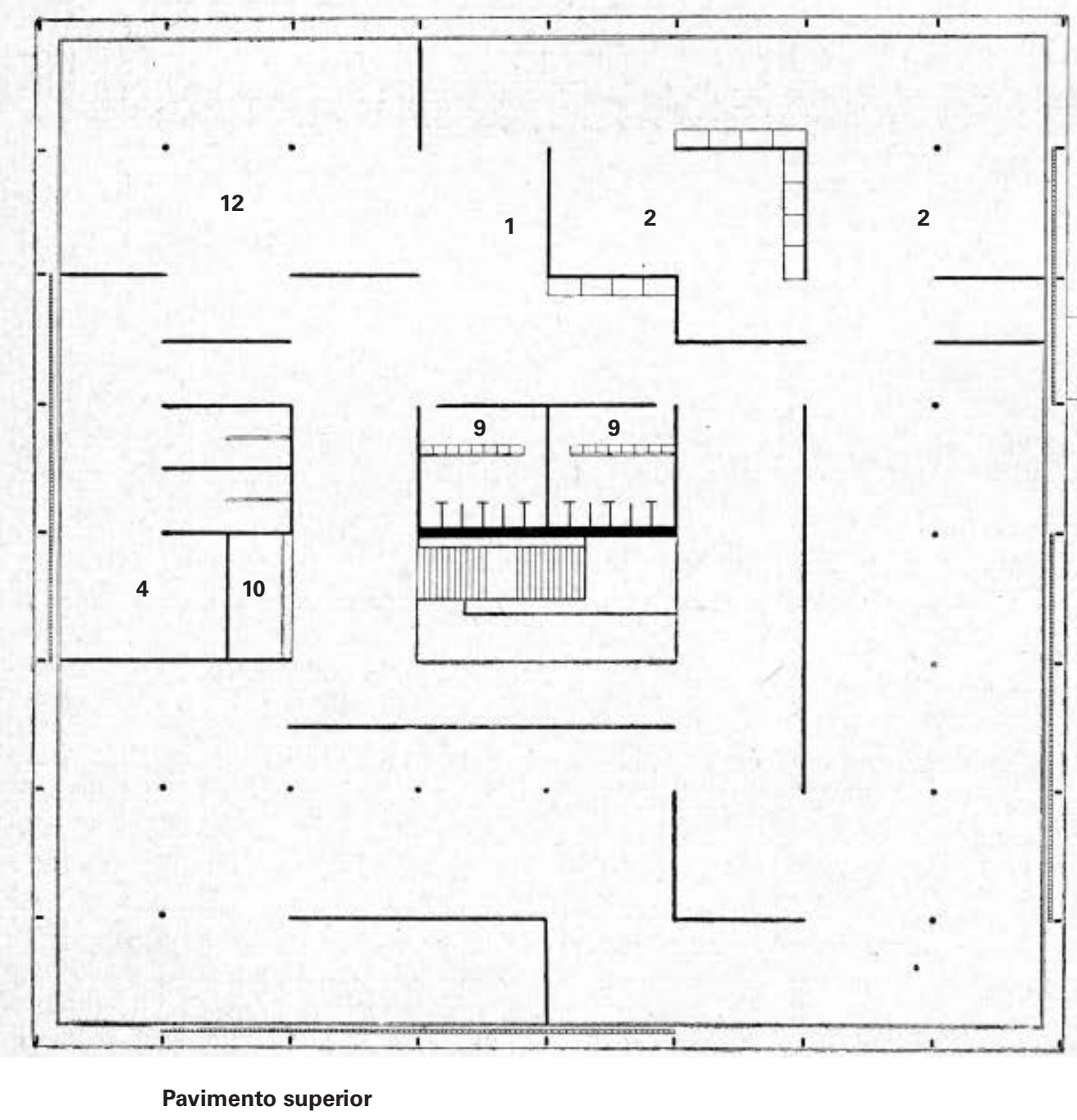

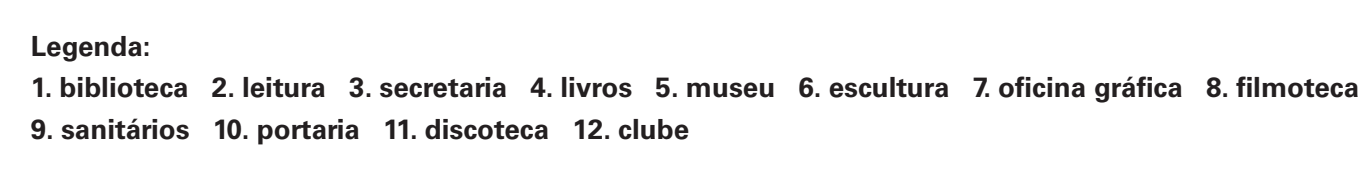

Escola-parque, entrequadras 3075 308S, Brasilia. Fonte: revista Modulo, n’ $20,1961$. 


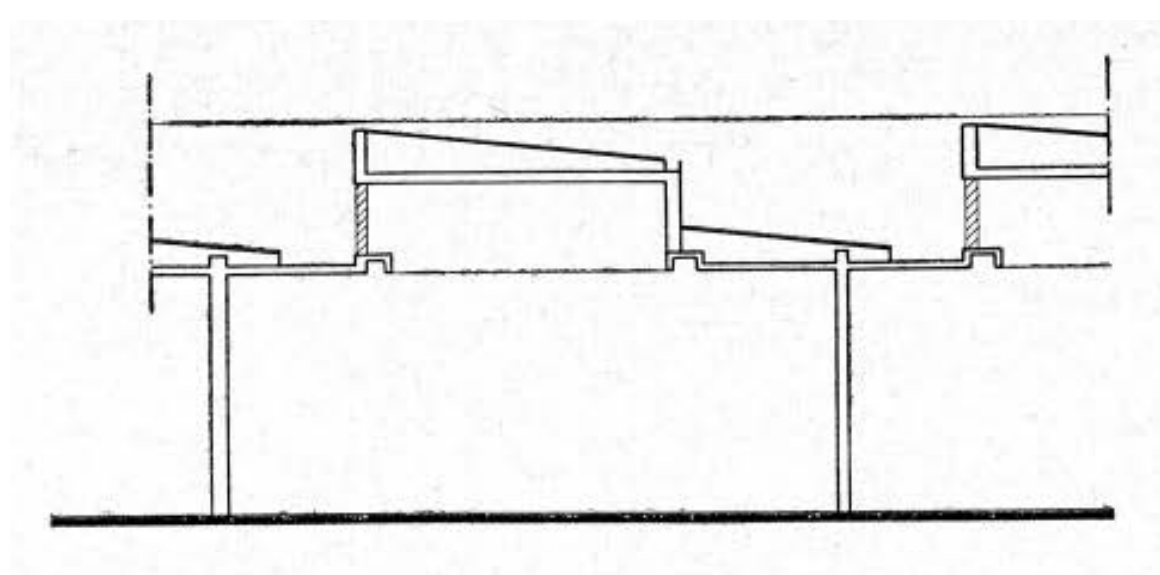

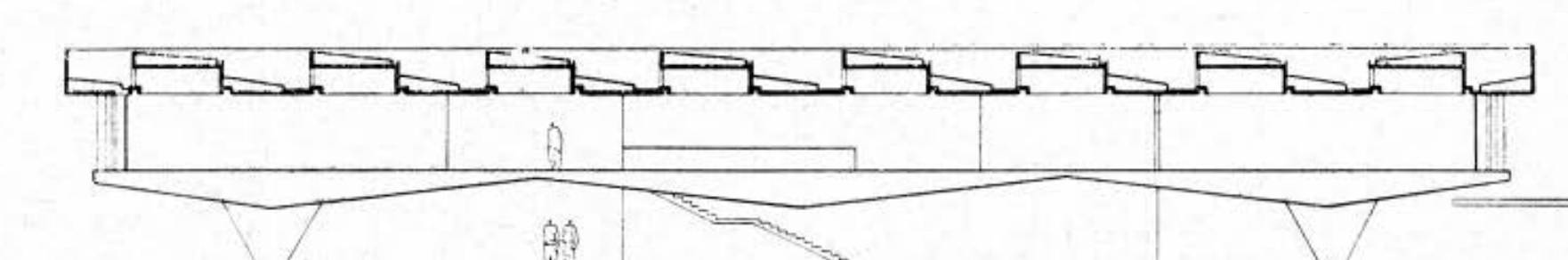

Escola-parque, entrequadras 3075 308S, Brasilia. Corte longitudinal edetalle da cobertura em shed. Fonte: revista Módulo, $n^{\circ} 20,1961$.

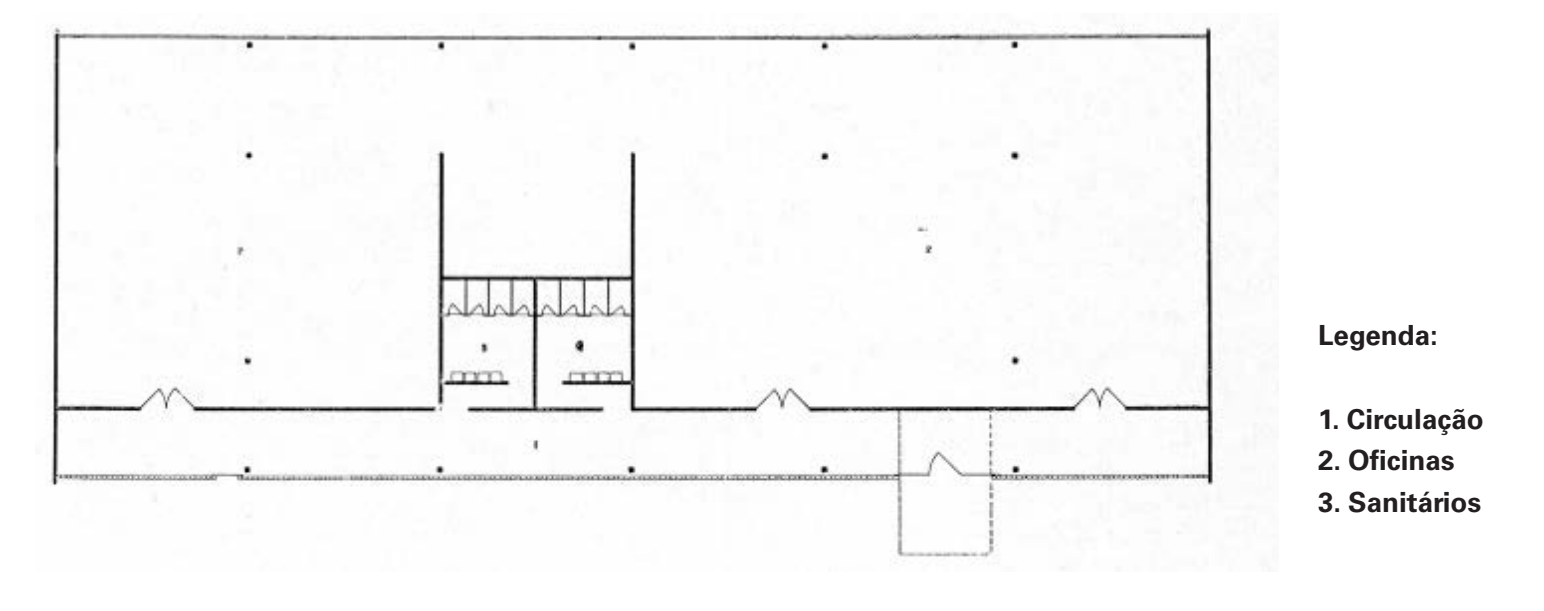




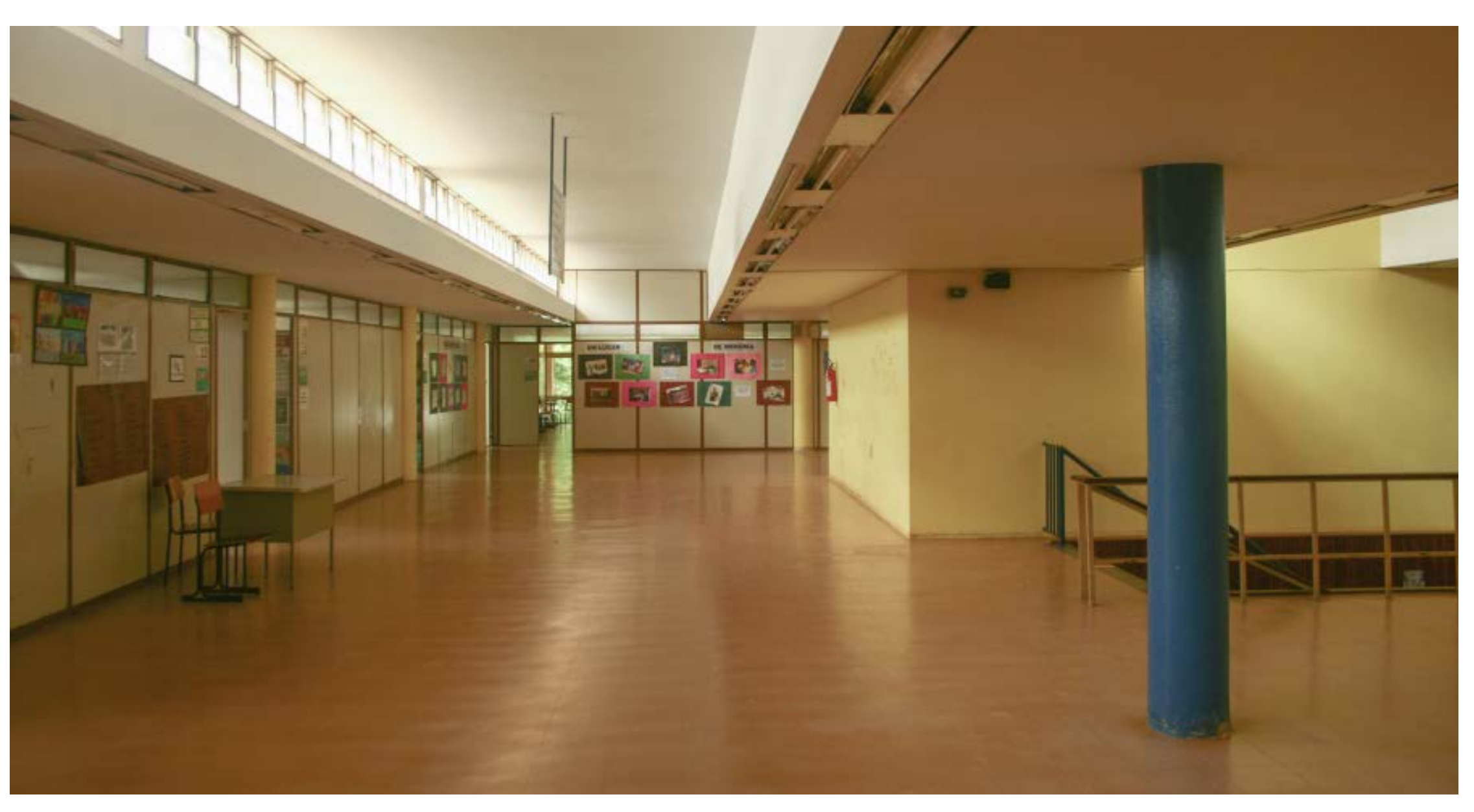

Escola-parque, SOS308, Brasilia, José de Souza Reis. Bloco central, pavimento superior. Foto: Valério Pietraraia, 2018.

É no pavimento superior da edificação principal, centralizada, que sua estrutura interior oferece maior diversidade e riqueza de situacões 0 arquiteto trata as fachana direção sul. Com a centralização da escada de acesso e dos sanitários, todo o restante dos $2.500 \mathrm{~m}^{2}$ está livre para ser ocupado com liberdade. Na configuração atual, cada esquina do volume envidraçado suspenso possui uma área

especializada: sala de dança, sala de ginástica, sala de mí-

de prática miscale teatral, con dversda de dines e orientação. 

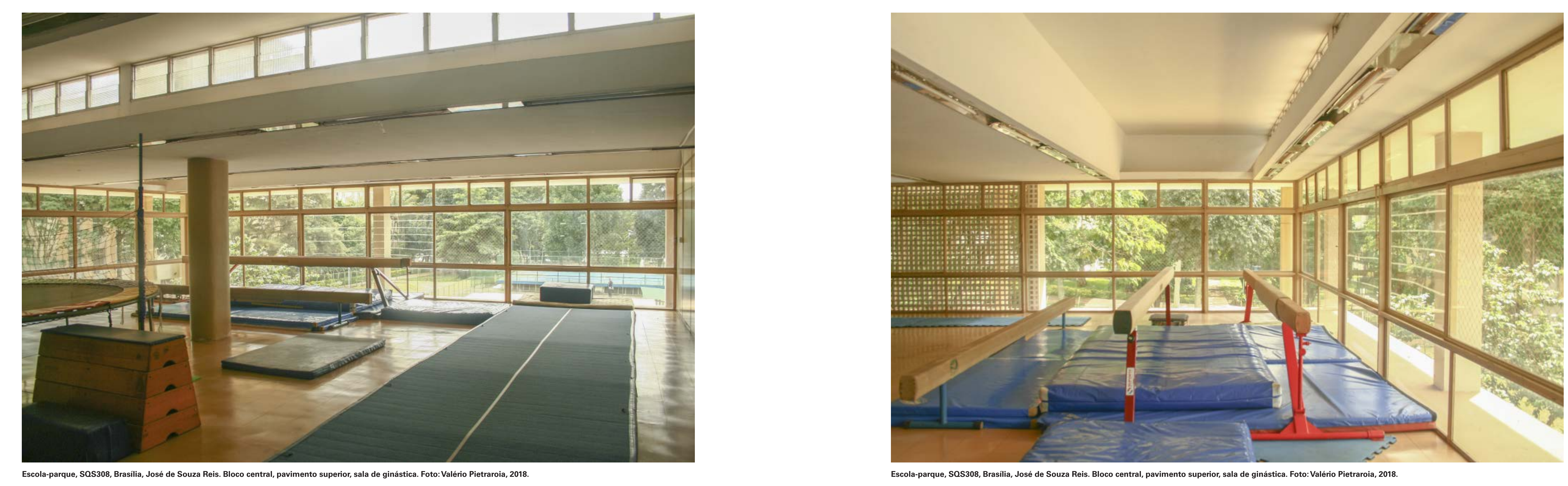

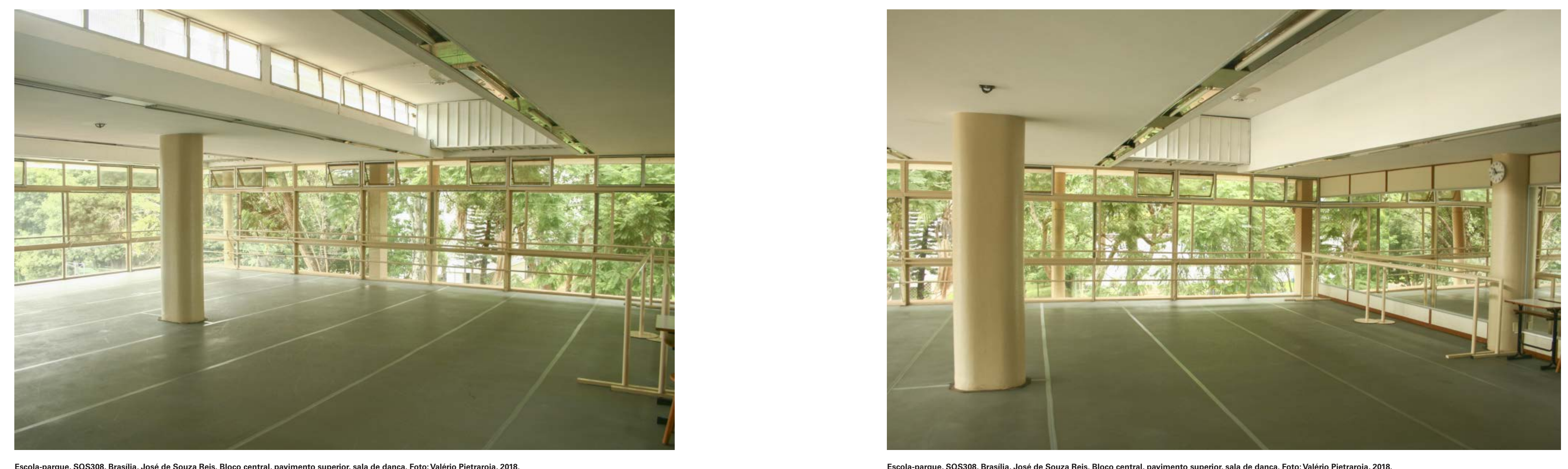

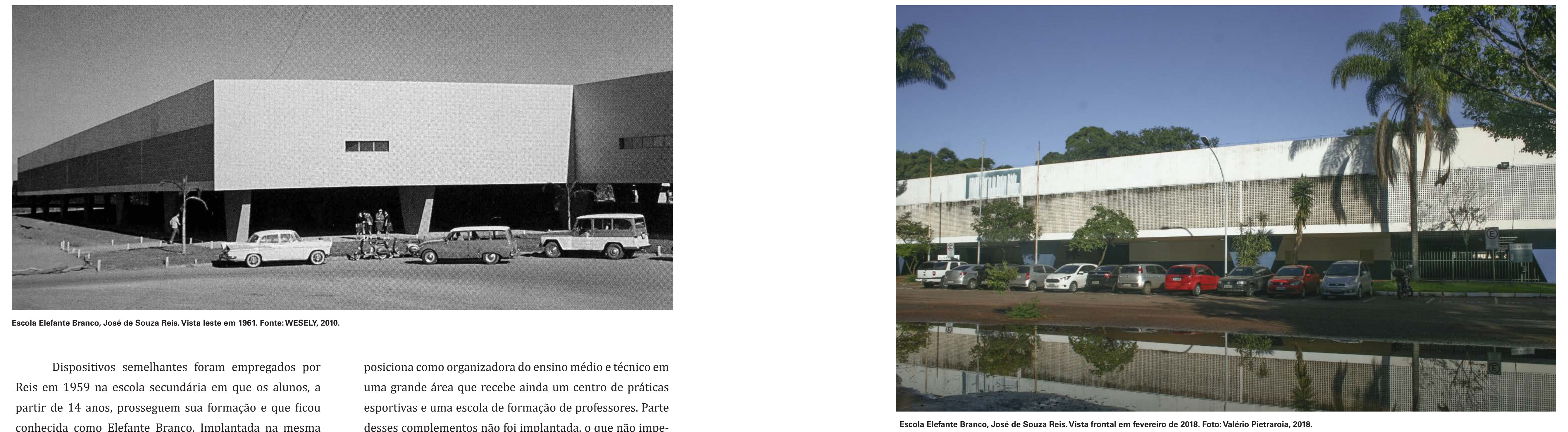
Reis em 1959 na escola secundária em que os alunos, a partir de 14 anos, prosseguem sua formação e que ficou conhecida como Elefante Branco. Implantada na mesma direção do entrequadras e ocupando um setor do Plano Piloto destinado ao ensino especializado ${ }^{97}$, a edificação se

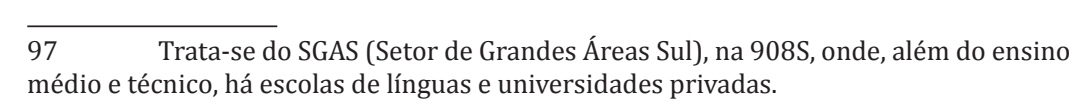

posiciona como organizadora do ensino médio e técnico em uma grande área que recebe ainda um centro de práticas esportivas e uma escola de formaçao de professores. Parte desses complementos não foi implontada, o que não impede que as previsões básicas do funcionamento em rede não se concluam. 


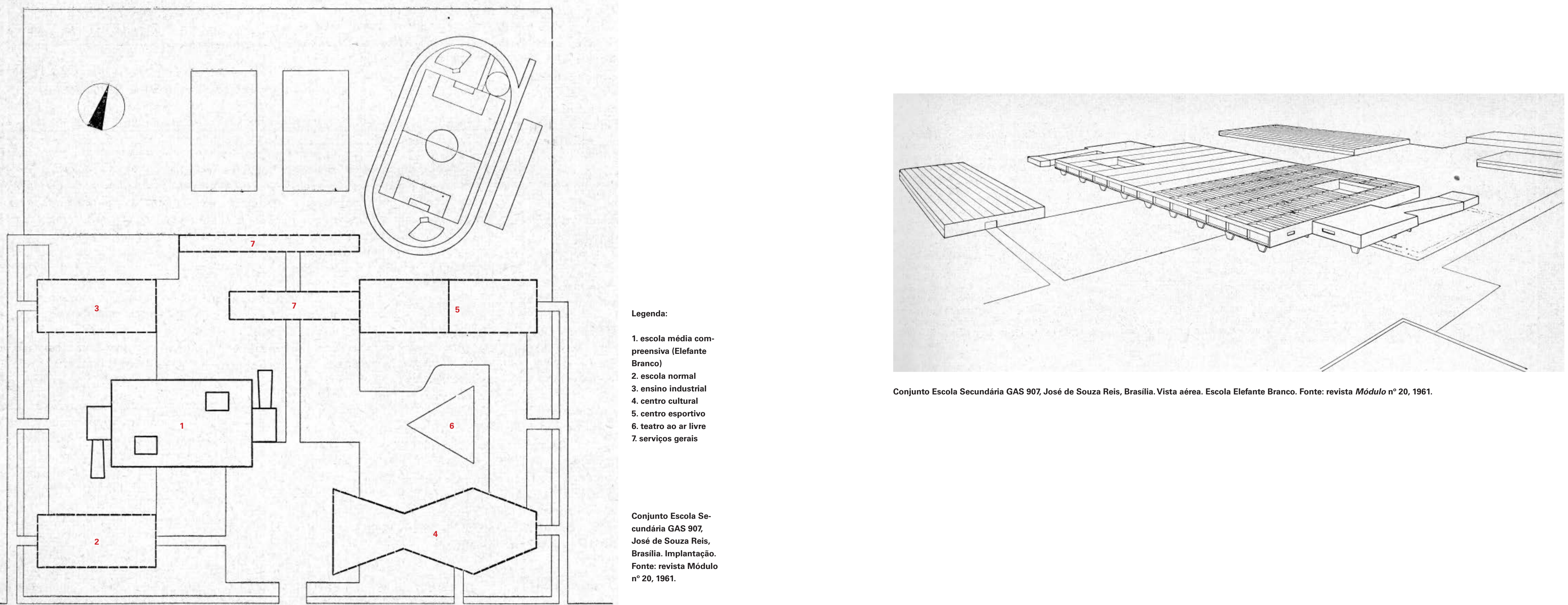


and

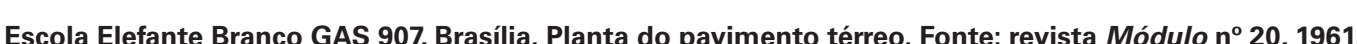

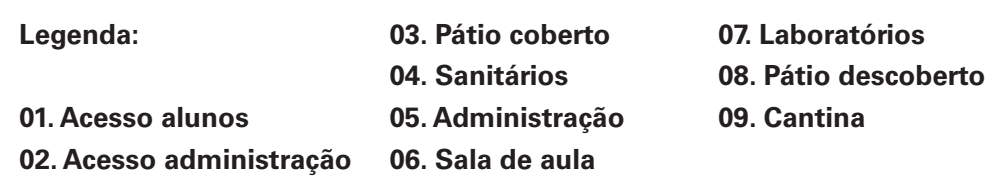

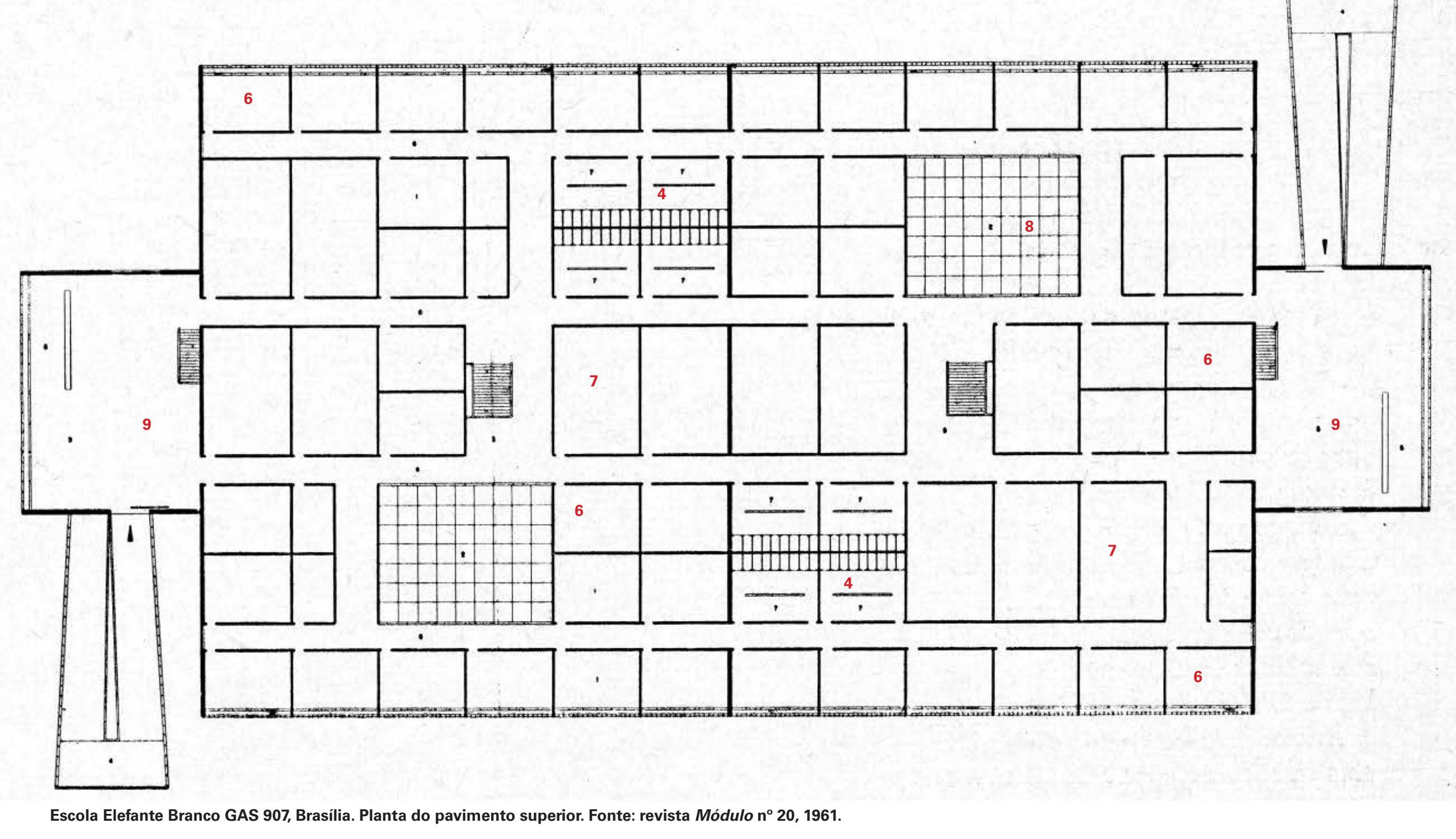

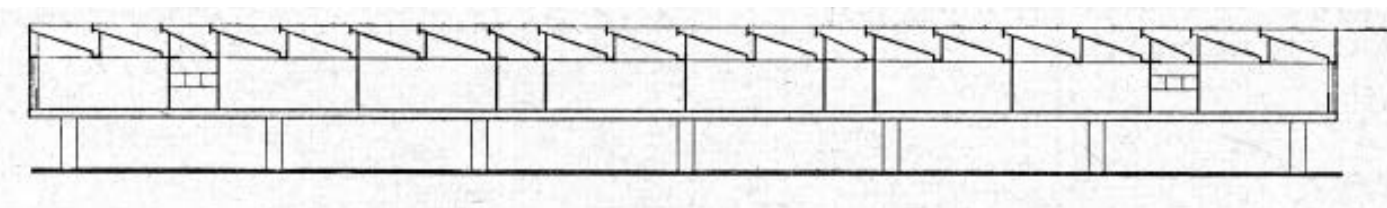




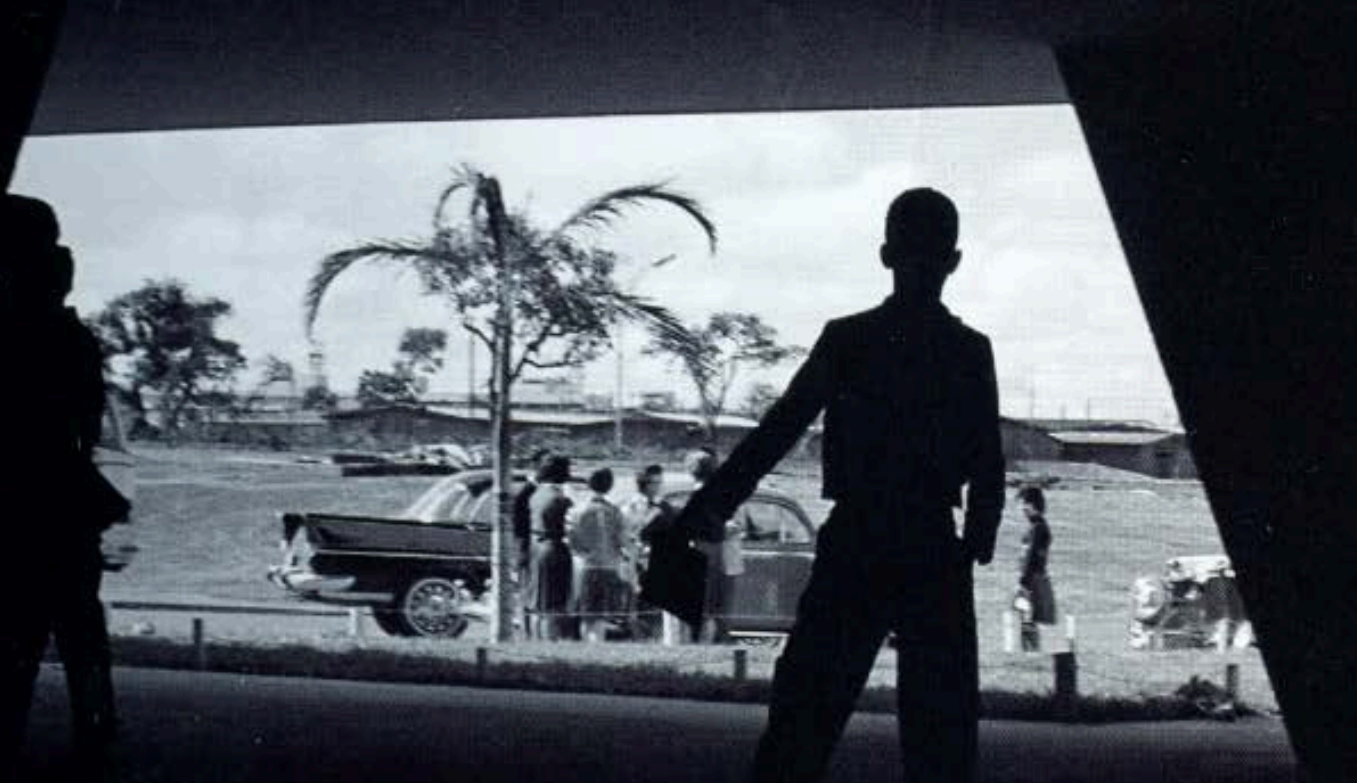

Escola Eletante Branco. Vista do pilotis em 1961. Fonte:WESELY, 2010.

Assim como na escola-parque, a edificação se organiza em dois pavimentos em que o pilotis forma uma importante sombra na paisagem. 0 volume superior, um prisma retangular compacto, repousa numa sequência de apoios triangulares, longitudinalmente distribuídos. Os volumes dos acessos em rampa ocupam as extremidades noroeste esudeste. A orgnizacão interna do volume suspenso é ba-

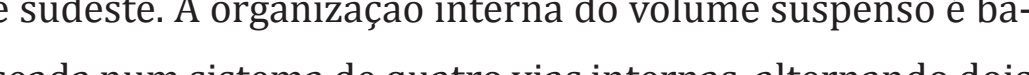

blocos sanitários e dois pátios externos quadrados. Como uma pequena vila, a malha flexível baseada no módulo de 7 × 9 metros comporta laboratórios, auditórios e salas de aula, atendidos pela cobertura em shed, semelhante à escola-parque da 308S. Ainda que o volume seja tratado externamente com longos panos de elementos vazados, pintados na mesma cor branca da alta platibanda o aspecto compacdo volume resultante inspirou co", que foi incorporado oficialmente pela escola.

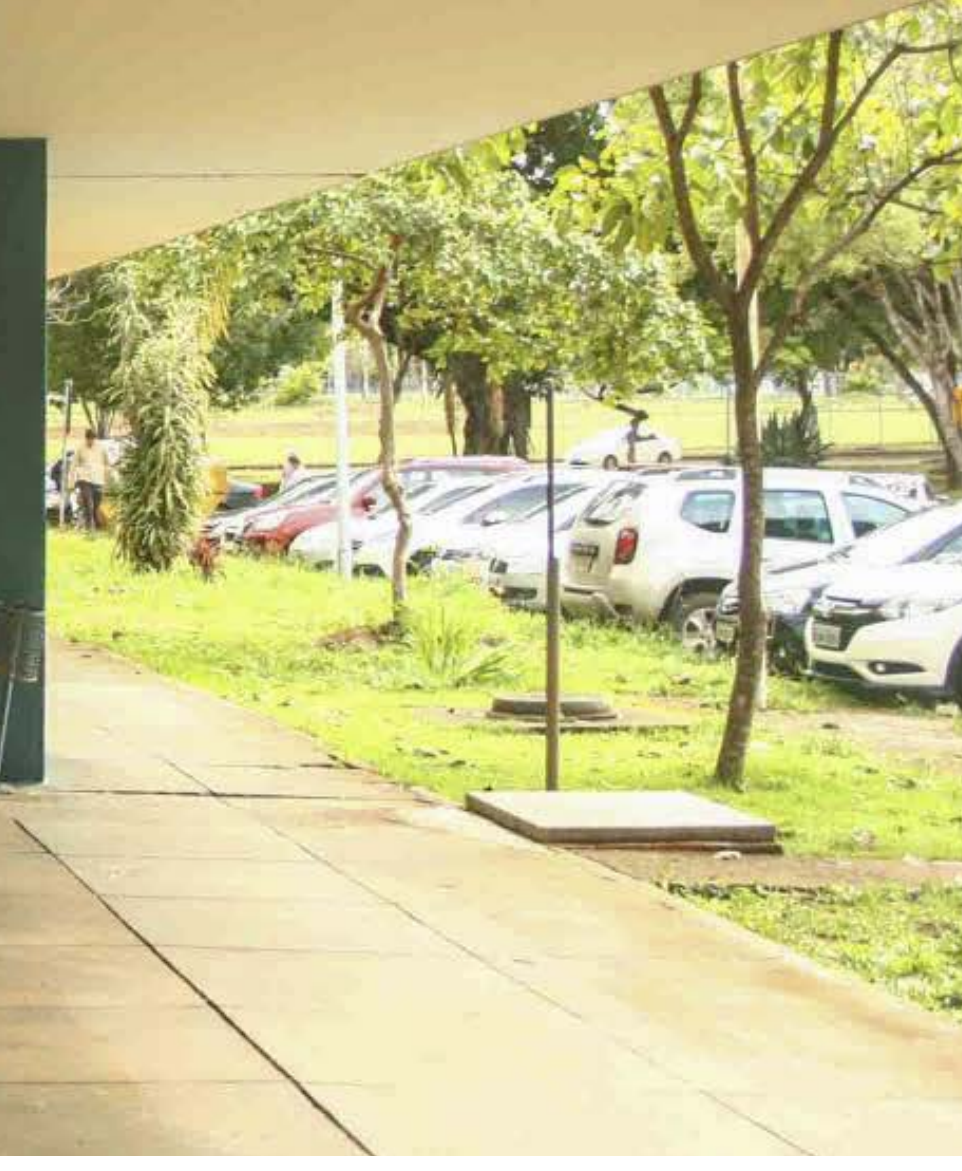



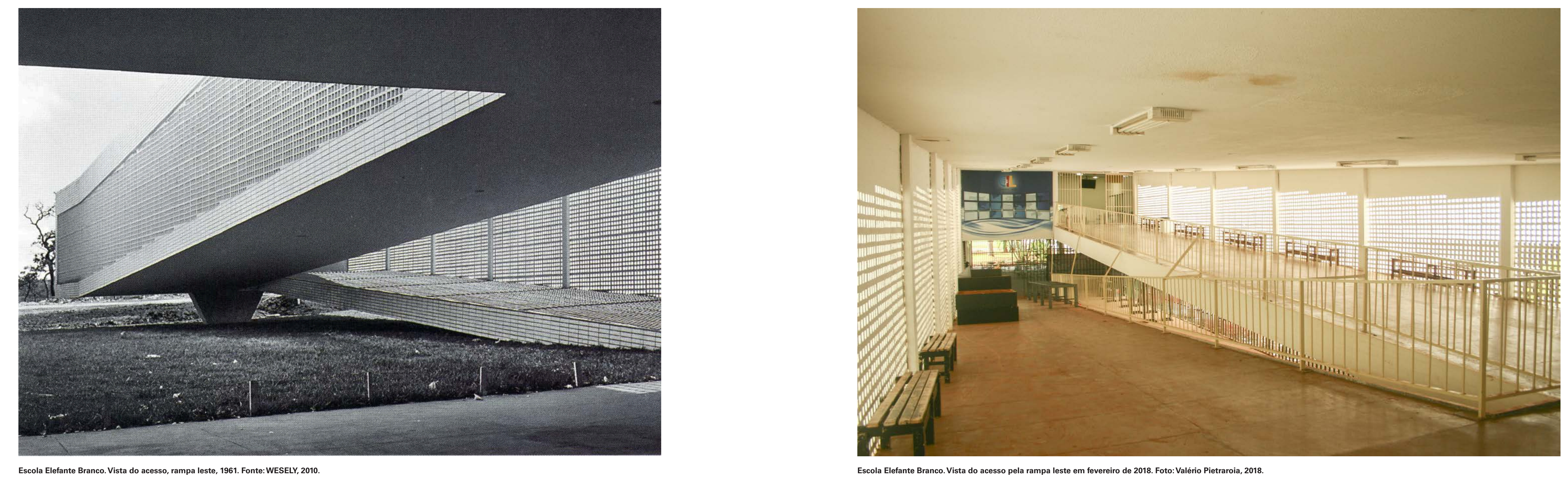


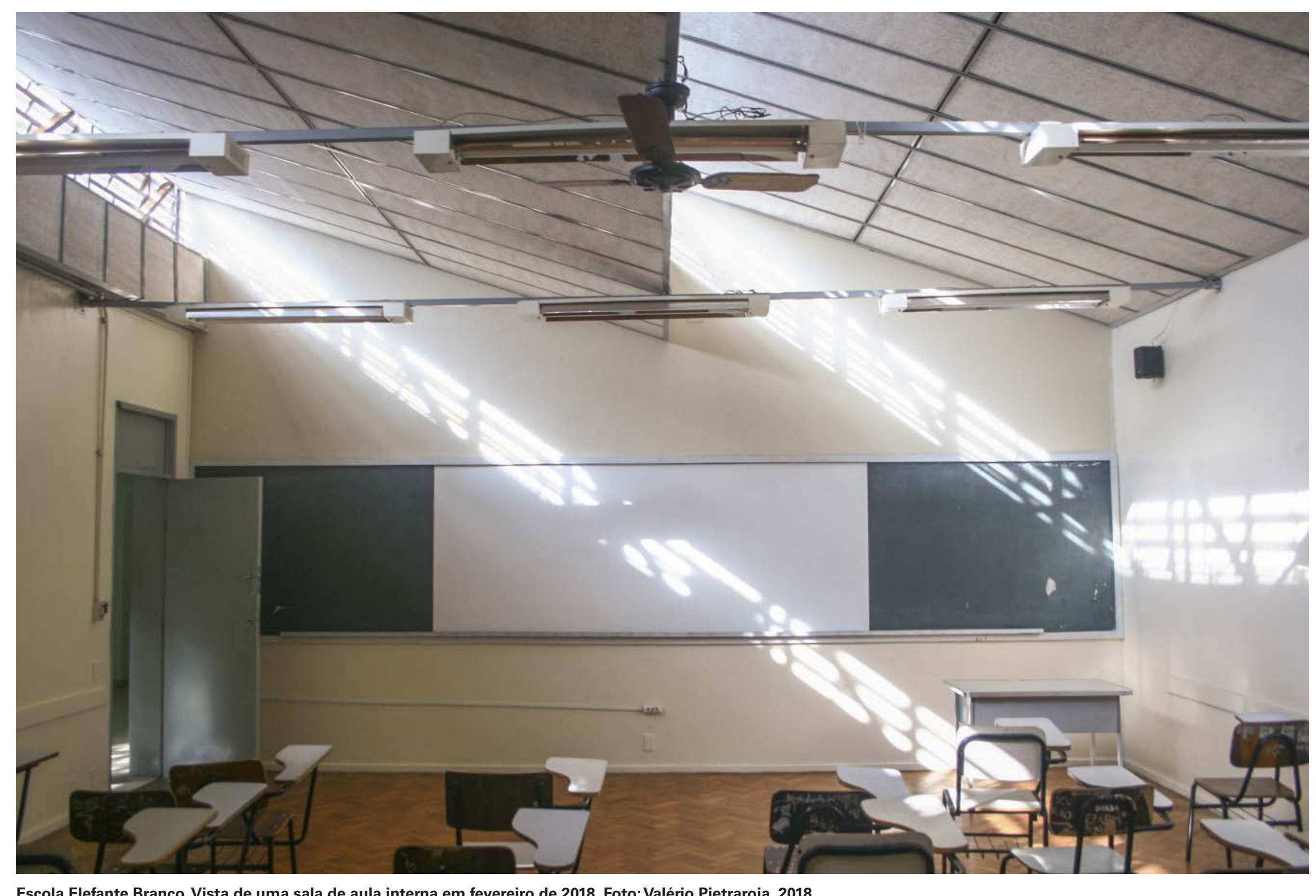

Teixeira e o programa como arquitetura

As redes de equipamentos de aprendizagem baseadas nos planos elaborados por Anísio Teixeira se materia lizaram durante sua atuação no Rio de Janeiro, em Salvador e em Brasília como apresentado acima. No entanto, a particularidades de cada contexto não exigiram estratégias distintas que se afastassem dos programas fundamentados pelo educador

Ficou claro o descompasso temporal da experiência carioca em que a arquitetura, ainda muito próxima às tradições ecléticas do século XIX, não revelava todo o potencial que o programa trazia. $O$ fato não impediu que as mudanças fossem pensadas de maneira sistêmica ao ser introduzida noção de rede de equipamentos.

Em Salvador, com a padronização evolutiva do ambiente escolar e com a experiência acumulada no Rio de Janeiro, a arquitetura de Diógenes Rebouças e a colaboração de Hélio Duarte se fizeram presentes de maneira definitiva, sempre como expressão do programa através das soluções pavilhonares.
Finalmente, Brasília proporcionou a experiência plena, ainda que a nova capital não tenha recebido toda rede prevista em seu Plano Educacional original. A siste tizzço rada para receber a rede educciona defend Teixeira pois Costa conhecia as experiências carioca e baiana, que vinham ao encontro da sua cidade moderna, visto que Rebouças e Duarte foram seus alunos. 
A arquitetura escolar [...] é essencialmente uma Arquitetura Experimental, à procura de uma solução.

Porque, na realidade, só poderíamos planejar uma escola nova sabendo de antemão para que tipo de educacãa ela se destina. $A$ faltou o conhecimento das experiências até agor faltou o conhecimento das experienncias ate agor
realizadas no mundo.

Parece evidente que a equipe reconhece traba-

Ihar sobre um dilema: a definicão de um determi-

nado partido arquitetônico para o equipamento escolar suporia a definição prévia de uma nova filosofia de ensino.

MARTINS, 1998

O final da década de 1940 vai alterar o panorama da rquitetura escolar na cidade de São Paulo. A celebração do 1ํo Convênio Escolar entre os governos municipal e estadual

O $2^{\circ}$ Convênio Escolar em São Paulo ocorrera em 1943, sob a administração do prefeito Prestes e a arquitetura como programa Maia, com o objetivo de suprir a extrema ausência de esco- 
las na cidade ${ }^{98}$. Entretanto, apesar da parcela significativa do orçamento municipal $(15 \%)$ destinada ao $1^{\circ}$ Convênio, as realizações foram insignificantes 9 .

Somente no final de 1948 , pela instalação do $2^{\circ} \mathrm{Con}-$ vênio Escolar, é constitúda a Comissão Executiva, prevista desde 1943, que foi composta por arquitetos formados n Escola de Belas Artes do Rio de Janeiro e na Escola Politécnica da Universidade de São Paulo ${ }^{100}$, cuja atuação foi responsável pelas transformacõos da arquitetura escolar na ue antecederam seu quarto centenário, experiência que o projeto dos CEU, como red de equipamentos, pretendeu recuperar (DELIJAICOV, 2004 e 2011).

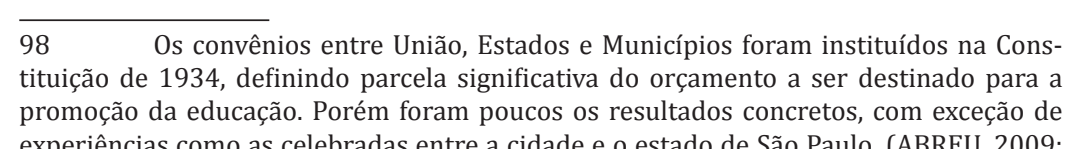

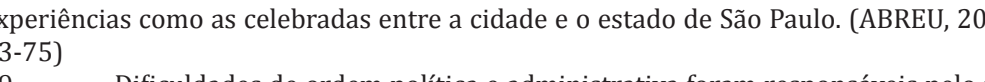

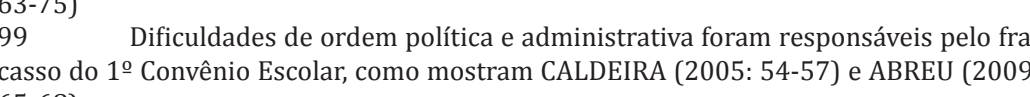

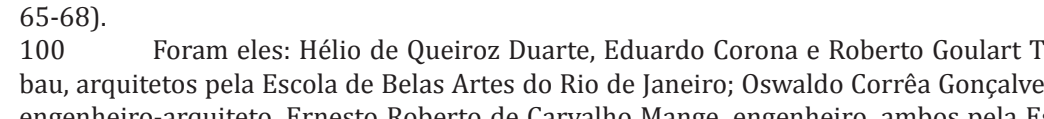

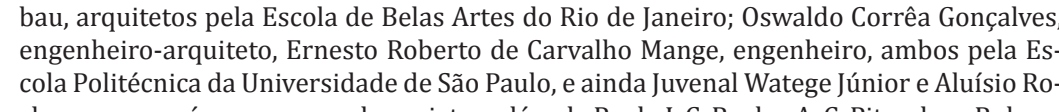

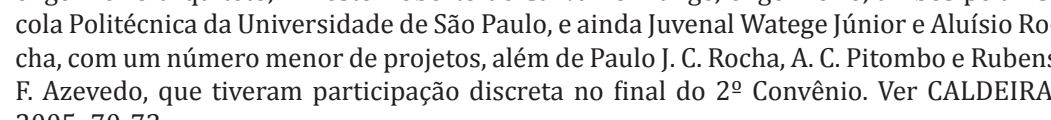

No contexto de nossa pesquisa, examinaremos as transformacooes a que estamos nos referindo e para isso, estudaremos a atuac̃o da equipe do Convênio na escala da

Em relação à cidade, cada escola foi considerada uma célula capaz de atender à comunidade num raio de aproxmadamente 1.500 metros. Os levantamentos e estudos realzados pelo Convênio desde o início da década de 1940 indicavam a necessidade de construça de 1200 salas de auh 0 unos, suprindo o déficit verificado projetado até 1954, quando a meta estabelecida coincidiria com as comemorações do IV Centenário da cidade ${ }^{101}$.

Ao optar por escolas de menor porte com 12 salas de aula, mais próximas da escala do bairro, a equipe do $2^{2}$ Convênio entendeu poder atender com maior precisão e velocidade as objetivos phanejos, invertendo a estraté

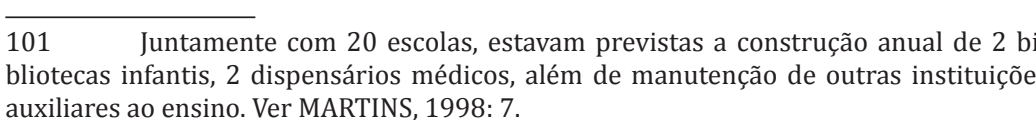

o 1ํㅡㄹenênio que, ao optar pela construção de grandes escolas, conseguiu implantar apenas 3 unidades no período de 6 anos.

Por esse raciocínio, podemos traçar um esquema abstato de rede pública de equipamentos que ocuparia uma superfície de $900 \mathrm{~km}^{2}$, como simulado acima, em que as 100 escolas previstas poderiam se articular com outros equipamentos públicos formadores, como bibliotecas, parques inequipamentos. 0 exercício indica que seria possível, como hipótese, atender à totalidade do território da cidade. 
No que refere ao bairro, a sistematização das implantações, resultado da articulação de 3 blocos ou pavilhôes funcionais (ensino, recreação e administração) envolvido pelas áreas livres dos terrenos ou das quadras abertas, fo um passo fundamental para aproximar a vida escolar da vida da comunidade local, rompendo com o distanciamento até então estabelecido pela imponência e, em muitos casos pela monumentalidade da arquitetura escolar oficial. A estratégia retoma a solução do Centro Educacional Carneiro Ribeiro, em Salvador, e auxilia o reconhecimento, por parte da população local, da presença do equipamento público na transformação e na construção de uma identidade do lugar Cabe-nos fazer agora um exame mais detalhado $\mathrm{d}$ transformações na concepção das edificaçõos desenvolvdas pela equipe do $2^{\circ}$ Convênio. Destacadas em epígrafe, as reflexões de Ernesto Mange e Hélio Duarte, ainda durante a vigência do 2 o Convênio Escolar em São Paulo, ilustram o protagonismo que o projeto assumiu naquele momento como instrumento para a construção de um programa
Primeiramente por introduzir a noção de padron zação e de repeticã̃o do projeto. Tal nocãa também deve ser destacada por padronização e repetição dos componentes e dos detalhes construtivos, dos pavilhões funcionais que puderam ser articulados de maneira distinta a cada implantação $0^{102} \mathrm{e} \mathrm{da}$ repetição da própria implantação, quando o contexto pudesse justificálla. Essa opção promoveu a racionalização dos recursos e dos mios de produc̃ão do projeto e da obra É importate trial de São Paulo atingira a lideran que pode ser apontado como um fator substancial para o resultados obtidos pela equipe do $2^{\circ}$ Convênio.

Em seguida, a identidade de cada pavilhão deve-se à sua concepção espacial:

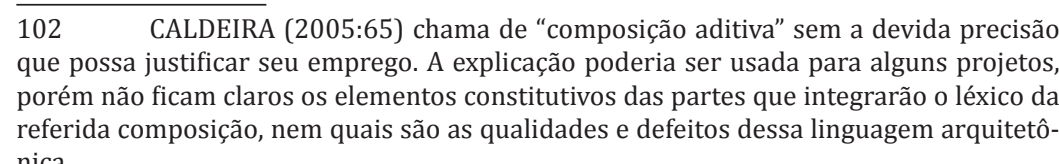

pacialmente, o rompimento da tipologia pahonar, assim como a busca de uma abertura para o ambiente extern leva à definic̃o de una Organizaç̃o em três setores espacisis bastante

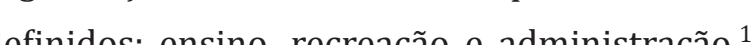
(MARTINS, 1998:9)

0 pavilhão do ensino obedece a uma ordem longituInal, priorizando uma face a ser melhor orientada em relada face oposta, resultando num prisma retangular quase da face oposta, resultando
sempre com dois pavimentos.

o pavilhão recreativo é composto por uma cobertura leve, sem fechamentos laterais, com maior liberdade formal, caracterizada pela estrutura em arcos de concreto armado ou madeira, formando uma abóboda. Está nessa edificação um dos elos mais claros da relação da arquitetura com o programa. Ainda que não possa atender a todas

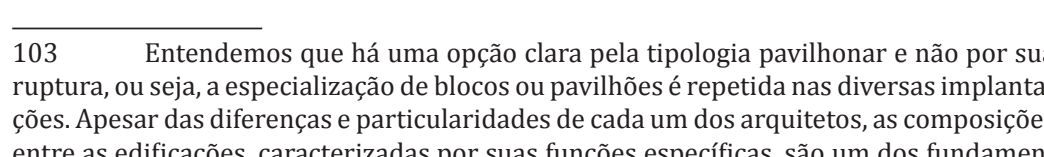

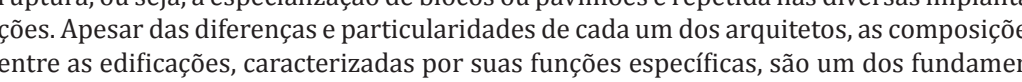

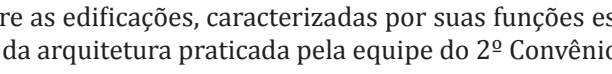

as atividades preconizadas pelas ideias de Anísio Teixeira e no "galpão para recreio coberto" que a escola vai ampliar suas possibilidades pedagógicas até então restritas à sala de aula. Invariavelmente, a presença de um palco e de vestiários de apoio permite a realização de apresentações musicais e teatrais, entre outras ${ }^{104}$

O pavilhão administrativo é uma pequena edificação terrea, de pequena proporção em relação ao conjunto e disposta junto ao acesso principal da escola.

Há nos projetos a expressão de cada membro da equipe, ainda que as características acima assinaladas estejam, em sua grande maioria, sempre presentes com maio ou menor intensidade. A descrição acima corresponde à parte significativa dos projetos realizados, porém, com maior proximidade à queles de autoria de Hélio Durte Incialmente poderíamos entender tais diferenças baseando-nos nas condições de cada contexto aos quais cada obra deveria se adequar

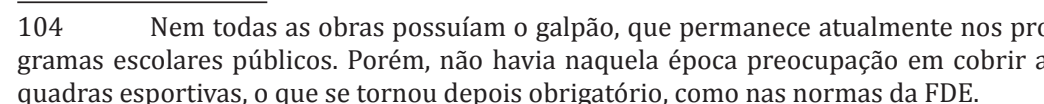




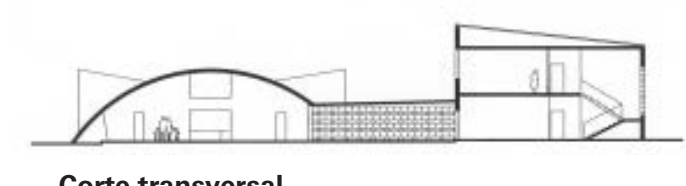 corte transversal}

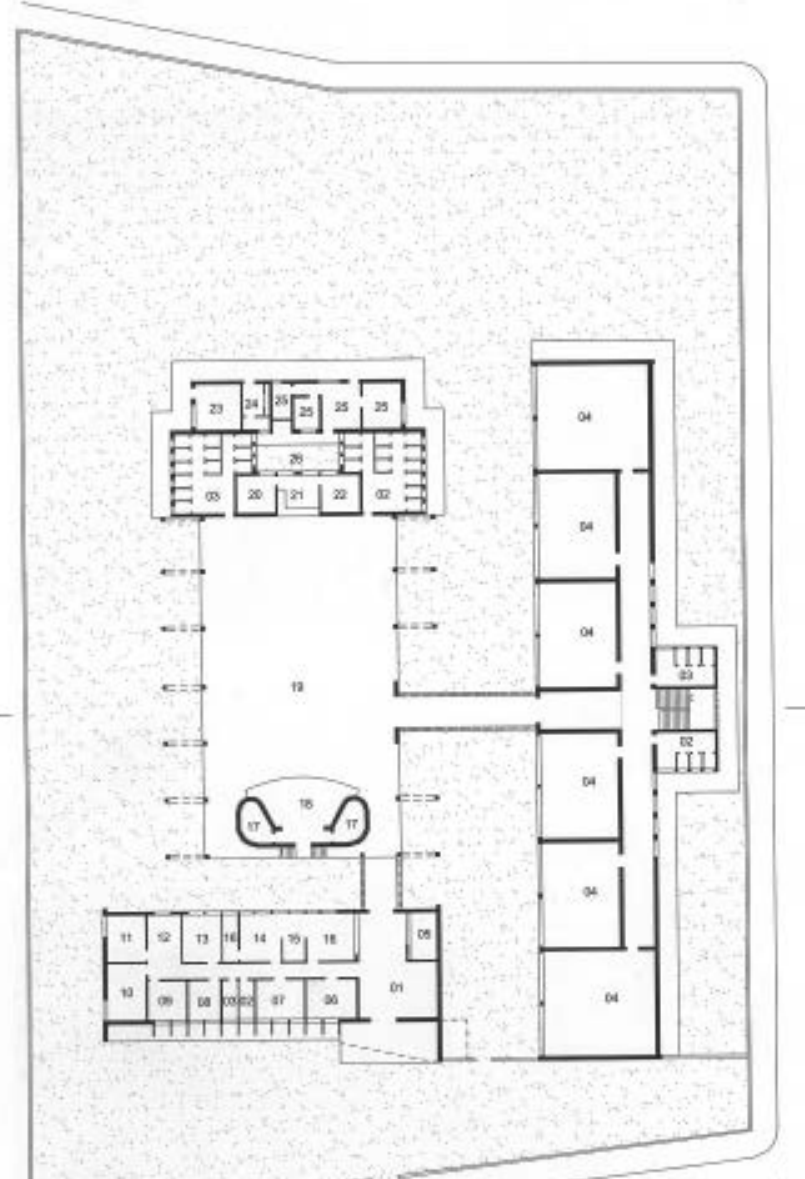

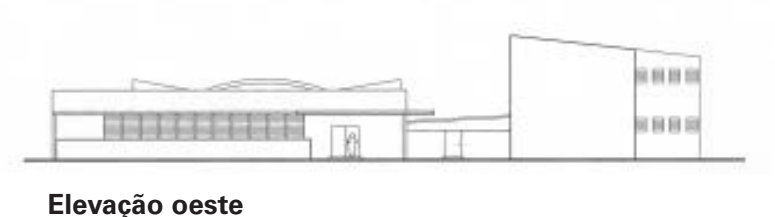
Elevąăo oeste

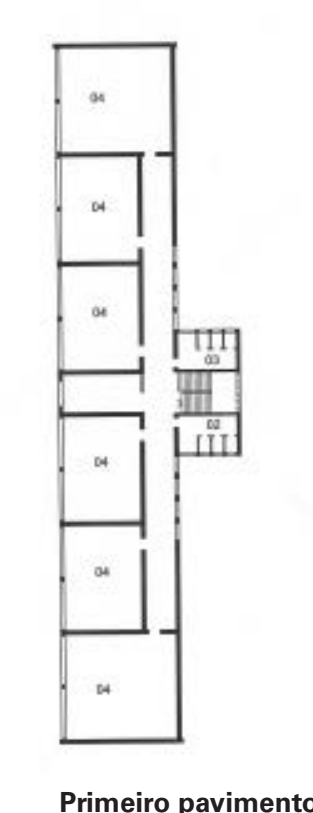

É acertado afirmar que a extensão do território da cidade de São Paulo no início da década de 1950 já apresentava grande diversidade de características físicas naturais e de urbanização, o que explica as variações dos projetos do $2^{2}$ Convênio que podemos notar. Entretanto, é possível traçar a identidade de cada projeto baseada na sua autoria e confrontá-la com as reflexões de cada um de seus autores.

Hélio Duarte, como vimos, trouxe toda sua experiência de atuação junto às políticas educacionais propostas por Anísio Teixeira em Salvador. Podemos identificar a presença dos pavilhões especializados cuja articulação variável segue a lógica funcional e obedece às preocupações higienistas, 0 que permite relações distintas com o contexto imediato. 0 arquiteto apresenta exemplos claros do projeto ao repeti-lo em regiẽes distintas da Capital Paulista como Indinget

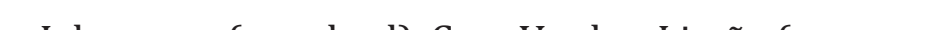
e Jabaquara (zonal sul), Casa Verde e Limão (na zona norte) ainda Lapa (zona oeste) e Mooca (zona Leste).

Os pavilhões são dispostos no terreno com variações de proximidade, sempre interligados por pequenas coberturas, uma referência à arquitetura carioca exercitada em sua passagem pela Bahia. As diferenças, no entanto, ficam evidentes em função da rigidez e da pouca liberdade com que esses dispositivos de protec̃̃o e de transicão são concebidos Há obras um eixo de composição simétrico em que a circulação participa como estruturadora, tanto interna como externamente. 0 tratamento desses espaços também é totalmente distinto da fluidez plástica que marcou a arquitetura carioca. 0 ritmo constante dos apoios e o fechamento com vidro preenchendo planos de elementos vazado Rinis Rino Levi em suas obras do início da década de 1940 em São Paulo, como o Instituto Sedes Sapientiae.

Nos projetos de Oswaldo Corrêa Gonçalves encontramos muita proximidade com as obras de Hélio Duarte, com destaque para a soluç̃o de articulaç̃̃o entre os pavi-

\section{Implantação / téreo}

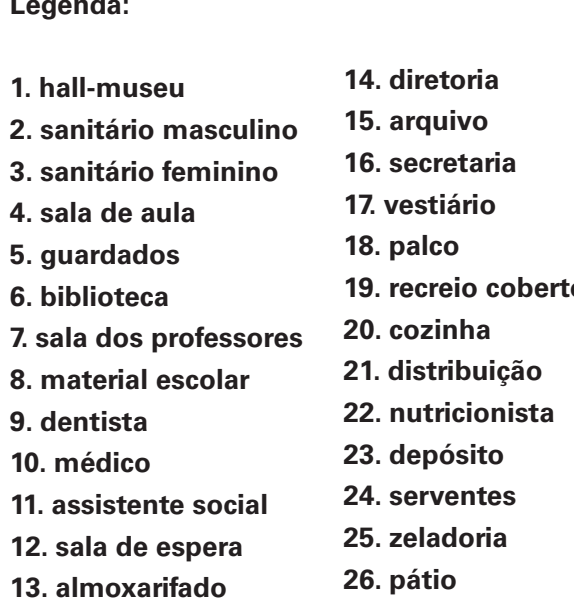




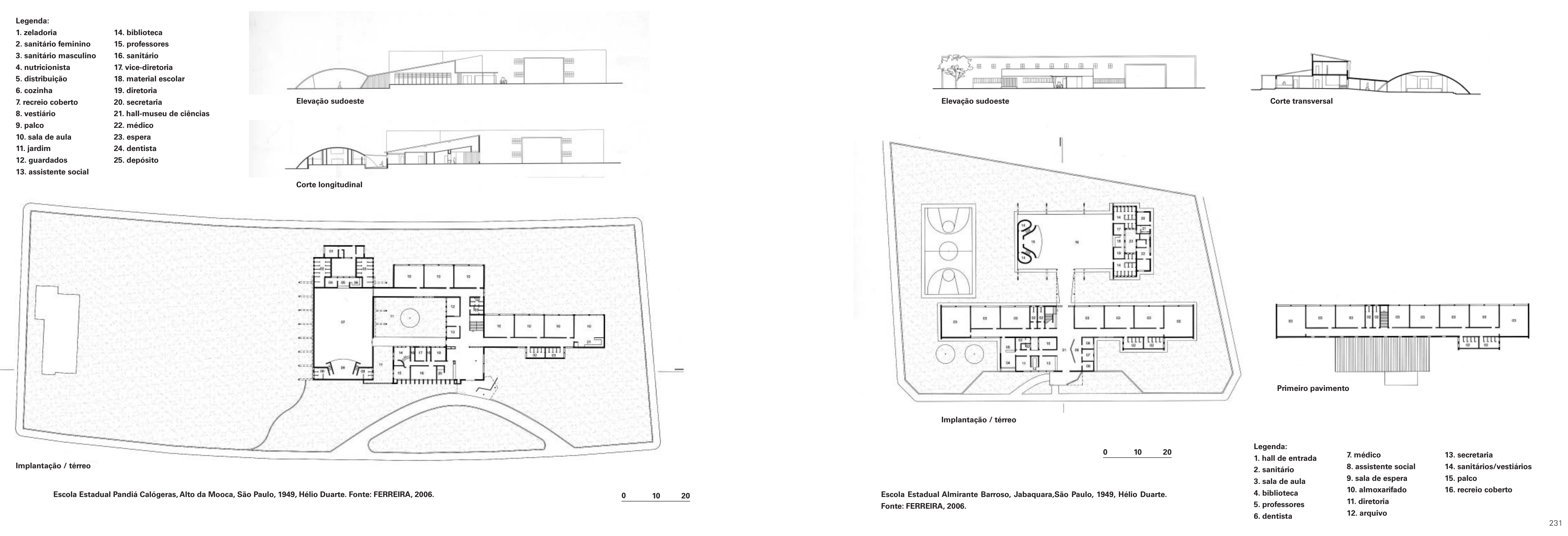


Thões e do tratamento tipológico dado à cada área funcional. Permanece o longo pavilhão de ensino em dois pavimentos relacionando-se com o recreio coberto por uma abóboda leve e as áreas administrativas próximas ocupando uma pequena edificação complementar.

Corrêa Gonçalves formula, no entanto, maior variedade de soluções, como os pilotis para o recreio coberto, em função das características dos terrenos. Assim, o programa pode ser distribuído em duas edificações de dois pavimentos em que as salas de aula ocupam o pavimento superior e as recreativas e administrativas, o térreo. A repetição dessa estratégia proporciona maior riqueza de espaços externos configurados pela arquitetura, como pátios internos protegidos, e não somente como espaços livres residuais resultantes dos objetivos funcionais.

As longas galerias resultantes da solução praticada por Corrêa Gonçalves e, principalmente, por Hélio Duarte, são pouco apreciadas por Ernesto Mange. Sua formação em

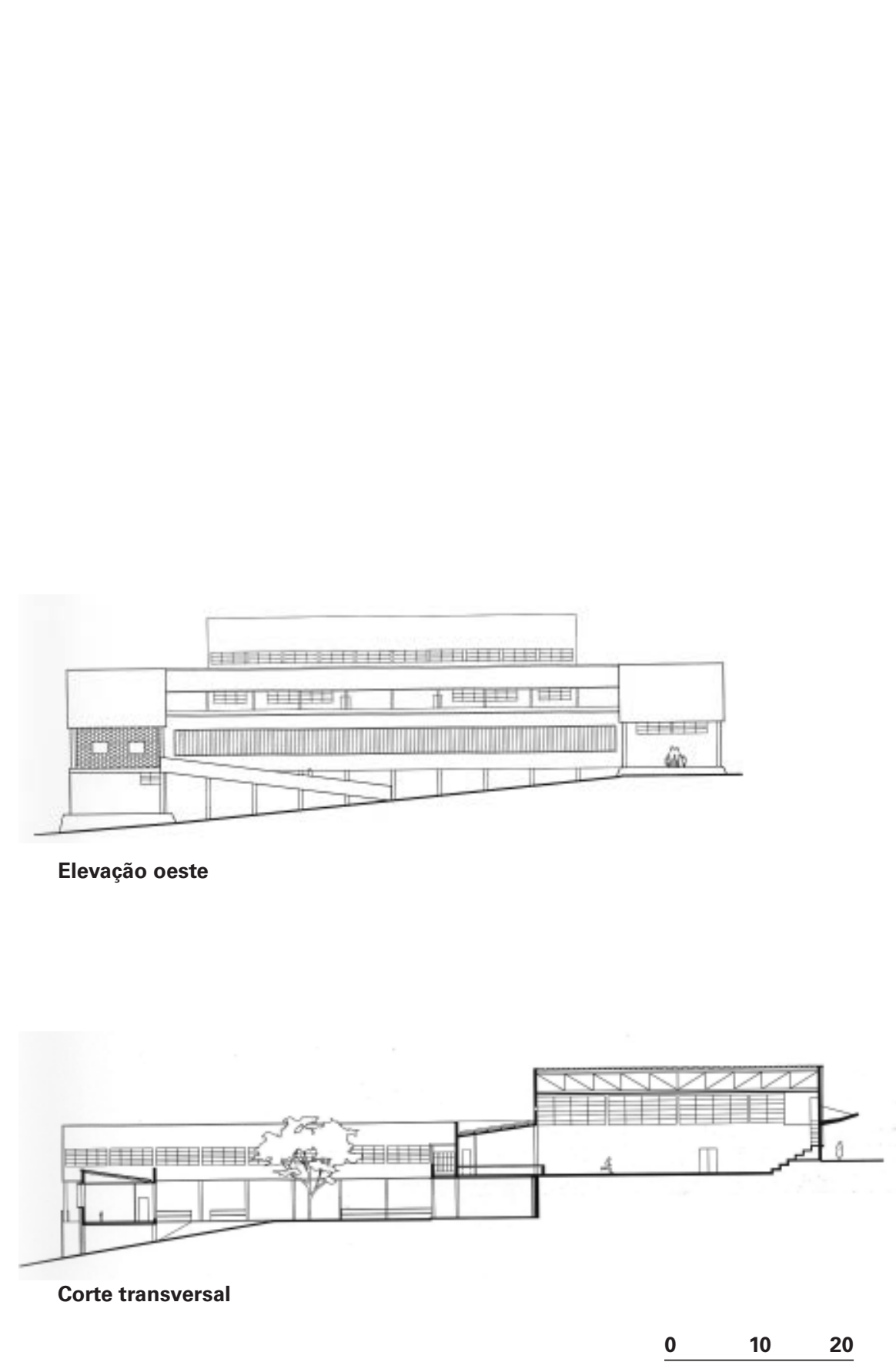

Legenda:
1. 1. sala de aula
2. sanitario fen

11. nutricionista
12. dentista

20. arquivo
21. secretaria

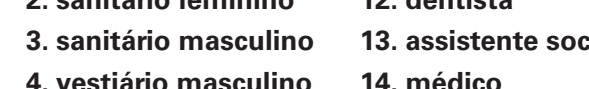

.

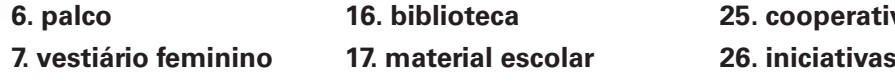

$\begin{array}{ll}\text { 8. cozinha } & \text { 18. materiário } \\ \text { 9. depósito } & \text { 19. diretoria } \\ \text { 1. } & \end{array}$

22. iniciativas
27. patio

28. ginásio poliesportivo

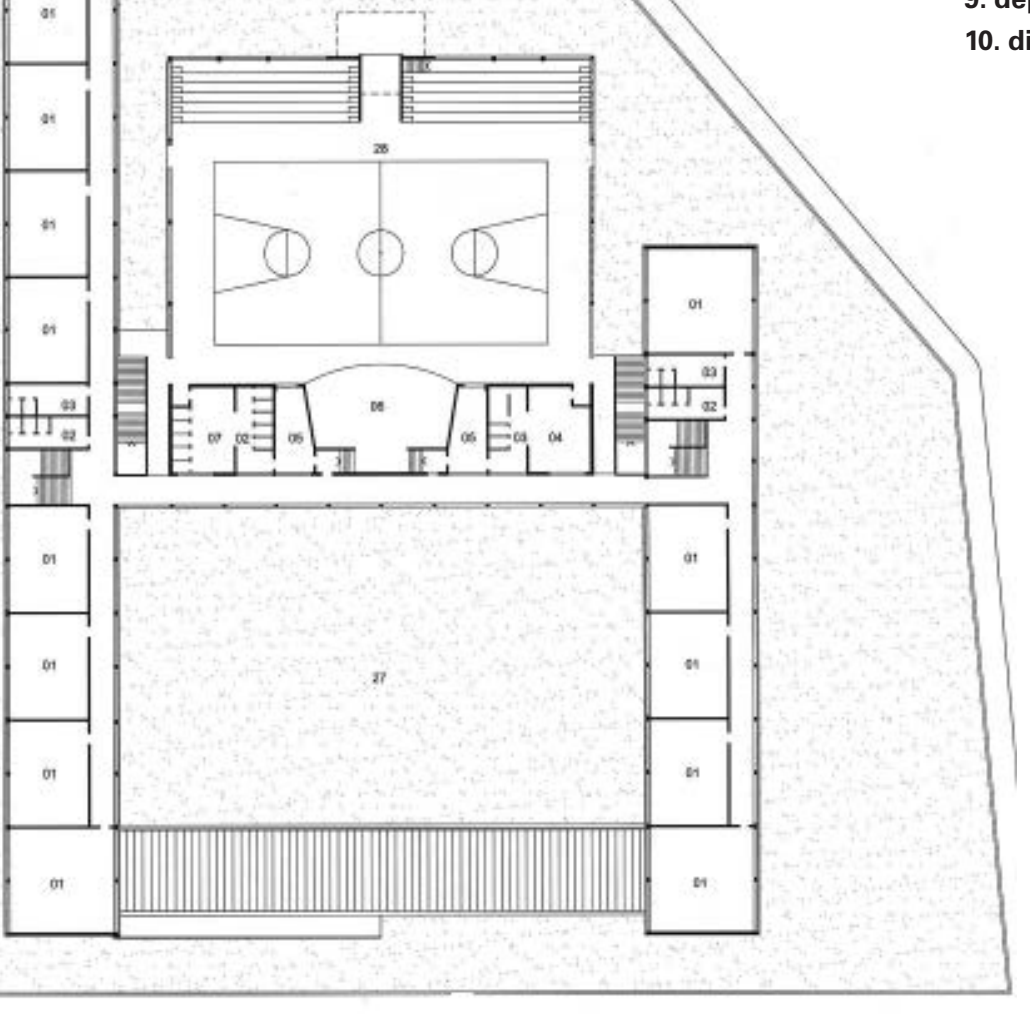

19. diretoria

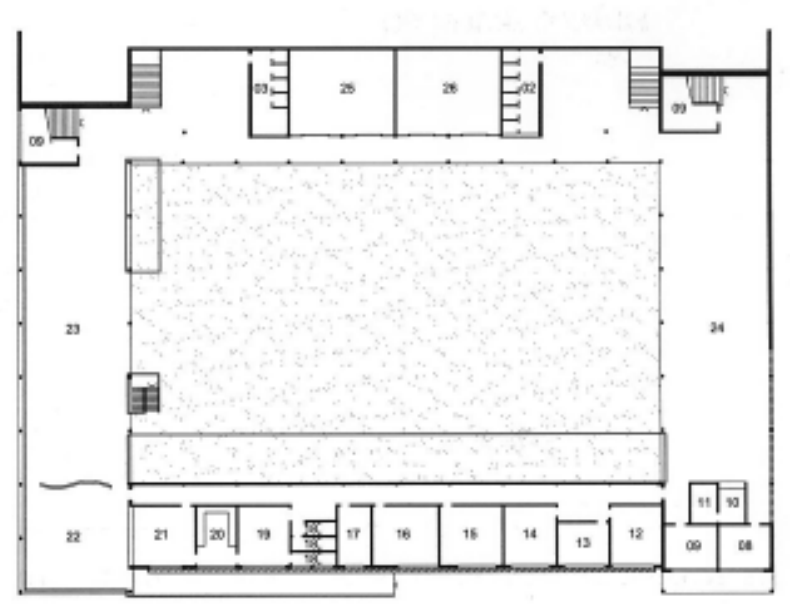

Implantação / Téreo

Escola Estadual Republica do Paraguai, Vila Prudente, São Paulo, 1951, Oswaldo Correa Gonçalves. Fonte: FERREIRA, 2006. 


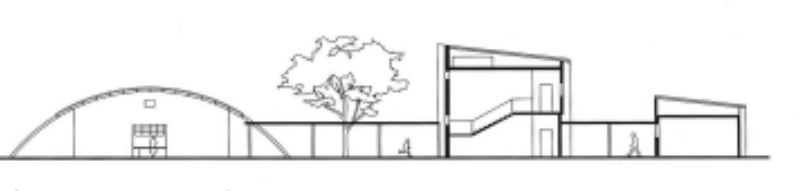

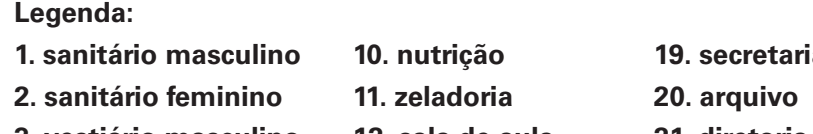
Corte transversal

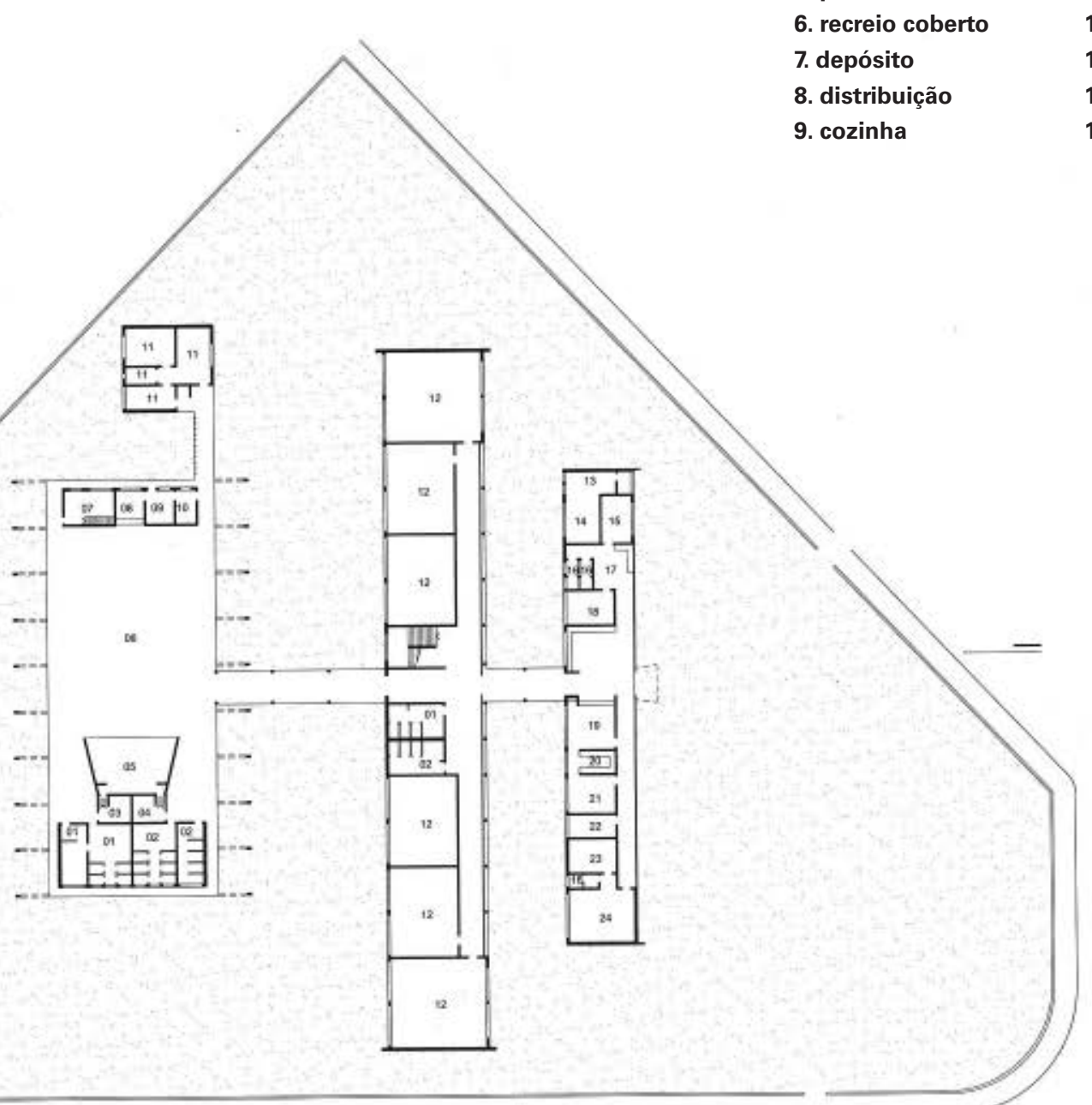

engenharia fica evidente pela busca de maior proximidade e de compactação entre as áreas funcionais das escolas. A tipologia de dois blocos paralelos um de ensino e outro a ferentes topografias encontradas, o que distancia sua obra em relação à dos outros integrantes da equipe. Para Mange a eliminação dos corredores proporciona redução de ruldos indesejados nas salas de aula, farta ventilação cruzada e iluminação natural em duas faces, atributos por ele va e in oproje, a raves dos sers elo pode ser entendido como o projeto, através dos seus elementos construtivos, incorpora o programa e soluciona as dificuldades do terreno, mantendo a mesma arquitetura proposta. Em outras palavras, há significativa independência da arquitetura de Mange em relaçã ao programa e, principame aula ou se no terreno predomina o aclive ou o declive, o projeto se comporta como conciliador dessas condicionantes sem abrir mão das suas características constitutivas. A formação na Escola de Belas Artes do Rio de Janeiro pode explicar a maior variedade nos projetos de Roberto Tibau e Eduardo Corona. No caso de Tibau, há obras $\overline{105}$ Ver MANGE, $1955: 122$
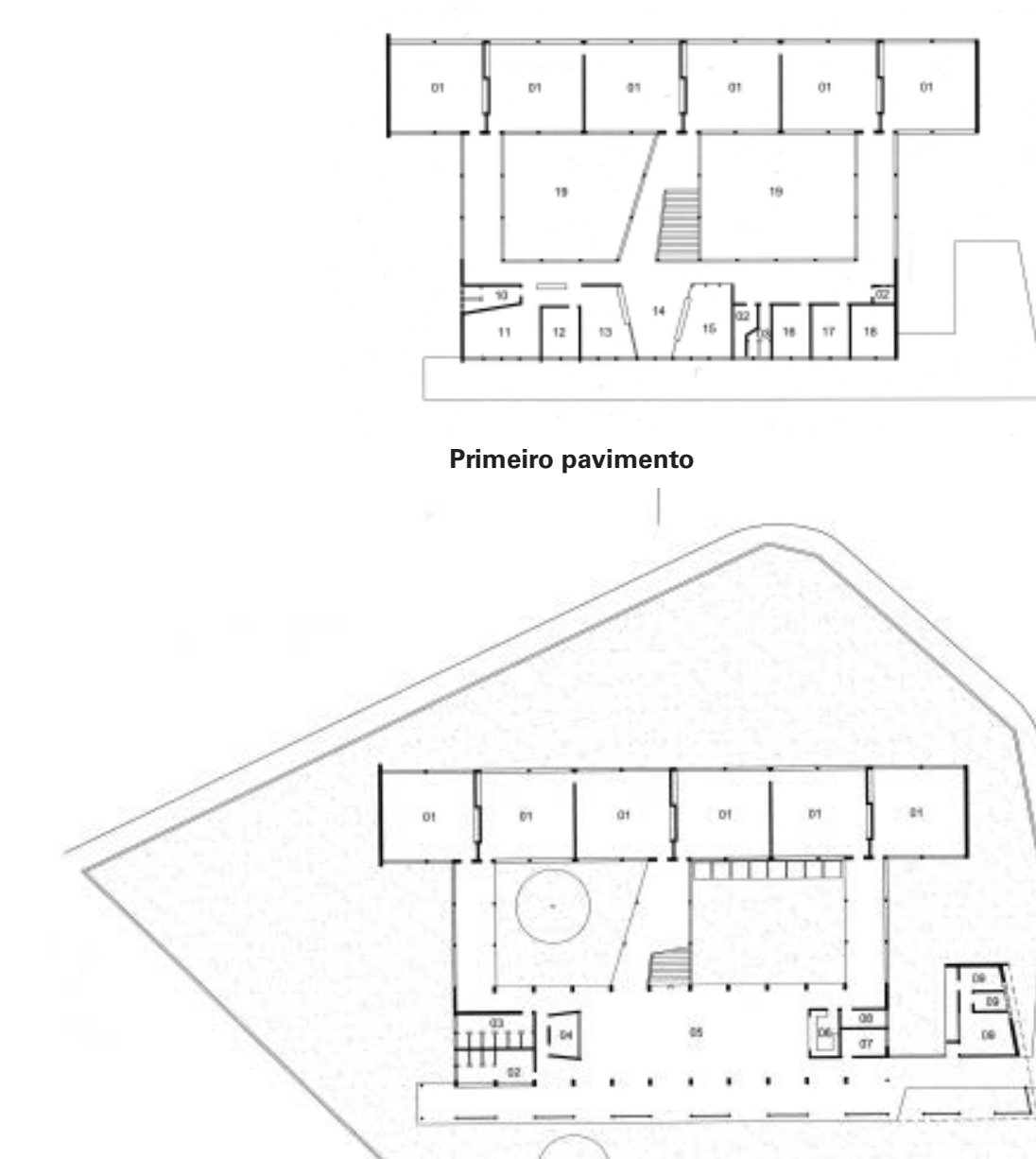

\begin{tabular}{lll}
$0 \quad 10 \quad 20$ \\
\hline
\end{tabular}

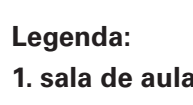
(1)
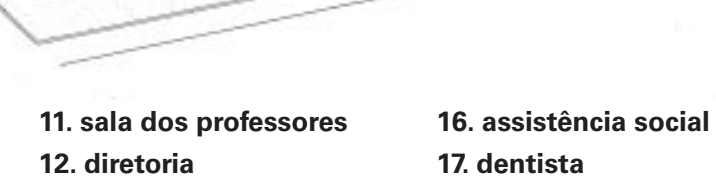
$\begin{array}{llll}\text { 2. sanitínio masculino } & \text { 7. deposito } & \text { 12. diretoria } & \text { 17. dentista } \\ \text { 3. sanitario feminino } & \text { 8. serventes } & \text { 13. secteraria } & \text { 18. medico } \\ \text { 4. palco } & \text { 9. zeladaroria } & \text { 1. hall-museu } & \text { 19. vazio }\end{array}$ 


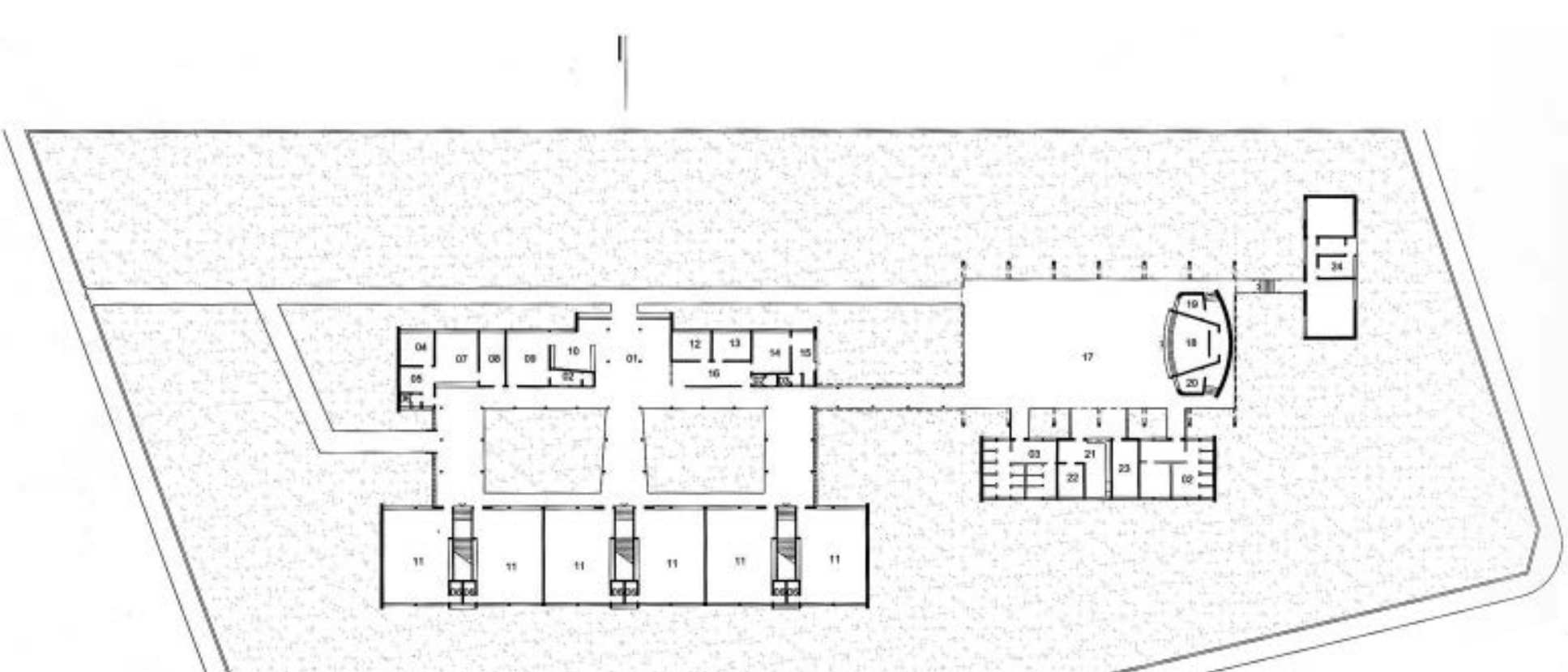

\section{喟・置・置}

Grupo Escolar Profes
Fonte: FERREIRA, 2010

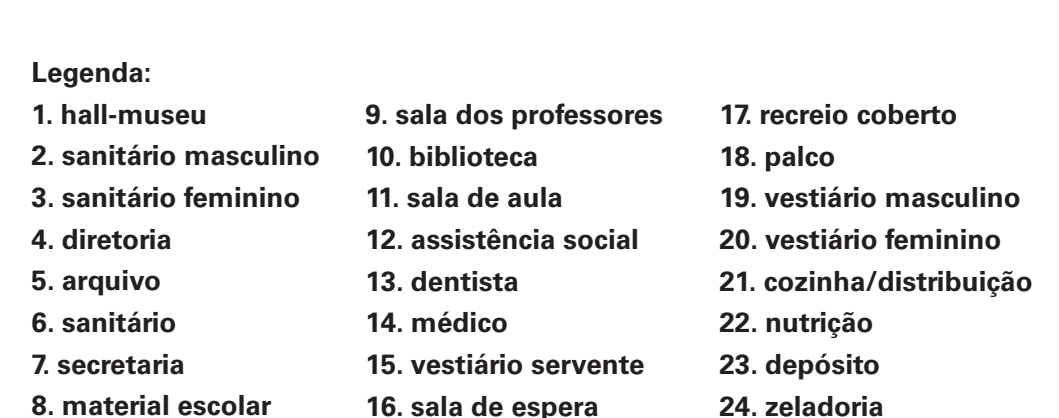

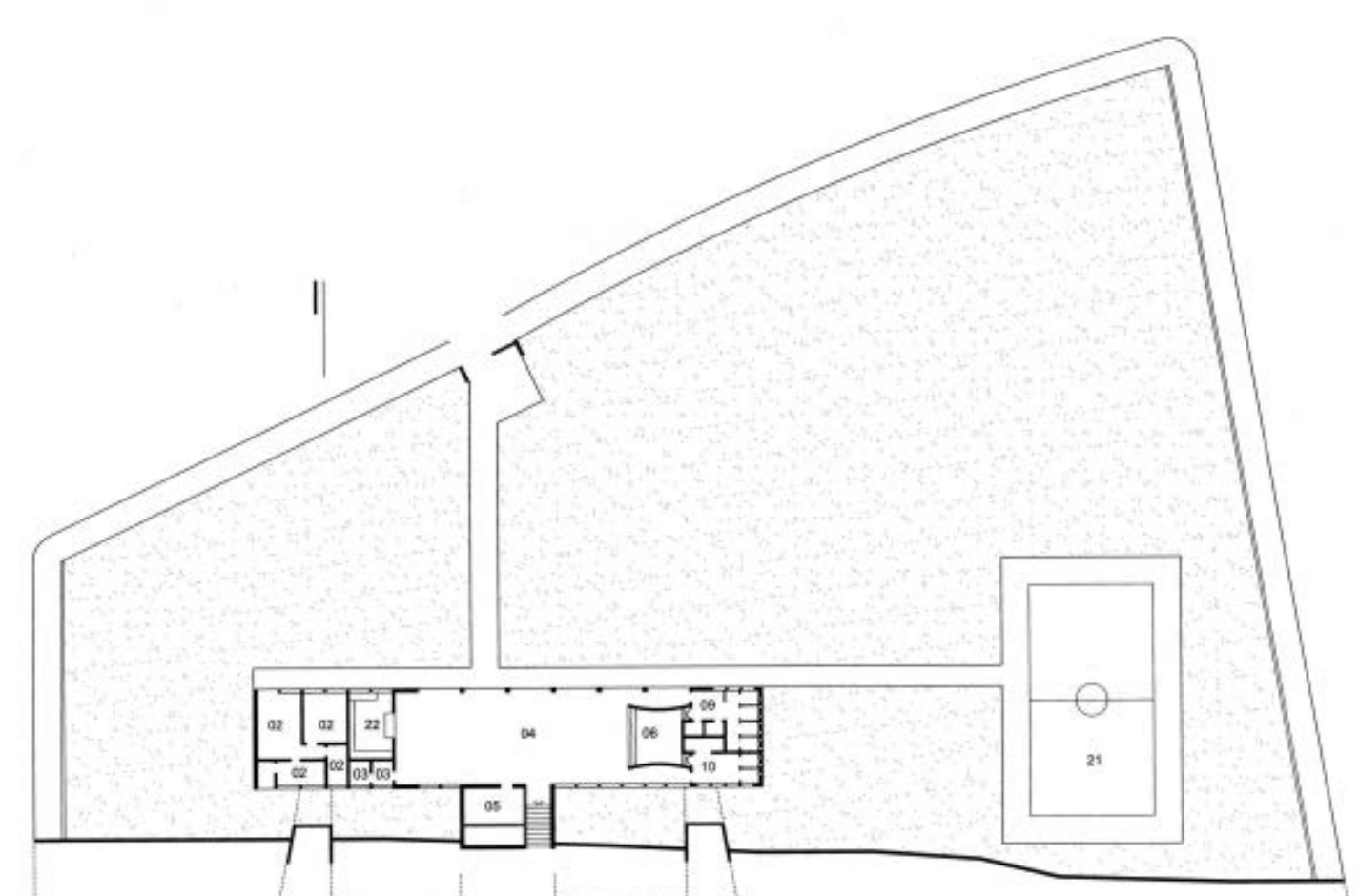

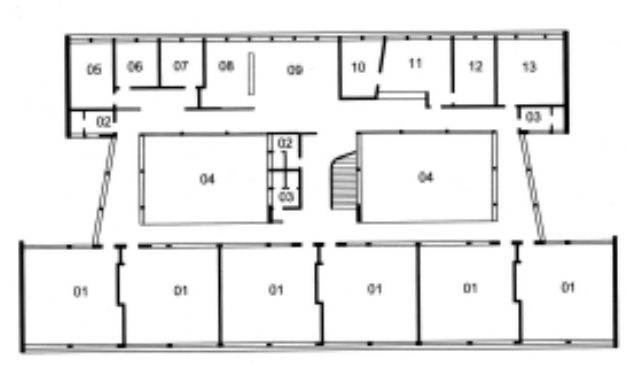

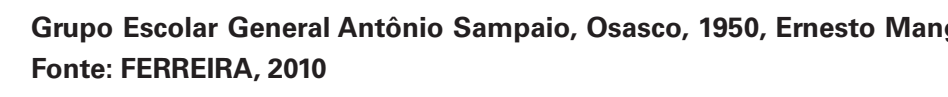

$0 \quad 10 \quad 20$
Legenda:
1.15ala de a
2. zelado

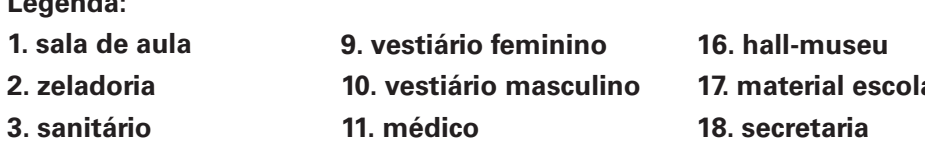

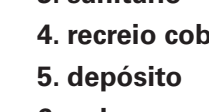

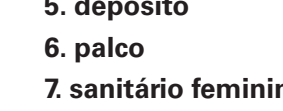

1. mindicio
12. dentista

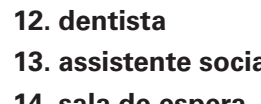

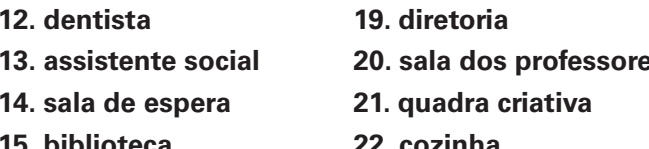




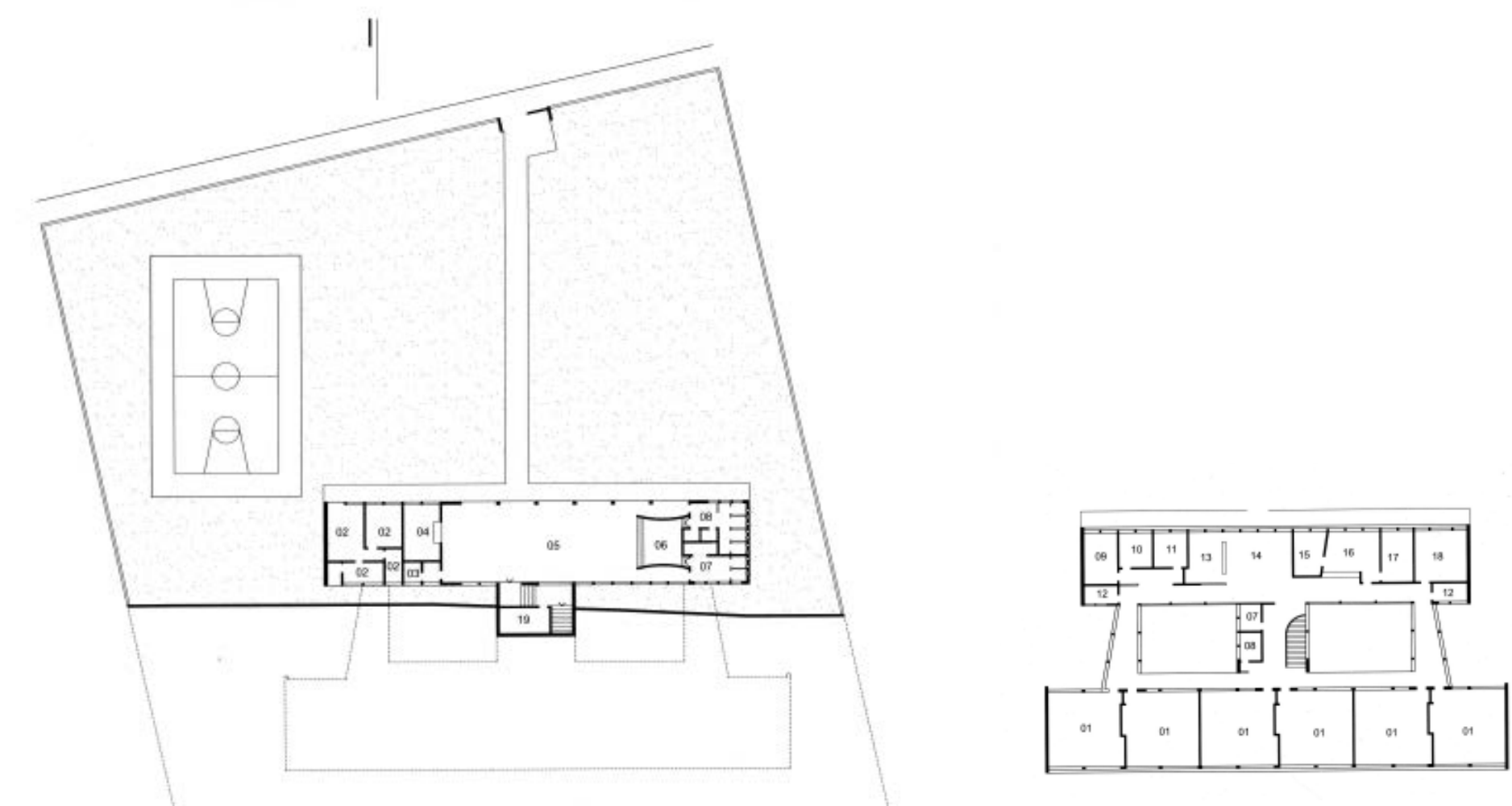

rimeiro pavimento

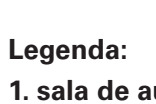

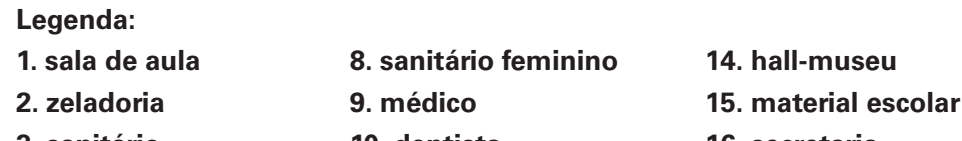
Grupo Escolar República do Chile, Vila Nova Cachoeirinha, São Paulo, 1951, Emesto Mange. Fonte: FERREIRA, 2010

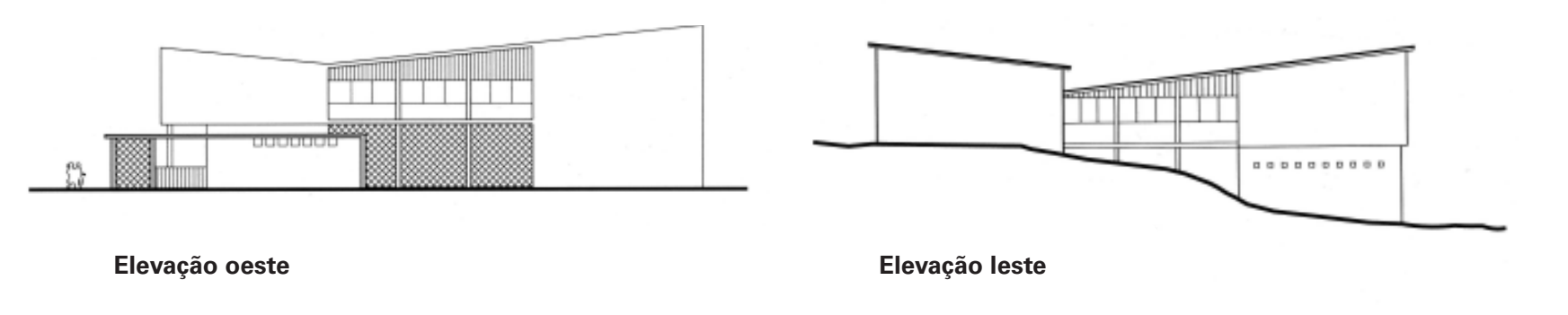

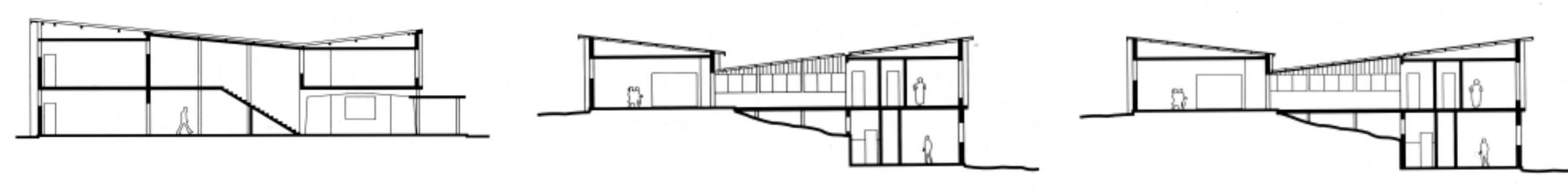

Corte transversa Gorte transversal Grupo essolar Repüblica do Chile 


\begin{tabular}{|c|c|c|c|c|c|}
\hline \multicolumn{6}{|c|}{ 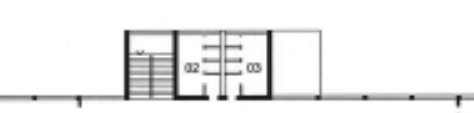 } \\
\hline${ }^{\prime \prime}$ & a & " & a & " & . \\
\hline
\end{tabular}

Segundo pavime

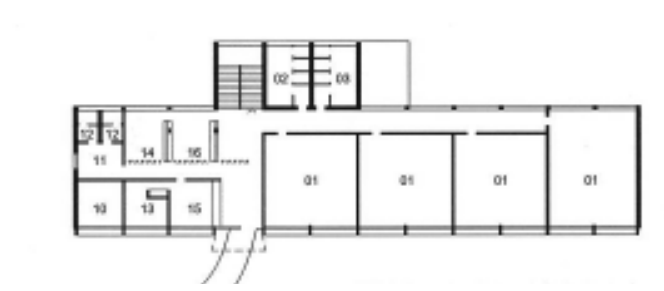

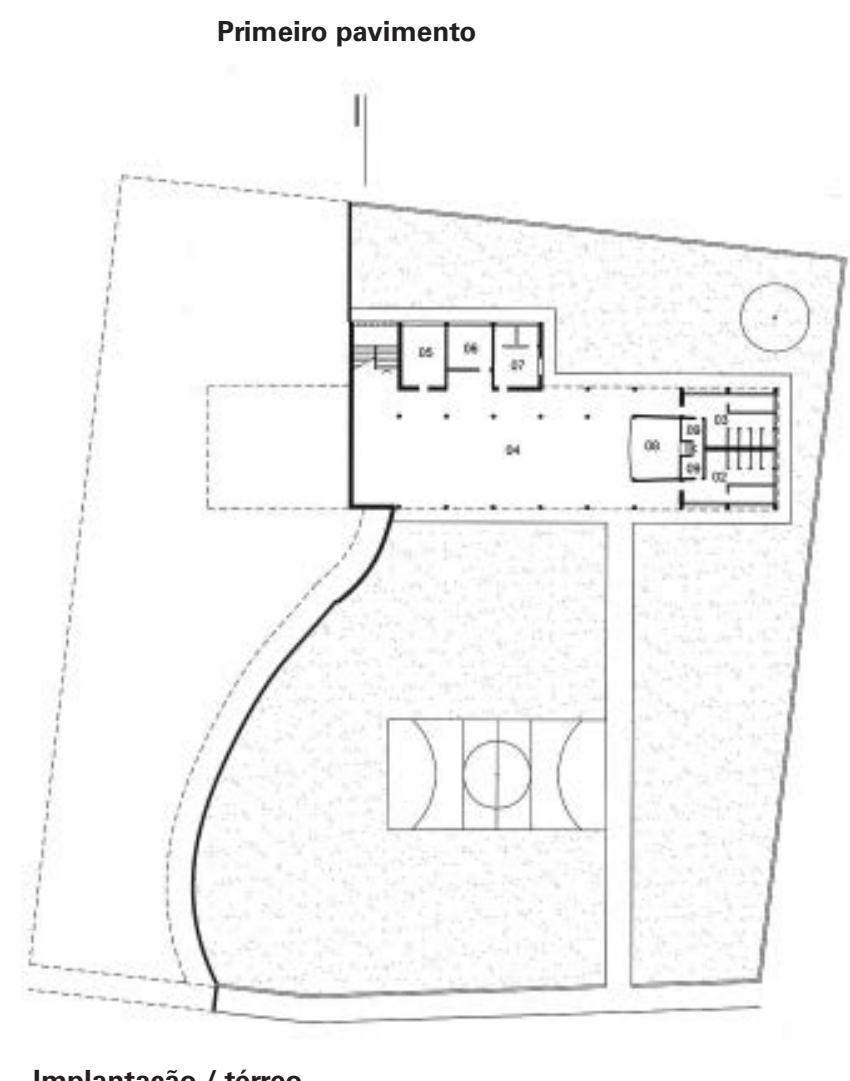

Implantaçăo / téreo os componentes e a implantação seguiram rigorosamente a padronização estabelecida pela equipe do $2^{\circ}$ Convênio, que são semelhantes às soluções de Hélio Duarte. No entanto Tibau tumbén buscor septrir e vertical em 3 pavimentos, mesmo para os programas menores em que a base em pilotis estava totalmente desvinculada das atividades de ensino. Em outras situações, quando programas esportivos foram incorporados às escolas pur quando cuidados da préescola exigiram, os projetos estiveram menos próximos dos padrões estabelecidos pela equipe e com maior riqueza de situações.

A complexidade obtida pelo projeto é mais um arg mento para aproximar Eduardo Corona e Roberto Tibau. Segundo depoimento de Corona a Mário Caldeira (2005:162)

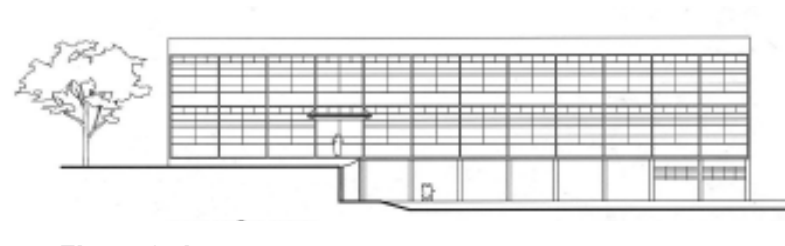
Elevaçăo leste sua busca pela diversidade de situaçôes deveria enriquecer a obra.Para Corona, a arquitetura deveria ser realizada com o máximo de definição espacial e de recursos financeiros possíveis, permitindo sua futura permanência e minimizando o impacto de sua manutenção e de sua evolução. Essa postura, claramente defendida pelo arquiteto explica a diversidade de suas obras, ainda que ele afirme haver total unidade do trabalho da equipe em torno da ar-

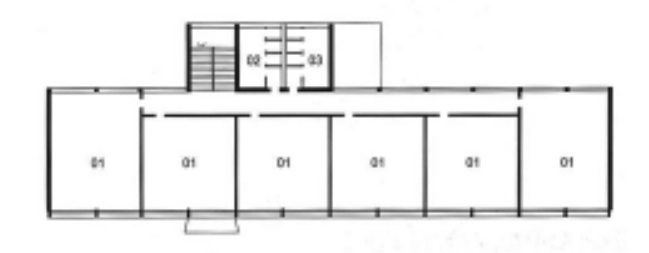

Segundo pavimento

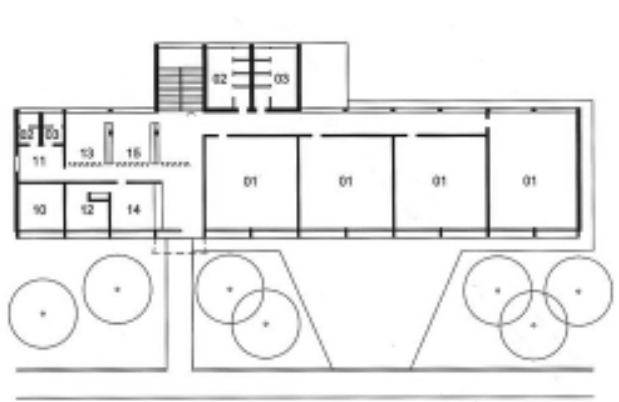

Primeiro pavimento

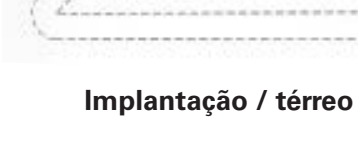

\begin{tabular}{l}
$0 \quad 10 \quad 20$ \\
\hline
\end{tabular}

Escola estadual Dona Surana de Campos, Perus, Säo Paulo, 1953, Roberto Goulart Tibau.
Fonte: ERRREIRA, 2010.

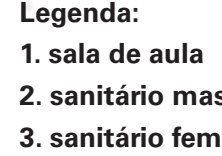

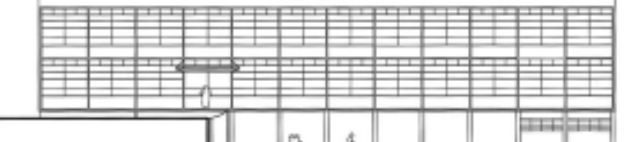

Elevaçä nordeste

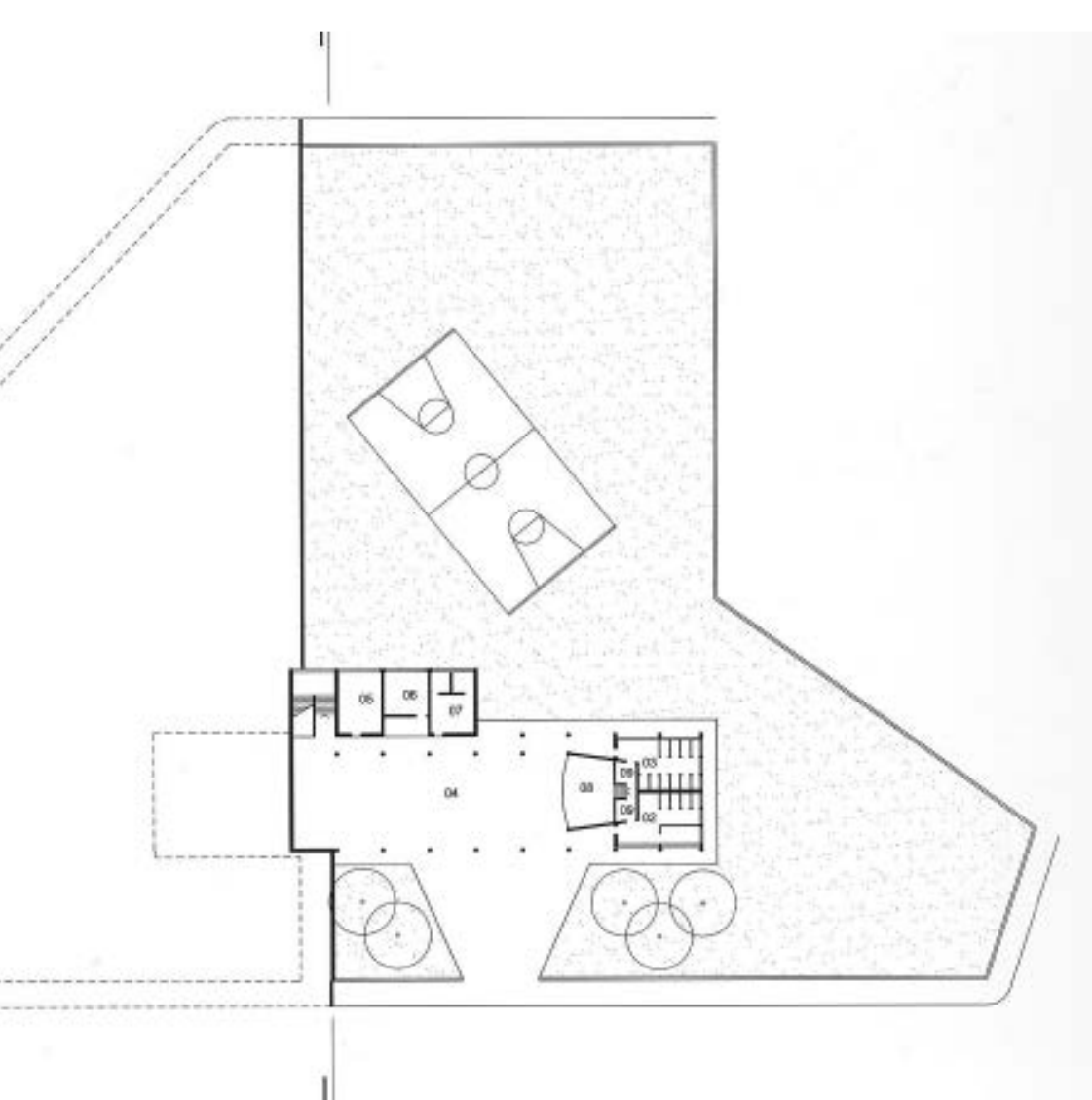

$\begin{array}{ll}\text { 6. cozinha } & \text { 11. sala de espera } \\ \text { 7. zeladoria } & \text { 12. diretoria } \\ 8 & \text { g.tatos }\end{array}$

8 . palco 13 13. diretoria

$\begin{array}{ll}\text { 9. vestiário } & \text { 14. secretaria } \\ \text { 10. medico } & \text { 15. biblioteca }\end{array}$ 

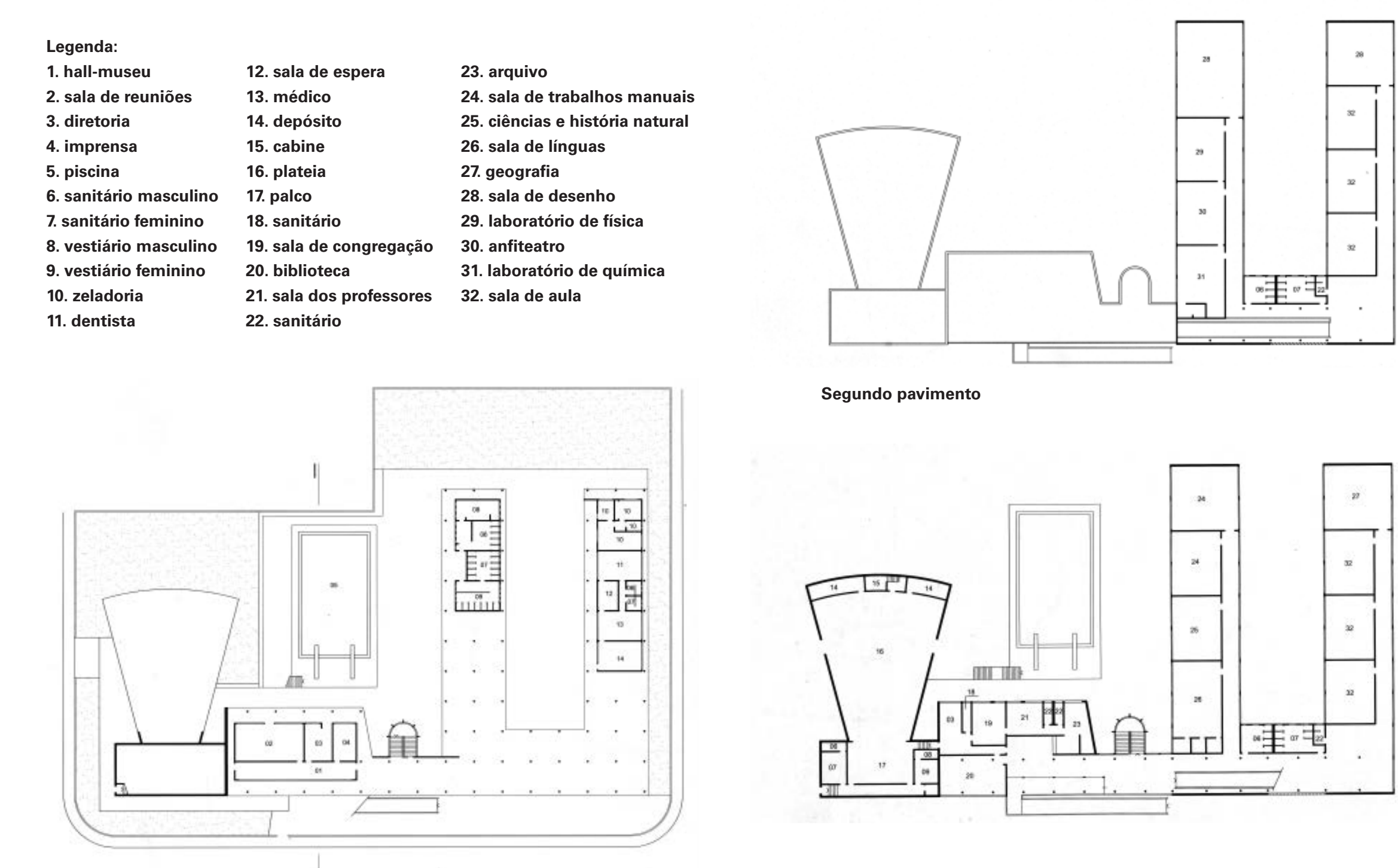

Implantaçăo / téreo

Primeiro pavimento
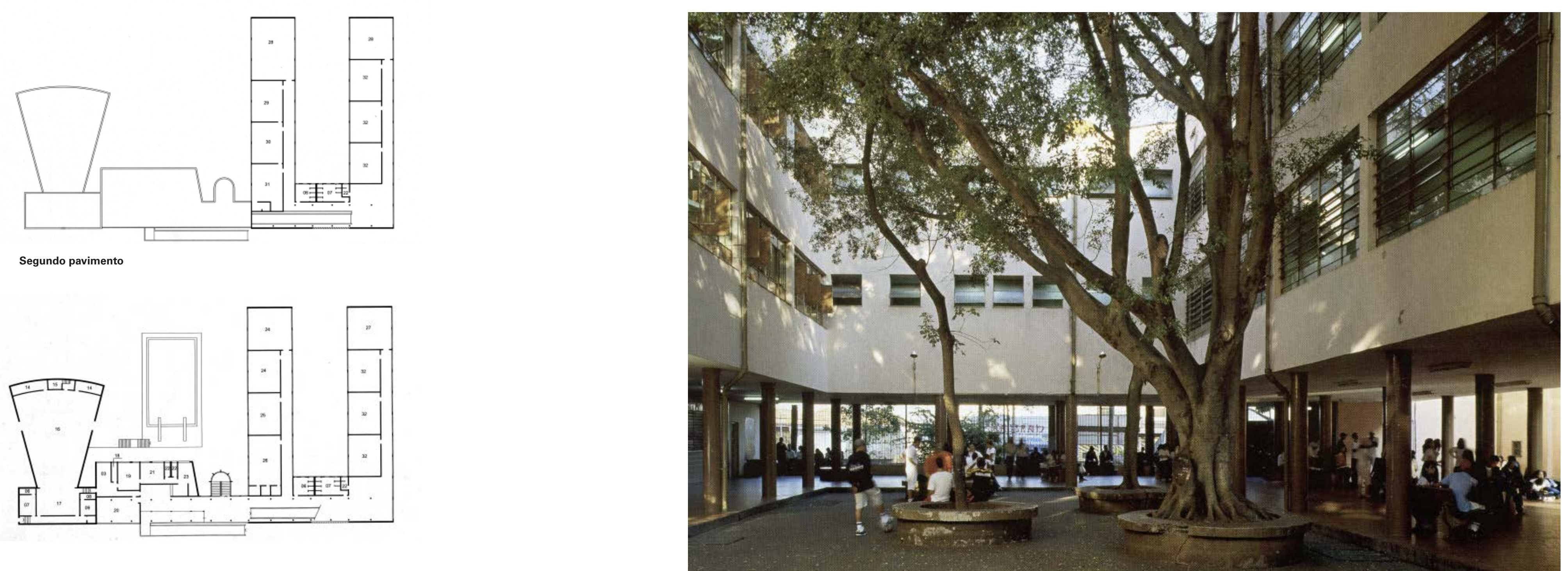
quitetura carioca. Mesmo dentro de um vocabulário comum aos arquitetos do $2^{\circ}$ Convênio, cada projeto seu é resultado de programas que admitem variação e que são adequados ao contexto, com maior definição e detalhamento dos espaços externos, A esse respeito, Corona comenta:

Quando o terreno era meio grande, a gente fazia quê? Nada? Fazia paisagismo. Fazia parque, zia isso, fazia aquilo, mas nunca foi feito nada. prefeitura naquela época não fazia nada, coisa ne nhuma. Então, plantava lả umas árvores sỏ e olle lá. (in CALDEIRA, 2005:167)

Outro aspecto importante no trabalho da equipe do 2o Convênio é que em algumas implantações as escolas foram acompanhadas por outros equipamentos públicos fora madores. A a teria sido da EDIF, quatro décadas depois (DELIJAICOV, 2004:3).

final do $2^{\circ}$ Convênio em 1955 encerrou um perí-

do criativo de extensa produção que modificou de maneir definitiva a arquitetura escolar em São Paulo As inovaç̄es na metodologia de projeto e na incorporaç̃o do conheci- mento científico como fundamento da arquitetura mantêm sua influência na producão atual, como ocorrida com o CEU.

Cabe salientar a projetos realizados com as propost por Anísio Teixeira, o que fundamenta parte significativa das decisões de projeto da equipe do $2^{\circ}$ Convênio. Sem que haja oposição, podemos afirmar que a contribuição da arquitetura proposta foi capaz de indicar um caminho possível e promissor no enfrentamento da condição urbana e somente daquele período mas, sobretudo, dentro de uma nova visão da atuação do projeto diante de novos desafios. Dito de uma outra forma, entendemos que não se trata de encontrar um meio ou um mecanismo capaz de recuperar o atraso encontrado em um setor tão sensível como a educação, mas demonstrar a capacidade do projeto de encarar as

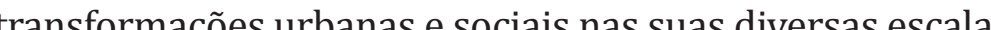

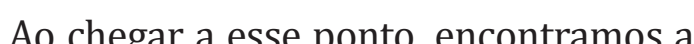
significativa das transformações do projeto de expressão moderna, que tem no trabalho de Affonso Eduardo Reidy, no Rio de Janeiro, seu principal fundamento. Para isso, propomos examinar com maior proximidade o que significou considerar a a cicou considerar a un 


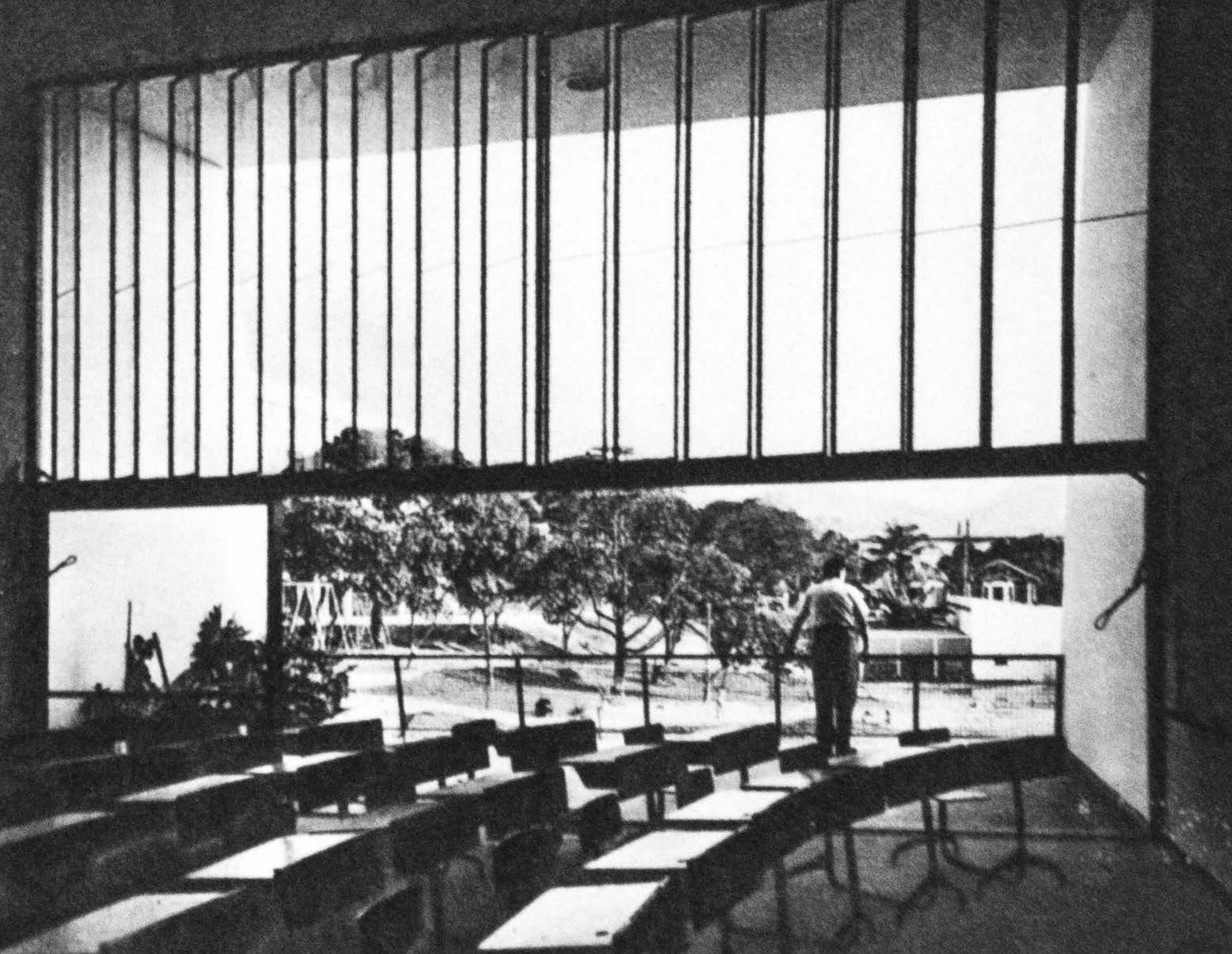
pectos da arquitetura escolar fotografada ${ }^{106}$.

Em primeiro lugar, cabe entender sua constituição física: a área ocupada pelo piso interno segue uma proporç̃o quadrada, cujo lado é rebatido na sua altura, configurando um espaço interno que se aproxima do cubo 0 teto chro, cente a dente ao exteror, assin como o piso interno, formando uma varanda com área equivalente à do piso interno. $\mathrm{A}$ face vertical do cubo que separa o espaço interno e a varanda são totalmente constituídos por esquadrias envidraçadas portas de correr na metade inferior que abrem três quar-

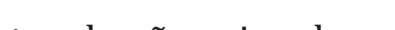
proporco e a cons pivore proporciona a conthireção à paisagem mas também das atividades didáticas internas em direção à varanda. Percebe-se ainda que, além da farta iluminação natural, esse dispositivo deve proporcionar ventilação natural igualmente abundante, pois o beiral generoso que cobre a varanda permite que as esquadrias per$106 \quad$ Exerćcici inspirado no trabalho de Ricardo Daza, Buscando Mies, 2000. 
maneçam abertas ao garantir sua proteção contra intempéries. 0 guarda corpo da varanda protege, mas não dificul a visão da paisagem.

Podemos também observar sua condição urban a perspectiva proporcionada pela face envidraçada em $\mathrm{d}$ reção ao exterior evoca a integração visual da sala com as areas livres adjacentes e o bairro próximo, pouco ocupado,

o que proporciona determinada interação entre o espaço de aprendizagem e a cidade.

É possível avaliar ainda suas características funciohais: a ocupação interna obedece à melhor orientação, pois a luz natural incide à esquerda, e indica determinada liberdade na distribuição das cadeiras, de maneira levemente curva, mostrando que há distintas possibilidades de ocupação. Isso se confirma quando observamos o desenho do mobiliário, constituído por cadeiras e carteiras individuais, construídas por bases metálicas, o que deve facilitar as mudanças internas ou mesmo o uso da varanda, ampliando as possibilidades do jogo pedagógico.

Como síntese do exercício acima descrito, não pod-mos deixar de mencionar que as características enumeraara afirmarmos que se trata de uma arquitetura de natureza superior. 0 projeto é portador de intençỗes claras que apontam para sua situação urbana aproximação do meio natural, dentro de uma condiç̃ão cias variadas, dentro de um quadro que aproxima mbiente construído em relação ao ambiente natural.

Tais fundamentos nos remetem à experiência da

modernidade ${ }^{107}$, pela busca da qualificação do espaço por seus aspectos técnicos e sua proximidade do meio a por na e o importante papel da educação nas transformações sociais dela decorrentes. Para confirmar nossa avaliação da referida imagem, a explicação do projeto por seu autor, Affonso Eduardo Reidy, é um importante testemunho:

A influência da escola ultrapassa a criança vai penetrar nos lares de seus pais, levando aos mesmos noções e conhecimentos que muito contribuem para elevar seu nivel de educação. A transformacão quase radical dos métodos de ensino acarretou naturalmente profundas modificações do edifício escolar. A tendência atual é no sentido de estimular o espírito de cooperação,

107 Ver BRUNA, 2012: 19; : FRAMPTON, 2003: 160 formar individualidade pelo livre desenvolvimento das aptidões de cada um. A sala de classe o elemento básico de uma escola moderna. S tipo tradicional para constituir uma unidade individual que permite uma relação mais íntima entre mestre e alunos, maior flexibilidade na disposição do mobiliário e maior contato com o exterior, utilizando espacos ao ar livre imediatamente ligado às mesmas. [...] 0 serviço de recreação [ginásio, piscina, vestiário e campos de jogos a al livre] funciona perfeitamente entrosado com a scola primária, e o ginásio é utilizado, também, para as solenidades e festas escolares. (in BONDUKI, 1999: 84-86)

atuação de Reidy e de Carmen Portinho à frente do Departamento de Habitação Popular do Rio de Janeiro marcou definitivamente a arquitetura brasileira a partir de sor ter Portinho teve papel fundamental nas mudanças das relações entre arquitetura e cidade, entre espaço construído e espaço livre, seguindo os intensos questionamentos que vinham ocorrenécadas de 1920 e 1930 . Fica bem 108 Ver BONDUKl, 1999 clara, nos projetos, a noção de "unidades de vizinhanç̧a", trazida por Portinho, apos suas visitas técnicas à Inglaterra, en 1945. Nota-se que, quando Reidy, no texto ao lado, apresenta a escola do Conjunto Pedregulho no Rio de Janeiro, o projeto do espaço da aprendizagem em 1946 não se limita às salas de aula e a suas áreas funcionais de apoio. A noção de equipamento é introduzida pelo projeto com a proximidade do ginásio, da piscina, do vestiário e dos campos de jogos ao ar livre, o que conforma um equipamento em que a educacão portadora de conteúdo social e ambiental.

A análise de um detalhe de uma sala de aula nos indica dois caminhos a serem investigados: inicialmente observar as origens das estratégias de projeto que pudemo apreender através de sua observação e, posteriormente, obras examinadas em nossa pesquisa. 


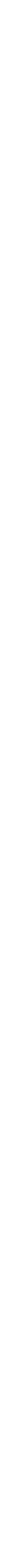




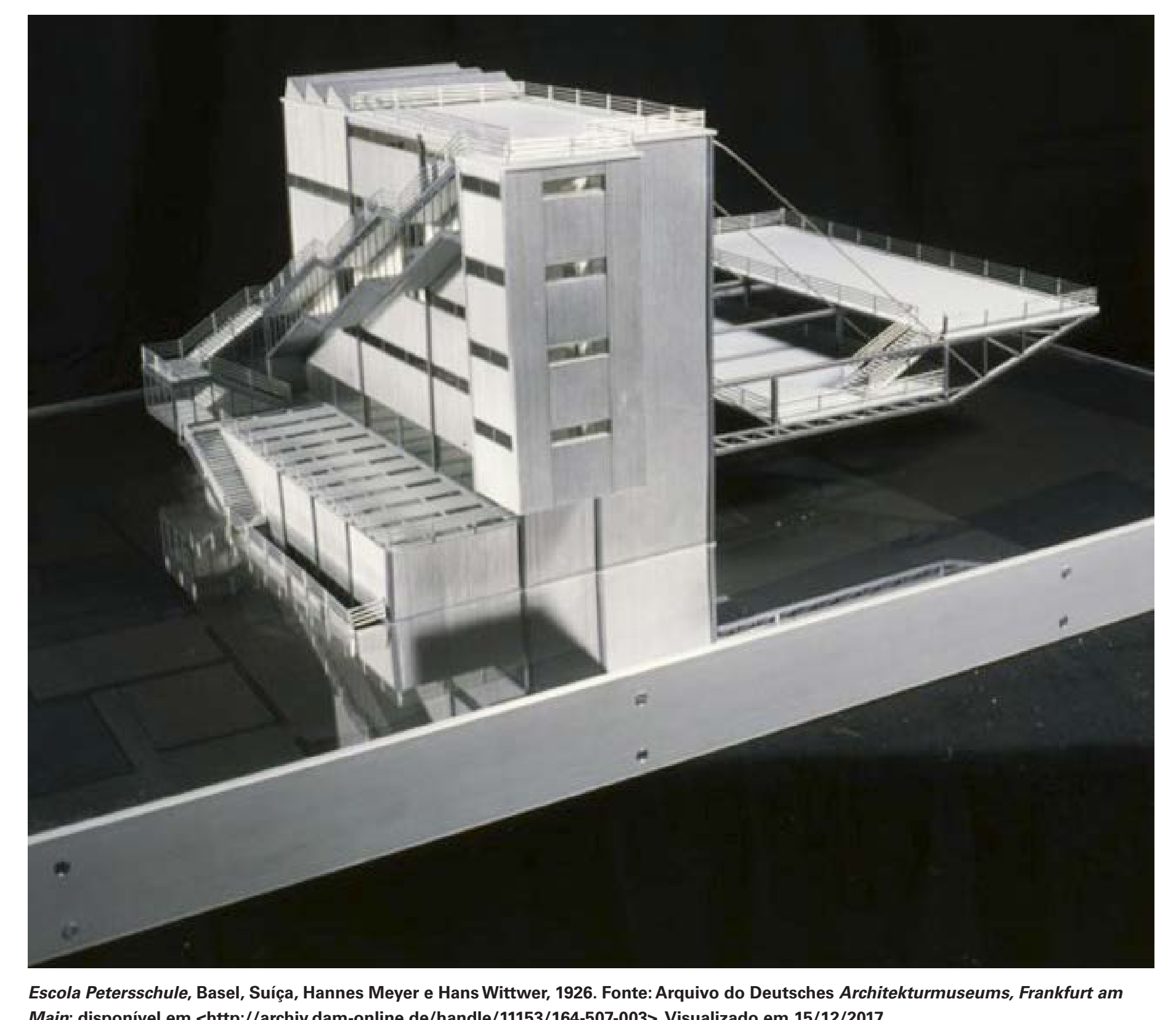

Ao recuarmos até o período entre as duas grandes guerras, encontraremos manifestações em defesa dos novos valores identificados acima, como os proferidos por Hannes Meyer a respeito do seu projeto para a escola Petersschule em Basel, Suíça, de 1926:

0 ideal seria deixar entrar a luz natural em todas as dependências [...] e isolar um novo local como parte da cidade. [...] A própria escola e erguida tanto quanto possivel do solo, num níve que exista luz do sol e ar fresco. .... Em vez $\mathrm{Ec}$ um playground, dois espaços abertos (platafor mas suspensas), e todas as coberturas planas do edifício ficam para a recreação das crianças. [...] peso morto do edificio é usado para segurar, con quatro cabos, a estrutura de aço sem suportes das duas plataformas suspensas. (MEYER, apud FRAMPTON, 2003: 160) fundamental que atesta a busca incessante da arquitetura daquele período por soluções construtivas que alterassem os padrões arquitetônicos historicamente estabelecidos. Meyer 
em parceria com Hans Wittwer, investe no desempenho técnico da obra para atingir as metas de qualidade an vencido de alcançar uma nova condição funcional do espaço de aprendizagem. osso entendimento, o projeto merece menção especialmente quando propõe a verticalização das salas de aula como contraponto estrutural e espacial das áreas livres de recre ão horizontais, dispostas em plataformas escalonadas e suspensas. Meyer e Wittwer aplicam o mesmo peso às duas áreas funcionais, em outras palavras, as áreas são equivalentes, num equilibrio em que a técnica não está a serviço da monumentalidade, mas sim à multiplicaç qualidade ambiental.

0 terreno escolhido no centro histórico de Basel tem sua área duplicada pelas áreas livres criadas. Seria a técnica como construçãa,

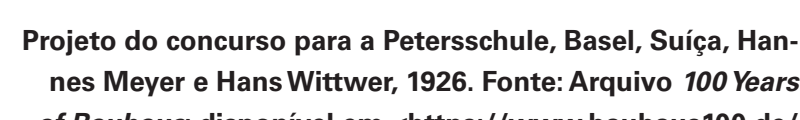
Bauhaus; disponivel em <https:///www.ba wettbewerbsentwurf-petersschule-inbasel/petersschule_o. ipg_9321 19001.jpg >VVisualizado em 15/12/2017

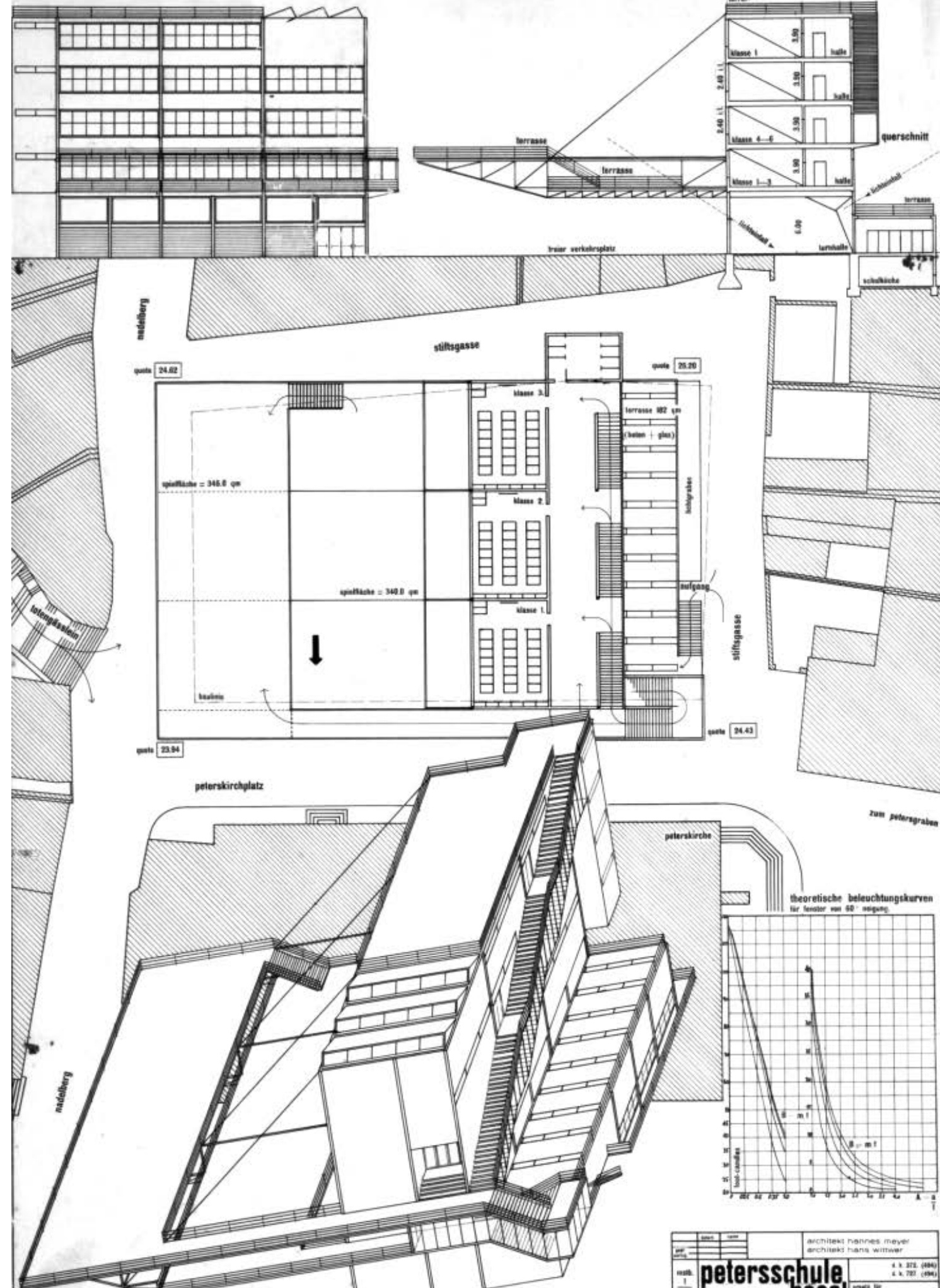

de organização do espaço e da vida social, a tese defendida por Meyer, que substituiu, dois anos depois, Walter Gropius na d $1930^{109}$ segindo o

não como estilo a disputar a preferência dos arquitetos, mas como uma causa impregnada de . (252-103) mal 102-103)

Quando comparamos a relação entre as áreas fechadas da escola e as áreas abertas, cobertas ou descobertas percebe-se que há uma equivalência direta, ou seja, o projeto faz um esforço para multiplicar as áreas livres como fundamento do espaco da aprendizagem. As qualidades ambientais são outro aspecto que orienta a obra: chama a atenção o gráfico que compõe o documento de projeto que simula as condiçôes de iluminação natural nos ambientes, nas diversas épocas do ano.

que também deve ser destacado é que toda essa busca por um racionalismo radical, em que a técnica pura protagonista, não impede que Meyer proponha uma arqui-

109 Sobre trajetótria de Hannes Meyer, ver ALLENSPACH, 2001. tetura conciliatória quando observada sua condição urbana. 0 edifício, que podemos considerar um artefato provido de estrutura e de dispositivos que possibilitam novas experiências sociais, não depende de uma intervenç̃o radical no tecido urbano histórico de Basel, ou seja, não prescinde do existente para ampliar o programa do projeto e ir além dos seus objetivos iniciais.

Apesar de sua aparência tecnicista, o projeto revela-se indutor de um novo espaço de convergência social, um largo público conformado pelas edificações existentes e pela projetada, entre a igreja de São Pedro no lado norte e a Petersgasse, que faz a ligação com o rio Reno.

A experiência de Meyer aponta para a estandardização das exigências humanas como tarefa necessária para dar nova forma aos tempos modernos, como proferido em seu ensaio $O$ Novo Mundo. Ele enumera novos usos que a arquitetura deverá enfrentar, sem que seja necessária a negação do passado, o que pode ser considerado o espírito de uma nova era de transformações sociais e de progresso tecnológico, ponto importante para a compreensão da modernidade. ${ }^{10}$

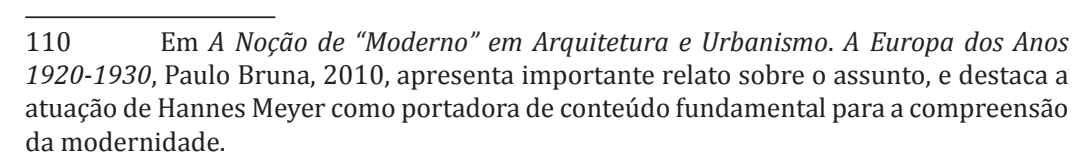


chamado de "Escolas ao Ar Livre" 111 que seguem intenç̃ós seres entre si e que merecem ser aqui estudadas. Po-

deríamos enquadrá-las como uma categoria do programa ou uma tipologia, mas, no nosso entendimento, é conveniente prosseguir na compreensão de sua genealogia e de seus desdobramentos em direção ao tema de nossa pesquisa.

Para o projeto da Fscola ao ar livre em Amsterdam

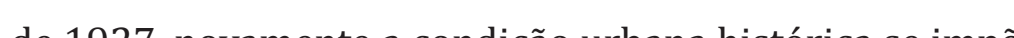
se segundo Herman Hertzberger (1999. 246-247), seus autores - Joannes Duiker e Bernard Bijvoet - só obtiveram permissão para a construção da obra ao implantá-la no interior da quadra, para que não destoasse da vizinhança abastada. 0 projeto extrai dessa aparente dificuldade a estra-

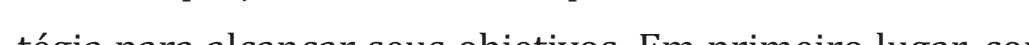
centra o programa de sete salas de aula em quatro pavimen-

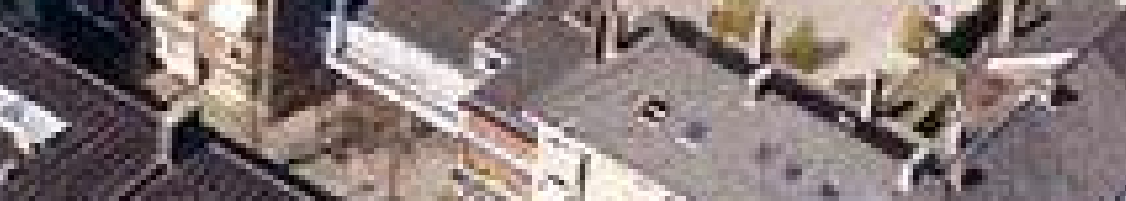
Joannes Duiker e Bernard Bijvoet 


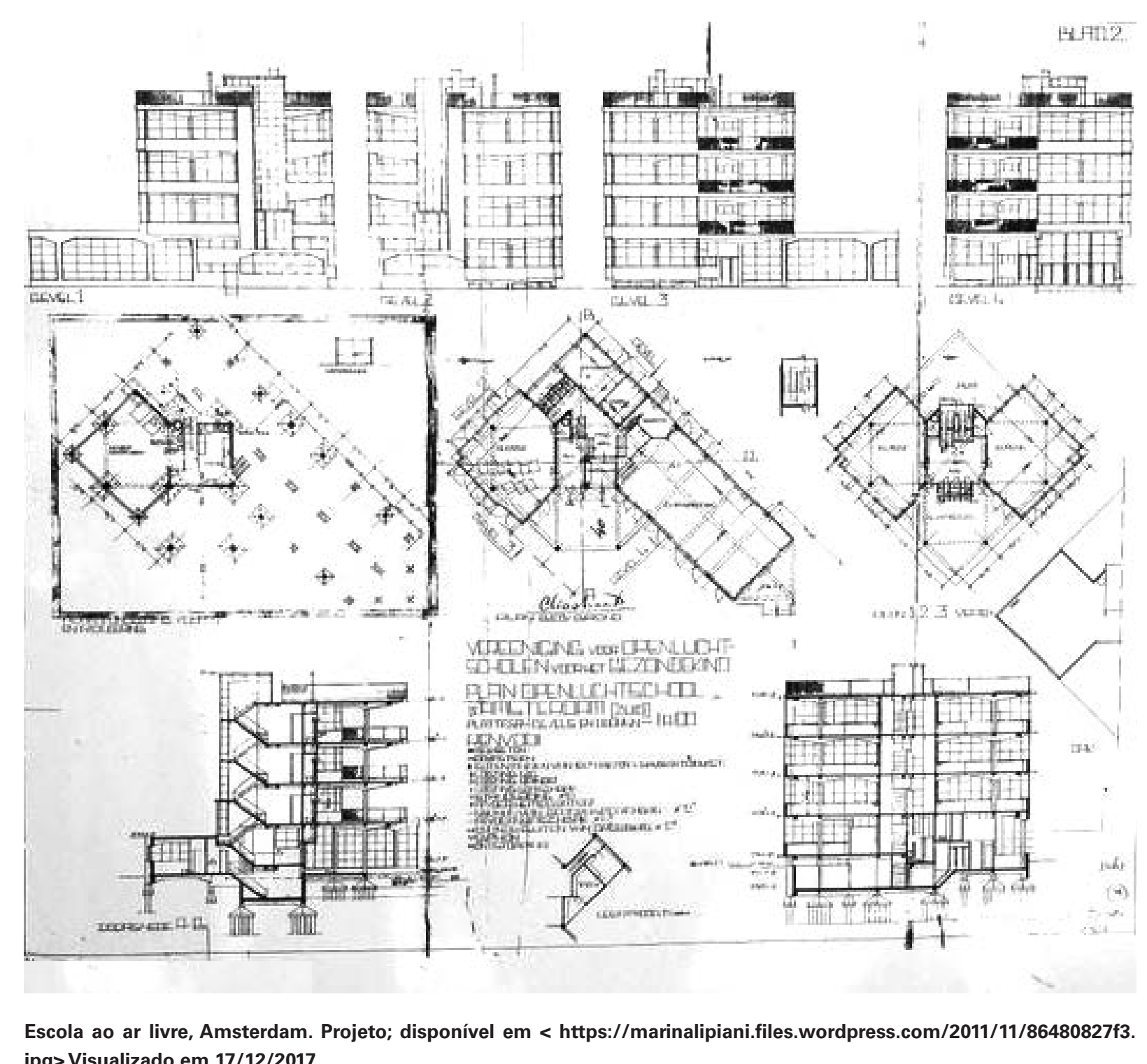

Ao marcar a estrutura seguindo a orientação das edificações habitacionais existentes que conformam o grande pátio interno e não a diagonal da planta quadrada da escopátio interno e não la, o proje estabece una reça forte con a orden do bairro e organiza sua dinâmica interna baseada no entorno mesmo ao girar sua implantação. Dessa maneira, Duiker Bijvoet garantem para o volume vertical toda a liberdade desejada para envidraçar grande parte de suas fachadas mantendo apenas o volume interno opaco que conforma a caixa de escada como apoio para as atividades didáticas. um suporte para o quadro negro, por exemplo.

Esse jogo geométrico simétrico é quebrado no pavimento térreo pelo número ímpar de salas de aula, o que sugere a colocação de um pequeno ginásio de esportes retangular, que se projeta em direção sudeste e se abre para o grande pátio externo. Dessa forma, a sala de aula do pavimento térreo é ligeiramente elevada - quatro degraus - em relação à área externa - altura que permite determinado isolamento, ao mesmo tempo em que acrescenta a altura necessária para as atividades esportivas do ginásio ao lado.

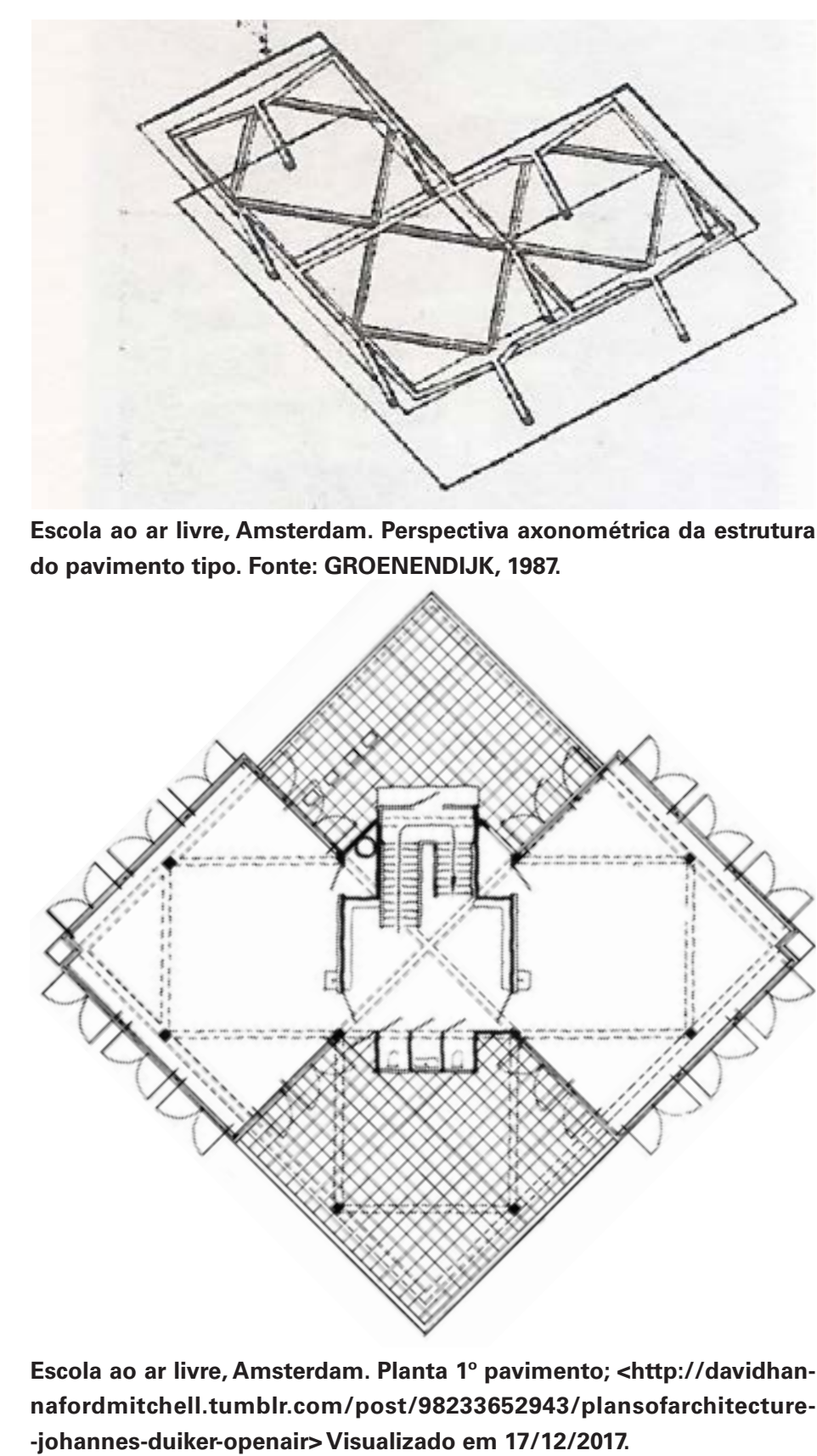




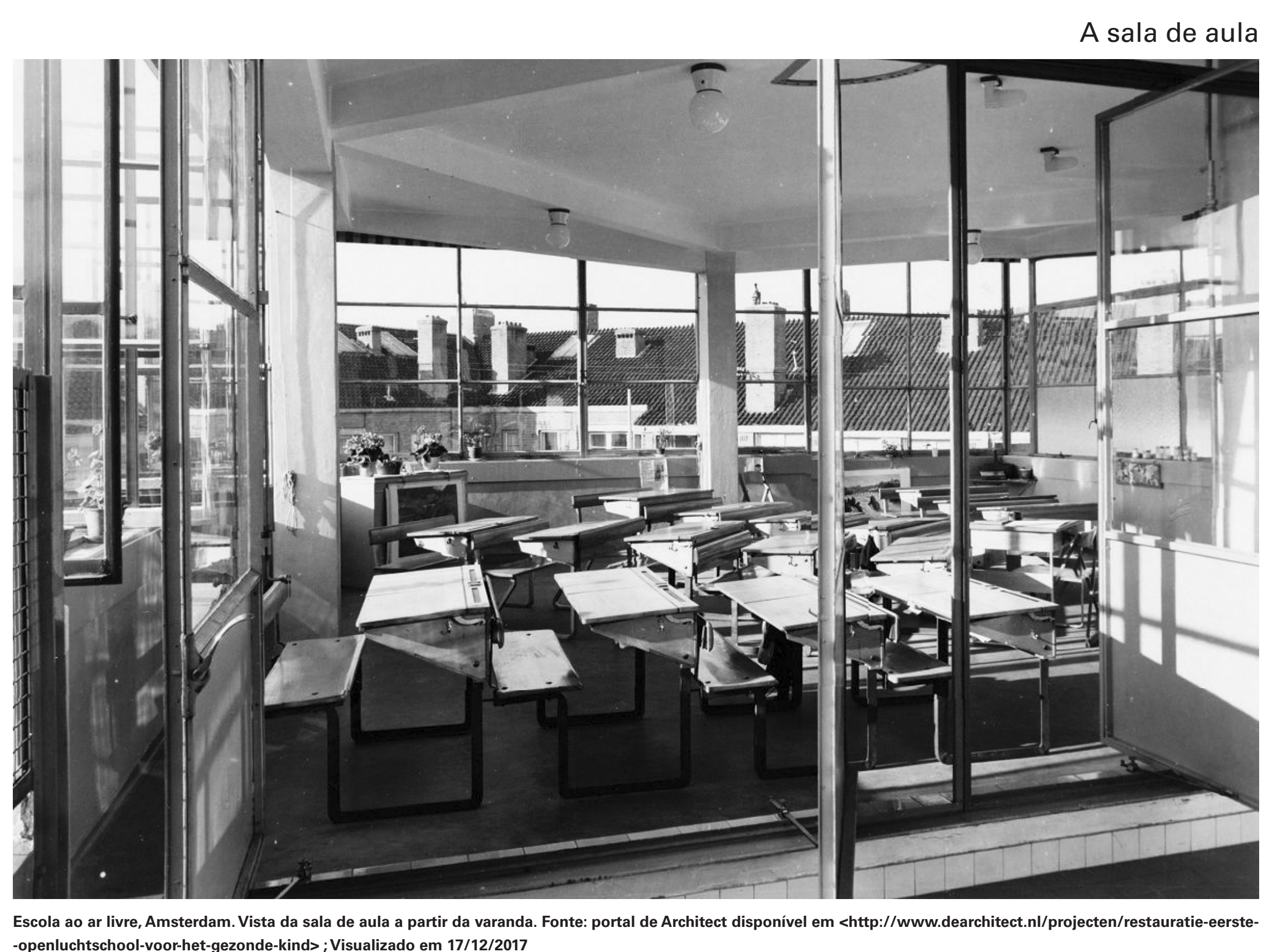

Do ponto de vista funcional, além da escola estender suas atividades pedagogicas para as areas externas ao incorporar a varanda, experiência rara até então o projeto flexibiliza sua ocupação, em anfiteatro, por exemplo, o que configura um desenho até certo ponto lúdico, como notado por Hertzberger (1999: 246). Nesse sentido, a forte presença da estrutura deslocada desenha a espacialidade do lugar de aprendizagem e revela sua identidade, ou seja não

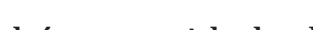
vos compene ou detahes decoratvos complementares para caracterizar a escola. 0 projeto prescinde de elementos ou figuras do universo infantil para construir a identidade escolar da edificação, pois a geometria espacial proposta é suficientemente forte. 0 projeto com seus atributos fundamentais, garante a consistênch necessária para atingir seu objetivo.
A descrição acima indica como na Escola ao ar livre de Amsterdam, construída em 1930, as decisões de projeto assumira ta e que reforça nossa hipótese de que os fundamentos de ordem estrutural interior foram responsáveis pelo resulta do, contribuindo para torná-la uma obra exemplar. As estratégias de Duiker e Bijvoet contornaram as dificuldades iniciais tornando-as atributos de qualidade do projeto. 0 rultado destaca a obra dentro de uma linha de raciocíni que busca obstinadamente os recursos ambientais como forma de enfrentamento da condição urbana. Não trata entretanto, de mimetizar com o cenário histórico próximo nem de negá-lo, mas sim se fazer valer das estruturas internas da obra para sua missão de transformaç̃õo social.

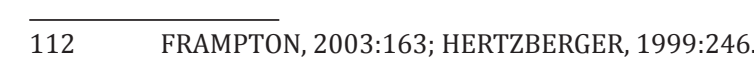




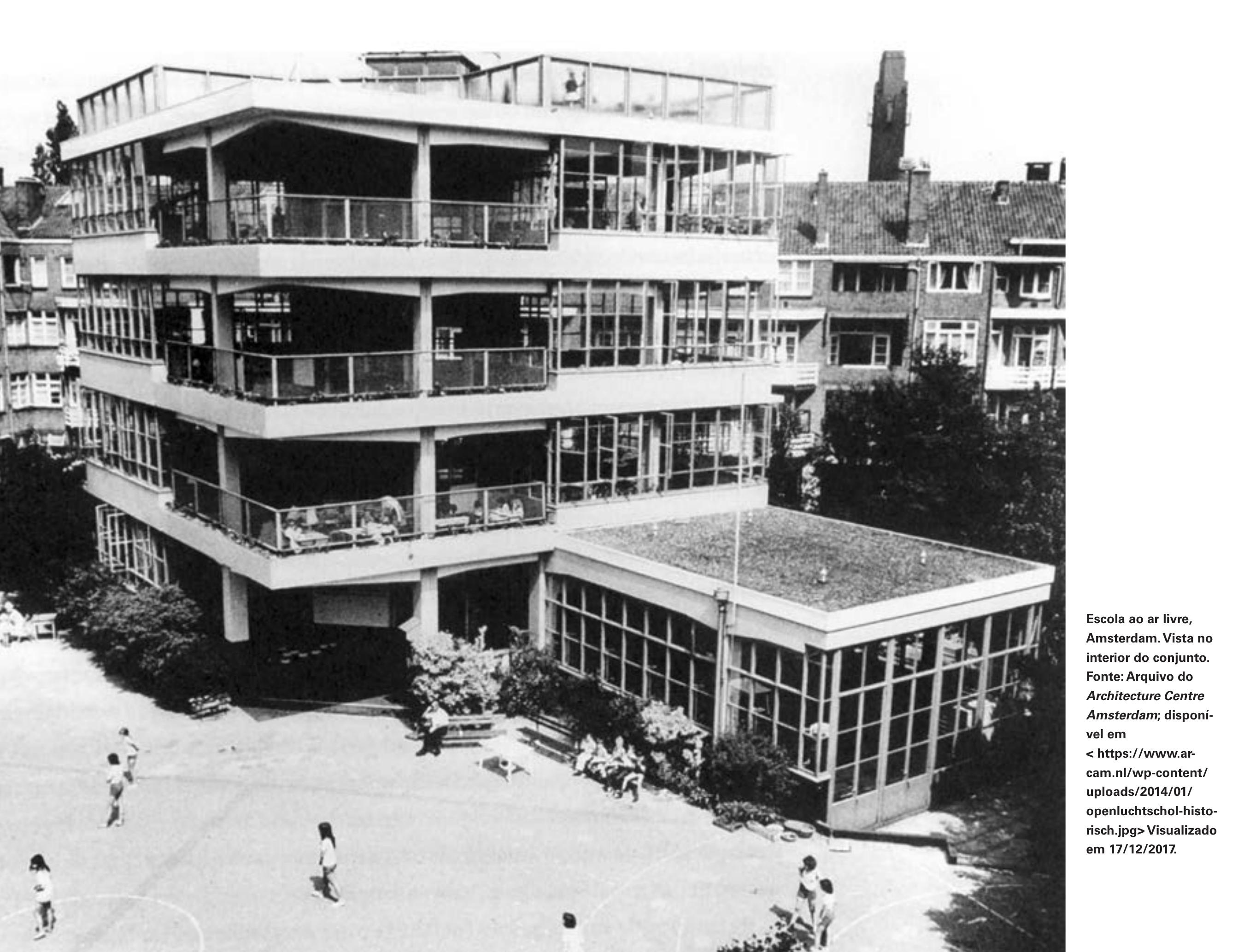



muito próximos, mas em contexto urbano distinto, implantada dentro

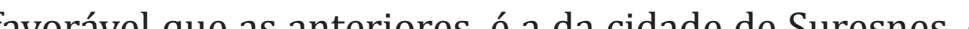
compõe o aglomerado urbano de Paris.

Suresnes foi a primeira administração municip socialista da França a partir de 1919, liderada por Hen Sellier, prefeito responsável pela implantação de bairros cidade-jardim desde 1921 com uma visão de urbanismo de características higienistas e de inspiraç̃o britânica, contribuindo de maneira efetiva para a implementação do prograFrança nes período. Sellier dirigiu o órgão regional responsável pela promoção de conjuntos de moradia econômica, instituiç̃ã responsável pela implantação de diversos bairros jardins essa região ${ }^{14}$. No contexto de reconstrução social implementado após o final da Primeira Grande Guerra, a proposta e associar educação e meio ambiente natural surge como consequência direta. A municipalidade irá confiar a Eugène

$114 \quad$ Ver COHEN, 2013: 186
Beaudouin e a Marcel Lods a missão de projetar a École en plein air de Suresnes em função da experiência acumulada pelos arquite cionais nos subúrbios de Paris ${ }^{115}$, como observa François Rougeron:

Eugène Beaudouin e Marcel Lods se inscrevem então, com seu edifício [Escola ao ar livre], em um contexto urbano, social e construtivo ainda mais importante que a propria cidade de Suresnes, no ânbitso de una reflexão mais ampla enpreendida por Henri Sellier 16 ROUGERON, 2017: 14

Suresnes viera testando a proposta de Escola ao ar livre desde 1920, improvisada, durante as estaçẽes

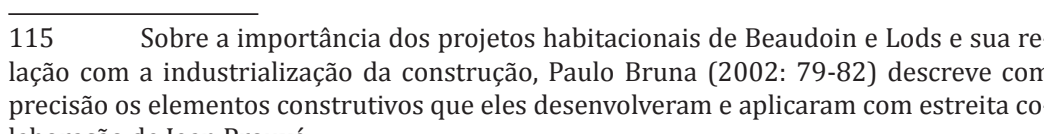

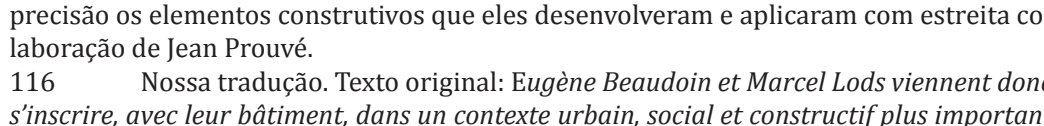

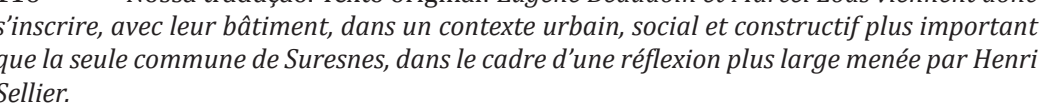

Ecole en plein air. Vista aérea do con-
junto, localizado na base do Monte Valeyen, ponto mais alto da regiāo. Fonte:
Arquivo do Musée d'Histoire Urbaine

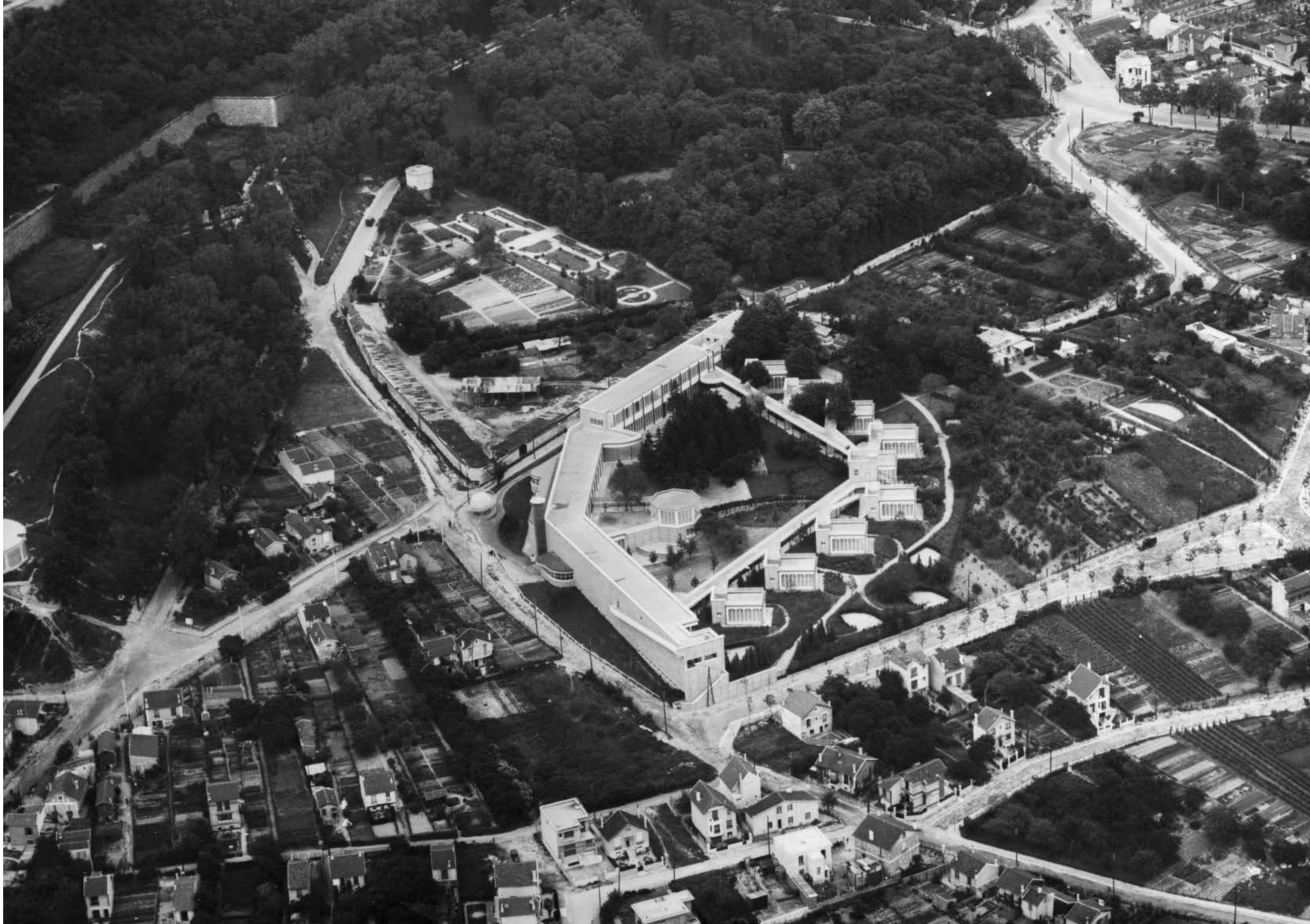


ano em que o clima era mais favorável, num terreno de um antigo haras para receber cerca de 100 crianças com dificuldades decorr In e Holanda, municipalidade e arquitetos puderam desenvolver propostas consideradas avançadas para a época, apoidos pelo desenvolvimento das práticas construtivas.

Em 1929, um terreno de $19.000 \mathrm{~m}^{2}$ foi destinado à implantação da escola com o objetivo de atender 350 crianças entre 4 e 14 anos de idade. Além das dimensões generosas, o local já era muito arborizado e com topografia em suave declive de cerca de $5 \%$ no sentido longitudinal, com uma diagonal de 250 metros voltada para o sul. Essa condição excepcional irá orientar as decisões de projeto. Assim como em Amsterdam a insolação é escolhida pelos arqutetos como matriz a ser seguida pela implantação predom nantemente horizontal do conjunto.

É visivel a influência de Duiker e Bijvoet no projeto de Beaudouin e Lods, porém ela se reflete muito mais traçado geométrico das diagonais para resolver a implan- tação do que na configuração dos espaços internos. Alén a visita à Escola ao ar livre em Amsterdam que Beaudouin e Lods fizeram acompanhados do Prefeito Sellier antes de iniciarem o projeto, Bijvoet foi colaborador de Pierre Chareau no projeto da Maison de Verre ${ }^{117} \mathrm{em}$ Paris, momento m que compartilhou alguns trabalhos com Beaudouin e Lods. Esse estreito intercâmbio pode explicar a proximidade de soluções não apenas de implantação mas também dos elementos construtivos das escolas de Suresnes e de Antsterdam, como veremos a seguir

Em Suresnes, o conjunto da escola é formado por um longo edifício com dois pavimentos, próximo à rua, junto face norte do terreno, constituindo-se como uma barreir aos ventos frios vindos do norte" ${ }^{118}$. Nele são distribuídas todas as funç̃es coletivas (refeitório, vestiários, dormito-

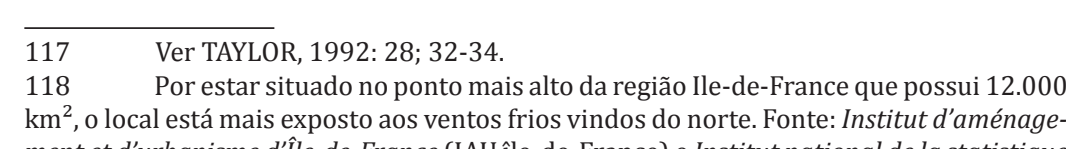

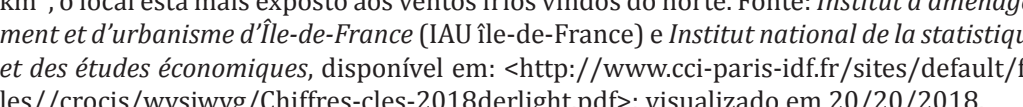
$\begin{array}{ll} & \end{array}$ 

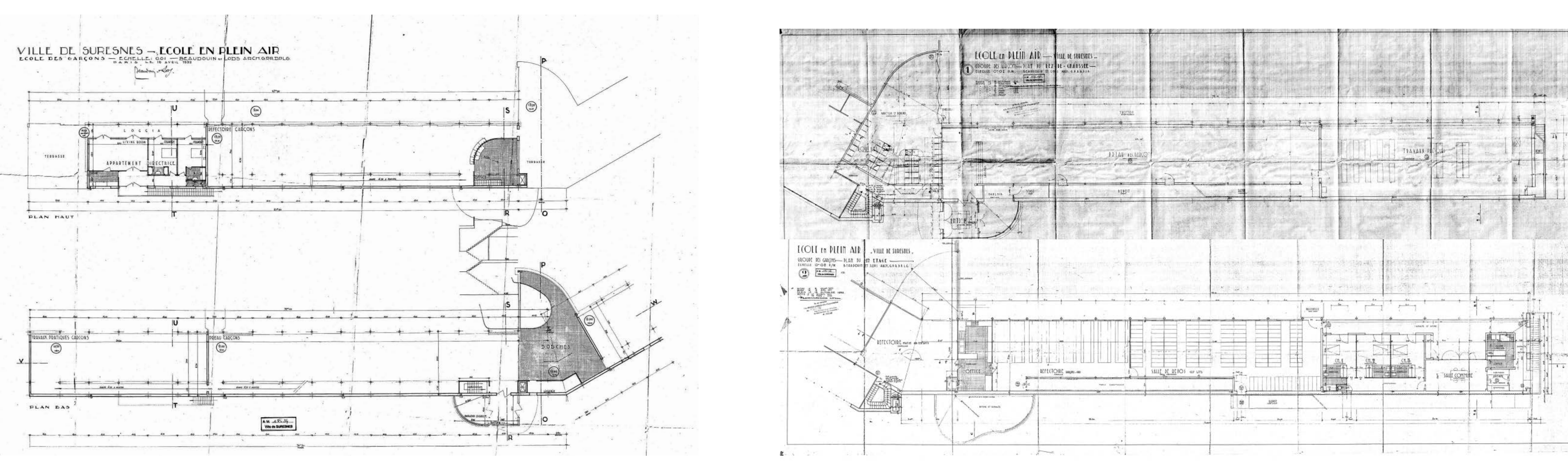
rios, pátio coberto) e administrativas, além de duas salas da escola maternal no centro. De suas alas leste - das meninas

- e oeste - dos meninos, partem em direção ao centro galerias cobertas e abertas em que são distribuídos 8 peque nos pavilhões isolados. Cada um deles recebe uma sala de aula, totalmente envolvida pelas áreas verdes e arborizadas que conformam um parque ${ }^{119}$. Outro pequeno pavilhão de atendimento médico ocupa o encontro dos dois conjuntos de 4 salas de aula, que originalmente separar meninas mas que logo tornou-se de uso misto. Como a declividade ocorre no sentido leste e oeste, cada conjunto de salas de aula está implantado no nível que corresponde ao nivel de cobertura do outro conjunto. Assim, o atendimento médico possui dois pavimentos para poder se conectar em nível com ambos os

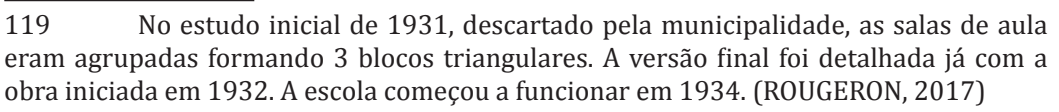

O uso do teto terraço é outra solução marcante da obra. Tanto a galeria de circulação externa como as salas Them terraços acessíveis que permitem seu uso para atividades didáticas e recreativas em dias em que o clima é favorável. Todo o sistema de solários formado é interligado por rampas junto ao edifício principal, conformando um percurso possivel de ser explorado.

Da mesma maneira, o percurso paisagístico no parernas para cada uma das salas de aula. Assim, o projeto de Beaudouin e Lods multiplica as possibilidades pedagógicas da escola, indo além do programa original centrado nos va lores higienistas e de socialização da educação.

Novamente pode-se observar a influência de Duiker e Bijvoët em que a arquitetura amplia os camin serem percorridos pelas atividades de aprendizagem, graças às condições ambientais excepcionais, a sensibilidade de Beaudouin e Lods aproxima a obra da naturez através do movimento promovido pela multiplicidade de ações e de percurso

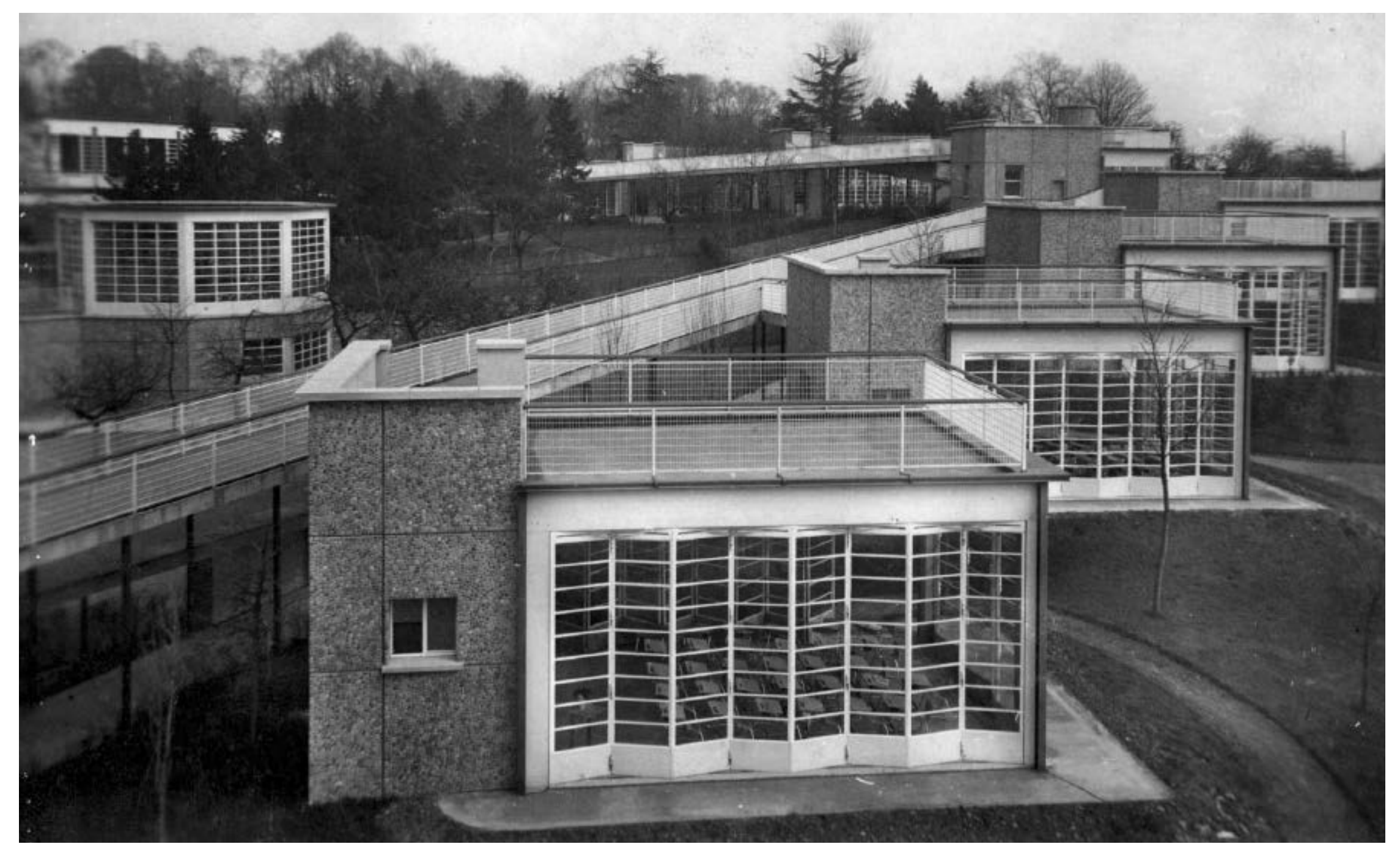

Ecole en plein air. Vista da ala oeste interligada por terracos acessiveis. Fonte: Arquivo do Musée d'Historie Urbaine et Sociale de Suresnes 


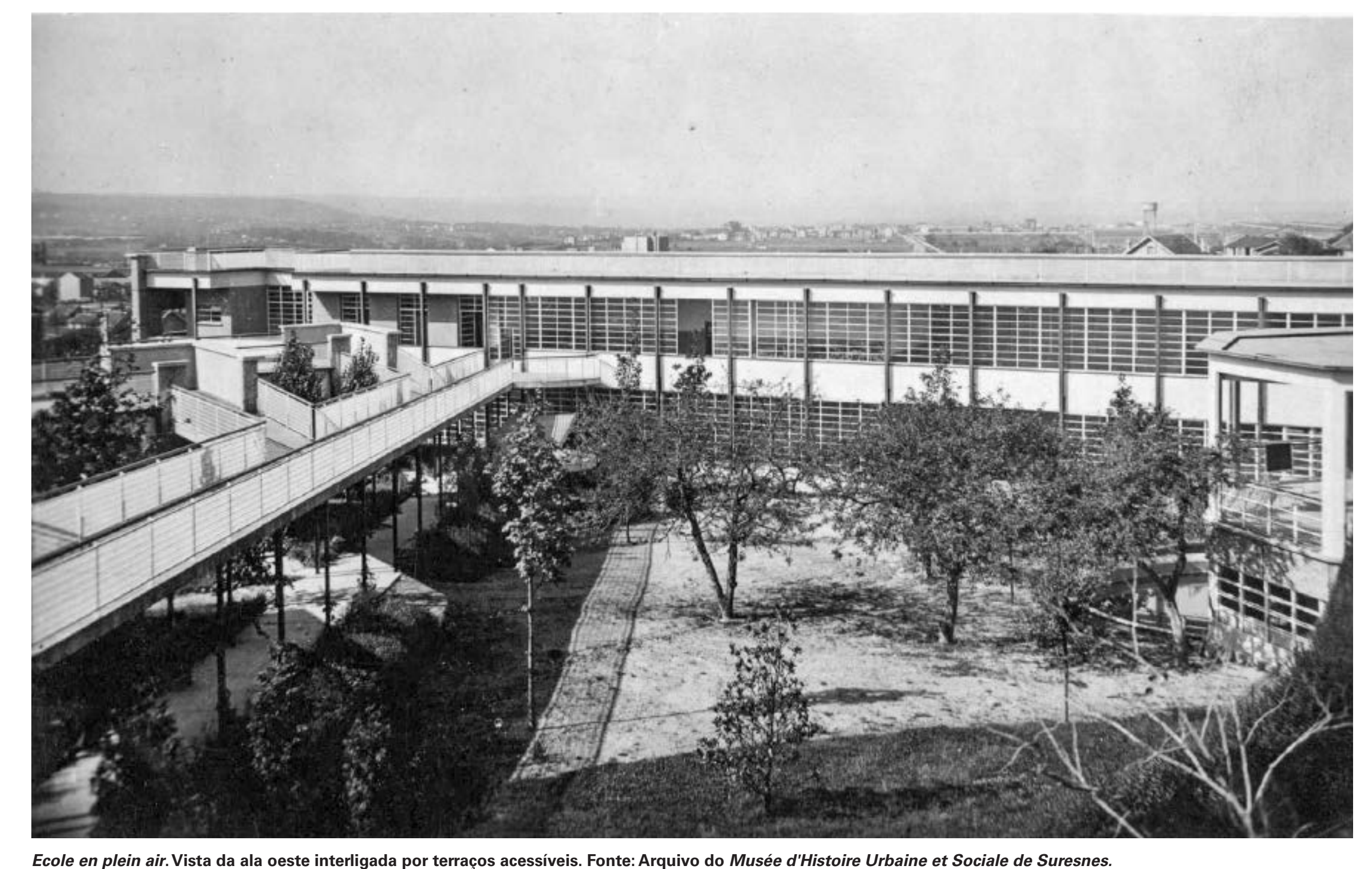
a escola de Suresnes é mais um testemunho do obstinado trabalho de Beaudoin e Lods pela qualidade e pelas possibilidades de industrializaçãa ${ }^{120}$. Tanto o edifício principal como os pequenos pavilhões utilizam perfis metálicos para o sistema de pilares $\mathrm{e}$ vigas aparentes (malha de $4 \mathrm{x}$ metros) que recebem lajes de concreto armado pré-fabricadas (placas de $2 \times 2$ metros). Todo o esqueleto estrutuda de "azul Suresnes", marcando o ritmo das fachadas e organização interna dos espaços coletivos - pátio coberto refeitório, dormitório e ducha. 0 local da ducha é posicionado na transição entre cada ala e o trecho central da edificação, na articulação do ângulo obtuso conformado pelo desenho da implantação.

0 ritmo vertical da malha estrutural formada por delgados perfis é valorizado pelas superfícies envidraçadas que conformam todas as faces voltadas para o sul. No caso das salas de aula, somente a face norte é opaca, pois recebe um local para vestiário e sanitário. 0 espaço interior se configura pela força da luz natural que banha sua totalidade e deixa clara a malha estrutural. A altura livre interna dos ambientes com cerca de $4 \mathrm{~m}$ reforça a esbelteza da estrutura. 


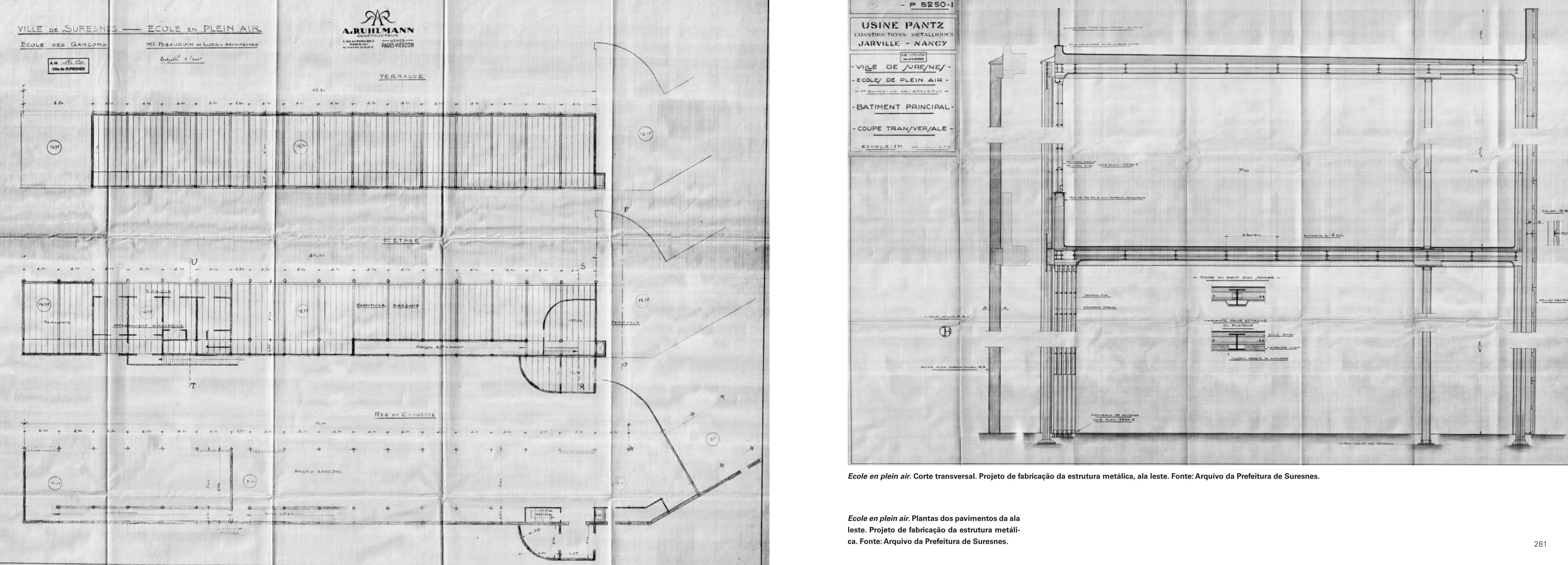




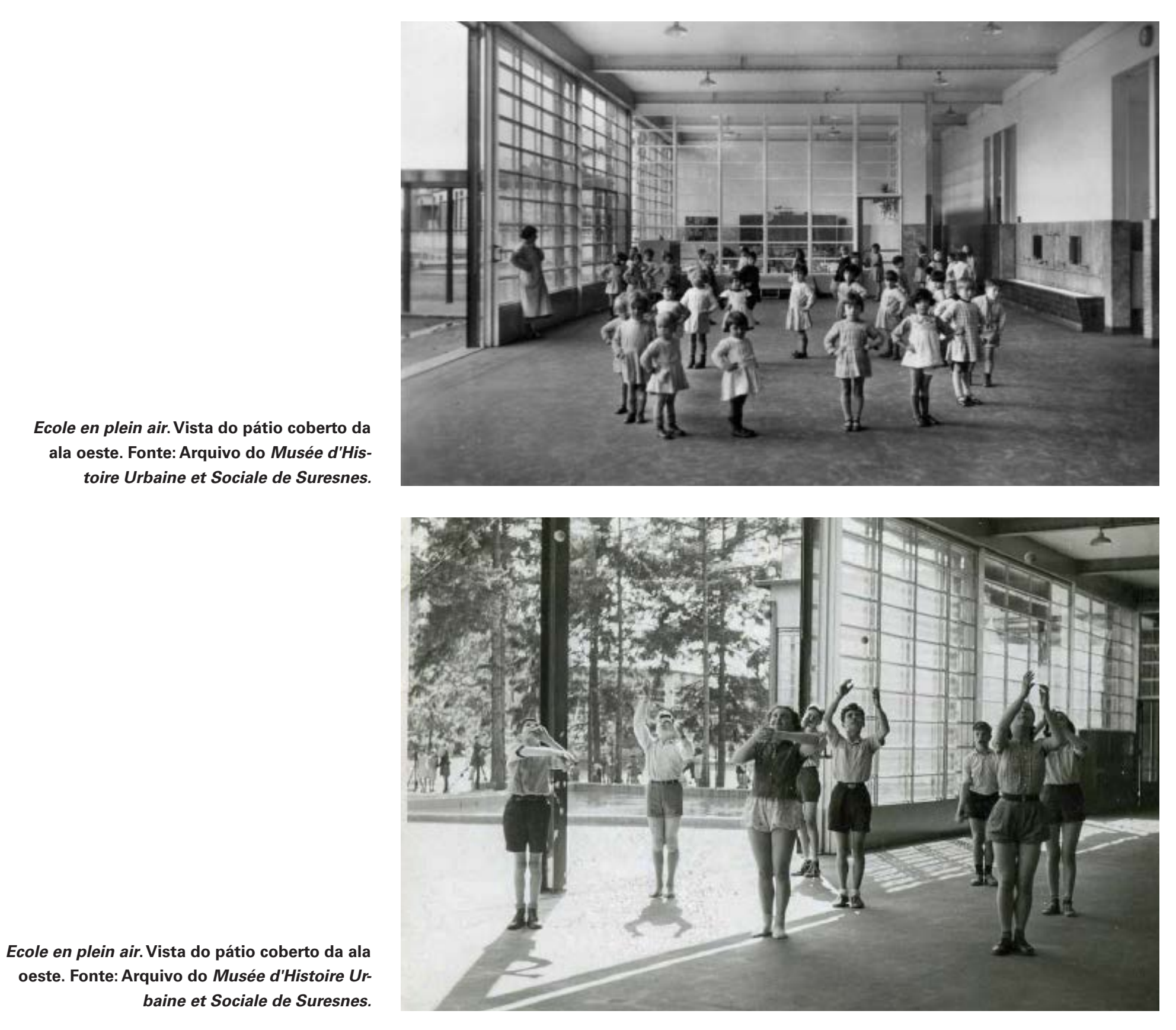

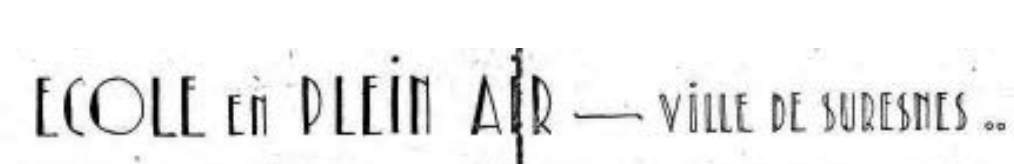

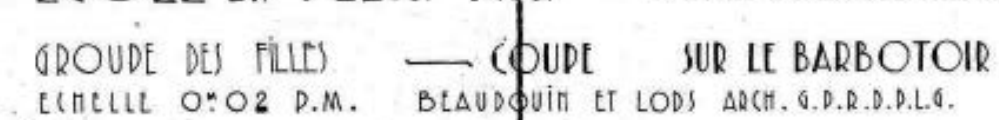
24.

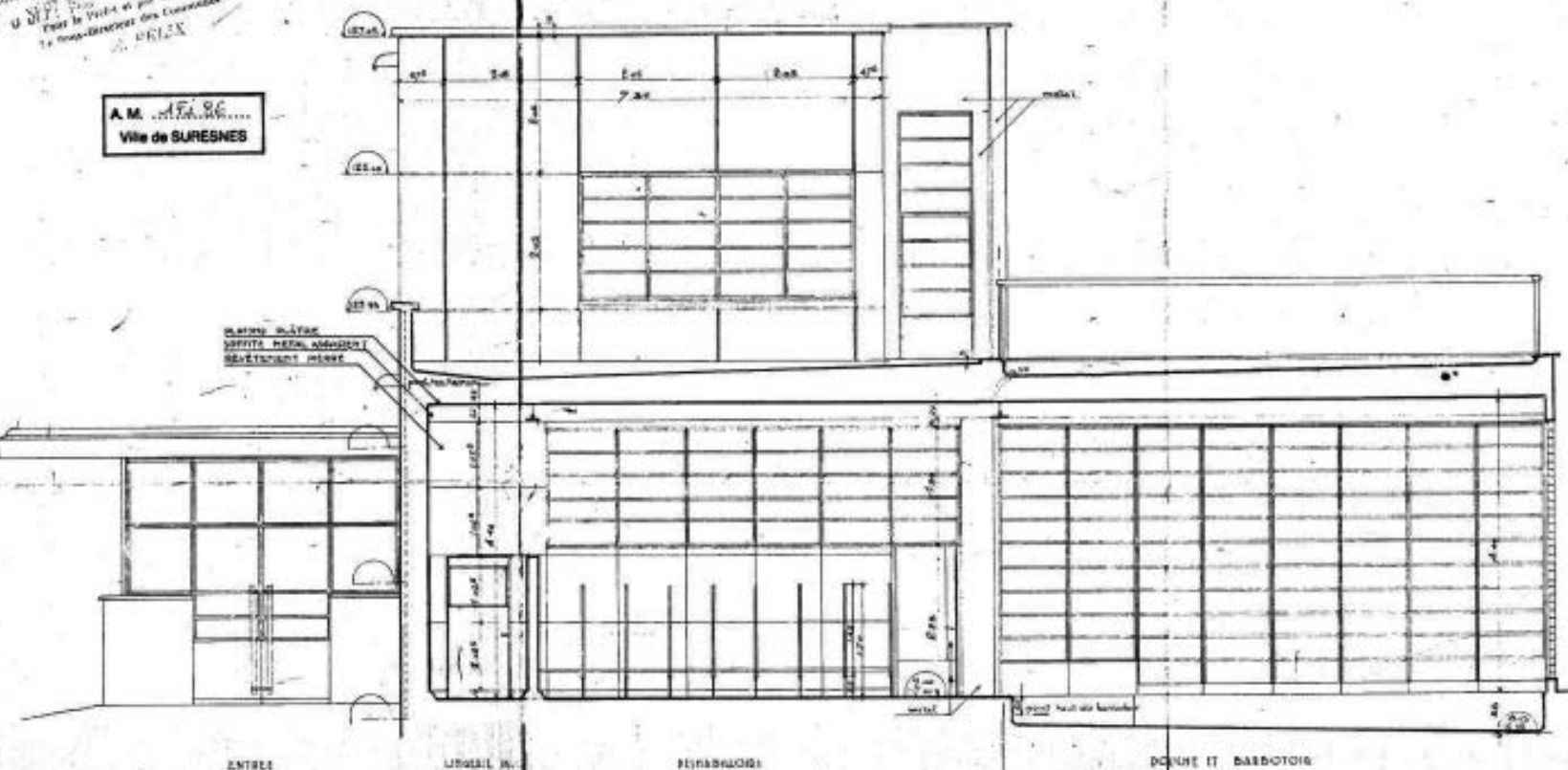

$$
\text { Ecole en plein air. Corte transversal. Duchas da ala oeste Fonte: Arquivo do Musée d'thistoire Urbaine et Sociale de Suresnes. }
$$

Tanto o edifício principal junto à rua como as salas de aula distribuidas no parque beneficiam-se dessa qualdade espacial interior, conforme descrito. Refeitório, do mitório e pátio coberto, assim como as salas de aula, não se rendem às pequenas dimensões, consideradas erroneamente como sendo próprias da escala da criança. Destaque especial para os ambientes das duchas, que se abrem totalmente para o exterior, como varandas, e se prolongam até um espelho d'água em que as crianças podem fazer jogos e brincadeiras beneficiando-se dos efeitos benéficos do sol e da água, como em uma verdadeira hidroterapia. 


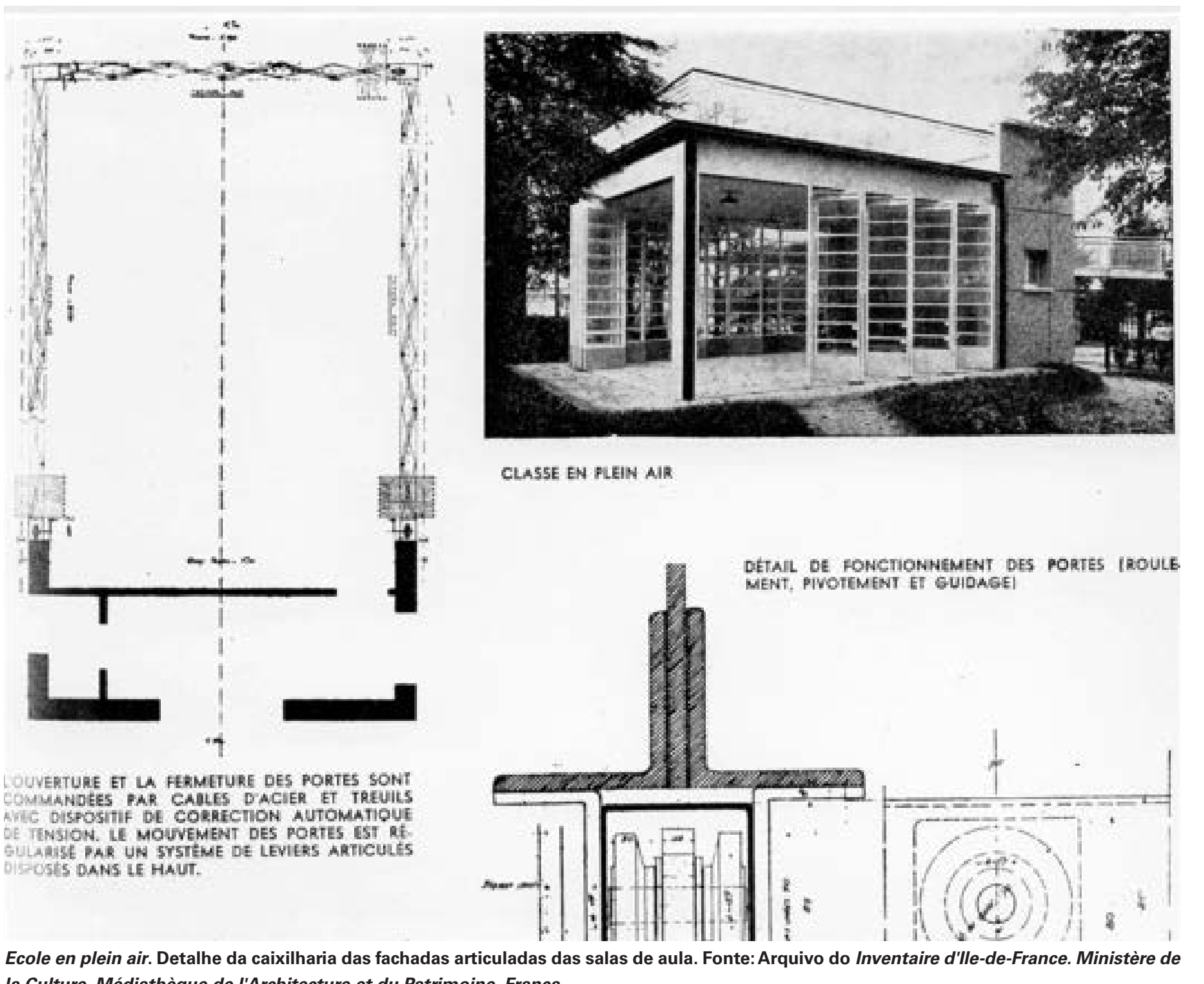

Para que todas as condiç̃es apontadas atinjam seus objetivos, os arquitetos vão dedicar especial cuidado com o detalhamento to envidraçados con móveis e articuladas - sistemas de correr, sanfonado e guiIhotina - que permitem variações de conformação e uso muito próximas da arquitetura de Pierre Chareau, com dispositivos articulados e mecanizados, em que o detalhe é fundamento primordial da arquitetura. Mais uma vez a equipe de Beaudone Lods contana com senvolvinesto dethas componentes metálicos que marcam a atuação profissional de Jean Prouvé. $A$ arquitetura francesa da primeira metade do século XX não pode ser descrita e avaliada sem sua presença $e$ aind colaboraçáo com equipes de arquitetos importantes daquele periodo, como Mallet-Stevens, Tony Garnier, Le Corbusie Candilis, Wood e Josic, além de Beaudoin e Lods ${ }^{12}$.

$121 \quad$ Ver VON VEGESACK, 2006
Em Suresnes, o detalhamento dos componentes etalicos, estruturais ou não, é um testemunho valioso da qualidade do tra o programa se o pog seu tempo. 

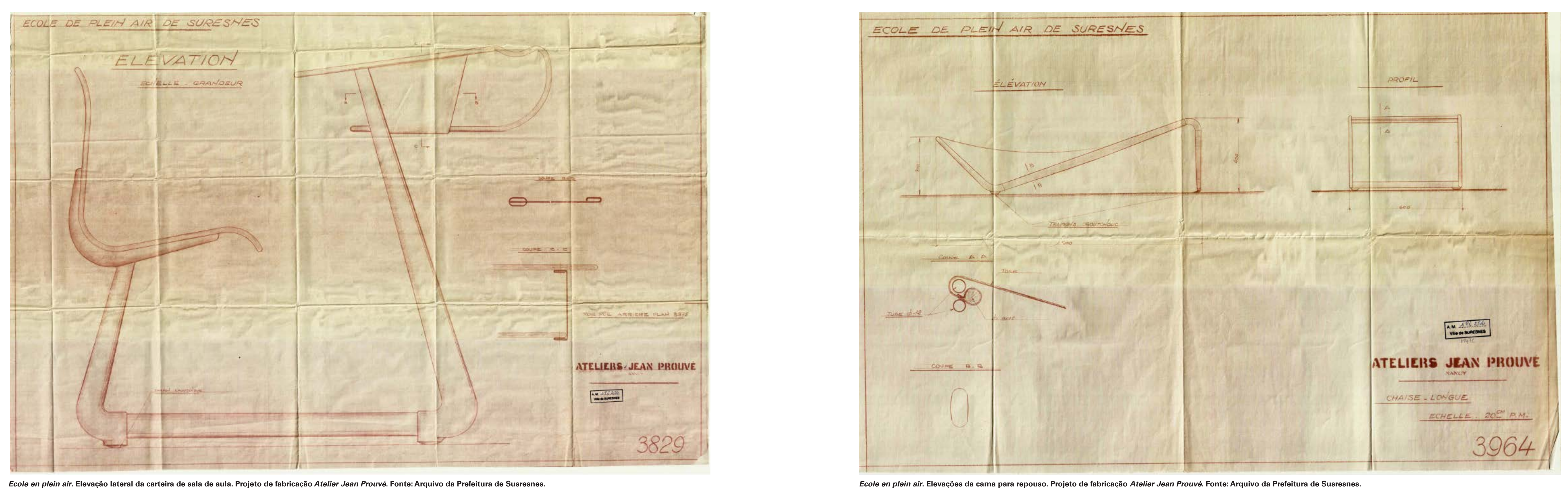
A consulta aos arquivos da Prefeitura de Suresnes revelou um significativo volume de propostas técnicas e comerciais de diversas empresas interessadas em realizar os serviços necessários para a construção da obra. Para tanto, cada uma delas apresentou soluções para os itens orçados como parâmetro para as especificações técnicas e os valores vo de viabilizar a obra da maneira mais próxima do que foi projetado, não apenas para garantir a integridade do projeto mas também para introduzir eventuais melhorias. 0 procedimento, ainda hoje usual não apenas na França mas em toda a Europa, pode ser apontado como fundamental para assegurar os princípios apresentados pelo projeto.

No caso de Suresnes, a participação de empresas especializadas, originárias das regiôes mais industrializadas da França, como Lyon, Strasbourg, Metz e Nancy, além de Paris, é o testemunho da importância assumida pela obra. São propostas para o detalhamento e fabricação da estru- tura metálica, dos painéis pré-moldados de fachada, das esquadrias metálicas, assim como dos blocos de vidro do mobiliário especialmente projetados para a obra. Cabe salientar que se trata de materiais e sistemas construtivos que se tornam elementos construtivos na medida em que compõem o projeto, ou seja, materializam o que o projeto enão o que aparenta ser. Como exemplo desse procedim to, empresas como E. Blondel, Etablissement Wanner, Thonet Frères e Atelier Jean Prouvé submeteram suas soluções construtivas aos arquitetos, antes da negociação definitiva dos orçamentos. Assim, podemos confirmar a intensa aproximação no período entre a indústria e a arquitetura, como apontado pela historiografia ${ }^{122}$

122 Ver BRINA, 2010.

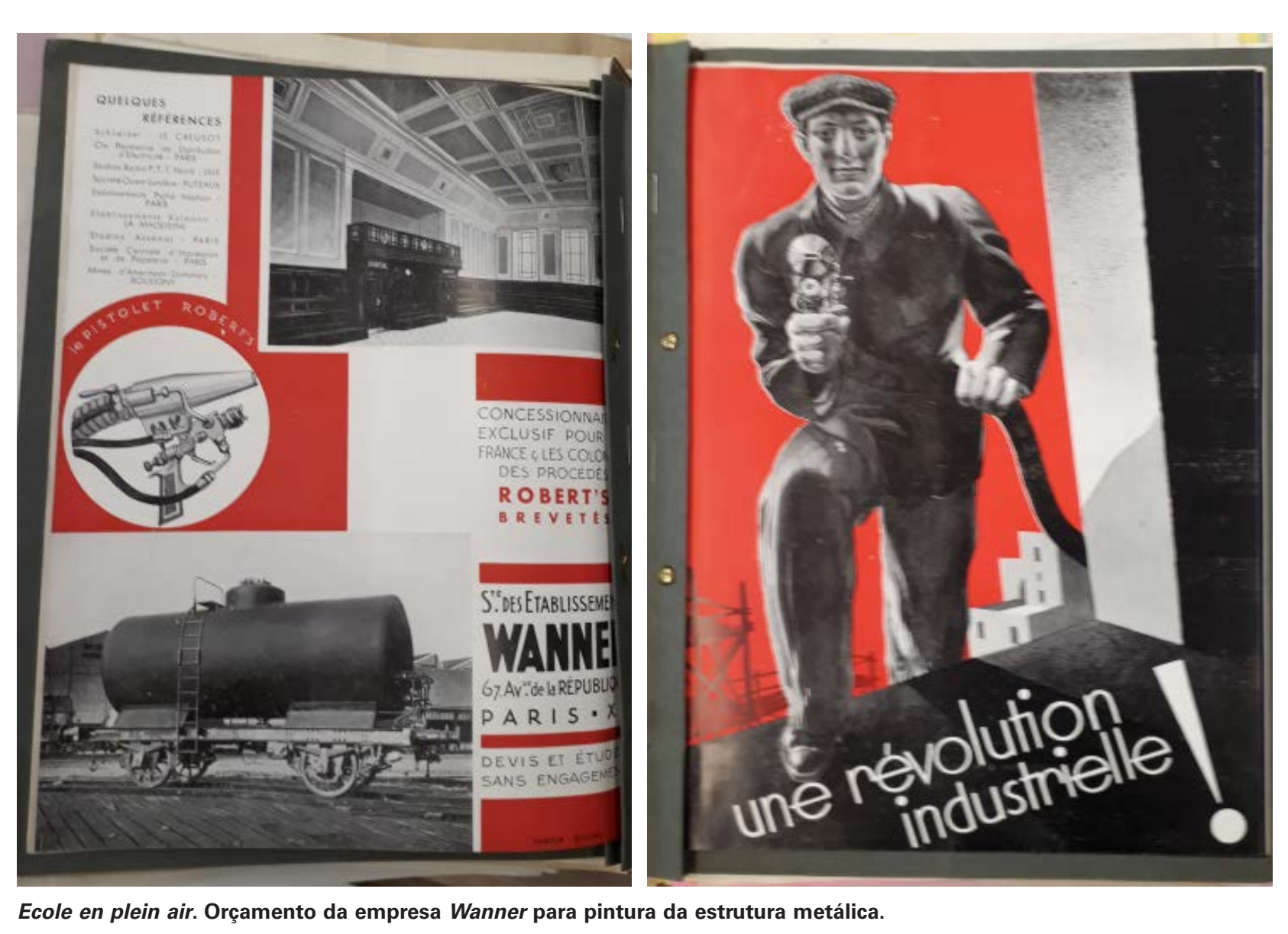

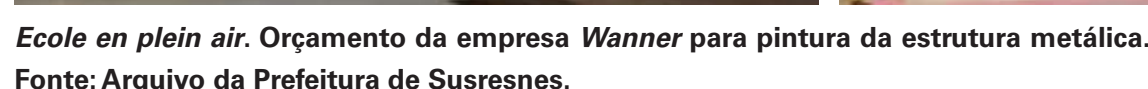

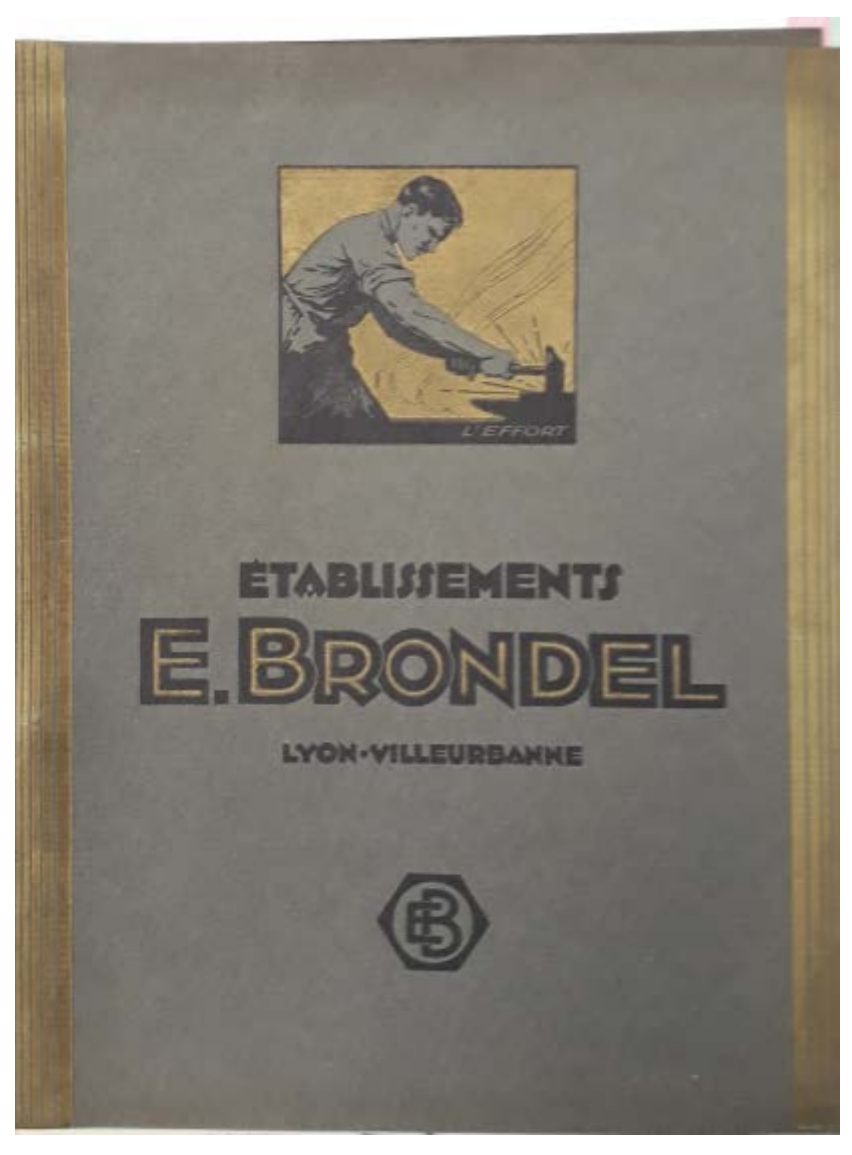

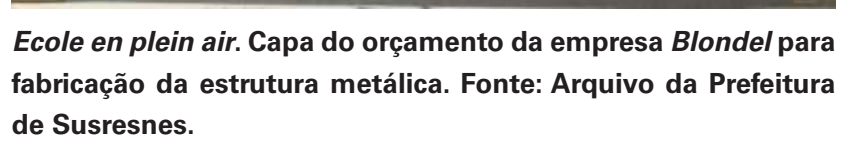



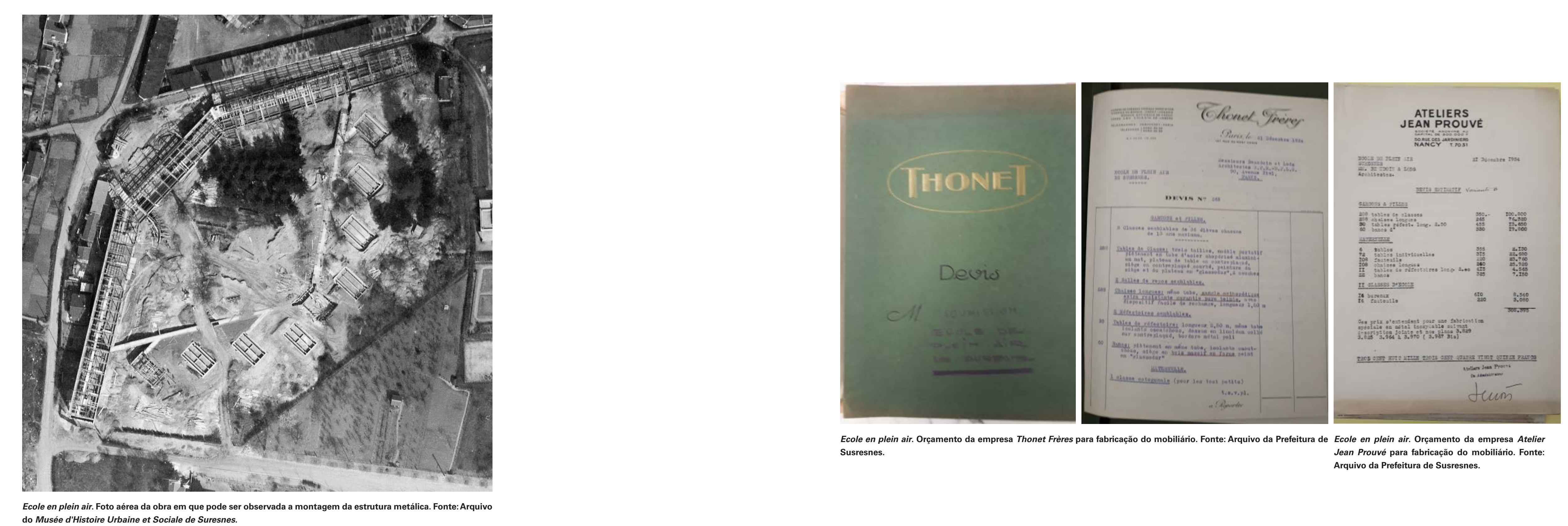
entendida como o encontro primoroso da interioridade da

arquitetura de Chareau com a inventividade técnica de Prou-

vé. A obra surge como um modelo de arquitetura moderna

francesa não corbusiana, lembrando que Beaudoin e Lods se

notabilizaram, antes e depois de Suresnes, por seus grandes

conjuntos habitacionais construídos com sistemas indus-

trializados ${ }^{123}$. No nosso entendimento foi em Suresnes que

esses arquitetos deram uma contribuiç̃o fundamental para

a compreensão da experiência moderna que ainda hoje é

revolucionária, na medida en que o projeto é o instrumen-

to de enfrentamento da difícil condição urbana e social do

período, valendo-se de seus fundamentos para responder a

um programa educacional experimenta, associando

ambiente construído ao meio ambiente natural.

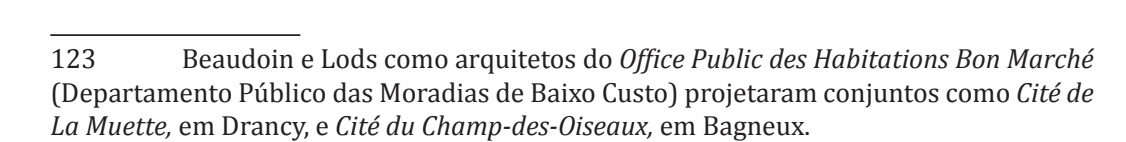

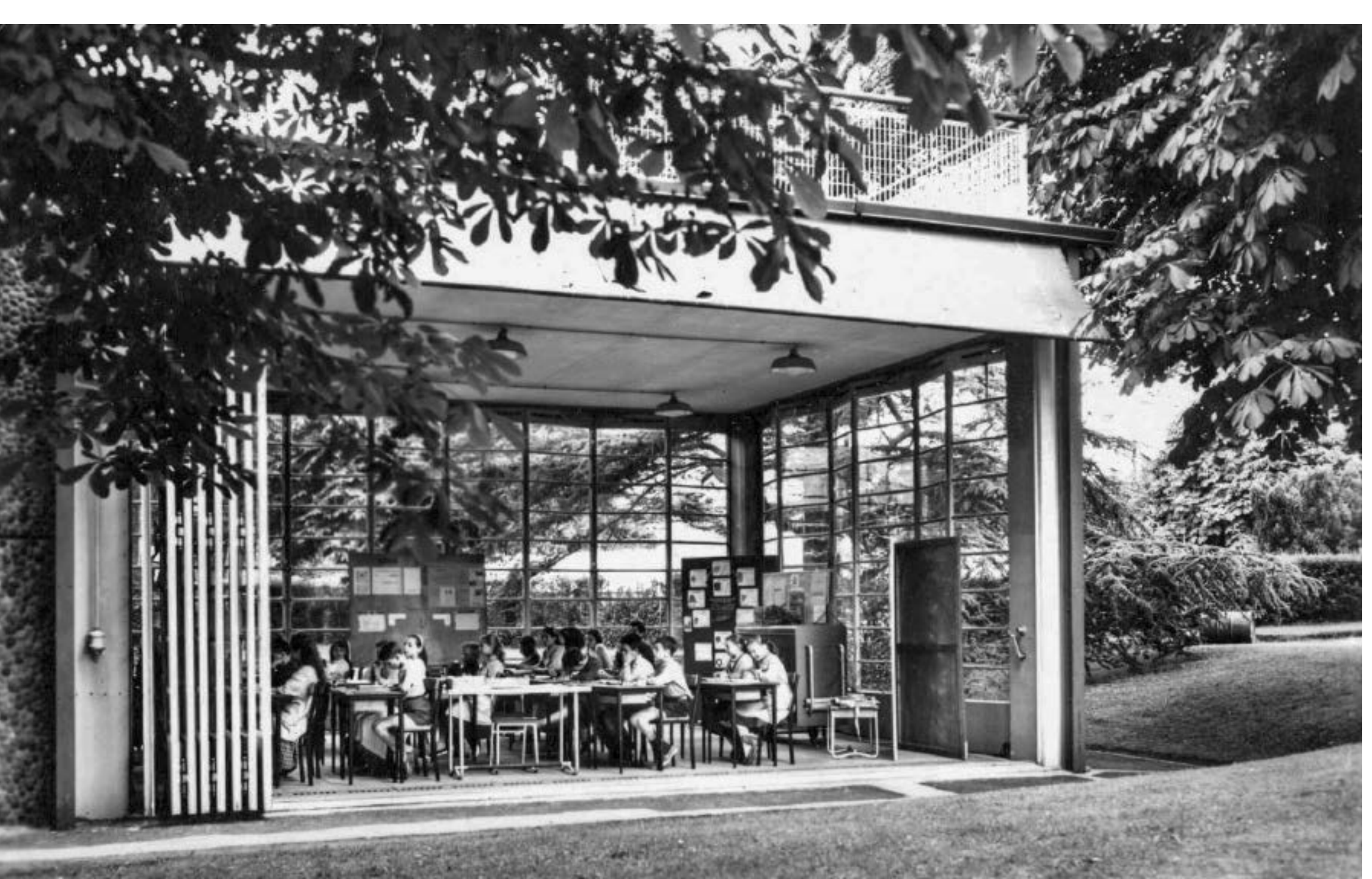

Ecole en plein air. Parede de bloco de vidro do es-
paço das duchas. Fonte: Arquivo do Musee d'tis-

Ecole en plein air. Sala de aula. Fonte: Arquivo do Mussé d'Historie Urbaine et Sociale de Suresnes. 
Como vimos até aqui, o projeto de Beaudouin e Lods se destaca por ser um sistema implantado de maneira exemplar em um ambiente natural privilegiado. Em certo sentido, podemos admitir que o projeto do lugar da aprendizagem reproduz determinadas situações urbanas que começavam a se tornar usuais dentro de uma sociedade em transformação. Podemos notar, por exemplo, que a verticalização funcional é acompanhada de elementos estruturantes formados por rampas e passarelas, que garantem ofluxo contínuo de professores, funcionários e alunos no interior e no exterior da escola, enfrentando tanto as diferenças de níveis que o terreno apresentava como as separações entra a ala dos meninos e das meninas. Nesse sentido, a estrutura física do ambiente construído é também formadora na medida em que simula situações da realidade urbana em construcão, ou seja, é formadora ao introduzir noç̃oes de mobilidade, de orientação e de setorização entre outras. Entretanto, acreditamos que é na aparente simplicdade da sala de aula que o projeto atinge seu ápice, ou, dito de outra forma, a sala de aula é a síntese do projeto.
0 ambiente "sala de aula" possui uma planta retangular de 6 por 8 metros e altura de 3,5 metros. Como vimos, cada unidade está implantada individualmente (a) por Beaudouin e Lods. A base menor do retângulo, voltada para o norte, é limitada por um volume fechado, que recebe o vestiário e um sanitário infantil. As outras três faces do prisma retangular são envidraçadas, compostas por esquadrias metálicas articuladas que podem ser abertas em totalidade graças a dispositivos manuais compostos por roldanas, cabos e contrapesos comandados por uma manivela. No piso elevado é instalado um sistema de ventiação e de aqimento, participando diretamente no co dicionamento climático do ambiente interno. $\mathrm{Na}$ cobertura, principalo teto terraço éusado para atividades ao ar livre. A descrição básica da sala de aula indica que o projeto foi além da destacada inserção do lugar da aprendizagem junto a um cenário natural qualificado. A arquitetura assume um papel ativo na oferta de dispositivos e de solucôoes espaciais capazes de amp à escola naquele momento histórico.

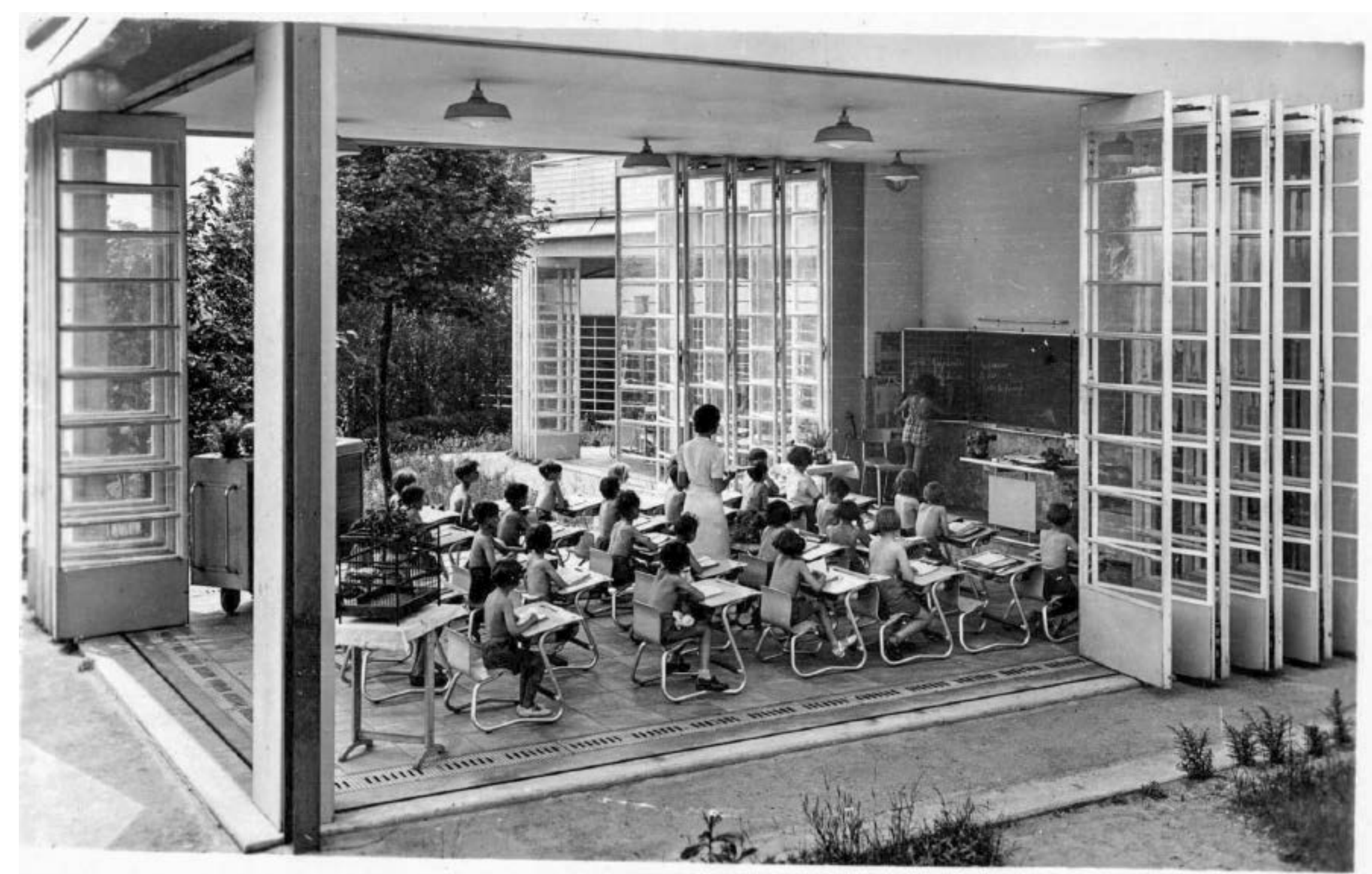

Ecole en pleir a ari. Sala de aula. Fonte: Arquivo do Musée d'Histoire Urbaine et Sociale de Suresnes. 


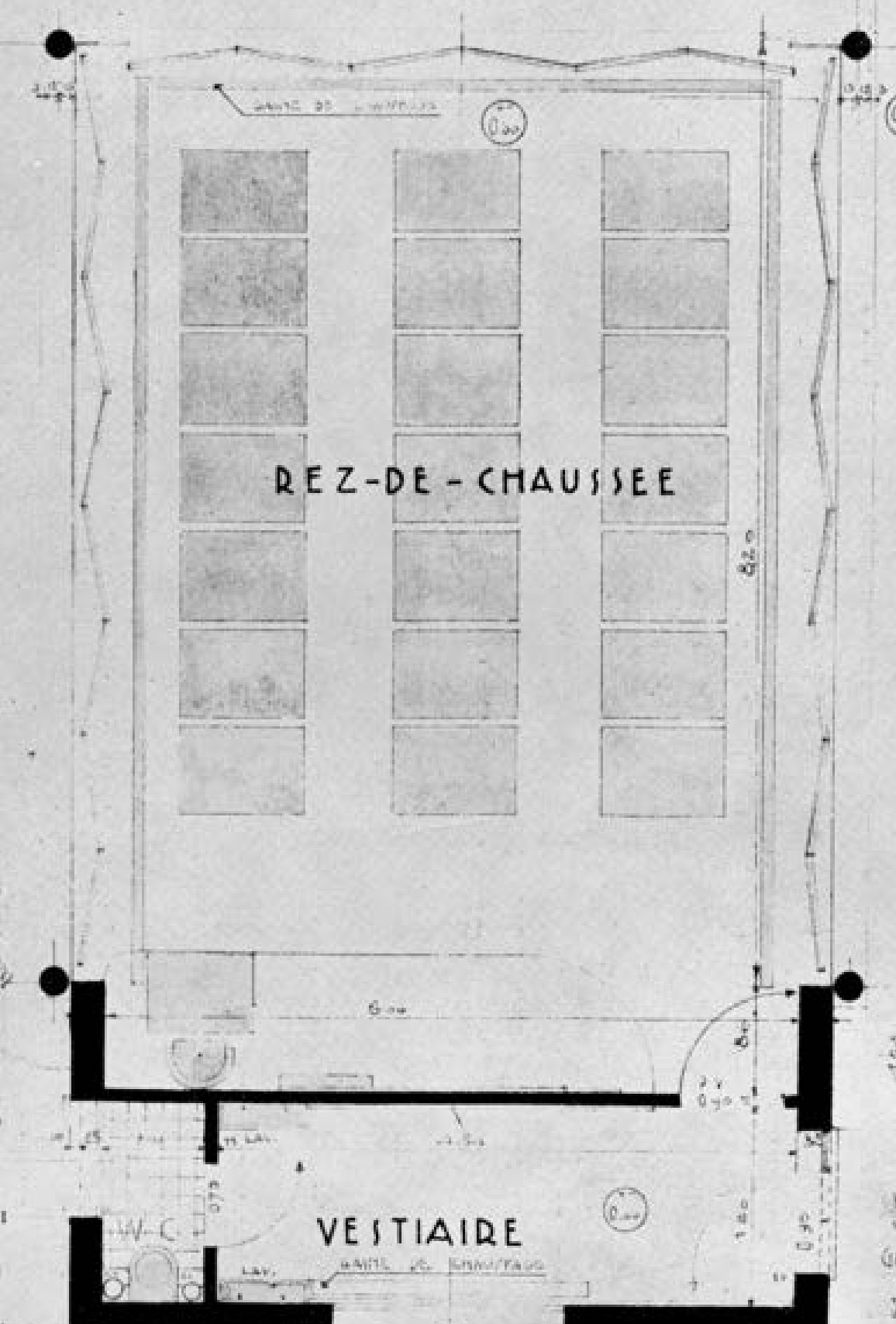

visita ao local mostra que o conjunto passa por um momento de transição entre a es-

cola propriamente dita, que funcionou até 1995 ,

0 atual Centre National d'Etudes et de Formation

pour l'Enfance Inadaptée $e^{124}$ (CNEFEI), que utiliza

tualmente suas instalações. Conforme depoi-

mento da conservadora chefe do Arquivo Munici-

pal de Suresnes, Haude de Chalendar ${ }^{125}$, a Prefei-

tura prepara um concurso público de arquitetura

para devolver ao conjunto sua vocação original.

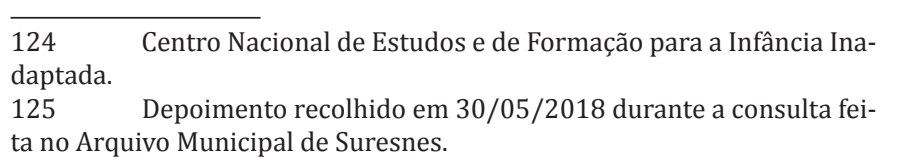

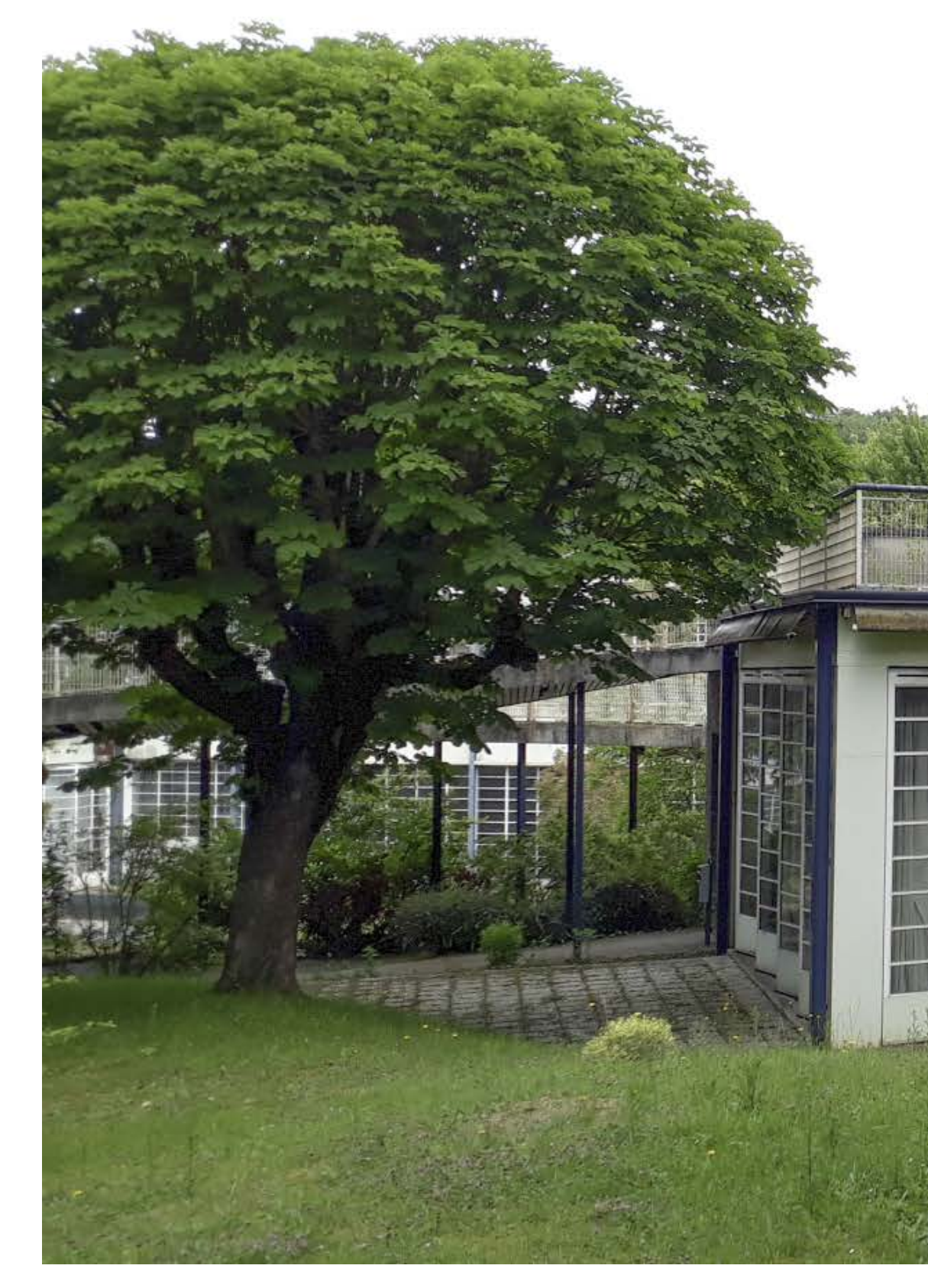

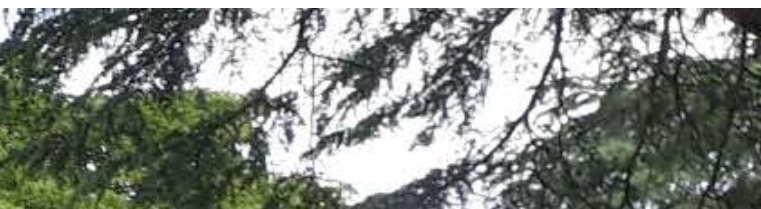
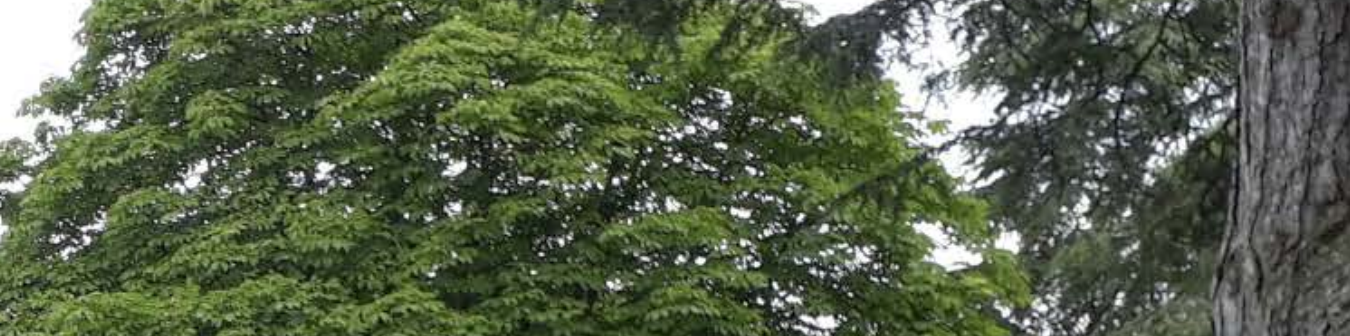

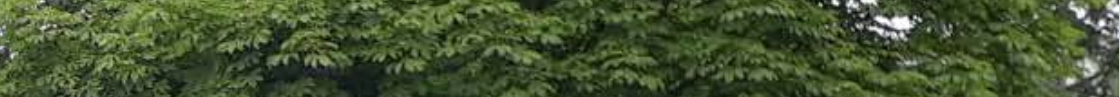

Ecole en plein air. Planta da sala de

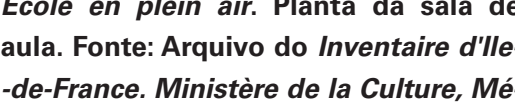

diatheque de l'Architecture et du Patri- 


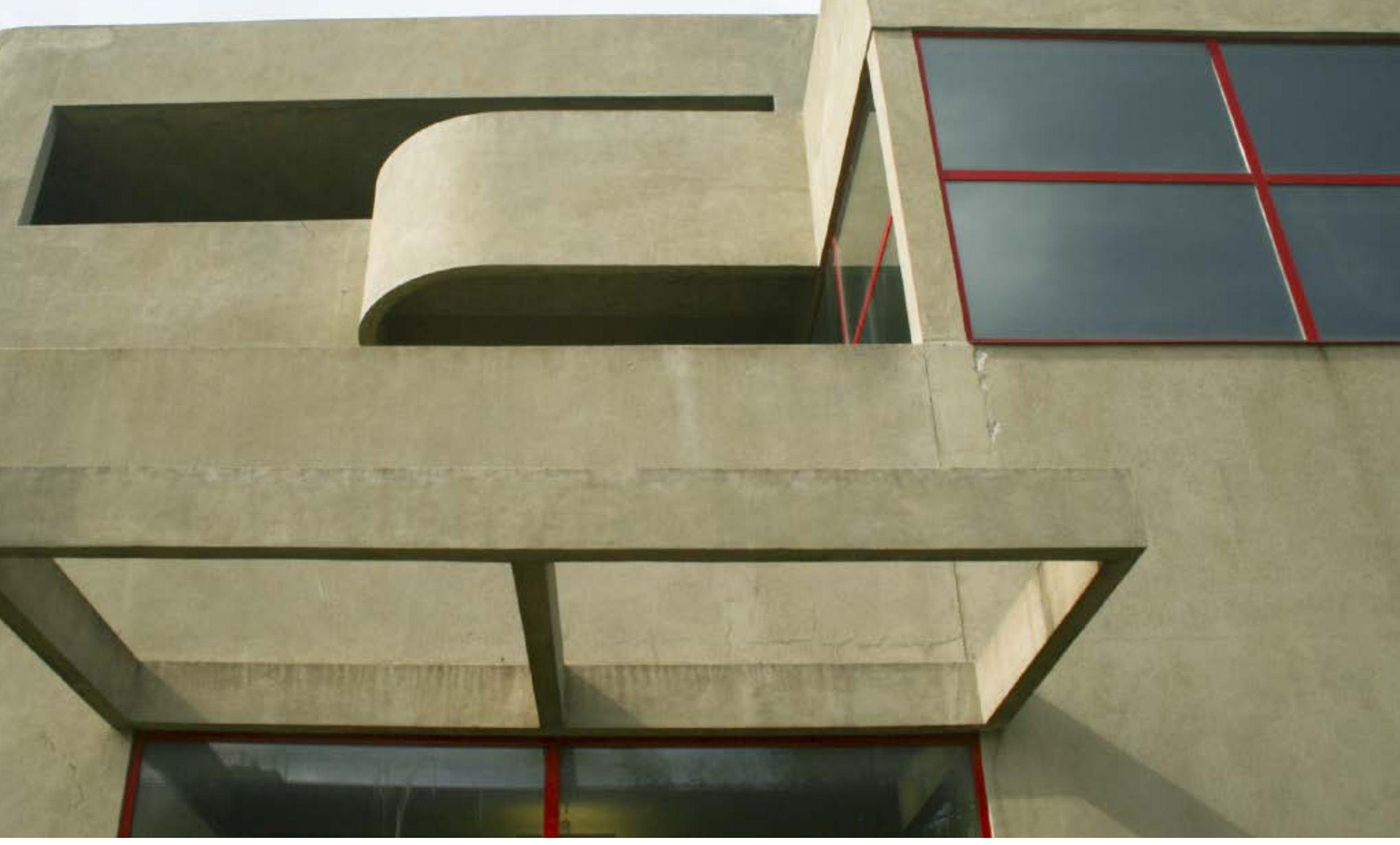
arquitetônica no período entre as duas grandes guerras teve um papel fundamental no crescimento e na transformação urbana da periferia parisiense. Para Paulo Bruna (2002: 79 82), houve uma importante contribuiç̃o das obras realizadas nesse período no que se refere às iniciativas de industrializač̃ da construỹa mas un a tim a ticular no que se refere à construção dos grandes conjuntos habitacionais. Conclusão semelhante é compartilhada por Jean-Louis Cohen (2013: 188-189) que chega a considera "medíocre" parte desses conjuntos construídos no período citado. Entretanto Cohen admite que o surgimento e a distribuição de equipamentos públicos, capazes de suprir as necessidades da vida comunitária, pode ser considerado inédito na estrutura urbana da periferia das grandes cidades, 0 que, segundo ele, levou a experiência parisiense a ser repetida em escalas europeia e mundial. 


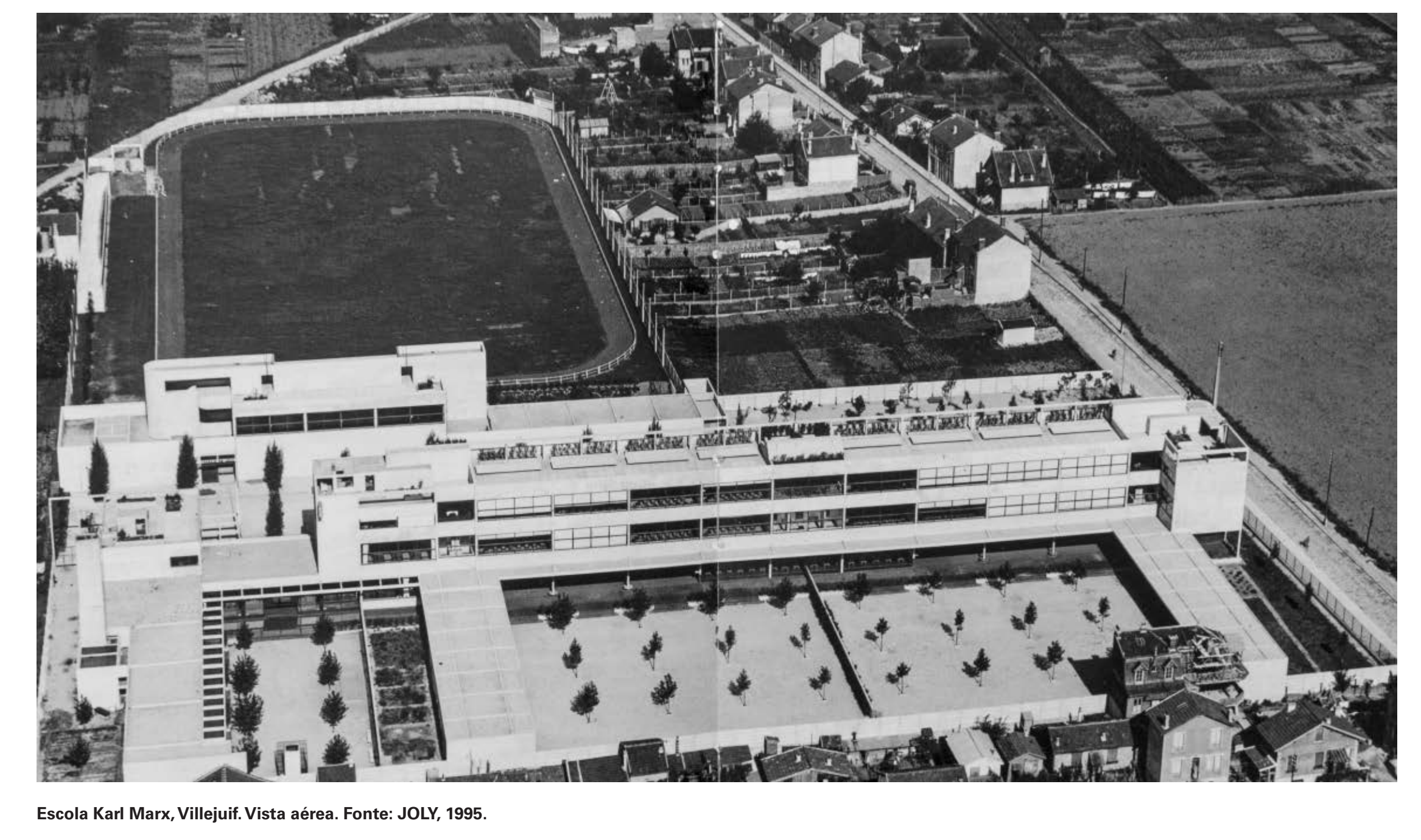

Foi com essa preocupação - de oferecer uma educação de qualidade nunca vista em bairros carentes - que, em 1930, foi organizado um concurso para o projeto de es cola em Villejuif, cidade da periferia sul de Paris, cuja administração comunista rivalizava com outras prefeituras de esquerda nas propostas de transformação social e de afirmação municipal em relação aos grandes centros metropolitanos ${ }^{126}$. Novamente Beaudouin e Lods foram chamados para participar do certame, além de Emile Aillaud, La Guilde des Techniciens, Forestier-Neumann e André Lurçat, que foi o vencedor ${ }^{127}$.

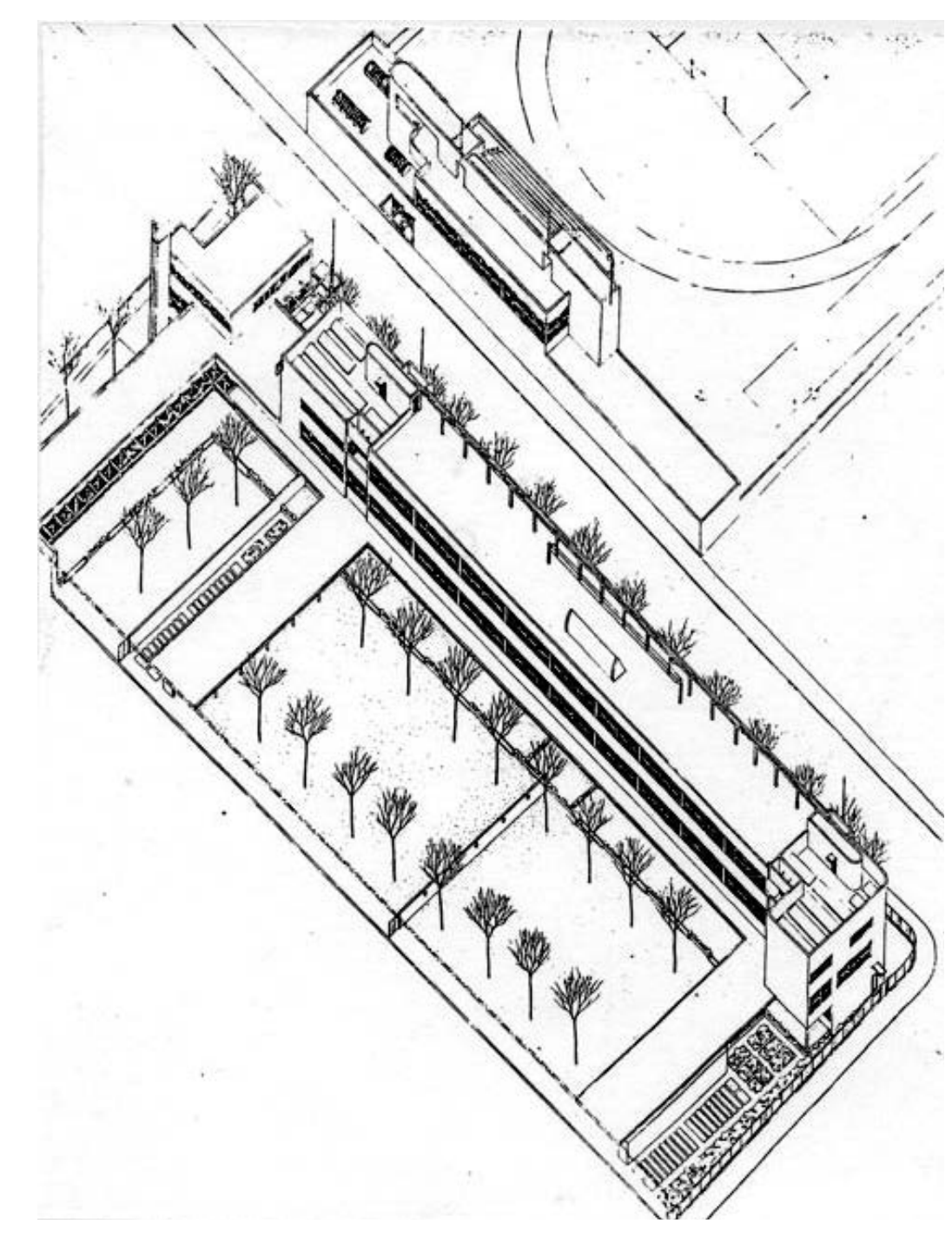

Escola Karl Marx, Villejiuti. Vista sudeste em axonometricica. Fonte: Arquivo do Ite ventaire dille-de-France,
et du Patrimoine, rança 
0 projeto de André Lurçat é portador de interess para nossa pesquisa em primeiro lugar pelo porte da obra que deveria atender 600 alunos de 4 a 14 anos, distribuídos em 20 salas de aula - e em segundo lugar pela importância de seu trabalho como arquiteto moderno, desde sua participação juntamente com o grupo de artistas e arquitetos nos Salões de Outono de 1922 e 1924 em Paris, como na Unio des Artistes Modernes - UAM ${ }^{128}$, ao lado de Robert Mallet-Stevens e de Le Corbusier ${ }^{129}$, entre outros.

O desafio que o programa da escola apresenta é muito mais próximo da construção e da gestão de um equipamento público de porte do que da propaganda polític que a obra poderia promover, sobretudo pela expressão de modernidade da arquitetura projetada. É certo que o promador, 0 que a rores a nolem

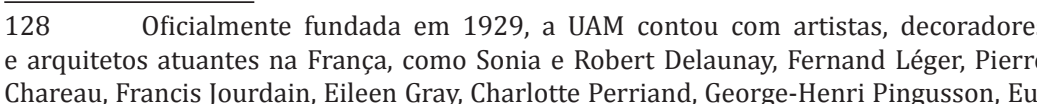
作

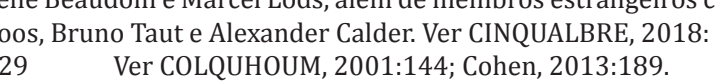

com a ideologia da prefeitura local. Assim, o equipamento publico torna-se referência, transforma o lugar, substitu a função urbana dos antigos campanários que orientaram os habitantes durante séculos. A imagem aérea de Villejuf com a obra de Lurçat, recém inaugurada em 1936, revela contraste entre o meio suburbano, até certo ponto ainda rural, e a força da arquitetura da escola, batizada não por acaso de Grupo Escolar Karl Marx. Para Pierre Joly (1995:106) havia na França uma dificuldade de aproximação entre a arquitetura moderna e os movimentos sociais, como aqueles linhados com o Front populaire ${ }^{130}$, ainda que defendessen ideias muito próximas. Surge, para Lurçat, a oportunidade de modificar essa situação, conclui Joly.

Outro aspecto significativo é que a implantação escola orienta c formação: as principais áreas edificadas do conjunto são verticalizadas em três pavimentos, e implantadas longitudinalmente nos dois lados da rua que seria aberta poste-

130 Sobre a arquitetura do Front populaire, ver também COHEN, 2017 riormente, reforçando seu caráter urbano. Se inicialmente solução possa parecer contraditória por aparentemente dm uma rua as atividades pedagógicas das atividades esportivas e recreativas, após uma observação mais atenta é possível afirmar que a proposta teve como intenção aproximar o equipamento público da vida urbana, demonstra que a comunidade contaria com o apoio não apenas das funções educacionais para as quais o conjunto fora edificado, mas também para a nova infraestrutura social que tabelecia, oferecendo oportunidades e diversidade de uso mesmo fora dos horários escolares.

A proposta de Lurçaté o núcleo inicial em que o equpamento público passa a ser o marco referencial de um novo bairro. Logo após a inauguração da obra, Lurçat apresentou conjunto de moradias composto por dez torres de doze pavimentos, a cidade vertical de Villejuif, que não foi construí$\mathrm{da}^{131}$. Entretanto, durante as oito décadas de transformações

241 O projetó a apresentado edescrito por Pierre e Robert oly. (1995: 110-111. do bairro, foram incorporados outros equipamentos, como um conjunto público com piscinas e outro com quadras de tênis, sem a participaç̃o direta do arquiteto, mas seguindo a vocação apontada em seu projeto original. 0 fato é significativo, considerando o entendimento do arquiteto para quem programa público do equipamento seria capaz de promover a ascensão da arquitetura moderna rumo às questões urbanas, como testemunha sua reflexão:

caráter particular de cada época é expresso pelo Conteńdo e pela Forma ${ }^{132}$ de um número re duzido de edifícios que nos resta. Entre todos as outras construcōoes para os mais diversos usos esses edifícios se apresentam como sendo os mais tipicamente caracterizados e os mais repre(195)

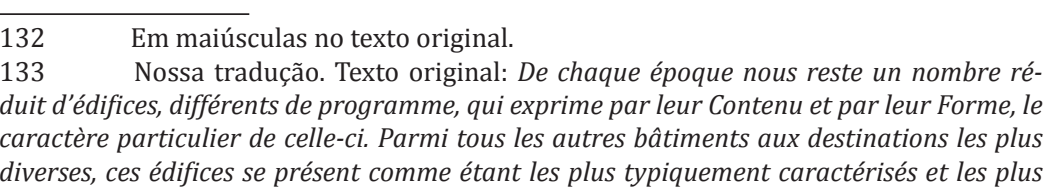

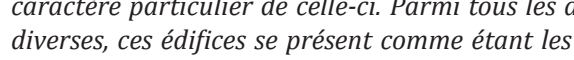


possível perceber que a iniciativa política foi responsavel pela construçăo da obra e que Lurcat respondeu com uma proposta consistente, seguindo os preceitos vinha defendendo e que tornara sua arquitetura conhecida com destaque para as características que elencamos abaixo. A edificação principal, com três pavimentos, define uma fachada urbana, ao sul da rua projetada ${ }^{134}$, uma barra com cerca de 100m disposta na direção leste-oeste. Sua porção norte, junto à rua, recebe a circulação horizontal en-

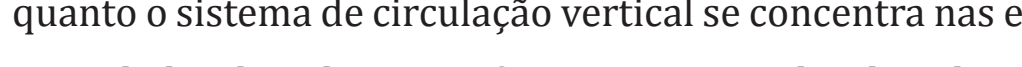
de aula são beneficiadas pela orientação sul. Na cobertura, um solári permite a aplicação das atividades higienistas, como o banho de sol, programa comum das escolas do período entre as duas Grandes Guerras, como já pudemos observar.

o grande pátio retangular que é formado no nível do térreo é dividido transversalmente por coberturas de lajes planas em pilotis delgados que vão organizar as crianças

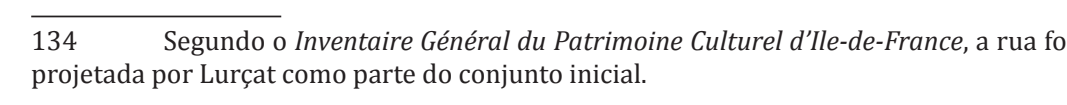

entre a escola maternal a oeste e o colégio a leste, este divi dido em ala das meninas e ala dos meninos, como mostra implantação ao lado. 0 refeitório ocupa a porção central do pilotis do térreo, atendendo às duas alas.

Um volume térreo, também transversal ao terreno recebe a escola maternal completando o conjunto a oeste, até hoje separada do colégio apenas por uma horta e uma mureta de $90 \mathrm{~cm}$ de altura, como mostra a imagem da página 310 .

Do outro lado da rua, paralelamente ao edifício educacional, são implantados um ginásio para práticas esportivas e o campo de futebol. A imagem da maquete mostra conjunto urbano em que os volumes edificados, face a face, definem a rua. A faixa livre a leste junto ao ginásio foi ocupada no início por um jardim de acesso e, posteriormente pela residência do zelador, projetada por Lurçat em 1945, completando o conjunto do equipamento público.

A observação do grande pátio criado no térreo, em parte coberto e ampliado pelo posicionamento do refeitório no corpo principal, identifica a força urbana da arquitetura de André Lurçat, mesmo que trinta anos separem as 

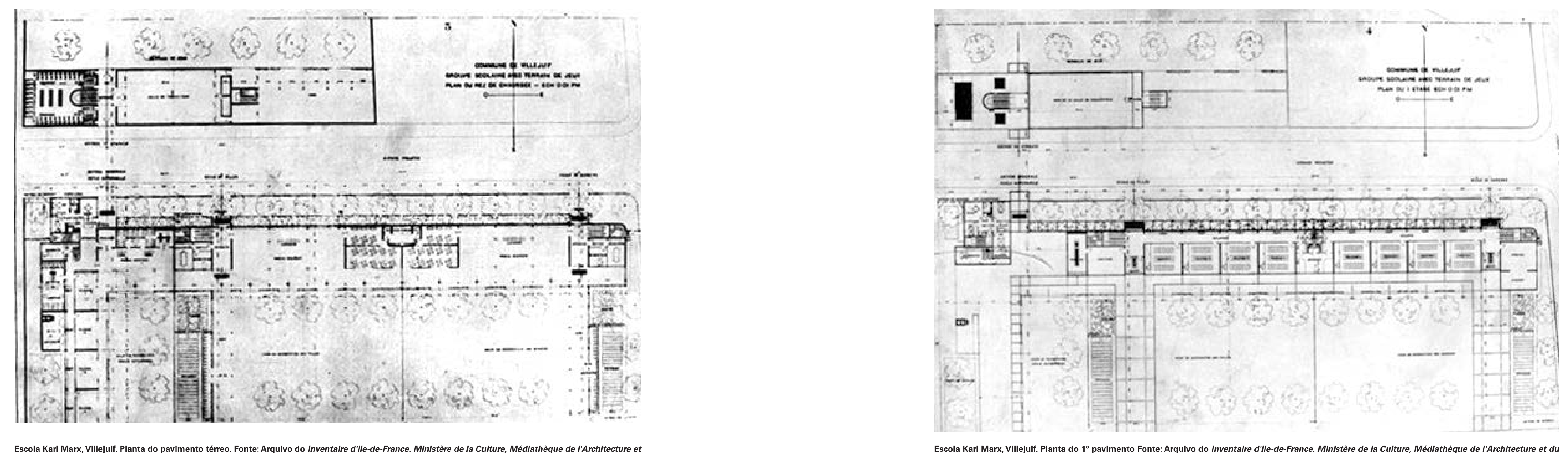


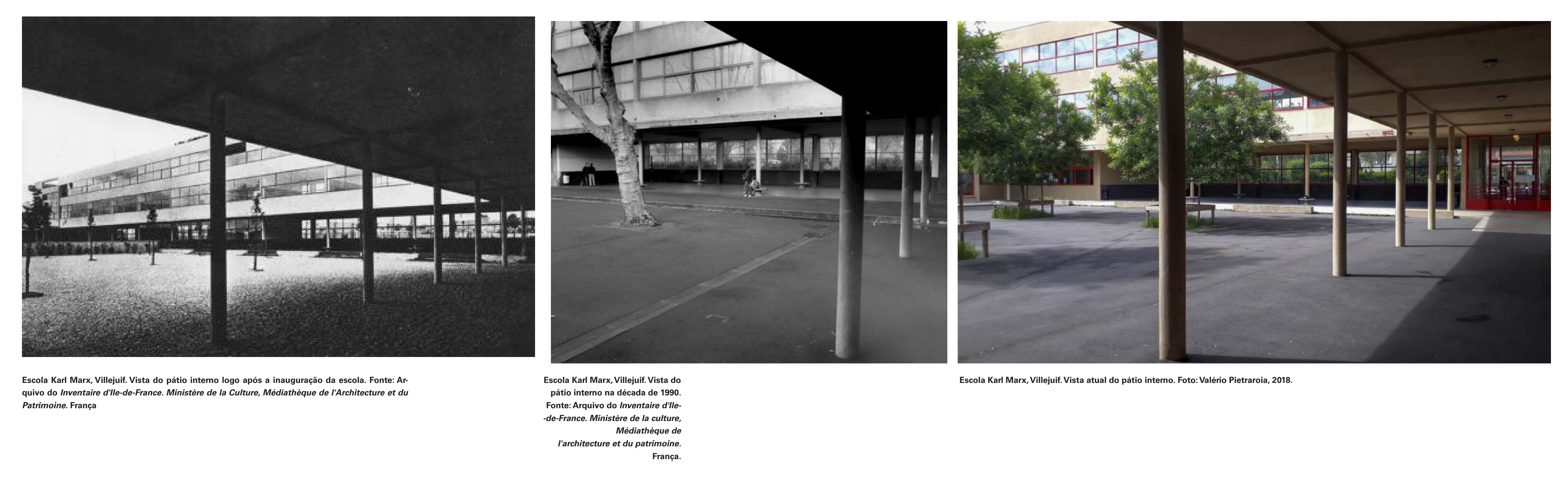



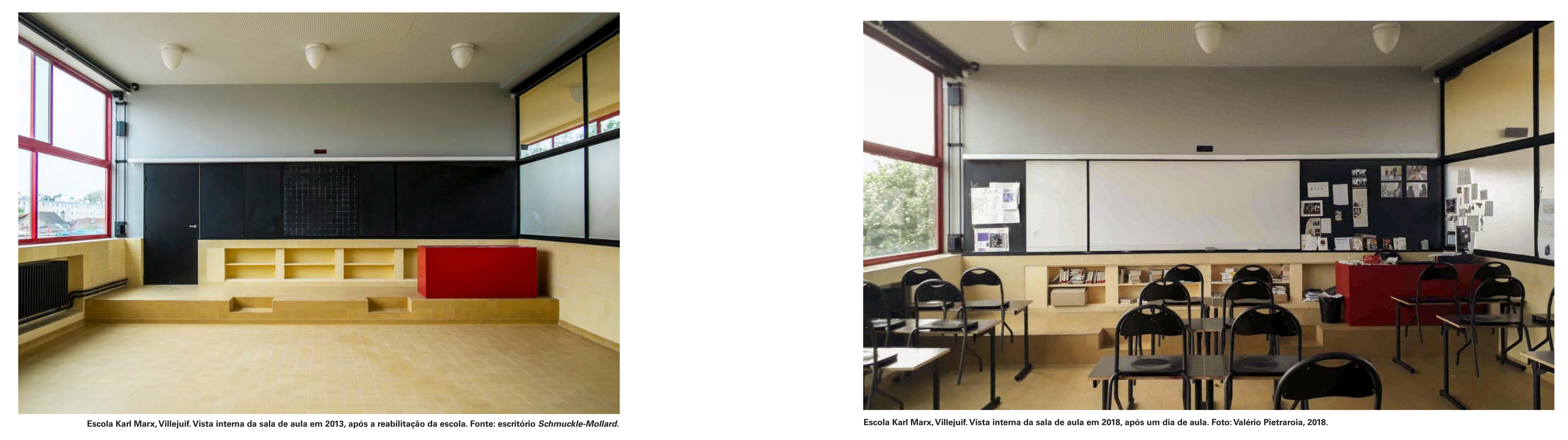
O projeto de reabilitação-restauração, implantado em 2013, garantiu a integridade do projeto de Lurçat, mesmo introduzindo algumas modificações de uso e acrescentando novos ambientes. 0 antigo ginásio no edifício esportivo fol transformado em refeitório, sem alterar os elementos construtivos primordiais e o refeitório original, localizado no centro do pilotis da escola, foi transformado em biblioteca.

Por outro lado, no limite entre os pátios das men-

nas e dos meninos, foi introduzido um volume transversa que abriga sala de migsca eofinas de tabalhos mans tendendo ao programa da escola en relaça das nom edrcis a educacionais atuais. A divisa sul do terreno recebeu santários e vestiários.

Mais uma vez é no interior da sala de aula que, no nosso entendimento, encontramos os elementos construtivos que melhor atestam a qualidade da obra. Como observado acima, a dupla orientação norte-sul é explorada pelas esquadrias envidraçadas que ocupam dois terços dos fe chamentos laterais. Assim, o generoso pé direito de 3,60m é fartamente provido de luz natural.
As linhas que estruturam os planos que compõem interior da sala obedecem a uma ordem estabelecida, que vai além da volumetria purista do exterior do conjunto. São peças e planos que convertem uns nos outros, gerando multiplicidade de superfícies que alternam luz e sombra, muito mais próxima de uma composição plasticista em que a simultaneidade de planos conforma o volume $\mathrm{e}^{137}$.

Mesmo após mais de 80 anos de existência da escola e da introdução ou modificação de usos, o conjunto man-

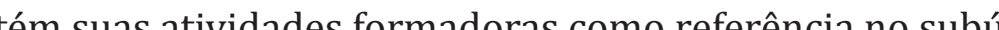
bio parisiense. Ainda que a intensa urbanização de Villejuif tenha modificado a paisagem mais próxima, o conjunto de equipamentos públicos iniciado com o projeto de Lurçat permanece exercendo sua força como polo de convergência social, tal como previsto em seu programa original.

No âmbito de nossa pesquisa, é possível afirmar que a Escola Karl Marx tornou-se referência, um "modelo" para a conformação do equipamento público escolar, como admitido pelo arquiteto Carlos Ferreira (1950: 53-61).

$\overline{137 \quad \text { Ver MONDRIAN, 2008: } 168 .}$ 


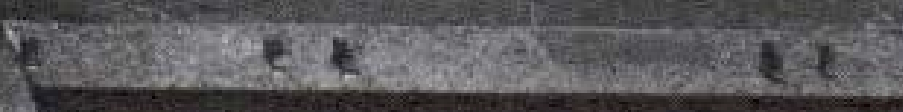

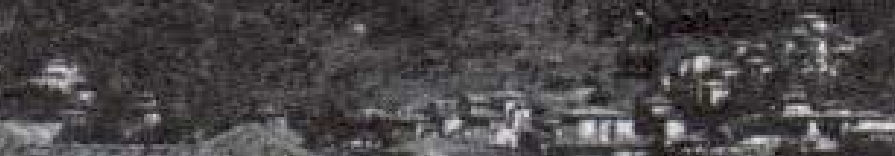
(1)

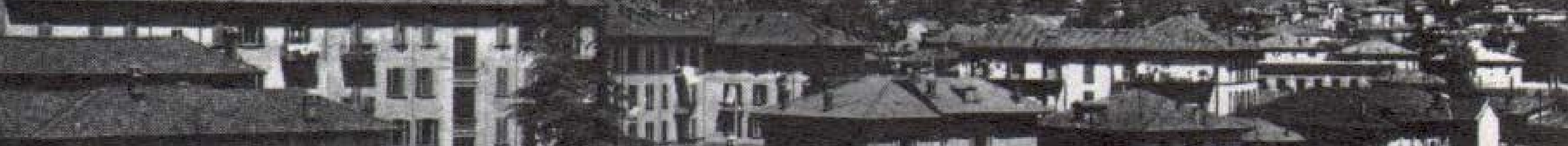

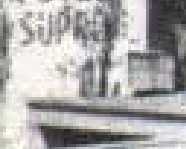

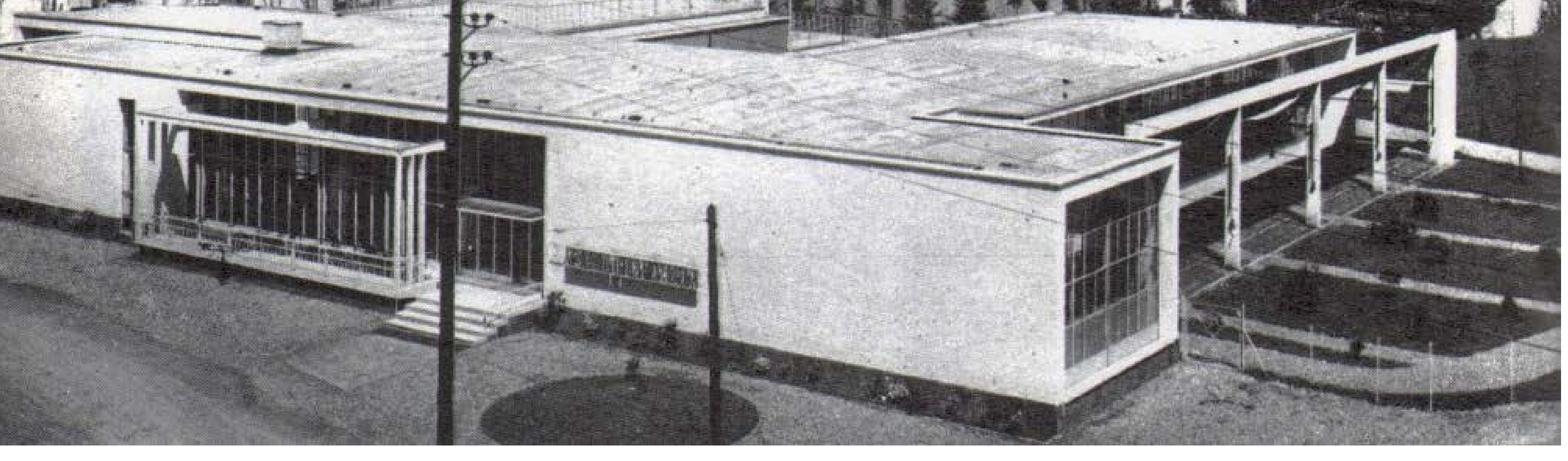

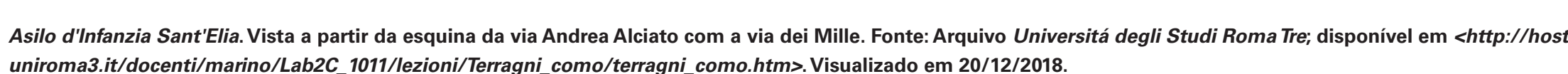

Casa del fascio (1932), Terragni, apesar de para evitar qualquer concessão à retórica exiga pelo próprio tema: um arquiteto que projeta sede de um partido é um arquiteto, e não um a co no texto original)

A postura ética e profissional de Giuseppe Terragni enfatizada acina de sua obra.

No período entre as duas grandes guerras a arquitetura moderna torna-se um veículo potente para a afirmação das administrações de esquerda, em especial na França da década de 1930, como demonstram as obras que pudemos examinar. A identificaç̃o às novas formas arquitetônicas

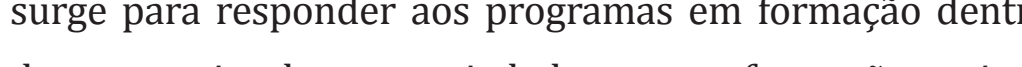
da perspectiva de uma socidade en transformaç̃o apoiad nas políticas municipais de esquerda. Todavia, como observa ean-Louis Cohen (1989), não podemos nos enganar e conGiuseppe Terragni, 1934 
a administração municipal de esquerda não foi condição suficiente para a atuação dos arquitetos modernos, pois nem sempre a expressão moderna foi o cenário idealizado pelas ideologias progressistas. Inúmeras foram as obras de caráter classicizante ou regionalista conservador empreendidas por políticas municipais de esquerda. Do mesmo modo, lembra Cohen, o momento fundamental para a consolidação profissional, garantida pela criação do Ordem dos Arquitetos Franceses, ocorreu durante a ocupação alemã e o governo colaboracionista de Vichy, entre 1940 e 1944

Um exemplo que demonstra a fragilidade dessa regra é a obra do arquiteto Giuseppe Terragni em Como, na Itália. Seu trabalho alcançou grande repercussãa ${ }^{138}$, mesmo tendo sua atuação profissional suportada, ainda que em parte, pela política fascista italiana da década de 1930, como é caso da Casa do Fascio de Lissone ou da Casa do Fascio de Como ${ }^{139}$, sua obra mais conhecida, ou mesmo as Casas do

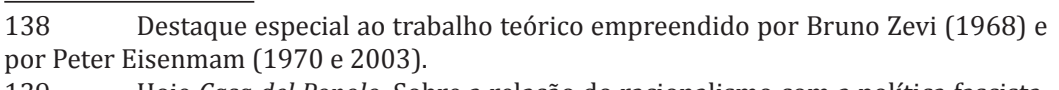

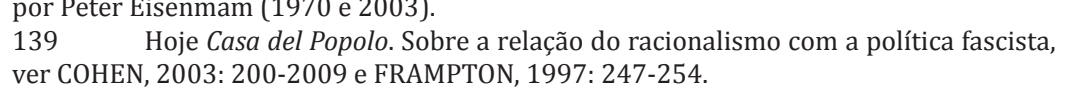

Fascio não construídas dos bairros Portuense-Monteverde Trasteverino, ambos em Roma. Outros exemplos comprovam a participação da arquitetura moderna trumento de propaganda do partido de Benito Mussolini, É um momento que merece atenção especial por r $r$ presentar o papel de uma jovem geração de arquitetos no nascimento de uma linguagem italiana completamente autônoma, como observa Ricardo Renzi (2017) Segundo esse utor podemos entender a renovaç̃ão da arquitetura italian empreendida nesse período, que desde o Renascimento não ocorria com tanta força, pela capacidade de filtragem da influência funcionalista europeia e, em particular, à superação através da linguagem trazida pela vanguarda futurista associada ao diálogo entre a arte e as reflexões urbanas, o que

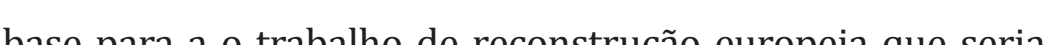
realiza Desde os primeiros projetos de Giuseppe Terra há uma busca em avançar nas reflexões de ordem funcionalista e, sobretudo, construtivas que vinham ocorrendo Europa, como aponta Enrico Mantero: e - escreve Enrico Mantero - os escritos do "Grupo $7^{1140}$ podem representar o testemunho de um esorço sobre o nível de avanço do conhecimento $d$ altura arquitetônica europeia, de uma tentativa ural o exemplo prático é represento pu projeto para o gasômetro, que fundamenta sua matriz stilística diretamente no corac̃̃o da exp europeia e portanto também na construtivista. Pode-se verificar a referência ao projeto para Peter's School em Basel de Hannes Meyer (1926) sempre de Hannes Meyer com Hans Wittwer ao rojeto para o concurso do Paĺcio das Nac̃es em Genebra. ${ }^{141}$ (in ZEVI, 1968:14)

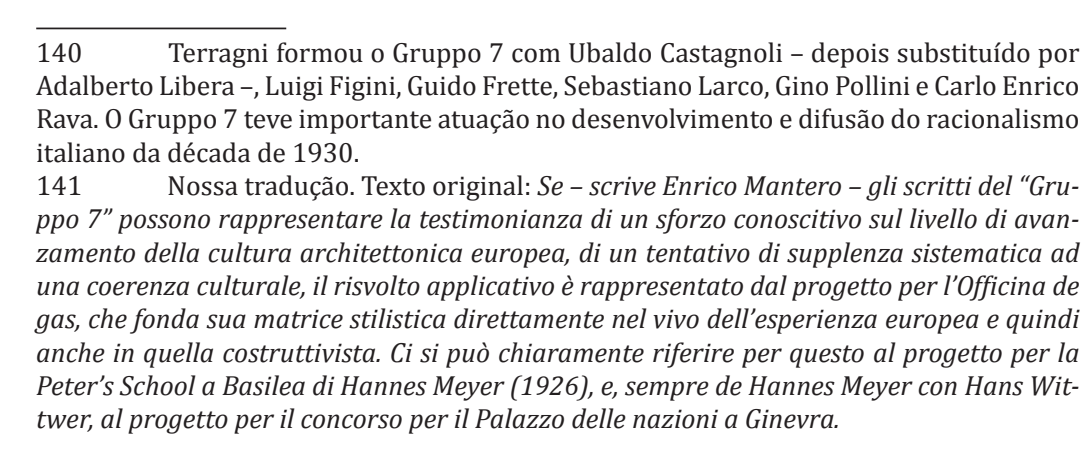



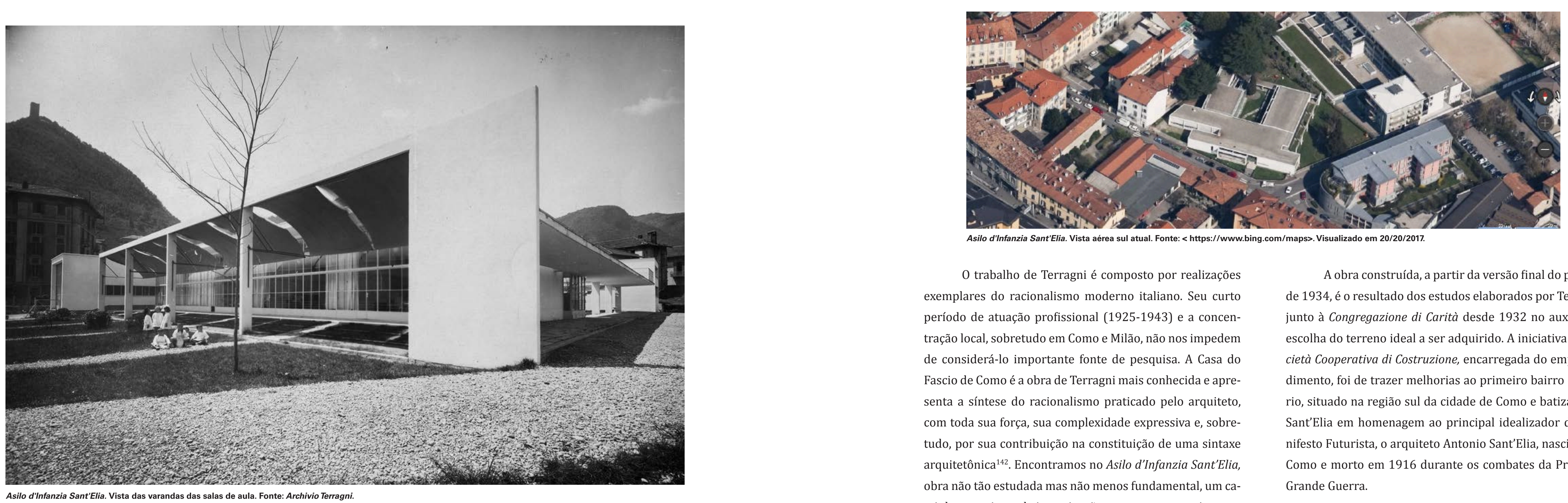

0 trabalho de Terragni é composto por realizaçõe exemplares do racionalismo moderno italiano. Seu curto período de atuação profissional (1925-1943) e a concentração local, sobretudo em Como e Milão, não nos impedem de consideŕ-lo importante fonte de pesquis Fascio de Como é a obra de Terragni mais conhecida e apresenta a síntese do racionalismo praticado pelo arquiteto com toda sua força, sua complexidade expressiva e, sobretudo, por sua contribuição na constituição de uma sintaxe arquitetônica ${ }^{142}$. Encontramos no Asilo d'Infanzia Sant'rlia a

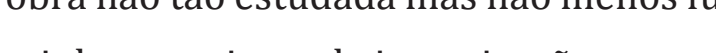
minho promissor de investigação para nossa pesquisa.

A obra construída, a partir da versão final do projeto de 1934, é o resultado dos estudos elaborados por Terragn junto à Congregazione di Carità desde 1932 no auxílio da cooperativa di Costruzione, encarregada do empreendimento, foi de trazer melhorias ao primeiro bairro operário, situado na região sul da cidade de Como e batizado de Sant'Elia em homenagem ao principal idealizador do Manifesto Futurista, o arquiteto Antonio Sant'Elia, nascido en Como e morto em 1916 durante os combates da Primeira

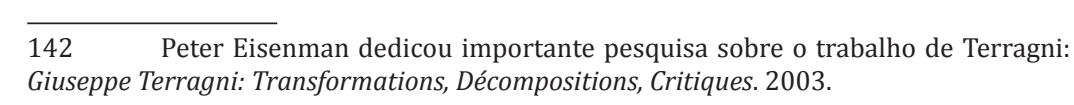


O Asilo d'Infanzia Sant'Elia ${ }^{143}$ foi um dos nove equpamentos públicos propostos para a área de expansão bana ao sul da cid é possivel testemunhar em San Rocco a intensa atividade promovida pela Societá Cooperativa Edificatrice e pelo IACP (Instituto Autonomo Case Populari), através de obras racionalistas exemplares, de autoria de arquitetos como Alberto Sartoris, Pietro Lingeri, Gianni Mantero, além do próprio Terragni. É importante assinalar que o limite norte da cidade é o Lago de Como e que, a leste e a oeste, a proximidade das montanhas dificultam o crescimento urbano. A direção sul foi, historicamente, a ligação natural com os grandes centros urbanos, como Milão, por onde passaram os caminhos e a estrada de ferro. Assim como em Villejuf, a nočo que vai identict inserida dentro de uma rede de equipamentos públicos, que potencializa ainda mais sua participação na construção da indentidade do bairro.

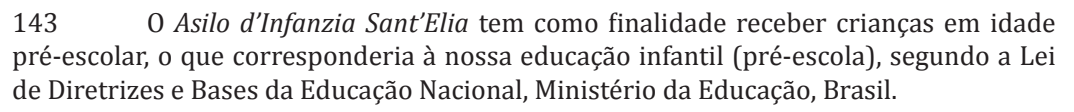

Conteúdo e Forma

ruptura do bloco implica uma interpretação turista; mas evita-se cuidadosamente a evidência física do impulso dinâmico. Não é uma forma colocada em movimento que se integra à forma erro do Futurismo residia em seu vanguardismo: a pesquisa moderna deve se inserir na situação historica, e não projetar-se no futur

RGAN, 1992

Para Argan, é no projeto do Asilo que Terragni "pe de a inibição". 0 volume horizontal, construído em estrutura de concreto armado moldado no local com um pavi$43 \mathrm{~m}$ de lado por $5 \mathrm{~m}$ de altura, uma matriz utilizada por Terragni para gerar e articular os espaços funcionais. Essa matriz é girada em relação ao lado maior do terreno trapezoidal irregular, cuja esquina aponta para o sul. os vértices do quadrado tangenciam os limites do terreno a oeste e ao dinâmica, e, portanto, um recurso à temática futorna-se estrutura. Terragni compreendeu que mento, foi organizado a partir de um prisma quadrado de sul. Assim, os espaços externos resultam em triângulos proporcionais às funções que desempenham. Ao sul, o acesso nhamento, configurando um pequeno jardim triangular, que altera a lógica de ocupação da quadra, marcada pela continuidade das fachadas junto ao alinhamento. A sudeste, a maior porção triangular externa é reservada para as sa- las de aula, sendo cada um dos espaços externos marcados e organizados pelo paisagismo. Ao norte, em continuidade com o pátio interno, a porção triangular foi reservada para uma horta e, a sudoeste, a área externa se destina ao apoio de serviço da escola. A relação de independência do volume é intensificada por sua elevação em 0,5m em relação ao terreno natural e às ruas que formam a esquina.

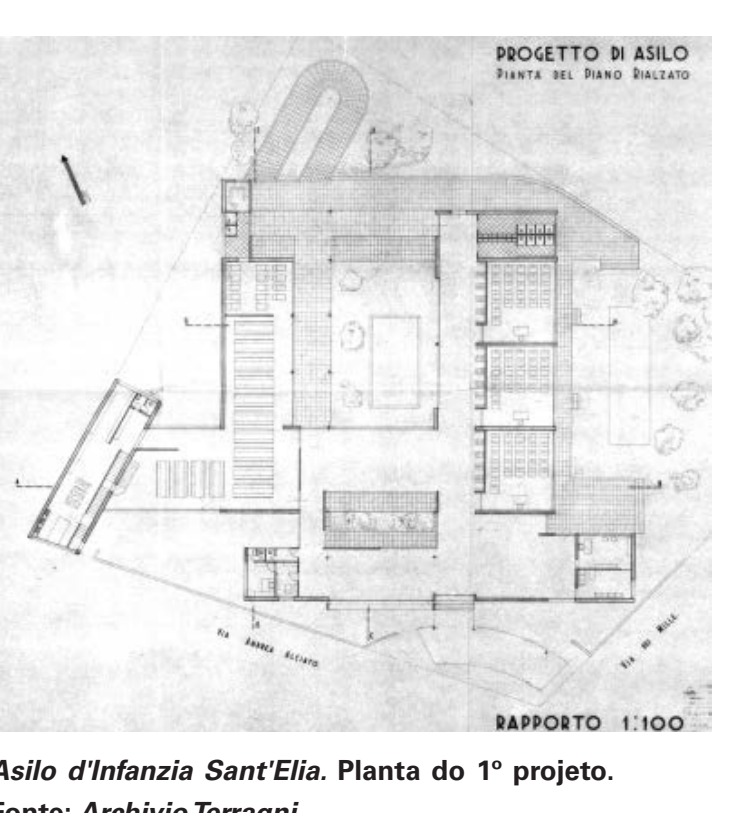

Asilo d'trantania Sant Elll
Fonte: Archivio Teragni

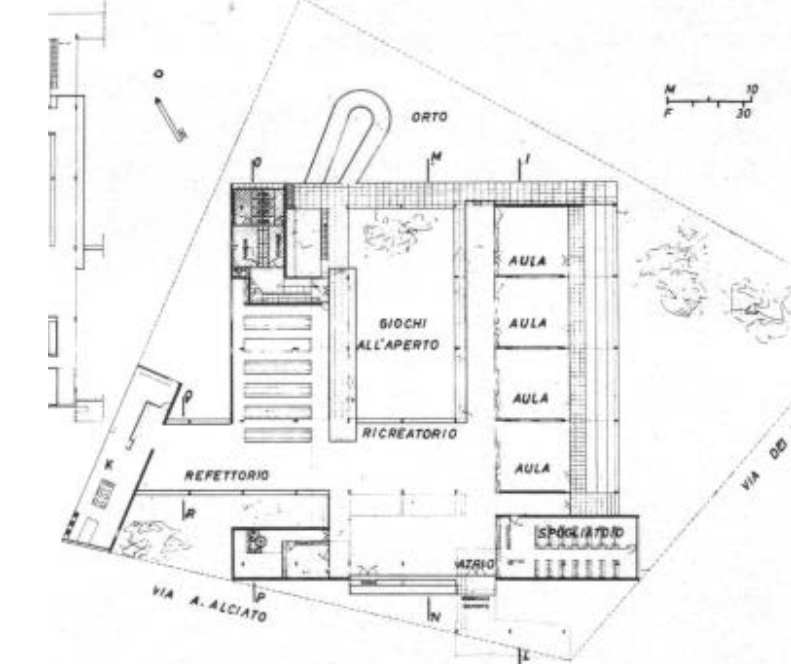

Asilo d'thranzia Sant' Elia. Planta do $2^{\circ}$ projeto com a zel-
doria no pavimento superior. Fonte Archivio Teragani.

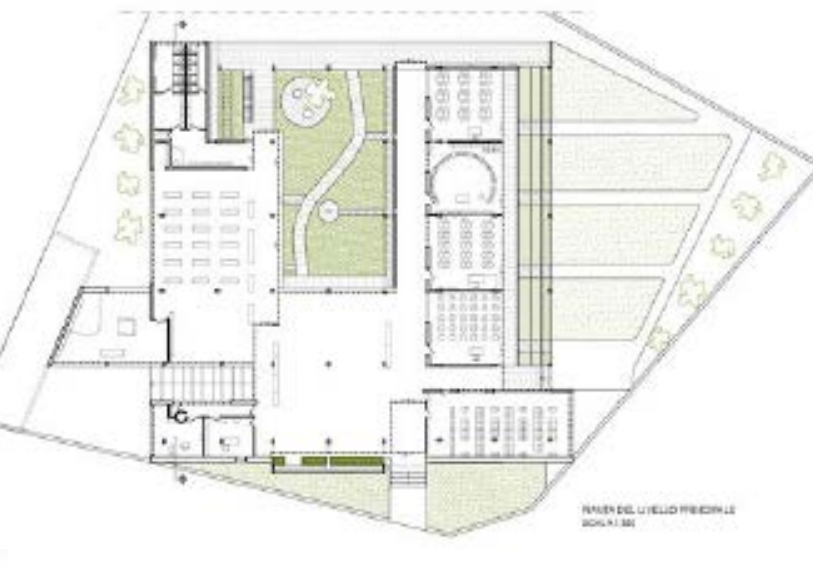

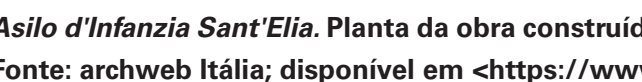
archweb.it/dwg/arch_arredi famosi/giuseppe tor agni/Asilo_Sant-_Elia/arasilo__ant-Elia_dwg.h.th 
Ao se ingressar na edificação, a partir de um foyer de recreação, é possível apreender todo o projeto e a espacialidade dominante. As áreas funcionais, organizadas em alas que não conformam blocos autônomos, partem do espaço recreativo coberto, chamado por Terragni de atrio, que se prolonga para o pátio central descoberto. É útil notar que mesmo interceptado pelo pátio interno descoberto, é na continuidade do chão e do teto que se desenvolvem todas as atividades de aprendizagem do Asilo: a sudeste, o vestírio e as salas de aula, a sudoeste, orfeitrioeos but o norte e ao sul, a recreação coberta e a administração. A rigidez da matriz quadrada é flexibilizada pela movimentação das alas funcionais. Vestiário, administracão e cozinha se destacam e formam um contraponto que prolonga a fachada junto à rua e cria uma sobreposiç̃o de planos. Esse movimento é seguido pelo avanço da estrutura interna do foyer recreativo envidraçado, formando um beiral pergolado que protege o acesso, substituindo a marquse prevista nas primeiras versões do projeto e contribuindo para escavar a longa fachada urbana.
Alem da marquise de acesso, a simplificação e a supressão de outros elementos construtivos presentes nas primeiras versões do projeto devem-se ao o posto pela Congregazione di Carità. Por isso, o volume adcional que receberia a cozinha do refeitório foi eliminado incorporado à matriz quadrada. Da mesma forma, a rampa externa curva de acesso ao teto terraço foi substituída por uma rampa-escada na face norte do volume. Esses ajustes promoveram maior clareza na identificação funcional das alas pois

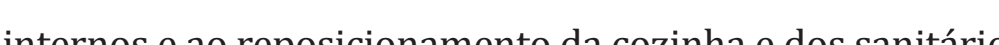
Os pilares de $20 \times 40 \mathrm{~cm}$ pontuam o espaço de 600 $\mathrm{m}^{2}$, constituindo uma malha regular da estrutura que assume orientação distinta para melhor definir os vãos de 5,71 x 7,54m e corresponder ao sentido mais favorável de luz 7. reção dos fluxos internos, a orientação dos pilares é revista seguindo a lógica funcional do espaço criado, pontuando barras retangulares esbeltas no teto plano contínuo, de altura livre de $4,50 \mathrm{~m}$.

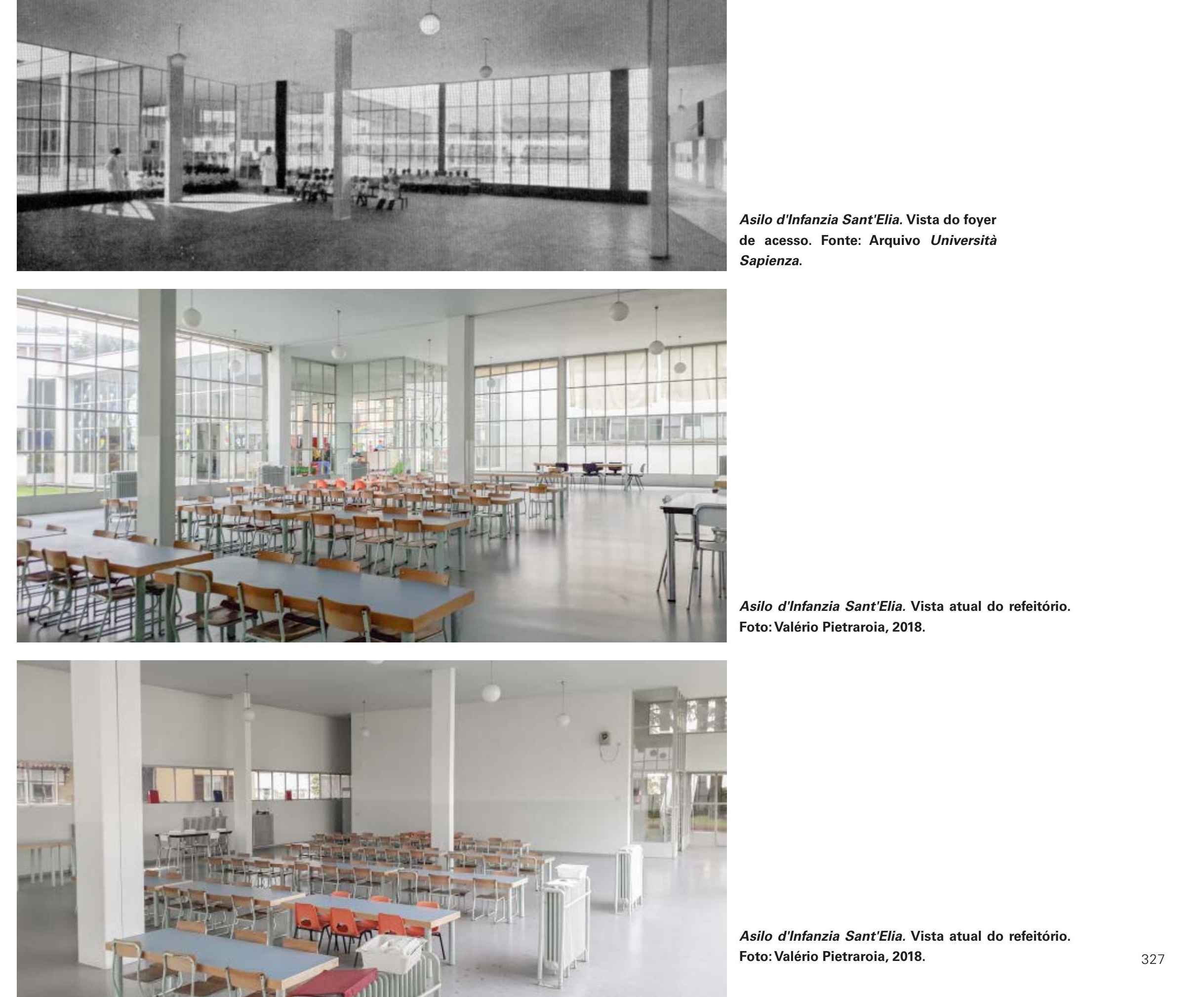


das alas funcionais que criam situações distintas dos pilares e vigas. Na ala das salas de aula, o lado da circulação voltada para o pátio interno é atravessado pela linha estrutural, que se encontra valorizada por planos de vidro verticais mas modulada e as atividades internas podem se beneficiar nos períodos vespertinos durante os dias de inverno. Do ado oposto, a sudeste, as fachadas totalmente envidraçadas podem ser sombreadas de maneira individual por toldos articulados instalados na linha estrutural externa criada pelo proteç̃ão, de fora para dentro, proporciona caracterizações distintas dessas salas de aula externas, ora com altura ampliada e maior insolação, ora com altura mais baixa, o que conforma uma situação de sombra, de proteção e de intimidade. 0 arremate dessas linhas estruturais encontra o proconstiuindo ao mesmo tenp conste entre as alas e uma plataforma elevada a meio nível.

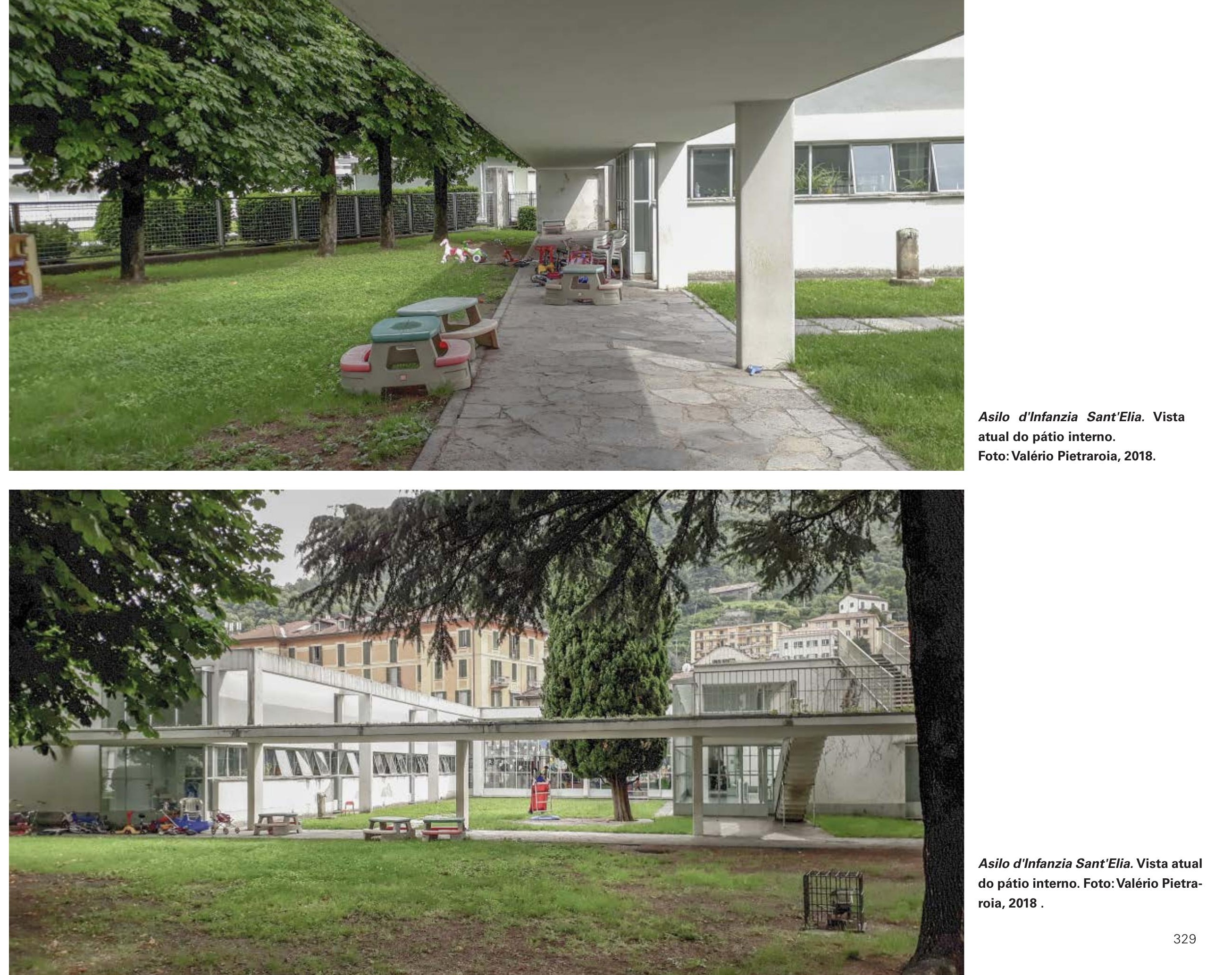


A generosidade na concepç̃o da sala de aula não se limita à amplitude da altura livre nem à face envidraçada voltada para o jardim lateral. Para nós, essas características já são suficientes para destacar a célula primordial do espaço de aprendizagem como dotada de qualidade superio por ampliar o volume interno e estendê-lo até o jardim. Termentos construtivos, como dispositivos funcionais móveis que promovem a transparência e a transformação espacial. The possuem mecanismos de articulação e de movimentação que permitem desde a integração visual dos ambientes funcionais até sua integracão física. Em certo sentido, podemos perceber a intenção de Terragni de desfazer os limites formais que separam tradicionalmente os espaços funcionais e, especialmente nesse caso, as salas de aula
Para nossa pesquisa, essa observação contribui no entendimento do projeto e de sua independência em relação ao contexto e ao programa. A permanência da obra com seu programa original da década de 1930 não significa que a arquitetura "engessou" nem as iniciativas pedagógicas nem as novas funções públicas que a edificação poderia asro décadas de existência 0 u seja o projeto de cortexto uba e socil aue acidr durante o período de existência da obra A visita à escola comprova o intenso uso dos espaços projetados e a inclusão de atividades ainda não imaginadas no momento da concepção da obra É possível também verificar o processo transformaç̃o urbana do bairro e a permanência das relações da obra com seu entorno imediato. 


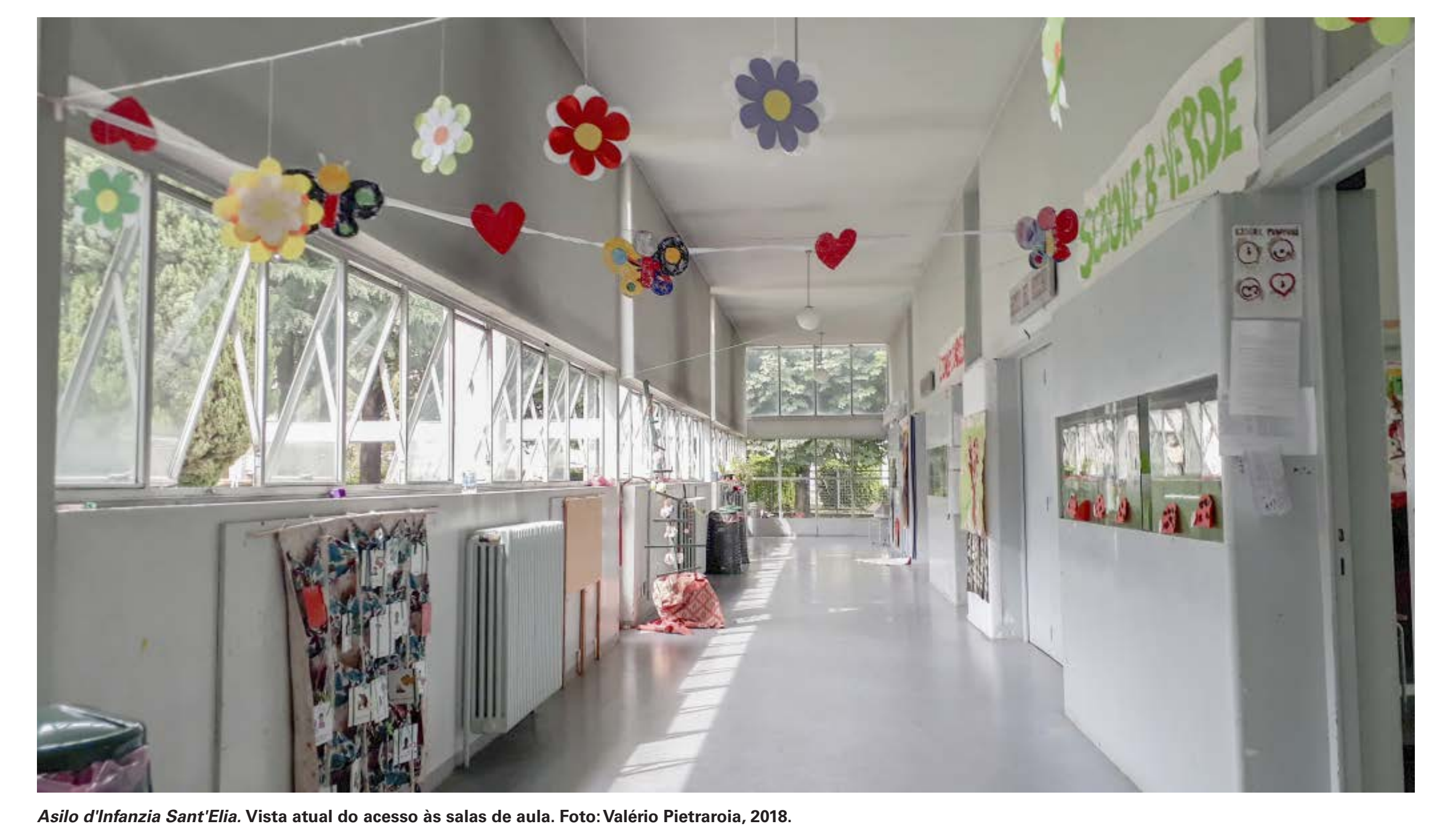

Ao consultarmos o recente trabalho de restauro do

Asilo, realizado por Elizabetta Terragni, verifica-se que ele

se limitou à recuperação de parte da estrutura e do mobi-

liário ${ }^{144}$, ou seja, houve apenas um trabalho de conservação

e de manutenção mais apurado perfeitamente normal em

uma obra com essa idade $\mathrm{e}^{45}$.

Como notado por Kenneth Frampton (1997: 250), a

obra de Terragni, ao se preocupar com os elementos cons-

trutivos, constituindo uma ordem tectônica e meticulosa,

foi capaz de transcender os aspectos ideológicos do período

fascista, o que explica sua resistência no tempo e consolida

o racionalismo mais intelectualizado de Terragni, acrescenta Frampton

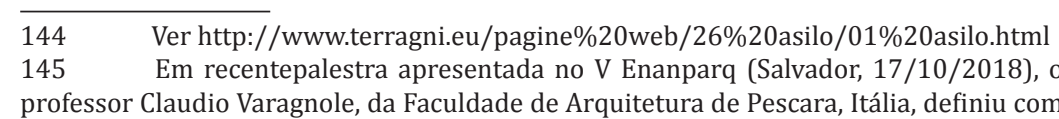

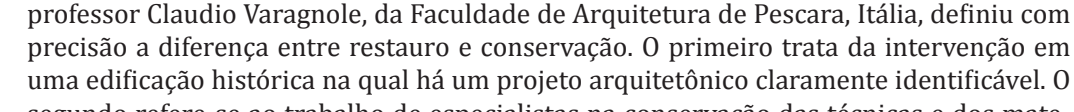

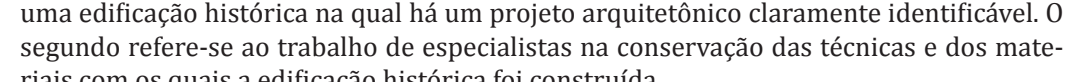


Para Neutra e outros arquitetos do seu tempo, a arquitetura era concebida como um poderos instrumento para a educacạão social, e nada era mais importante do que o primeiro ambiente institucional vivido por uma crianca: a escola ${ }^{146}$

O conhecido livro editado por Alfred Roth em 1940 A Nova Arquitetura apresentada em 20 exemplos, é uma das obras fundamentais para a compreensão da arquitetura produzida no período entre as duas grandes guerras. Se The International Style de Henry-Russell Hitchcock e Philip Johnson ${ }^{147}$ é uma das publicações de referência da Arquitetura Moderna da década de 1920, a obra de Roth, publicada na Suíça, vai concentrar seu interesse na década seguinte

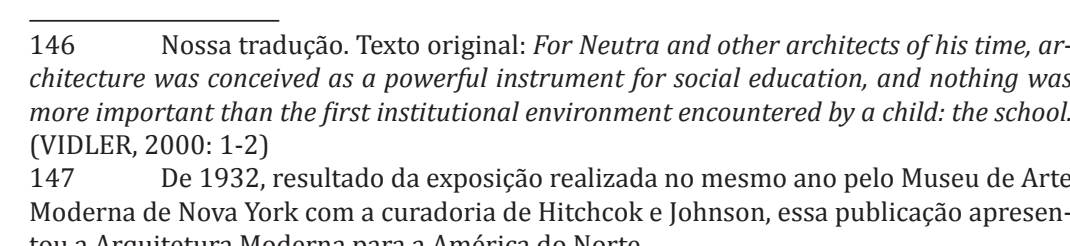
segundo Alfred Roth. 
vitar como referência fundamental uma abordagem doutrinária da criação da obra construída, como analisa Kenneth Frampton ${ }^{148}$. A Nova Arquitetura atingiu seus objetivos quando evitou que tanto as soluções espetaculares espaciais quanto as técnicas se tornassem fins em si mesmas. Como manifestado por Roth,

[p]retender se ater apenas a princípios forma ou a simples esquemas construtivos seria queer desprezar as próprias premissas da vida, cuja transposição bem compreendida deve, ao contr io, resultar em um enriquecimento, igualmen vivo, das criações arquitetônicas. Com a integ cão orgânica da construção com seu entorno inediato e com o conjunto da paisagem, as condiçỗe locais constituem, em certo sentido, o que podemos chamar de escala natural ${ }^{14}$.

Rотн, 1946: 2-3

A antologia apresentada no livro reúne vinte obra que, segundo o autor, constituem a expressão clara e direta

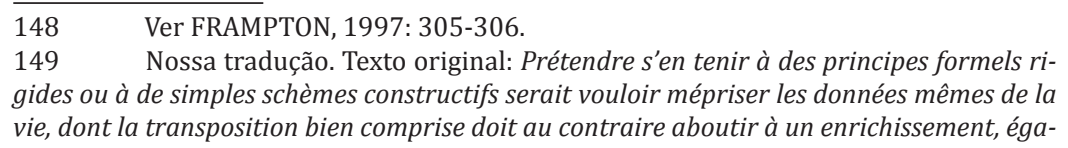

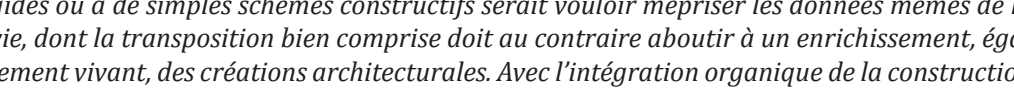

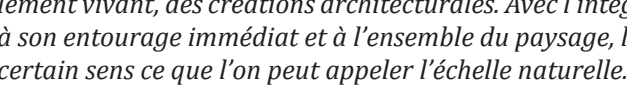

da consciência da época, que não para de se expandir pois as criações da Nova Arquitetura confirmaram que, se a razão comanda o vés dos valores intrínsecos e não por meio de sua exteriordade formal.

Chama a atenção o protagonismo que Roth dispen as obras em si, ou seja, desde o sumário organizado pelas magens dos 20 exemplos até a qualidade e profundida textuais ${ }^{150}$. Ao evitar o desenho esquemático e o discur retórico que caracterizam esse tipo de publicação, Roth estabelece um verdadeiro tratado que organiza e compartilh o conhecimento de uma época sem a pretensão de transformá-lo em manifesto.

A importância dispensada na publicação de Roth para escola como tema é outro aspecto relevante que pretende reforçar a crença do autor de que a Nova Arquitetura

150
Bill
É importante mencionar também que o projetto gráfico é de autoria de Max tem nesse equipamento publico um elemento fundamenta no processo de urbanizacão e de socialização. Para Christoph Allenspach (2001: 99), Roth sempre lutou para que a escola fosse uma pequena cidade em que a sala de aula como ponto de partida, facilitasse a promoção de novos processos pedagógicos e que os espaços de convivência se transformassem em fóruns, visto que na Suíça as escolas já eram usadas para atividades da comunidade local.

Dentre as 20 obras publicadas no livro encontramo duas que merecem atenção em nossa pesquisa: a Experi mental School, construída por Richard Neutra no distrito de Bell, Los Angeles, em 1935, e a Ecole en plein air de Eugène Beaudouin e Marcel Lods, já estudada aqui. Além delas. Roth ilustra seu texto introdutório - A Realidade da Nova Arquitetura - com outras 23 obras mais conhecidas naquele momento, como a Ville Savoye de Le Corbusier e a Fallingwater de Franck Lloyd Wrigth ou ainda a Bauhaus em Dessau de Walter Gropius. Ele sinaliza, assim, que a publicação não pretende se opor ou romper com a expressão da modernidade estabelecida, mas sim demonstrar uma outra via baseada em fundamentos de ordem construtiva, an- parados pelos aspectos de natureza ambiental e social. No nosso entendimento, essa posição explica a profundidade das 20 ob as te analisadas.

Para nossa pesquisa, as ilustraç̄eses do texto introdutorio também são úteis pois comprovam a pertinência do conjunto de obras que selecionamos para a compreensão do período entre as duas grandes guerras e da noção do projeto como expressão da modernidade no enfrentamento da realidade urbana e social, tal como nos propusemo no início deste capítulo. A observação é válida pois, alén das duas escolas que mencionamos, Roth inclui, dentre as 23 obras ilustradas no texto introdutório, a Escola ao ar livre em Amsterdam de Joannes Duiker e Bernard Bijvoet e a Casa del Fascio em Como, de Giuseppe Terragni, cuja arquitetura, como vimos, guarda estreita relação com o Asilo d'Infanzia Sant'Elia, do mesmo arquiteto.

s a tarefa a que nos propusemos, resta-nos entender quais são as contribuições da obra de Richard Neutra para nosso tema. 
Da Ring Plan School da Rush City Reformed Experimental School em Bell, L.A.

Nestes anos difíceis sem contratos, Neutra continua a projetar os elementos de sua metrípole ideal - Rush City Reformed, um nome inventdo para evocar o rápido ritmo de vida american e os lendários boomtown ${ }^{151}$ A geometria partana das lajes de seus arranha-céus regulamente espacados evoca as utopias un regul Futuristas Italianos, de Le Corbusier e de Ludwig Hilbersheimer embora as áreas contrastantes do espraiamento orgânico cos areas contrastantes espraiamento orgánito con habitaçōes de baii pouco ocupadas de Los Angeles.
pousidade DREXLER, $1984^{452}$

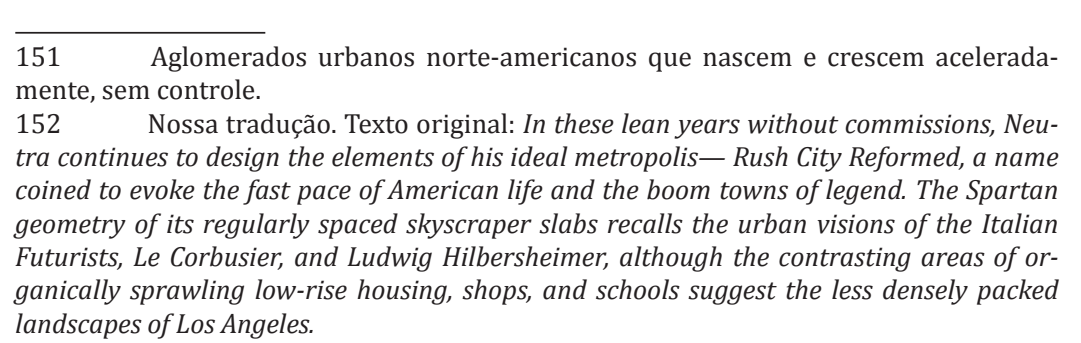

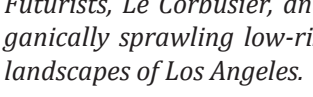

No trecho acima, Arthur Drexler descreve as dificuldades profissionais de Richard Neutra em 1926, dois anos após ter se estabelecido nos Estados Unidos ${ }^{153}$, situação que permitiu suas pesquisas conceituais. De seu projeto utópico - Rush City Reformed - destaca-se a proposta para a Ring Plan School, escola modelo a ser repetida na sua cidade ideal. Para Anthony Vidler (2000:2), o projeto de Neutra é o exemplo mais marcante de sua crença na extraordinária importância que a escola exerce nos processos de formação social. 0 modelo foi adotado em 1934 pelo Los Angeles School Board ${ }^{154} \mathrm{e}$ aplicado no distrito de Bell, a escola foi construída em 1935 por Neutra e foi publicada por Alfred Roth com o título de Experimental School.

$$
\text { A proposta para a Ring Plan School, mesmo antes de }
$$
er aplicada em Bell, já havia chamado a atenç̃o de Henry-Russell Hitchcock e Philip Johnson que, como curadores do departamento de arquitetura do Museu de Arte Moderna de Nova York, selecionaram Richard Neutra como um dos nove arquitetos a serem apresentados na exposição Modern Ar

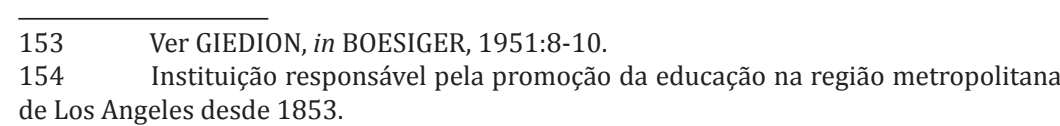

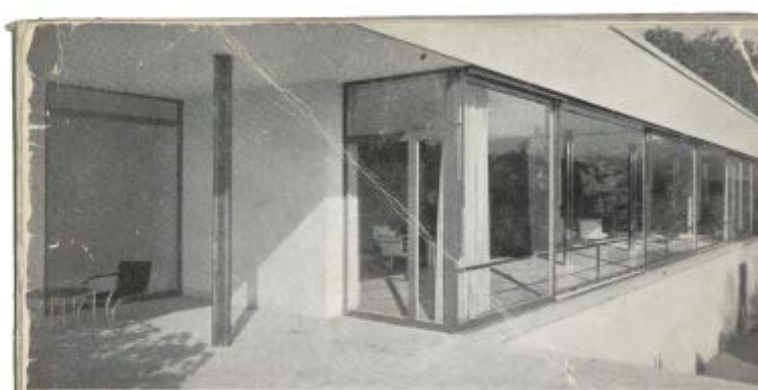

MODERN ARCHITECTURE

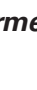

chitecture: International Exhibition em 1932 ${ }^{155}$. No catálogo da exposição, os projetos de Neutra destacados são a Lovell Health House, em Los Angeles, e a Ring Plan School, dentro da proposta para a Rush City Reformed pois, segundo Hitchcock

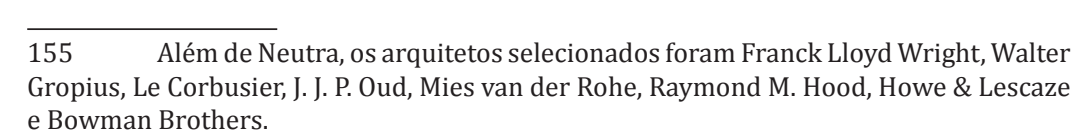

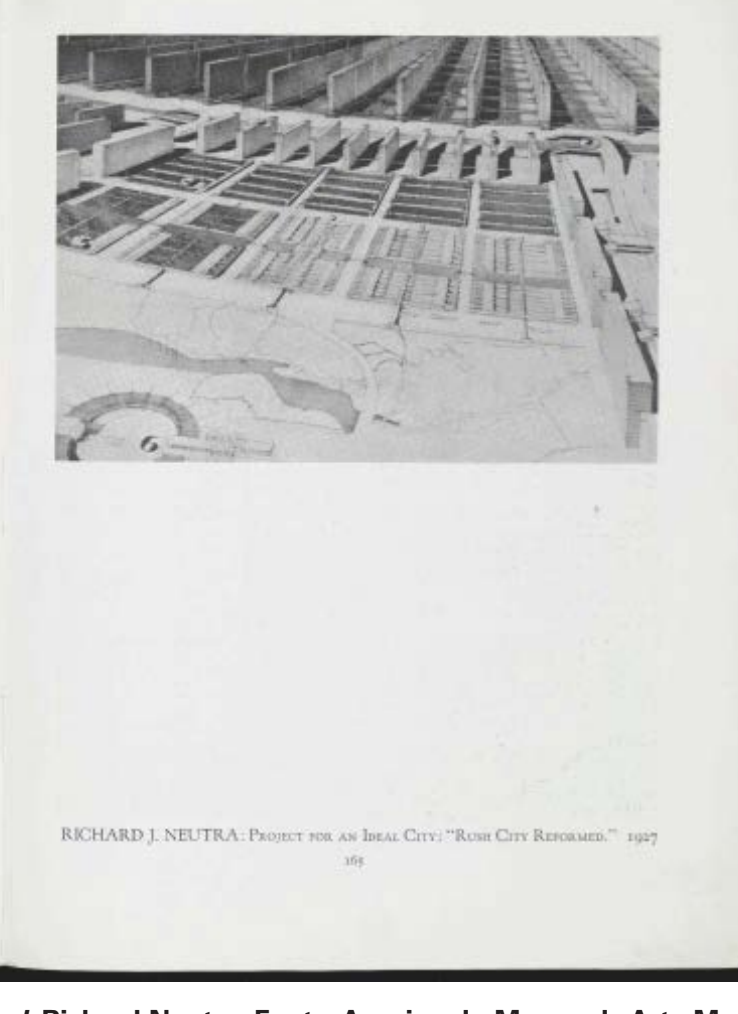

[a] organização do ponto de vista do projeto expressa claramente e coerentemente a construcão utilizada e o propósito de suas partes. Uma importante forma de avanço na arquitetura é elaboração de projetos utópicos ainda que a $\mathrm{Ci}$ dade do Futuro deva na realidade ser tanto uma modificacão das cidades do presente quanto uma concepção totalmente nova e livre $156(1932: 160)$ 


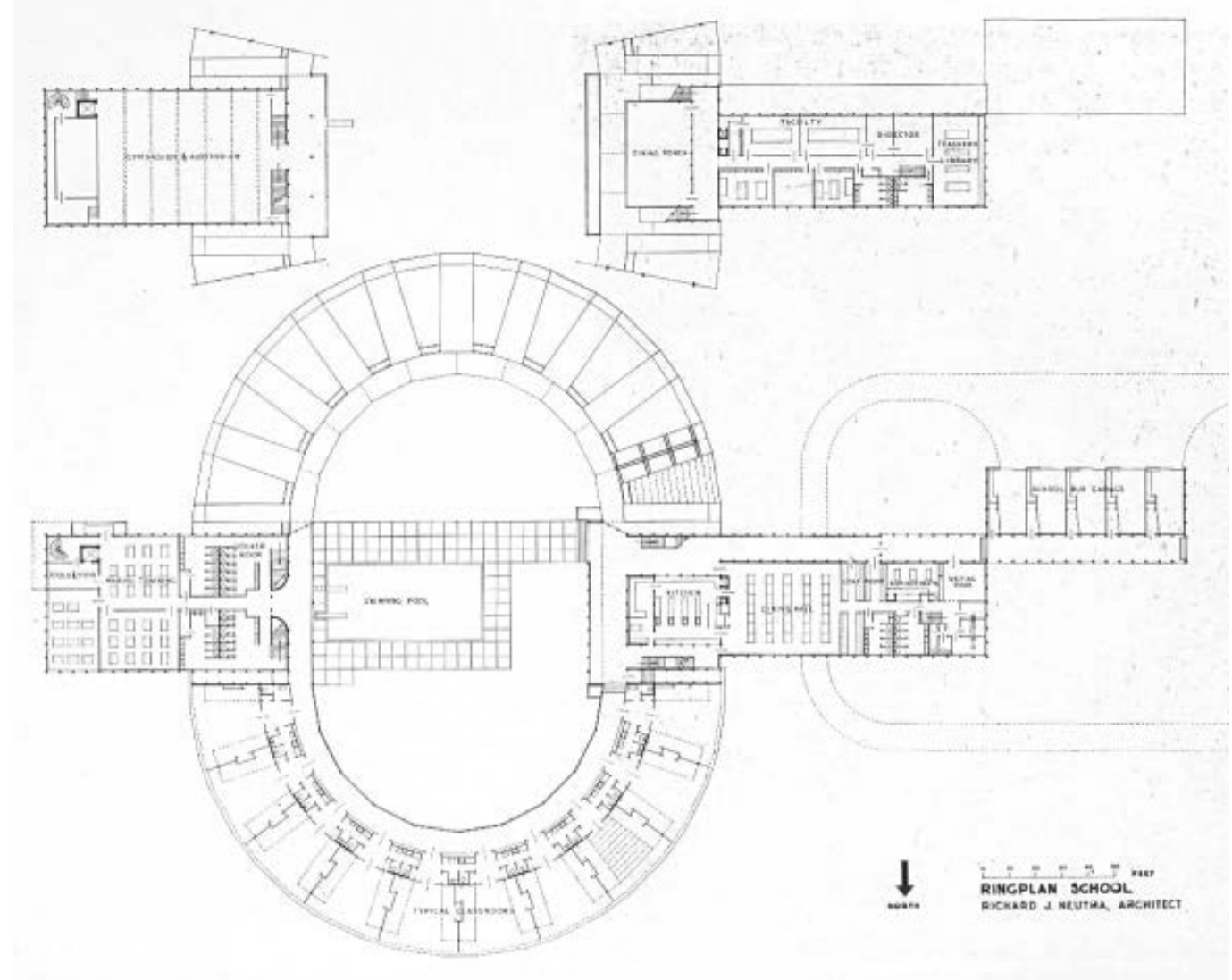

Plantas do pavimento superior e do pavimento terreo da Ring Plan School. Richard Neutra. Fonte: Arrqu
vo do Museu de Afre Moderma de Novay Volth
Na mostra, a ausência dos arquitetos expressionistas e dos construtivistas notada por Jean-Louis Cohen (2013: 194) ño impediu a participaç̃ de cujo trabalho já demonstrara sus posi-

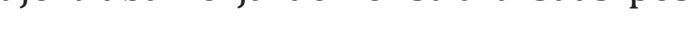
ções sobre o projeto e a resolução dos elementos construtivos e, ainda, sua relaçãa com o meio ambiente social. Uma possível explicação seria a atuação de Neutra nos Cstos Unidos, inicila de nos escióros de Lous Sulliva e de Fran rios de Louis Sullivan e de Franck Lloyd Wright em Chicago, e posteriormente na Califórnia, associado a Rudolf Schindler ou individualmente ${ }^{158}$, como nos projetos apresentados na exposição.

Antes de se instalar nos Estados Unidos, Neutra
157
traballhou com Scharoum em Berlim e e com Otto Wagner em
Visa

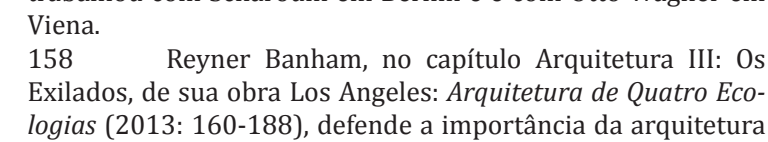

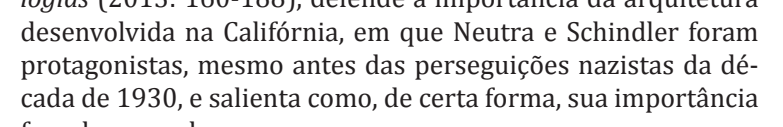

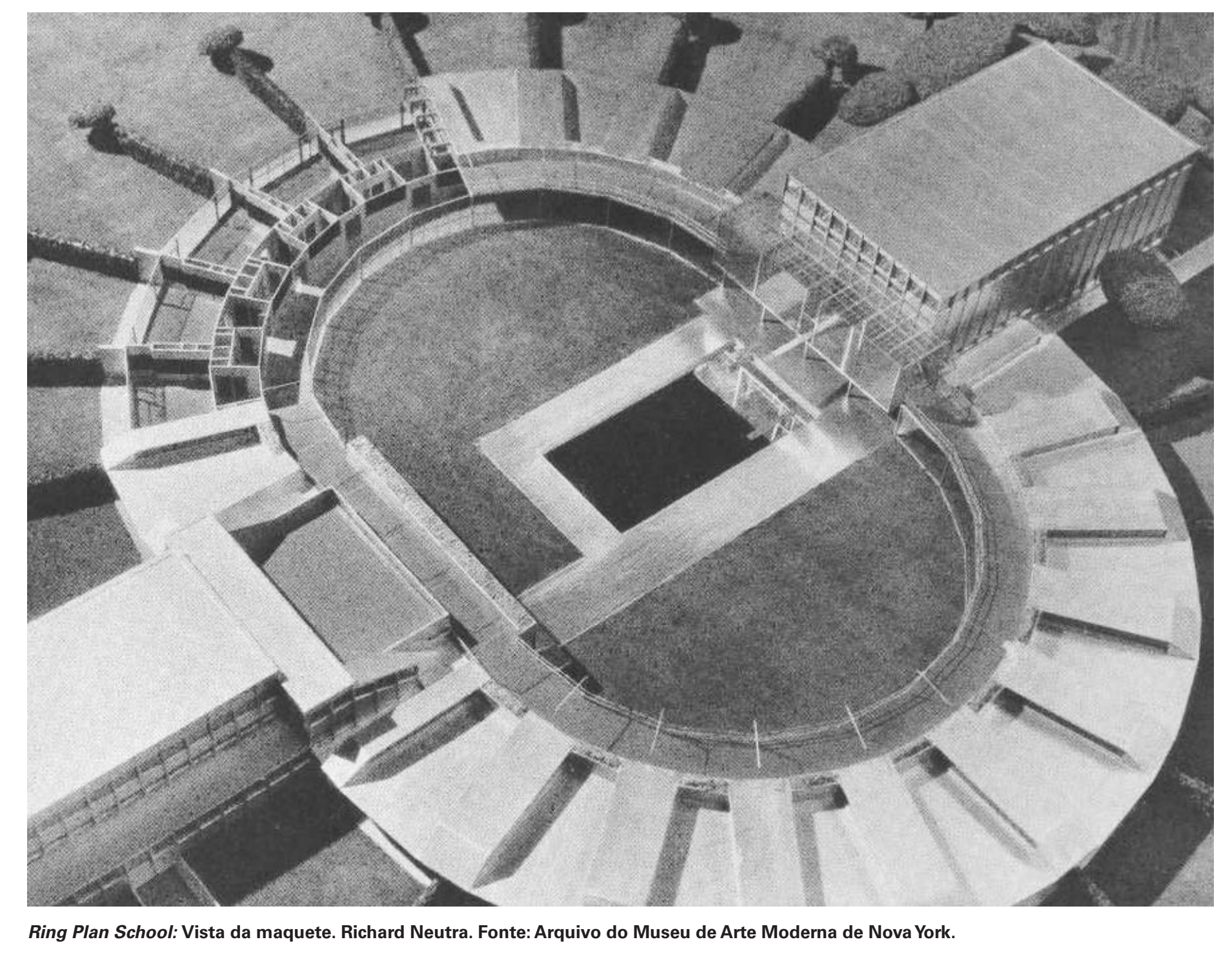


Apenas um ano após a Experimental School em Bell ser inaugurada, o trabalho de Richard Neutra é novamente destacado, desta vez por Ernestine M. Fant ${ }^{159}$ na exposição Architecture in California:

De seus edifícios recentes, talvez o mais interessante seja a Experimental Public School an Kindgarden, mérito não apenas de Neutra ma também da visão do Los Angeles Board of Education. A extensão do trabalho executado por Neutra permite-he se posiconar como um dos principais arquitetos na América e, por meio seus projetos e de suas obras, ele ten dado blemas. ${ }^{160}$ (FANTL, 1935: 10)

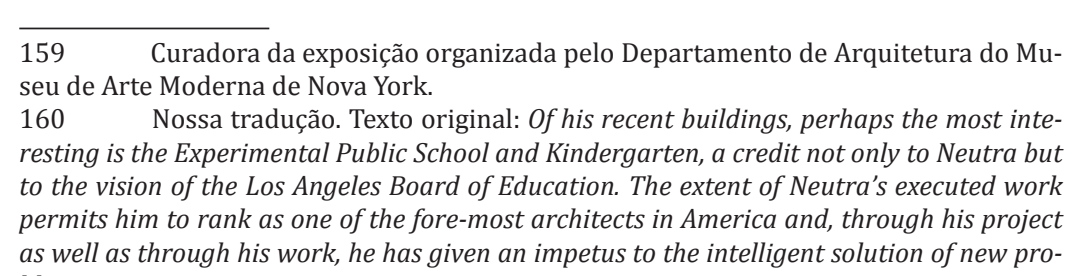

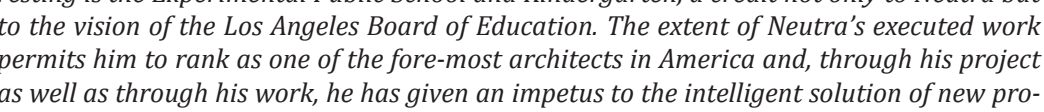

Mesmo com o reconhecimento de instituiçôes e publicações responsáveis pelo estabelecimento da Arquitetura Moderna na América do Norte, como o MOMA de Nova York e o The International Style de Henry-Russell Hitchcock e Philip Johnson, o trabalho de Neutra não deixa de estabelecer a conexão com a visão defendida pela Nova Arquitetura de Alfred Roth, o que explica sua presença para ilustra as noções de modernidade expressas pelas publicações citadas Na vis̃o de Kenneth Frampton as preocupačes an作 de "biorrealismo", estavam totalmente desvinculadas das motivações exclusivamente formais atribuídas ao "Estilo Internacional", o que deve ter motivado Roth a se interessar por sua obra ${ }^{161}$. Em certo sentido, o trabalho de Neudo Neues Baue 162 germânico do que dos questing

\section{162
162}

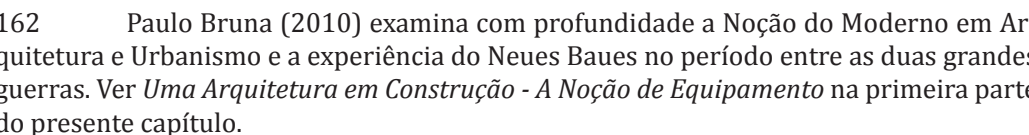

esteticos dos protagonistas do International Style, por sua visão científica da arquitetura como um meio racional e objetivo na concepção do meio ambiente construído, ou seja, por sua obra ter

[...] um ar não de um artefato físico, mas de um construção intelectual, expresso no detalhamento diagramaticamente esquelético que se torna-

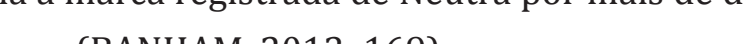
nos. (BANHAM, 2013: 169)

caminho para entender as propostas de Richar Neutra passa pela compreensão dos elementos do projeto. o que nos auxilia a percorrer o itinerário entre a utópica Ring Plan School e a Experimental School em Bell.

Em primeiro lugar, devemos citar o forte esquema diagramático que gera a implantação da edificação, citado por Banham. As escolas são organizadas a partir de longos eixos de circulação, tratados como galerias de convivencia não apenas como corredores de passagem, ou seja, são de- senhados para potencializar as principais intenções do projeto, seja do ponto de vista ambiental ou social. Se na Ring Plan o porte da escola para 400 alunos, aproximadamente, exigiu que o eixo principal leste-oeste fosse desmembrad em dois arcos, formando o "anel", em Bell, por outro lado, galeria se abre para os outros edifícios existentes, confor mando uma "praça" interna.

configuração em anel impede que a longa galerì tenha um fim de linha, ou seja, uma direção sem saída. É verdade que as duas alas criadas podem facilitar a organização dos alunos, entretanto Neutra está mais preocupado com integração de todos os envolvidos no processo de aprendizagem e desses com o meio ambiente. Assim, em cada encontro do eixo longitudinal com o anel foram posicionados os ambientes coletivos: a leste, o refeitório, a oeste, os vestiário e as oficinas de trabalhos manuais, e sobre essas, o ginásio-auditório. No interior do grande pátio interno formado pelo anel há uma piscina e um campo gramado para jogos. 


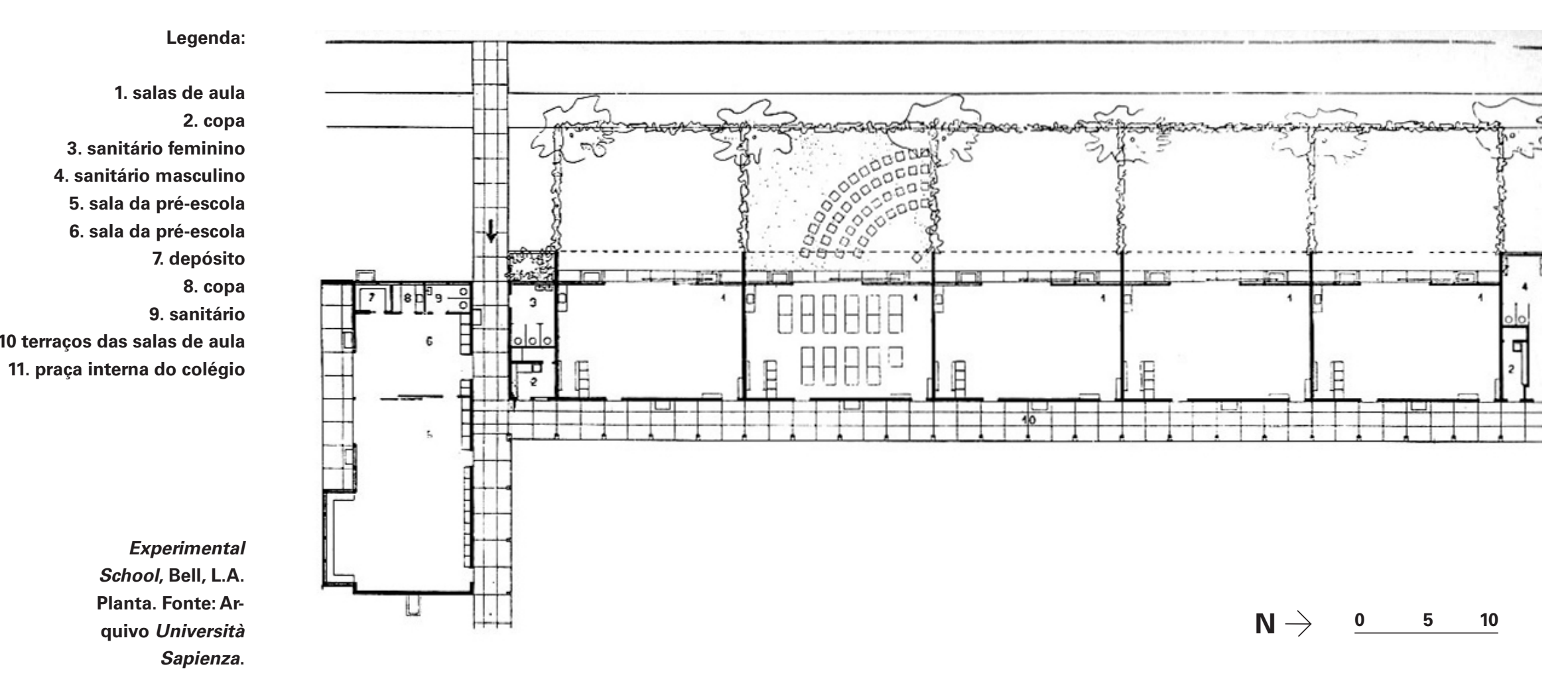

Em Bell, o cruzamento da galeria norte-sul com a galeria de acesso pela Bear Avenue abre-se para duas salas da pré-escola. Por se tratar da ampliação de uma escola de bairro, os 120 alunos atendidos pelo projeto de Neutra po- dem usufruir de outras instalaç̃os complementares existentes, o que explica a escala reduzida da obra e, principalmente, a opção pela integração da galeria de circulação com a praça interna que sua implantação criou.

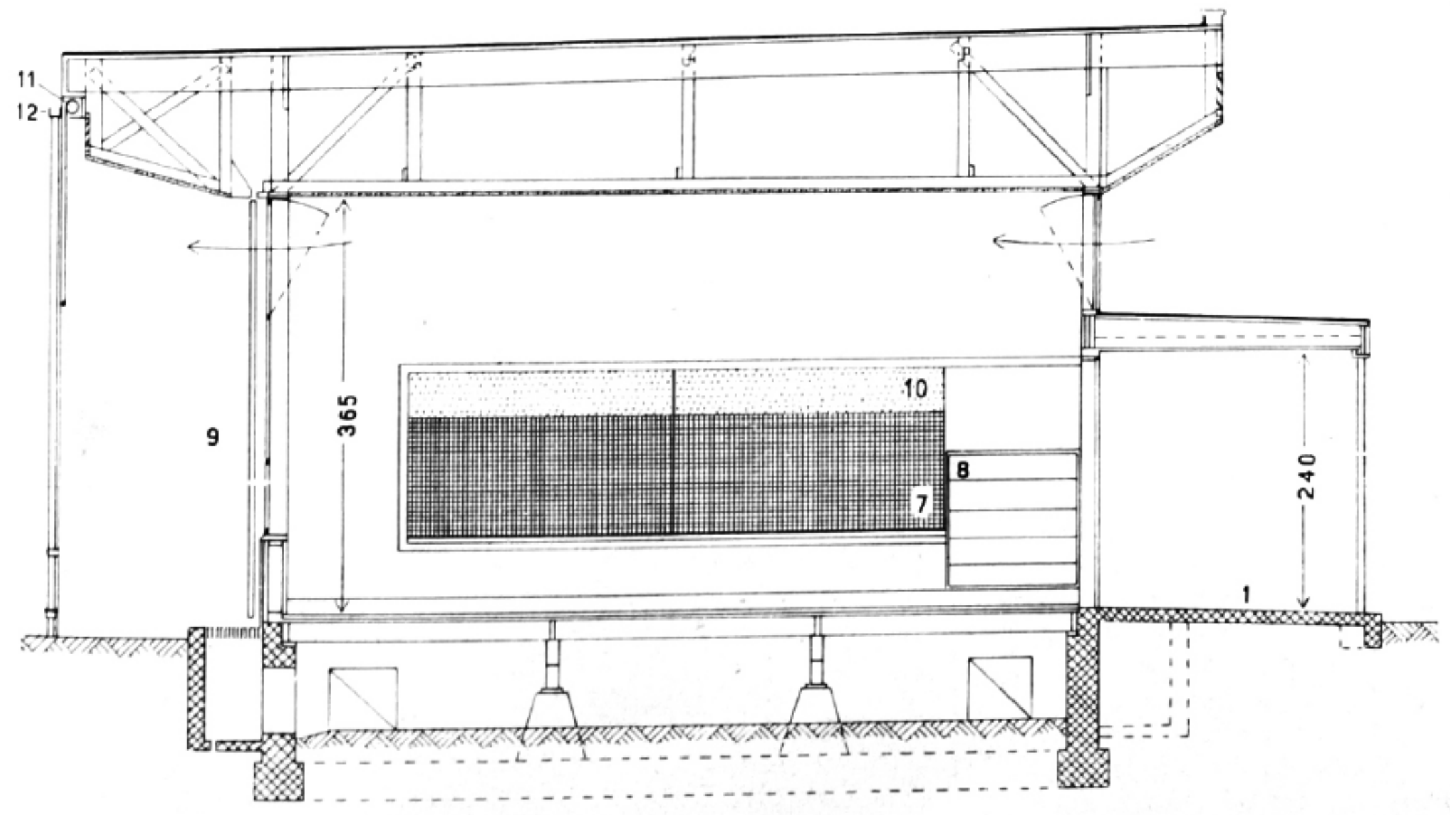

Experimental School, Bell, L.A. Sala de aula, corte transversal. Fonte: ROTH, 1940. 
Em segundo lugar, cabe destacar a importância da cobertura não somente como elemento de proteção e de expressão formal mas, fundamentalmente, como um dispostivo que proporciona ativamente a qualidade ambiental do espaço interno.

Assim, em Bell, a peça mais importante para o e endimento do projeto passa a ser o corte transversal pe sala de aula, que demonstra todo o cuidado no desenho, no posicionamento e no dimensionamento das coberturas. A sala de aula é fartamente iluminada e ventilada naturamente mas com a possibilidade de controle em função da altura livre de 3,65m e do funcionamento das amplas esquadrias em fachadas opostas. Essa condição seria prejudicada sem a eficiência da cobertura. A treliça em madeir de 1,35m cria um colchão de ar, ventilado por venezianas, que isolam as salas do forte calor do sul da Califórnia. Nos beirais, Neutra projeta painéis verticais de enrolar em lon que sombreiam as fachadas. Todo o conjunto é apoiado en estrutura leve de madeira que se mostrou mais adequada para enfrentar os riscos sísmicos da região.
Apesar de não haver o projeto detalhado da Ring Plan School, e possivel observar que Neutra previu uma cofor tação, posicionados entre cada sala de aula e cada um dos sanitários compartilhados entre elas. Dessa maneira, a cobertura pode espalhar luz natural pelas únicas paredes das salas e proporcionar a saída do ar quente, como utilizado em ambientes industriais. A ocupação interna pode, assim ser feita com liberdade por não depender de uma única posição de aberturas.

0 terceiro aspecto que sublinhamos, e certamente o que reúne um conjunto mais amplo de características, é a extrema preocupação de Neutra com a qualidade, a pertinência e a precisão dos elementos construtivos. Prova disso é esforço dispensado para encontrar o método construtivo mais adequado para viabilizar o mesmo corte transversal proposto para a Experimental School em Bell. Na publicação de Alfred Roth é possível observarmos cinco soluções distintas detalhadas e compará-las como realizações técnicas, estéticas e financeiras.
A sala de aula

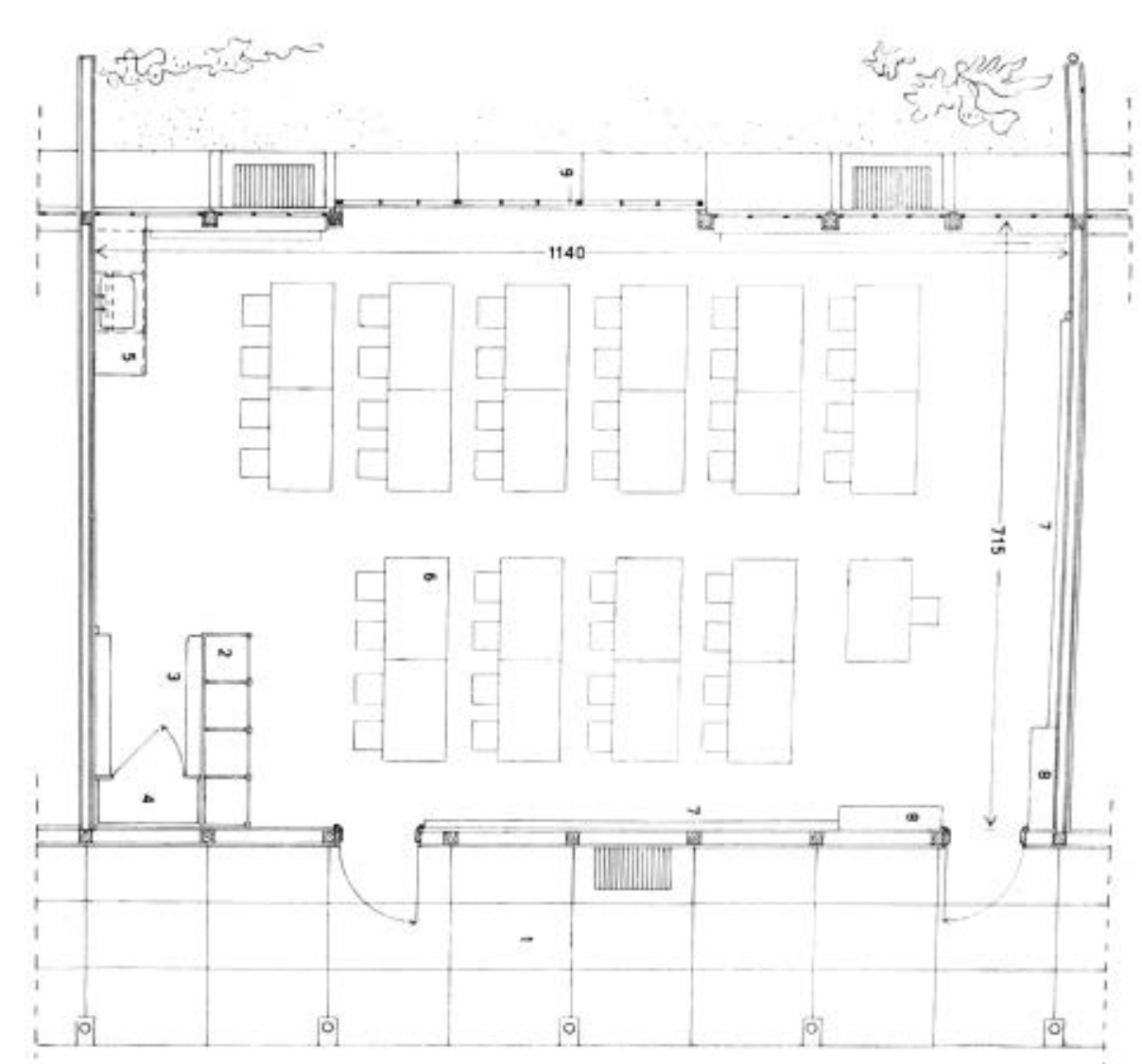

Legenda:
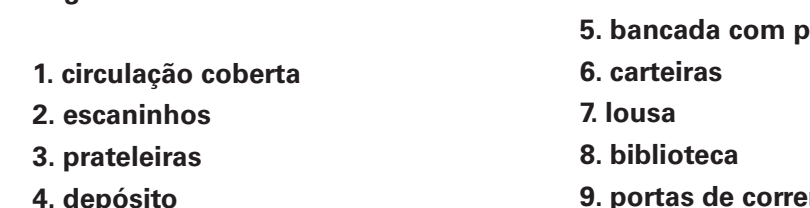

A verdadeira educação não é ensinar como fazer as coisas. É fazendo as coisas que o aprendizado da criança é facilitado ${ }^{163}$ (NEUTRA, 1935: 28: en negrito no texto original)

Novamente, a observação da imagem da sala de aula ostra-nos os princípios que levaram a escola em Bell ser denominada Experimental School.

É fato que a extensão das atividades de aprendizagen ao ambiente externo estáligada às mesmas preocupac̃os de ambiental que norteavam as experiências pedagógcas higienistas europeias por nós destacadas nos projetos $\mathrm{d}$ Basel, Amsterdam, Suresnnes, Villejuif e Como. Todavia, Neutra tem que enfrentar as dificuldades do clima extremamente quente e seco do sul da Califórnia sob o risco de prejudicar o protagonismo das atividades ao livre, sempre delimitadas pelo prolongamento externo da sala de aula

0 esforço de Neutra na concepção de uma arquitetura baseada nos elementos construtivos, adequada ao meio ambiente natural e social encontrado em regiões de clima quente, pode ser compreendido ao examinarmos sua obra

Nossat traducasa. Texto original: True education is not teaching about doing
thingss 
Arquitetura Social em Países de Clima Quente ${ }^{164}$, publicada em 1948, após diversas viagens realizadas por ele pelas Américas, que incluíram o Brasil em 1945, e sobretudo após um extenso trabalho de planejamento e de projeto de equipamentos sociais - escolas e hospitais - em Porto Rico Apresentados e detalhados com extrema profudidade ${ }^{165}$, os projetos propostos fundamentam os ensaios em que Neutra defende seu entendimento frente à condição moderna, consolidada após o final da Segunda Grande Guerra. Neles, Neutra se ressente de ser considerado, de maneira equivocada, um engenheiro e não um artista produzindo arquitetura, mesmo porque para ele

[a] época em que vivemos favorece aquilo que chamado de "ciência", em detrimentor - especialmente quando se trata de realizar planejamento como uma ação social ${ }^{166}$. (NEUTRA 948: 212, em itálico na versão original)

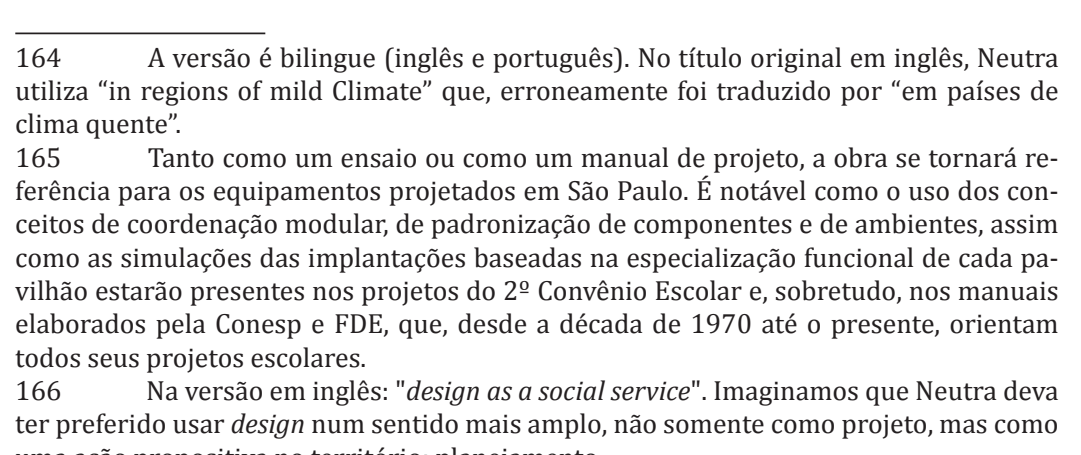

Em certa medida, ao denunciar o que ele chama de "cienticismo", que domina a produção da arquitetura socis Neutra pretende demon com a qualidade dos elementos construtivos, baseada nos seus aspectos técnicos e econômicos, é fruto de um entendimento de que o meio ambiente construído é o responsá vel pelo enfrentamento da condição social urbana e rural, como na experiência de Porto Rico, pois para ele

[há] muitos determinantes fora do domínio estreito dos consagrados "fatos reais", quando se trata de uma coisa tão complexa como, por exemplo, planejar uma cidade, arrabaldes, uma moradia ou um quarto de criança, seja pré-fabricado ou não. A ciência pura e viva precisará ainda de várias gerações para esclarecer e plenamente resolver esses problemas. Enquanto isso, devemos viver e construir para poder viver; e teremos de fazê-lo com arte, com aquela faculdade humana da qual dependeu a cultura de séculos. (NEUTRA, 1948: 216) importância do resultado e da divulgação desse trabalho pode ser percebida na introdução do livro, elaborada por Gregory Warchavchik. Nela Warchavichik, consciente das carências sociais que marcaram as cidades brasileiras, destaca como a arquitetura de Neutra é portadora de um caráter formativo

Em sua escola experimental para Los Angeles nefícios às crianças de sua cidade e à junta loca de educação. [...] pela primeira vez e combatendo doda a oposiçẵo convencional desta epoca, Neutra cabou criando uma combinaçáo flexivel da sala de aula ligada com o ar livre, própria para um método de ensino em que $o$ aluno aprende variando de ocupaçōes. (in NEUTRA, 1948: 18)

Para Warchavichik, trata-se portanto da defesa do rojeto como meio de enfrentamento da condição urbana social, muito mais do que a construção da referência forma como transformadora do lugar o que não significa oposição à modernidade expressa nas obras dos grandes mestres presentes na The International Style de Henry-Russell Hitchcock, pois

[do] ponto de vista econômico, técnico, estético e humano, essa estrutura oferece uma settico ideal, um melhoramento sobremodo feliz e que abre caminho para maiores aperfeico A fama dessa escola já se espalhou pelo mundo afora e ela foi considerada um exemplo ́́nico. NEUTRA, 1948: 20)

Dessa maneira, além dos citados aspectos técnicos climáticos e econômicos, a influência das propostas de Neutra sobre a sistematização das redes públicas de equipamento no Brasil se deve particularmente pelo estabelecimento de uma metodologia de projeto e pela organização espacial da obra, como observam Claudia Loureiro e Luiz Amorim (2002), para quem o impacto de seu livro, apesar de pouco referenciado, foi particularmente significativo para os projetos nas redes de ensino e saúde das regiões nordeste e sudeste. 
A conclusão deve ser estendida à sistematização da rede física de ensino implantada no estado de São Paulo a partir da década de 1970, com a criação da CONESP. Ao examinarmos os manuais produzidos por seu corpo técnico ${ }^{167}$, cuja evolução e atualização ainda hoje orientam os projetos escolares coordenados pela FDE, sua sucessora, podemos comprovar a grande proximidade entre os conteúdos dos referidos documentos.

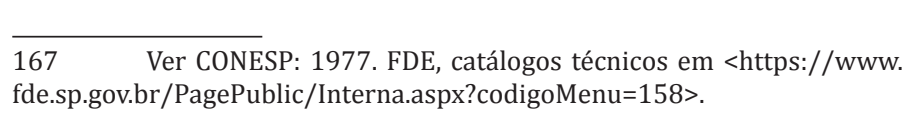

unidades componentes da planto
de uma escola urbana de 8 salos

plan units of 8 class
room urban school

It

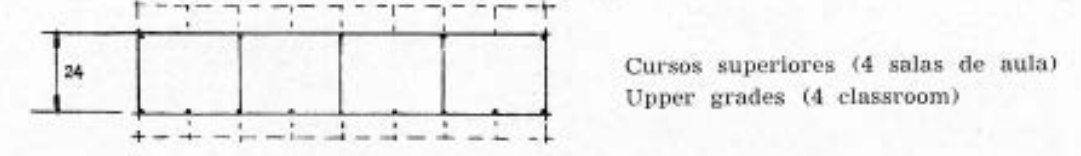

Sula de renibess (Cursos intertoress)

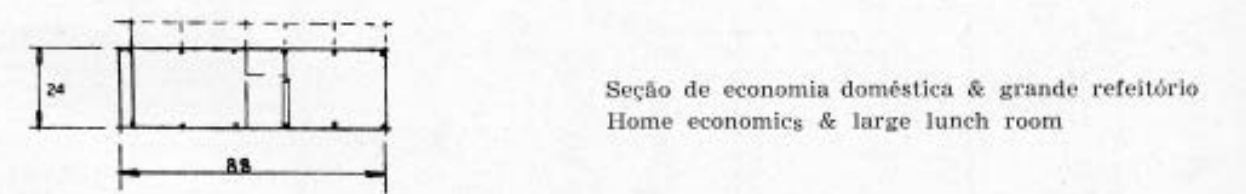

-

Cienciass naturats

5

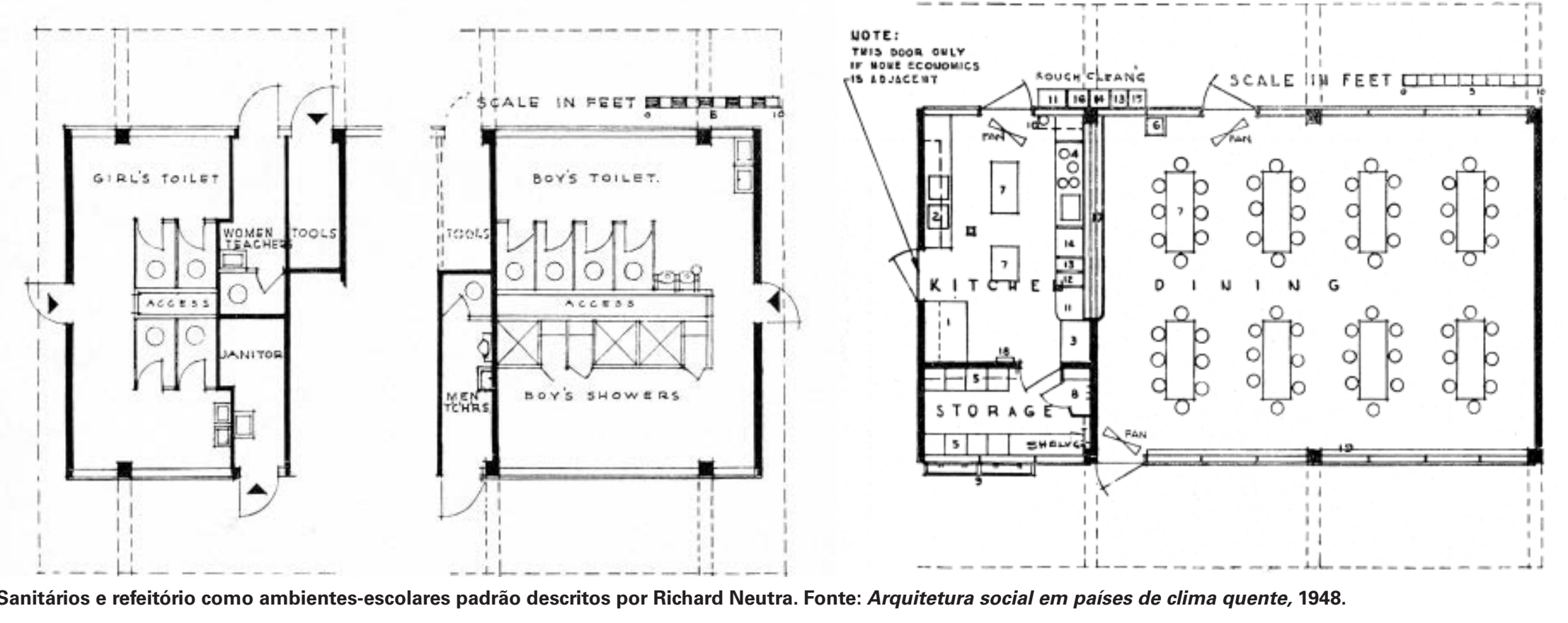

(C)

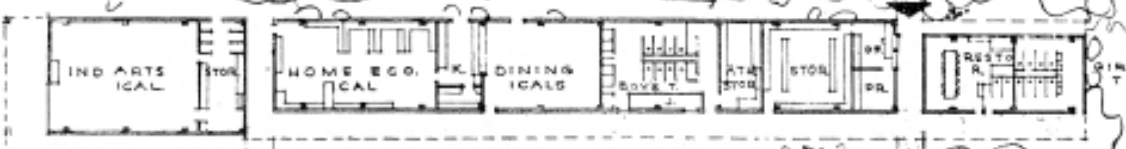

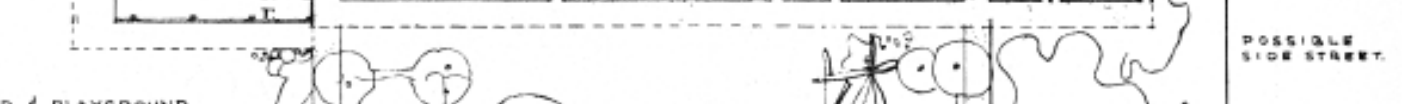

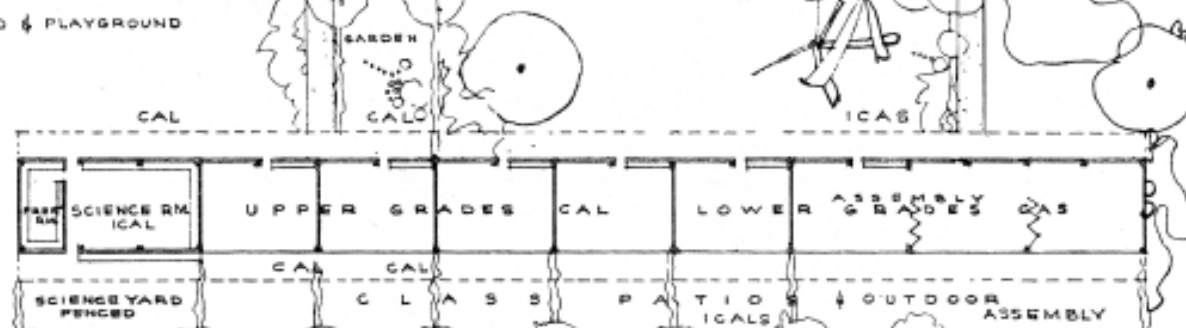

$3=0,30=0$

Exemplo de implantacăa padrāo descritos
por Richard Neutra. Fonte: Araud 
Não podemos mensurar com segurança até que ponto as influências apontadas até aqui se refletiram diretamente na producão arquitetônica da equipe do $2^{\circ} \mathrm{C}$ Con (Ex Esco da obra de Affonso Eduardo Reidy no Rio de Janeiro. No entanto, ficou evidente a convergência das obras públicas de aprendizagem realizadas nas décadas de 1940 e 1950 por Reidy e pelo $2^{\circ}$ Convênio com as realizaç̧ões e os textos não somente de Richard eutra, mas também dos outros arquitetos estudados neste capitulo: Hannes Meyer e Hans Wittwer em Basel, Joannes Duiker e Bernard Bijvoet em Amsterdam, Eugène Beaudouin e Marcel Lods em Susrennes, André Lurçat em Villejuif e Giuseppe Terragni em Como. Mesmo com todas as particularidades de cada contexto, o projeto atuou como medo e ombiente natur como observamos, enfrentando as transformações urbanas
e sociais em suas diversas escalas.

Apesar de alguns autores considerarem que a possível genealogia da arquitetura escolar paulista de expressão moderna esteja mais enraizada nos textos e nas utopias de
Le Corbusier ${ }^{168}$, pudemos observar que, na prática, a arquitetura como instrumento de atuação baseada no conheccomo for evidencido no como foi ende proximidade com o pensamento construtivista e funcionalista que consolidou a noção de equipamento público, en especial no período entre as duas grandes guerras.

Dito isso, podemos prosseguir no estudo de um projeto de equipamento público de educacã̃o que marca defin-

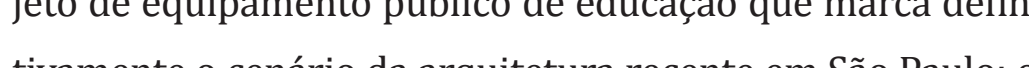
CEU (Centro Educacional Unificado).

168 Ver: WISNCKK, in FERREIRA, 2006:68 a construção da nova arquitetura 

intervenção urbana, em que é parte de um complexo conjunto de ações do poder público, visando o atendimento das fortes demandas sociais.

A opção da sua primeira equipe de projeto ${ }^{169}$ pela determinação de uma tipologia composta por três blocos principais dispostos em uma esplanada e uma plataforma mineral que se organiza em função do desenho do lote, baseia-se na tradição da Arquitetura Moderna Brasileira oficial. As variaç̃os são dadas pela relação geométrica entre esses blocos e os equipamentos esportivos externos complementares. A predominância física do bloco educacional plementares. A predominanncia fisica do bloco educacional
com $145 \mathrm{~m}$ de comprimento é determinante nas decisões de implantação. Seguindo a estratégia por ele imposta, são criadas as relações com os outros blocos, num jogo em que tanto o bloco creche, um disco metálico suspenso, como o bloco esportivo cultural, maciço e vertical beneficiam-se de

toda a infraestrutura do primeiro, demonstrando sua total dependência. Por esta razão, pode-se dizer que os blocos creche e o esportivo são anexos do bloco educacional por não possuírem independência funcional plena.

Esse modelo, previsto para ser implantado macicamente nas diversa regiñes perifericas do mulopio, foi apresentado para ela

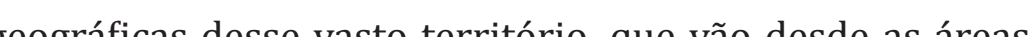
proteglas da Serra da car protegidas da Serra da Cantareira na zona norte, com sua topografia acidentada e os remanescentes da Mata Atlântica, até as áreas de mananciais da zona sul, próximas às represas de Guarapiranga e Billings, passando pelas extensas regiões de córregos das zonas leste e oeste.

São nessas condições que o objeto arquitetônico surge com total independência. Ao se avaliarem as $45 \mathrm{im}$ plantações propostas, fica clara a intenção de se dar a essa tipologia o valor de protótipo, o edifício público como referência identifić́vel nos quatro cantos do munić́pio A relação com o lugar é secundária, é fruto de resoluções funcionais e operacionais.

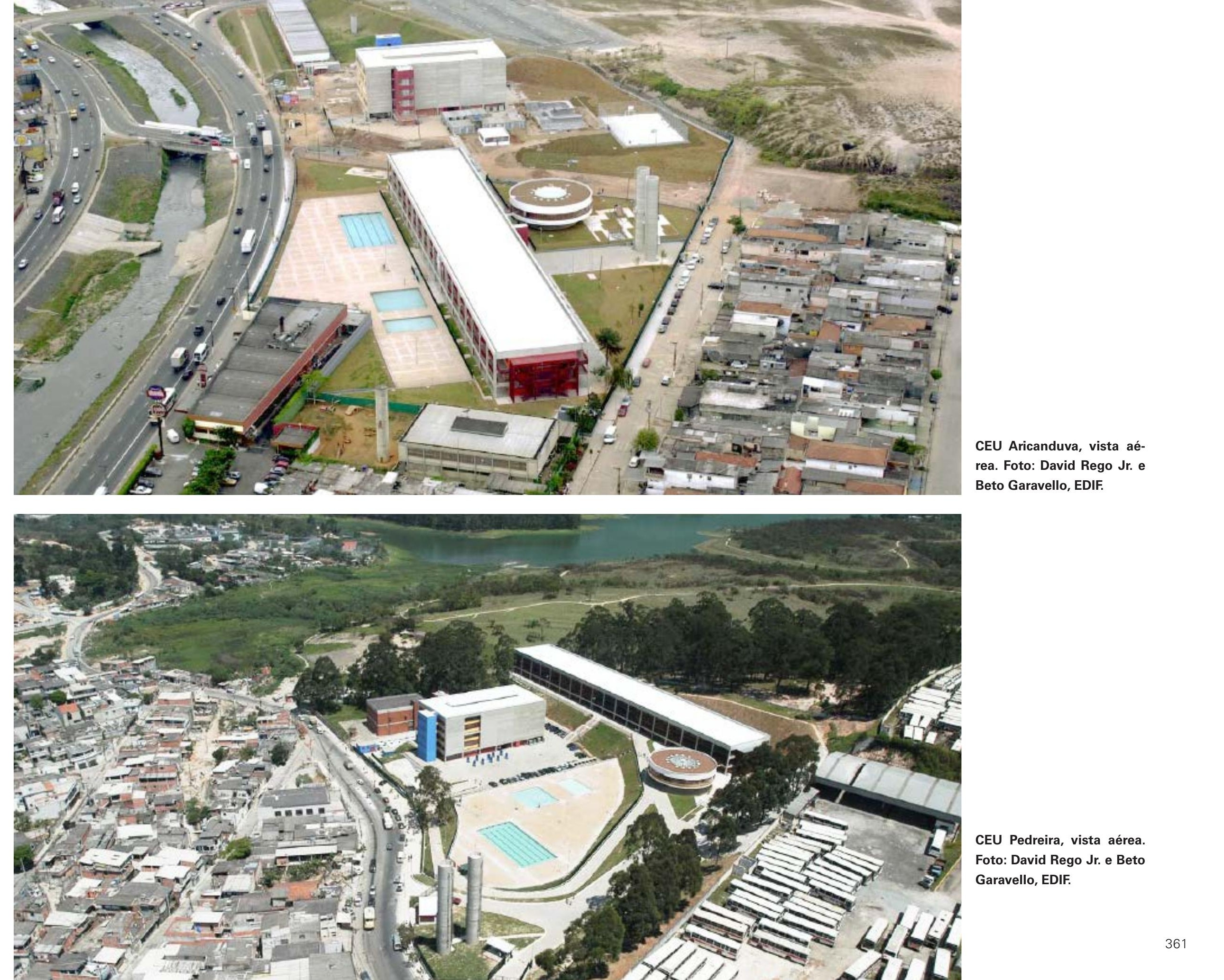



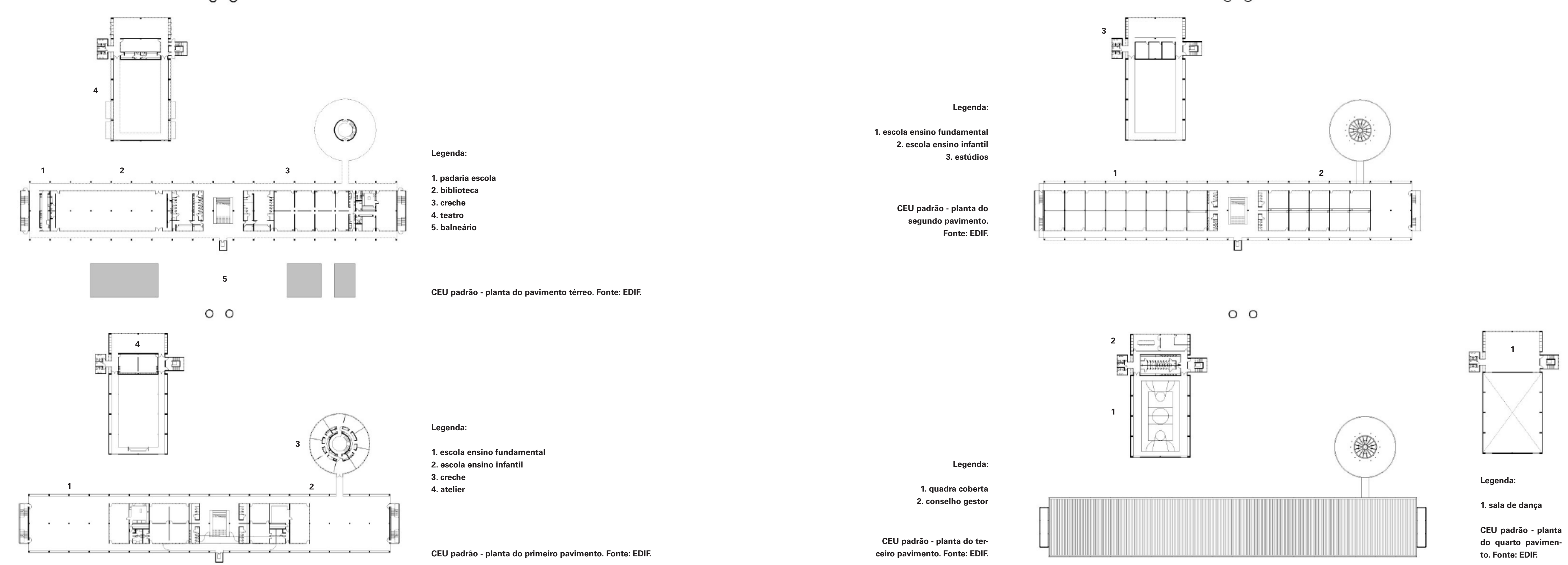

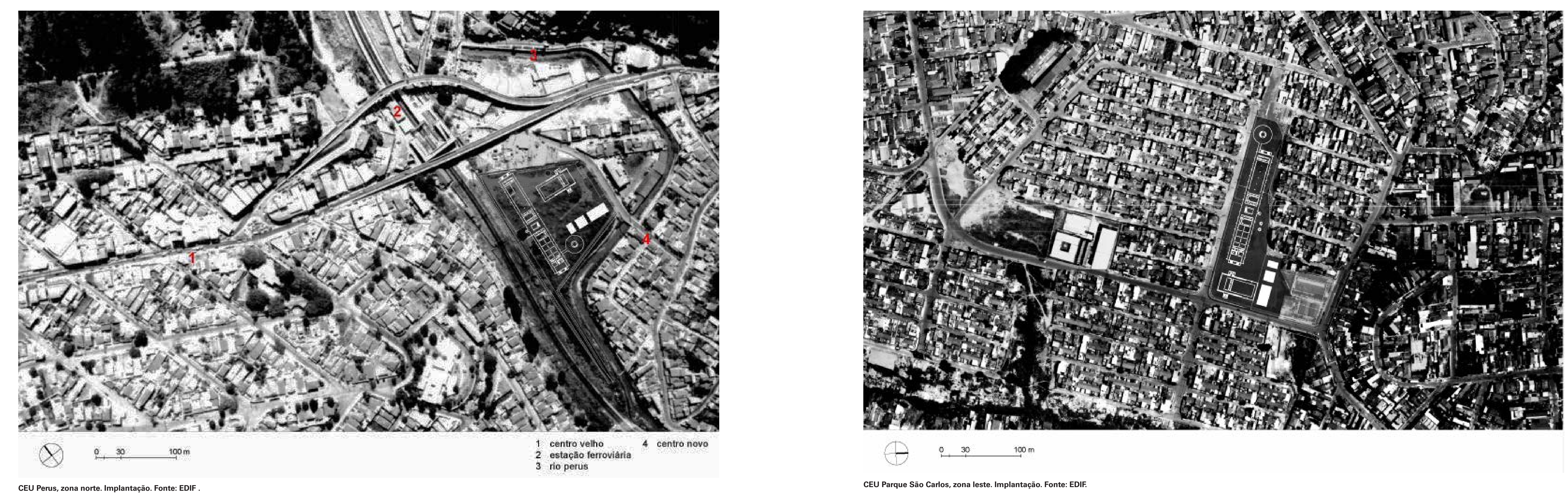


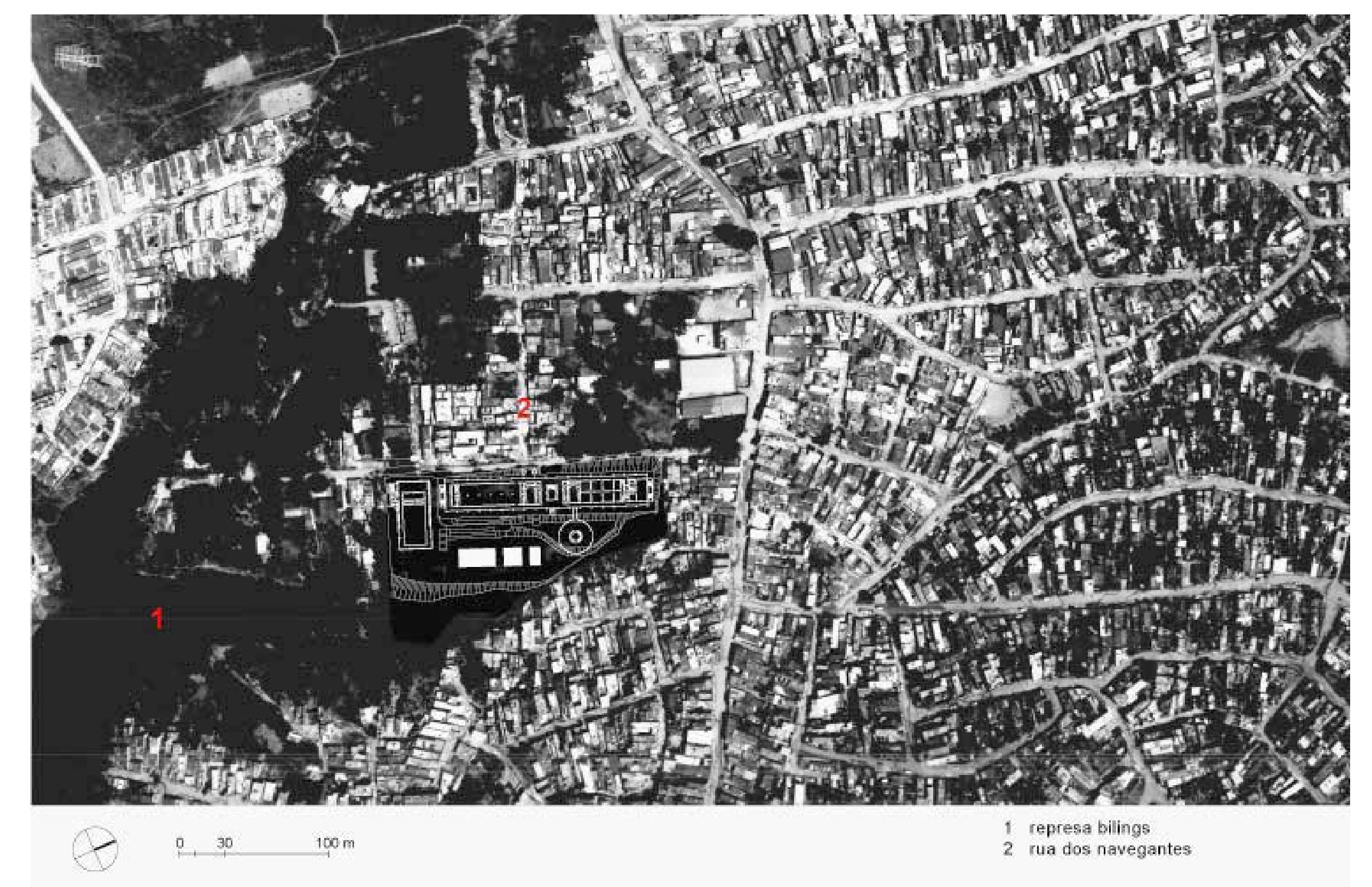

Nesse sentido a proposta distancia-se da arquitetura do Convênio Escolar predominantemente pavilhonas geradas pela preceitos modernos disseminados en Brasli. Entretanto diferentemente da liberdade proporcionada pelo ilimitado horizonte do Planalto Central, as características dimensionais de cada lote dos $\mathrm{CEU}$ determinam as leis básicas de implantação a a mesmo não sendo definição das relações espaciais entre os blocos projetados testando assim os limites do projeto, como salientamos. Esses lugares, apesar de desprovidos das qualidades urbanas tradicionais e pouco consolidadas, possuem um nome, un significado, uma história recente que gerou o vazio ora ocupado pelo CEU. Há décadas, seus habitantes são protagonistas, através da autoconstrução, em um cenário marcante da realidade recente de nossa metrópole.

Outra decisão que deve ser destacada refere-se à ocupaç̃o do chão, a grande esplonada mineral, pelo batneário. As três piscinas e o solário domin neáric. As tés pischas e o solfio dor das áreas livires do pavimento térreo, tranformando-se en um quarto bloco edificado.
Essas decisões levaram à verticalização do projeto tanto das áreas educacionais quanto das culturais e esportivas, como pode ser verificado nas phas do projto padrão A veric contrar terrenos amplos para a implantação do conjunto principalmente, para promover sua construção através do uso de sistemas construtivos pré-fabricados em concreto e aço, como foi o caso.

Cabe sublinhar que o resultado distancia as atividades de convivência do nível do chão, confinando-as nos pavimentos superiores. Se nos CIEP Niemeyer prioriza a formação de um espaço coletivo gerado pelo piloti do térreo procurando articulá-lo com o bloco esportivo e a biblioteca, no chão do CEU, o que predomina é o balneário sempre isolado por alambrados por questões funcionais e de segu-

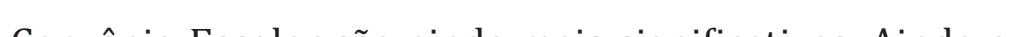
estejamos tratando de três escalas distintas de equipamento de aprendizagem, pois o programa do CEU incorporou as atividades culturais e esportivas inspiradas na escola parque, o projeto abandona a solução pavilhonar que intedes formadoras e que marcou signif tivamente a arquitetura escolar paulista, o que, num certo sentido, pode ser também observado no CIEP. 

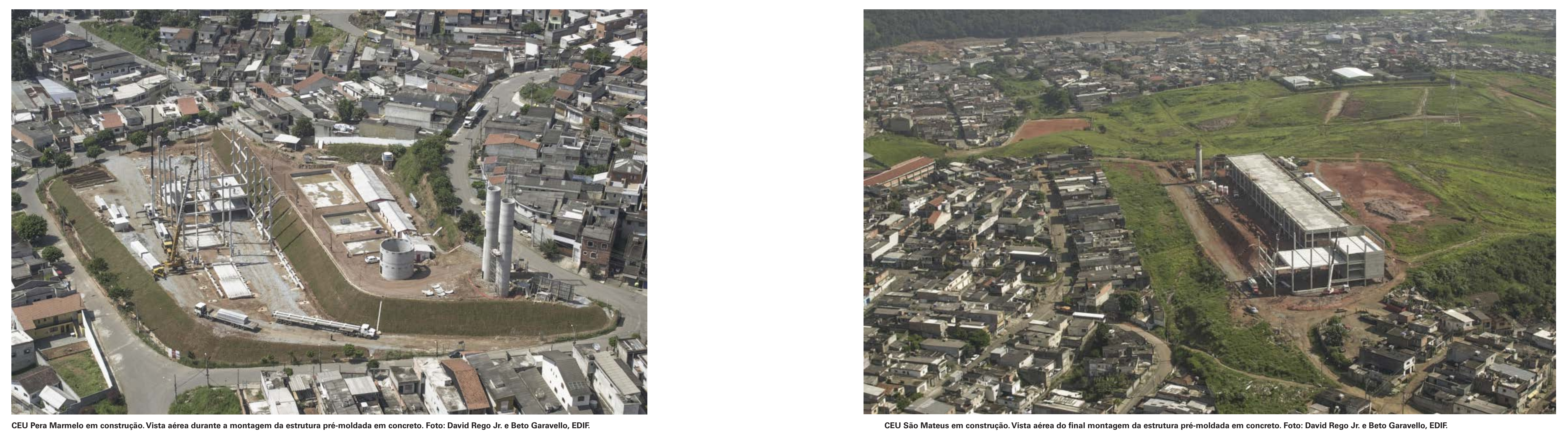


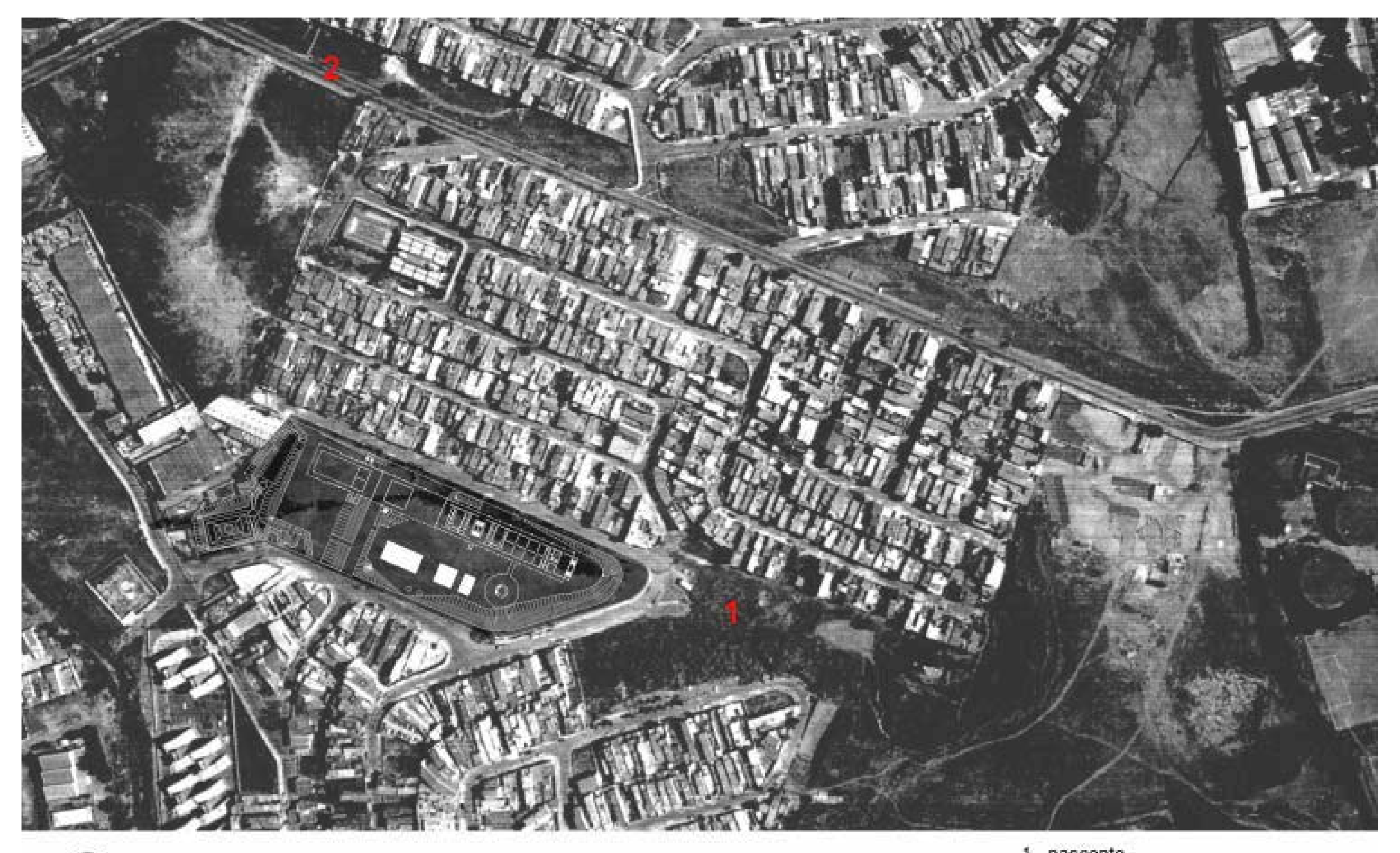

Q $\quad 0.30 \quad 100 \mathrm{~m}$

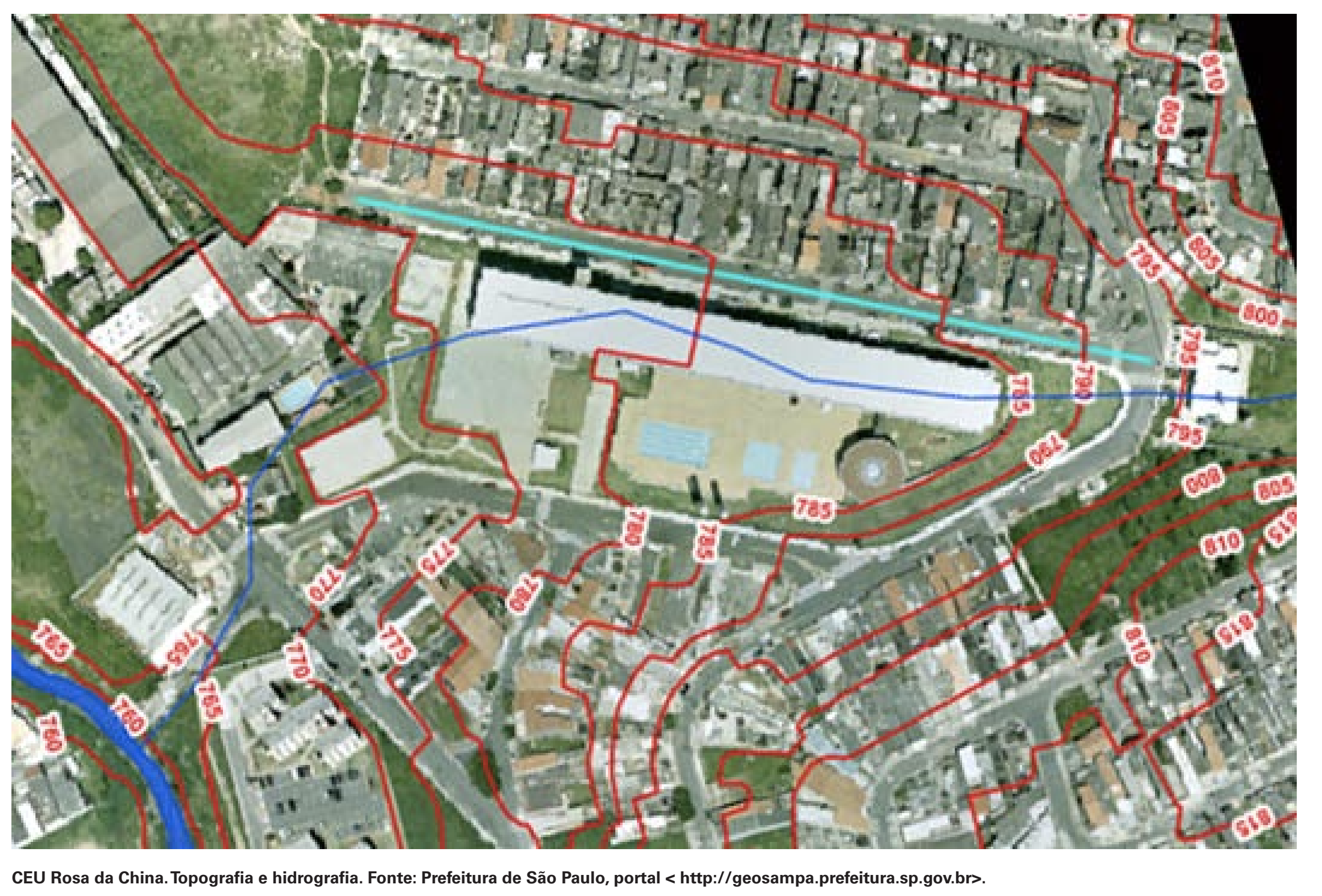



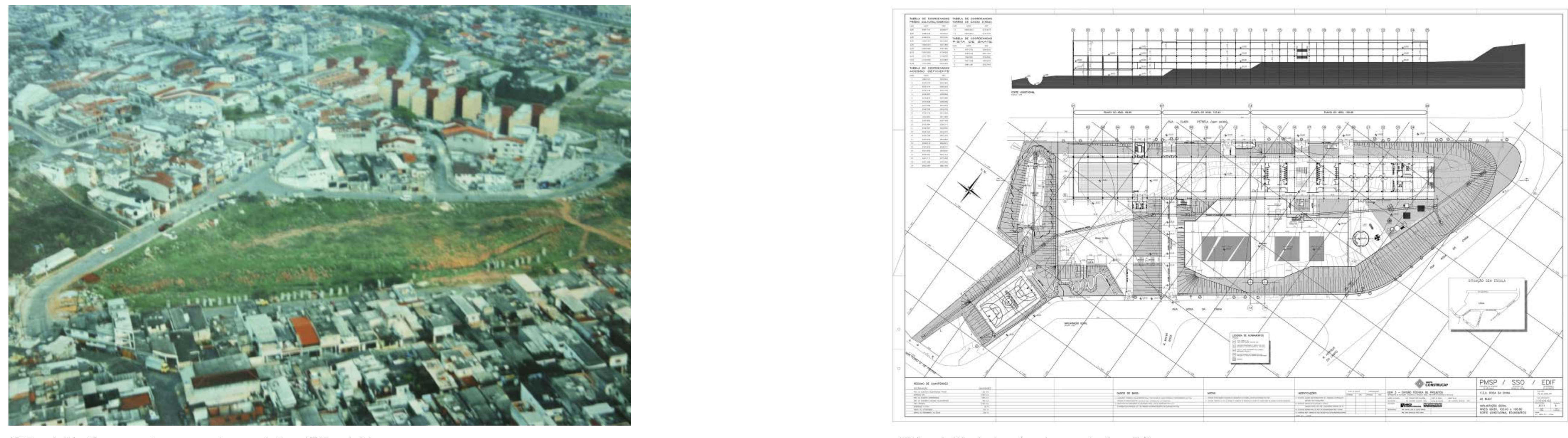


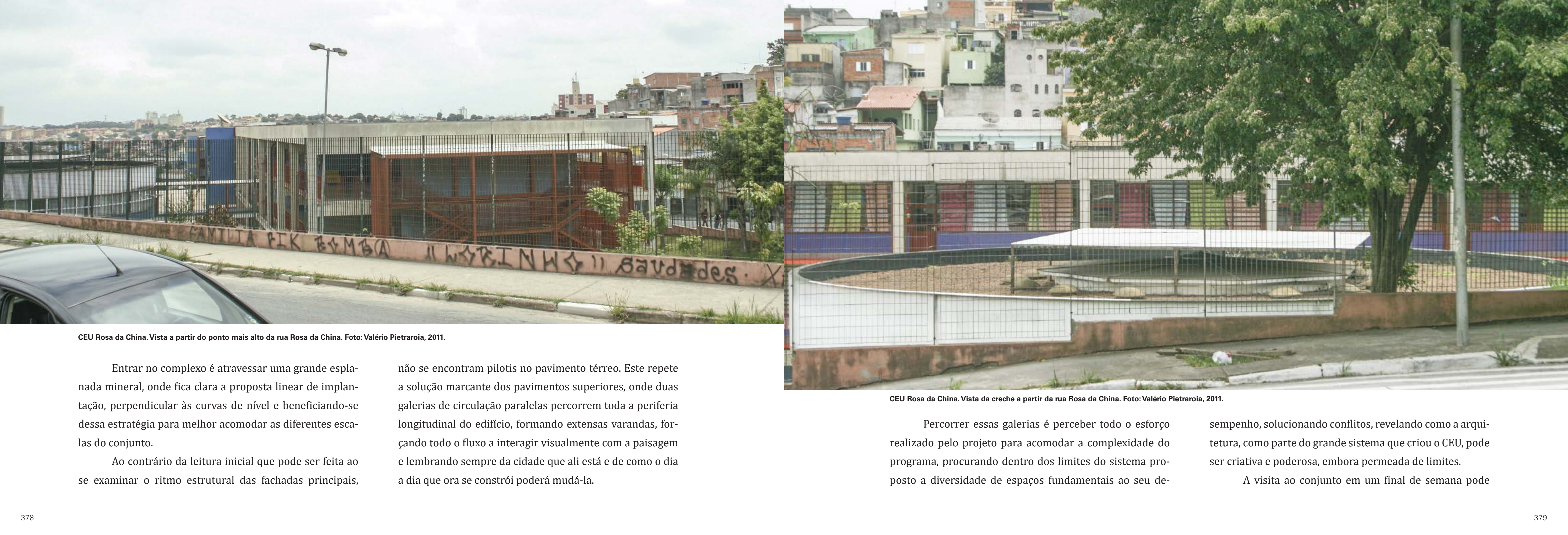




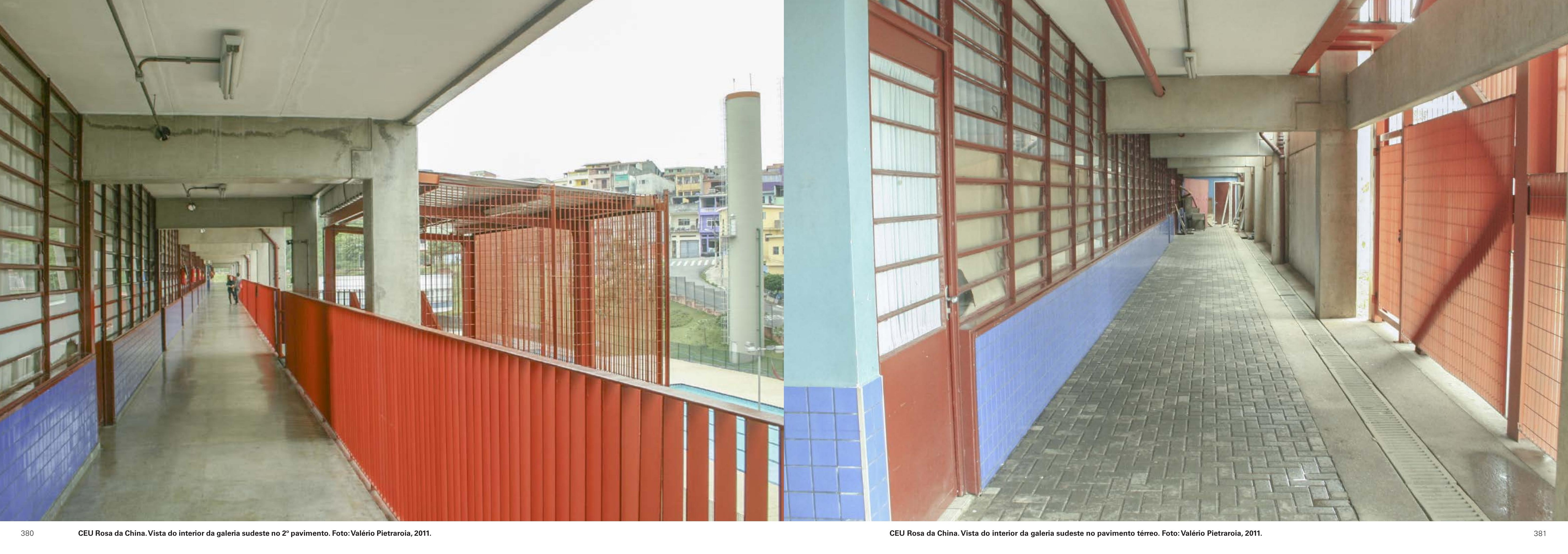


dadas na vizinhança, conforme a proposta original do programa. Por isso, espantou-nos a baixa frequência dos mo-

radores no local, resultado das dificuldades de acesso, da necessidade de um maior número de opções ou até mesmo da carência de recursos humanos para melhor explorar sua capacidade instalada.

Fica claro, depois de quase quinze anos de existência, que o CEU Rosa da China tem dificuldades para manter e expandir as funções para as quais foi concebido ${ }^{174}$. Fica claro também que essas dificuldades, bem como as de manutenção e de operação do conjunto, ultrapassam os limites da arquitetura proposta. Não nos cabe, no contexto de nossa pesquisa, avaliar essas dificuldades, mas pretendemos entender quais são os seus limites.

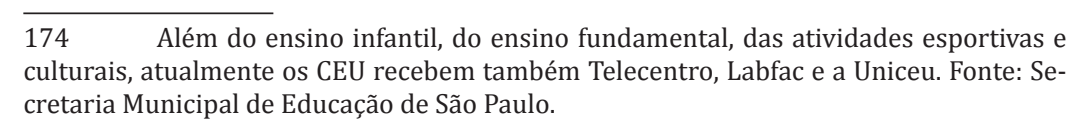



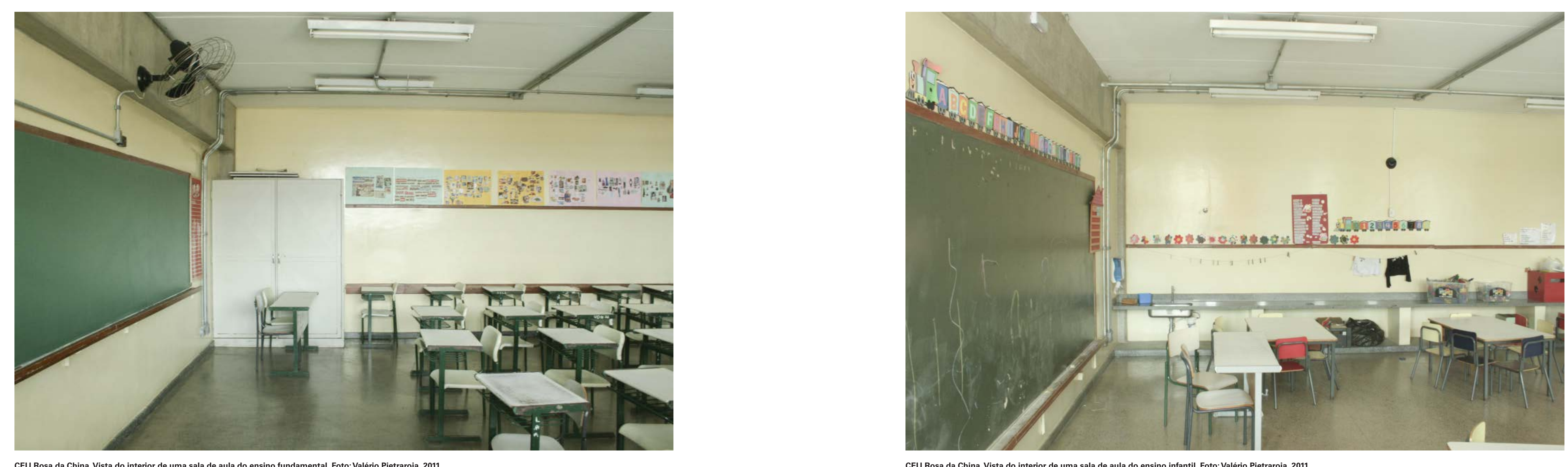

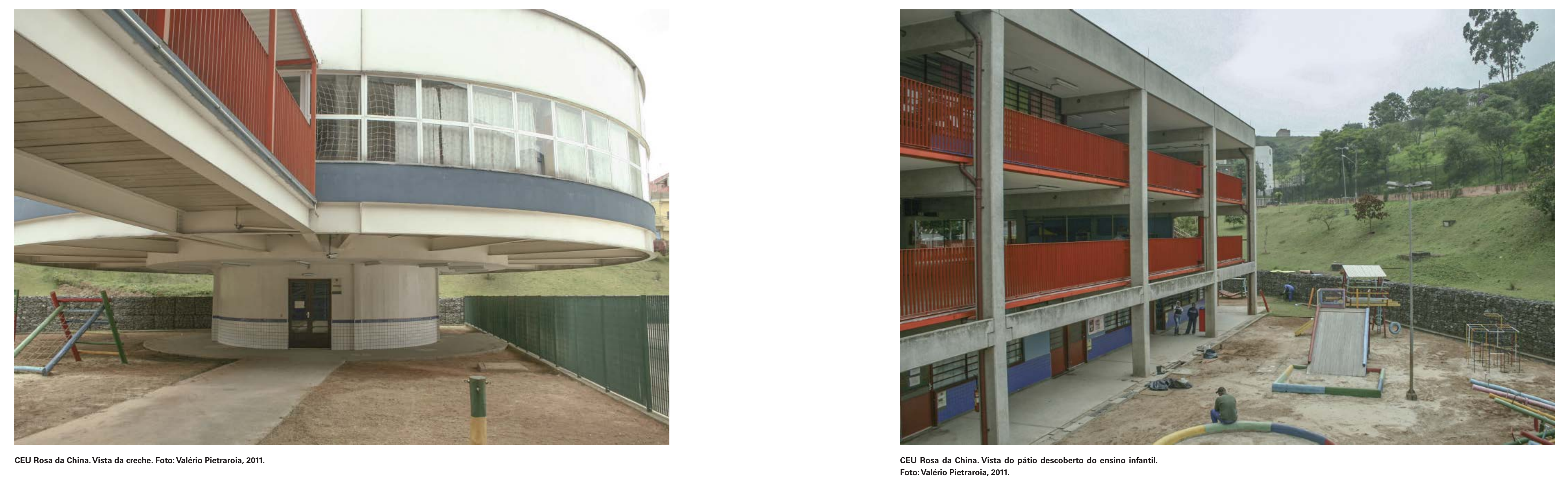


\section{3}

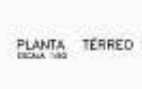
$\sin =$ 1 rempras reanew to executivo da creche. Fonte: EDIF

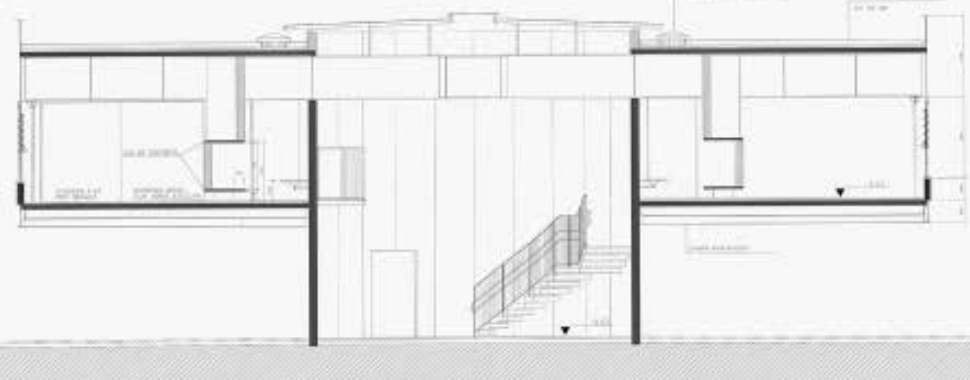

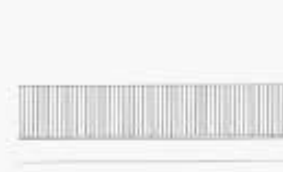

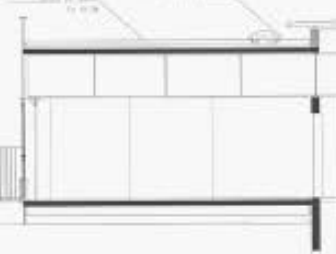
III I IIII||

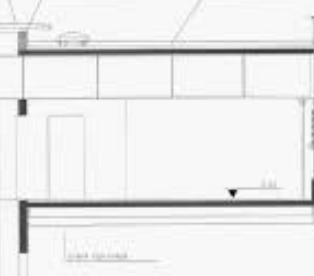

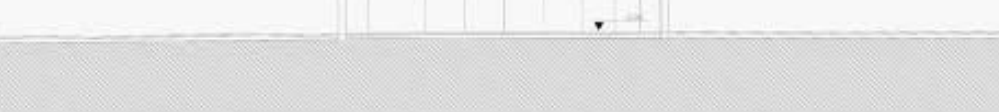

\section{CEU Rosa da China. Vista do interior do pátio coberto do ensino fundamental no $1{ }^{\circ}$ pavimento, junto à tachada nordeste. Foto: Valério Pietraroia, 2011.}

Estamos referindo-nos a um objeto arquitetônico primordialmente escolar. $\mathrm{O}$ CEU é antes de tudo uma escola, onde devem conviver crianças de diversas faixas etárias e ocorrer as atividades necessárias para o desempenho de suas funç̃oes. Há um cuidado relevante em relação à concepção da célula fundamental do ensino, a sala de aula dentro de padrões tradicionais, adotados por diversos organismos públicos que tratam do assunto $0^{175}$. A associaça per

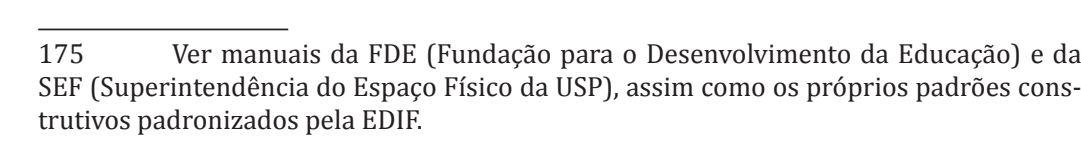

principal, dispostos nos pavimentos superiores e em par. configurando cada etapa do desenvolvini Concentraç̃o da infraestrutura, bem como o ordenamento interno baseado no posicionamento das atividades complementares e dos pátios cobertos. Os alunos fazem um percurso vertical na chegada e na saída, mas se beneficiam da predominância dos fluxos horizontais no próprio pavimento durante o período em que permanecem na escola 
Se considerarmos cada fase da formação escolar uma unidade autônoma dentro do bloco, a horizontalidade inicial da arquitetura proposta dá lugar à verticalização. 0 s espaços comuns de convívio onde, para muitos educadores a escola acontece e permite as trocas e a integração de seus públicos, estão confinados em cada pavimento. Fisicamen transversal ao bloco, esse espaço entre as etapas escolare é delimitado pelo ritmo estrutural, permanecendo contido dentro do mesmo limite vertical previsto para todo o edício, da sala de aula ao refeitório, sanitários e biblioteca As variações admitidas restringem-se à alternância entre o fechado e o aberto, ao transparente e ao opaco. Novamen aqui predomina a estratégia ordenadora do espaço que vai ao encontro da tradicional visão estruturante da educação.

O CEU inova ao permitir que equipamentos culturais e esportivos d tetura insere-se no sistema escolar instituído oficialme- te, pretendendo qualificar o lugar criado, dotá-lo de um sentido que vá além do cumprimento dos currículos escolares institici 作 Teixeira, mas se distancia significativamente do ponto de vista da arquitetura proposta e de sua relação com o chão, como pudemos verificar.

bloco cultural e esportivo surge de maneira marunç̃es sucedem-se verticalmente, como estratos não identificáveis, ou seja, trata-se de uma organização em camadas que não se comunica com o exterior. En oposição ao bloco educacional, esse outro bloco mantén a mesma modulação e ritmo estruturais, mas não visíveis. Predomina o volume fechado por painéis pré-fabricados em concreto e não há referência às funç̃os desempentadas em seu interior. Sua concepcão original pretendia levar diante a proposta de espaço indeterminado.

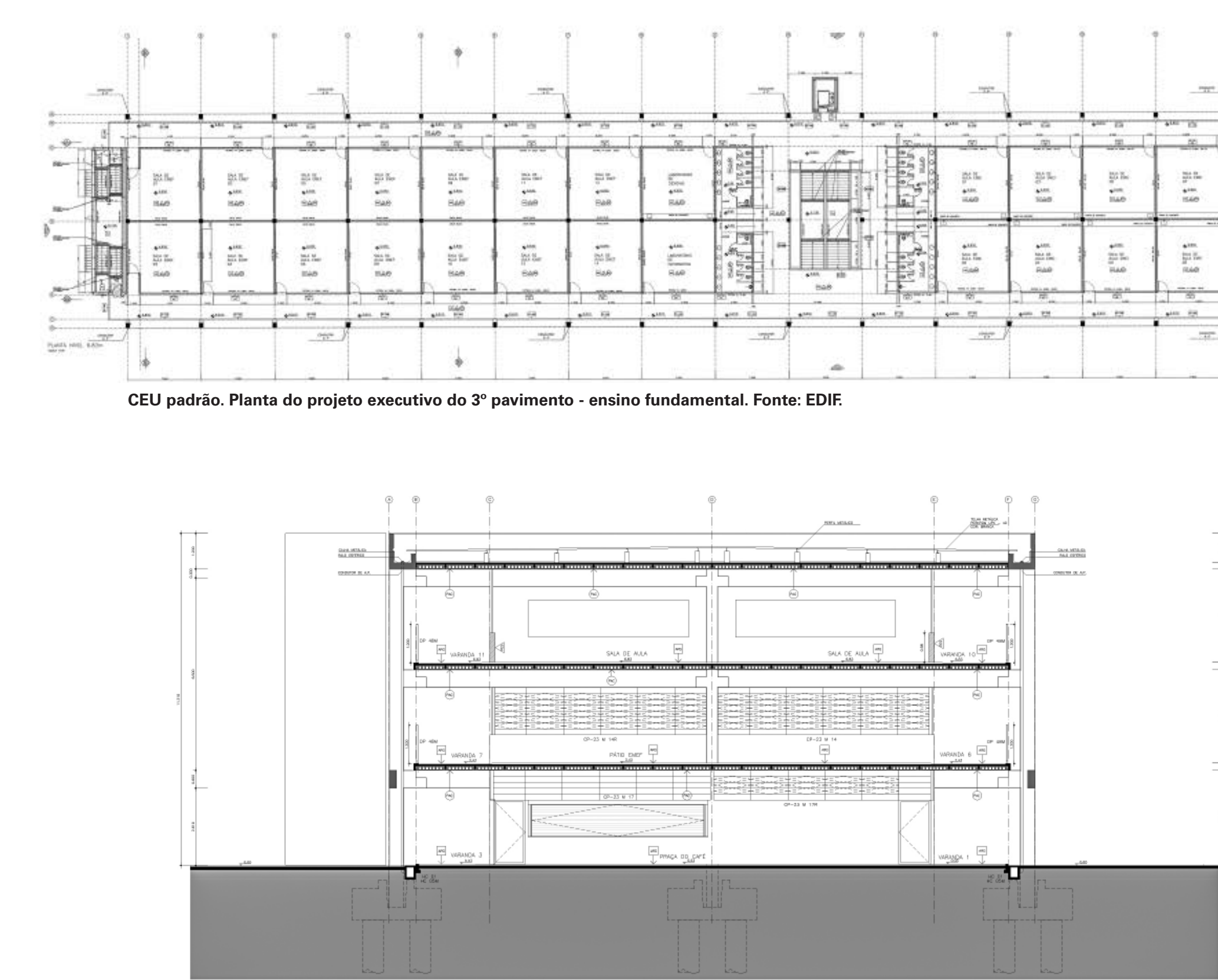

CEU padrâo. Projetto executivo do corte transversal junto aos patios cobertos do téreo, $1^{\circ} 2^{2}$ pavimentos. Fonte: EDIF 

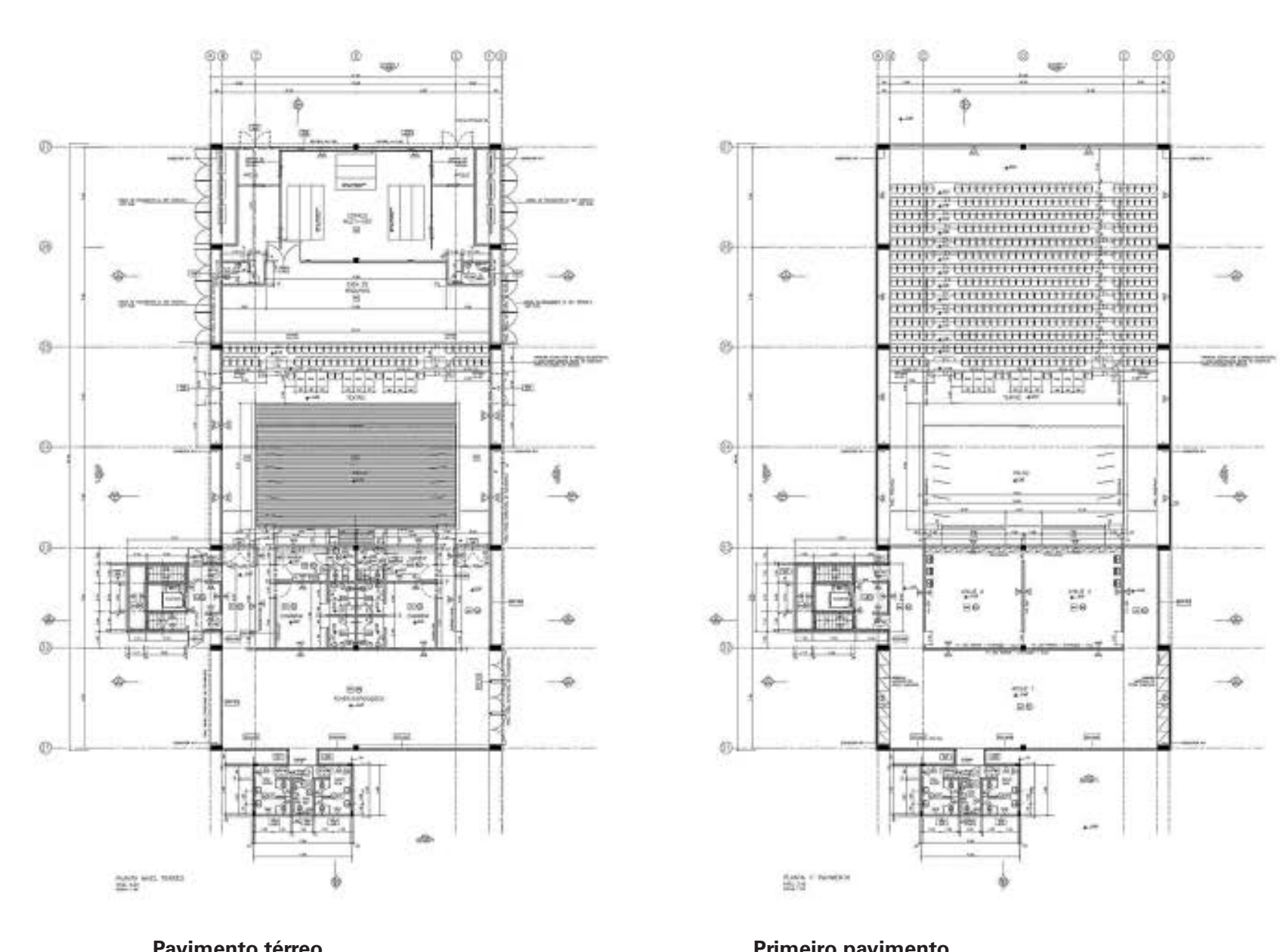

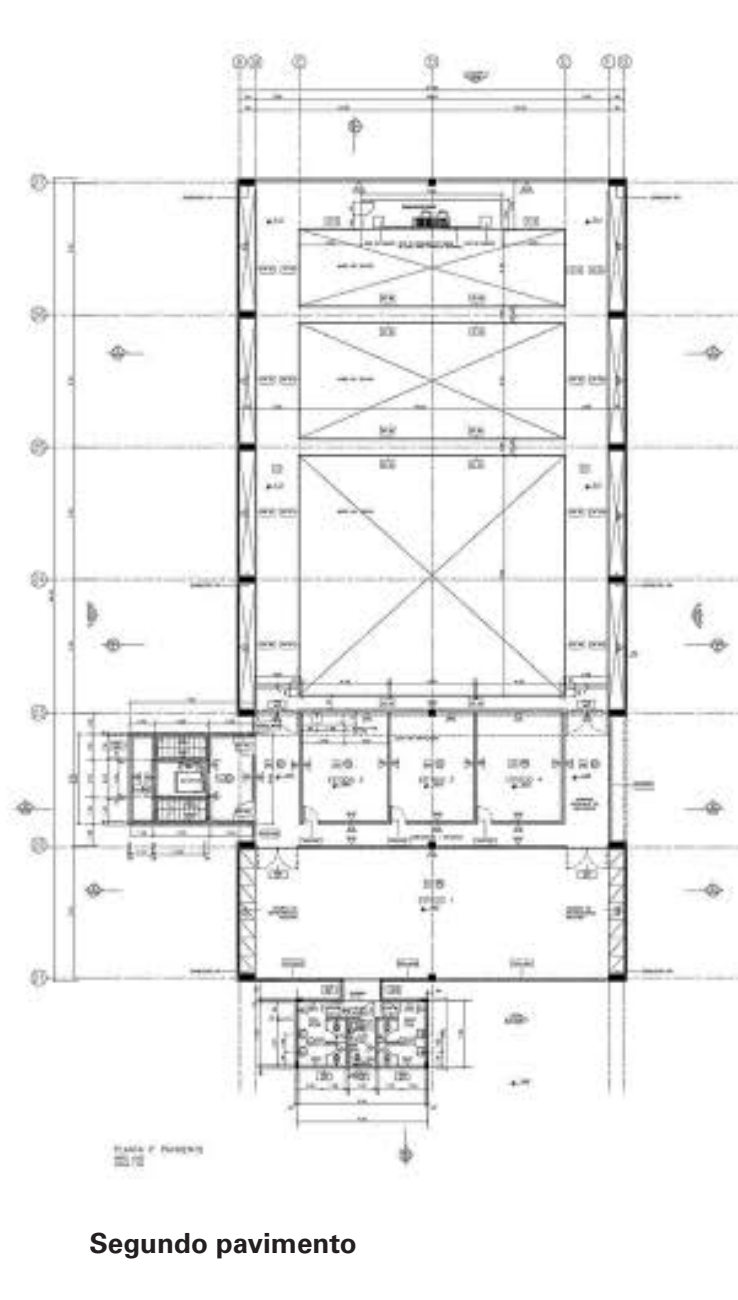

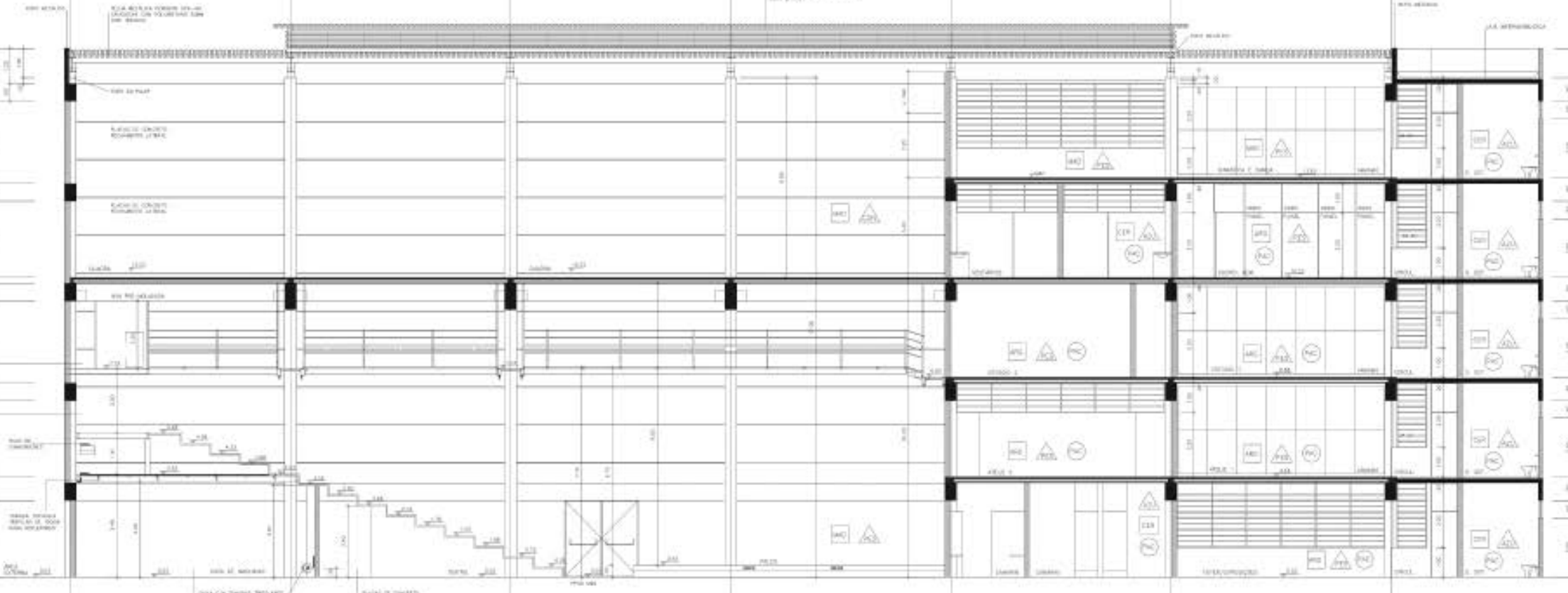

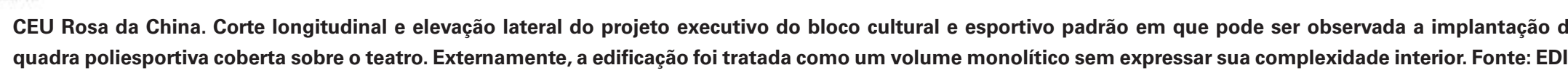

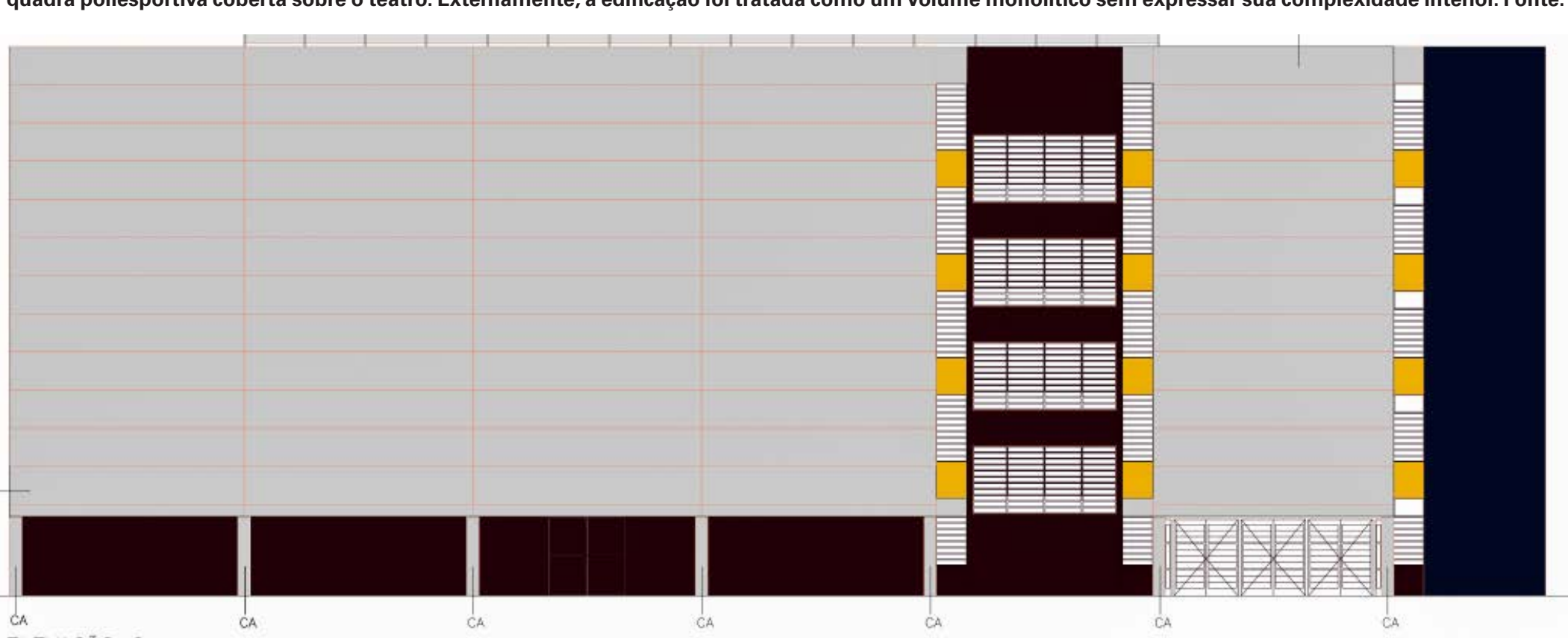


local, deu lugar, no entanto, a uma configuraç̃o tradicionl fron

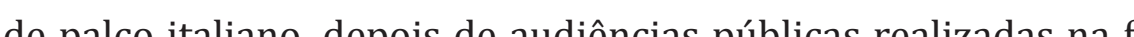

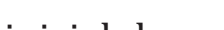

. A mobilidade, entretanto, ainda persiste nos paberta e salas de ensaio, de dança ou de ginástica.

Ao conectar o bloco cultural e esportivo em continuidade a bloco educacionto $\mathrm{C}$ CU Rosa da Chim apresentou una virante do padrão original. Das 45 implantaç̃oes propostas, apenas em três a variação ocorreu, nos CEU Pera Marmelo e Veredas, além do Rosa da China. Segundo Alexandre Delijaicov, em função da diversas audiências públicas realizadas com os moradores, foi decidido que as implantações seriam "todas iguais", ou seja, as três variações realizadas nõo se repetiram como estratégia de projeto. No nosso ely ences des deveriam receber as três edificaçooes, sem a associação formal entre elas, como ocorrera no CEU Rosa da China, e também o balneário, que foi majoritariamente solicitado pela população, segundo Delijaicov. Entretanto, as implantações foram significativamente diferentes em decorrência das dificuldades físicas de implantaçâo principalmente a do extenso bloco educacional.

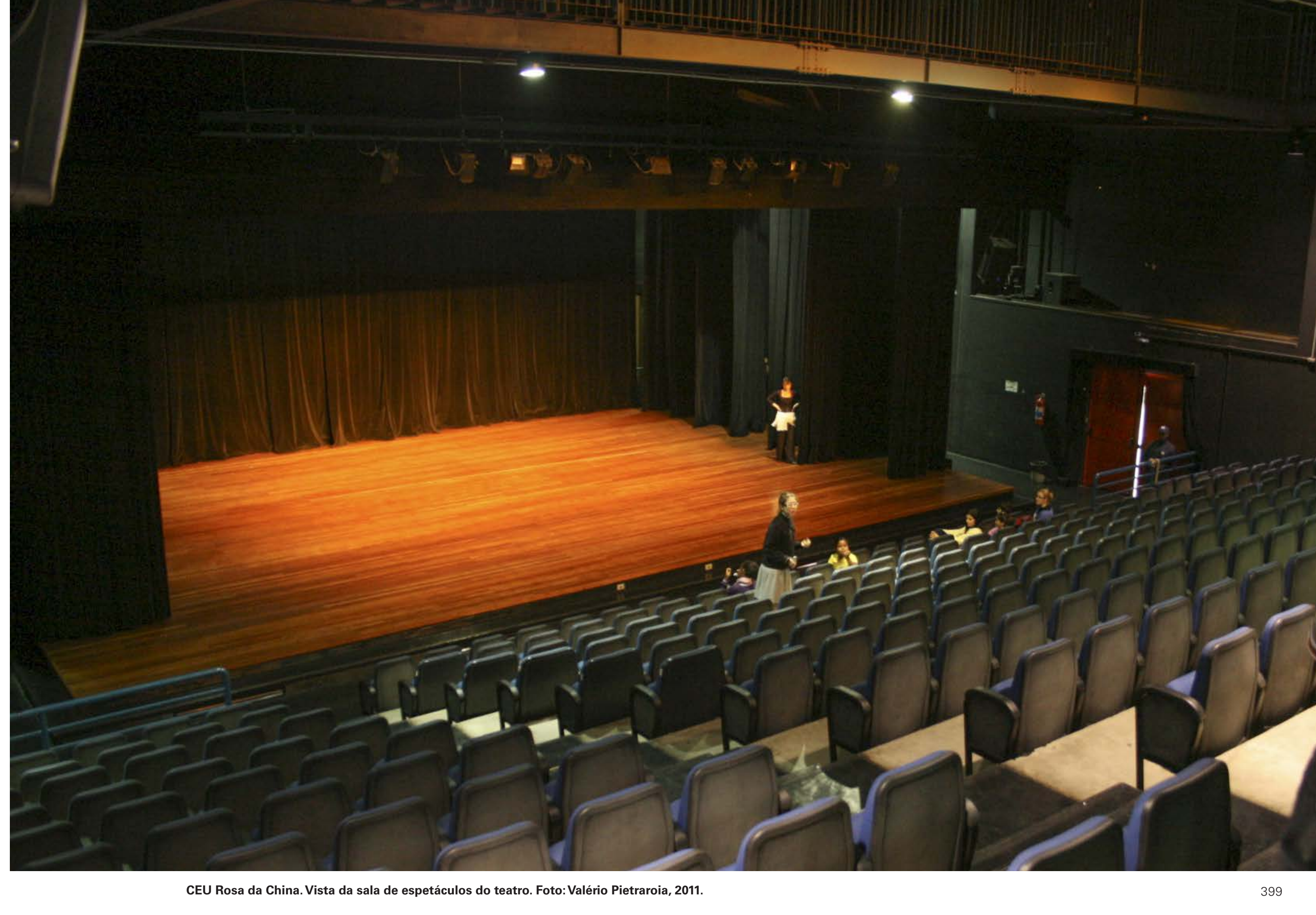




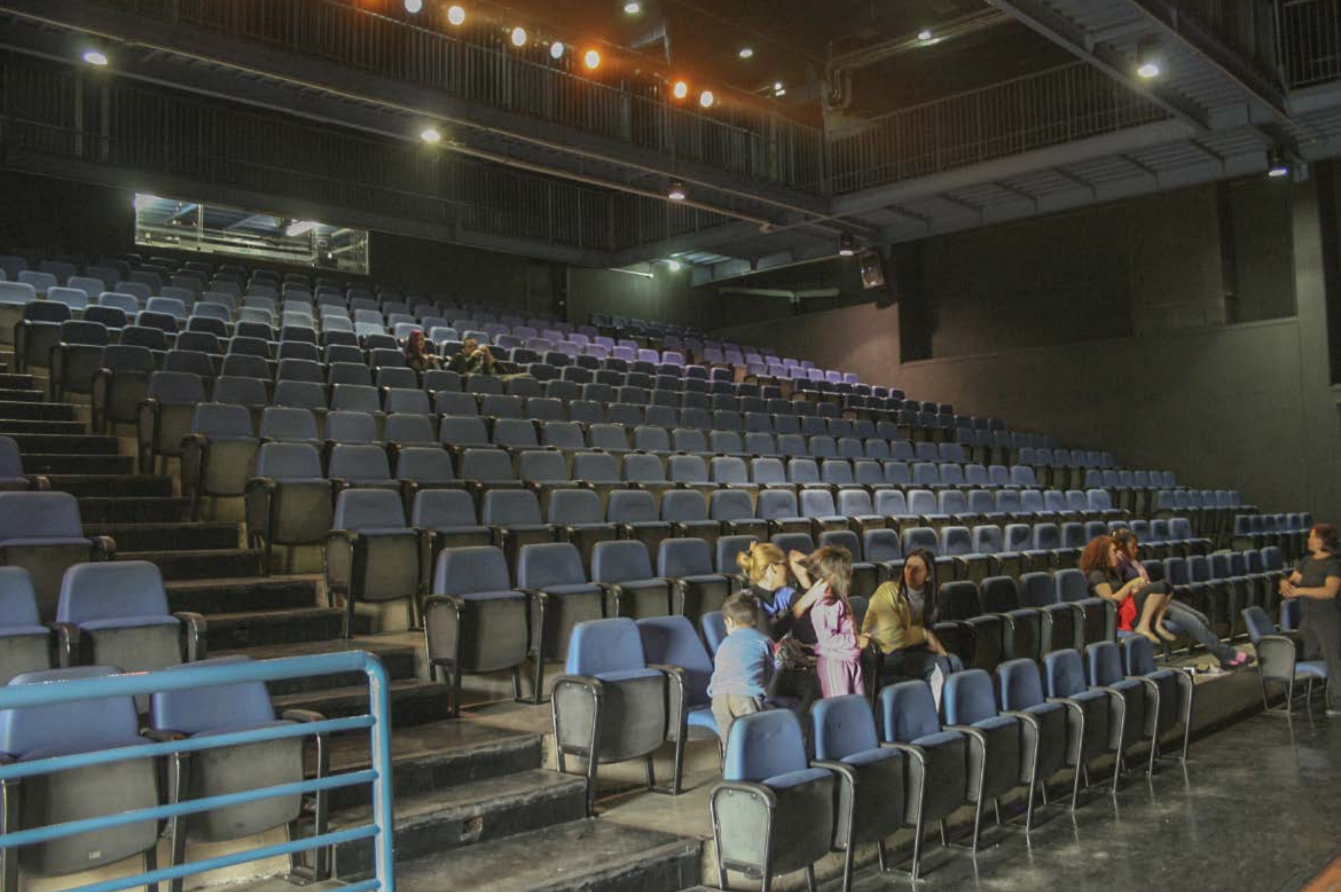

[... todas essas ideias, a pequena florestinha, a divisão da escola por meio de aquários, dividir as classes por meio de aquários, o museu infantil, fazer-se e desfazer-se, a biblioteca infantil, todas essas coisas, foram os arquitetos que fizeram.

Neste depoimento marcante, Hélio Duarte testemuha como a arquitetura deve ir além da resolução pragm tica dos programas propostos. A escolha da escala dos edifícios e as situaçoes de implantação obtidas proporcionam ainda hoje, a inovação de usos, fundamental para um equipamento público formador.

or essa via o CEU responde com extrema precisão às urgências impostas pelo cenário caótico da periferia $\mathrm{d} a$ metrópole. Sua arquitetura austera pretende-se duradoura no entanto, faz-se refém de seu próprio determinismo.

A arquitetura paulista tornou-se célebre quando os projetos escolares que Vilanova Artigas desenvolveu para o Plano de Ač̃o do Governo Paulista na década de $1960^{12}$ alteraram a lógica pavilhonar e seus frágeis elementos de li- gaç̃o (coberturas e marquises), propondo o encadeamento das atividades didáticas e de convivência em um único edfício, capaz de atender de maneira inovadora aos progra mas tradicionalmente estabelecidos. Mesmo com todas a restrições construtivas e orçamentárias da época, a escola proposta admitia variações de escala dos espaços interno ede sua relaç̃o com o contexto imediato. Essa estratégi

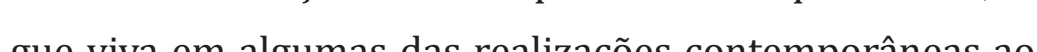
CEU, que foram implantadas pela FDE, como a Escola Jardim Ataliba Leonel, São Paulo, concebida pelos arquitetos Ângelo Bucci e Álvaro Puntoni, em 2003.

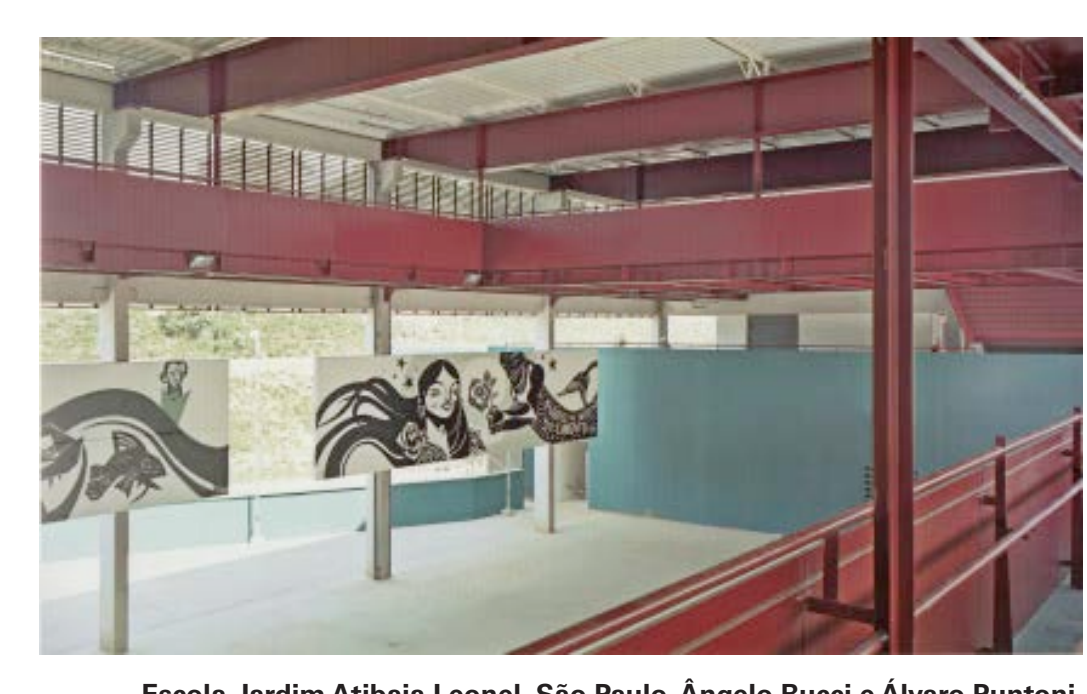




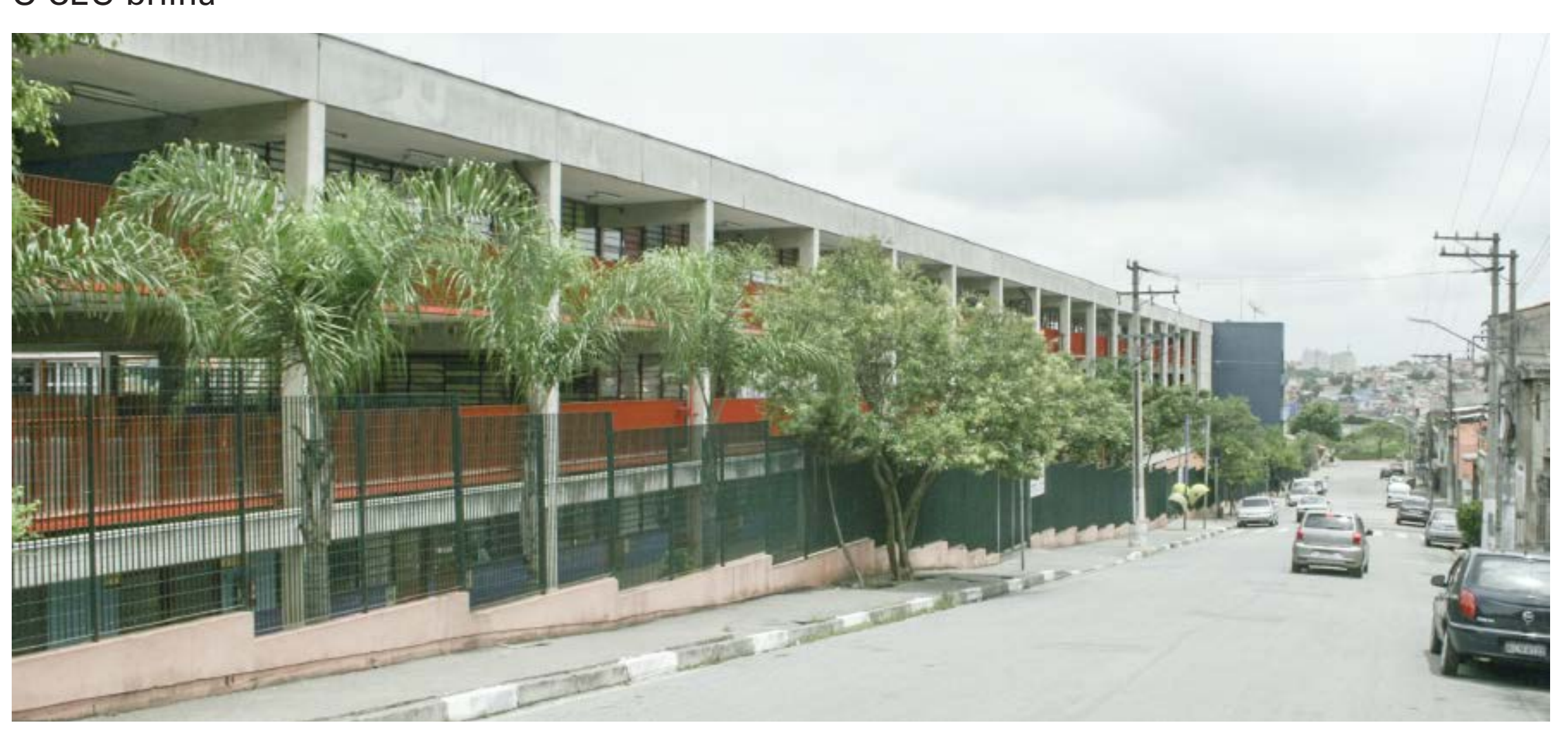

CEU Rosa da China. Vista da fachada nordeste a o longo da rua Clara Petreia. Foto: Valetrio Pietrartia, 2011

Como vimos acima, as hipóteses recentes da arquitetura paulista identificaram caminhos que, $c$ alcado tradição experimental e edificante, apontam para possibildades importantes que devem ser investigadas. Dentro dessa perspectiva, o programa dos CEU, após quase quinze anos de sua concepcão, mantém-se sólido na sua proposta de pe-manência e transformação em continuidade, assumida por

seus autores, defensores dessa tradiç̃̃o. Estaríamos então un sisten de intervenção amplo no qual ela parece menos relevante do que em outros momentos de nossa história recente?

Acreditamos que não. 0 CEU mostra que é possível encarar os desafios com a experiência consagrada para consolidar a permanência da arquitetura. Marina Waissmann

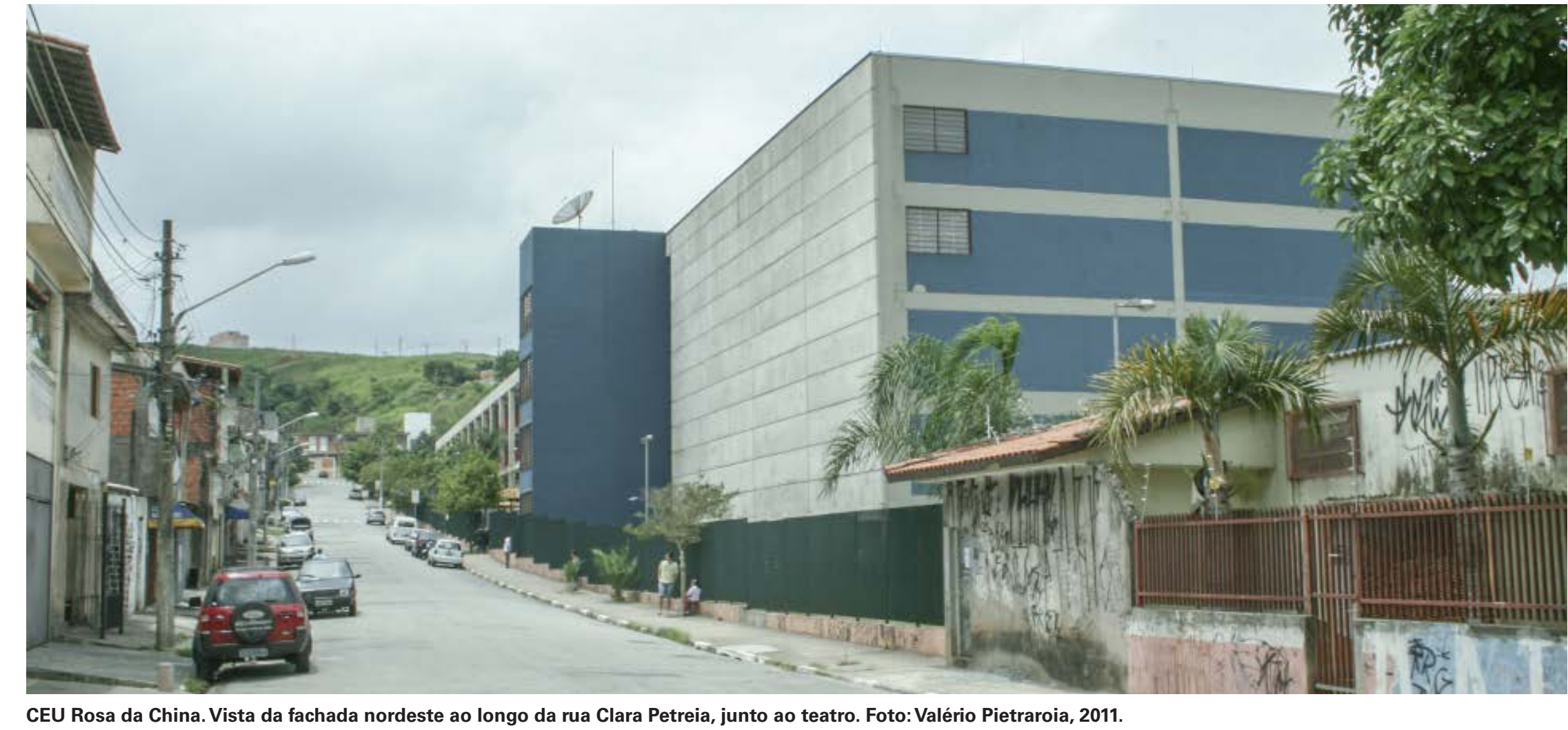

bem assinala: "a tipologia não é suficiente para permanecer mas o tecido, como matriz sim, reproduzindo-se e verticalzando-se sem a devida adaptação" (WAISSMAN, 1993: 58). Mas por que as novas geraç̃̃es não encaram esses desafios procurando reverter essa constatação com a exploração de novos caminhos e propostas de hipóteses que possam ir além das solucões instituídas? A capacidade transformadoGer mensurada num curespaço de tempo mas fica evidente que sem sua contribuição vamos permanecer dependentes de todas as outras forças que determinam a realidade metropolitana, tanto do ponto de vista econômico, quanto político e social. 


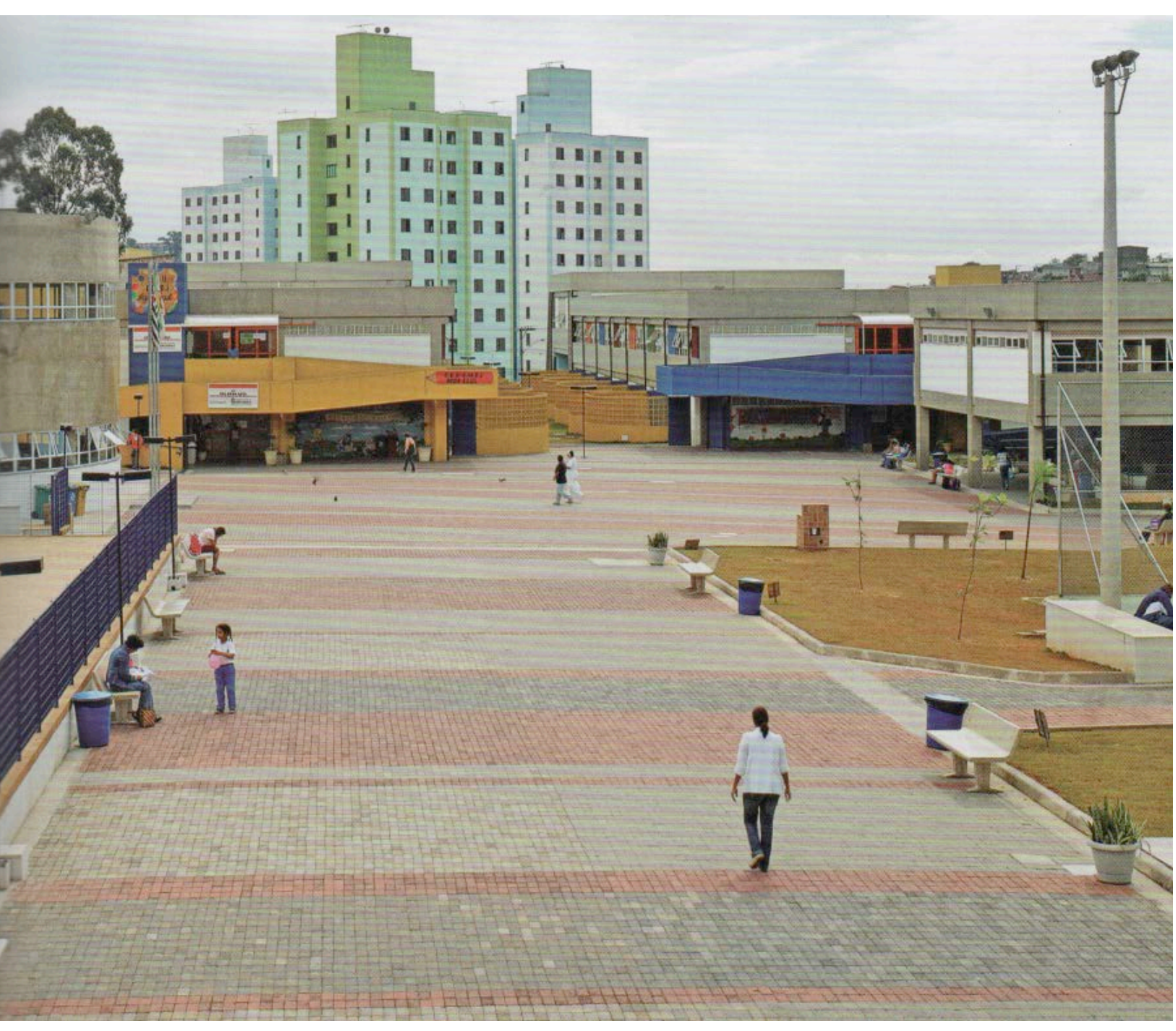

CEUÁgua Azul. Vista da praça central a partir da varanda da sala de dannga do bloco cultural. Foto
Como foi possível observar até aqui, a continuidade do programa no qual o CEU se insere por mais de 15 anos merece destaque. A força de sua primeira fase de implantação, que chamamos de CEU I, reside na abrangência das atividades formadoras presentes no programa e na capacidade do projeto $\mathrm{d}$ ser implantado através de elementos construtivos pré-fabricados. 0 primeiro aspecto ampliou o atendimento das carências sociais das diversas regiões periféricas do municipio de São Paulo enquanto o segundo permitiu que o programa CEU fosse desenvolvido e implantado durante o ciclo administrativo de quatro anos. Em função disso, o CEU tornou-se referência como equipamento públco de maneira relativamente rápida. e a rede de escolas-parque e escolas-classe idealidas por Anisio Teixeira precisou de três décadas para ser implantada e, cono vimos, viabilizourse com plon par ser nte coma const vecta como programa mesmo com as mudanças de ordem política administrativa ocorridas no município ${ }^{177}$. A continuidad do modelo inspirado na escola-parque como programa fo aém das pretensões político-administrativas de um mand ao contrário do que ocorre historicamente no Brasil.

Quando o II Programa Especial de Educação do Rio de Janeiro retomou a implantação dos CIEP no final da dé cada de 1980, a equipe liderada por Oscar Niemeyer manteve o projeto original ultrapassando a meta de 500 unidades mplantadas, mas não podendo garantir a mesma diversiade de atividades oferecidas pelo equipamento, além de sua função de educação formal, como assinalamos na primeira parte deste capítulo.

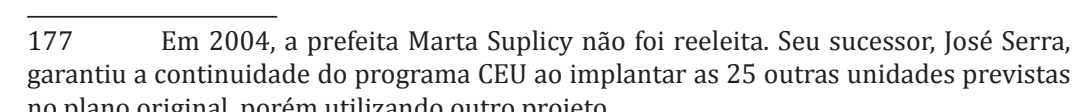

CEU II teve sua implantação iniciada com um plano já aprovado, ou seja, os 25 locais que receberiam o equipamento já estavam definidos e os procedimentos de orden legal e administrativa equalizados. Entretanto, duas orientações da nova administração municipal levaram ao desenvolvimento de um novo projeto. Segundo o arquiteto Walter Makhohl178, o objetivo foi distribuir o programa em um número maior de edificações especializadas de menor porte, que permitiu maior independência funcional, especialmente (a) flexibilidade de implantação do conjunto em terrenos de menores dimensões. Makhohl liderou a equipe autora do projeto do CEU II, escolhido após consulta realizada pela Prefeitura de São Paulo. Ainda segundo ele, os projetos executivo de cada implantaç̃o foram fornecidos por cada sempre sua equipe para o desenvolviment $0^{179}$.

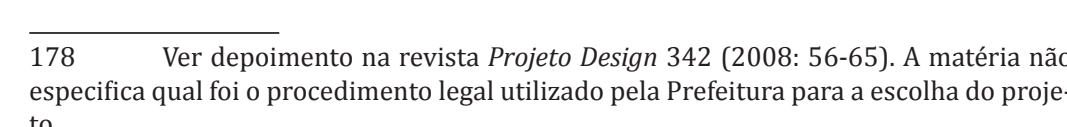

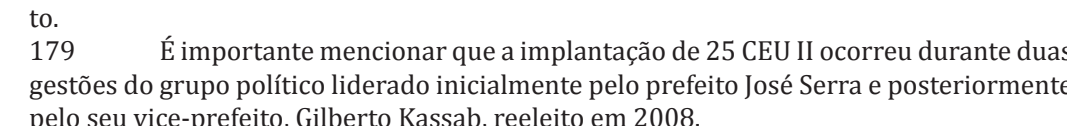


projeto das edificações do CEU II manteve apenas a opção pela construção pré-fabricada das estruturas em concreto e aço. distintos do foi distribuído enter privilegiou a horizontalidade de cada bloco especializado todos com apenas dois pavimentos, $\mathrm{e}$ a independência total entre eles. Como pode ser observado nas plantas apresentadas a seguri diferentemente do projeto do CEU I Ca possui seu próprio sistema de circulação vertical, se próprio conjunto de sanitários e de refeitório, quando necessário. Nesse sentido, as novas implantações superam certa dependência entre os blocos que assinalamos no projeto do CEU I. Por outro lado, a concentração da infraestrutura que orientou de maneira decisiva o projeto original abandonada em favor de maior liberdade nos arranjos de cada implantação.
Inicialmente, ao comparar as diversas implantaçōes fica evidente o retorno à organização pavilhonar, em certa medida muito mais próxima da experiência do $2^{\circ} \mathrm{Conven}$ Escolar ou mesmo do CIEP de Niemeyer ${ }^{180}$. A grande forç do projeto de Makhohl é a praça que domina o conjunto substituindo o balneário do projeto original. A praça ou esplanada é a plataforma para onde todas as atividades convergem ao mesmo tempo em que se relaciona com a cidade.

A praça vai sendo conformada em função dos limites físicos do lugar em que o equipamento será implantado. No CEU Água Azul ela ocupa o centro do conjunto graças à generosidade da frente do lote voltado para a rua, enquanto no CEU Vila do Sol, a implantação exigiu um espaço linear mais próximo de uma rua interna. Em situações mais consolidadas, a praç redesenha a esquina como no CEU Jaguaré, ou cria um espaço interno acolhedor, protegendo-se do meio urbano dominado por complexos viários, como no CEU Tiquatira.

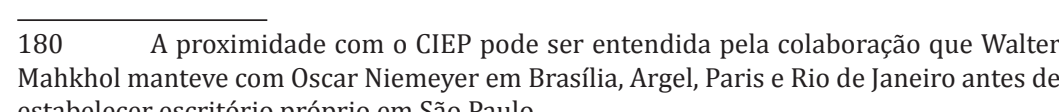




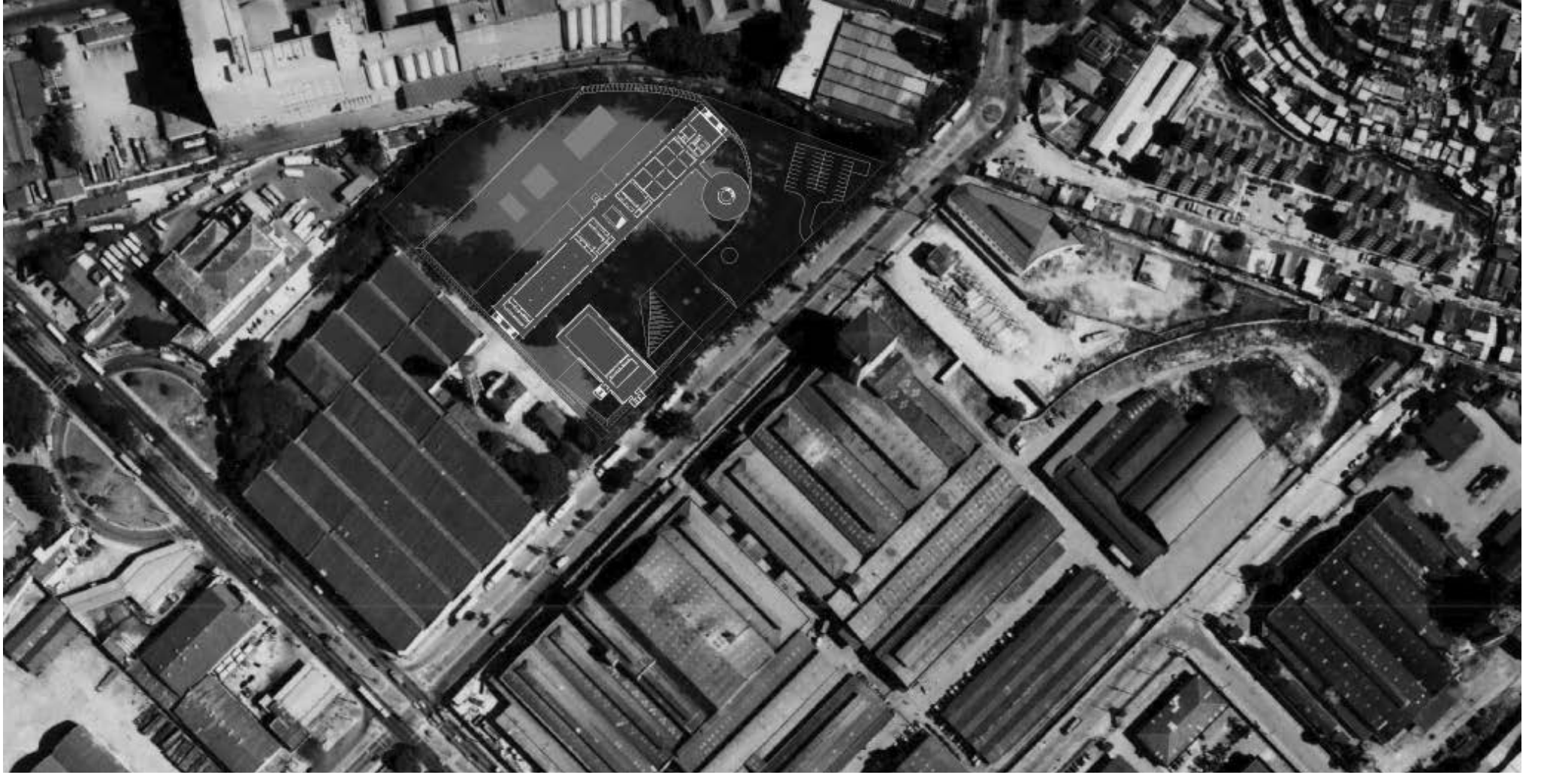



-

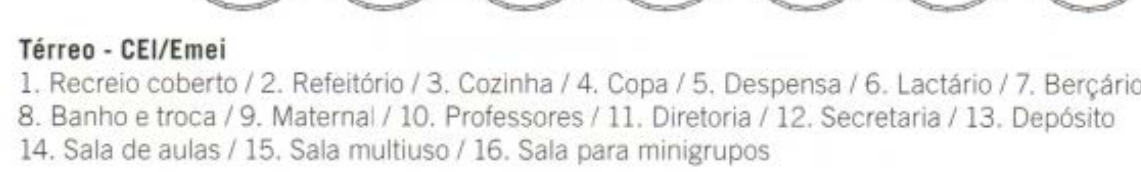
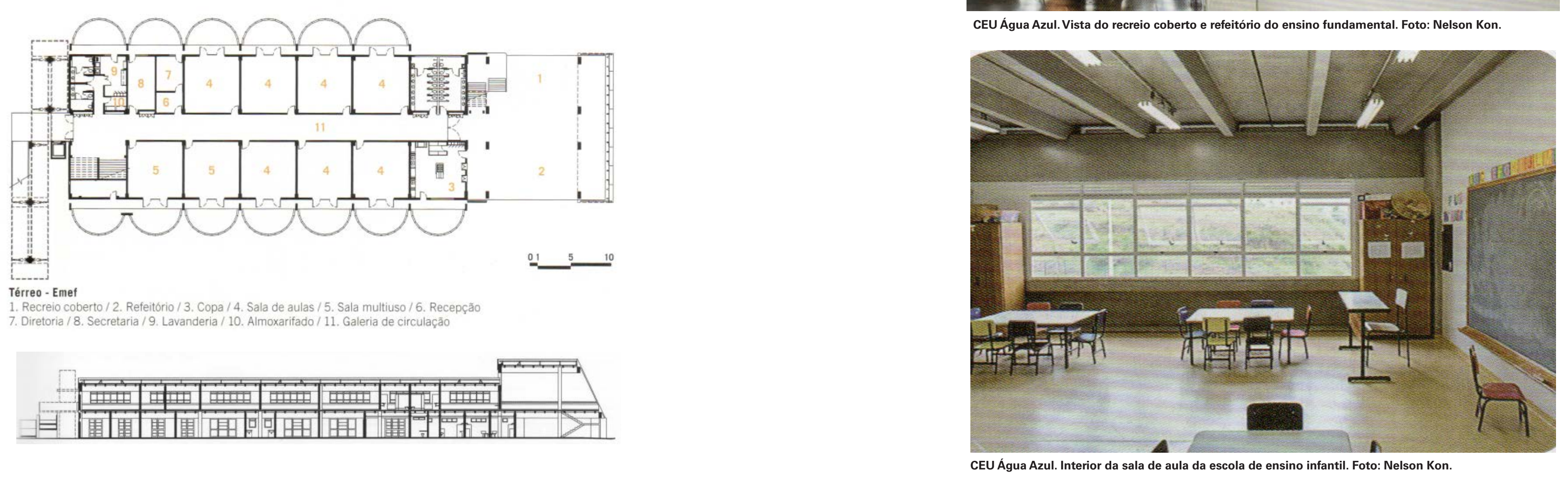


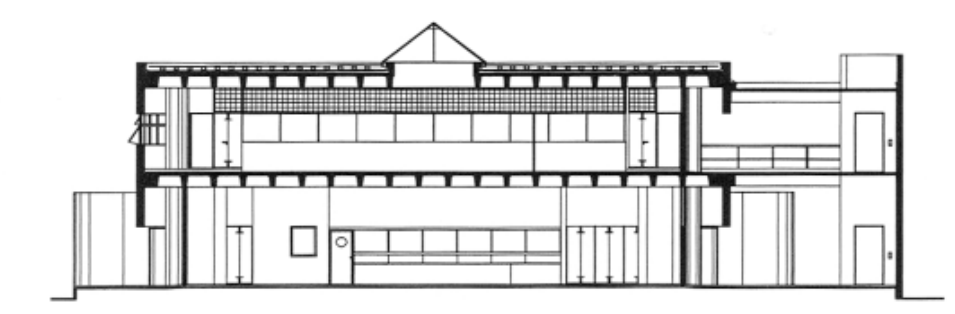

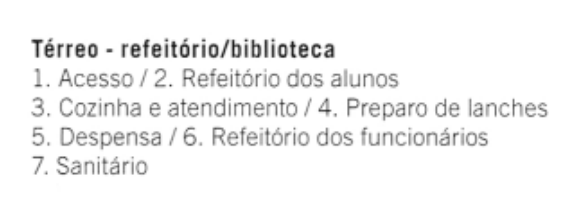
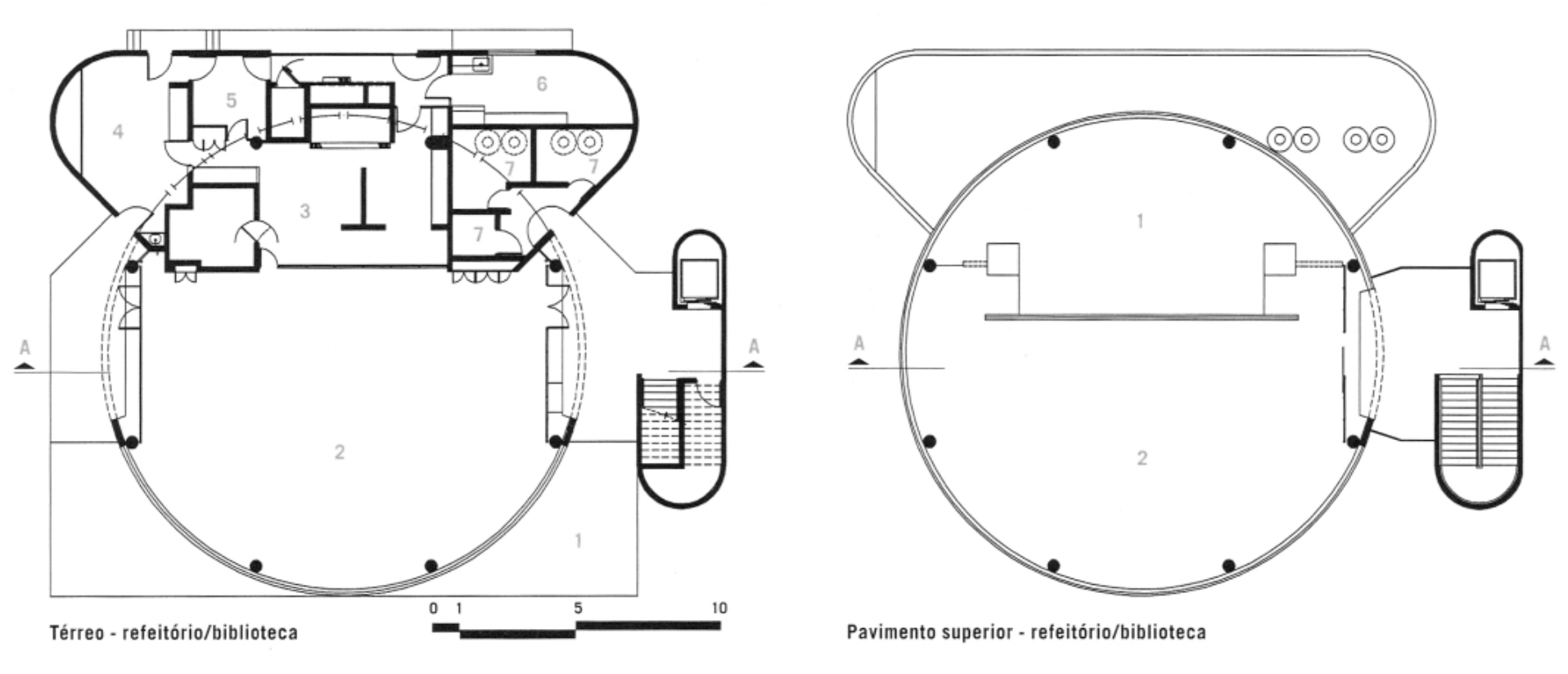

Cabe ressaltar ainda que a concepção da edificação de vocação cultural e esportiva, que atende também à comunidade local, mantém a proposta original do $\mathrm{CEU}$, po

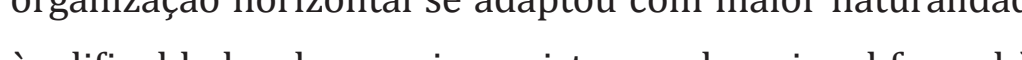
às dificuldades de associar o sistema educacional formal às atividades sociais do bairro. Isso significa que os fluxos internos e externos podem ser melhor organizados graças à diversidade de acessos e de orientaç̃o trazida pela proposta.

Por outro lado, a falta de identidade entre os blocos e principalmente a pouca integração entre eles contribuíram para afastar as atividades formadoras complementares como parte fundamental do equipamento de aprendizagem diferentemente do que ocorreu com as obras do $2^{\circ}$ Convênio Escolar. Sem a proximidade das edificações, sem os singelos percursos entre elas e, principalmente, sem a abertura para nente, sem a abertura para a cire, quild coordenada por Hélio Duarte, o isolamento das escolas reduziu as possibilidades de aproximação entre todas as atividades, apesar dos benefícios administrativos obtidos. 
CEU III

O CEU como território

integrada de Equipamentos visa melhorar a acessibilidade do cidadão a serviços públicos de qualidade. A implantação d novos equipamentos sociais - creches, escolas de educação infantil, de educação integral, unidades básicas de saúde e pronto atendimento, hospitais e centros culturais, centros esportivos, dentre outros - deve se dar de forma articulada no território. Assim, a implantação de novos equipamentos deve ser feita, sempre que possivivel, pela integraçáo de dois ou mais equipamentos num mesmoterteno, com una arqutetura que facilite ficidales fon eles, preservando suas especi-

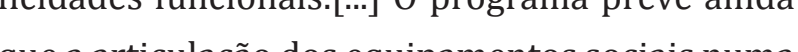
que a articucacao dos equipanentos socials numa socis ex

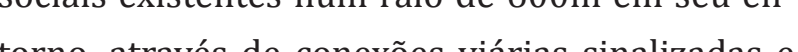
torno, atraves de contoes varias sinalzadas e a

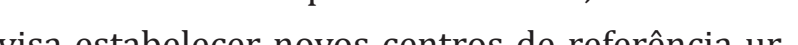

bana, que agregam diversos serviços sociais num unico lugar, facitrando 0 acesso dos cidadaos

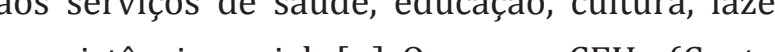

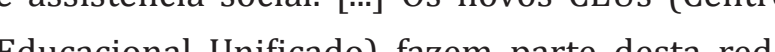

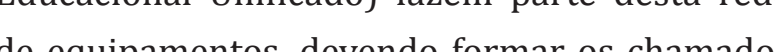

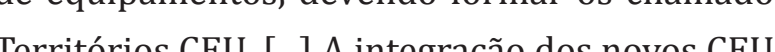

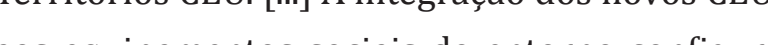
assim

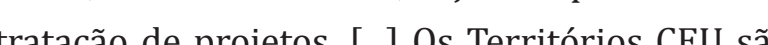

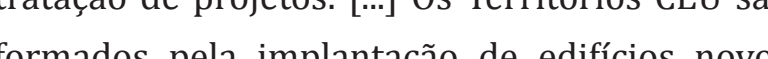
(blocos de educacão, cultura esportes) mos (bros esportivos existentes, assocides à reform de suas instacõos à res, assocãos à refor equipmestos existentes, com remogão dos obstáculos que impedem sua maion into dos obsquadra e da impementac̃o de acessibilio melhorias nas calcadas sinalizaño e pisagisno das vias de ligac̃o entre o futuro CEU eg equ pamentos públicos do entorno.

Termo de Referência, SP Urbanismo
A continuidade do programa CEU a partir de $2013^{18}$ retomou o projeto original procurando consolidar a noçãa de rede de equipamentos em que o CEU é a referência em torno da qual todos os outros equipamentos sociais irão se integrar. No trecho ao lado, o documento publicado pela Prefeitura indica uma mudança significativa de rumo ao introduzir a noção de território como fundamento para o desenvolvimento e a implantação do projeto. Nesse sentido, o programa amplia o raciocínio de projeto não somente ina rede pública do município mas especialmente a da infraestrutura de mobilidade urbana para viabilizar a integraçãa da referida rede, constituindo assim o Território CEU.

No que concerne nossa pesquisa, deve ser destacad a decisão da Prefeitura de São Paulo de revisão do projeto original ${ }^{183}$, abrindo caminho para transformar em sistema modelo original repetido na primeira etapa de implantação o CEU I. Em outras palavras, para atingir a meta de constitui um território em que o CEU articule a rede de equipamen-

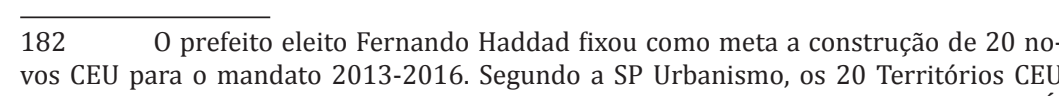

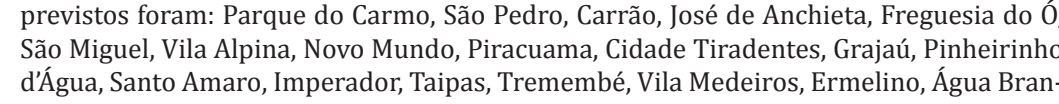

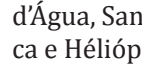

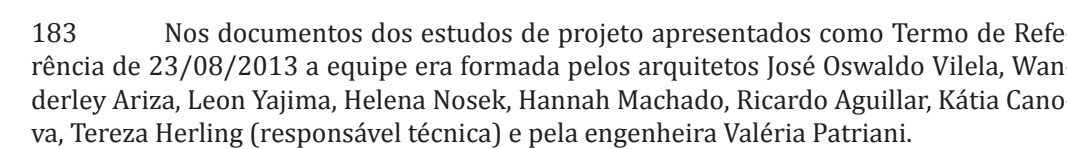

tos, o projeto deveria oferecer variações, chamadas de "tipologias" pelo Termo de Referência, em que as condições do lugar pudessem ser melhor consideradas. Para tanto, as implantacọoes dos CEU seriam feitas em Centros Esportivos Municipais existentes que possuíssem potencial para ampliar sua capacidade de atendimento, ou seja, que funcionassem com certa ociosidade. A decisão nos parece acertada na medida em que trouxe para o projeto as qualidades locais sem abrir mão da repetição do padrão. 0 projeto agora incorpora a missão de contribuir na recuperação do ambiente urbano e de redirecionar suas vocações não se limitando, portanto, à prestação de serviç̧os de natureza social.

Assim, o projeto do CEU III pretendeu resolver os limites do projeto original através da sua revisão e da sua maior flexibilidade, ao mesmo tempo em que desenvolve diagnósticos da estrutura urbana na qual será instalado, considerando seu raio de aç̃o de $600 \mathrm{~m}^{184}$.

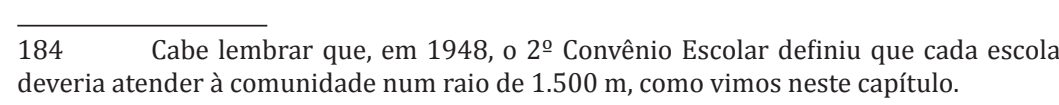




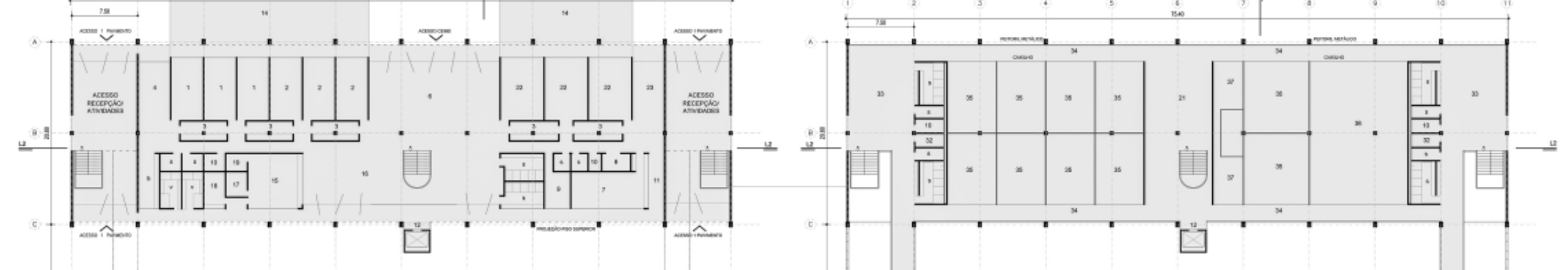

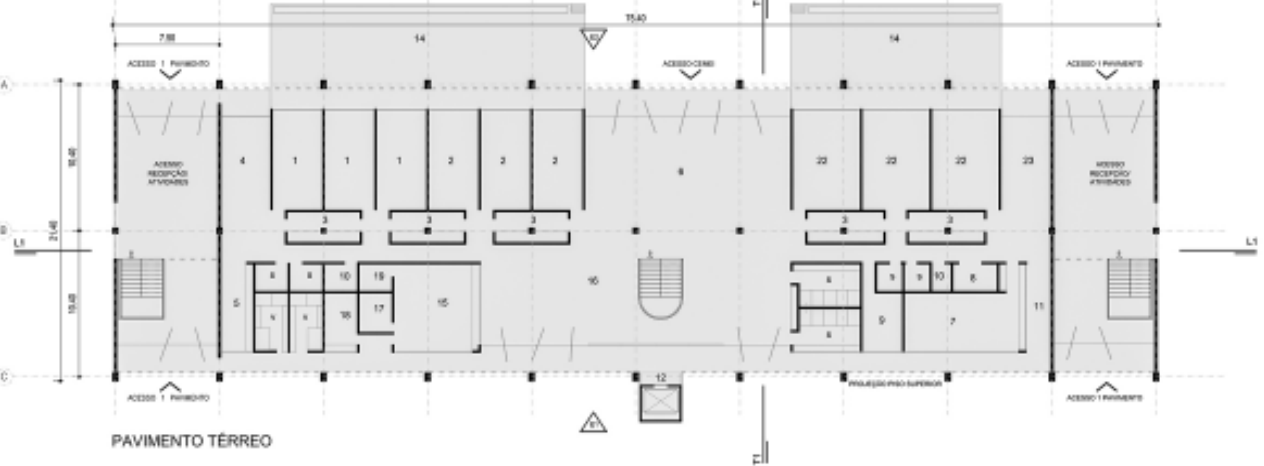

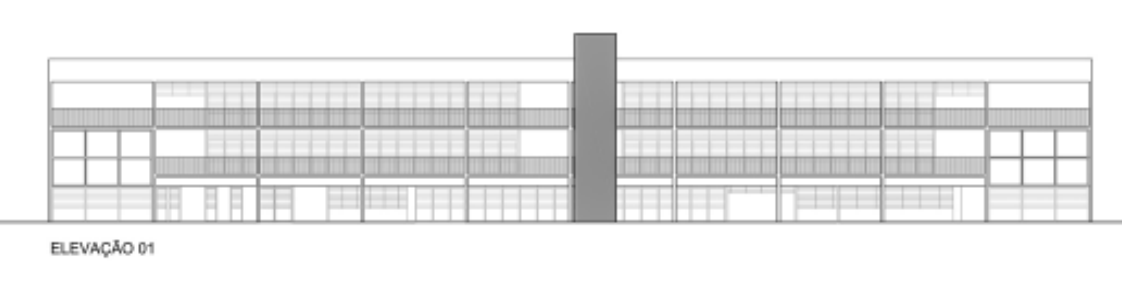

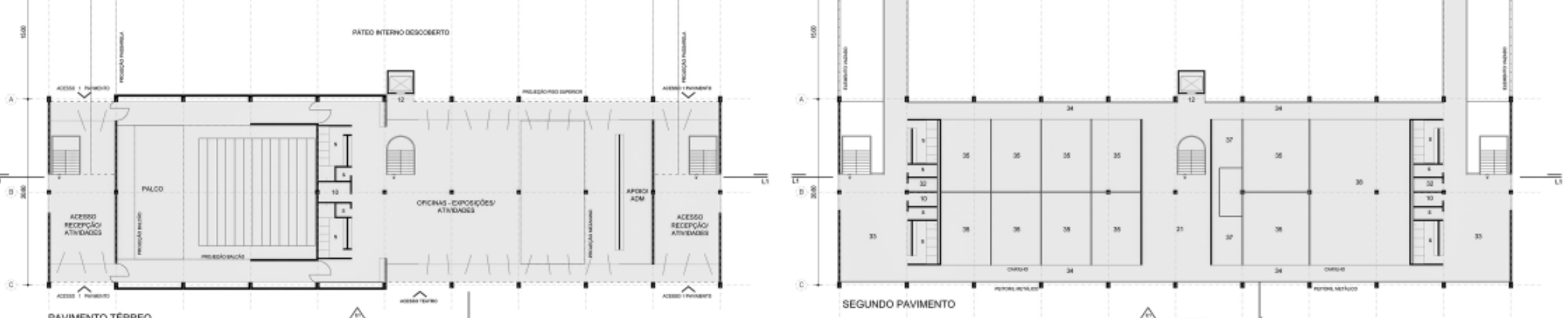

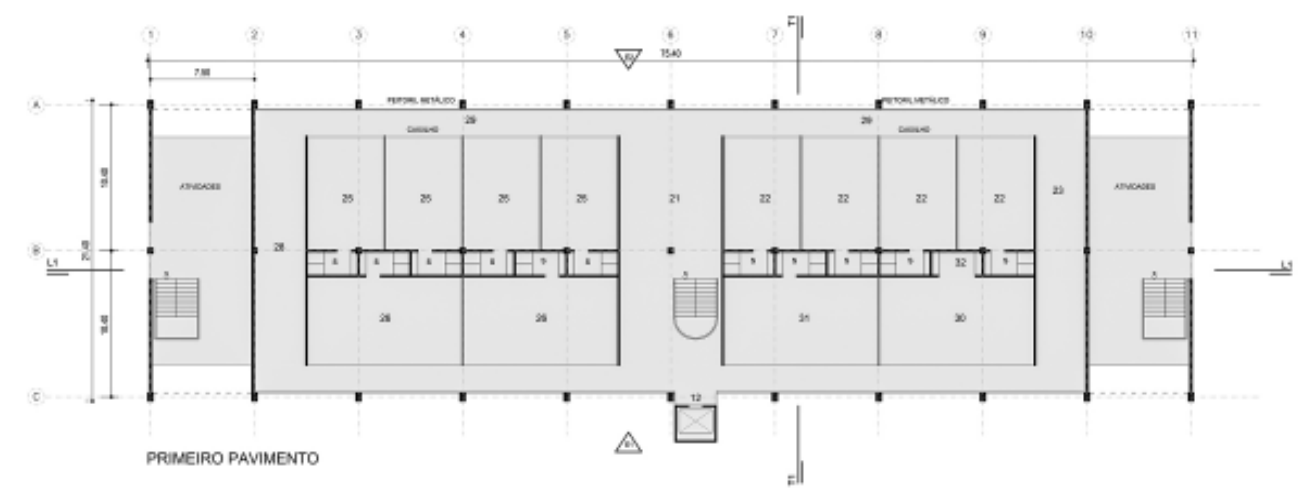

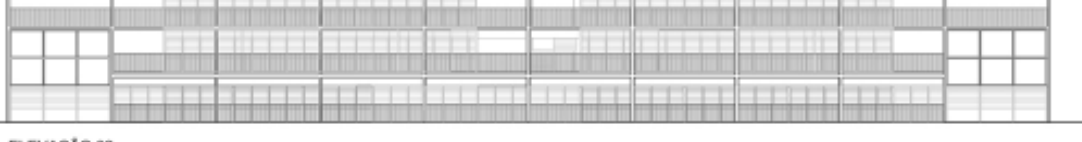

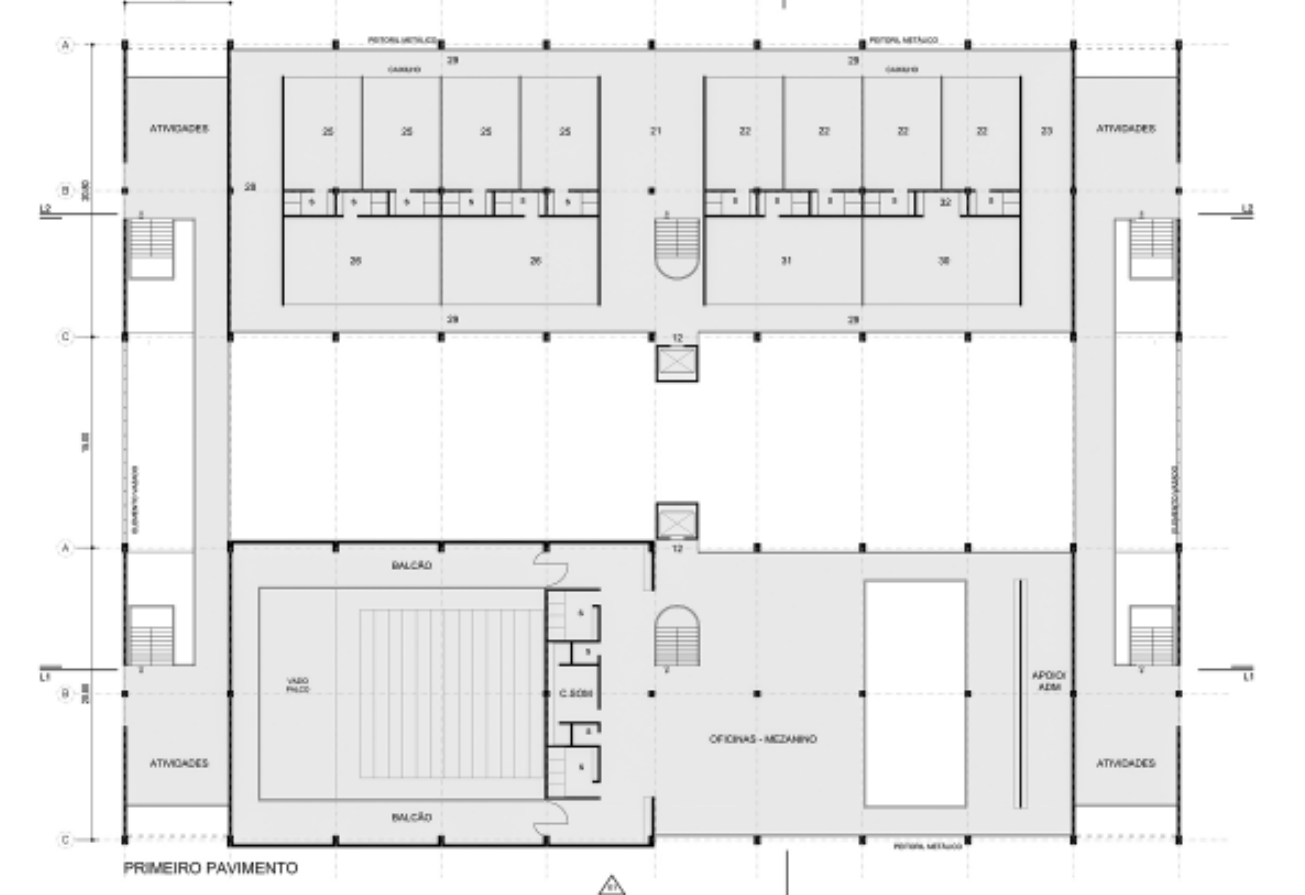

Hit

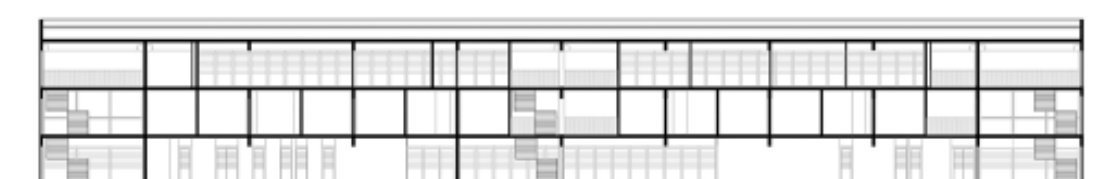
Teritítio CEU. Plantas, corte e elevaçäo do projeto básico da variante da
tipologia. Fonte: SP U Urbanismo. 
0 processo de desenvolvimento do projeto executivo padrão do CEU III e de suas implantaçōes ocorreu segundo semestre de 2013 e durante 0 ano de 2014 de licitações públicas. Vale salientar que nosso objetivo não é entender e avaliar o referido processo e sim examinar as modificações introduzidas no projeto e em sua aplicação.

Após a revisão do padrão, o CEU assumiu uma visão muito mais sistêmica do projeto. Em certa medida, é notavel como os blocos originais foram flexibilizados, passand ser denominados "agrupamentos funcionais". As simula cões de associação entre os agrupamentos funcionais foram chamadas de "arranjos" compostos de "composiçõe de articulaçoese". 0 sistema manteve os agrupamentos educação, cultura e esportes, sem que nenhum deles constituísse obrigatoriamente uma edficaça isolada É ainda o agrupamento de uso múltiplo, pois ficou claro o potencial que tem o CEU para atender a programas ainda nã elaborados ou consolidados, como ocorreu com os Telecentros, a UNICEU e os Labfabs ${ }^{18}$

0 padrão apresentado pela Prefeitura em abril 2014 sugeriu quatro "arranjos lineares", quatro "arranjos paralelos" e quatro "arranjos verticais" em que os agrupamentos são associados ou separados e complementados por "elementos de conexão" (escadas e elevador) e "ambientes de apoio" (sanitários).

Cabe sublinhar que o projeto pretendeu reseatar fundamentos do padrão original desenvolvido em 2003 mas reconheceu a necessidade de resolver seus limites. 0 projeto agora parte da independência funcional em direçã à integração desejada. Em outras palavras, a experiência do CEU II demonstrou ser fundamental para que o equipamento de aprendizagem desempenhasse inicialmente sua missão primordial de aprendizagem para poder expandi-la em direção às outras atividades formadoras. 0 caminho inverso materializado no CEU I exigiu a introdução de dispositvos administrativos e físicos complexos, alheios à intenção de simultaneidade funcional, atestando , como pudemos observar, uma certa rigidez formal.

Ao examinarmos os documentos do projeto básico, é possível verificar que, ainda que a modulação estrutura a determinação dos elementos construtivos indiquem un grau significativo de padronização extremamente próxim do projeto do CEU I, há uma sinalização clara de que a liberdade de implantação oferecida ao projeto é o fundamento principal na construção da noç̃ão do Território CEU.
0 documento ${ }^{186}$ anterior sugere doze implantações que apresentam significativas diferenças entre si. Em prmeiro lugar, permitem estabelecer relações de proximidade variada entre as áreas funcionais, tanto através da verticalização do conjunto quanto de sua organização pavilhona Em segundo lugar, permite maior liberdade na orientação de cada área funcional em relação ao conjunto implantado. A partir desses procedimentos iniciais é possível eleger con maior precisão o nível de implantação do conjunto e principalmente potencializar suas relações com as áreas livres próximas e com o contexto urbano. É uma mudança substancial em relação ao projeto original na medida em que considera aproximação do meio ambiente construído com o meio ambiente natural um fundamento necessário para que as ativas quais se deparou o programa CEU como as dimensões reduzidas dos terrenos ou sua topografia acidentada, situações frequentes no município de São Paulo são encaradas como atributos do projeto na medida em que

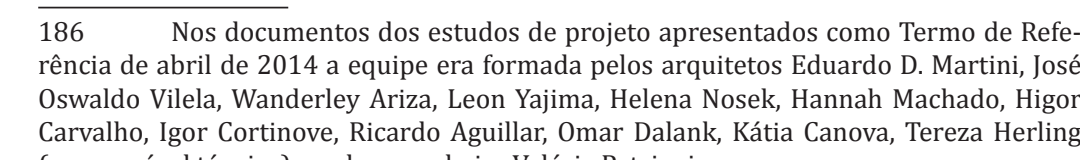
materializar situações espaciais inovadoras.

Cabe destacar que o projeto CEU III, ao assumir a noção de sistema, abre caminho para soluções de implantação. Como exemplo, podem ser citados pátios interno totalmente contidos pelas edificações, como praças interiores ou, ainda, a decisão de partir de um procedimento de transposição para vencer grandes desníveis do terreno, minimizando a necessidade de obras de contenção e estabelecendo nova relação com o entorno.

Além disso, quando se examina a mobilidade no interior das edificações, pode-se constatar que os novos arranjos permitem fluxos de pessoas com maior variedade maior aproximação, reduzindo o isolamento funcional que marcou o projeto original.

O desenvolvimento do projeto executivo do CEU III teve como desafio manter os rígidos critérios de padronização construtiva do CEU I mas mantendo sua nova orientação que permitisse a variabilidade de agrupamentos e de implantações ${ }^{18}$

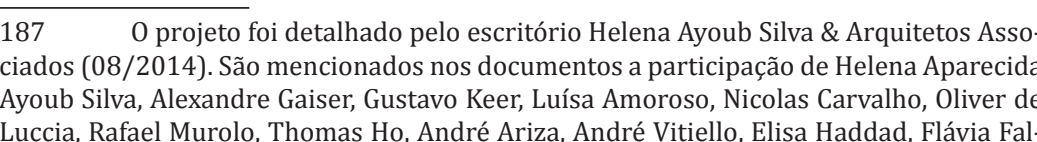




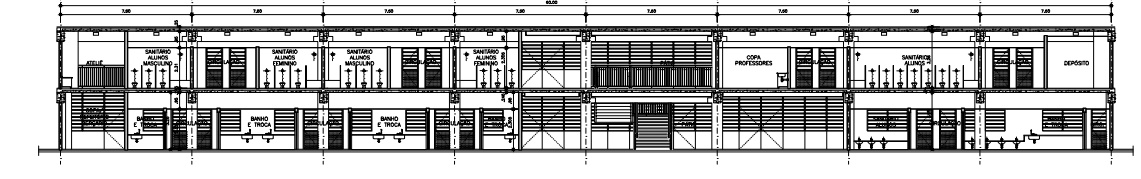

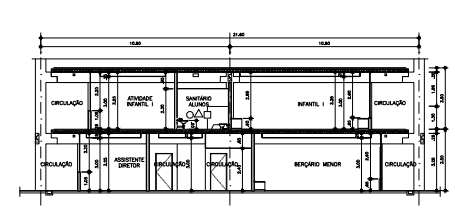

correA
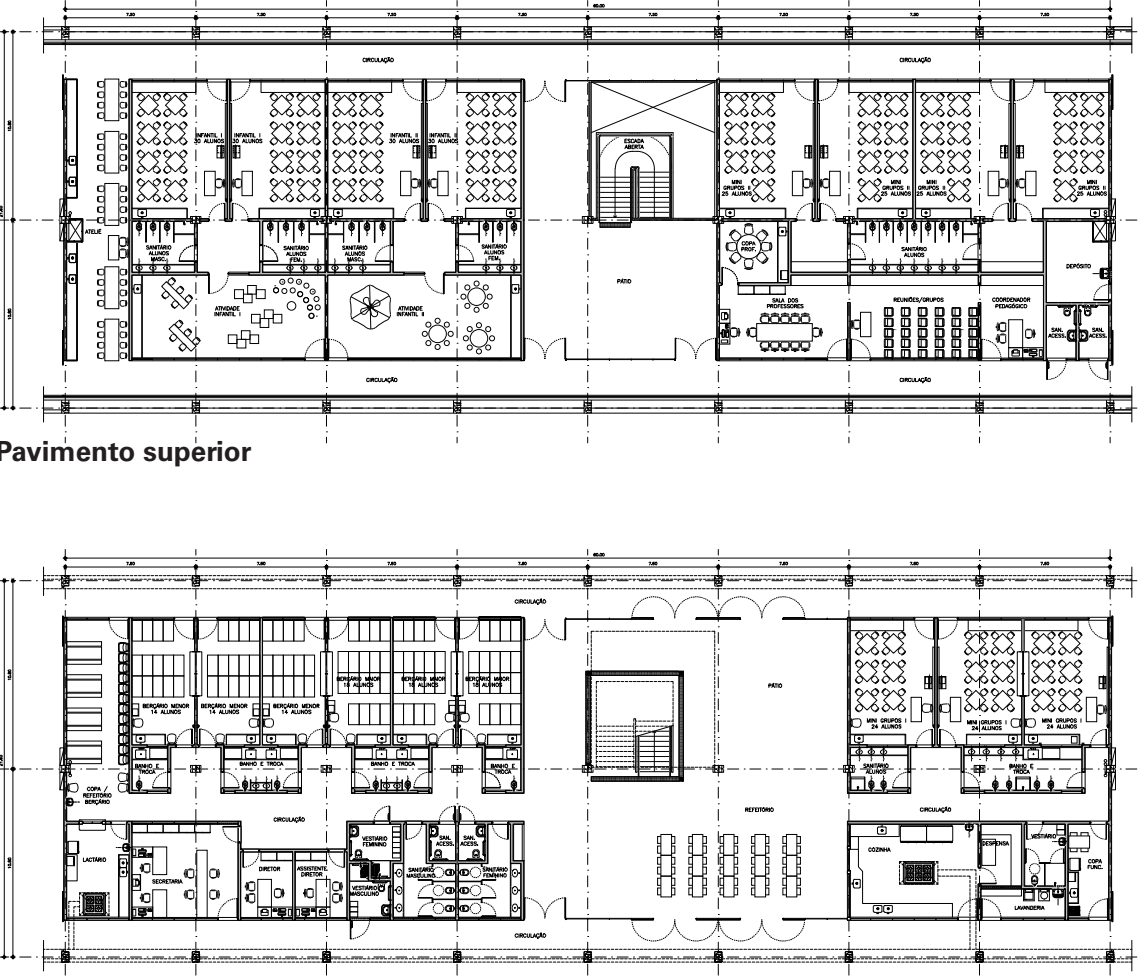

corte

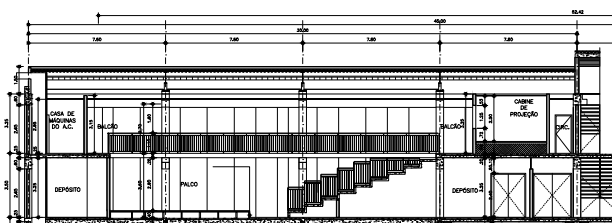

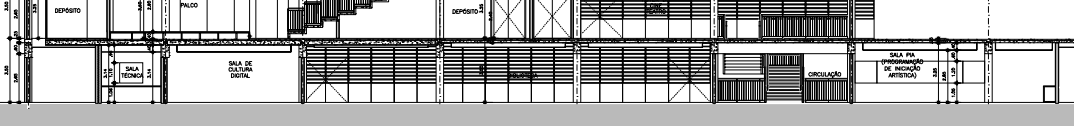

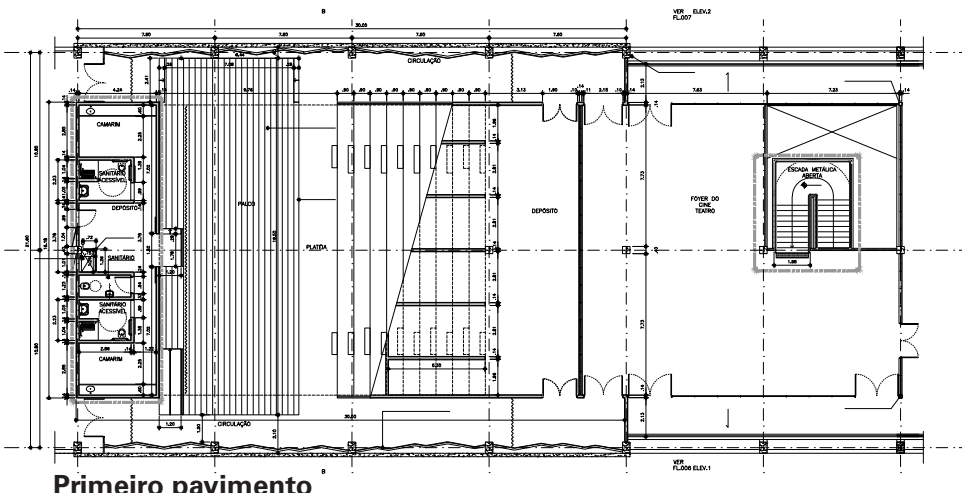

(-Lin
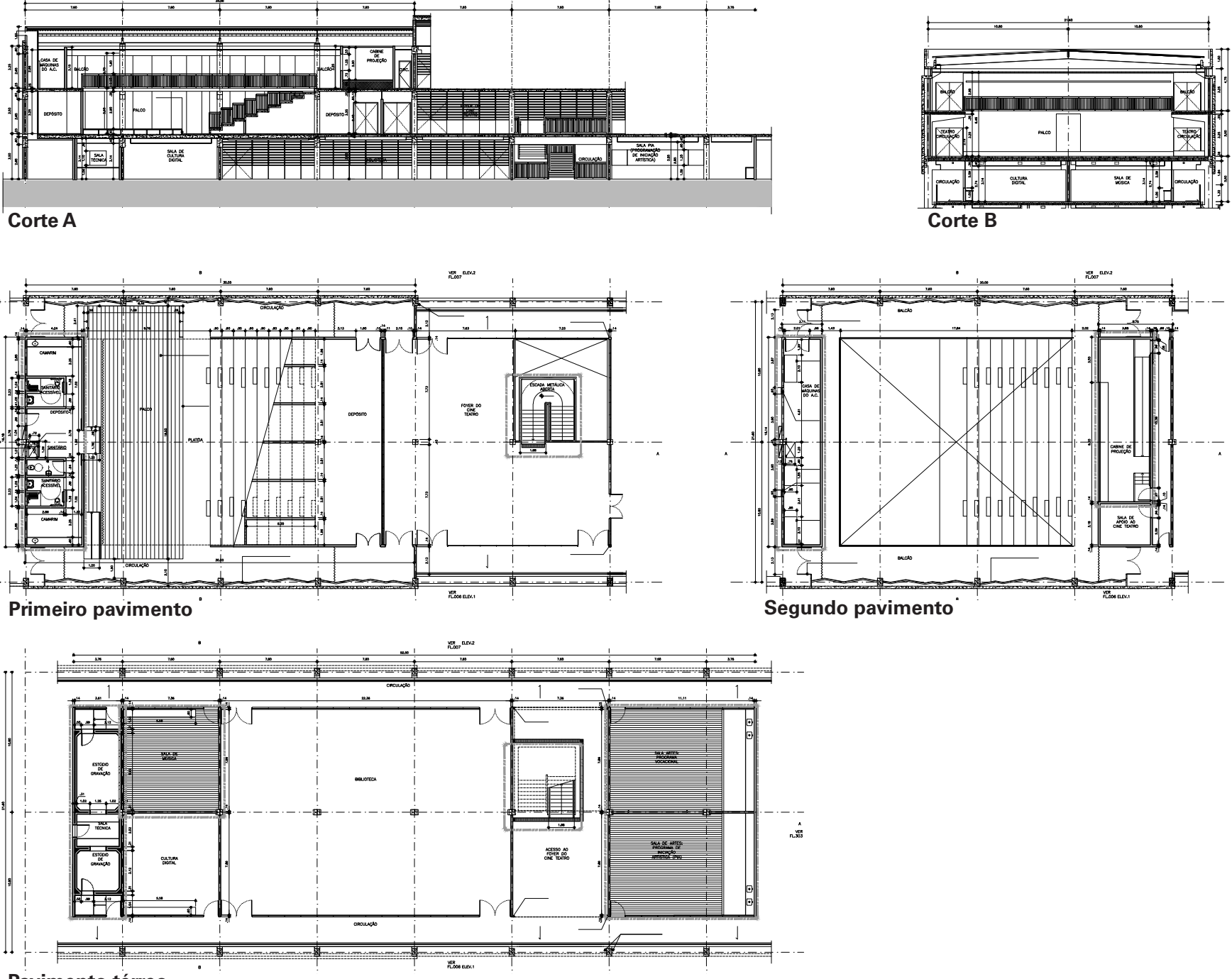
não concluídas. Se por um lado, a obra vai se beneficiar da

infraestrutura existente da rede pública de Centros Espor-

tivos, por outro lado o programa deverá não somente cons-

truir o CEU como recuperar toda essa infraestrutura local,

incluindo os dispositivos que favoreçam a mobilidade. Esse

fato torna o programa muito mais ambicioso e abre um ca-

minho promissor para que o equipamento público se dis-

tancie de certo isolamento, como destacamos aqui.

Ao examinarmos as implantações previstas e em an-

damento, é possível confirmar que o CEU III, enquanto sis-

tema, aproxima o projeto da cidade, como veremos a seguir

no estudo de algumas unidades em particular.

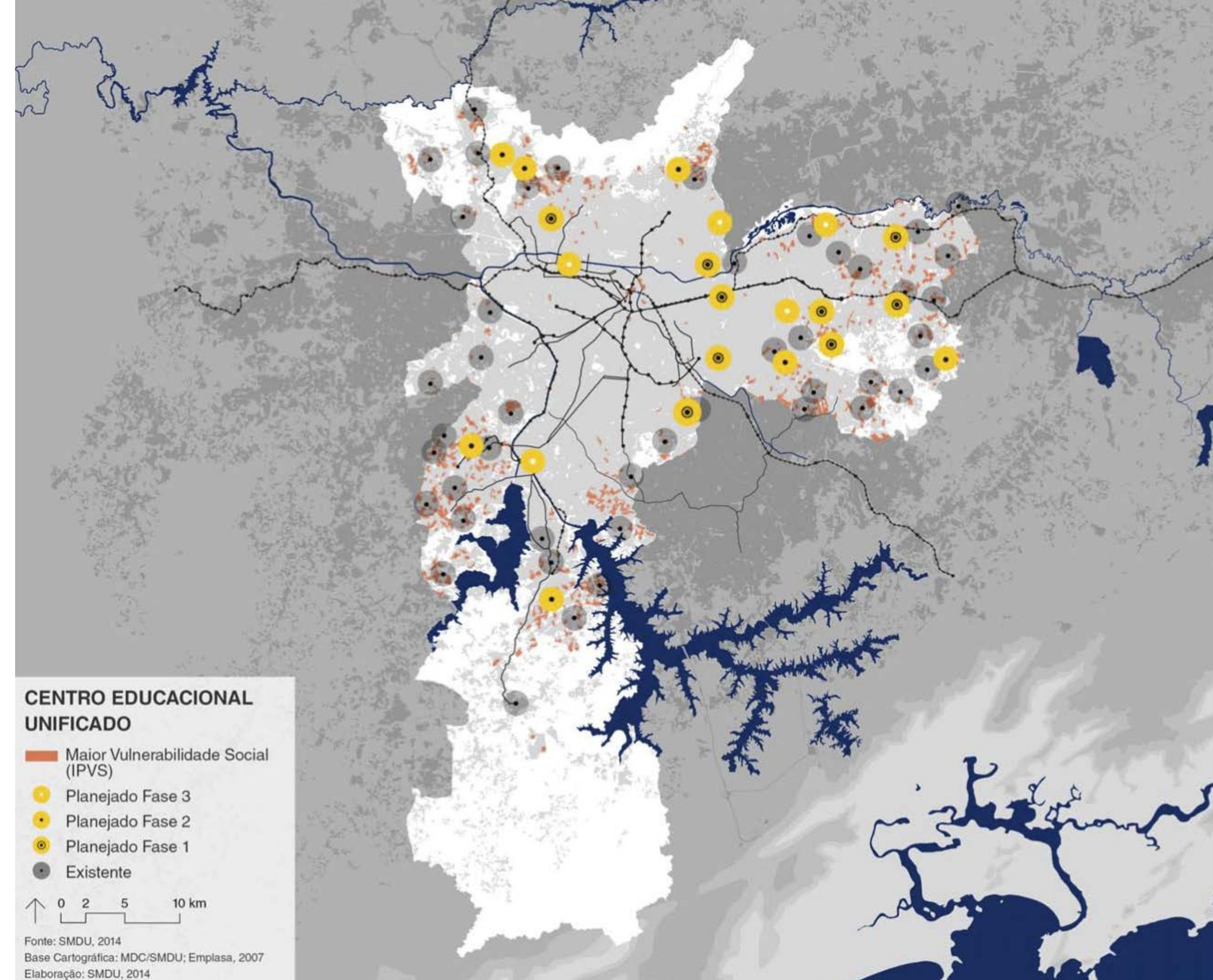


No Território CEU Parque do Carmo, a implantação alterna, longitudinalmente, áreas edificadas e áreas livres Na extremidade sudoeste, a praça esportiva arborizada é um prolongamento natural do vizinho Parque do Carmo, um dos mais importantes do município. Na porção oposta a noroeste, outra praça esportiva, agora dotada de balneário e

do agrupamento esportivo coberto, encontra a porção mais urbanizada da vizinhanç̧a, ou seja, está fisicamente voltad para a comunidade, uma rica relação entre os elementos do conjunto e desses com a cidade pelas possibilidades de percursos e de integração fisica e visual, como pode ser observado abaixo.

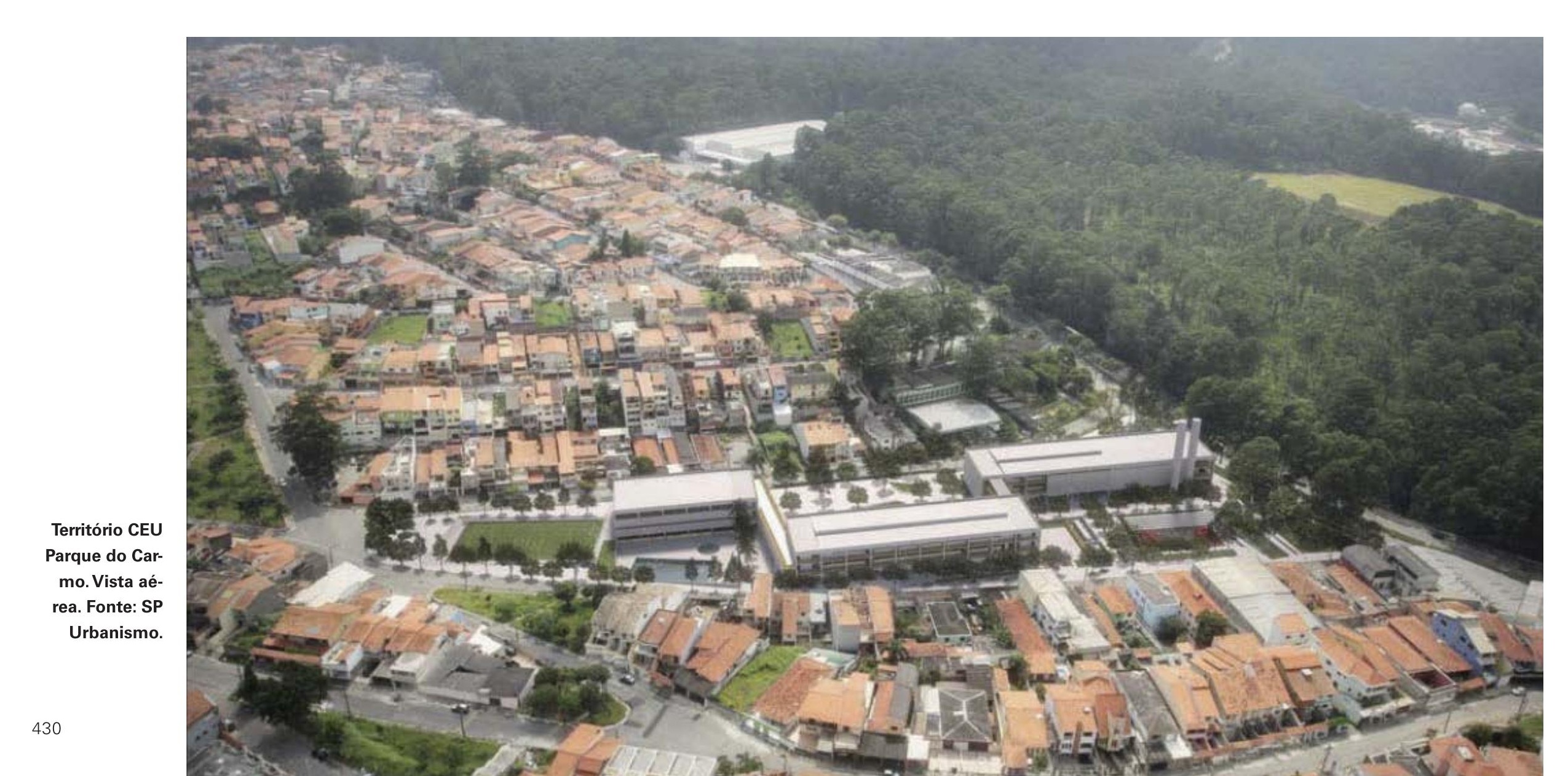

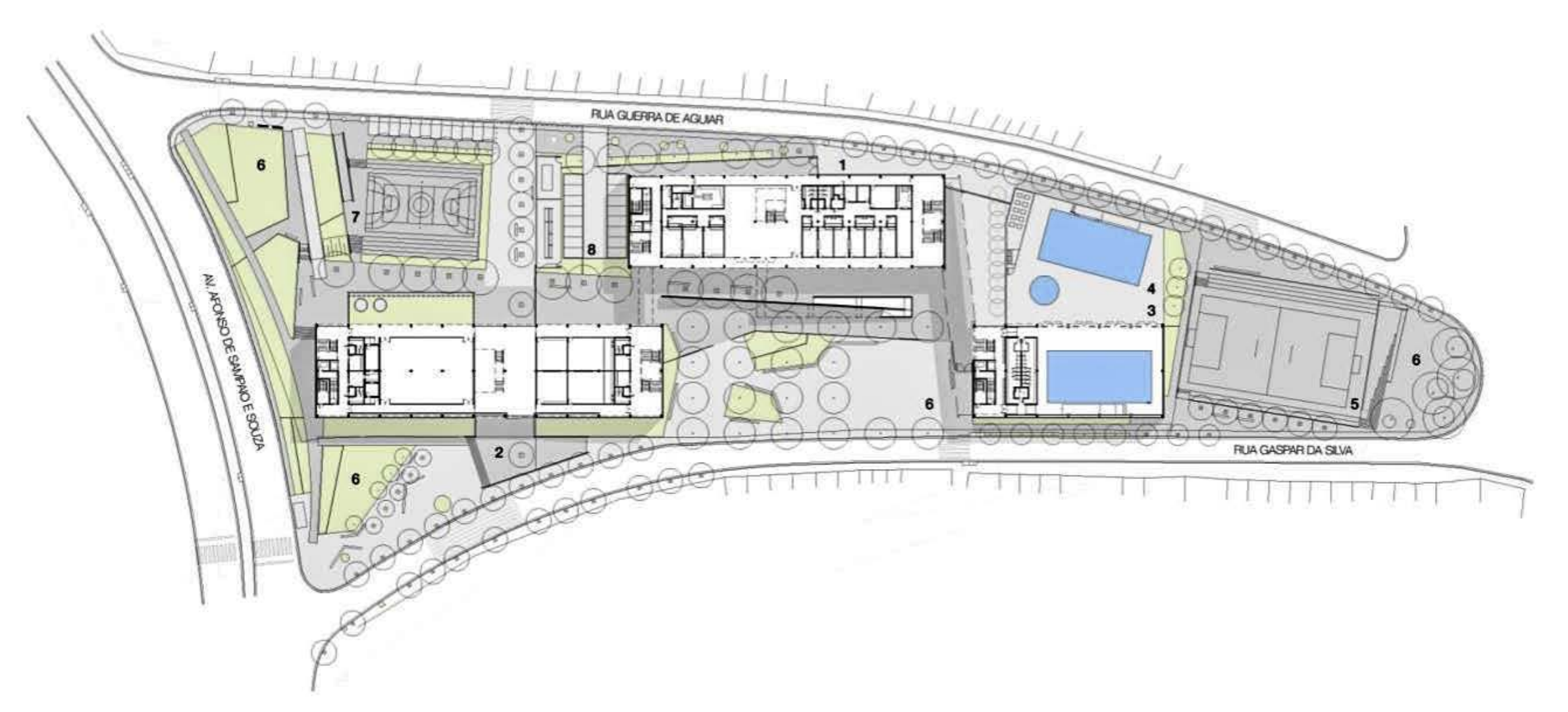

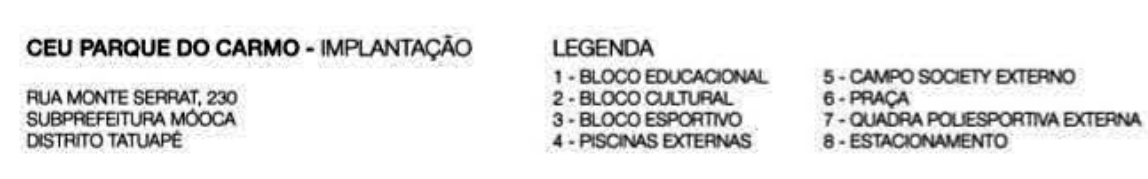
Teritório CEU Parque do Carmo. Implantaçăo no nivel do téreo. Fonte: SP Urbanismo. $\rightarrow " \underbrace{10}$ 
O Território CEU Mooca está inserido em um bairro bastante consolidado e muito próximo do centro histórico do município. A área é ocupada por diversos equipamentos públicos, como teatro, corpo de bombeiros, terminal de transporte público e escola de educação infantil, além de uma extensa área arborizada e esportiva, como pode ser atividades oferecidas. A implantação reorganiza os fluxos internos e suas relações com a cidade tomando o centro d da área urbana, como a oeste, voltado para a área verde. Esse procedimento sinaliza de maneira clara que o equipamento oferece maior grau de permeabilidade física e visual observado O CEU completa o conjunto ao ser implantado

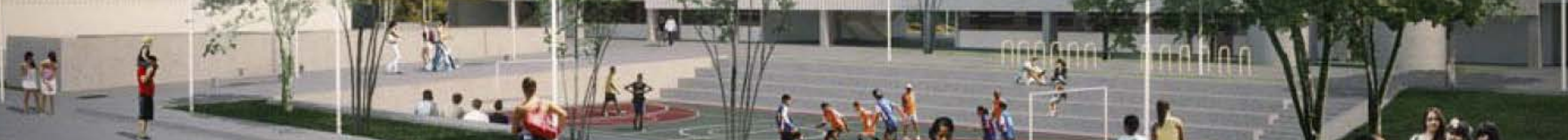

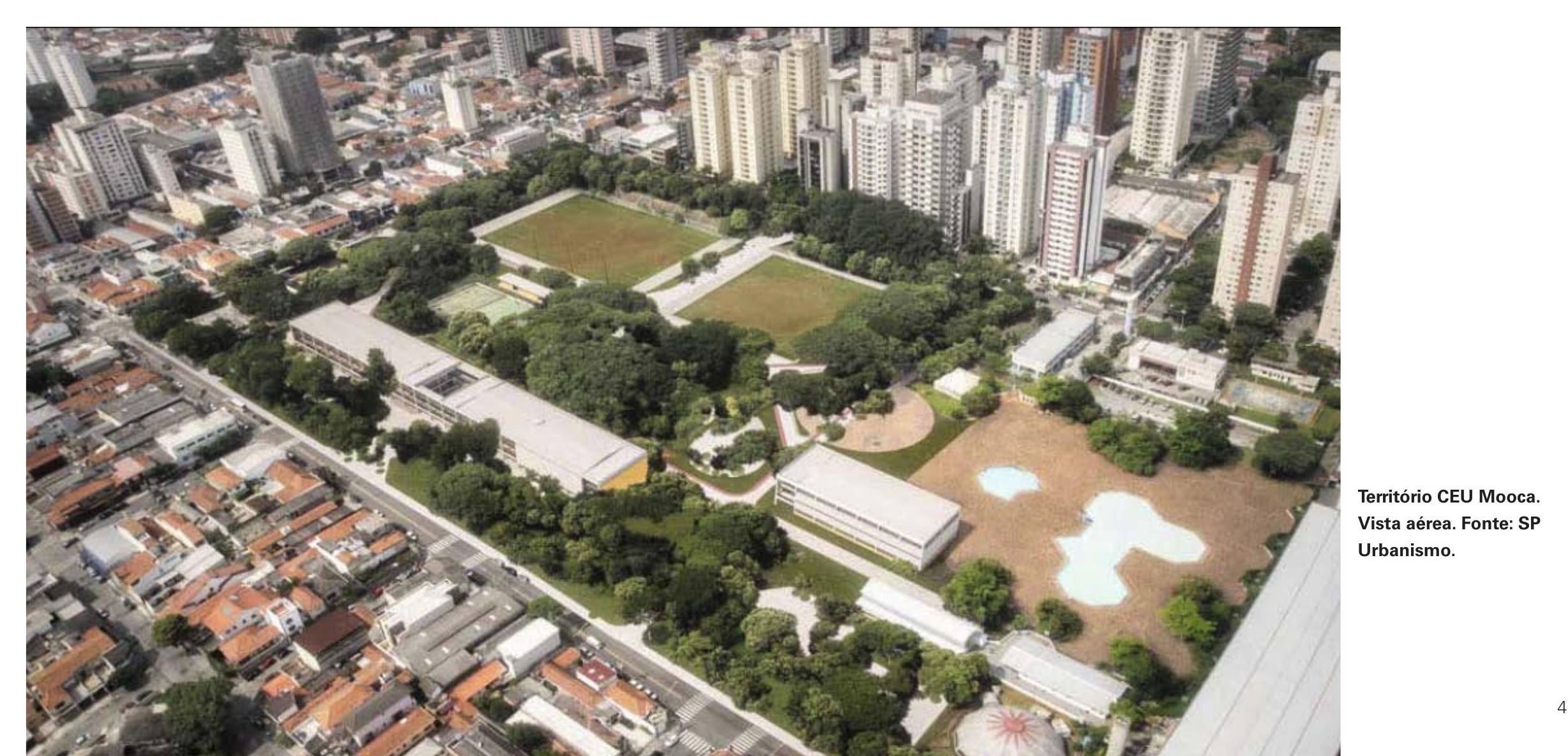



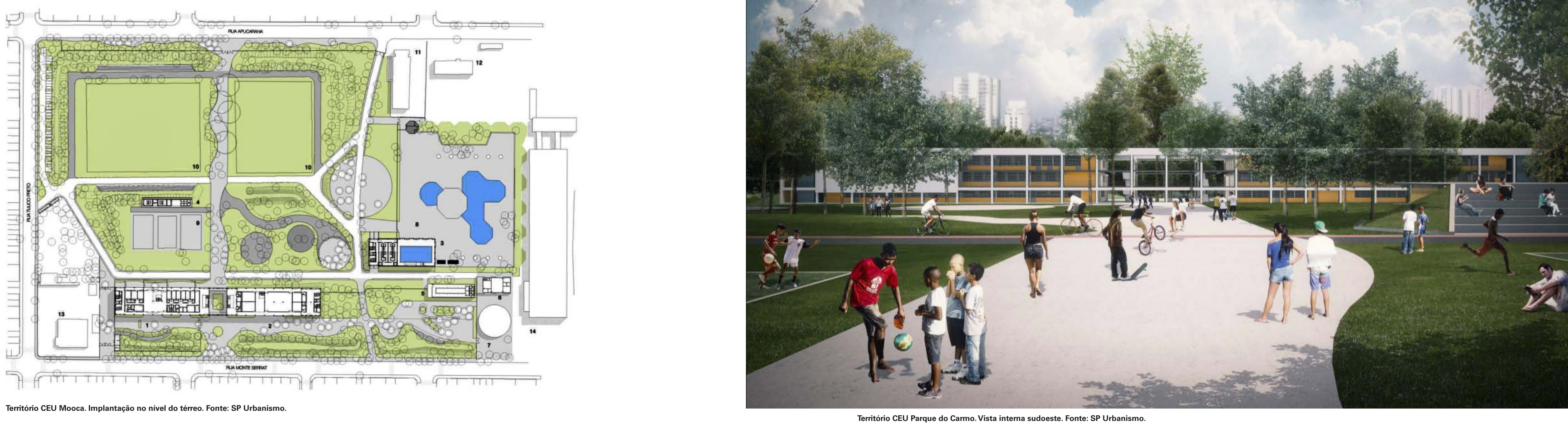
A condição urbana desfavorável exigiu do projeto a

Sem as mesmas qualidades ambientais das implantações anteriores, o Território CEU Novo Mundo caracteriza-se por uma situação de maior interioridade para enfrentar as dificuldades urbanas locais. Como o bairro está próximo de dois importantes eixos rodoviários nacionais (a Via Dutra, ligando São Paulo e Rio de Janeiro, e a Rodovia Fernão Dias, ligando São Paulo e Belo Horizonte), predomina a ocupação urbana de terminais de carga e empresas de logísticas, como pode ser observado nas imagens a seguir. m pátio interno protegido e materializado pelo posicionamento paralelo das edificações educacional pátio abre-se para a área esportiva e o balneário é delimitado ao sul pelo agrupamento esportivo coberto. Há nessa implantação a inédita previsão de trazer três edificações habitacionais para completar o conjunto na parcela norte. Essa seria mais uma decisão para enfrentar a predominância das grandes áreas ocupadas pelos pátios rodoviários. cultural, na direção norte-sul. o prolongamento natural do

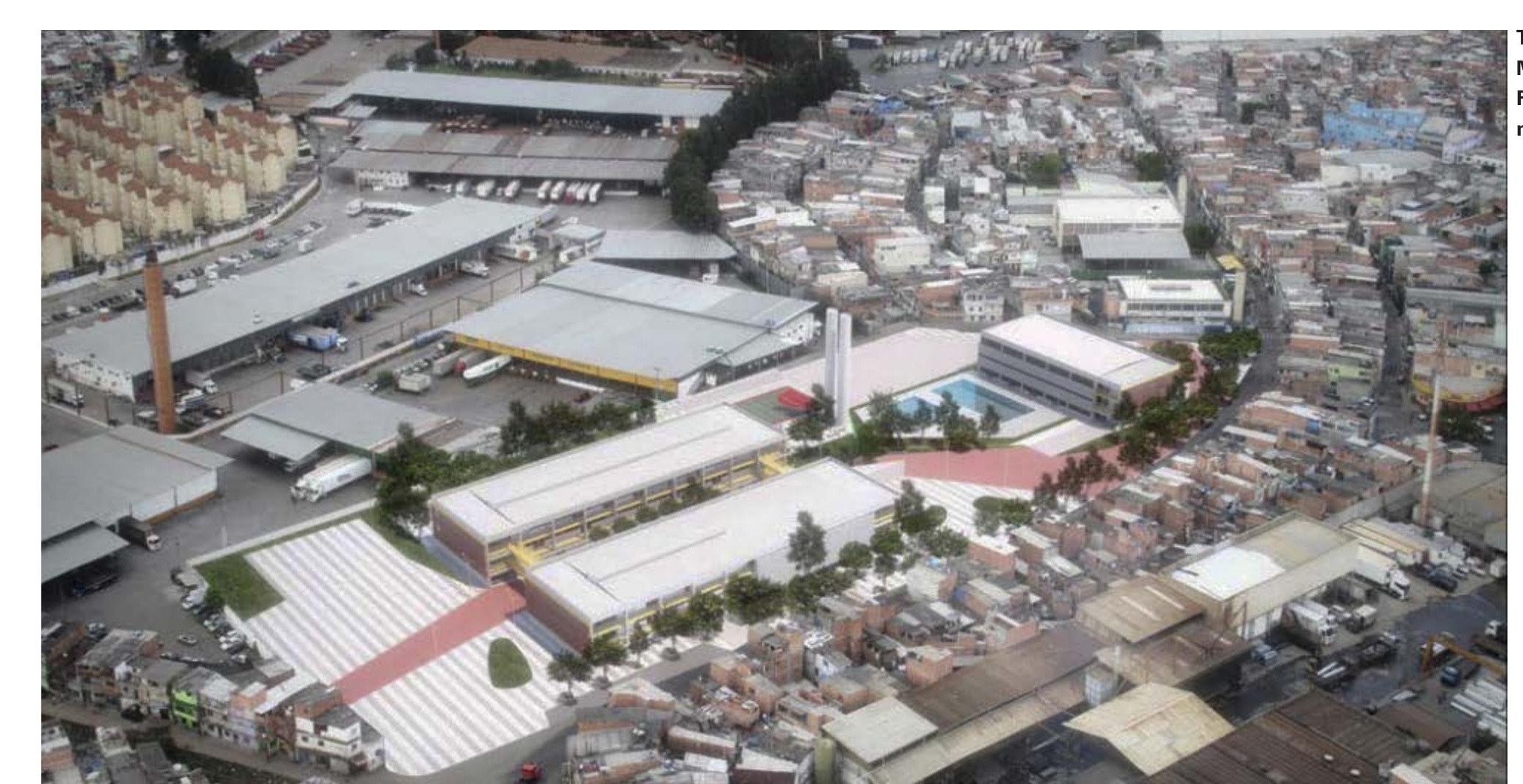

Território CEU Novo
Mundo. Vista aérea.
Fonte: SP Urbanis-

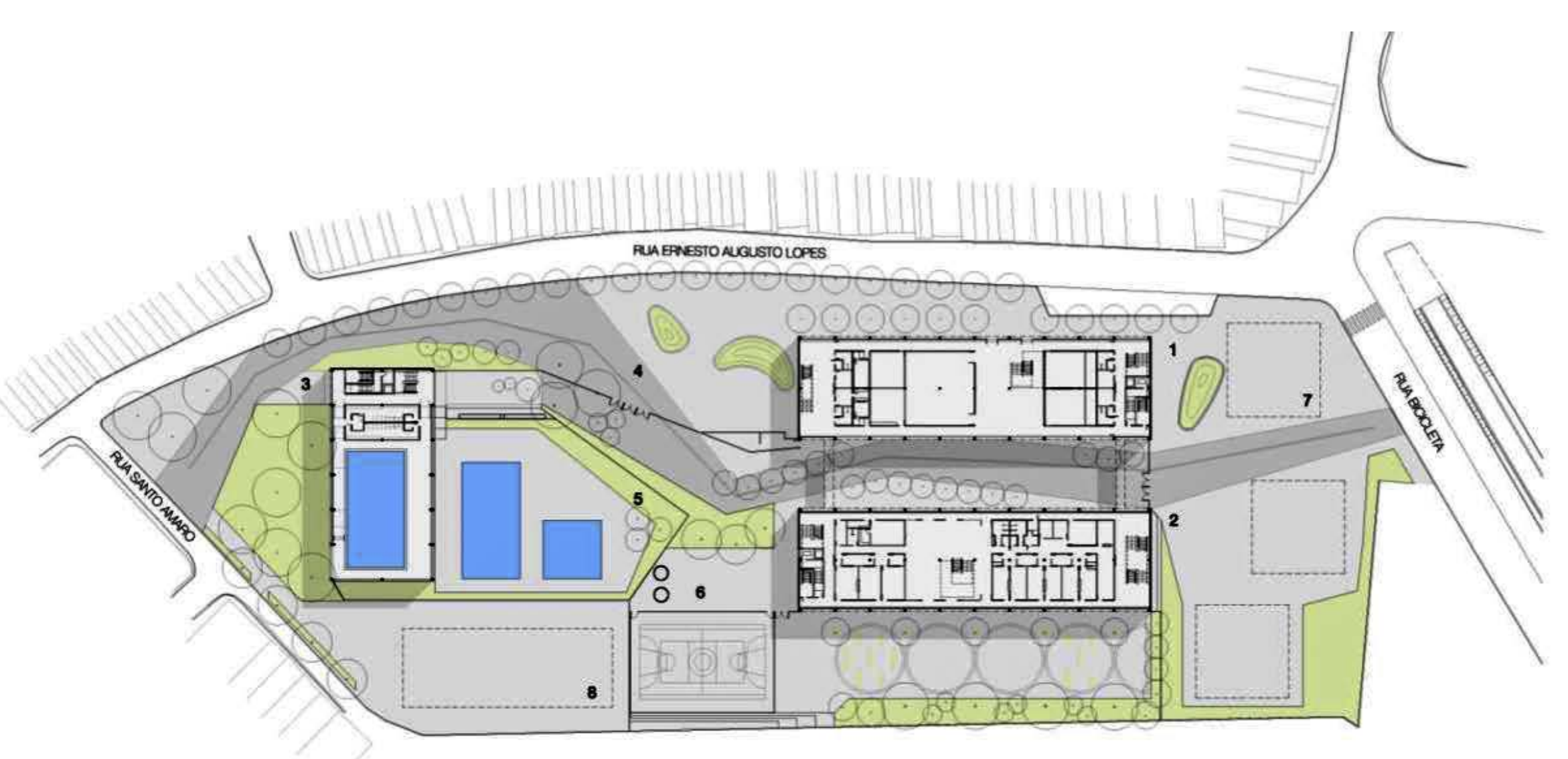

CEU NOVO MUNDO - MPLANTACÁO

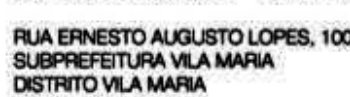

1: 


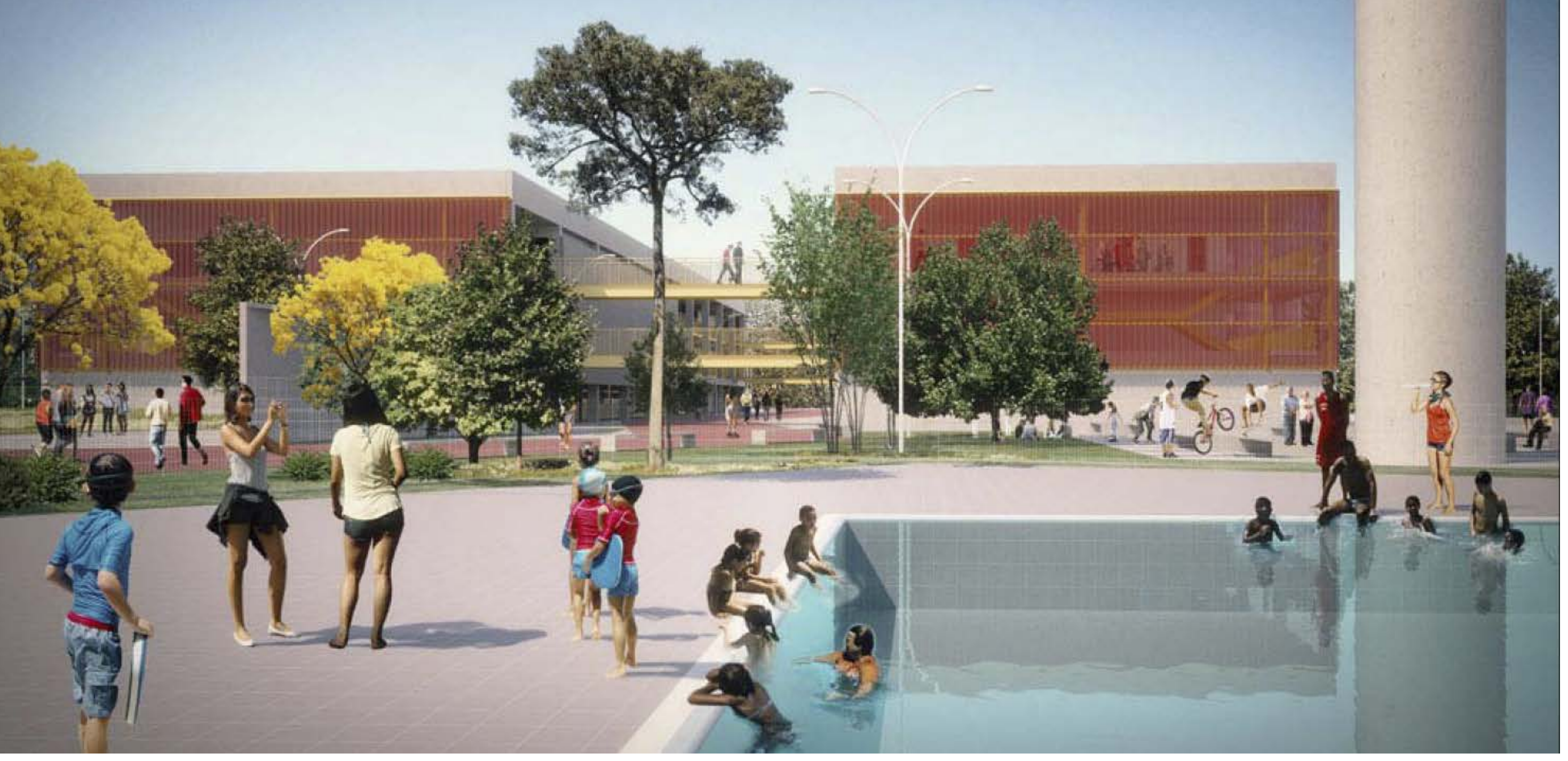

Teritionio CEU Novo Mundo. Vista intema sudoestel Fonte: SP Urbanismo
A implantação do Território CEU São Pedro pode ser entendida como uma releitura da proposta original. A longa barra que associa os agrupamentos educacional e cultural é, num primeiro momento, muito próxima das implanta ções realizadas no início do programa, como o CEU Rosa da

China estudado em nossa pesquisa. 0 projeto beneficia-se dos desníveis do terreno da mesma maneira, porém, ao ser

implantado transversalmente ao terreno, abre um novo caminho de integracão do conjunto com o bairro. Além disso a junção central aberta entre os agrupamentos, que marca o acesso principal da edificação resultante, cria outro c minho marcante perpendicular ao primeiro, ligando a área esportiva projetada à área esportiva existente e aos outro mental, e unidade básica de saúde).

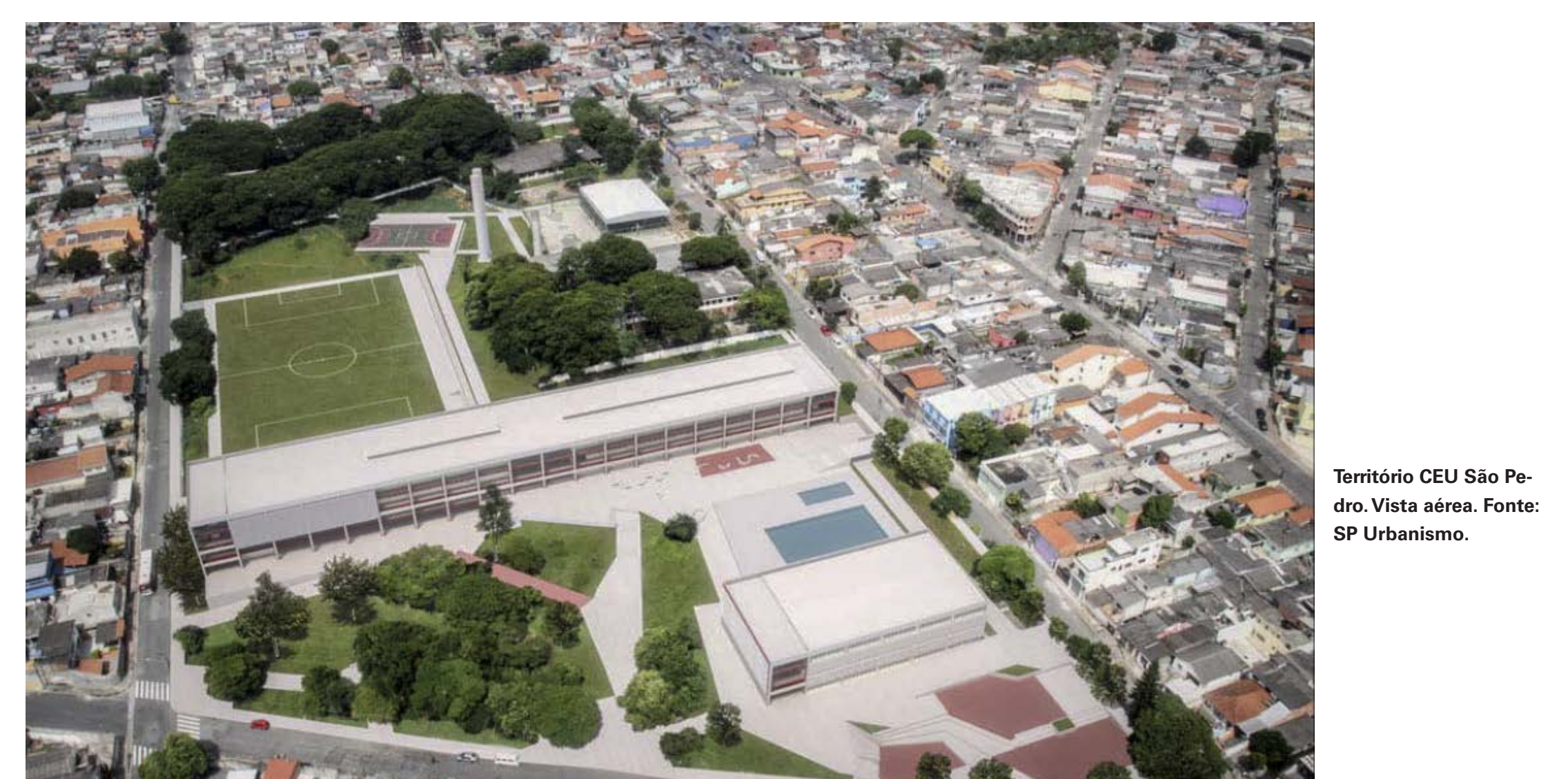




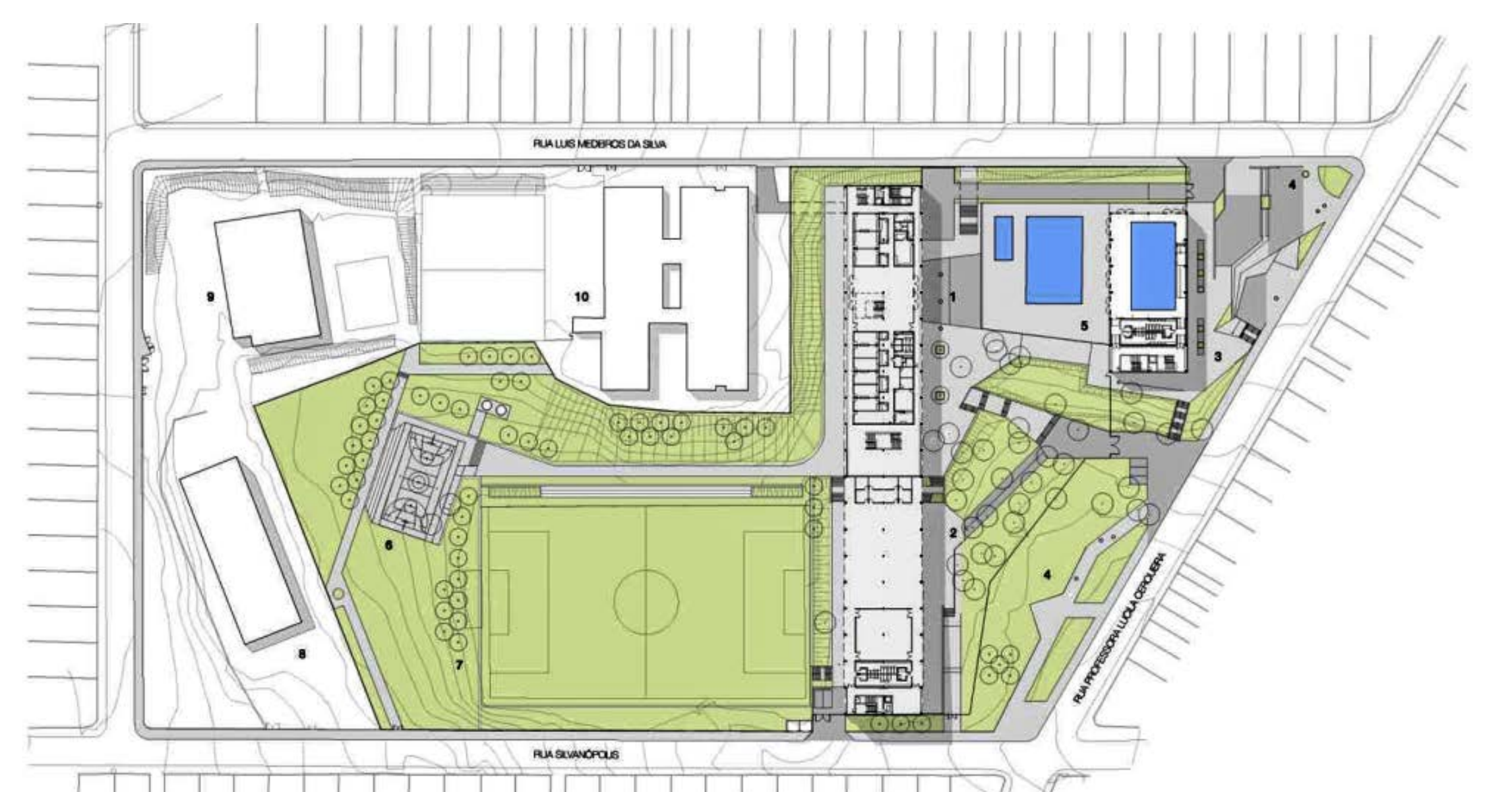

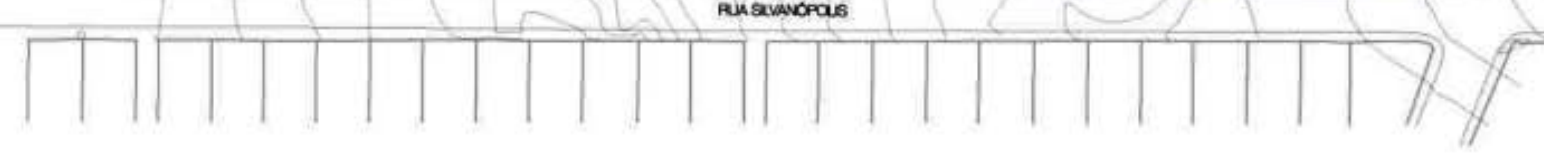

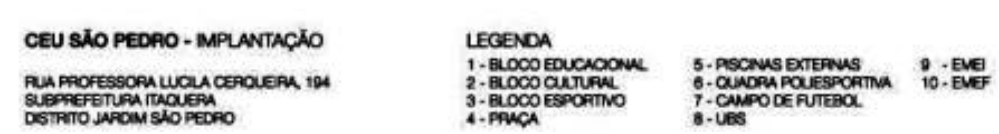

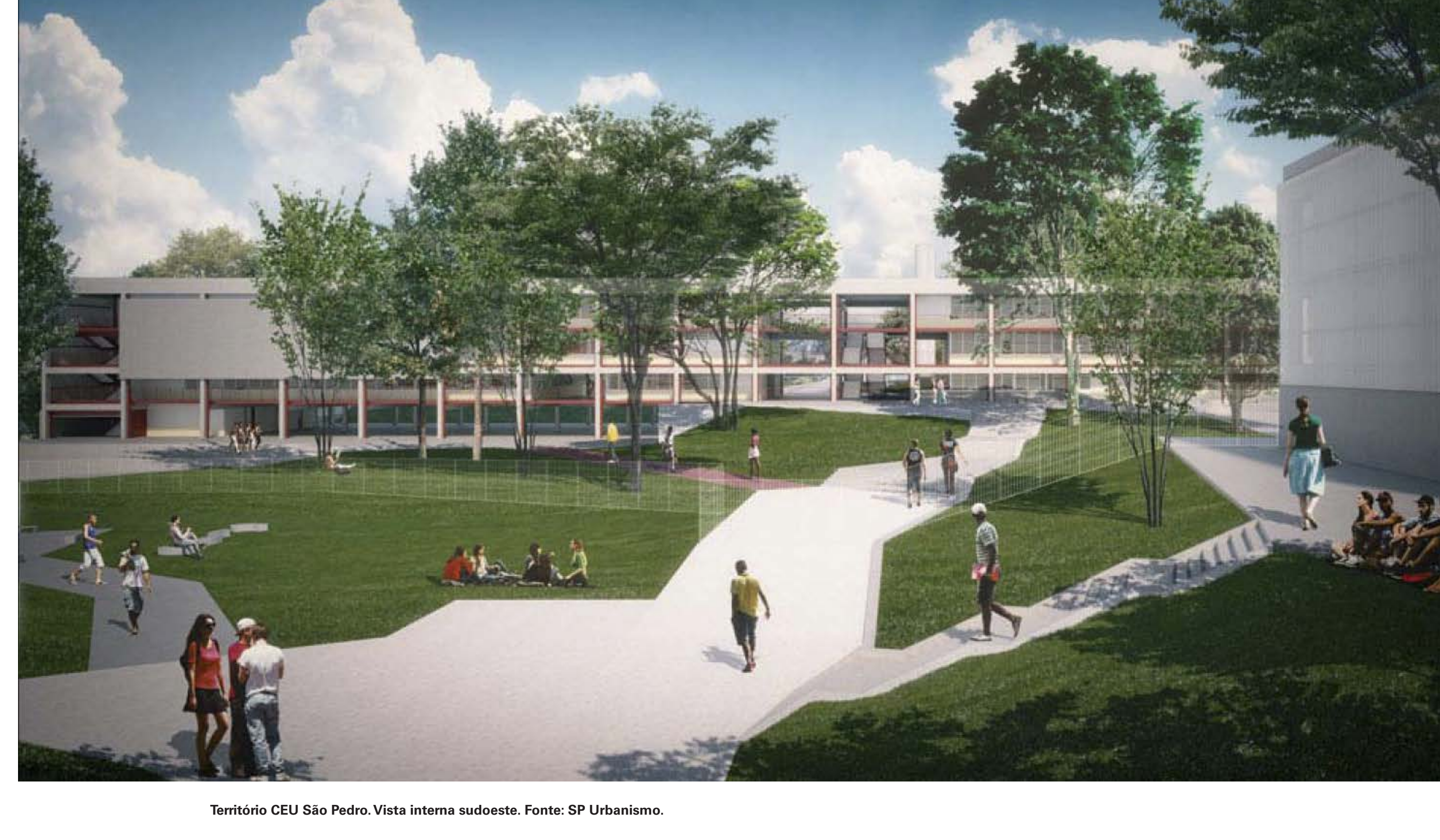


Os exemplos acima examinados demonstram que a revisão do projeto do CEU, ao introduzir a noção de sistema flexibilizando o padrão original, enfrenta com maior prero os descios do Parion as de Paulo. Ainda que, em certa medida, os limites apontados até aqui possam permanecer, o projeto como instrumento para suprir deficiências da metrópole permanece ativo e com um caminho para evoluir, o que nos parece acertado. Mesão sejam tão favoráveis ão sejâ tá factán equipamento público oferece agora maior força ordenadora graças aos atributos de ordem construtiva gerados pela revisão do projeto original.
Nesse sentido, podemos afirmar que o projeto apreendeu com o tempo os fundamentos necessários para sua permanência e sobrevivência do ponto de vista da arpuitetura proposta, sosrive

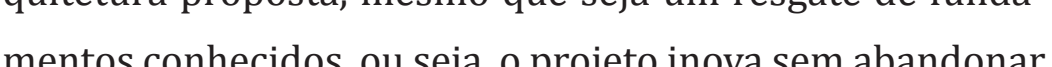
o conhecimento acumulado pela arquitetura como prática. Vale destacar que o caminho proposto indica que o projeto deve permanecer ativo como instrumento de pesquisa e ão somente como padrão.

Essas considerações nos apontam a necessidade de examinarmos as relaçôes do projeto com o tempo, tema do capítulo 4 , mas antes nós nos deteremos sobre o programa e a independência do projeto. 
Capítulo 3

O programa e
Livro IV

ins universais

Capítulo I

evidente que os edifícios nasceram para cum-

prir as necessidades dos homens. Em origem, se

otharmos bem, eles começaram a construir para

mparar-se e para proteger suas coisas das in-

temperes. Em seguida, não somente buscaram

deixaram de providenciart tudo aquilo mas nầ pudes-

se proporcionar-lhes bens e conforto. Mais tarde,

atraídos e estimulados por novas possibilidades

chegaram a conceber, e a buscar com o tempo,

os instrumentos para satisfazer seus prazeres

De modo que se pode afirmar com razão que un

edifício pode ser construído ou por necessidades

vitais, ou por conveniência prática, ou por satisfa-

ções temporárias.

Mas, observando a variedade de edifícios que se

pode encontrar, compreende-se facilmente que

sua execução não está voltada tanto para os fins

acima mencionados, ou mais especificamente

para alguns deles e menos para outros; a razão

fundamental dessa variedade infinita está, ao

contrário, nas diferenciaç̃oses existentes na natureza humana.
Na passagem ao lado, Leon Battista Alberti introduz o capítulo em que fala sobre certos edifícios cujos fins seriam universais. O livro IV de sua obra, A Arte de Construir é iniciado discorrendo sobre os desafios que a arquitetura tem de enfrentar para satisfazer às necessidades vitais o temporárias da natureza humana.

O presente capítulo propõe-se a estudar os projeto em que o programa não foi considerado como limite para projeto. Ainda que determinados programas assumam em suas definiç̃es certo grau de flexibilidade, de cresciment e de evolução, a própria natureza quantitativa e qualitativa de suas premissas são frequentemente utilizadas como justificativas para as tomadas de decisão no momento da concepção. Não nos referimos à arquitetura do programa mas sim aos projetos que entenderam estar no programa o caminho para enfrentamento da realidade, garantindo a consistência e coerência da arquitetura sem oferecer resistência à sua evolução

a independência do projeto

ALBERTI, 2012 
As condições do contexto estariam, neste caso, definidas somente pelos parâmetros físicos do sítio e pela conpreensão na int sente Assim a

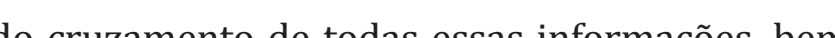
me pressane to de dados capaz de resolver con um processamento de dados capaz de resolver conflitos e contradições, com o objetivo de estabelecer o perfeito funcionamento da obra. Nesse caso, poder-se-ia considerar que a tecnologia digital estaria a serviço do projeto, como imaga $(1961)^{189}$, por exemplo, na condução do processo em que a rquitetura se propõe a ir além dos limites do programa.

Todavia, essa condição não seria suficiente para que as incertezas de uma realidade em constante evolução pudessem ser enfrentadas pelo projeto, no esforço de se atum com independência.

O problema que aqui se coloca é o de verificar quais fundamentos o projeto irá buscar para que a desejada in-

188 Ver Introducăo e Capítulo 1.
189 Ver PIETRAROIA, 2014. dependência seja capaz de garantir a permanência da obra no tempo.

Nesse sentido, investigamos nesta pesquisa exemlos tender quais foram as estratégias encontradas pelo projeto no enfrentamento do problema colocado.

Consideramos que parte significativa da obra de Mies van der Rohe pode nos auxiliar a responder à hipótese coprojeto perante o programa. Estamos nos referindo especialmente em seu período americano ${ }^{190}$ à frente do IIT (Illinois Institute of Technology), em Chicago, como veremos a segui Examinamos também outras obras significativas na continuidade da pesquisa e incluímos o Learning Center em Lausanne, Suíça, do escritório japonês SANAA, projeto que

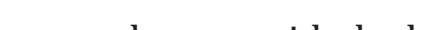
nascer de re tivo de referência na École Polytechnique Fédérale, um polo de convergência do mundo acadêmico local, cujo programa não limitou o projeto.

$190 \quad$ Ver FRAMPTON, 1997. 
3.1. Mies e a independência do programa

Arquitetura e permanência [...] Bem, indiscutivelmente no caso da arquitetura se coloca um verdade, que normalmente os materiais duram muito mais do que as atividades sociais. Isso foi uma preocupação tão grande nos últimos tempos que Mies, como vocês se lembram, por ocasião do concurso para a Ópera de Mannheim, há uns 30 anos, chegou até a formular um princípio para a obra dele, que foi na ocasião de grande importância, que a forma não segue a funç̃oo, a forma segue a economia. Form follows economics. [...] ele dizia o seguinte: "Eu estou fazendo aqui uma construção máxima, mas é certo que daqui a al-

guns anos esse teatro não estará mais localizado no melhor lugar para ser um teatro, talvez seja, supermercado". As funç̃es sociais mudam com uma rapidez muito grande, enquanto as construmuito mais do que permanecem nas cidades hoje as funçōes correntes.

[...] nós caminhamos para uma arquitetura em. que se alguma cosa deverá ser permana em que se alguma coisa devera ser permanente,
como, por exemplo, os grandes eixos de circulação, [...] mas que certamente aquilo que vai atender aos homens, à vida humana, e abrigar as atividades humanas, estou sendo muito impreciso na maneira de conceituar, tende a ser cada vez mais móvel [...]

GUEDES, $2001^{191}$

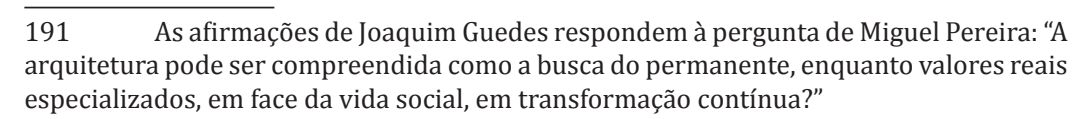

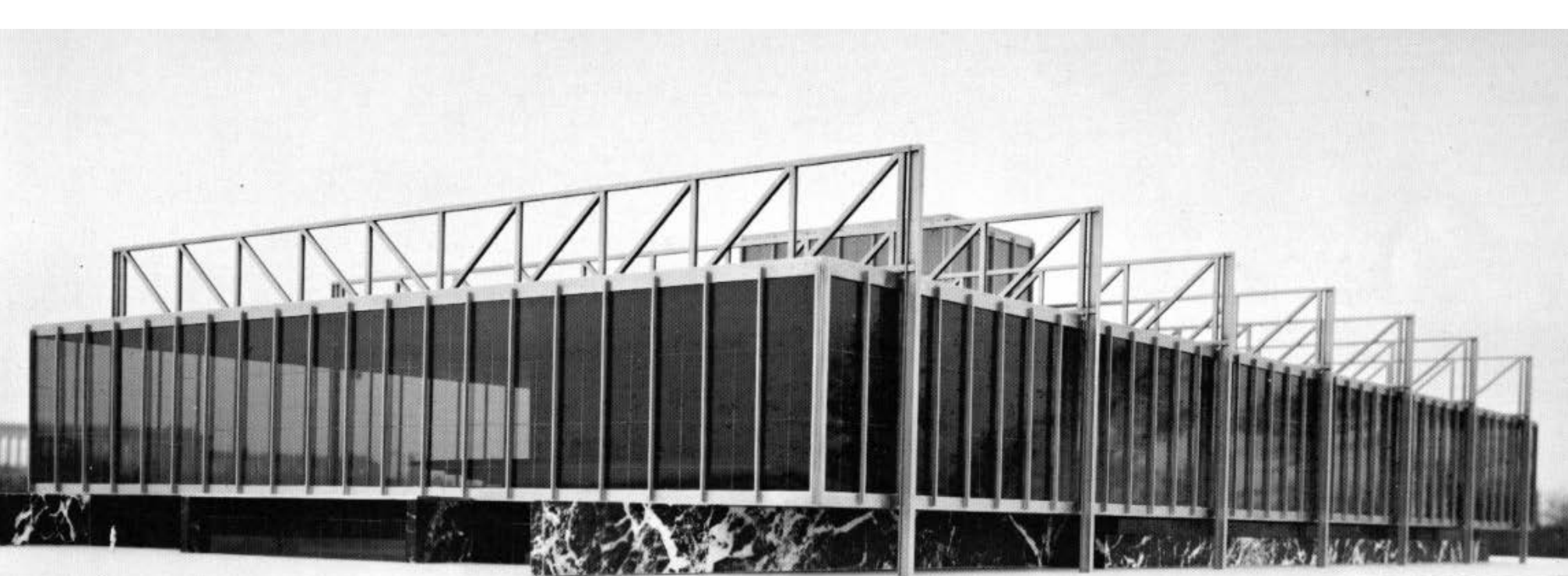

0 projeto elaborado por Ludwig Mies van der Rohe para o concurso do Teatro Nacional de Mannheim (1953) é merecedor de grande interesse. Em primeiro lugar, pela oportunidade de expressão das posições de Mies em relação à arquitetura do espetáculo, como pudemos observar en nossa dissertaç̃o de mestrado (PIETRAROIA, 2014: 135) Esse interesse é compartilhado por Luciana Fornari Colombo (2015), para quem pouca atenção tem sido dada às ideias de Mies a respeito do teatro. A pesquisadora discute os execícios acadêmicos sobrch 1940 no IIT (Illinois Institute of Technology) e que fundamentam o projeto para o concurso em Mannheim.

Em segundo lugar, os projetos de Mies naquele momento confirmam, como poderemos observar, a consolidação de uma determinada unicidade espacial baseada nas estruturas internas da obra, algo que marcou definitivamente o seu trabalho na América (ROWE, 1999: 144 e FRAMPTON 1997: 281).

Feitas essas consideraçoes iniciais, retornamos ao depoimento de Joaquim Guedes, recolhido em 2001 por Miguel Pereira. Segundo ele, Mies, ao falar sobre o projeto de Manhern de 1953, to de Manne relação à velocidade com que as mudanças sociais vinhan ocorrendo e de como alterações nas funções correntes e as novas atividades humanas obrigariam o projeto a considerar fatores de imprevisibilidade muito mais significativos do que anteriormente. Guedes prossegue discorrendo respeito da intensificação de tal situação sobre o projeto ao chamar a atenção para o papel que deve ter a arquitetura na definição do permanente, daquilo que deve ser pensado para suportar as novas relações humanas.

Peter Blake deixa clara a importância de determinada universalidade proposta por Mies no enfrentamento das supostas incertezas:

Quanto mais imprevisíveis a evolução da técnica de construção e as necessidades de nossa sociedade, mais se tornava necessaria aos olhos de Mies a criaçăo de um sistema universal de ordenação que pudesse fornecer uma resposta a todos
os problemas colocados. (BLAKE, 1958: 25)

Mas qual seria o significado da afirmação de Mies ao considerar seu projeto para o Teatro Nacional de Mannheim uma "obra máxima"? Ter a intenção de torná-lo um modelo, um prototipo ou um monumento? Não estaria ele propondo o genérico ou o universal?

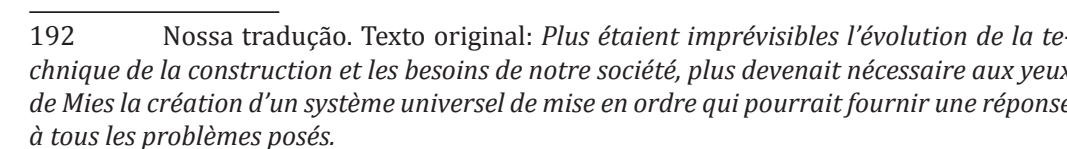


Devemos lembrar que o concurso representou un momento importante na reconstrução da Alemanha no pós Segunda Grande Guerra, o que por si só era um período de muita incerteza. Porém, as incertezas a que Mies se referia há mais de meio século, lembradas por Guedes em 2001, não seriam decorrentes somente do momento histórico. Mies, com sua afirmação, estaria muito mais preocupado com a expressão de suas ideias arquitetônicas. 0 concurso seria, para ele, uma grande oportunidade de responder às perguntas que sempre desafiaram o projeto e às quais sua arquitetur se propunha responder. Em outras palavras, ele não deixo de considerar a grande carga de imprevisibilidade que o momento apresentava, mas sabia que arquitetura tem a incerteza na sua origem, assim definida por Peter Brook:

[...] estamos menos acostumados a observar como uma ideia uma aitude on ma a passar da vitalidade à ruína (BROOK. 2015: 20 )

Em nossa pesquisa de mestrado, o concurso para o Teatro Nacional de Mannheim ${ }^{193}$ revelou-se portador

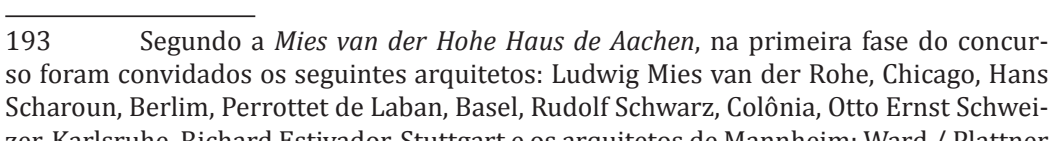

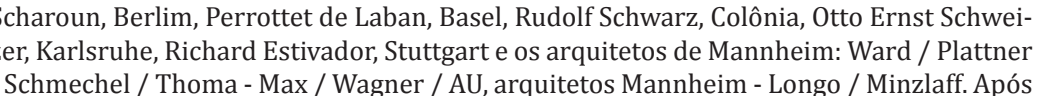

extenso conteúdo que ultrapassaria o tema investigado naquele momento: a arquitetura do espetáculo. Além da presença de Mirs, desenvolvimento das ideias que seriam expressas de maneira definitiva anos mais tarde no projeto para a sede da Orquestra Filarmônica de Berlim. A pesquisa mostrou ainda que o projeto de Gerhard Weber, ao vencer o certame ${ }^{19}$ materializou as aspiraçõos do meio teatral originadas $\mathrm{n}$ década de 1920 o que comprovou ser este um campo muito fértil de investigaç̃o (PIETRAROIA, 2014: 150)

Com relação a Mies, devemos relembrar que, pela enerosidade da solução adotada ficam chras as intenç̃õ do arquiteto em liberar de qualquer interferência o funcionamento dos dois auditórios e em valorizar a técnica como verdadeira natureza da arquitetura Há um entendimento que nos parece fundamental e que se refere à relação de liberdade espacial e ao mesmo tempo às restrições simbolizadas pelo grande volume, precisamente definido. Assim como no Crown Hall, a rigidez não limita o domínio espacial, não impede que naquela extensa plataforma suspens

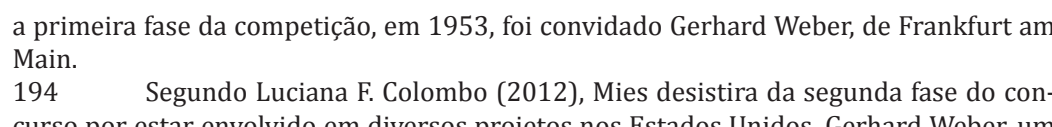

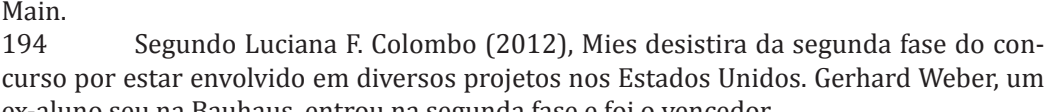

possa ser desenvolvida a liberdade criativa dos espetáculos. 0 que fica demonstrado quando esse aspecto é observado com mais profund dade da técnica da da tecnologia para distribuir equipamentos transforma dores, capazes de criar um novo espaço a cada espetáculo como propusera Walter Gropius no Teatro Total. Entretant o esforço técnico do projeto permitiu que fossem novos caminhos a serem traçados por seus

A importance desse paraconpressodo

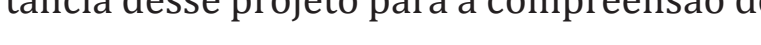
trabalho de Mies van der Rohe foi confirmada por autores importantes, como Philip Johnson (1960: 183), que considerou o projeto "a forma que satisfaz as exigências funcionais mais severas de todos os tempos, (1986: 275).

Luis Espallargas Gimenez (2016a) apresenta um explicação importante ao interpretar as simulações de alunos de Mies no IIT ${ }^{195}$. Em seu raciocínio, que nos parece

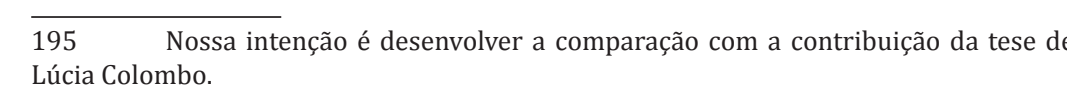

revelar um possivel caminho para a pesquisa, Espallargas aponta a independência das operações como mecanismo de projeto, o que, segundo ele, seria responsável pela rialização do clear space ou clear span ${ }^{196}$, citado por Phiylis Lambert (2001). E conclui:

[A independência] permite com isso imaginar autonomia das operações de arquitetura. Essa hipótese de Mies para construir com uma únic edificação, primeiro o envoltório, depois o programa. É assin, no concurso para o Teatro Naciode Mannheim, 1951-1953. (ESPALLARGAS, 2016a: 49)

Certamente, Espallargas apoia-se em análise de Peter Carter, apresentada em sua obra Mies van der Rohe at Work que demonstra haver "possibilidades de prever mudanças no interior, precisamente porque a casca estrutural era independente da divisão das funções" (CARTER, 1974: 79)

196 Peter Blake fala de fowing space, espaco flúdo. (BLAKE, 1958) 

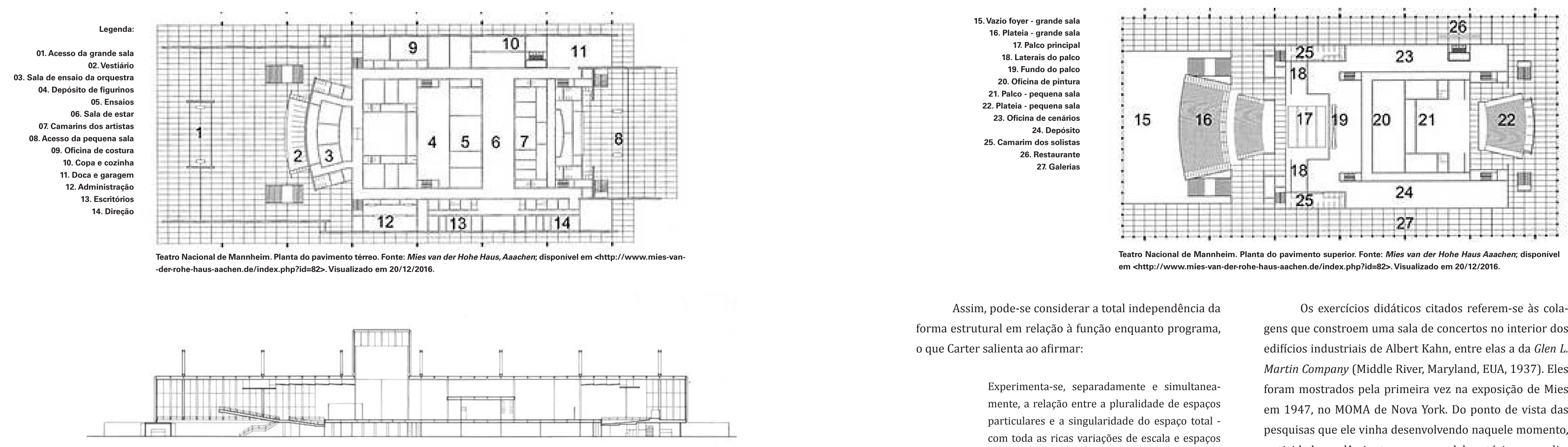

Assim, pode-se considerar a total independência da forma estrutural em relação à funç̃o enquanto programa o que Carter salienta ao afirmar:

Experimenta-se, separadamente e simultanemente, a relação entre a pluralidade de espaços particulares e a singularidade do espaço total com toda as ricas variações de escala e espaço que ela engendra. (CARTER, 1974:79)

Os exercícios didáticos citados referem-se às colaens que constroem uma sala de concertos no interior dos edifícios industriais de Albert Kahn, entre elas a da Glen L Martin Company (Middle River, Maryland, EUA, 1937). Eles foram mostrados pela primeira vez na exposição de Mie em 1947, no MOMA de Nova York. Do ponto de vista das a atividade acadêmica tornou-se um laboratório para a discussão de suas ideias (CARTER, 1974: 79). 

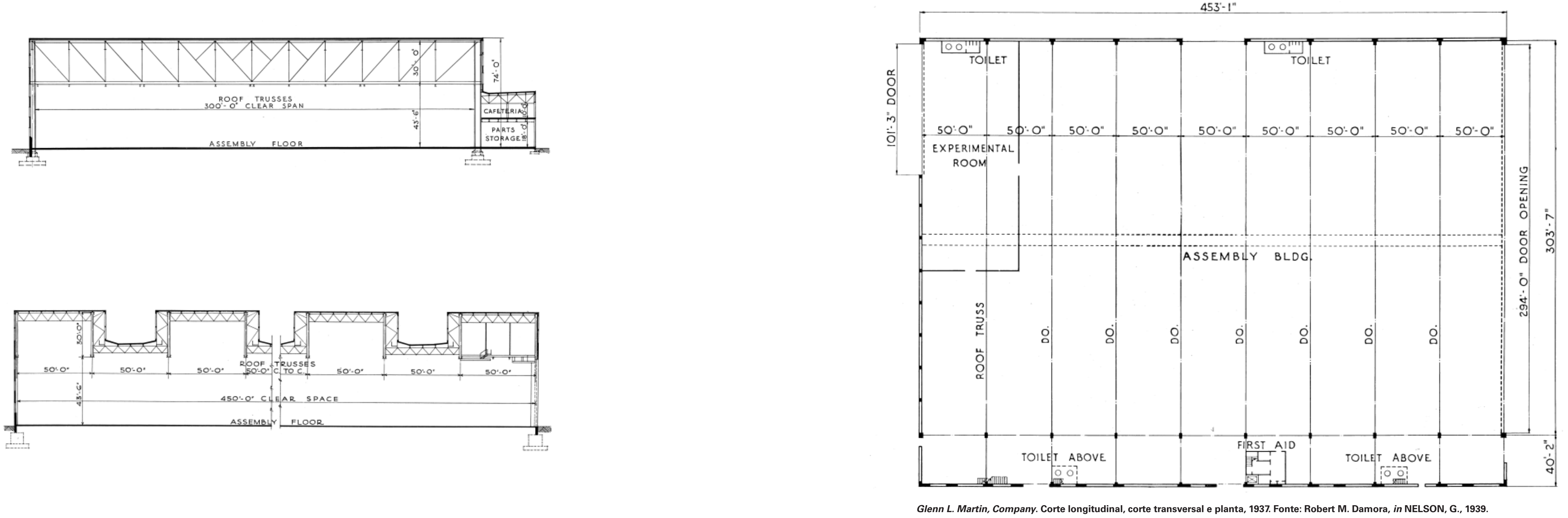
com a mesma proporỹo do projeto Glem L Mortin Con-

pany de Albetron

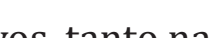

Vos. Live $(1 / 10)$ como em relação à altura livre $(1 / 1,5)$. Porém, a situação interna da estrutura no projeto de Kahn diverge da solução estrutural externa do Teatro de Mies. Há nesse aspecto uma significativa do que a expressão de ordem programática,

ou seja, entre a expressão industrial e a atividade teatral. É

certo que para o ambiente de trabalho industrial, em que a precisão visual é fundamental no desempenho das funcões, Kahn valorizou a presença da iluminaç̃õo natural em sua extensa experiência profissional ${ }^{197}$. As trelicas configuram sheds com orientação alternada, o que proporciona melhor qualidade e uniformidade da iluminação natural, como pode ser observado

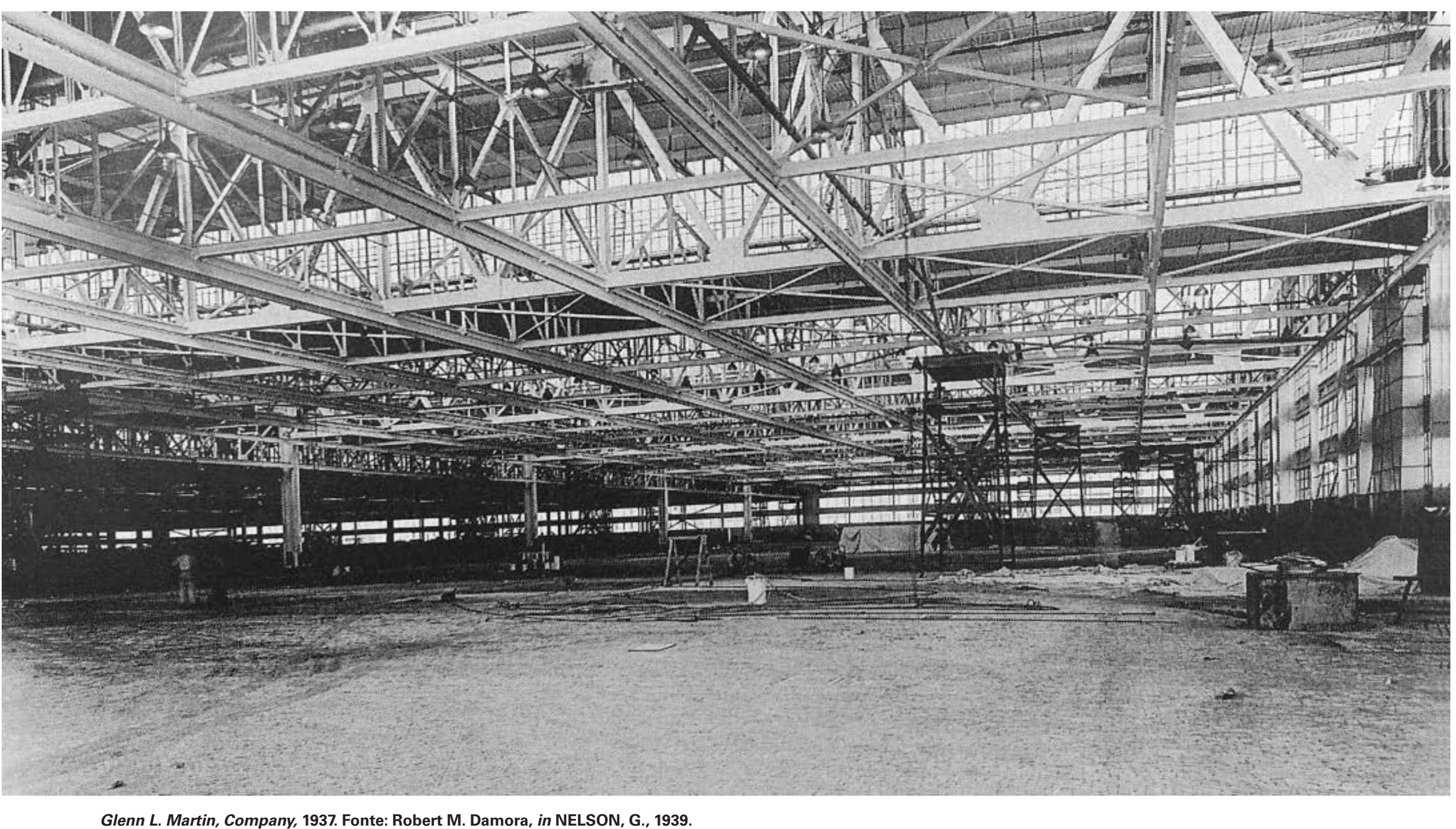




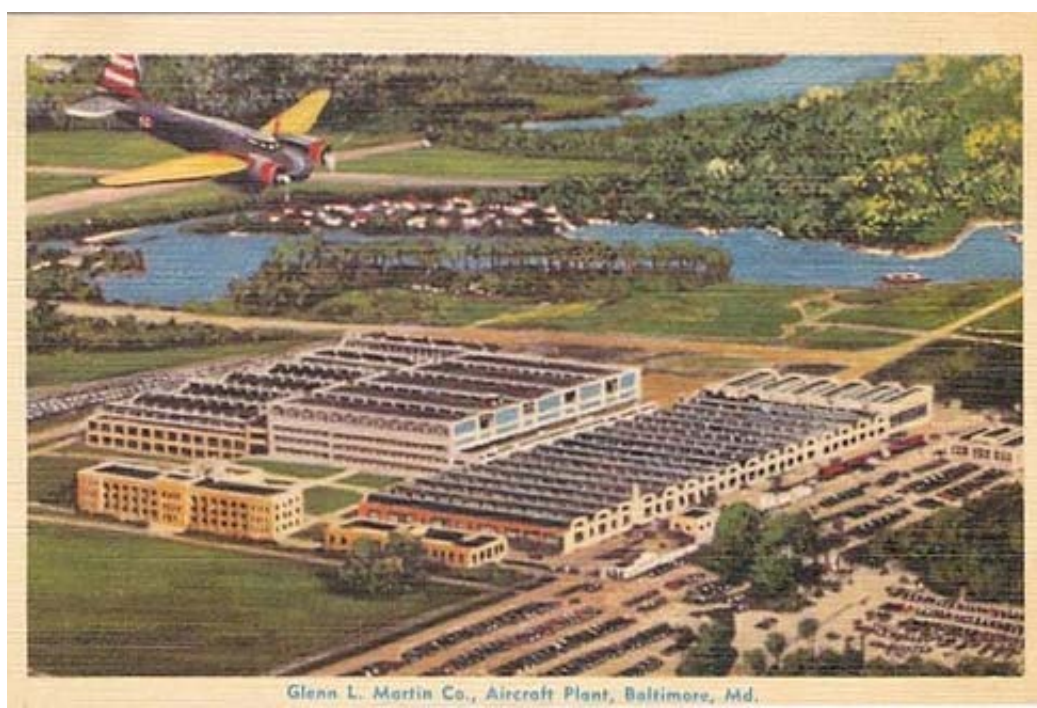
Glenn L. Martin Company, Cartä postal com a vista a área. Allbert Kahn, 1937 .
Fonte: http://lockheedmartinshare.blogspot.com.br/2013_05_01_archive.htm1. Fonte: hthp:///ockheedmartinst
Visualizado em 01/10/2016.

No Teatro de Mannheim de Mies, o teto internamente é plano, único, contínuo, e a estrutura não está presente é externa. Assim, a cobertura plana é marcada externamente pela grande escala das treliças metálicas, definindo o ritmo das fachadas longitudinais e acentuando a suspensã de todo o volume para além de sua base, constituída pe

exas plataforma mineral. Há também em Albert Kahn a expressão da cobertura, entretanto a solução materializa-se através de volumes transversais formados pelos sheds

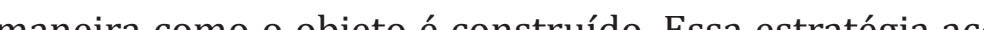
tua o caráter abstrato do espaço interno pois a estrutura não pode ser notada objetivamente, não interfere diretamente na organização espacial, tornando-se responsáve pela liberdade de como a ocupação interna do edif́cio pode ser materializada.

Na Glenn Martin Company de Kahn, o prisma retangular resultante tem a relação de $1 / 1,5$ entre o vão estrutıral e o comprimento da nave. Podemos considerar que esse fato decorre da intenção de compactar a linha de montagem dos aviões e de aproximar suas etapas, pois trata-se da movimentaç̃o interna de peças e de um produto fin de grande porte. Isso pode ser confirmado pela análise de projeto cujo programa era semelhante, construído no estado de Nebraska, onde a Glenn Martin montou outros aviôes bombardeiros no final da Segunda Grande Guerra, os conhecidos B-2

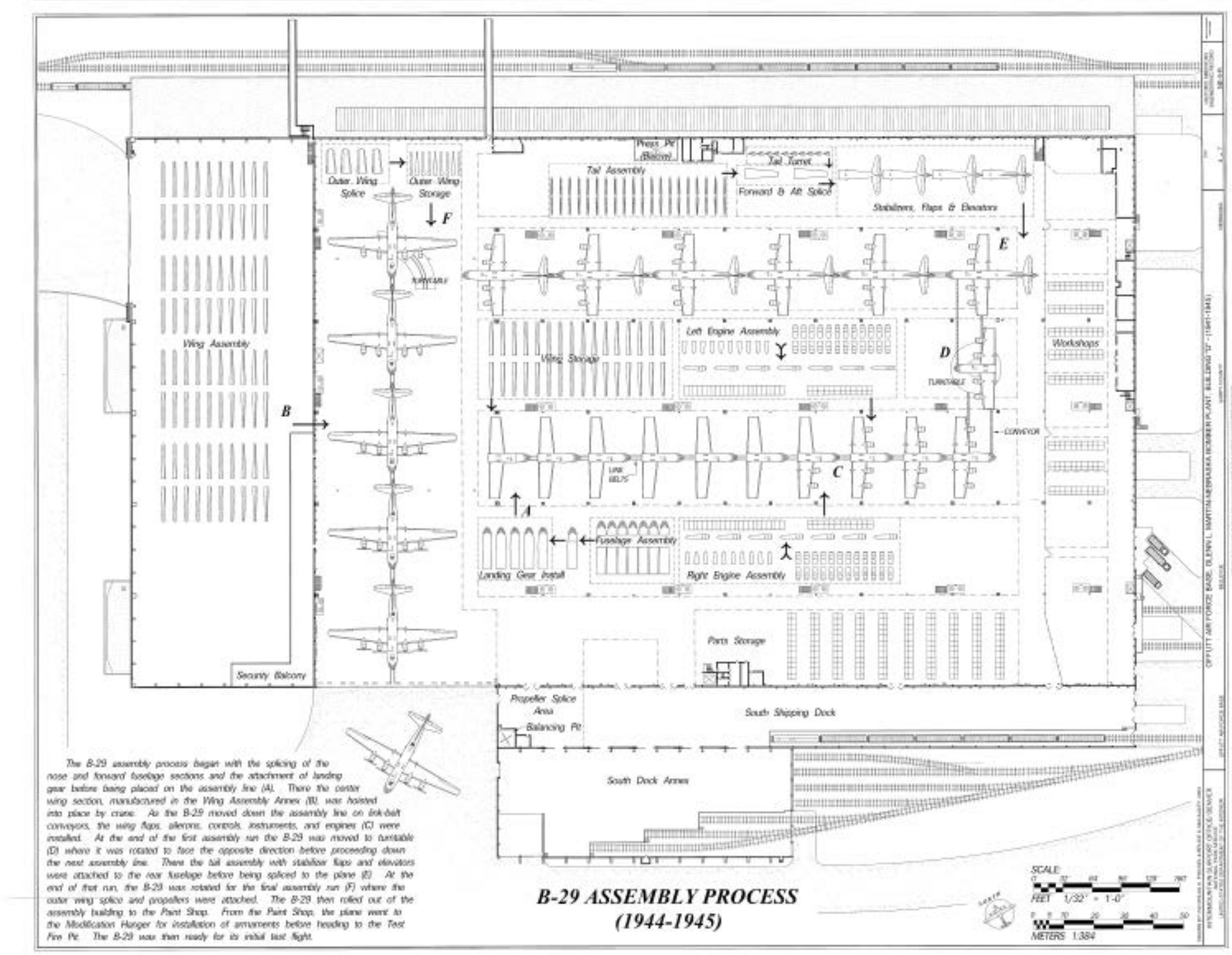

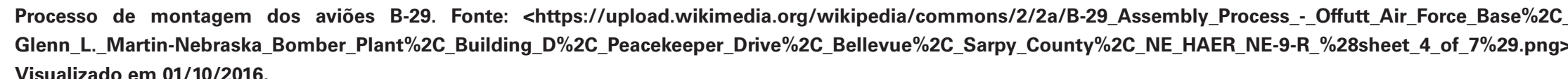


Por outro lado, nesse aspecto a proposta de Mies para Mannhein é alongada pela relação $1 / 2$, que traz ainda mais leveza ao volume suspenso e que permite organizar de maneira mais precisa o programa. Cada ala concentra uma das salas de espetáculos previstas, cada uma com características distintas de uso, estratégia que orienta o público em relação à cidade.

Ao criar a base mineral sobre a qual repousa o volume alongado, Mies projeta o pavimento junto ao solo em que pode ser distribuída toda a infraestrutura que permite a realização do espetáculo. Já no ambiente fabril de Albert Kahn, as instalações também puderam ser dispostas de forma livre, mas aéreas, sustentadas pela estrutura, o que interfere na percepção espacial da obra.

Ao retornarmos às colagens apresentada na exposicão do MOMA para a sab de conctos proposto por Mies (1940-1941), a participaca da es participação da estrutura é efetiva, porém os painéis acústicos do forro configuram o amplo plano contínuo definidor do espaço do espetáculo, o que seria ampliado à totalidade do espaço interno. Para muitos autores, essas especulações ndicam o princípio de uma série de projetos definidos pelo grande vão livre abrigando pro riam além do ambiente fabril, como o Centro de Convencoes de Chicago (1953-54), e que culminaria com o Crown Hall (1950-56). ${ }^{198}$

Em Mannheim, mais do que uma base, o pavimento técnico é uma plataforma sobre a qual o público vai circular, instalar-se e apreender o espetáculo. 0 plano contínue do chão suspenso projetado relaciona-se com o teto também livre e contínuo, o que aproxima as ideias de Mies às aspirações do meio teatral desde as vanguardas da décad de 1920. Isso confirma sua intenção de encarar a atividade teatral com a máxima liberdade, com a capacidade de trithar novos caminhos mesmo dentro de uma proposta de

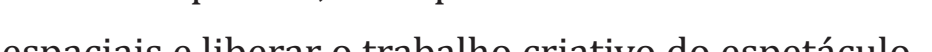
Com a solução em que há o predomínio da fachalongitudinal, ritmada pelos expressivos pórticos trel-

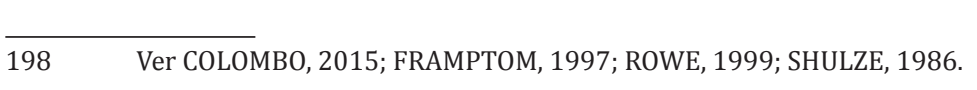

\section{Sala de Concertos. Colagem de aluno, 1992.
Fonte: Arquivo MOMA, NY.}

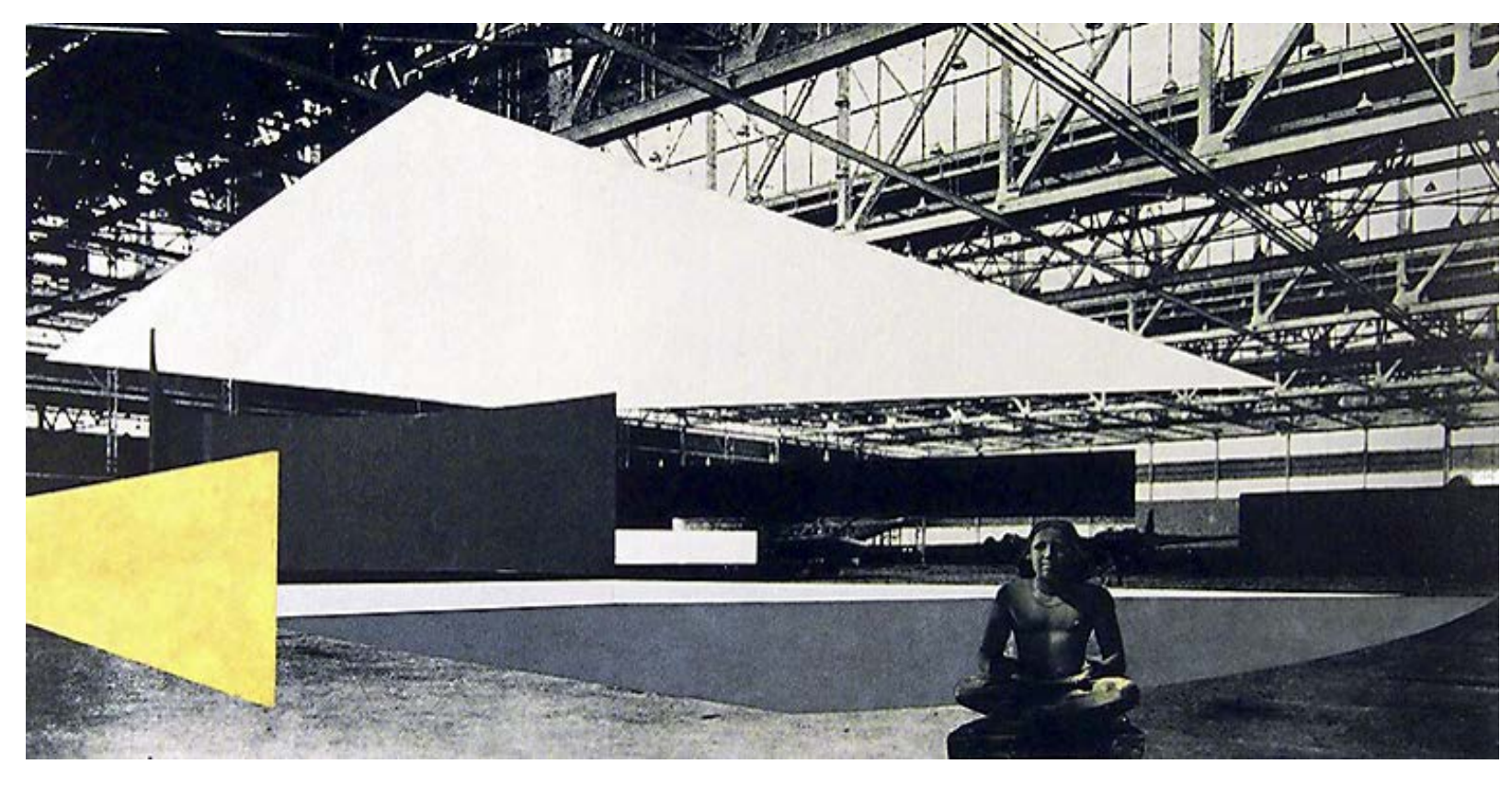

Projeto de Teatro Miss, 1947. For

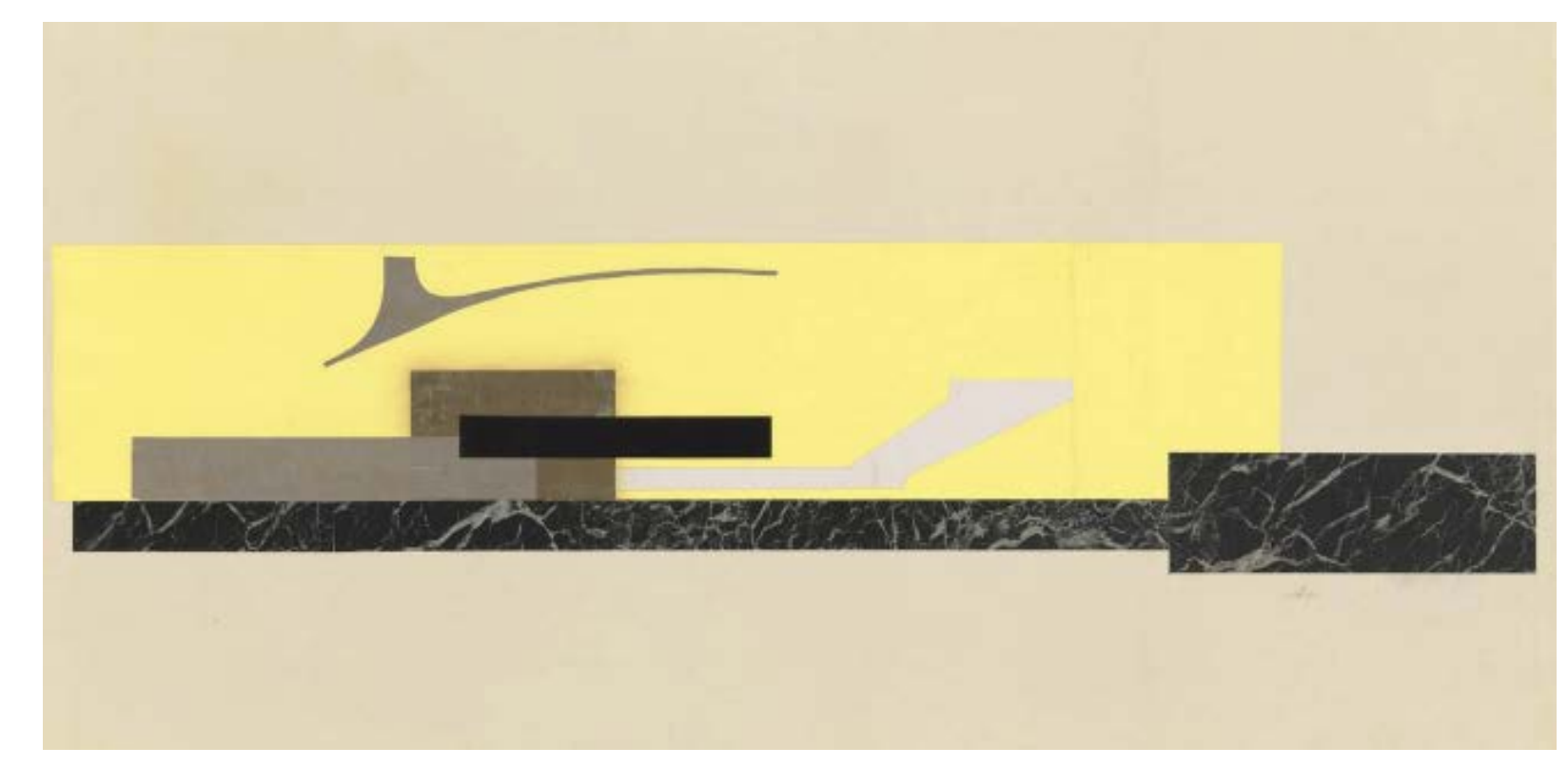




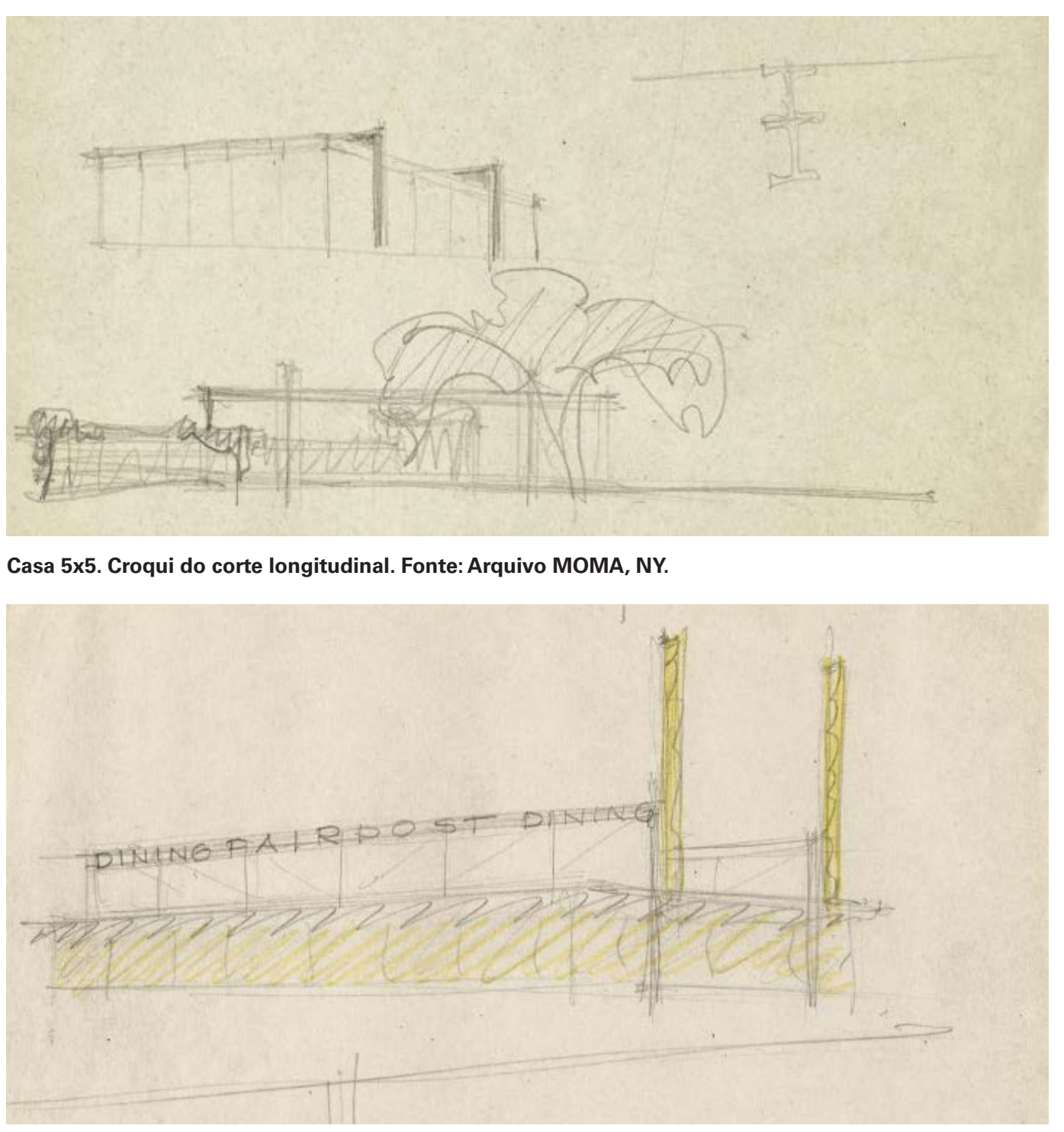

Cantor Drive-in, Indianápolis. Croqui, vista exterior. Fonte: Arquivo MOMA, NY cados, Mies vai resolver outros projetos com

pogramas distintos: a Casa 5×5 (1951-52) e (1946)

Essa pluralida de de progranas renete-nos novamente à epígrafe deste subcapítul em que Joaquim Guedes relembra as palavras Mies a respeito da imprevisível evolução dos usos. Estamos, então, diante de situações em que a obra constrói sua espacialidade pela força de sua técnica, por sua expressão estrutural. O caráter da obra encontra-se nas rela-
ções estabelecidas com o território e pela maneira como é apropriada pelos seus usuários, como observou Peter Blake:

A expressão particular. a particuE ão dos homens que o utilizam a maneira como eles se servirão. (BLAKE, 1958: 25)
Pelo que foi observado no presente capítulo até agora, a obra, segundo Mies, poderia admitir mudanças radicais de uso, $\mathrm{p}$ supermercado, como citado por ele quanto ao projeto de Mannheim, valendo-se da qualidade de suas estruturas internas e de sua capacidade de se relacionar constantemenaproximar este capítulo do capítulo 4, em que são estud sistema em que estão inseridos

Podemos, ainda, mantendo o foco na independência funcional da arquitetura em relação ao programa, observar

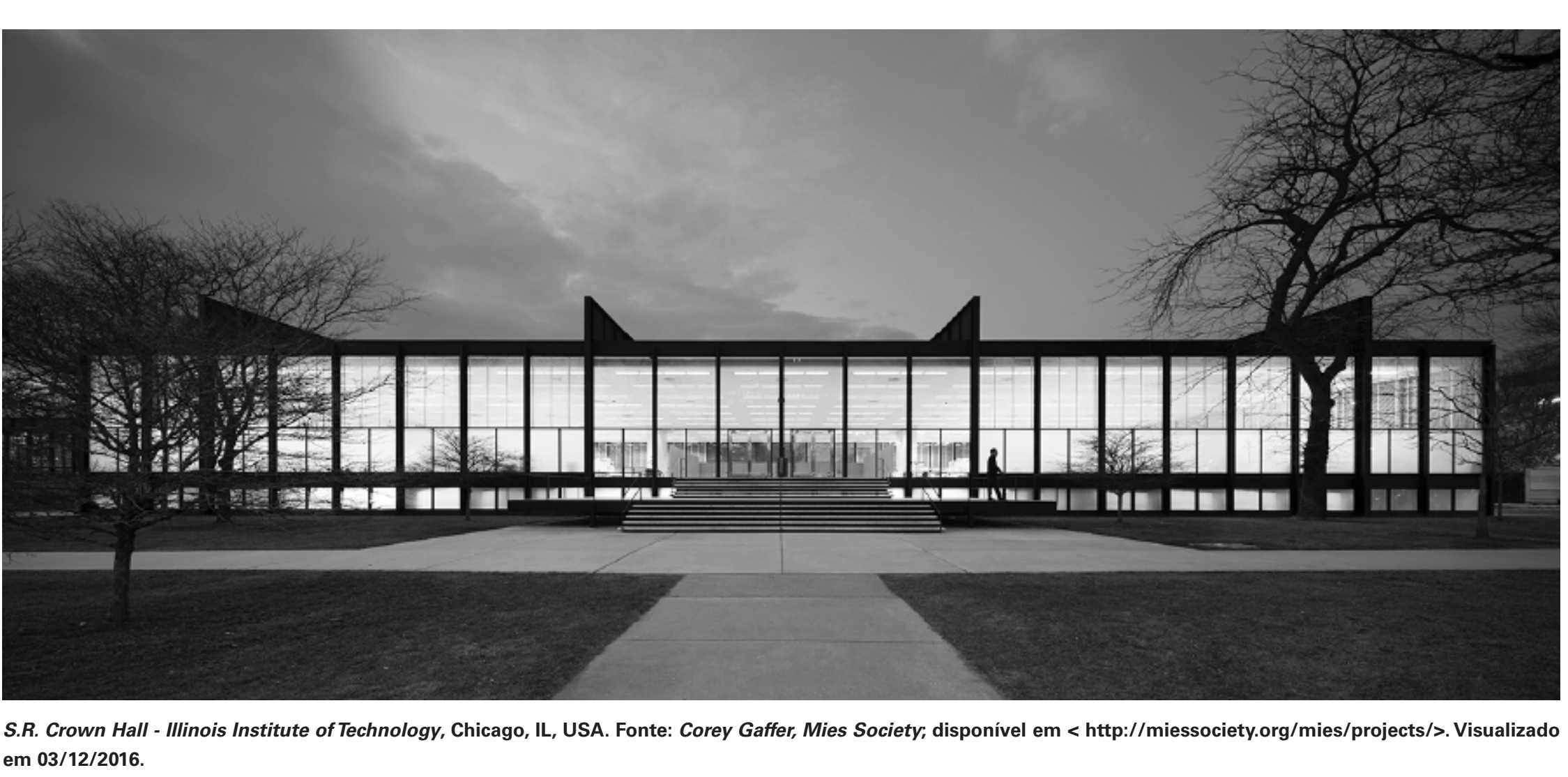


que um raciocínio semelhante explica a mudança significativa ocorrida na obra de Oscar Niemeyer na segunda metade da década de $1950^{199} .0$ arquiteto passou a se interessar muito mais pelas formas simples e compactas, como analis Paulo Bruna:

A descoberta da arquitetura europeia e de seu passado funcionou como um amadureciment como uma revelaçăo da permanencia $\mathrm{e}$ da his ria, do valor de seus montmentos simbolos, estágio de uma civilização, por oposição aos fa tores transitorios representados pelas funções pelo programa. (BRUNA, 2017: 93)

Bruna lembra-nos que a referida mudança ocorre após uma longa viagem de Niemeyer pelo continente europeu, em 19

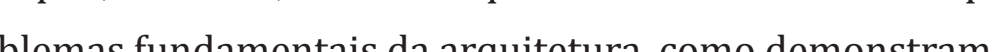
depoimentos publicados por ele na revista Módulo em 1958 (NIEMEYER, apud BRUNA, 2017: 95). A arquitetura de Nie-

199 Ver também: QUEIROZZ, A Revisiä Crritica de Oscar N Niemeyer, in BRUNA, 2017 meyer passou a expressar-se muito mais por meio de uma concepção plástica baseada na estrutura do que nos elemuladas por Aldo Rossi anos depois, conclui Bruna

Podemos considerar, portanto, que a permanêndo progras estaria patores transitórios quando entendidos apenas como elementos funcionais. Em outras palavras, a arquitetura concebida stritamente por suparão social ocorrida sobretudo a partir da segunda metade do sé culo XX. Acreditamos assim que somente a arquitetura dotada de qualidades estruturais interiores é suficientemente consistente não apenas para resistir às citadas transformações mas, sobretudo, para inspirar a criaç̃o de novas prátcas e novos usos.

Essa é uma de nossas respostas à questão de como a ndependência ao programa explica a sobrevivência da arquitetura no tempo.

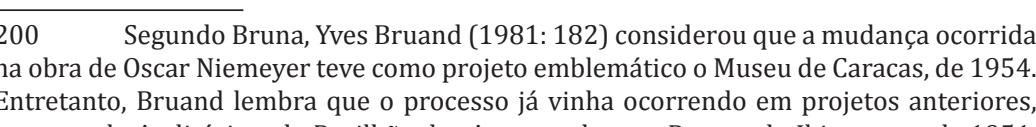

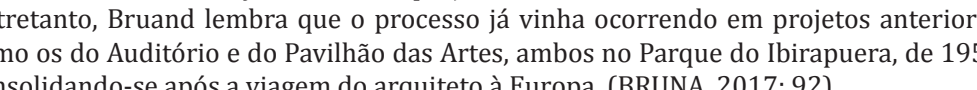

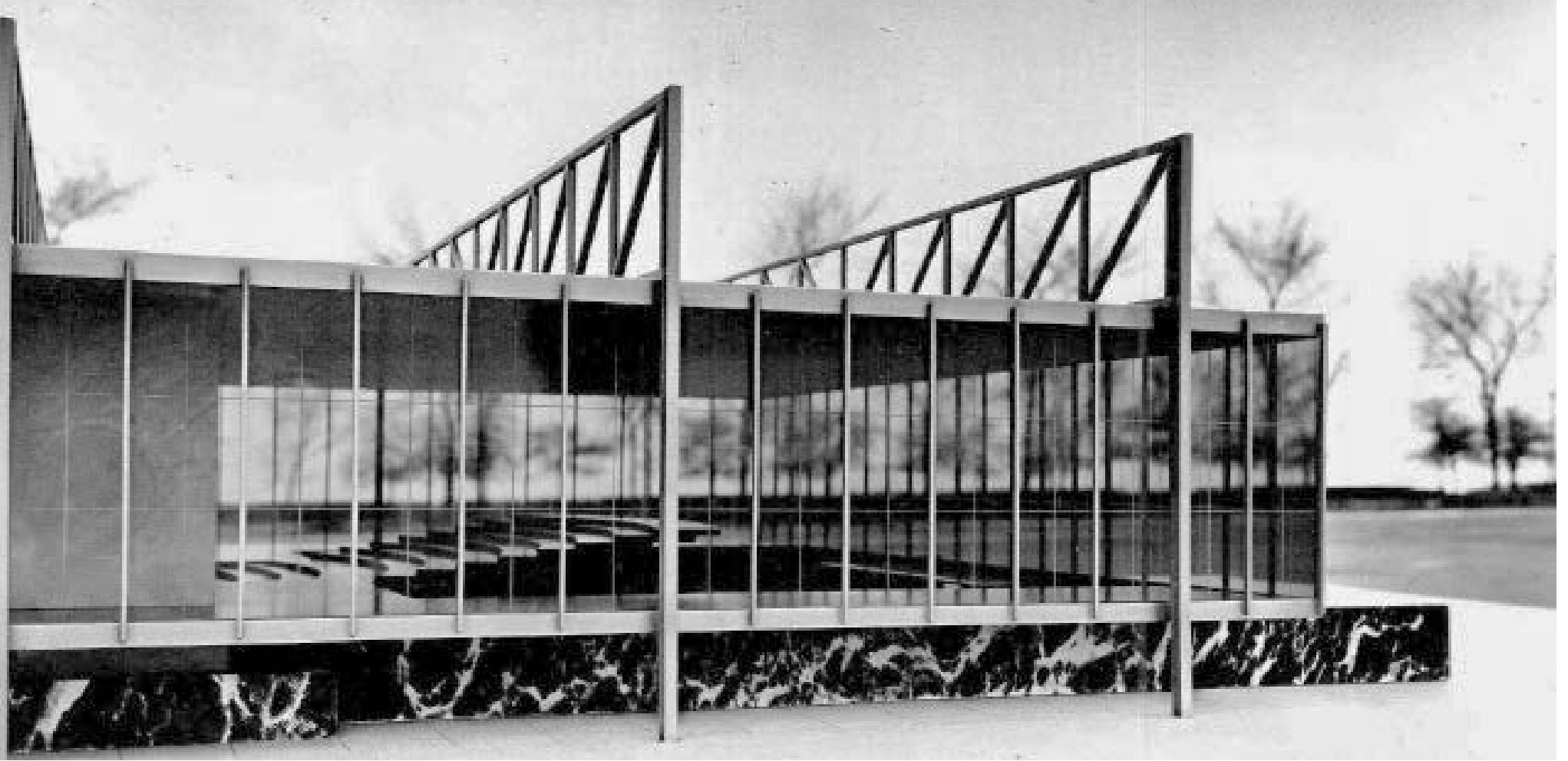

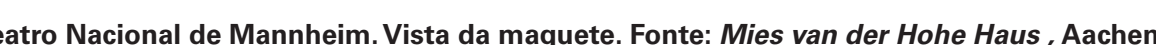




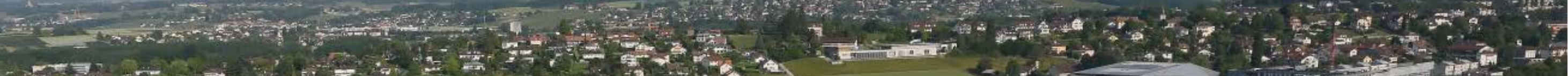

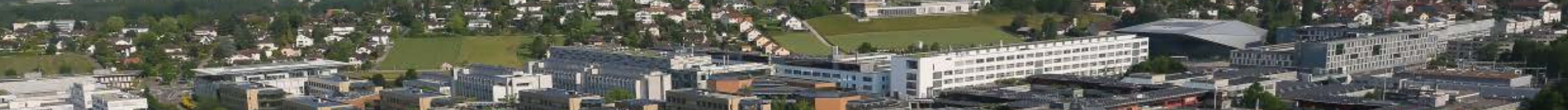

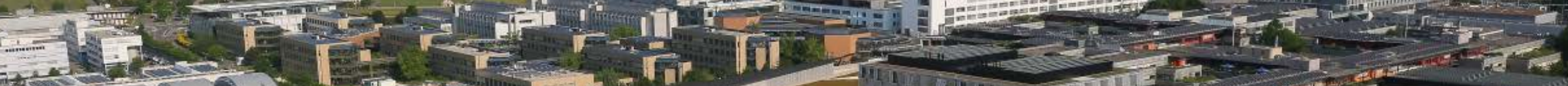

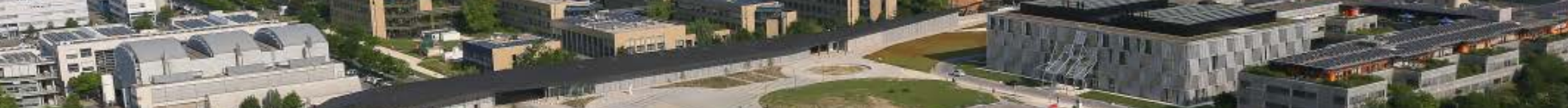

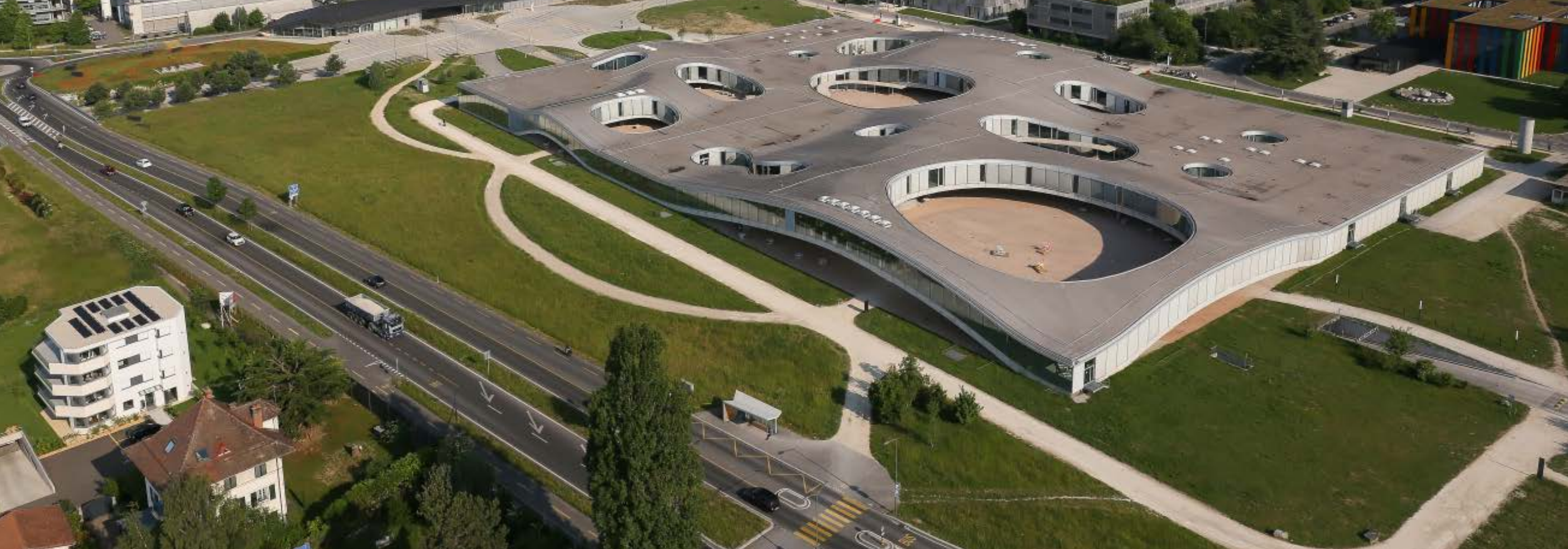

[...] é talvez na massa interior que reside a profunda originalidade própria da arquitetura. Ao dotar de forma definida esse espaço cavado, ela cria verdadeiramente seu próprio universo. [...] 0 único privilégio da arquitetura entre todas as ar-tes, mesmo que ela edifique moradas, igrejas ou pavilhões, é não abrigar somente um vazio confortável e envolto em defesas, mas sim construir um mundo interior que configura o espaço ea lur segundo as leis de uma geometria de uma meçnica e de uma ótica que são necessariamente inplícitas na ordem natural, mas que a natureza nâo capaz de fazer ${ }^{201}$

FOCILLON, 1947 
Um Learning Center pode ser entendido como um novo programa ligado às instituiç̄ôs de ensino e pesquisa que pretende reunir os mais avanç̧ados meios dis de tecnologia com o objetivo de integrar as áreas do conhe cimento e as pessoas, aproximando-as da sociedade.

Em recente concurso de arquitetura para o Learning Center da Universidade Paris-Saclay na França, os promotores do certame descreveram o novo equipamento como um lugar de mediac̃a cientifica apoiado por um centro de documentač̃o, ou seja um espaço de trabalho colaborativo que favorecerá o intercâmbio entre estudantes, pesquisadores, empreendedores e habitantes da região, oferecendo instrumentos adaptados aos diferentes modos de trab hho ${ }^{202} .0$ programa pretende favorecer a difusão do espírito de inovação através de espaços para encontros, exposições demonstraç̃oes, debates e seminários, dentro de uma ampla visão de trabalho individual, coletivo ou telepresencial.

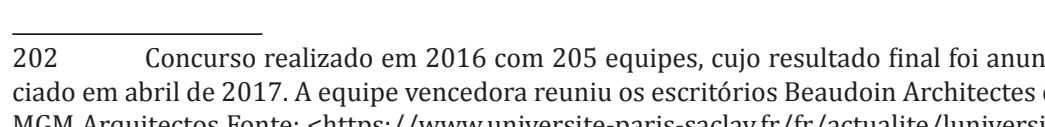

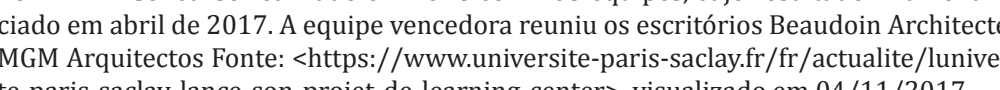

Os objetivos citados acima se alinham aos objetivos iniciais ainda mais ambiciosos que foram responsáveis pela criação de em 2007. Com a construção de um Campus ao sul de Paris, pretendeu-se promover, de maneira inédita na França, o luxo bidirecional do conhecimento das ciências fundamentais e das ciências aplicadas, dando ênfase à interdisciplinaridade e à internacionalização das instituições envolvidas.

E possível encontrar outras experiências semelhaconexão do conh Um exemplo notável é o do Education Center que a Universidade de Columbia em Nova York inaugurou em 2016. A solução proposta pela arquitetura do escritório Dillier Scofidio e Renfro vertic zou os espaços de encontro e de estudos que representan mais da metade do volume construído e dedicado a diversas disciplinas ligadas às áreas médicas e biomédicas.
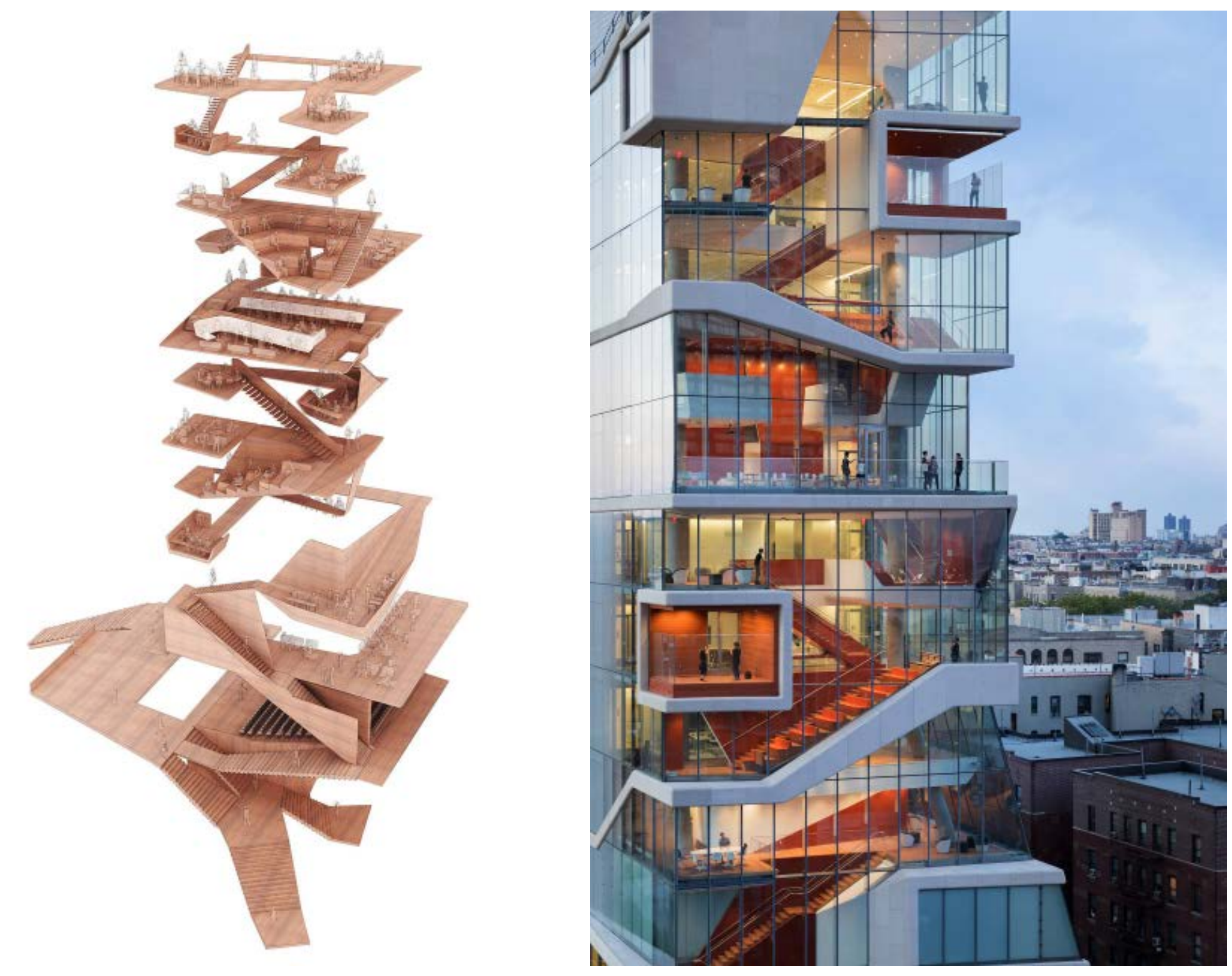

Education Center, Universidade de Columbia , Nova Vork 
Fica nítido, porém, o grande contraste entre os citados espaços de interação e estudo e os espaços de ensino formal, tradicionalmente frontal como as salas de aulas e os laboratórios. Há uma diferença marcante de espacialidade, o que pode ser observado na planta e no corte, o que fragiliza extrema liberdade dos primeiros, muito próxima de uma arquitetura espetacular voltada para a cidade, um pequeno High Line $e^{203}$ vertical, e a frontalidace radicional com que os locais de ensino propriamente ditos foram projetados. 0 contraste entre os espacos não contribui para ampliar as possibilidades de integração desejada. Entretanto, esse fato não reduz a significativa importância dedicada à concepção dos espaços comuns, os espaços "sem nome", como tentativa de promover o intercâmbio interdisciplinar tão almejado pelas instituições de ensino e de pesquis

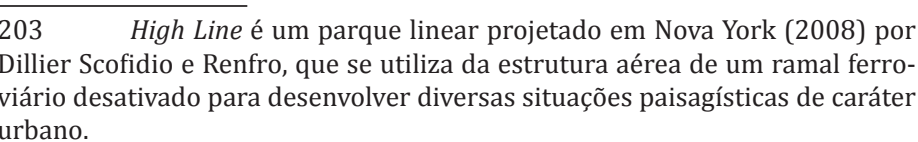

\section{Sin}

Planta do déc

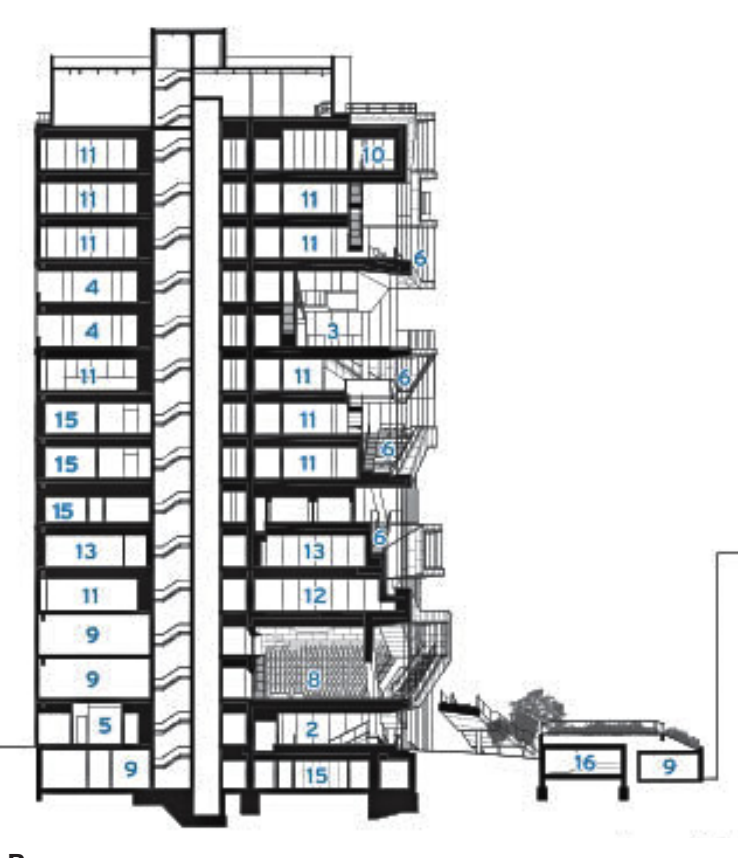

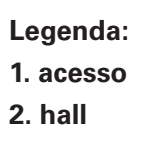

Education Center-Universidade de Columbia - Nova York
Planta do $12^{\circ}$ pavimento e Corte longitudinal.

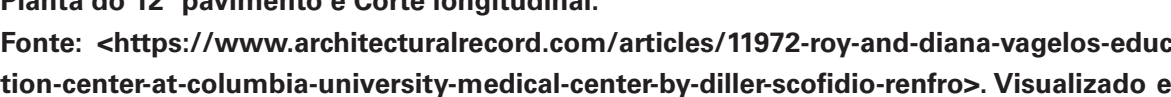

Ainda mais distante dos programas bem definidos, o Kanagawa Institute of Technology (KAIT), no Japão, recebeu duas edificaç̃os projetadas pelo arquiteto japon Junya Ishigami. 0 pr do 20008 con 0 a organização orgânica de uma floresta, segundo Ishigam distribui de maneira aleatória 300 colunas metálicas sob uma cobertura de $1.990 \mathrm{~m}^{2}$, configurando inúmeros espairregularidade que amplia a diversidade de situaçoes e de possibilidades de uso, completa Ishigami

Muito próximo a KAIT Workshop, Ishigami projeto em 2008 o que foi chamado de University Multipurpose Plaza. Com $4.100 \mathrm{~m}^{2}$, diferentemente do pavilhão anterior, o grande espaç concebido privilegia as atividades de conviUma cobertura levemente curva, composta de uma chapa metálica tensionada e de uma fina laje de concreto, cobre toda a superfície, com altura livre variando entre 2 $3 \mathrm{~m}$. Uma série de aberturas quadradas, livremente distribuídas, perfuram a cobertura deixando os elementos naturais - sol, chuva e vento - entrar, novamente conside os elementos naturais como elementos de projeto.
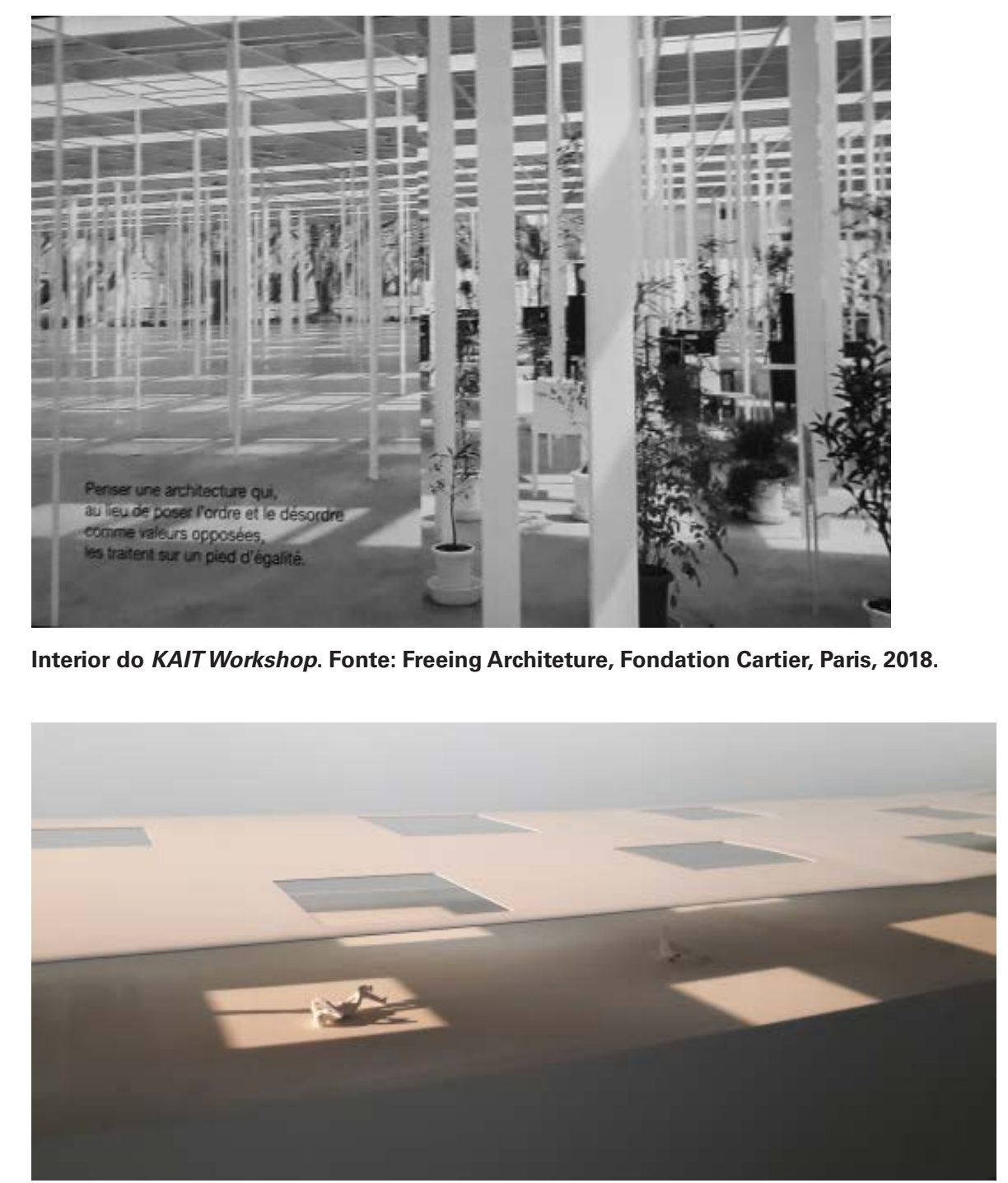

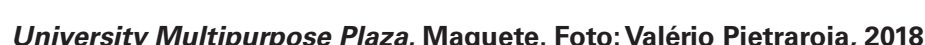




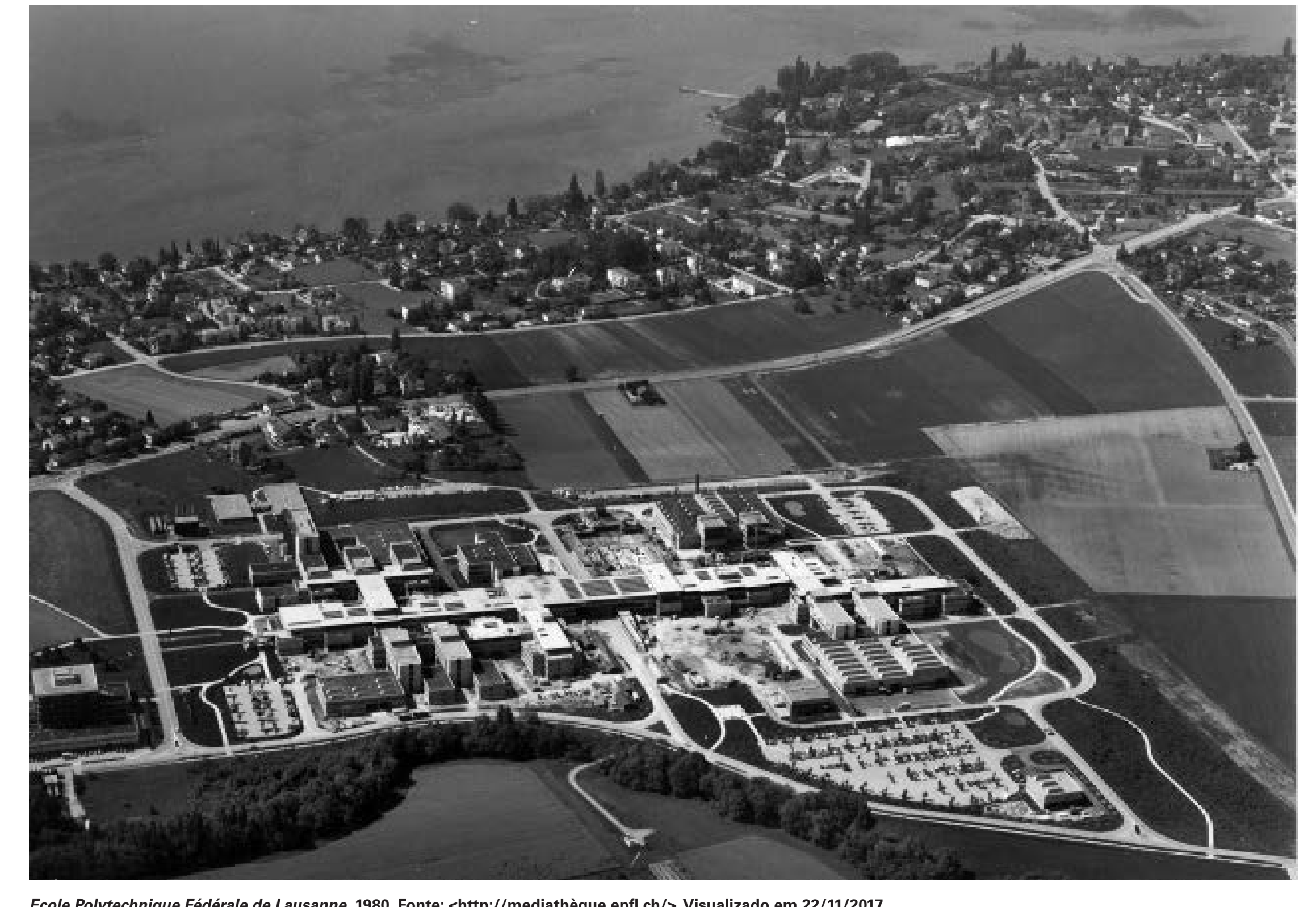

oi com preocupações muito próximas às de Ishiga i que a École Polytechnique Fédérale de Lausanne - EPFL (Suíça) lançou um concurso internacional em 2004 para a criação de um Learning Center como espaço dedicado ao universidade fracesa Paris-saclay, a EPFL tem um século de existência; seu campus atual é extremamente heterogêneo, denso e com uma organização pouco clara. Ele fo implantado em Écublens, municipalidade que compõe a aglomeração urbana de Lausanne e e o rique liderado por Jacob Zweifel, com um projeto bastante compacto, segundo uma organização ortogonal em pente baseado em critérios de eficiência funcional dos diversos departamentos e laboratórios instalados. Segundo Chris-

Ecole Polytechnique Fédérale de Lausanne, 1980. Fonte: shttp://mediathèque.epfl.ch/>. Visualizado em 22/11/2017 
toph Allenspach ${ }^{200}$, a solução consistia na estruturação das células em torno de um centro de capacitaçăo fechado sobre si mesmo. Os edifícios foram construídos sem a preocupação de interação entre as diversas áreas do con em que a universidade atua ainda hoje. Não havia um local definido para que houvesse vida social entre a comunid de universitária e entre essa e a própria cidade, apesar do campus fazer parte da cidade, implantado de frente para o Lago Leman.

No momento do concurso, havia uma certa desurbanizaç̃o caótica da aglomeração de Lausanne, o uso agrí́col inda prevalecia no local, configurando uma paisagem rur muito comum nas proximidades das cidades suíças, como pode ser observado na imagem aérea de 1980, quando o complexo ainda estava em construção.

Vale lembrar que o concurso ficou mais conhecid pela proposta do grupo de arquitetos da região suíça do Ticino, composta por Luigi Snozzi, Aurelio Galfetti, Mario Botta, Flora Ruchat-Roncati e Tita Carloni, que viriam a ter importante papel na produção de uma arquitetura com grande identidade cultural, conhecida como regionalismo crítico $0^{20}$

A proposta do grupo tessinês organiza as atividades

malha expansível que se estr

sistema formal 10

centradas todas as áreas comuns, de convivência e infraes-

trutura. Essa visão sistêmica do projeto está totalmen vinculada à noção de urbanidade pela qual as ruas internas promoveriam a integração da vida universitária ao mesmo tempo em que sua expansão seguiria um traçado regulad or $\mathrm{ha}^{208}$. Podemos afirmar que se tratava de uma arquitetura de estrutura espacial forte e consequente, capaz de enfatizar a relação com o entorno e a cidade, sem maiores preocupações com o desempenho funcional do conjunto, o que causou dura reação do júri por considerá-la formalista e antifuncional, como recorda Allennspach (2011).

Após trinta e quatro anos, a situação diagnosticada o campus confirma as previsões iniciais do projeto tessinês: um conjunto extremamente eficiente que não promove a convivência e o intercâmbio científico desejado para uma instituição importante

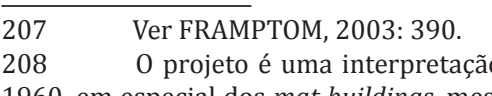

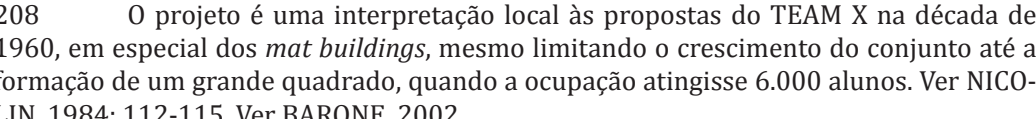

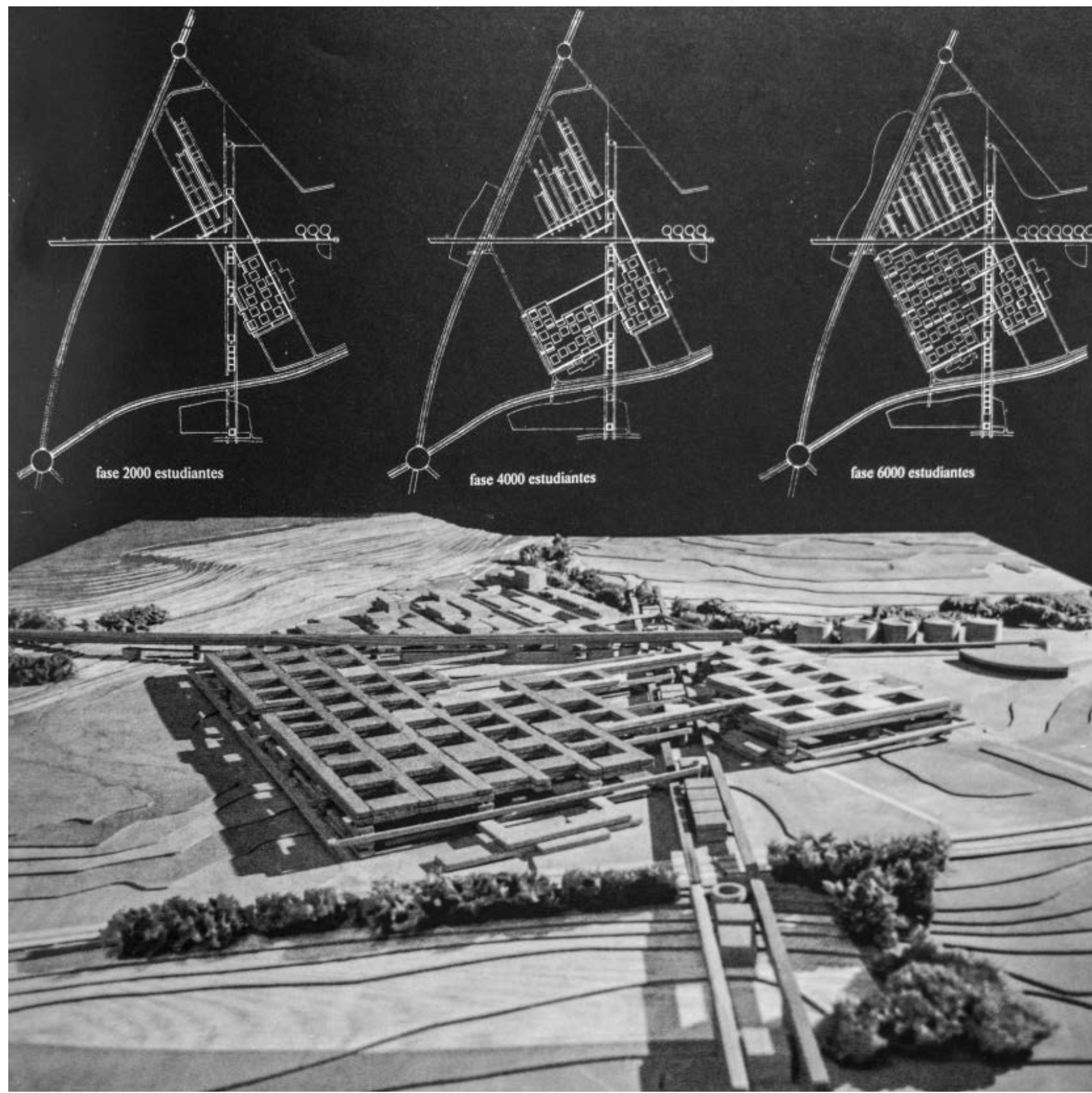


Em 2004, o programa para um novo concurso solictou aos arquitetos a criação de uma " plataforma de aprendzagem que fosse capaz de anular as fronteiras físic comunidade e as disciphas" (flme Le 2010), o que seria um grande lugar de encontro, o lugar do conhecimento, dentro do espírito de uma praça públca protegida. Ou seja, a intenção principal foi a de criar un grande espaço de convivência que, ao materializar as novas relacões promovidas pelo desenvolvimento da tecnolog da informacão, intensificasse as trocas de conhecimento entre toda a comunidade acadêmica, que conta hoje com mais de 8.000 estudantes e pesquisadores vindos do mundo inteiro. Em certa medida, seria o coração pulsante do campus, proposta não muito distinta do que foi formulado por Josep Llús Sert em seu livro Centros para la Vida de la Comunidad: "a história nos demonstra que sad

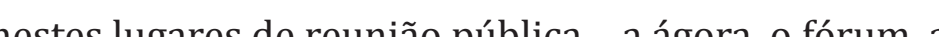
ça da catedral - onde se tem conseguido a plena integração entre as artes.".209 (SERT, 1955: 14)

David Aymonin, diretor da biblioteca da EPFL, que ocupa parte do edifício, acredita que vivemos um período

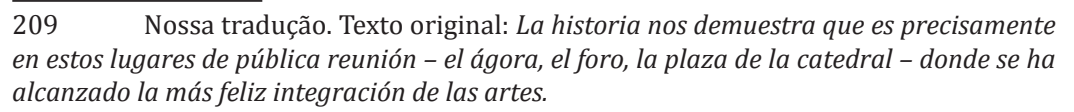

de mudança de ponto de vista do que deverá ser uma biblioteca, o que divide opiniões de pesquisadores e de cienconvivência, de de vamos ver se vamos acertar", completa Aymonin, no filme Le Paysage Intérieur, de 2010.

O trabalho de Kazuyo Sejima, que lidera com Ryūe curso ${ }^{210}$, não parece direcionar sua arquitetura para a sociedade da informação, como observou Pierluigi Nicolin (1998:7). Em seus projetos, a desaceleração do culto da imagem e o pensar à deriva seriam responsáveis por permitir que os edifícios contribuam para a integração das pessoas e da cidade, completa Nicolin. Isso fica evidente quando observamos os demais concorrentes do concurso, que apostaram na grande impacto de uma edificação farol, dominando o campus, que se encontra em situação privilegiada, muito próxima das margens do Lago Leman.
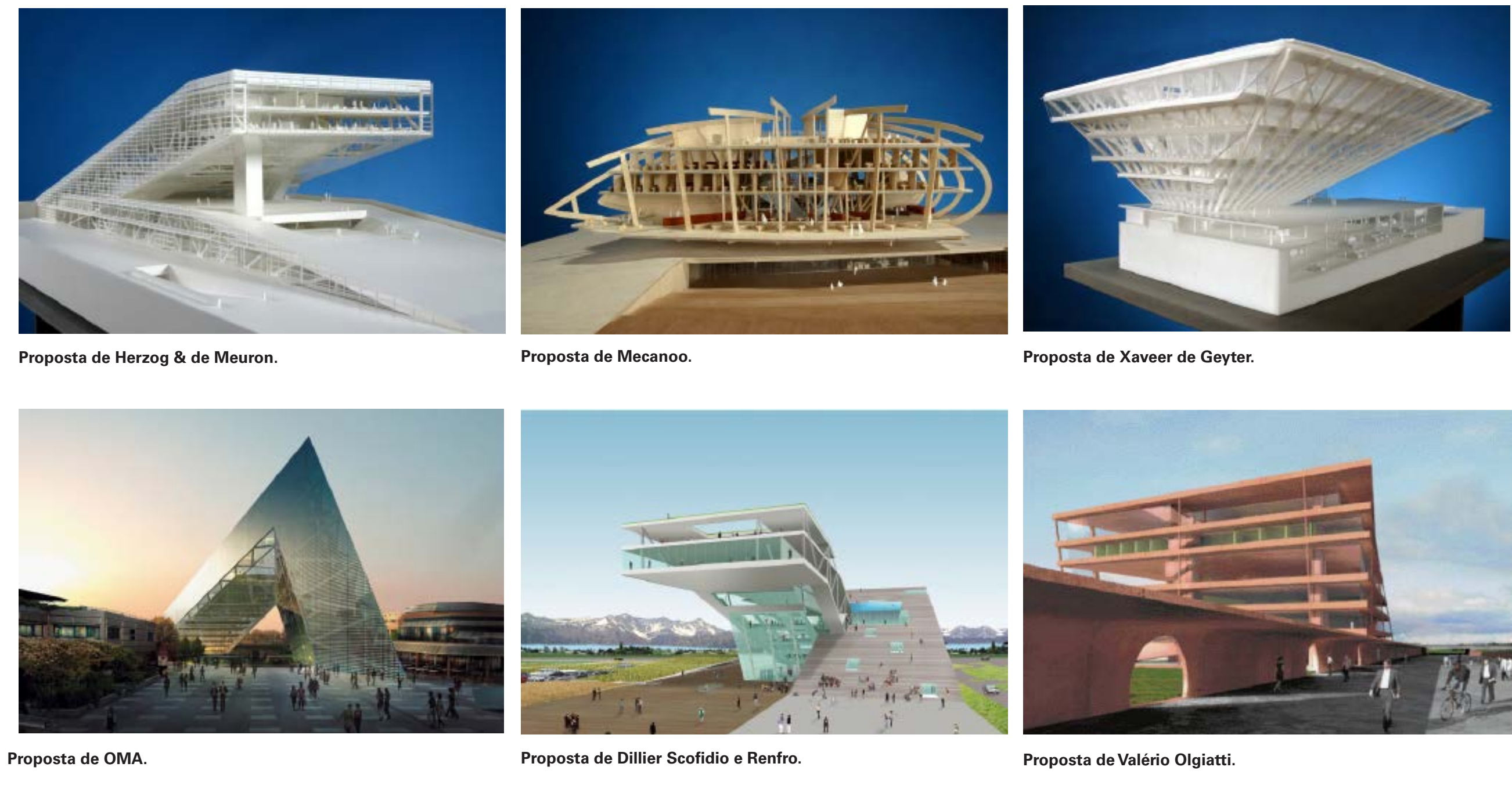

oposta de Mecanoo.

Proposta de Xaver de Geyter

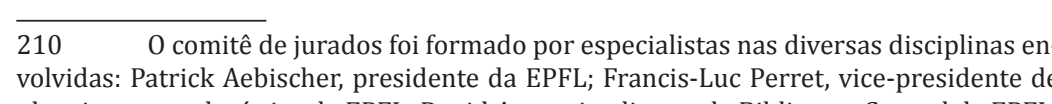

fonte: http://mediattèque epflch/ Visualizado em 04/11/2017
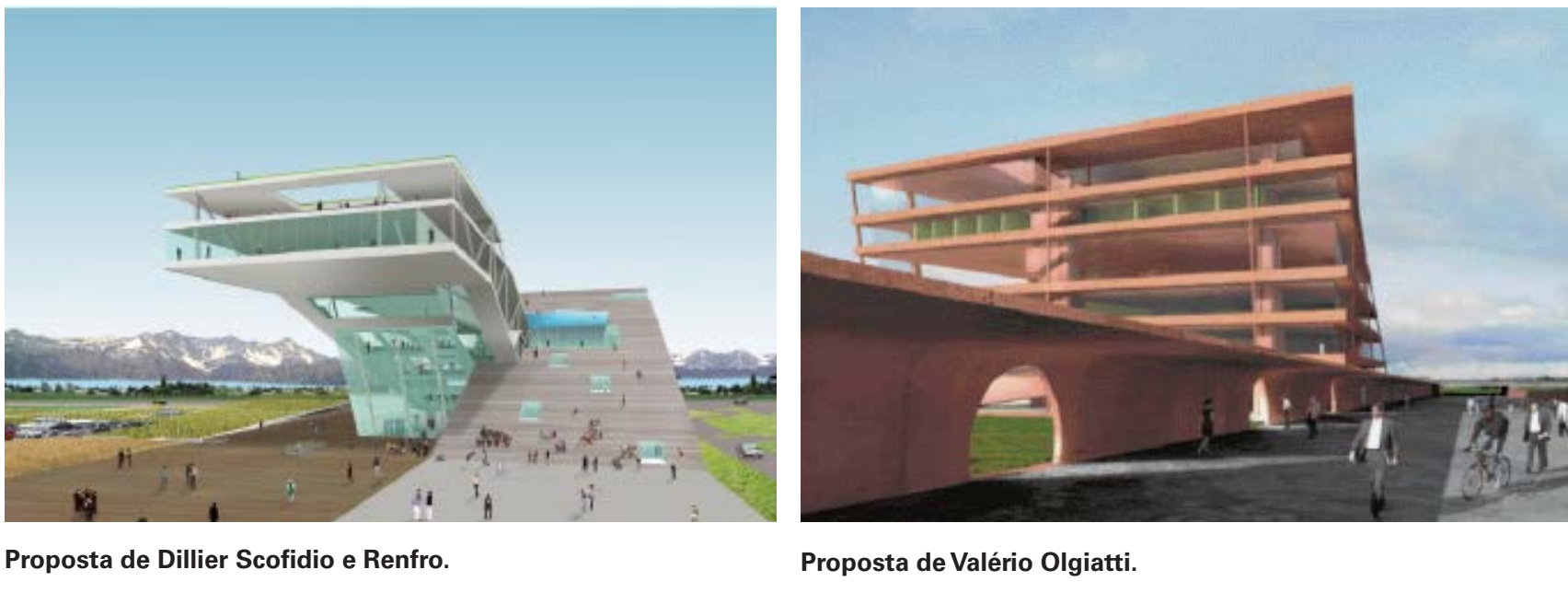

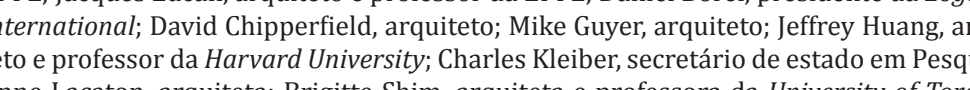

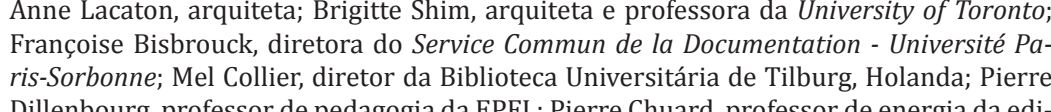
inlenbourg professor de pedagogia da EPFL; Pierre Chuard, professor de energia da de 
Mas por que a mesma tecnologia digital viabilizou propostas tão distintas como o Learning Center de Lausanne e o Museu Guggenhein de Bilbao na Espanha, obra emblemática do arquiteto Frank 0 . Ghery construído na mesma época?

Uma das respostas aponta para o fato de que, em re lação à obra construída em Lausanne, o programa original se comportou como objeto de interesse inicial, porém delxou de exercer sua força à medida que a arq posta tomer conta das maneira, a tecnologia maneira, a tecnologia nimizou as barreiras, abriu cam nhos para que o projeto amplificasse o próprio programa, intensificando a dinâmica dos usos. Ainda que a tecnologia digital tenha sido largamente utilizada para a concepção e rojeto, SANAA não se valeu dela para dar sentido à sua obra.

Em outra vertente, ainda que com a intenção de dinamizar a cidade Bilbao, a obra de Ghery se cerca da tecnologia como instrumento de projeto, um meio fundamental para viabilizar tecnicamente sua força criadora, assim descrita por Rafael Moneo:
0 computador - e a aplicação de um programa utilizado pela indústria aeronáutica, o CATIA ${ }^{212}$ permite que ele [Ghery] use qualquer forma, sem [ẽo poder representá-la. Hoje, a mais exuberante das formas é passivel de ser descrita e representada, e consequentemente, construída. A extensão do que entendemos como linguagem arquitetônica a um mundo infinito de formas que não precisam, necessariamente, ser descritas pelas geometrias convencionais destró os limites do território onde o arquiteto pode se mover. (MONEO, 2008: 278) correntes, o projeto vencedor aponta para a horizontaldade da edificaçãa a partir de um novo chão que cria uma topografia artificial, mas mantém pouca altura em relação ao campus e à cidade. É possível desfrutar da paisagem única do Lago, em primeiro plano, e dos Alpes na margem oposta, sem que seja necessário concorrer com ela. Como consequência dessa estratégia, a arquitetura proposta é dominada pelas áreas cujo uso é indefinido em princípio, não previsto inicialmente, mas cuja função indeterminada ga-
列 lin (1998), por meio dessa postura, a arquitetura japonesa passa de uma fase sociológica e mimética na relação com o ambiente informatizado, para uma fase científica e filosófica. Em outras palavras, a arquitetura passa à reflexão através da proposição, passa a pensar e a construir formas de relacionamento que de certa forma haviam sido apartadas pelas divisões funcionais, ao mesmo tempo em que apoia novas iniciativas, novas formas de aç̃̃o e interaç̃o.

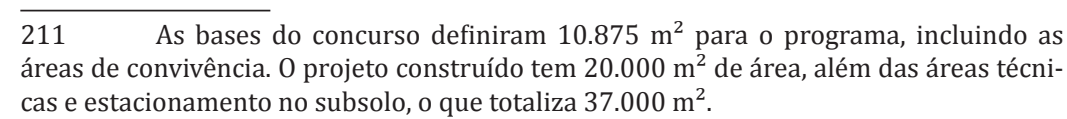




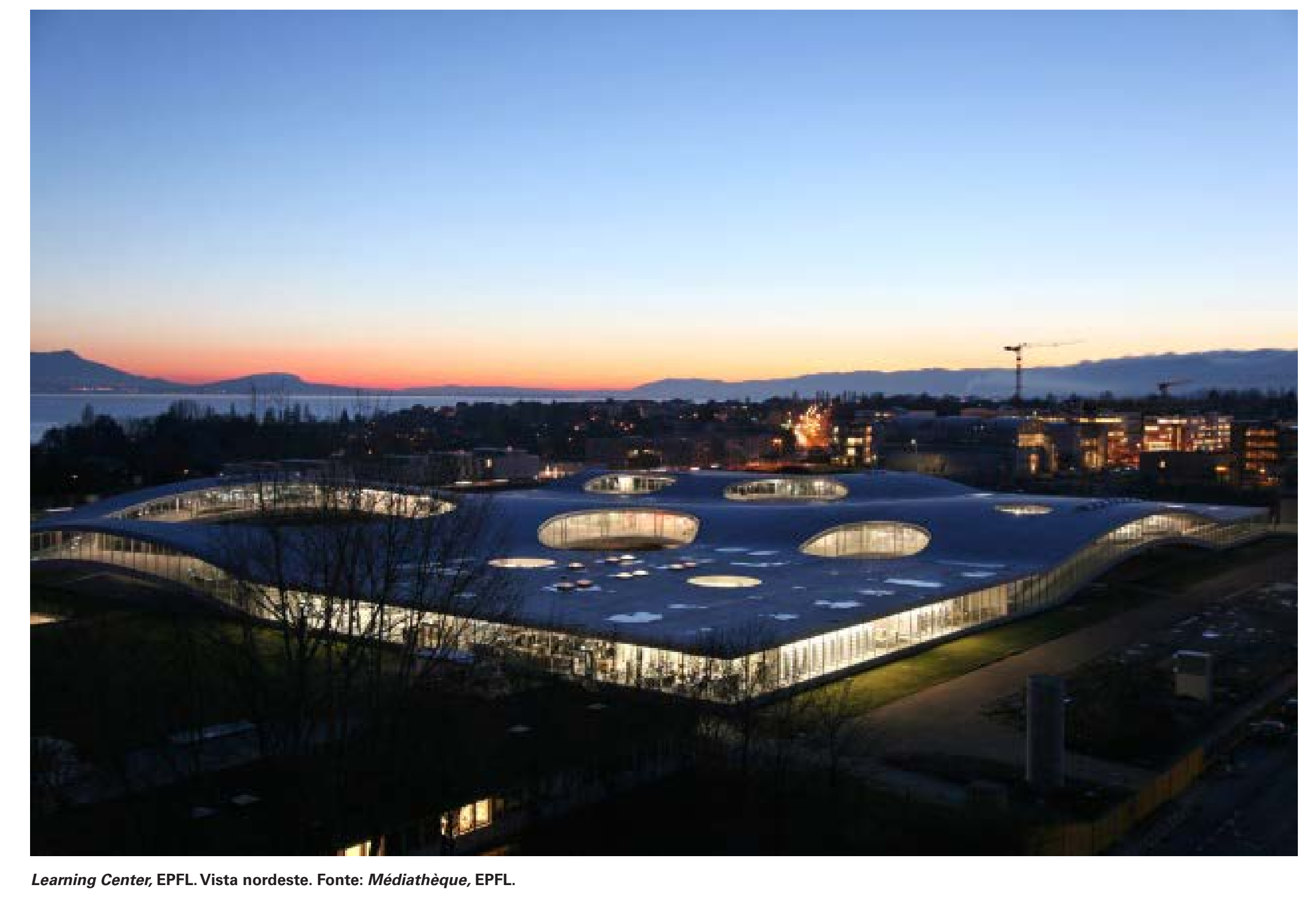

A aspiração de reduzir a arquitetura a sua condiç̃o construtiva é, mais exatamente, a ambiçâa de modelar o espaço por meio de perfis, paredes, colunas e coberturas -uma tentativa de alcançar a ordem utilizando a geometria. 0 objetivo nada menos do que criar una condiçăo antina-

tural', isto é, um espaço que não pode existir na natureza.
KISH, 1996

Fazer o máximo de espaço com o mínimo de

mánimo derial material.
YAMADA, 2010

o Learning Center de Lausanne foi instalado em uma dificação composta por um único pavimento horizontal que forma natatorma ondulada e per furda por pitios curvos, apoiando-se no terreno natural totalmente plano projetando uma ocupação de $120 \mathrm{~m} \times 160 \mathrm{~m}$. As áreas técni- 

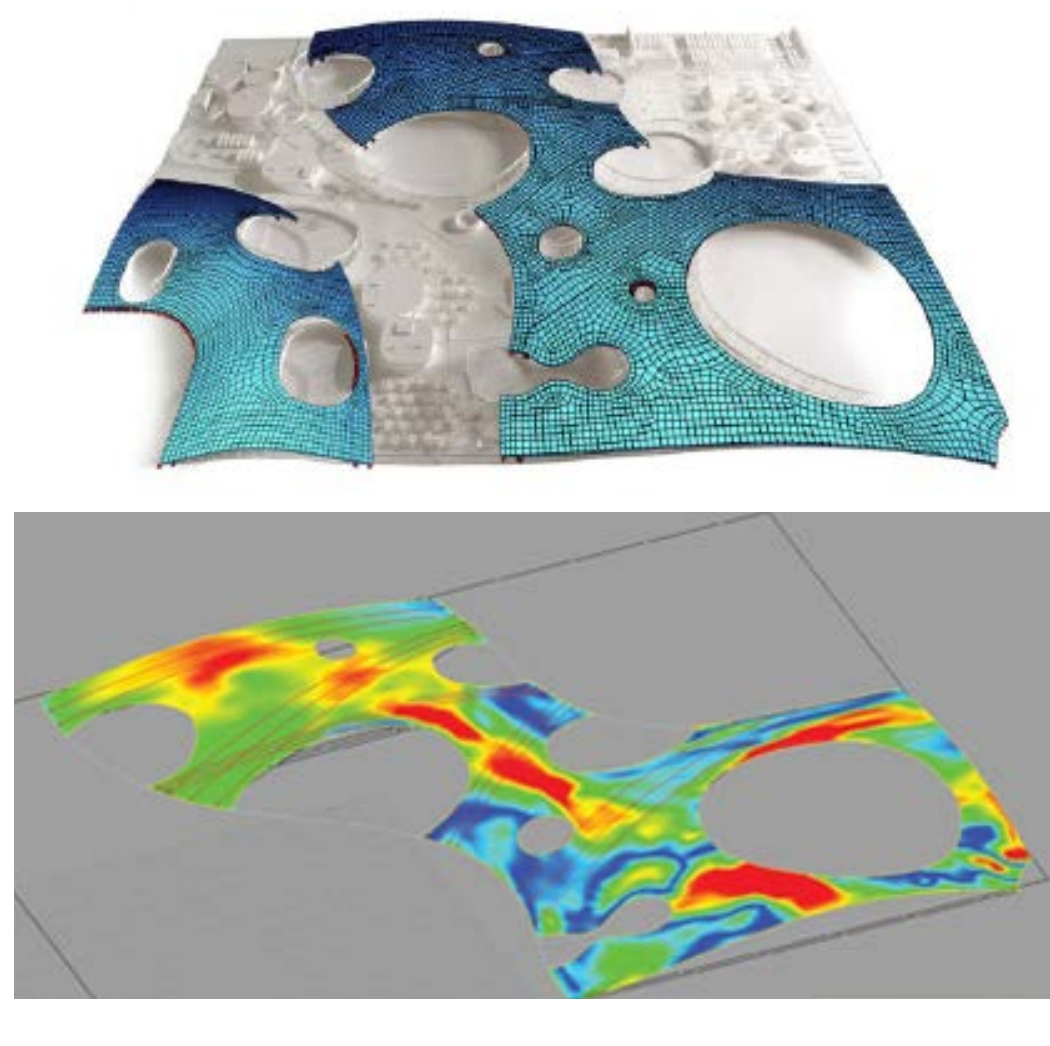

Learning Center, EPFL. Diagramas da casca em concreto que forma a platatorom

Essa plataforma, que conforma um novo chão, é suportada por duas cascas em concreto armado moldado no local que possui onze arcos em concreto protendidos, que vencem vãos de até $90 \mathrm{~m}$ nas suas regiões mais acidentadas. A solução estrutural introduz arcos "embutidos" na casca de concreto e se beneficia da laje do subsolo que se comporta como corda para travar os arcos.

Para confecção dessa superfície com curvatura varínel perfin peças distintas realizada durante 48 horas ininterruptas, para que pudes ser garantida a continuidade estrutural desejada. Foi necessário atingir uma plasticidade do concreto capaz de atender ao desempenho estrutural solicitado mantendo a qualidade a continuidade visual desejados ${ }^{214}$

Sobre essa topografia artificial criada foi distribuía uma malha regular de colunas em tubos de aço formando vãos de $9 \mathrm{~m}$, que suporta a estrutura mista com vigas longitudinais em aço e transversais em madeira laminada colada, que acompanha a mesma geometria ondulada e as tura é garantida externamente por uma manta sintética em evalon branco e internamente por chapas de gesso acartonado pintadas de branco, sem nenhum equipamento ou dispositivo embutidos.

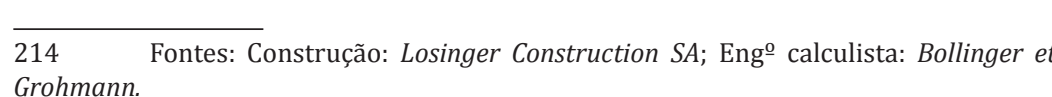

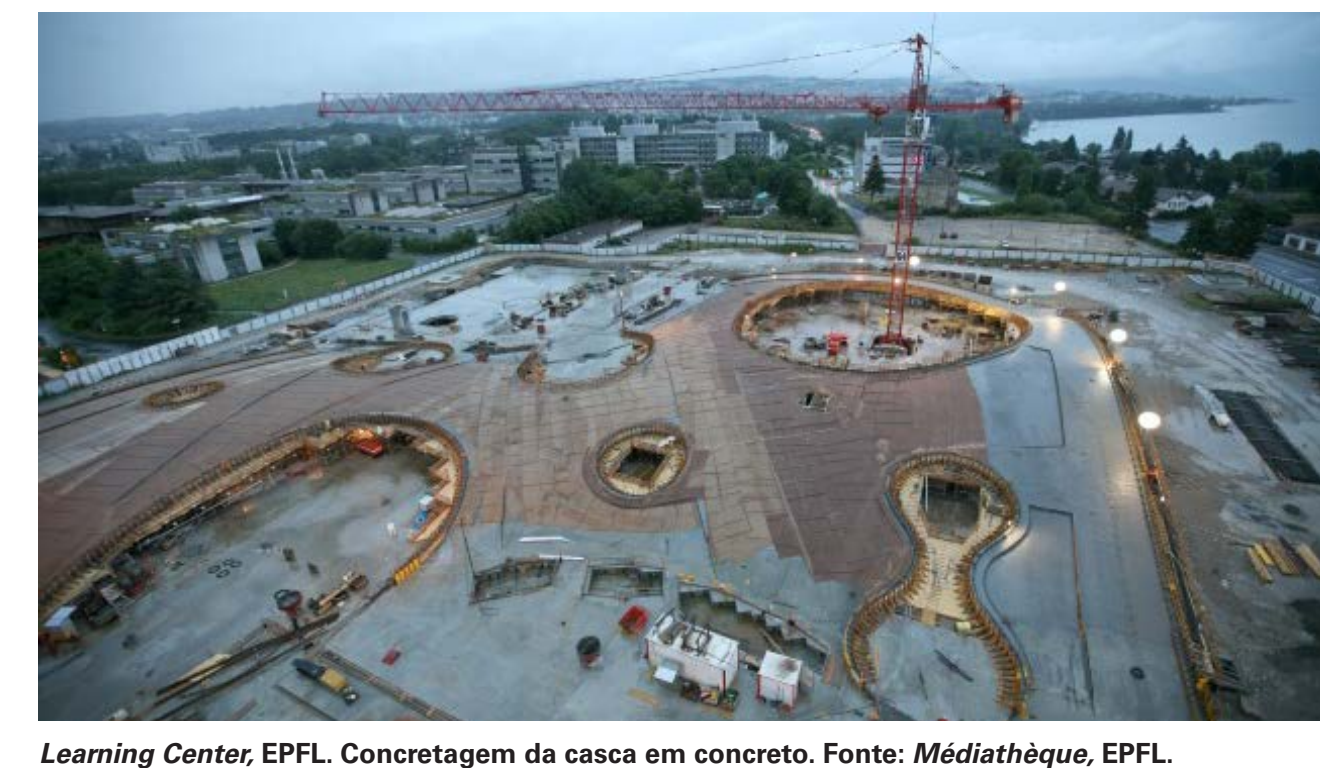

Ao concentrar todos os locais técnicos no o projeto permitiu que o grande piso dulado criado se transformasse em menta mais de 1.500 postos de trabalho além da infraestrutura móvel.

Para o fechamento vertical do prisma re tangular e dos pátios internos curvos, foram fabri$90 \%$ confeccionados em peças unicas. Mesmo con nvidraçada, a edificação fo

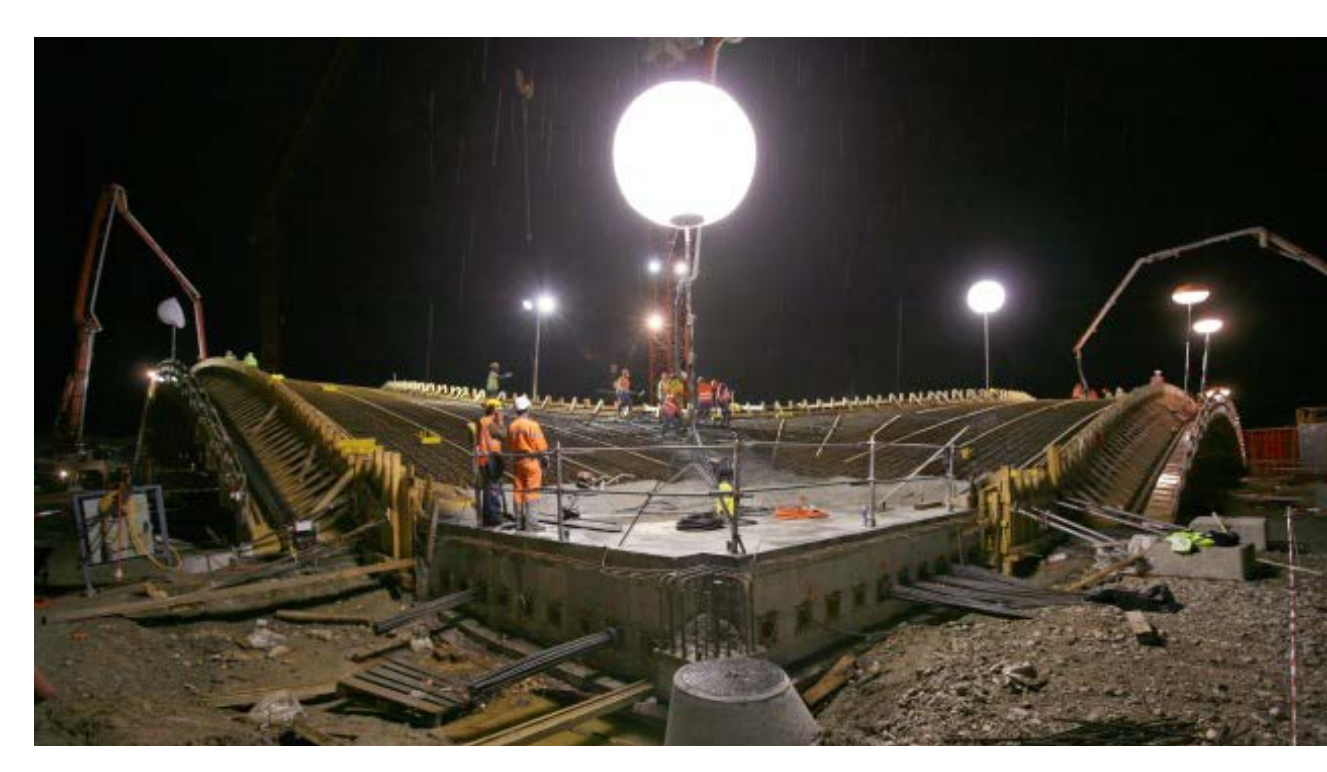
as instituições responsáveis, por atingir um consumo de energia de $38 \mathrm{KWh} / \mathrm{m}^{2} .215$

Todas essas informacões demonstram To projeto, como testemunhado por Francesco Della Casa, chefe de redação de revista Tracés:

A questão mais banal torna-se un enigma a resolver, a inventar, o que torna bonito no canteiro é que arquitetos e engenheiros fazem um esforç para manter a simplicidade da forma.
(DELLA CASA, in MAILLARD, 2010: 38') 


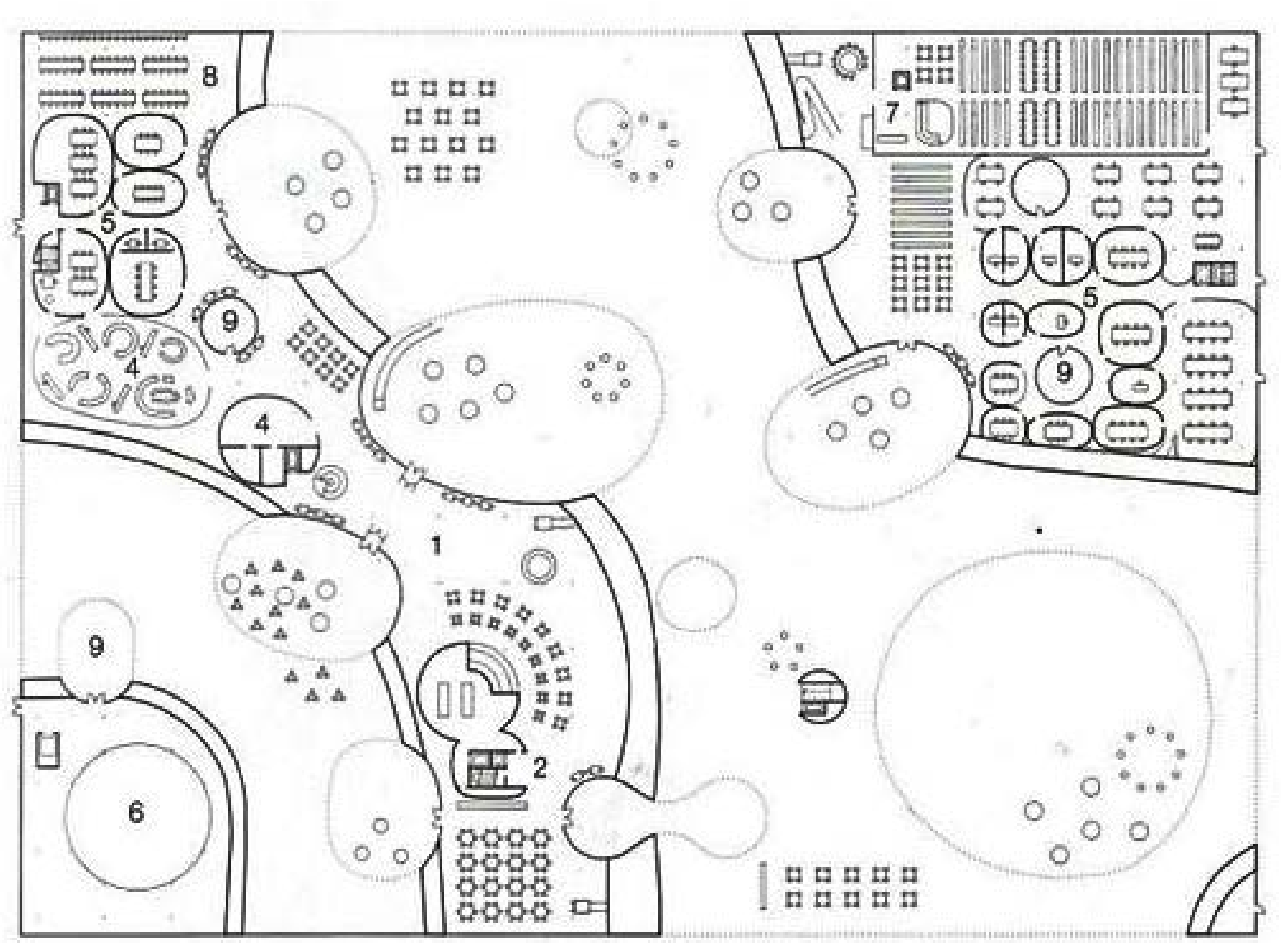

Legenda: 1. Acessos 2.
9. Pátio 10. Restaurante

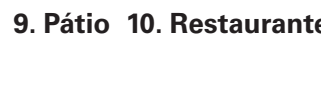

Learning Center, EPFL. Plant

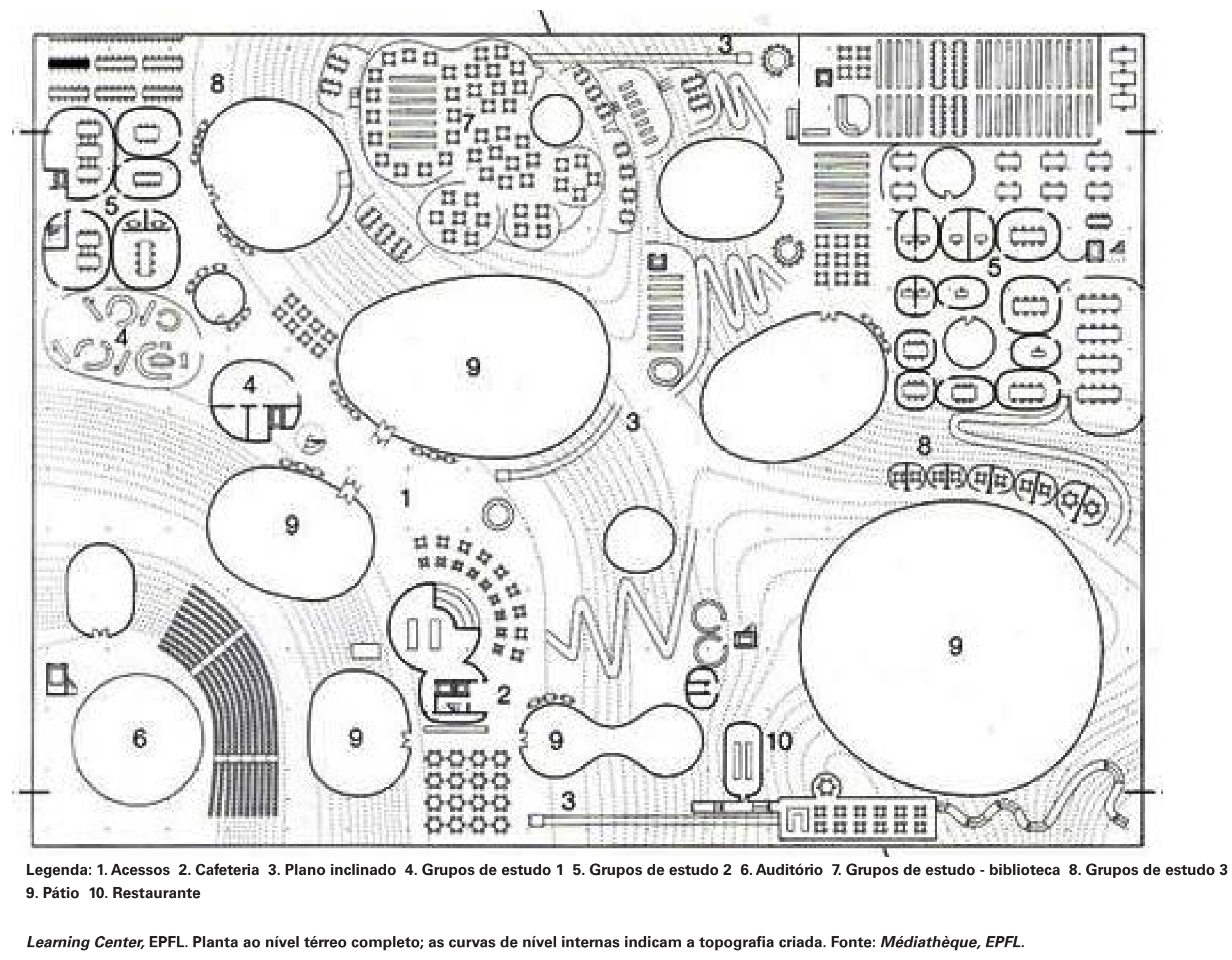


Quando nos dirigimos à Coordenadora de Recepção e de Visitas do Campus da EPFL em 2018, com o objetivo de conhecer o Learning Center, a resposta nos trouxe algumas informações relevantes: em primeiro lugar, trata-se de um equipamento público, portanto, sem necessidade de qualquer tipo de autorização para visitá-lo. Em seguida, o Learning Center fica aberto das 7 às $24 \mathrm{~h}$ durante todos os diss da semana, o que amplia as possibilidades de uso. E, finalmente, avisam-nos de que é necessário observar as melhores condições de convivência para melhor aproveitamento do local.

As informações descritas acima são indicativas da intensificação e da diversificação do uso do equipamento. intensificaç Durante todo o dia e grande parte da noite, é possível realizar alguma atividade direta ou indiretamente ligada ao ensino oferecido pela EPFL. Os conflitos gerados por essa proposta de diversidade de usos podem originar dificuldades que devem ser minimizadas pelo comportamento individual e coletivo dos usuários.

Assim, decidimos realizar a visita ao Learning Center em horários e dias alternativos: sexta feira à noite e sábado pela manhã.
A visita teve como objetivos principais o reconhecimento da obra como resultado do projeto, o que significa verificar se as condições expressas nos elementos de projeto correspondem às observações físicas encontradas; 0 reconhecimento da obra como resultado da construção, ou seja, confirmar se os elementos construtivos confirmam e garantem as premissas do projeto; e finalmente, o recombecimento da obra em função dos usos praticados depois de mais de oito anos de funcionamento do equipamento. Diversas situações puderam ser confirmadas: enquanto algumas unidades do Campus realizavam encontros e manifestações festivos, muito usual para uma sexta-feira à noite, diversos grupos de estudantes realizavam suas atividades de estudo no Learning Center. Outros se valiam da qualidade da paisagem exterior que o equipamento oferecia, para atividades de convivioo, protegidas pela edificação. Vale destacar que o período da visita, realizada em 30 de maio e 1 de junho de 2018, é um momento de intensa atividade por se estar a um mês do final do ano letivo e, alen 政 C, favorece a prática de atividades externas.
Learning Center, Lausanne, SANAA. Área dos grupos de
estudos nummero 2. Fotot: Valetrio Pietraroia, 2018.

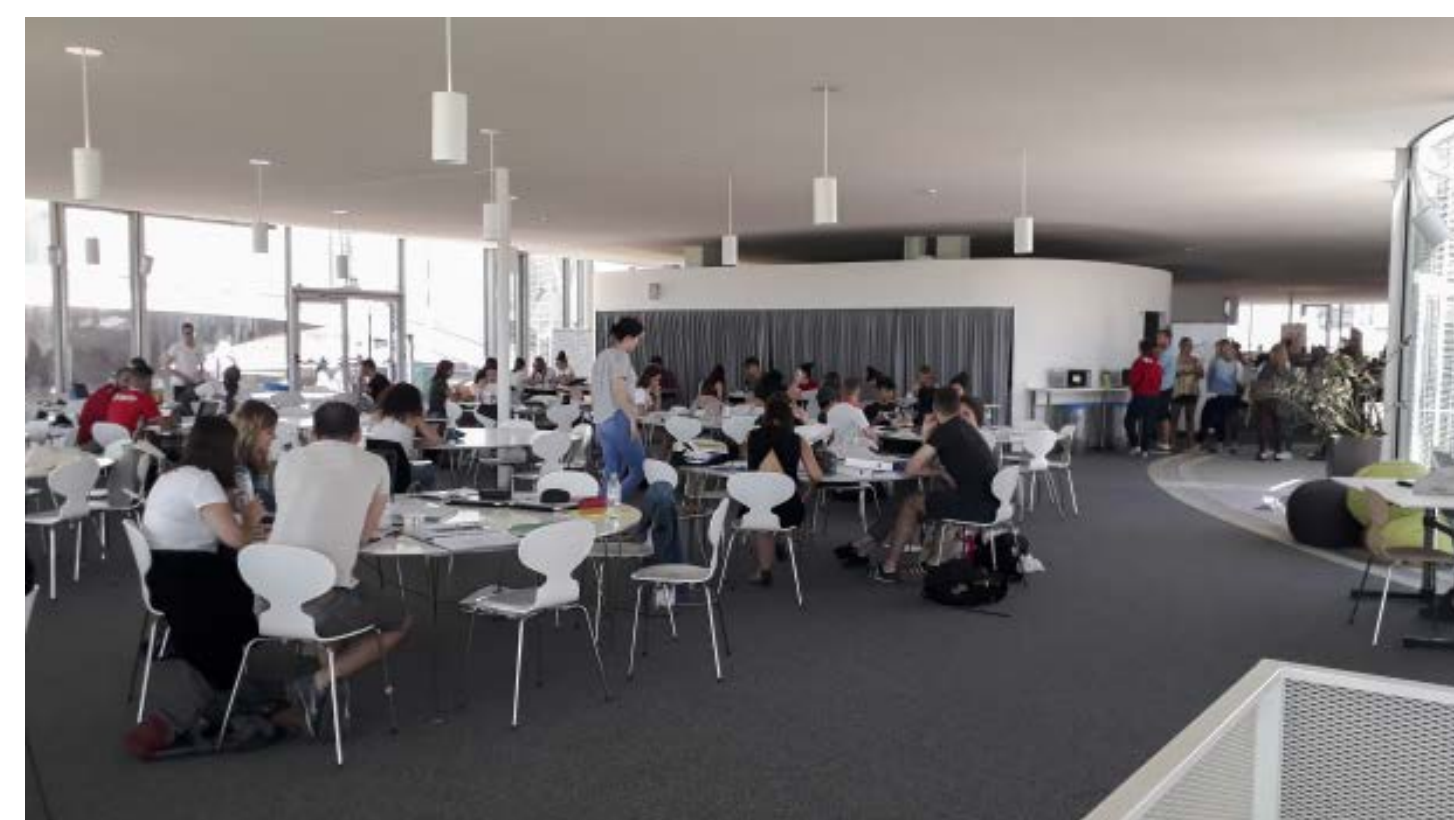

Learming Center, Lausanne, SANAA. Area dos grupos
estuduos da biblioteca. Foto: Valerio Pietraroia, 2018

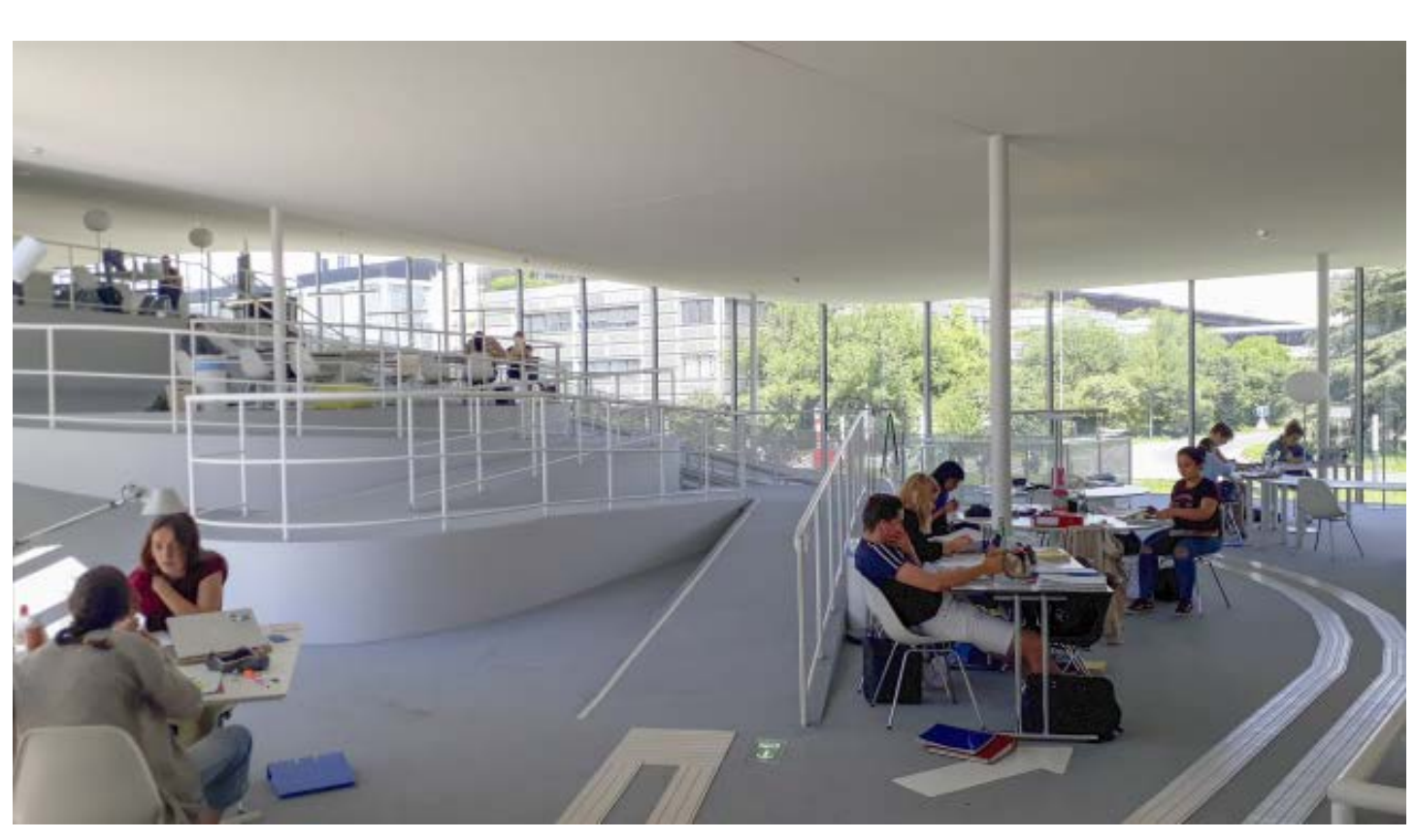




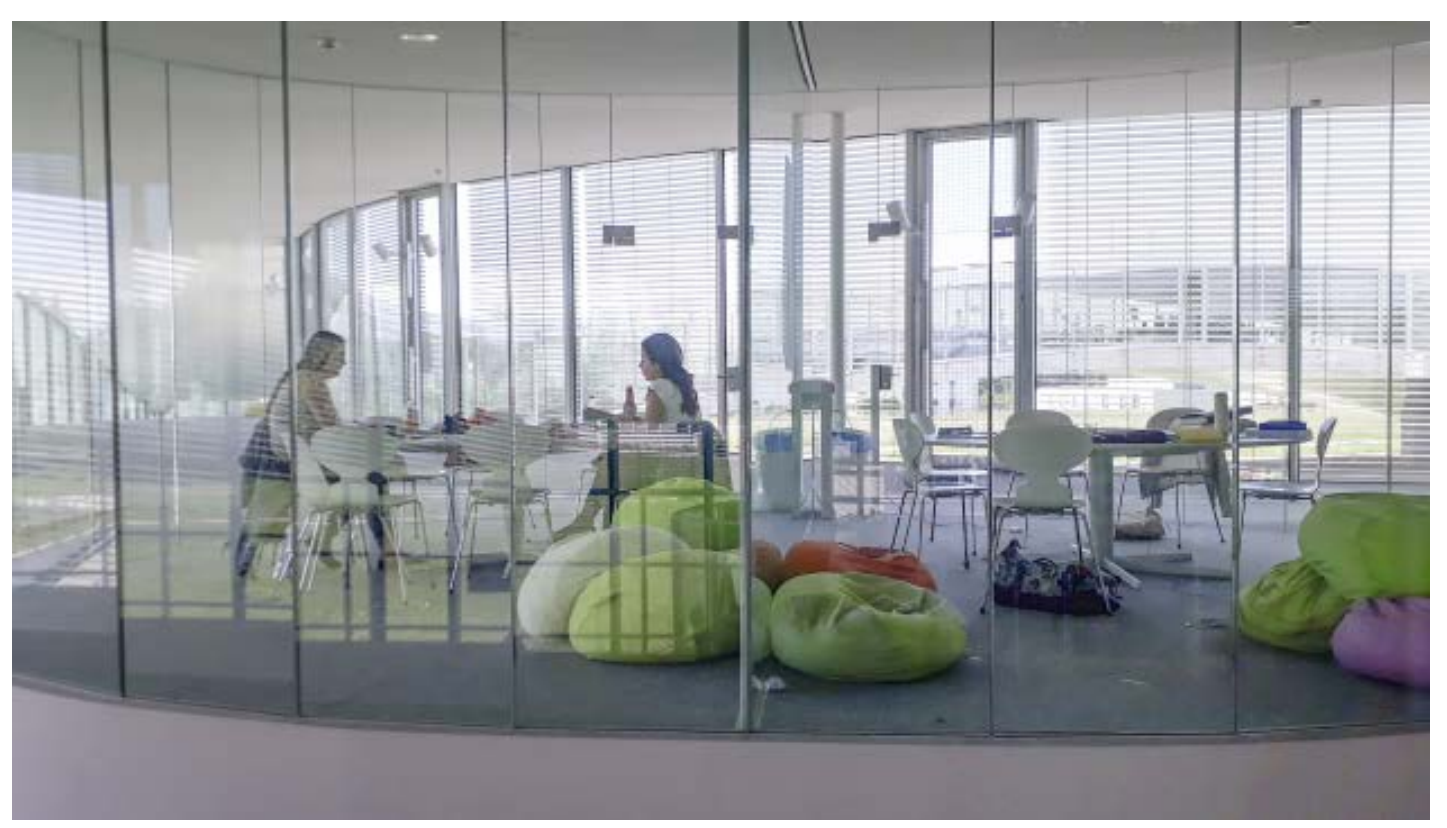

Learning Center, Lausanne, SANAA. Área dos grupos de
estudos número 3. Foto: Valério Pietraroia, 2018.

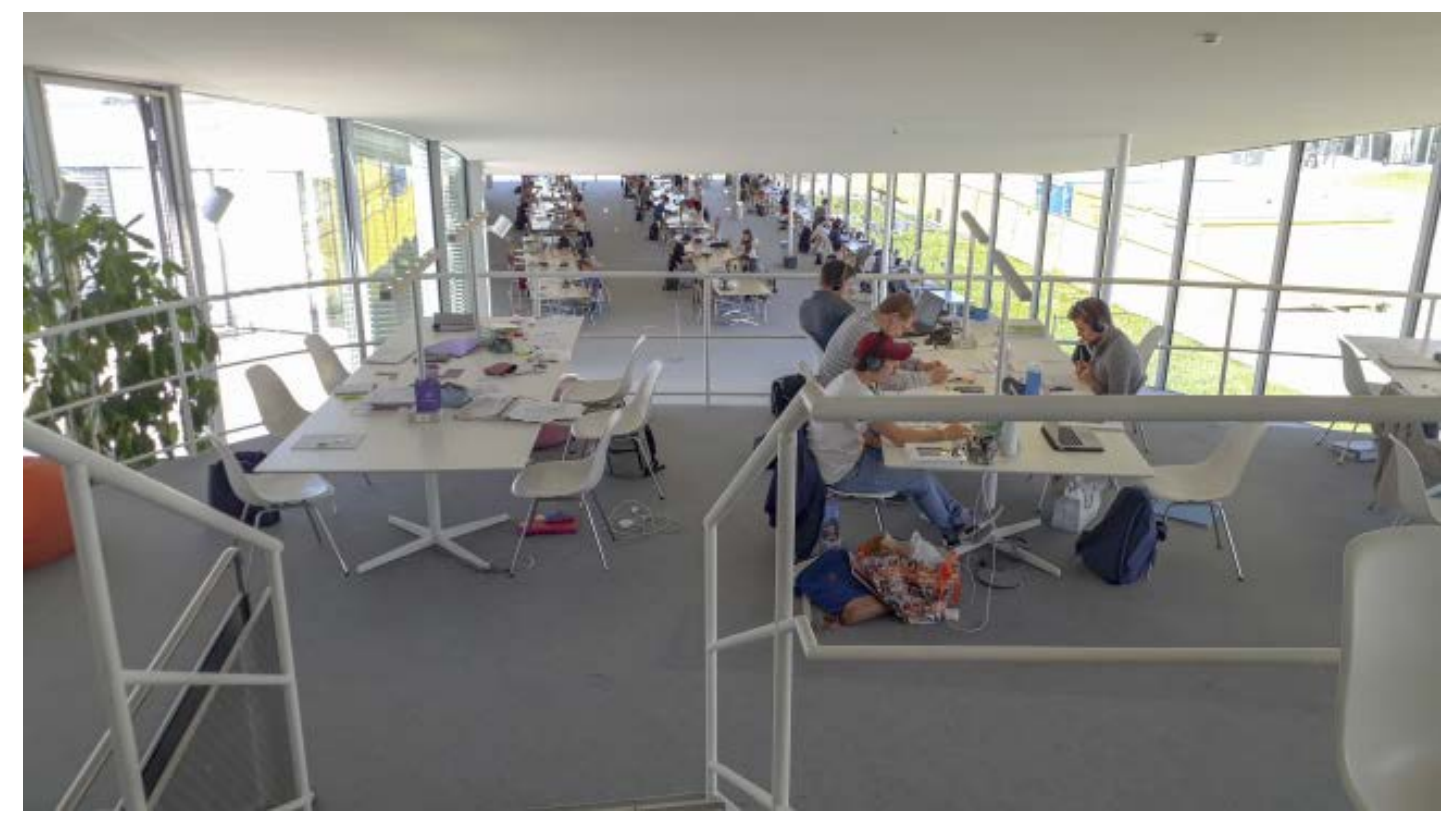

Foi possível verificar que o grande espaço é modulado pela topografia artificial criada, 0 que traz uma divesidade de acessos, de configurações espaciais e de usos a partir de um reduzido número de elementos construtivos regularmente dispostos, tanto interno como externamente. Como vimos acima, a obra é realizada seguindo critério sistêmicos de modulação estrutural e construtiva, valendo-se da repetição de poucos elementos para a realização do projeto.

É no interior da edificação que a diversidade citad se apresenta de maneira mais intensa, porém o grande pris ma retangular, que repousa no limite sul do Campus, ofere ce notáveis possibilidades de relação com os espaços externos, como pode ser constatado tanto no período noturno da sexta-feira como durante a manhã do sábado.

Outro aspecto relevate se refere à configurača do

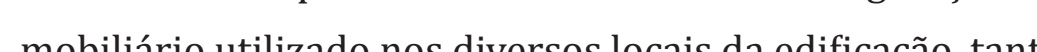
nos externos como, principalmente, nos internos. Há uma preferência para a constituição de grupos de trabalho usando configurações mais tradicionais de mesas redondas o bancadas lineares, e também grandes conjuntos de almofadas dispostos nos lugares menos planos da edificação, configurando grupos informais.

Há ainda um significativo grau de isolamento visual e acústico, mesmo tratando-se de um grande salão com o mínimo de divisões ou fechamentos, como pode ser observado nas plantas. A continuidade espacial é, em certa medida, modulada pelas diferentes ondulações do volume. As "colinas" internas organizam os lugares que vão sendo percebidos na medida em que se circula. Nas situaç̃es limites volumes envidraçados são dispostos em conjuntos, onde pode-se realizar tarefas que exigem maior concentração isolamento. Essa estratégia não nega a vocação primordial da obra na medida em que a interação visual no interior da edificação e dest cos mesno nos horatios nenos usurs en que nossa vista foi realizada. 


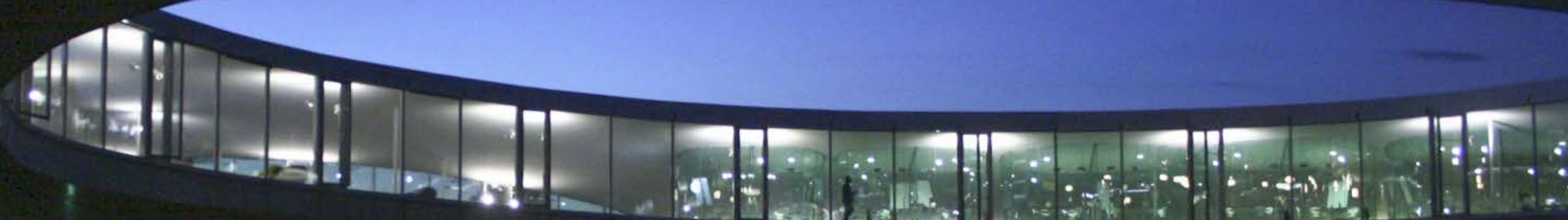

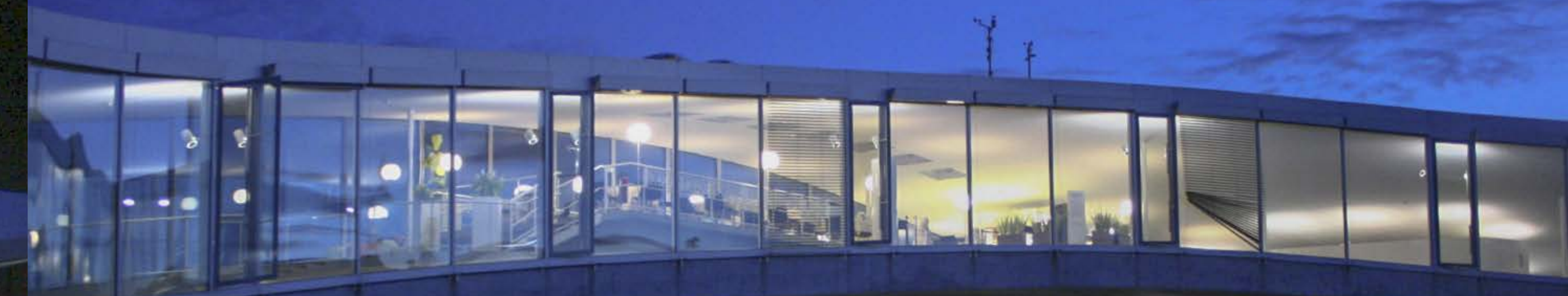
1.

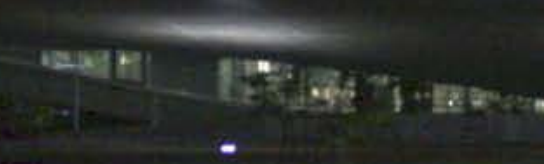


disso tem o seu tertitrio partilar, e transmite Un prazer tipicamente seu. Ela possui o monopodo do espaço. Apenas a arquitetura, entre todas . hes e prazer que de dom que só a arquitetura nos pode dar ${ }^{16}$.

der SСотT, 191

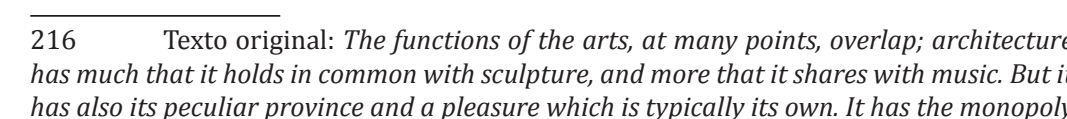

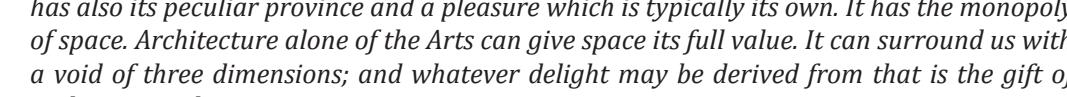


O Parque comemorativo do quarto centenário da cidade de São Paulo, em 1954, urbano em sua essência é é un ensaio relevante do que viria a se materializar com o projeto de Lúcio Costa para Plano Piloto de Brasília poucos anos depois ${ }^{217}$. É Luís Antônio Jorge (2014) quem apresenta re ferências fundamentais para sedimentar as relações cita das a respeito do Conjunto do Parque do Ibirapuera em São Paulo, projeto da equipe liderada por Oscar Niemeyer ${ }^{218}$. As diferenças de escala não impedem que se possa compreender como entre a arquitetura e a cidade podem ser criada relações de natureza superior. No Parque, Jorge aponta a marquise como elemento primordial responsável pela dnâmica e pela evolução dessas relações durante suas seis décadas de intenso uso. Seria "o parque plano como a própria laje, como o terreno da cidade onde se erguerá a capita do país. Com o modernismo, o chão definitivamente entra como forma e conteúdo no imaginário poético do Brasil", completa o autor.

creditamos que a leve declividade do chão oferece determinada tensão à espacialidade tanto do Plano Piloto

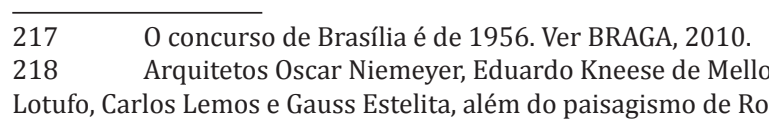

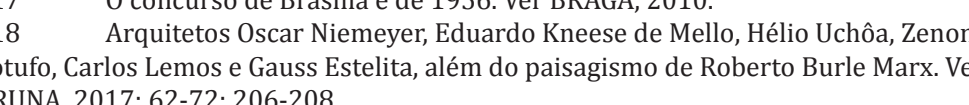

como do Parque. A marquise surge para intensificar aind mais essa condição porém, ao adotar outra inclinação, anplia a diversidade de

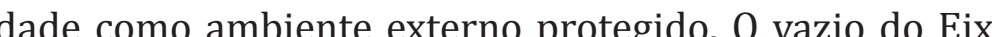
Monumental do Plano Piloto é, no caso do Ibirapuera, ocupado pelo construído, pela marquise, entretanto é sob su sombra que a ocupação do Parque se mostra mais intensa. Seria então o próprio chão, o plano inclinado da vastidão cão "a criaç̃o do lugar que não existe, a transformaç̃o do não lugar americano em lugar", como afirma Josep Maria Montaner (2001: 41)

identificação do Parque com a metrópole tem se intensificado ao longa de sua existência. Segundo Jorge, estariam na "lič̃o de modernidade transcendente da marquise" as razões que explicariam a permanência da vitalidade do Ibirapuera em relação a outros espaços públicos paulistanos. É acertado observar que o parque urbano se torno de certa forma, ilhado em relação à cidade. 0 grande cinturão verde que faz sua transição com os bairros vizinhos é um atributo fundamental que não responde por este isolamento, entretanto o protege. Na realidade, o projeto $m$ sua totalidade estaria muito mais em interação com a cidade do que outros exemplos. Aquilo que promove a dificuldade para que a interação atinja sua plenitude está relacionado com o sistema de vias de tráfego rápido e intenso que o circundam, reflexo das grandes dificuldades de mobilidade que a metrópole enfrenta.

No entanto, a natureza edificada em seu interior representada por seus palácios de exposições ${ }^{219}$ e por sua marquise, em especial, são testemunhos da capacidade que a arquitetura possui de se manter presente mesmo quando a evolução dos usos se manifesta. Ao propor um ambiente externo protegido, um lugar não definido no programa original do Parque, Niemeyer e sua equipe anteciparan novas situaç̃os para novos relacionamentos, enfim, novas atividades que surgiram e continuam a ser criadas. Enconatividades que surgiram e continuam a ser criadas. Encontramos nessa presença da arquitetura razões para verificar como suas qualidades constitutivas são suficientemente superiores para oferecer as condições à plena evolução, com observa Hélio Piñon

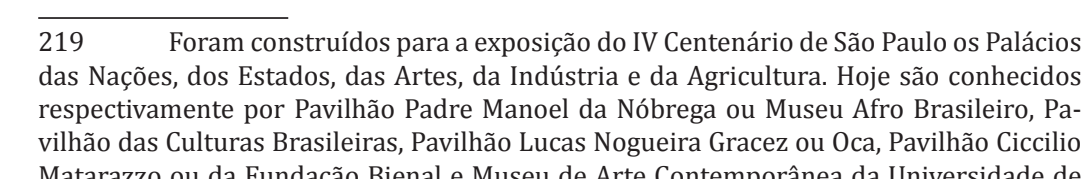

a realidade, a arquitetura autentica deveria ser sempre reversivel, já que sua identidade formal precisamente o que fica quando se prescinde do eu destino específico: dita identidade se baseia no uso mas, por sua vez, o transcende, na medid em que o edifício está ordenado de acordo com uma estrutura autônoma e consistente. (PINON 2006: 180)

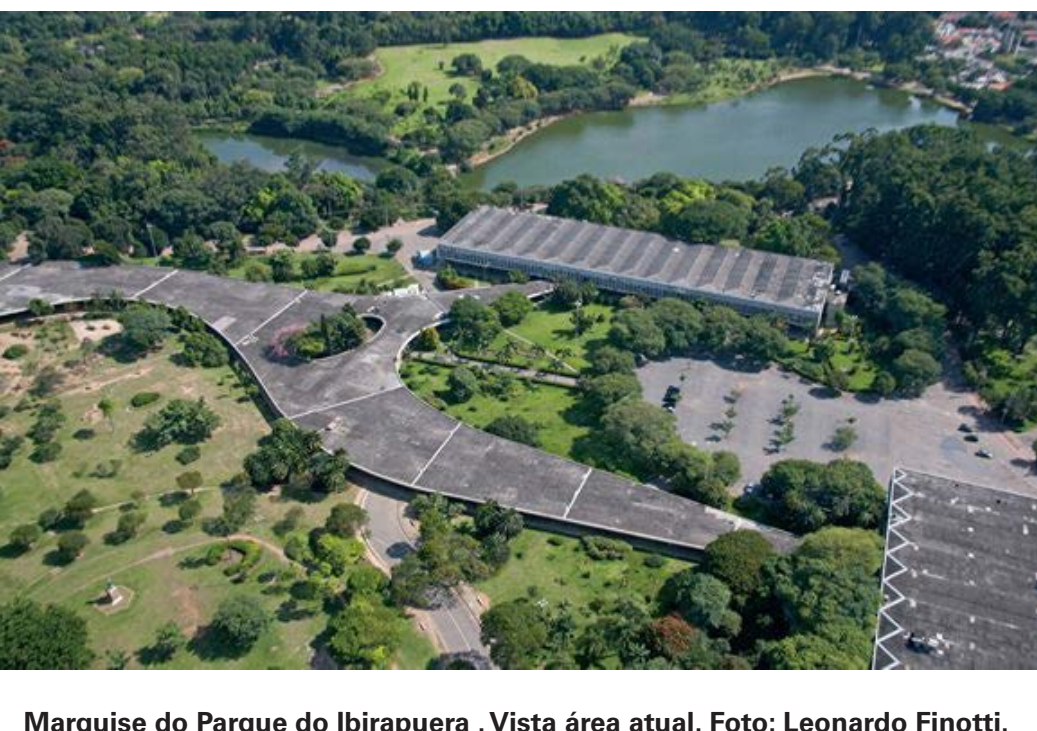


O projeto do vazio ou da exterioridade do Parque é expresso pela interioridade de uma edificação potente, a Marquise, não prevista no programa original do projeto e sem uma funcão definida, que ilustra de maneira precisa as palavras de Focillon citadas na epígrafe deste capítulo. Seria um conceito de espacialidade interna que amplia a noção formulada por Geoffrey Scott (1914) ao potencializar

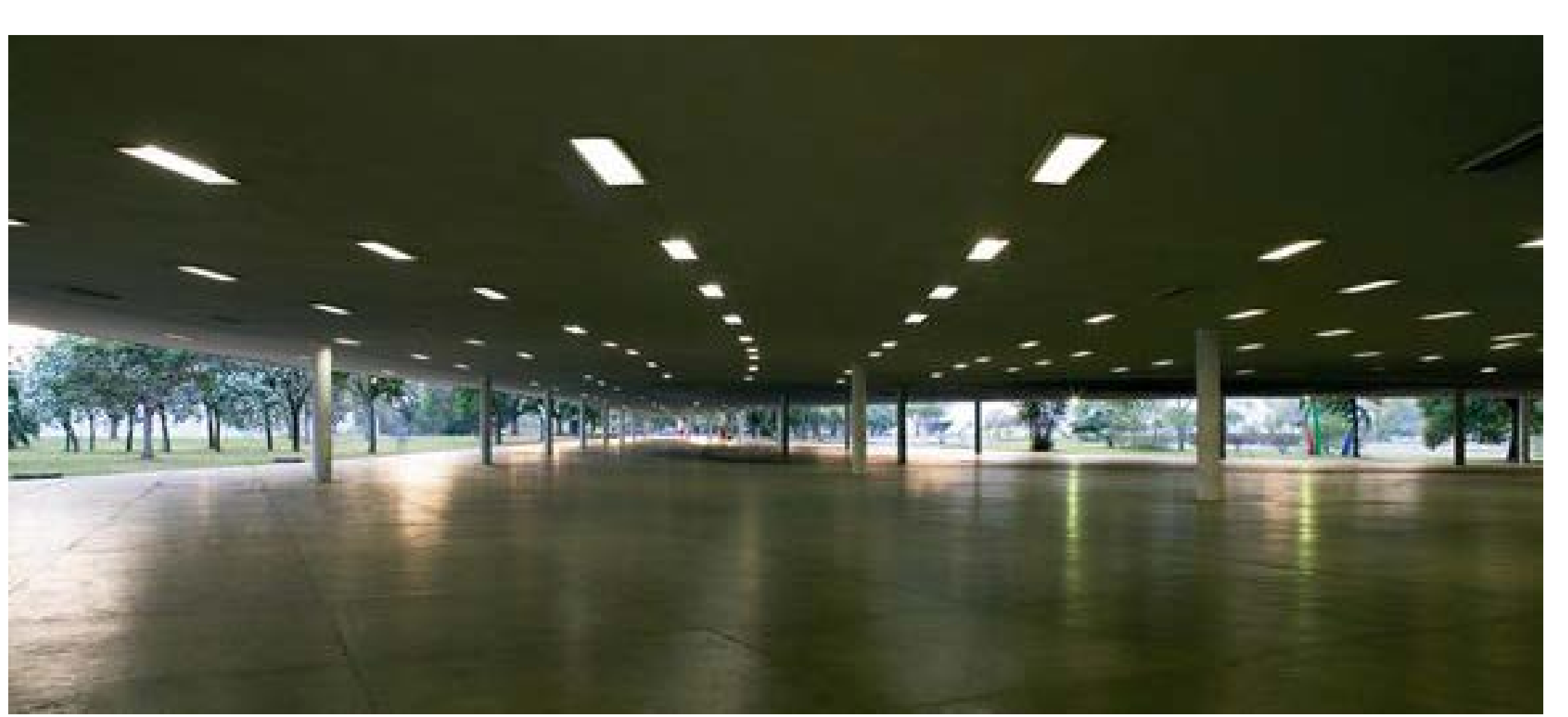

Marquise do Parque do lbirapuera. Vista interna atual. Foto: Leonardo Finotti tos construtivos e o sítio. Tanto Focillon como Scott entendem ser esta a chave para diferenciar a arquitetura lã̃o às outras artes. Niemeyer compreendera ser este un caminho valioso para que o projeto do Ibirapuera não se mitasse a um parque de exposições comemorativas.
Assim como no Learning Center da EPFL de Lausan, muito próximo à natureza e sem uma fronteira aparené é com a marquise que Niemeyer vai abrigar deste 1954 sos ainda não con ovas atividades. çóes próprias da realidade em mudança. Devemos lembrar que nesse período o processo de crescimento da cidade de Na publicação da revista Acrópole, no 185 (1953: 210), a equipe, ao descrever o projeto do conjunto, indica que será sob a grande "marquise" que o público devidamente abrigado poderá atingir os demais setores da exposição. Ao colocá-la entre aspas, há a consciência de que se trata muito mais do que um dispositivo de proteção conhecido

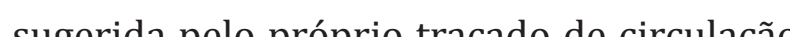

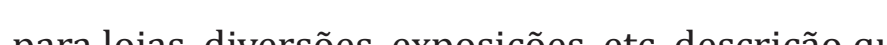
(an

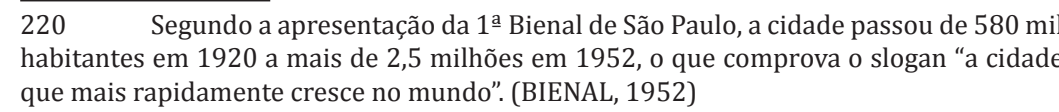

No Ibirapuera, o vazio monumental é ocupado pela marquise. Seu desenho livre pretende expessar a liberdade do próprio uso do espaço pelo público. [..] A solução estrutural da marauise voca a liberdade, seja pela sua imensid̃o, pelo eu desenho livre ou pela sua leveza 0 desenho livre é garantido pela plasticidade do concreto. (BARONE, 2007: 101)

E completa:

A marquise foi concebida dentro do princípio $\mathrm{mo-}$ dernista da continuidade espacial A continuidade espacial, no Ibirapuera, é dada pelo discurso das superfícies. Evocando a abstração do plano contínuo, já sugerida pela imensidão da marquise, a superfície adentra os edifícios por meio de rampas, como planos se desdobrando em novos níveis. (BARONE, 2007: 105)

A referida imensidão é materializada por uma superfície que ocupa $28.000 \mathrm{~m}^{2}$ de área construída, o que 


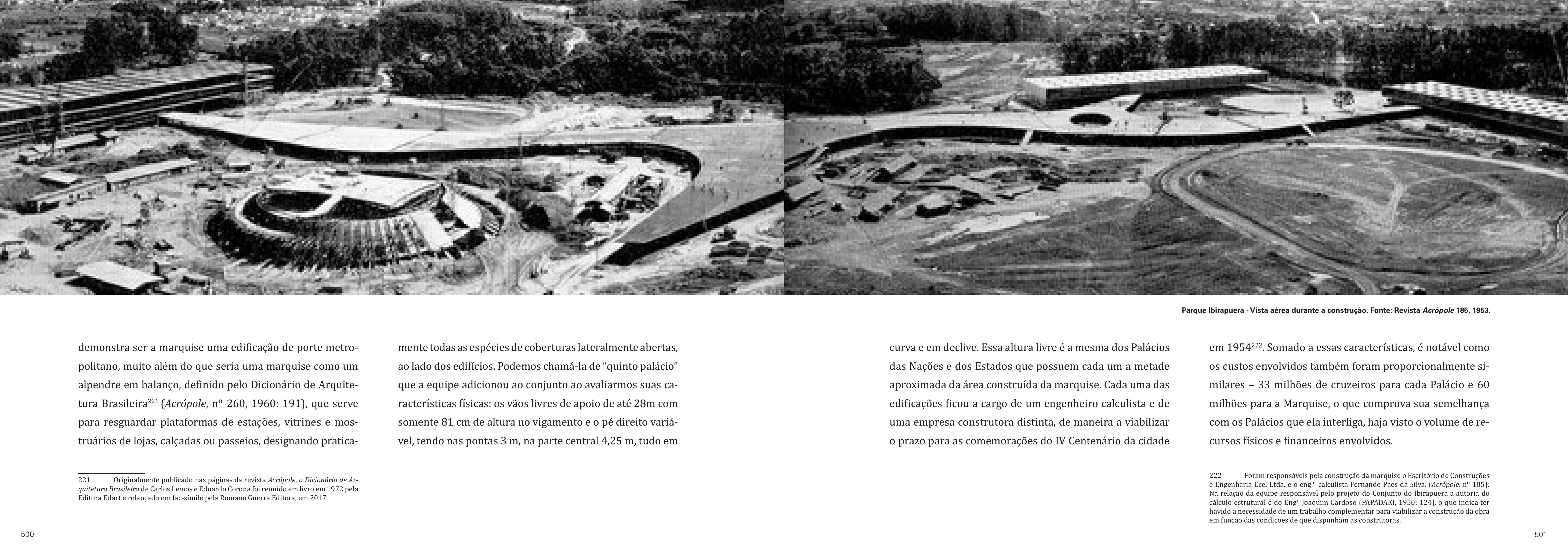


Do ponto de vista dos seus elementos construtivos, possivel verificar que a Marquise, assim como os Palácios que ela conecta, é constituída por uma laje nervurada em concreto armado, apoiada em colunas recuadas, configurando sempre balanços generosos, como mostram as imagens a seguir durante sua concretagem.

As especificações utilizadas para o traço do concreto e a proporção de aço empregada demonstram ter sido Marquise uma proeza estrutural e construtiva extraorensão, com mais de $600 \mathrm{~m}$ de cobertur também se destaca dentre as obras do Conjunto e de outras obras públicas construídas no período.

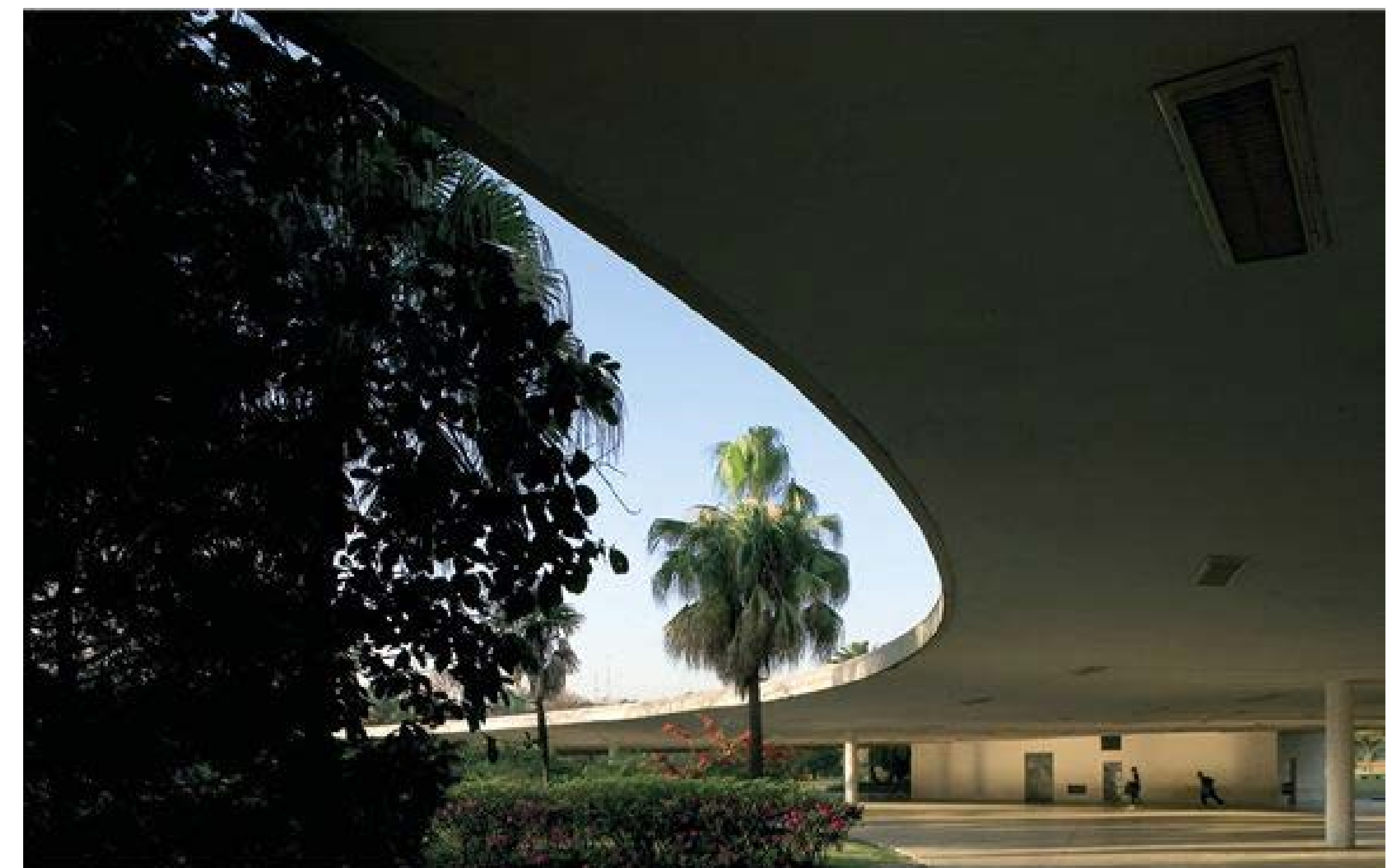

Marquise do Parque do Ibirapuera, Săo Paulo. OScar Niemever, 1954. Foto: Leonardo Finotti. 
Em função do exposto acima, encontramos um paralelo da experiência da Marquise do Conjunto do Ibirapuera, como o lugar inicialmente da transição e posteriormente de convergência dentro do sistema de objetos que integram o Parque, com os objetivos de projetos recentes, como o Learning Center.

Podemos primeiramente encontrar semelhanças entre as obras segundo a noção de sistemas discutida por MONTANER (2009: 16-18): a crise do objeto moderno manifesta-se por sua extrema objetualidade, o que estaria dinifesta-se por sua extrema objetualidade, o que estaria di-
retamente vinculado à própria crise do sistema clássico do qual a arquitetura moderna descende. Como saída restaria, então, a possibilidade de relacionar os objetos segundo sistemas abertos e complexos, através da diversidade das formas dinâmicas, que não são impostas nem definidas a princípio, completa o autor

No entanto, sem que seja necessário classificar os sistemas, como considerado por Montaner, é possível entender o esforço do projeto em construir as possibilidades de articulação fisica e funcional nas obras citadas.

Em 1953 Niemeyer já manifestara sua preocupaç̃o dotá-la de uma simplificação da forma capaz de resistir ao programa e ao tempo. A experiência do Ibirapuera prenuncia as mudanças na sua obra que iriam ocorrer de maneir definitiva a partir de 1954, como aponta a historiografia (BRUNA, 2017). Não é possível afirmar que Niemeyer se sensibilizara pelos questionamentos críticos à arquitetura moderna ocorridos no início da década de $1950^{224}$, mas evidente que o projeto do Conjunto do Ibirapuera, como sistema urbano de objetos que orbitam em torno da Marquise, apresenta um poderoso sistema de relações entre os objetos, seu interior e a cidade, muito mais intenso do que as obras distribuídas às margens do Lago da Pampulha, como consideram alguns autores.

$224 \quad$ Ver BARONE, 2004

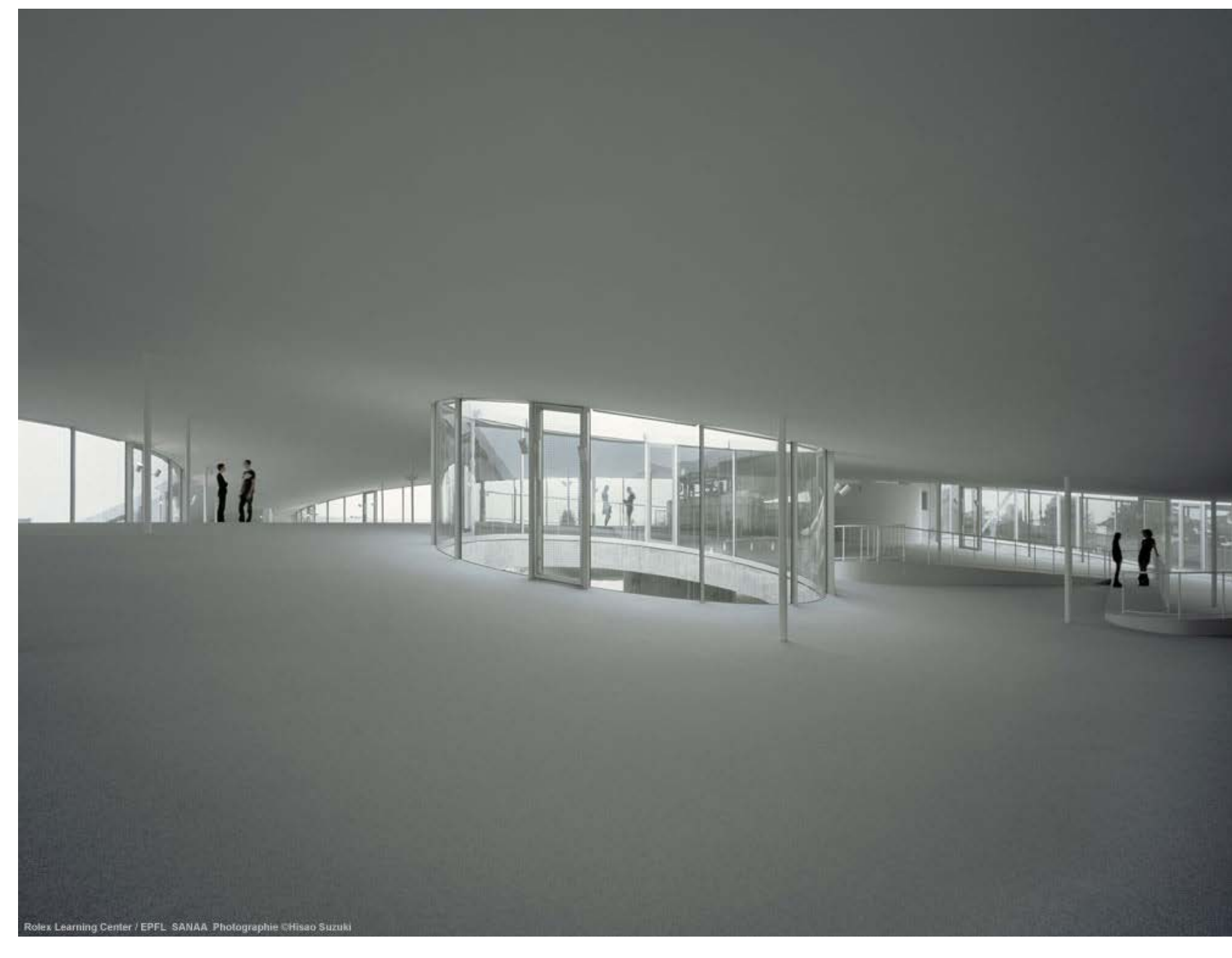

Learming Center, EFFL, SANAA, 2004. Fonte: Mediathieque, EFFL 
Da mesma maneira, o Learning Center de SANAA surge com a missão de superar a falta de articulação das formas distribuídas no sistema do Campus. A nova a tura vem tura ven para restabeleceros nexas fisic nunca se efetivaram. SANAA, em 2004, vislumbra assum o protagonismo das conexões que no sistema campus seria representado pelo contexto, pelos espaços livres exteriores, visão que ilustra a posição de Montaner, para quem, percebam sejam os objetos.

Visto sob outro ângulo, a obra

[é] apenas um branco espaço vazio em suave declive, que se percorre quase sem se ver, cujos esbeltos apoios mal se percebem, pois não mpõem em sala hipóstila ${ }^{225}$ nem prevalecem excessivamente, cumprem seu papel de, bem espaçados, duplicar o chão para conformar um teto evemente emoldurando uma faixa de verd. Aberta disponivel, suas cores são as das pessoa que estão automaticamente convidadas a flü andando a pé, de skate, de patins, de bicicle (ZEIN, 2012)

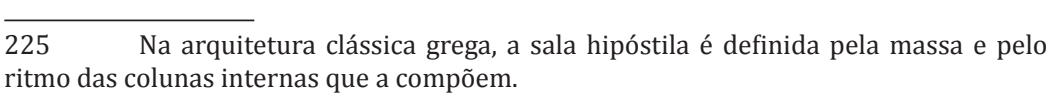

As considerações acima feitas por Ruth Verdi Zei avaliam com precisão a edificação materializada pela stcessão de colunas que não configuram uma sala ao contra ta. A dinâmica de utilização do espaço é responsável pelo seu colorido, como ressalta Zein, ou seja, a arquitetura abre o caminho de possibilidades para os utilizadores. 0 texto poderia ser usado para entender o Learning Center, entretanto a autora está se referindo à Marquise do Conjunto do Ibirapuera em São Paulo

importante notar que, em certa medida, a arqutetura praticada atualmente por SANAA dialoga de manera atemporal com certas realizações de Niemeyer, como a tetura do escritório japonês é o que pode ser entendido como "arquitetura inorgânica", na medida em que se afasta das soluções miméticas de ordem biológica e edifica um universo artificial cuja leveza promove a incorporação visual e física da natureza propriamente dita, isto é, funde-se à natureza sem deixar de se separar dela, como bem os arquitetos demonstraram uma sensibilidade em rela ção às questões de ordem natural e ambiental que é altamente pessoal e, em muitos sentidos, bastante promissor para a disciplina da arquitetura.

Ao nos debruçarmos sobre algumas de suas obras, torna-se evidente o diálogo estabelecido com o trabalho de Niemeyer, em especial aquele desenvolvido na década de 1950, que produziu exemplares notáveis como a Fábrica Duchen ${ }^{226} \mathrm{e}$ o próprio Conjunto do Parque do Ibirapuera en São Paulo, ou ainda a Casa das Canoas no Rio de Janeiro.

Ainda que seja de fácil entendimento a associaç̃o entre 0 aparente desenho livre das superfícies contínuas da cobertura dos por da cobertua dos projes, podemos tamén en un elo promissor em relação à organização da estrutura que se estabelece como campo de pesquisa do projeto. Com observou Zein, é pouco perceptível a distribuição dos esbeltos apoios da Marquise do Ibirapuera, o que evidencia as pretensões de Niemeyer na multiplicidade funcional da edificação sem comprometer suas fachadas "naturais", materializadas pela exuberância do Parque.

Do mesmo modo, o Learning Center se caracteriza pela criação de uma paisagem interior em que a estrutura regular, quase imaterial, dá forma a seus usos, respondendo diretamente pelo desempenho funcional de distintas ações distribuídas em sua extensa superfície contínua. जister campus no sentido original do termo (MOSTAFAVI: 250) como pretendido pelos promotores do concurso em 2004. Nesse sentido, a obra se aproxima da ideia de arquitetura como sistema (MONTANER 2009) e não como objeto isolado, qualidade inquestionável que a obra de Niemeyer no Parque sustenta desde sua inauguração. 


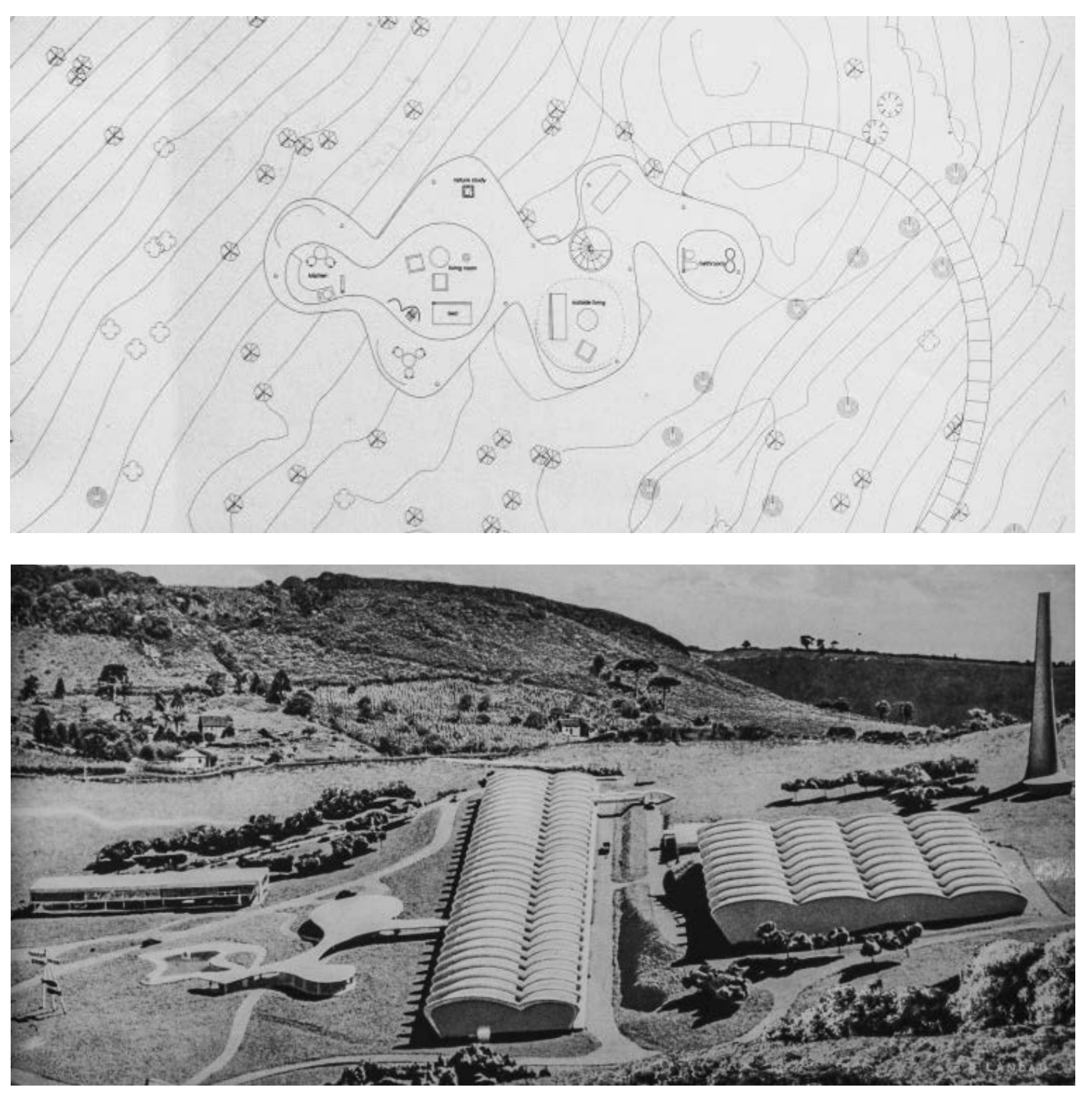

Ny House, Nova York Planta, SANAA, 2008. Fonte: EI Croquis no
155,2007 .

Fabbrica Duchen, São Paulo. Foto-montagem da maquete. Oscar
Niemeyere e Hêlio Uchoa, 9950. Fonte: BIENAL, 1951.

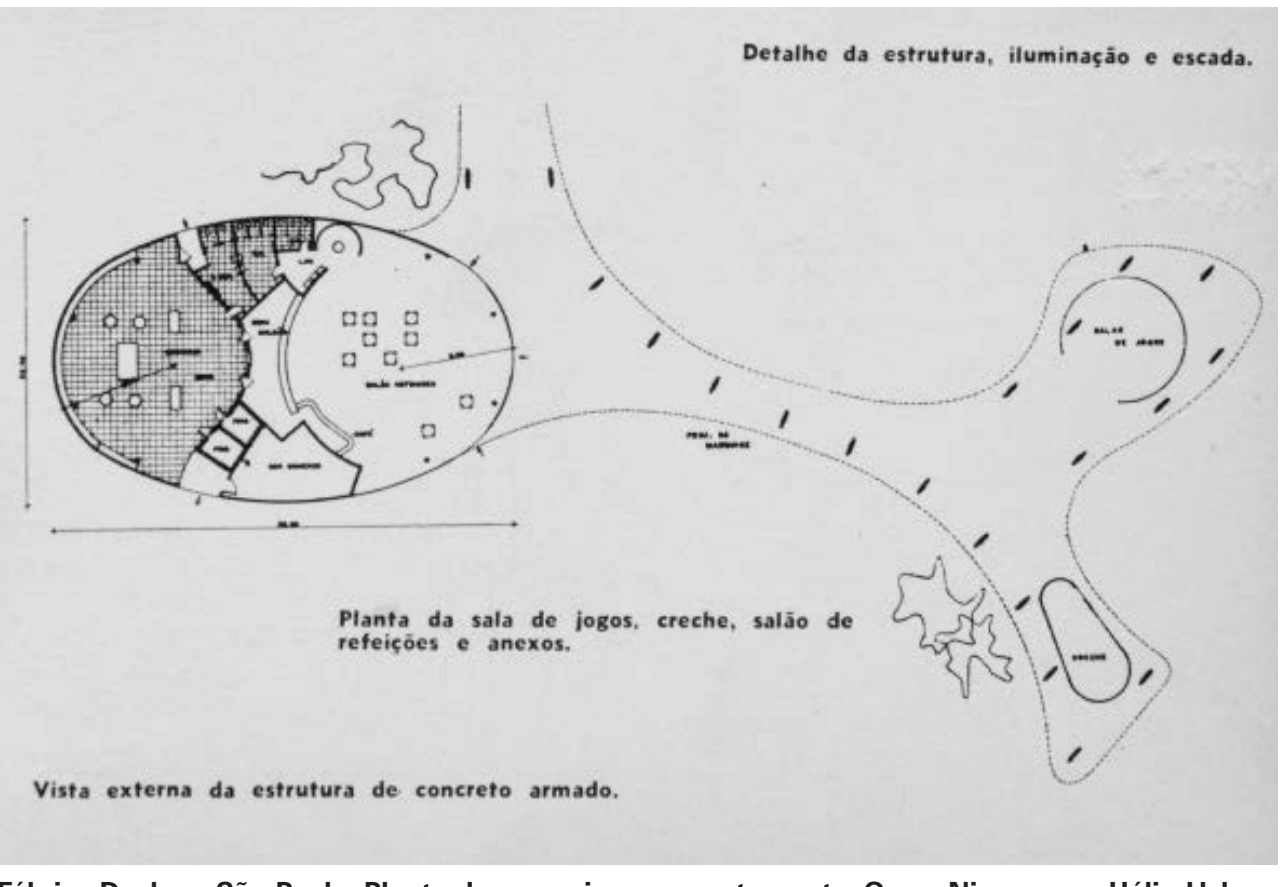

Fabrica Duchen, São Paulo. Planta da marquise com restaurante. Oscar Niemeyer e Hélio Ucho
1950. Fonte: BIENAL 1951

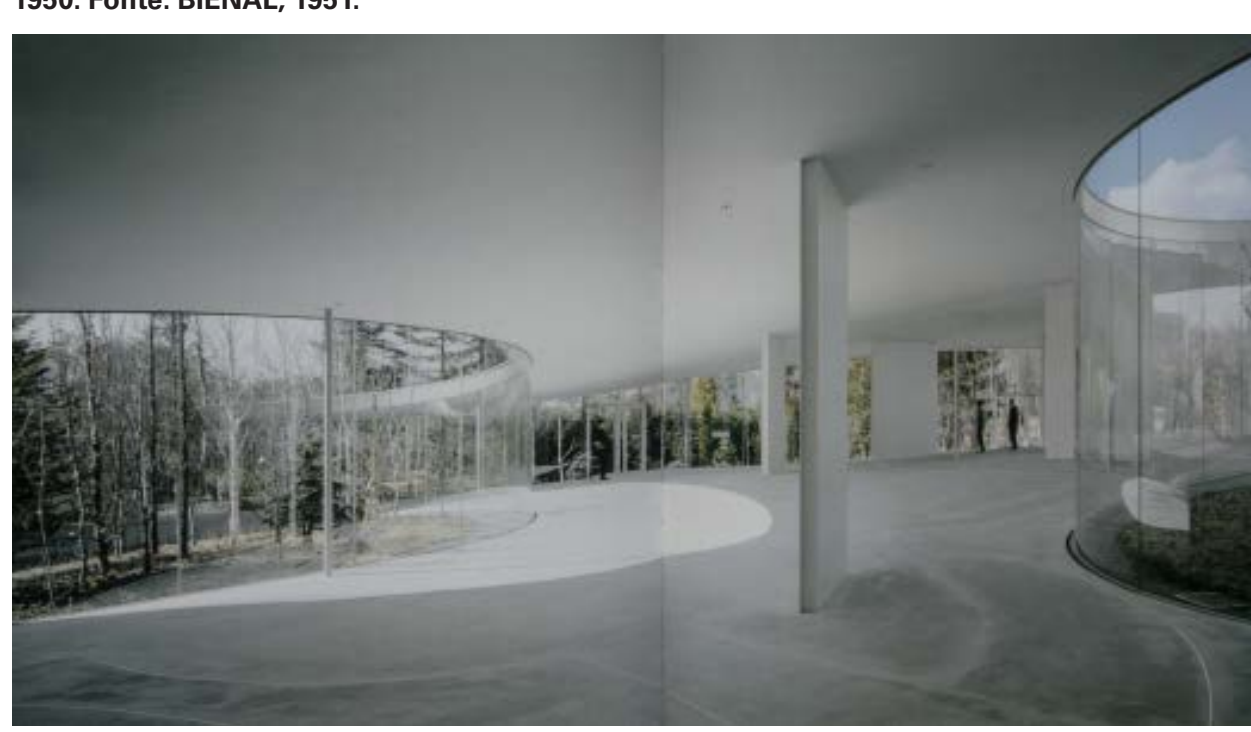

Projeto K, Nagano, Japão, SANAA, 2007; Fonte: El Croquis n n155, 2007.
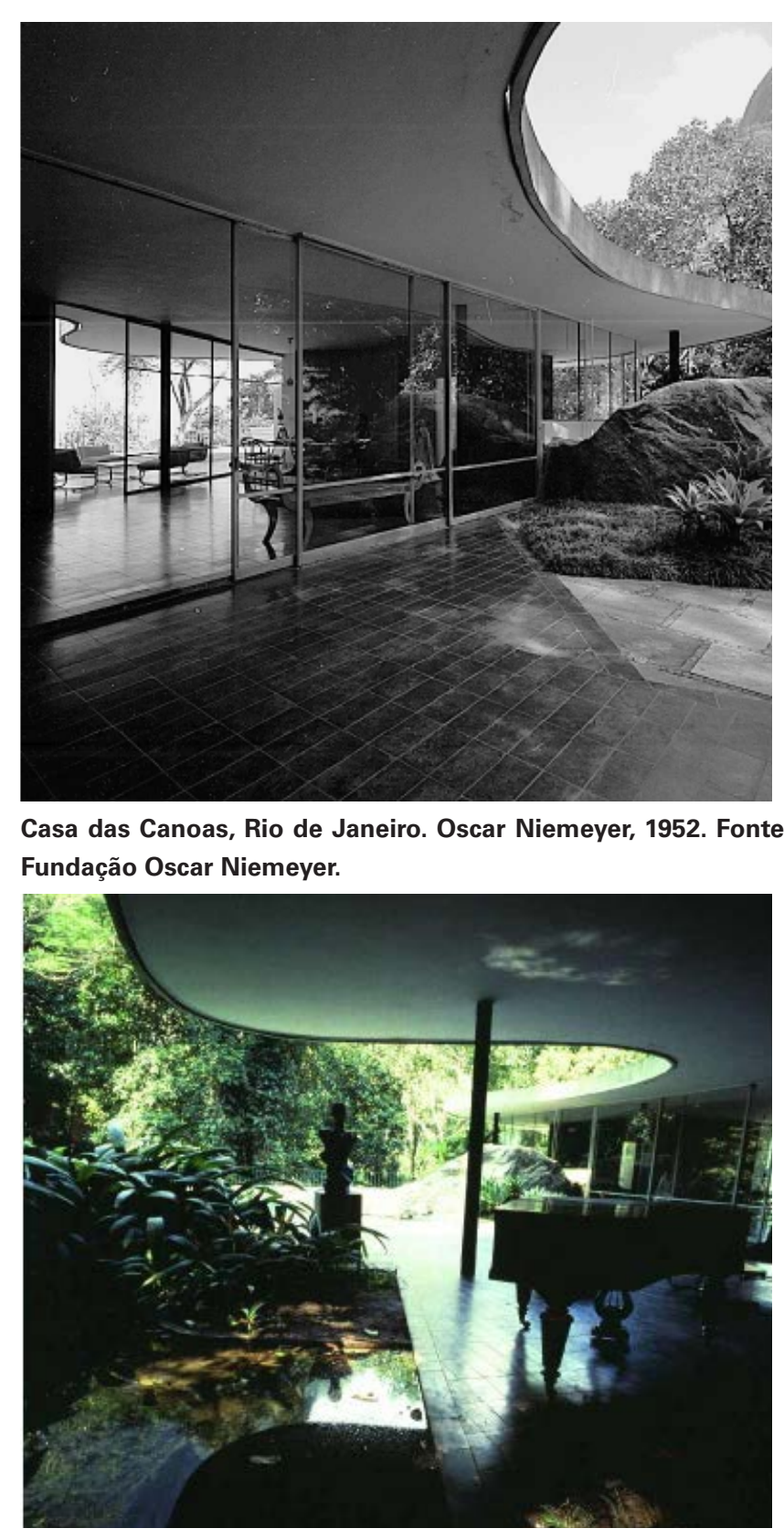

Casa das Canoas, Rio de Janeiro. Oscar Niemever, 1952. Fon 
Como fundamento, a continuidade espacial das superficies é responsável pelo espaço único criado por SANAA, como rel Learning Center, considerada o embrião do projeto, e para quem o projeto

[...] foi o que melhor interpretou a noção de hib dação, de cruzamento entre os diversos espaço. Não faz mais sentido ultrapassar paredes para de um lugar a outro, porém viver num espaço únco apresenta contradições e desafios enormes representa, sem raptras, a poli fancionalidac de uma biblioteca. (AYMONIN - in MAILLARD 2010: $15^{\prime}$

0 exemplo de Lausanne, e de outros projetos do escritório japonês, indica seu compromisso em se expressar com o mínimo de recursos materiais, sem a necessidade de recorrer à imagem figurativa ou ao ornamento, seguindo uma tradição de racionalidade construtiva que 0 aproxim Encontros e desencontros: SANAA, Niemeyer e Mies.

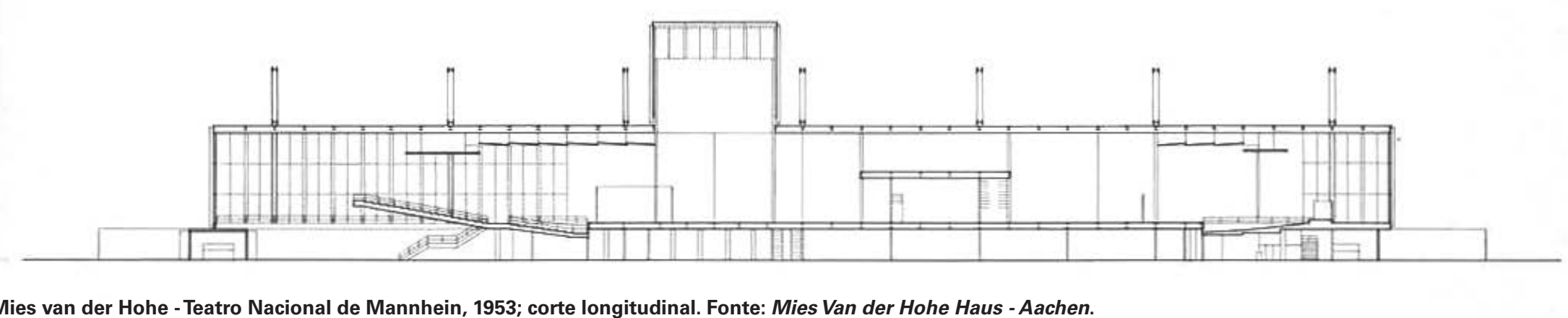
Wies van der Hohe - Teatro Nacional de Mannhein, 1953; corte longitudinal. Fonte: Mies Van der Hohe Huus - Aache

americano de Mies, considerado pela historiografia como fundamental em seu trabalho, particularmente do ponto $\mathrm{d}$ vista da idealização do espaço, pois o edifício é agora uma sucessão de espaços livres, garantida pela horizontalidade do teto (ROWE 1999: 144). Como observamos na primera parte desse capítulo (ou PIETRAROIA, 2014), no projeto de Mies para o Teatro Nacional de Mannheim, a arquitetura se desmaterializa ao ser convertida em construção de planos mutáveis suspensos num espaço transparente, fluído (FRAMPTON, 1997: 281
Essa condiç̃õo também foi responsável por destacar proposta de SANAA em relação aos demais concorrentes durante o Concurso Internacional do Learning Center en Lausanne, o que foi decisivo na escolha do júri. 0 fato deve ser assinalado pois naquele período a arquitetura cular dominava certames internacionais semelhantes ${ }^{227}$. A análise dos demais projetos apresentados para a EPFL indica a multiplicidade de esforços construtivos capazes de transformar o lugar através da imagem impactante, o que seria um acontecimento arquitetônico sem precedentes naquele território. 


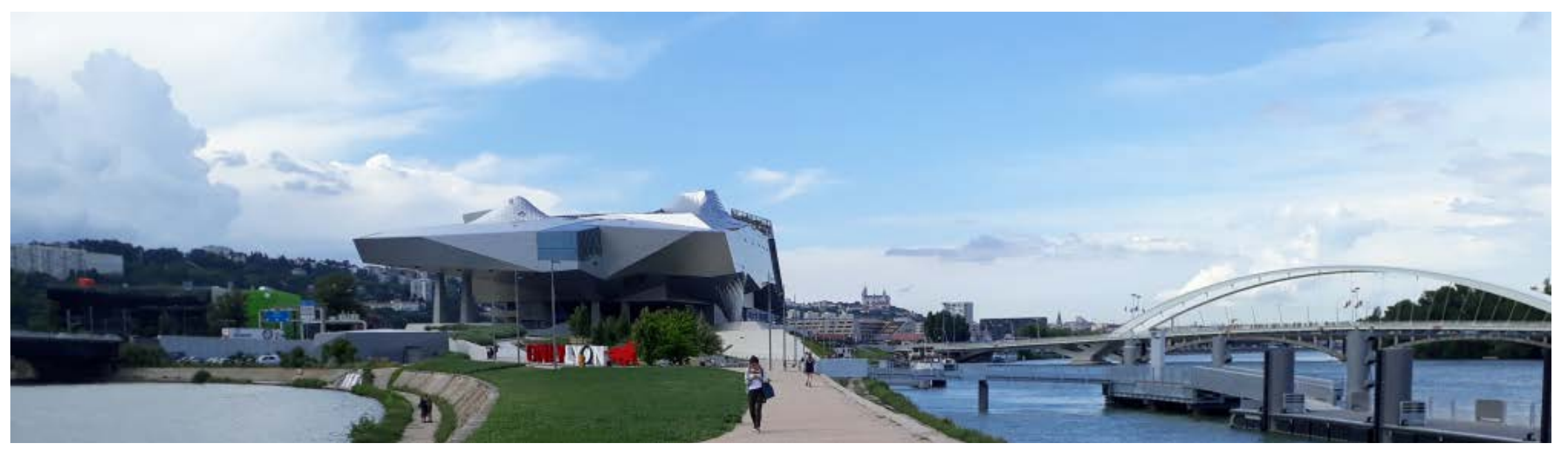

Musée des Confluences, Coop Himmel(b)lau, LYon, França, 2001. Foto: Valério Pietraroia, 2018.

Ao contrário, SANAA investiu na extensão do ediffcio, na multiplicação das suas fachadas transparentes e na amplificação de sua escala em relação ao campus. Ao invés do marco monumental o lugar para o intercâmbio do cohecimento foi tratado com simplicidade e leveza, que distancia do genérico ao promover a densidade das ações no seu interior. No entanto, o que observamos é que, de modo distinto do espaço universal de Mies, a concentração e a distribuição de instâncias específicas e da estrutura permitem dar forma tanto à estrutura espacial como a seu uso, ou seja, as especificidades do lugar criado é que dão forma a seus usos, ao seu desempenho funcional. Em outras

palavras, a organização espacial não se dá através da un formidade repetitiva de Mies, mas, sim, pela relação entre a pequena escala e a massa resultante, isto é, os espaços estrutura geral do projeto (MUSTAFAVI, 2011: 248).

Do mesmo modo que o discurso das superfícies garante a continuidade espacial (BARONE, 2007: 105), princípio modernista que domina o trabalho de Niemeyer, o projeto como estratégia de ocupação funcional do território, que transforma o programa em instrumento de ativaço dos usos, parece-nos uma maneira de entender o resultado atingido pelo Learning Center:
0 proieto oferece uma interessante continuidaprimeiro estácio de construc̃ão da EPFL: importância dos percursos do movimento dos pátios internos com diferentes tratamentos, dotmosfras, riqueza de vegetaç̃o, singularidade e unidade 30 mesmo tempo que garante a diversidade. 0 pro- grama proposto oferece um novo espaço de conJe aprendizasem, tudo integrado em um ́rico edifício como lugar de convergência e celiro para o enriquecimento dos encontros e da sinergia. (BISBROUCK, 2006) ${ }^{220}$

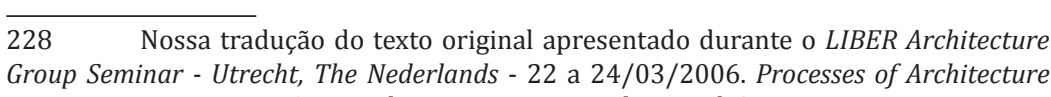

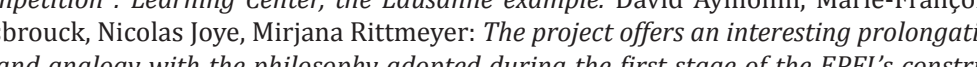

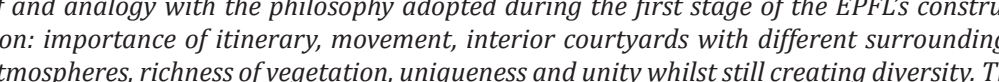

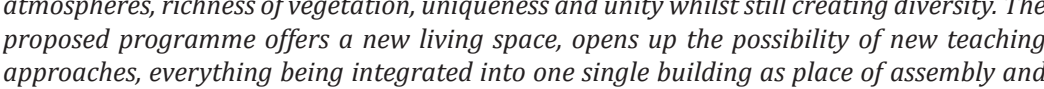
Weding-ground for enriching encounters and synergies.

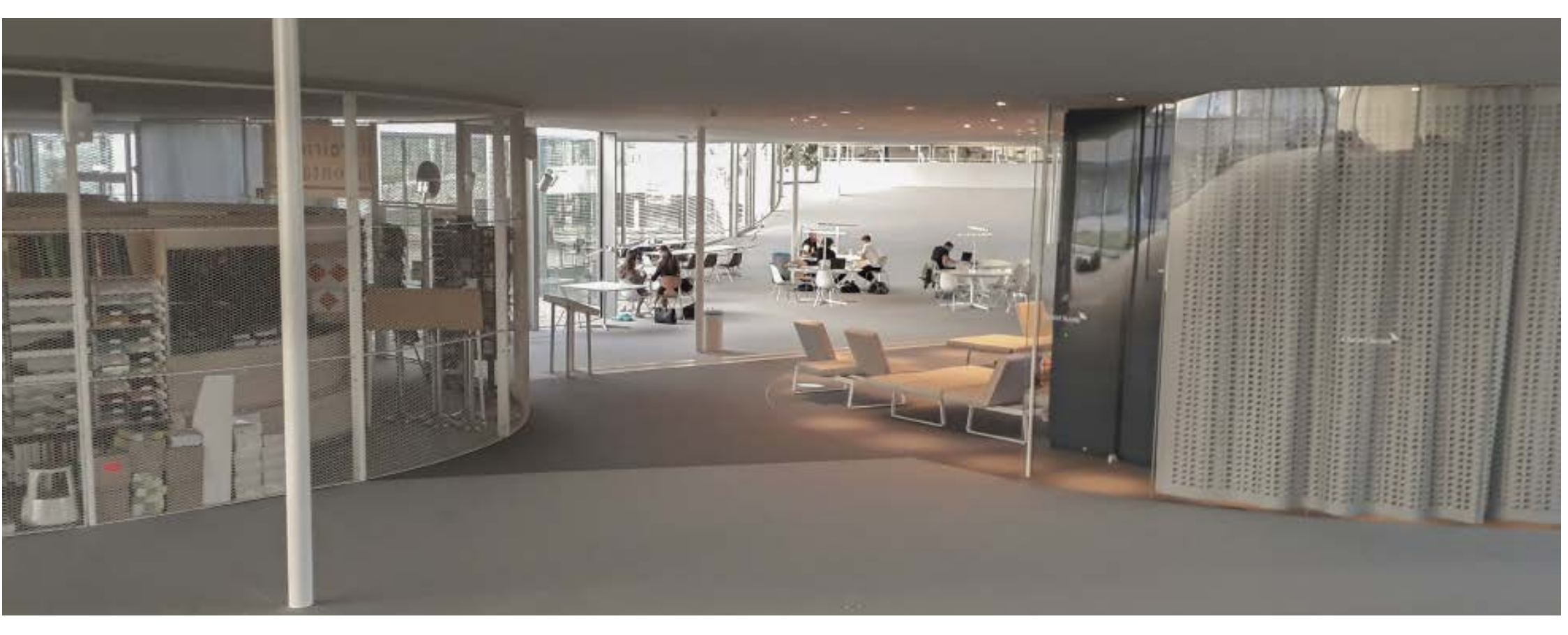




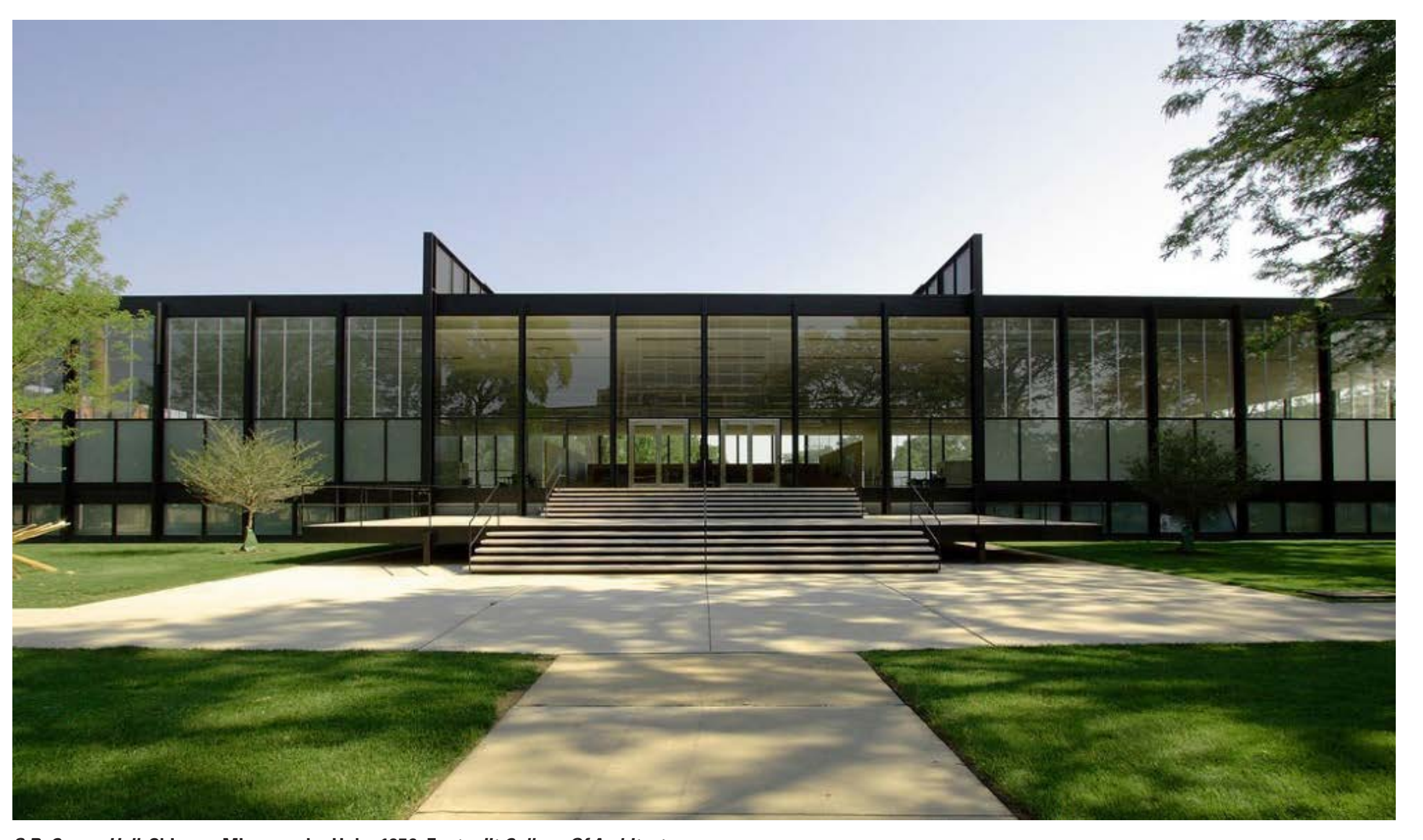

S.R. Crown Hall, Chicago. Mies van der Hohe, 1956. Fonte: lit College of Architecture.
Encontramos no depoimento acima a avaliação de um especialista em documentação e aprendizagem sobre os desafios superados por um equipamento conformado par que "as possibilidades de múltiplas utilizações se manterão permanentes", o que nos permite novamente fazer um analogia com a afirmação elaborada por Christian Norberg Schulz (1958: 42) a respeito do trabalho de Mies no perído americano, em especial sobre o projeto para Crown Hall (1955) no Instituto ( n cago. Da mesma maneira que nos projetos para a Bibliote ca do IIT (1942) $)^{229}$ e para o Teatro Nacional de Mannhein (1953), ambos não construídos, as grandes dimensões acançadas pela superfície contínua representada pelo teto branco, limpo e plano apontam para a monumentalidade da técnica em virtude do seu gigantismo e nos remete também à imensidão da Marquise de Niemeyer.

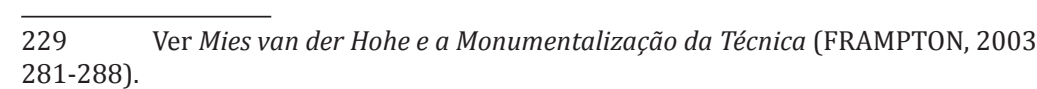

Em oposição à condição de monumentalidade, SANAA oferece a justaposição funcional e a solução topológica do espaço, entendido muito mais pelas suas possibildades formais do que por sua geometria, com a intenção $\mathrm{de}$ caracterizar o espaço por seus atributos de uso, sem abandonar os fundamentos da continuidade espacial e da un cidade do espaço. Assim, o projeto do Learning Center da EPFL poderia ser entendido como a aplicação e a evolução natural dos preceitos elaborados por Mies para explicar a opção por um espaço único, como evidenciado na entrevista a Schulz:

Acreditamos que, hoje, esta ca nandra mais economica e mais prática de construir. 0 destino $\mathrm{d}$ edificio muda sem parar, mas náo podemos nos permitir demoli-lo a cada vez. É por isso que invertemos a formula de Sullivan: A forma segue a funçăo e construímos um espaço pratico e eco4) 
de construço

confortável, mas sim um espaço cuja qualidade interior se baseia nas leis necessariamente implíitas na ordem natural, mas que a natureza não é capaz de realizar, o que nos remete ao ponto de partida - as consideraçães de Focillon.

Em momentos distintos os programas em formaç̃o u em transformação foram fundamentos importantes da arquitetura realizada por Mies, por Niemeyer e por SANAA, sem no entanto limitarem o projeto, conclusão que pode orientar sua independência. São arquitetos formados por culturas diferentes - a europeia, a latino-americana e a asiática - que encontraram estratégias de projeto semel hes para contextos dif e o suíço.

Nesse sentido, fica mais claro o papel do projeto para que a arquitetura assuma o protagonismo, baseando-se na consistência interna da obra capaz de se relacionar com o contexto, independentemente do programa.

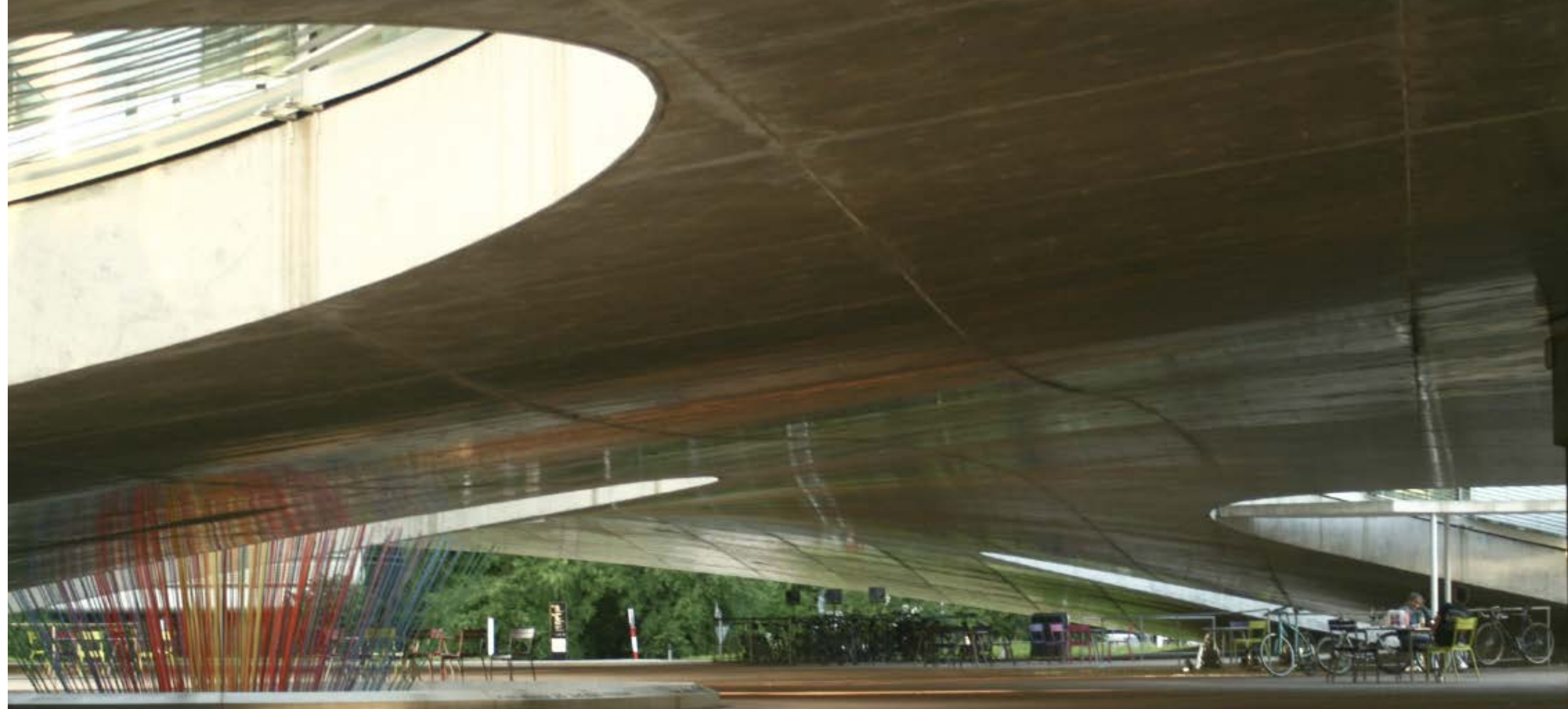




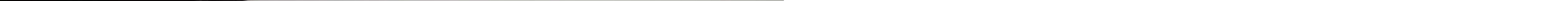


Por que você gosta tanto do jazz?

Porque é algo improvisado, mas se deveria ter

VAN DER ROHE, 1935

O projeto deve ser um fator de intervenção ativa na realidade para resolver as contradicōes existentes. 0 programa não se configura como valor. ARGAN, 198

Entender os vínculos do projeto com o tempo é um dos problemas apresentados no momento da concepcão uma obra. Tal desafio coloca-se de forma cada vez mais urgente em função da velocidade e da dinâmica com as quars a realidade vem se transformando. Parece-nos pouco relevante, como observamos na introducão deste trabine que uso de tipologias baseadas nos valores acumulados pela história da cidade seja capaz de garantir a permanência da obra face às constantes mudanças do contexto em que está inserida. Assim como os protótipos da industrialização, há também no tipo certa incapacidade de lidar com a imprevisibilidade representada pelo tempo Sua maneira de opera
作 para novas relações sociais - não encontra sintonia com o grau de incerteza em que o projeto se insere.

0 que pretendesos estur neste capló cono determinados sistemas de abstração podem auxiliar-nos na concep̧̧̃̃o e no desempenho do objeto arquitetônico, cuja autonomia está comprometida por sua inserção num sistema mais amplo e dinâmico, em contextos cada vez mais complexos e indefinidos.

O caminho proposto leva em conta a observação de projetos cujas estruturas internas baseiam-se em noçõo de diagramas e sistemas com a finalidade de garantir parte significativa da autonomia perdida.

Cabe frisar que essa hipótese não pretende tratar do artir de um diagrama, como represen cão visual de uma ideia ou de um esquema conceitual, ou seja, como expressão arquitetônica de determinada linguagem diagramática, o que aproximaria a arquitetura da escultura, estando muito mais próxima de uma solução formal, sem nenhuma preocupação funcional ou contextual (VIDLER, apud MONTANER, 2009).
Não seria, tampouco, o diagrama, funcionando como uma base cartografica, capaz de estabelecer com exatidăo o posicionamento físico das partes e seu relacionamento, isto é, como esquema projetual.

diagrama é aqui entendido como projeto, ou seja, spaço materializado de maneira diagramática (EISENMAN 1999). Assim, o capítulo desenvolve uma linha de investigação muito próxima da abstração. 0 projeto apoia-se em diagramas e sistemas para a materialização do programa, de forma a reservar amplo espaço para sua evolução, ao incorporar a variabilidade como fundamento. Estaríamos, nessa hipótese, menos interessados na linguagem multidisciplinar gerada pelo diagrama como instrumento de projeto, ou seja, pela figura, e muito mais próximos da compreensão de mapas ou mecanismos de abstração espaçotempora em que estariam contidas as relações funcionais e sociais da obra, confrontadas com os sistemas urbanos em que se

O programa, assim, vai além da definição dos crterios quantitativos e funcionais da obra. Ele assume próprio ato de projetar ou programar, constitui a mate- rialização das estruturas possíveis de serem executadas e adaptadas em um sistema (ROCHA, 2016). Nesse caso o programa seria então o projeto? Nuno Portas deixa-no claro que não, como veremos mais adiante, pois ele não suficiente para uma concepção unitária e coerente, capaz de ser a detentora do "direito à apropriação e invenção do espaço". (PORTAS, 1965: 22)

A imagem que abre este capítulo, de um dos arquitetons projetados por Kasimir Malevich ${ }^{231}$ em 1919, é significativa pois ilustra com um dos seus protótipos o que seria novo sistema suprematista, assim definido por seu autor:

Havendo estabelecido os planos determinados do sistema suprematista, a evolução posterior do suprematismo, em diante arquitetônica, eu confio aos jovens arquitetos, no sentido mais amplo do ermo, já que percebo a época de um novo sistede arquitetura dentro del MONTANER, 2009: 28)

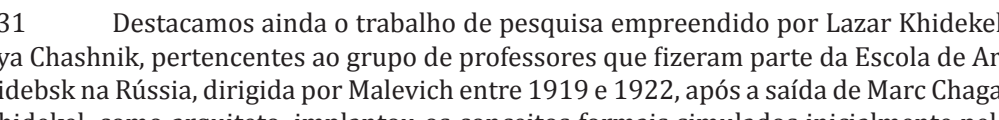

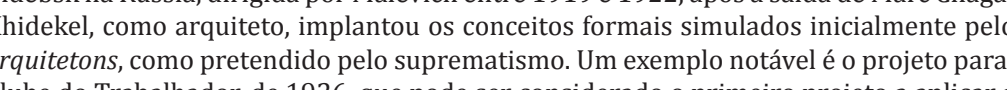

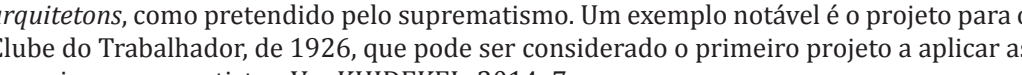


É importante notar como é introduzida a noção de sistema, do suprematismo e da arquitetura, em substituiç̧ ao projeto ou à obra arquitetônica. Malevich aponta, assim para a necessidade de se criarem estruturas, instrumentos mentais ou dispositivos destituídos de valores artísticos prévios, capazes de mediar os conflitos entre o mundo interior e o exterior, como observa Giulio Carlo Argan (1992: 325), o que nos levaria a considerar o projeto uma equação entre o programa e 0 contexto, entre funcão e lugar. Segundo 0 sip provido de significado assume determinado caráter a partir da emoç̃ão, isto é, do seu uso. Este, como atividade, adquire forma, inscreve-se no espaço e no tempo, pois a forma é o modo de vida (FOCILLON, 1947: 8-9). Nessa hipótese da arte não-objetual, poderíamos admitir que, para o projeto, o tempo assume papel fundamental na medida em que estaria na evolução da obra um de seus atributos, sem o qua não seria possível encontrar seu significado.

historiador Robert Head observa que a estratégia suprematista, ao distanciar o objeto de possíveis significa- dos e de distrações desnecessárias, proporciona os meios adequados para a "mais completa expressão de pura emo(A que a arte chegasse "à representação não-objetiva - ao su prematismo"(HEAD, 1980: 202; 291).

Pode-se perceber determinada proximidade da formulação suprematista, até certo ponto utópica naquele momento histórico, com algumas noções do diagrama come gerador, como mediador entre o material o constrú́d e o que pode ser d SENMAN, 1999: 94-95). A aproximaç̃o entre programa e o que seriam linhas invisiveis, diagramas de uma condição intermediária, que poderia ser chamada de anterioridade da arquitetura, não seria, no entanto, suficiente para justificá-lo. Sua missão não seria a de responder às formulações pré-estabelecidas mas sim de ampliá-las, abrindo caminho para questões não formuladas ou que ainda não tomaram forma, ou seja, novas atividades e novas relações ainda não conhecidas.

[...] a construção musical que emerge do pensamento serial náo desconhece a força do que se ferece como intuçâa, pois sabe que o compositor não é apenas unm matemático mais elaborad. Ele é alguém capaz de encontrar a força dos conceitos nos gestos aparentemente mais naturais alguém capaz de decompor os parâmetros naturais do som, suas distinç̃̃es entre ritmo e altur timbre e pulsação.

SAFLATE, 2018

Numa leitura preliminar, as afirmações de Argan de Mies van der Rohe, destacadas em epígrafe deste capítulo parecem opostas em relačão ao programa Háum 列 poderia nos ajudar a entender as posições expressas pelos dois autores. Do ponto de vista de nossa pesquisa, a investi- 
Assim, podemos considerar, num primeiro momento, que tanto Mies como Argan estão de acordo em relação à importância do programa na definição da obra.

Mies sabe que o improviso no jazz está baseado estrutura melódica e harmônica precisamente definidas na partitura. A liberdade criativa de cada performance jazzístca estaria em estreita relação com a repetição do tema que, invariavelmente, organiza e oferece campo para a inovação, porém mesmo com a clara manifestação de presença, el constrói uma "nova" obra233. 0 programa arquitetônico se ria o tema que o jazz repete exaustivamente sem, contudo repeti-lo efetivamente, ou seja, sua materialização deve ser apreendida durante o desenvolvimento da obra enquanto instrumento para a inovação, como vimos no capítulo 2.

Nesse sentido, 0 tempo poderia participr ativa mente não apenas da definição da obra mas, sobretudo, de sua evolução e, mesmo, da elaboração das novas relações sociais ainda a serem criadas, numa possibilidade em que o próprio tema (no jazz) ou programa (na arquitetura) seja o suporte para a invenção de um novo tema ou de um novo programa. De onde a preocupação de Mies em relaç̃o ao improviso, ou seja, na hipótese de não haver um tema ou um programa a ser explorado pela capacidade criadora do artista.

Henry Sanoff observou recentemente como a analogia da arquitetura com o jazz pode ser um instrumento de projeto através da incorporação de criações baseadas no improviso:

A analogia da improvisação [no jazz] auxilia no entendimento de como é possível operacionalizar essa indisciplina que se faz presente em todo processo criativo, do qual o projeto faz parte, a partir da definição de estruturaçôes mais flexíveis nas metodologias projetuais. (SANOFF, 2007, apud ROСHA, 2016: 108)

Para Argan, as contradições são expressas na medida em que o programa é elaborado, estudado e se torna-se fundamental para o projeto sem, contudo, ser capaz de determinar suas qualidades. Assim como Nuno Portas (1965), Argan não acredita que o programa seja o projeto, porém sua pré-existência é, para ele, garantia de que as referidas contradiç̃oes serão compreendidas, isto é, sua presença, ainda que difusa, pode ser a garantia da boa evolução $d a$

Por outro lado, podemos identificar formas concretas que trataram o programa como desenho, que foram além do programa-desenho apresentado por Nuno Portas 1965 23), gerado pela síntese de cada disciplina que alimentou elaboração do projeto. Nesse sentido, as afirmações a se-

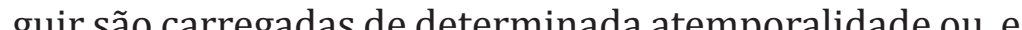
outras palavras, procuram qualificar obras sem relacioná -las precisamente com o momento histórico ou com algum momento histórico a que se referem:

Sua expressão é simples, pura e geométrica. [.] um edifício no fundo é o equivalente ao diagram de espaços que se usa para descrever de forma bstrata as atividades cotidianas que se pressupóem nele. [...] a sensaç̧ão de relaçãao física con espaço que se obtém ao ver os croquis de seus edifícios, não e a mesma relação física expermentada até agora pelo que poderíamos chamar de "arquitetura anterior", senão algo que pura mplesmente radica nas formas e modelos abs.

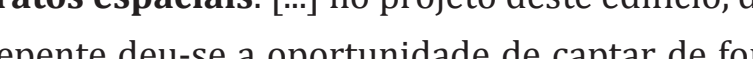
ansimbólica nossa sociod de captar de forais levar a casso o diagrama moderna, e aind turo. (ITO, 1996: 20, en

As reflexões acima, desenvolvidas pelo arquiteto Toyo Ito, são parte do texto Arquitetura Diagrama, que analisa a obra de Kazuo Sejima e a considera detentora de qualidades advindas da busca intensa pela materialização espacial de novas práticas sociais em constante evolução inseridas em contextos dinâmicos e muito pouco consolidados (a realidade da metrópole pós-industrial). Ito conclui:

Apesar de tudo, com a mesma velocidade con que a tecnologia dos computadores irrompe de forma tão rápida em nossa sociedade, tombén mudam aceleradamente nossos sentidos ou sensaç̃es físicas em relação ao espaço. ITO 1996: 24, em negrito no texto original) 
Outra reflexão que podemos destacar refere-se à relação entre a "WEB" (sic) e o meio ambiente edificado:

A "web" deve ser um sistema altamente flexíve num mundo de uma grande mobilidade [-] A num mililade é garantida pela uniformidade da tensidade inicial das atividades na "web", de forma que possa ser conectada em qualquer ponto ma que possa ser conectada em qualquer ponto, mis importantes em qualumer $\log ^{233}$. (WOODS, 1962: 4)

A proposta de espaço seguindo a noção de rede parece-nos bastante atual, no entanto as afirmações acin fazem parte do artigo WEB de Shadrach Woods, publicado na revista Le Carré Bleu em 1962. 0 texto fundamenta os projetos desenvolvidos pelo TEAM X, do qual Woods é un dos principais integrantes, que desde a década de 1950 não se limita a propor sistemas de circulação mas sim sistema enquanto meio ambiente (WOODS, 1962: 4). Nesse sentido, como na citação acima, ele antecipa propostas que po-

dem ativar os lugares gerados pela cidade moderna por su intensidade, como nas ideias defendidas por lane Jacobs (2000: 425) na década posterior.

o que nos interessa neste capítulo é traçar um camihho passível de ser identificado a partir dos questionamentos críticos à modernidade, como os do TEAM X iniciados na década de 1950 (PIETRAROIA, 2014), e que permanecem vivos até o momento, como poderemos observar. Trata-se de projetos muito mais preocupados com aspec mobilidade e transformaç̃o,o, distantes de preocupações relativas à forma e ao estilo. Tais projetos estariam mais pró ximos de uma nova identidade territorial, na qual o objeto arquitetônico perde em protagonismo em favor de um sistema de objetos (MONTANER, 2009).

Portanto, há uma linha de raciocínio segundo a qual podemos associar ao nosso tema, num primeiro momento os trabalhos de Cedric Price e os do TEAM X, em especial os de Alison e Peter Smithson, e os de Candilis-Josic-Woods. No período de 50 anos que nos separa desses arquiteto encontramos de maneira recorrente projetos cujas preoci- pações assemelham-se. Como já haviamos observado en ossa pesquisa de mestrado (PIETRAROIA, 2014: 41), a ercepcão sobr anifestada por Ito mostra-se recorrente, como é o caso da rquitetura de Sejima

a historiografia da arquitetura, o tema mostrou-se pouco relevante até as últimas décadas do século XX (GARCIA, 2010). 0 caminho é pouco evidente na medida m que tais construçoos mentais, que se aproxima ão de sistemas, nem sempre apresentam-se de maneir monsparente no resultado final da obra. No entanto, seria mportante entender, neste caso, quais são os dispositivo utilizados pelo projeto na construção de uma determinada consistência espacial, capaz de materializar ampla inter cyo com o meio ambiente natural e, sobretudo, con o construído ao longo do tempo.
Programa como projeto?

sciências parcelares, a ciência em geral, não poem senão intervir como contribuição para un programa: de fato, os dados que uma disciplin pode dar não chegam para, nem podem conduzir uma totalidade (a uma forma) pois, se assim contecesse, reduzia-se o objeto habitável a objeto técnico. [...] Mas, de outro lado, como program e desenho são elementos não sucessivos mas inerdependentes temos de apelar para uma form de integrar, por exemplo, dois dados quaisquer de programa cuja comparação não teria sentido, seria indeterminada ou desconexa sem a fora ostrasse que havia conexão interdisciplinar. A realização da "coisa" reforma o "programa", chama a uma nova avaliação e re-forma-a por se turno passando de hipotese lançada sobre o cohecimento anterior à realidade, ainda e sempre hipotese, lançada agora sobre a vida, o uso, o consumo dos homens. [...] Se não introduzirmos este processo complexo de açă, que diftulta a metodologia do desenho, reconhecemo-lo, estaremos perante um ambiente fisico sem modelação críta, de pura expressão tecnocrática. 
A complexidade das demandas sociais crescentes e, principalmente, as dificuldades de se identificarem maneiras de se estabelecerem relações perenes entre elas são situaç̃os que o projeto encontra no momento em que a arquitetura parece ter perdido o sentido. ${ }^{235}$

Diante da vastidão com que o problema da arqutetura se apresenta, o projeto depara-se com a dificuldade de retirar do extenso conhecimento em que vivemos os elementos para a criaç̃o arquitetônica É o que apontaram autores como rama mentos gerais e específicos das disciplinas envolvidas em determinado processo tende a gerar um objeto de "pura expressão tecnocrática", nas palavras do autor. No limite, a tecnologia da informação seria capaz de tratar todos os dados envolvidos como necessidade do programa, respondendo de maneira objetiva ao problema colocado. Não nos parece, entretanto, como poderemos observar, que a tecnologia digital, neste caso, faça arquitetura pelo simples fato de somar racionalmente componentes e ambientes de um difício. Como assinala Nuno Portas, tal somatória não é ficiente para fazer um edifício significativo, assim cono a sence soma de edifícios, ruas e parques não e suficiente para fazer uma cidade (PORTAS, 1965: 18). 0 autor acrescenta:
0 dado "objetivo setorial não pode entrar diretamente no resultado de uma sítese mental gestual e gráfica sem que, através desta ou da sucessão de tentativas desta, seja posto em causa e, ort, interpretada no seu sentido conexão com outras fontes. Com efeito, o projetista le de outra forma informação alheia porque busca nela o que poss formar ideias de ambientes, sugerir relaçỗes de funç̧ões que apenas lhe interessam se implicaren espaço"; assim como, por outro lado e mais excitante lado, a ideia de relação de espaço que na sua mente se esboça pode reorganizar tais interpretações setoriais abrindo outros aspectos a pesquisar que não tinham ainda ocorrido. (PORTAS, 1965: 24, em negrito no original)

No debate acadêmico atual, podemos verificar a permanência das preocupações levantadas por Nuno Portas como na afirmação do professor Alexandre Delijaicov, para quem "o programa é uma certeza, o terreno, uma variável e o projeto, uma visão" (01/08/2017 - AUP 0162).236

A tecnologia digital e

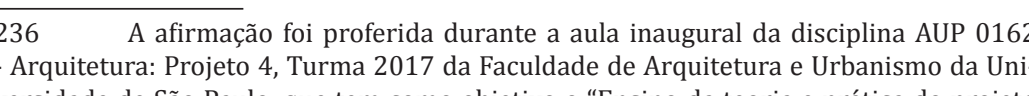

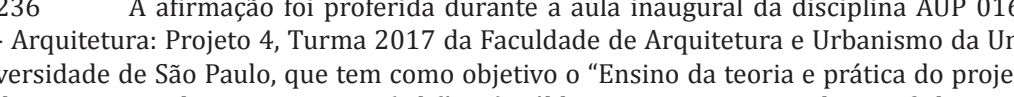

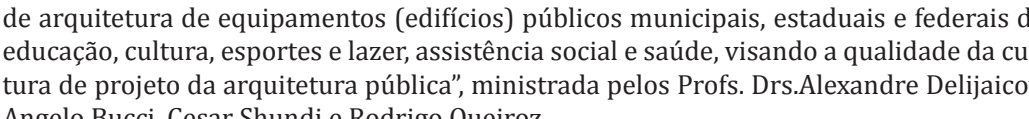
a autonomia da arquitetura
Vivemos em tempos incertos, mas a respeito $d e$ ricamente executadas em forma visiońria. Pelo contrário ela élevada pela necessidade de inovar de criar soluções plausíveis para problemas preentes, mas cujas implicacõos mais amplas aind ão encontram formulação. Isso só pode ser realizado com inteligência. Do contrário, o projeto consiste apenas em resolver um problema sem ada acrescentar.

SPEAKS, 2002

Como citado na introdução desta tese, as possibilldades oferecidas pelas inovações da tecnologia digital intensificaram não somente as possibilidades de repetição do acervo, um conhecimento acumulado no interior das equipes interdisciplinares, antes mesmo que os problemas se coloquem. Em outras palavras, como define Michael Speaks na citação acima, é através de mecanismos de análise e inoprânea não é movida por ideias visionárias he- 
realidades que surgem permanentemente.

Dentro dessa perspectiva que se apresenta pouco definida, o que nos interessa é compreender em que medda as transformacõos nos métodos de representação e de senvolvimento do projeto contribuem para a investigaçã de modelos, padrões ou sistemas arquitetônicos capazes de responder a realidades cada vez mais dinâmicas e ao mesmo tempo difusas. Trata-se de um desafio que se manifesta em escala global mas que pode ser revelador de caminhos em países em desenvolvimento, como é o caso da realidade brasileira. Nesse sentido, apresentamos e relacionamos pontos de vista de autores preocupados com os impactos da tecnologia digital na arquitetura.

As considerações de Michael Speaks, para quem a tecnologia tem papel fundamental na construção do chamou de "inteligência do projeto", podem indicar-nos como as práticas coletivas assumem a iniciativa na renovação que a arquitetura reclama, visando recuperar seu protagonism no cenário das intervenções urbanas.

Essa visão é ampliada por Antoine Picon, para quem a busca de uma nova materialidade arquitetônica pretendida pela tecnologia digital trouxe "a generalização do projeto como prática relativa não só às construções vírios sistemas tecnológicos mas também aos materiais lém deles, à natureza, como realidade engenhada" (PICON 2004: 217). Não se trata de uma ameaça à materialidade d arquitetura que parece questionar os pressupostos com re lação à natureza da disciplina da arquitetura, observa o autor, assinalando a importância da arquitetura em operar en duas categorias aparentemente opostas: de um lado o totalmente abstrato, os fluxos geométricos, e de outro o que ele chama de "ultraconcreto", representado por propriedades dos materiais até então desprezadas ou de difícil apreensão.

É importante lembrar que parte da força crítica ao Eoarismo da Arquitetura Moderna iniciado durante a década de 1950, esteve ancorada na compreensão da cidad genérica e na riqueza de situações que ela apresenta. 0 trabalho do Team X e do Archigran, por exemplo, partiu de tais considerações e firmou-se ao incorporar a tecnologia como estratégia para viabilizar sua utopia, alinhada com os movimentos da cultura pop e da contra-cultura na década seguinte.

A situação fica evidente na afirmação que faria $\mathrm{Ce}$ dric Price anos depois a respeito do seu trabalho: "A tecnologia é a resposta, mas qual é a pergunta?" (PRICE, 1990: 32). Devemos nos lembrar de que Price, ao mostrar sua força criativa no projeto do Fun Palace, assume a postura do arquiteto como pesquisador capaz de compreender e responder a todas as variáveis da obra, lançando mão da te ologia para antecipar o comportamento dos utilizadores. Speaks não inclui tais manifestações (como o trabalho de Cedric Price, do Team X e do Archigran supra citado) quando, em seu ensaio, descreve as vanguardas do final do século XX que, para ele, apoiaram-se em teoria para se oporem ao B ño se pode des não se pode desconsiderar a infhência desses arquitetos visionários que buscaram na tecnologia o caminho para renovação espacial de uma sociedade do conhecimento que prosperava. E certo que o Fun Palace influenciou toda uma geração de arquitetos que se destacaram na década seguinte, como Renzo Piano, Richard Rogers e Norman Foster, en especial pelo us construtivos empregados como principal força de expressão de suas obras. Entretanto, é no expressivo volume de dados processados por Price em suas tabelas, gráficos planilhas que podemos encontrar o elo de sua atuação com as práticas atuais.

Dentro dessas novas práticas arquitetônicas apresentadas por Speaks está o versionamento (versioning) técnica de prototipagem rápida amparada pela tecnologia digital, capaz de se adaptar e intervir em diversas escalas urbanas. Cabe lembrar que Cedric Price não dispunha da tecnologias atuais. Porém, é verdade que ele percebeu a importância de se estabelecerem novas práticas para respasumindo 0 Fun Palce pode ño ter se vablyado obra, em parte por ser o símbolo do esforço intelectual de seu autor, mas não podemos desprezar sua experiência como sistema, capaz de assumir configuraçoes distintas 
em meios variados, promovendo a reflexão em torno de uma materialidade dinâmica do projeto. Ou seja, para nós, a espacialização pretendida por Price estaria amparada na mudança constante do ambiente construído, o que nos leva a pensar em uma materialidade cuja dinâmica citada estaria além das funções e dos fluxos internos e externos dos usuários. 0 Fun Palace permitiria a dinâmica de sua própria espacialidade. Dando seguimento a tais considerações, podemos afirmar que Price teria antecipado a inteligência do projeto como inovação para a prática arquitetônica ou ainda, estaria na maneira diagramática de concepção do Fun Palace a garantia de variabilidade e de evolução pretendidas por seu autor. Os procedimentos de Price são relembrados abaixo por Will Alsop, em uma citação que ilustra com precisão nossas considerações:

Algumas coisas, como o tempo, são muito difíceis de desenhar se você não usa um diagrama. Ce- dric sempre se interessou pelo tempo e por suas cones com seu trabalho; isso tornou-se uma especulação e uma predileção do futuro. Era in"se....e........". Lembro-me trabalhando com ele no Inter-Action Centre, tentando fazer um diagram Inter-Action Centre, tentando fazer um diagran munidade. 0 tempo também é ímportante para a narrativas em arquitetura. (ALSOP apud GARCIA 2010: 215 $)^{237}$

Podemos também observar a utilizaç̃ão da tecnologia digital como possibilidade de manipular a complexidade do projeto para alcançar uma arquitetura excepcional. A pesquisa de Pedro Luís Alves Veloso (2011) apresenta trabalho de Enric Ruiz-Geli, do Cloud, para quem a existência de uma cultura diferenciada e a disposição tecnológica devem reivindicar a inovação formal e metodológica do rojeto, rompendo com diversas predisposições disciplin

O próprio Veloso adverte que os modelos digitais não são apenas responsáveis pelo aumento da eficiênc

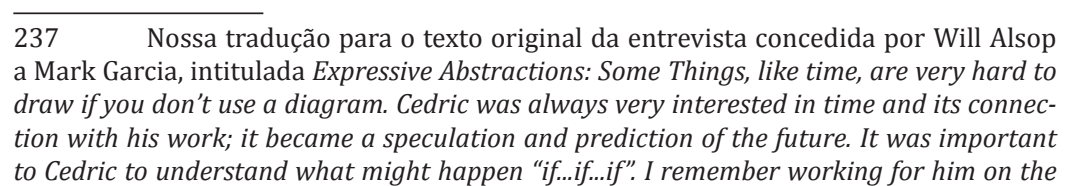

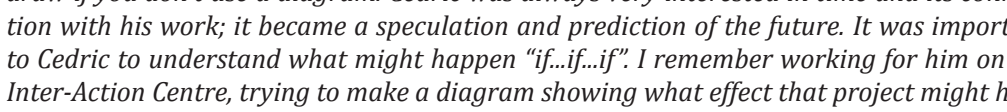

do projeto mas, principalmente, servem como materia conceitual de criação. Nas ficcõos arquitetônicas seria centuado seu pa sentido, seria possível admitir que as formas têm tanimportância quanto o conteúdo. A cultura precederia o conhecimento através do cultivo da forma que daria sent do ao conhecimento, o que se aproxima de noções da alta cultura defendida, por exemplo, por T. S. Eliot, como anasa Mario Vargas LLosa (2012: 14). Haveria, entretanto, Mercas fundamentais nos métodos de apreensão e de distribuição desse conhecimento, que nos parecem opostos ao que a alta cultura representara, na medida em que o acesso a eles se dá de maneira imediata e global, muit distante, portanto, da rigidez e da impermeabilidade caacterísticas da alta cultura.

Podemos ainda notar que ao utilizar a noç̃o de ficcão e de "poder ser" para relacionar a tecnologia digital ção e de "poder ser" para relacionar a tecnologia digital pecífica da obra, o que lhe confere uma identidade concreta ou, como destaca Hélio Piñon, lhe faz "ser algo", sem neces- sidade de "se parecer algo":

identificação do problema, previa à propos arquitetônica - de caráter artístico - seria necessariamente racional, mas a arquitetura não baseia seus critérios de concepção em preconceitos racionais, senão em processos de intelecç̃a visual nos quais a proposta de forma resolve situaç̧o es de projeto, ao mesmo tempo que revela o caráter atíico de sua natureza. (PIÑNoN, 2006: 50)

Podemos ainda acrescentar ao exposto as reflexões os balanços realizados em meados da primeira década do século XXI que dão conta das novas possibilidades de atuaç̃o da arquitetura na produção dos componentes industriais utilizados na construção graças à

Seria possível recorrer aos instrumentos de tratamento da continuidade matemática para produzir em sé rie as infinitas variações de um mesmo objeto, a um custo equivalente a uma única versão desse mesmo objeto, o que permite produzir por encomenda, indiferentemente e sem 
custo adicional, como observou Mario Capo (2003: 100). As novas formas não respondem a nenhum standard, são variáveis e adaptáveis ao infinito e são resultado dos programas controlados por seus conceptores, completa o autor

Consideramos esse aspecto fundamental na transformação dos meios de produção da obra, em especial por ampliar e reintroduzir a arquitetura na coordenação interdisciplinar do projeto. Tal aspecto pode ser uma contribuiç̌̃o valiosa para o enfrentamento de realidades cada vez mais complexas. Entretanto, pergunta Axel Sowa (2003b: 95) estariam os arquitetos prontos para reassumir o papel protagonista, em função da demanda crescente e diversificad das formas arquitetônicas e das técnicas informatizadas, que permitiria a essa demanda ser menos utópica, e que suscitaria um savoir-faire e novas maneiras colaborativas?

Estaríamos, então, no momento de serem estabele-

cidas metodologias de projeto, não como sequência teórico-prática para sua concepção e desenvolvimento através do cumprimento de etapas claramente definidas, mas si como construção de um acervo, nas palavras de Speacks, em que o projeto é o próprio método, muito mais que apenas uma referência. Seria, as sim, a compreensão de seus mecanismos e de seus princípios o caminho para a construcão de uma nova epistemologia projetual, como observou Bruno Massara Rocha, ao citar Marcos Novak:

[...] pela primeira vez na história o arquiteto é demandado a projetar não o objeto em si, mas os princípios pelos quais ele é gerado e variado a longo do tempo. (NOVAK, apud MASSARA, 2016: 114)

Segundo Novak, os conhecimentos da tecnologia digital recodificam o conhecimento da arquitetura, permitindo que suas qualidades morfológicas possam ser trabalhadas muito além das referências, estabelecendo estratégias próximas da dinâmica das partituras musicais.

Conforme exposto, o que nos parece claro é que, mesmo que as questões levantadas não apontem conclu- sões definitivas, há uma evidente indicação de que a tecnologia digital é um instrumento poderoso não somente para a percepção de uma materialidade alinhada com uma nova sociedade, como também e fundamentalmente por ser responsável pela ampliação das possibilidades de atuação da arquitetura no campo interdisciplinar, diante da cidade. Seria uma constatação que vem ao encontro da importante reflexão de Saskian Sassen:

Assim, no que tange ao impacto do digital sobre arquitetura, o urbanismo e a cidade, houve, sim ma profunda transformacão, mas não, nim, ramente marcada pela neutralização do capita fixo, do ambiente constrúdo ou, enfim, da cidade. Em vez de neutralizados, eles emergem con uma importância estratégica renovada no que diz respeito a algumas de suas características, isto é não como condiç̃o generalizadd, e sim como condição específica. (SASSEN, 2014: 137)
As considerações ao lado introduzem as noções de sistemas e diagramas dentro de uma visão de instrumentalização do projeto. A tecnologia digital surge como instrumento inevitável para a construção da chamada "inteligência do projeto", no âmbito de uma metodologia sistêmica e diagramática de concepção da obra.

A seguir, passaremos a examinar projetos que consideram tais nocõos como respostas aos problemas colocados pela indefinição do programa e do contexto:

Na interioridade da arquitetura há também uma stória $a$ priori, o conhecimento ac (E) 


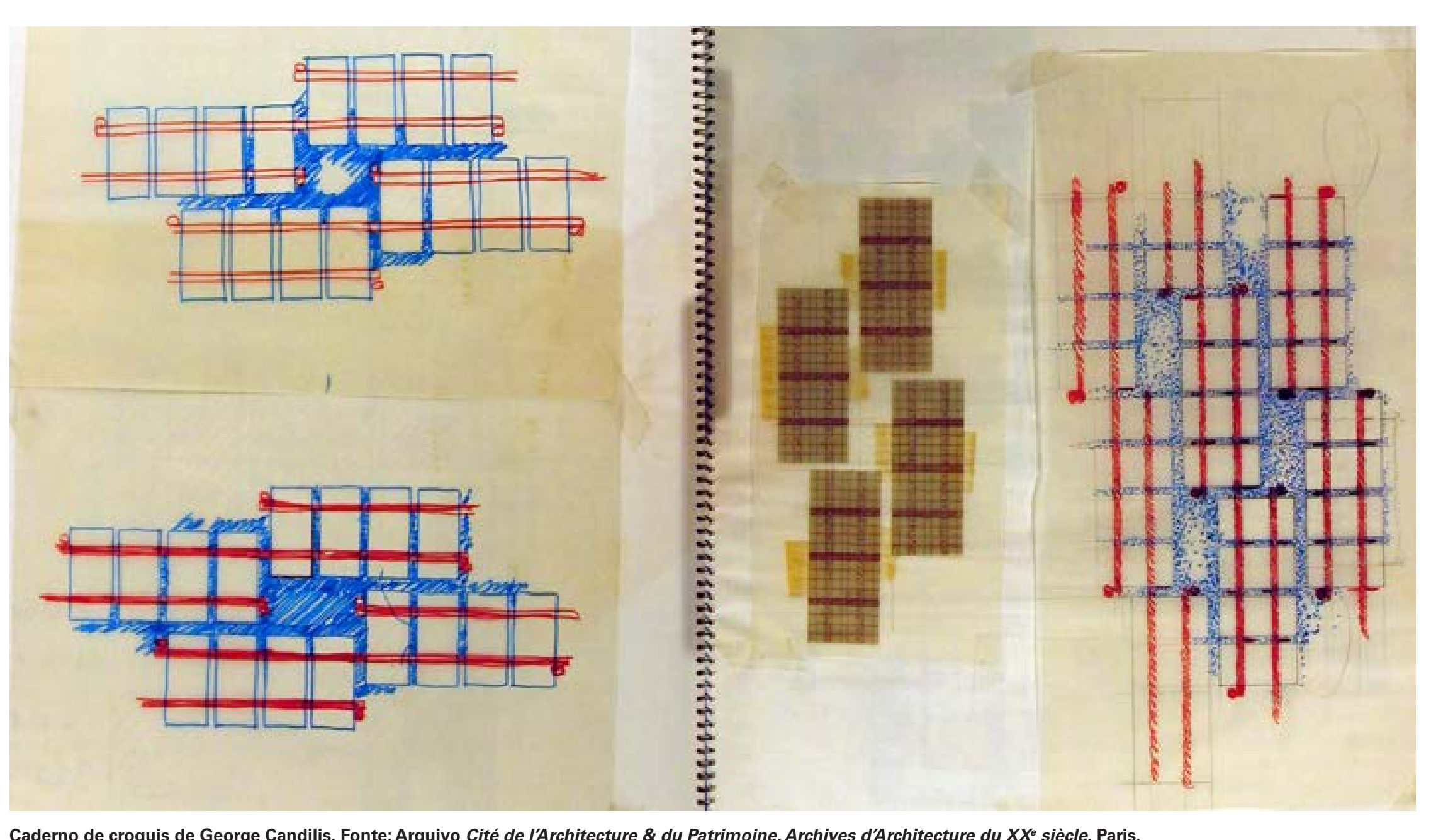

Tomemos a imagem de um tecido, constituído pela urdidura ${ }^{238} \mathrm{e}$ pela trama Pode-se dizer que a urdidura estabelece o ordenamento básico do tecido e, ao fazê-lo, cria a oportunidade para gue se consiga a maior variedade e colorido possveis junto com a trama [ I A urdidura deve en primeiro lugar e acima de tudo ser forte e possuir a tensão correta mas, no que diz respeito cor, tem apenas de servir de base Éa trama que dá a cor padrão e textura ao tecido, dependerdo da imaginaç̃o do tecelão. Urdidura e tram constituem um todo indivisivel; uma não pode existir sem a outra e cada uma empresta à outra seu objetivo.

HERTZBERGER, 1999

Um sistema complexo demais, que deve corresponder à necessidade de adaptação imediata, teria sido rapidamente ultrapassado pela realidade. BANHAM, 1975 
O projeto para a Universidade Livre de Berlim-Dahem (1963) e considerado pela historiografia da aquitetura ${ }^{239}$ um exemplo de megaestrut minou parte significativa do debate na década de 1960 . Outro exemplo notável, a Universidade de Toulouse-Le-M rail (1969), assim como o projeto de Berlim, é um desdobramento natural das propostas desenvolvidas por Georges Candilis, Alexis Josic e Shadrach Woods, a exemplo do projeto para a reconstruc̃ã do centro de Frankfurt apresentado pela equipe no concurso promovido em 1963.

Baseados nas ideias de uma arquitetura aberta, cujos spaços funcionais são estruturados por malhas de circulção, os mat-buildings inspirados na arquitetura vernacular do norte da África alcançaram maior força quando da existência de um contexto denso e historicamente consolidado como em Frankfurt, mesmo sem terem sido implantados. Para alguns autores, como Kenneth Frampton (1997), estaria na ausência desse contexto a razão para um certo fracasso em Berlim, o que poderíamos afirmar também para Toulouse, por analogia, ou seja, a falta de pré-existências às quais 239 Ver BANHAM, 2001; RRAMPron, 1997 as estruturas urbanas projetadas pudessem se conectar.

Ainda que na cidade do sudoeste francês a unive -

sidade fizesse parte significativa de um projeto urbano de grande escala, o novo bairro Le Mirail ${ }^{20}$. Franpton aponta a ausência de uma "cultura urbana" como responsável pela dificuldade em gerar o microcosmo urbano desejado no interior da universidade.

0 que nos interessa ao confrontar essas duas importantes obras - a Universidade Livre de Berlim e a Universidade Toulouse-Le-Mirail - com o problema colocado no presente capítulo ou seja, o tempo e a independência do projeto, é poder examiná-las como materialização de parte significativa das ideias de uma arquitetura não simbólica, flexível e evolutiva que caracterizou o questionamento critico à cidade moderna na década de 1960:

Uma grelha pode se tornar a materialização física de um processo de design, ou deveria desaparecer

$240 \quad$ Ver JOEDICKE, 1975 própria, ou deveria incluir e estar inclúda na (DE CARLO, 1975: 48) $)^{241}$

A reflexão de Giancarlo de Carlo, publicada na edição o periódico L'Architecture d'Aujourd'hui dedicado ao TEAM após vinte anos de sua formação, questiona a permanência do projeto segundo as estruturas urbanas propostas por Candilis-Josic-Woods para a Universidade Livre de Be m, dez anos após sua construção. 0 tempo de existênci obra teria contribuído para que sua dinâmica urbana se ntegrasse à "lógica do contexto social e físico" da cidade pergunta De Carlo, ou sua excessiva força seria responsável por um determinado isolamento da universidade? A rigide fisica apontada pelo autor como obstáculo para a integraos elementos construtivos que fundamentariam a permanência da arquitetura?

Para responder às perguntas formuladas por $D$ Carlo, entenderemos a obra através do exame de projetos que notadamente anteciparam e inspiraram as propostas de Candilis-Josic-Woods.

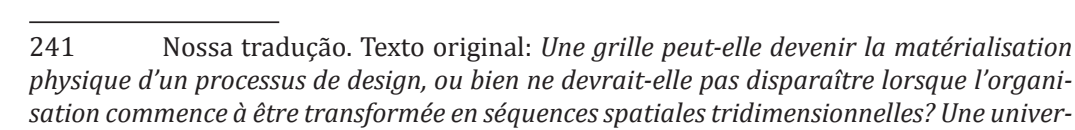




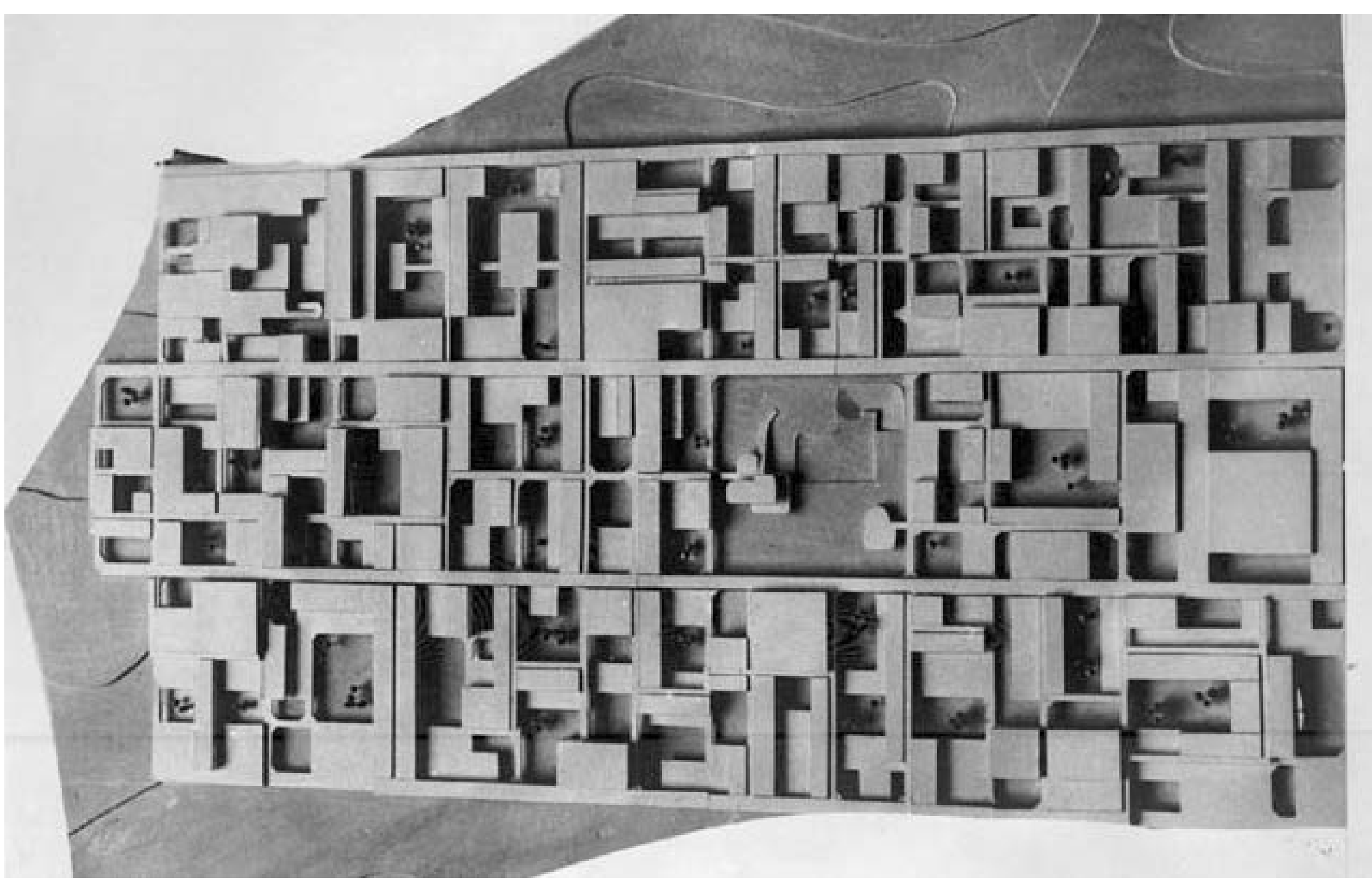

Maquete do concurso
du XXo siecle. Paris.

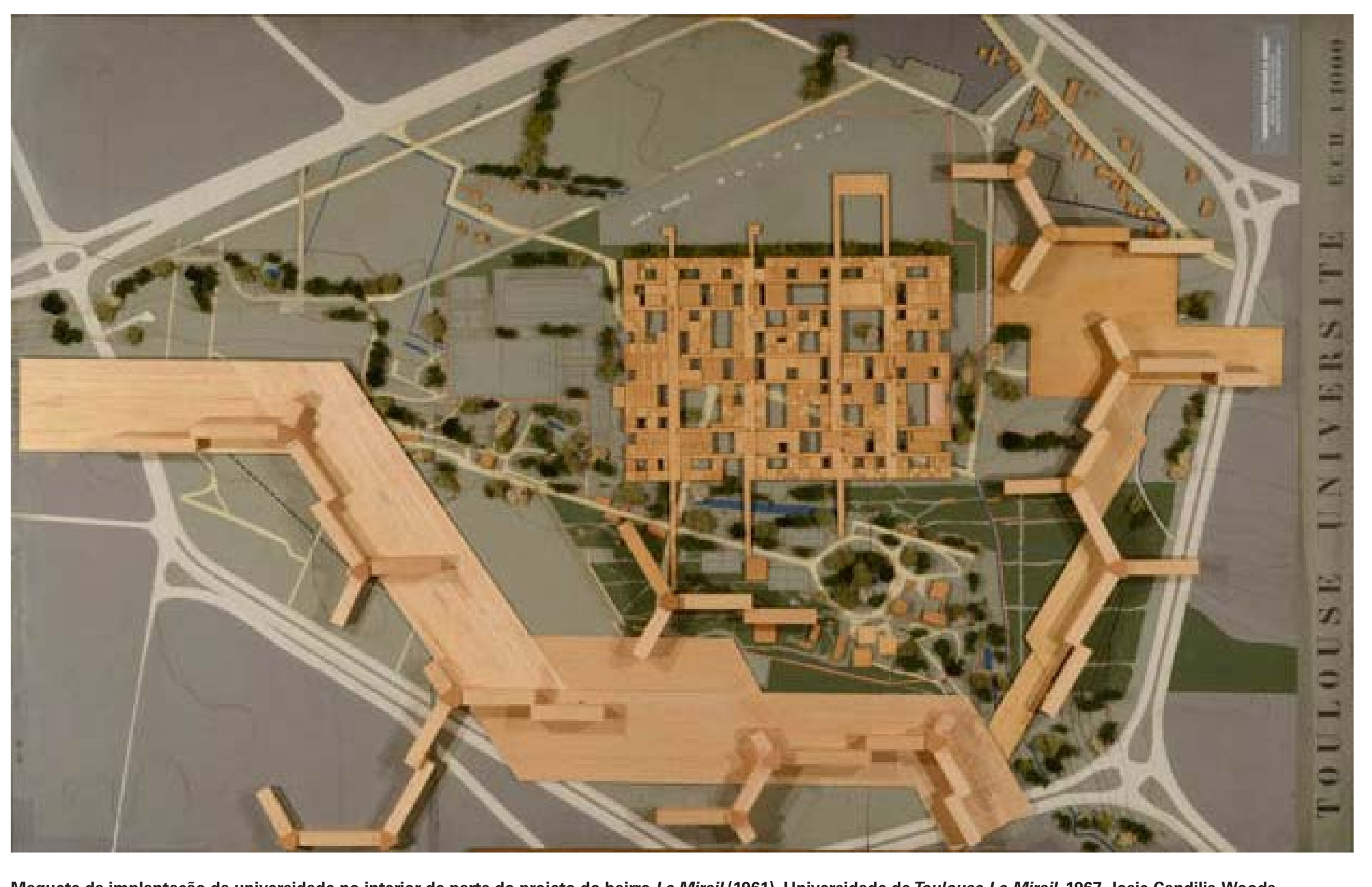

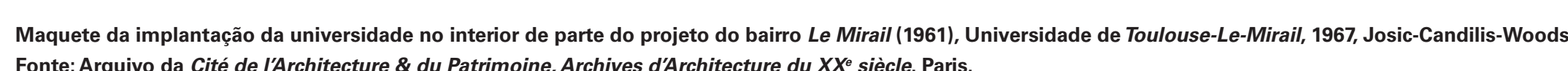


A voz da arquitetura segundo Louis Kahn Entendo a escola como um ambiente de espaces em que é bom ensinar [-] Mas Escola o espírito da escola, a essência de sua existência é o que arquiteto deve expressar em seu projeto. Edigo de à verba disponível. Desta maneira o arquiteto se destaca de um mero projetista. [-] Os corredores serian transformadosem salas de aul dos próprios estudantes tornando-os mais amplos oferecendo-Ihes alcovas com vistas para os jardins. Eles poderiam se tornar o lugar onde os me ninos encontram as meninas, onde os estudantes que ele deve, mesmo se o projeto não correspon-

discutem o trabalho do professor com seus colegas. Permi ços em vez de passagens de sala para sala, os corredores poderiam se tornar um lugar de encontro e não mero corredor, ou seja um espaço para auto aprendizagem. Faz com que a sala de aula pertenca aos estudantes. As salas de aula devem evocar seu uso por sua diversidade espacial eñ̃o seguir a espacialidade militar tradicional porque uma das características mais extraordinárias do homem sob a árvore é o reconhecimento da singularidade de cada homem. Um professor ou um estudante não são os mesmos quando estão con algumas pessoas numa sala com lareira do que quando estão em um grande salão com muitas pessoas. E a lanchonete não precisa estar no subsolo, mesmo que o tempo de sua utilização seja pequeno? A hora da refeição não é também parte do aprendizado? ${ }^{24}$

KAHN, 2009

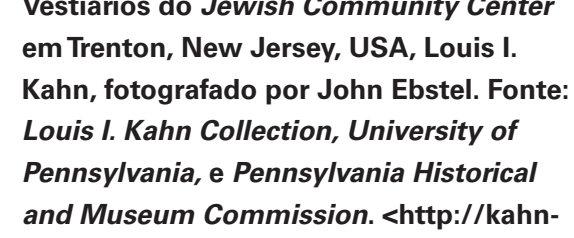

and Museum Commission. . http: //kahn
trentonbathhouse.org

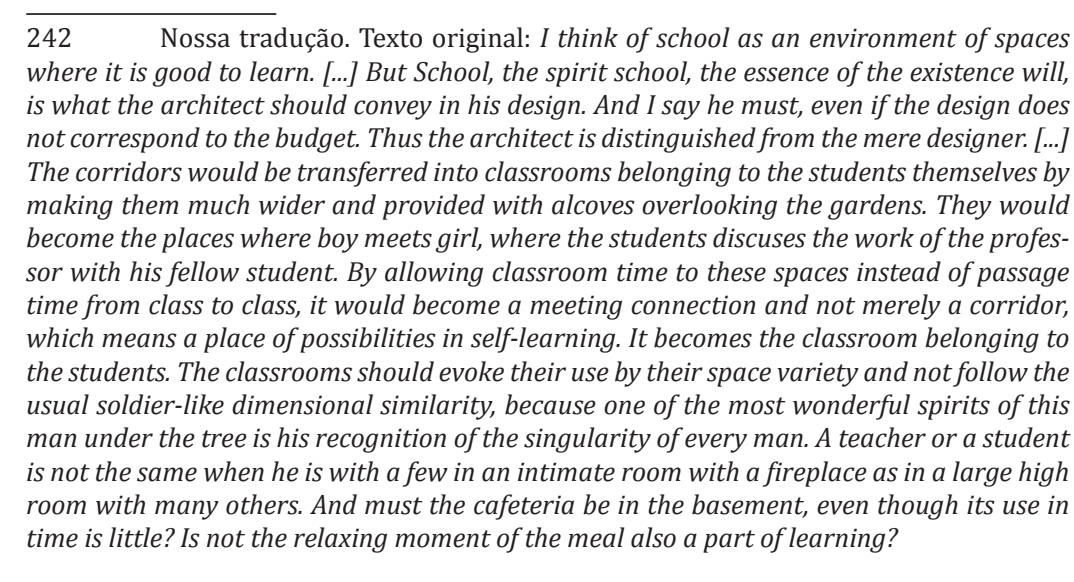


A passagem acima foi extraída da transcrição da emissão radiofônica Voice of America, de novembro de 1960, Forma e Projeto (MCCARTER, 200: 465-466), em que Louis Kahn, a partir da pergunta de um estudante, apresenta, em forma de diálogo, sua visão do projeto. Apoiando-se em temas, como os edifícios institucionais, Kahn introduz seus conceitos chave, baseados no retorno aos valores primordiais da arquitetura, como a estrutura e a luz, para 0 enfrentamento dos desafios da cidade moderna.

No trecho em que fala da escola, Kahn insiste na va

lorização dos lugares intermediários, que tradicionalmente são tratados como lugares de passagem, mas que deveriam adquirir um valor essencial na construção do lugar aprendizagem. Por serem fundamentais para a mobilidad a conexão entre as pessoas, esses lugares deveriam projetados e qualificados como em continuidade, ou sej como extensão das atividades didáticas exercidas nos anbientes especializados (as salas de aula e a biblioteca). Dito de outra forma, a funcionalidade seria dependente de espaços cuja indefiniçãoo programática inicial não deveria se suficiente para desqualifić-los. Para Kahn, todo esse conjunto conformaria um meio ambiente constrúdo necessrio para a constituição da identidade da instituição Escola.
Cabe salientar como os conceitos de movimento, fluxos conexões assumem importante papel no projeto, numa visão para a a dqu são em relaç̃o à cidade moderna.

Assim como a escola, a cidade moderna deveria ser um lugar de intercâmbio de experiências, de conhecimento muito mais do que um lugar de trocas materiais. 0 projeto promoveria a aproximação funcional da cidade e não se distanciamento para isso, a mobilidade seria um instrumento fundamental. Estaria nesse raciocínio uma pista inportante para entendermos como Kahn se vale do aparente transtorno causado pela convivência no interior da cidade do automóvel para extrair um caminho promissor para a arquitetura.

Ao examinarmos alguns de seus projetos, dentro da sua extensa e fundamental obra, encontraremos exemplos significativos que ilustram de maneira objetiva as posições acima descritas e que introduzem o tema que devemos estudar nesse capítulo

Em 1954, Louis Kahn inicia o projeto para o Jewish
Community Center em Trenton, New Jersey. Desde os primeiros estudos, o projeto se organiza a partir de uma malha estrutural, conformando um diagrama em que os ambientes especializados do programa são envolvidos pelos espaços de circulação, a transição entre o que Kahn chama de "espaços servidos" e "espaços servidores". No nosso entendimento, vale observar que uma das plantas iniciais (1955) apresenta os primeiros como módulos octogonais e os segundos como módulos qundrados indicando determinada hierarquia geométrica na escala e na complexidade da figura. Quando observamos a proporção entre os módulos verificamos que há cinquenta por cento a mais de espaços servidores - os quadrados - do que de espaços servidos os octógonos. Isso significa que os quadrados, distribuídos de maneira ortogonal em relação aos lados dos octógonos, totalizam un tabela resumo apresentada pelo próprio Kahn. Porém, que é fundamental compreender é que a construção de cad octógono é o resultado do posicionamento dos quadrado ou seja, as funções se organizam e interagem em função das conexões e dos fluxos entre elas. Em outras palawras a figudente dos quadrados que representam a solidez estrutural a disponibilidade de infraestrutura e, principalmente, o fluxo de pessoas.

Nas versões posteriores do projeto, de 1956 e 1957 o octógono é abandonado e o módulo quadrado assume protagonismo. Kahn adota o ordenamento ortogonal e introduz o distanciamento entre cada figura formando um malha em duas direções. As coberturas, em tronco de pirâmide, reforçam ainda mais a repetição e a regularidade do padrão proposto. Num primeiro momento, fica clara referência à malha urbana ortogonal em que as variaç̃es são estabelecidas pela supressão estratégica de alguns mó dulos, conformando praças e outros intervalos urbanos. No entanto, quando observamos com maior atenção a planta gerada a partir do traçado proposto, verificamos uma extrema riqueza de situações cuja variabilidade vai além do jogo dualista en

Na proposta mas conecida defiva, a mala Na pror constiue por quadrados de mesma dimensão em que elementos construtivos são tratados, procedimento que nossa pesquisa vem defendendo. Kahn repete elementos

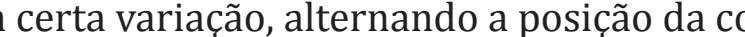
bertura, a posição dos fechamentos e, sobretudo, a incidên- 


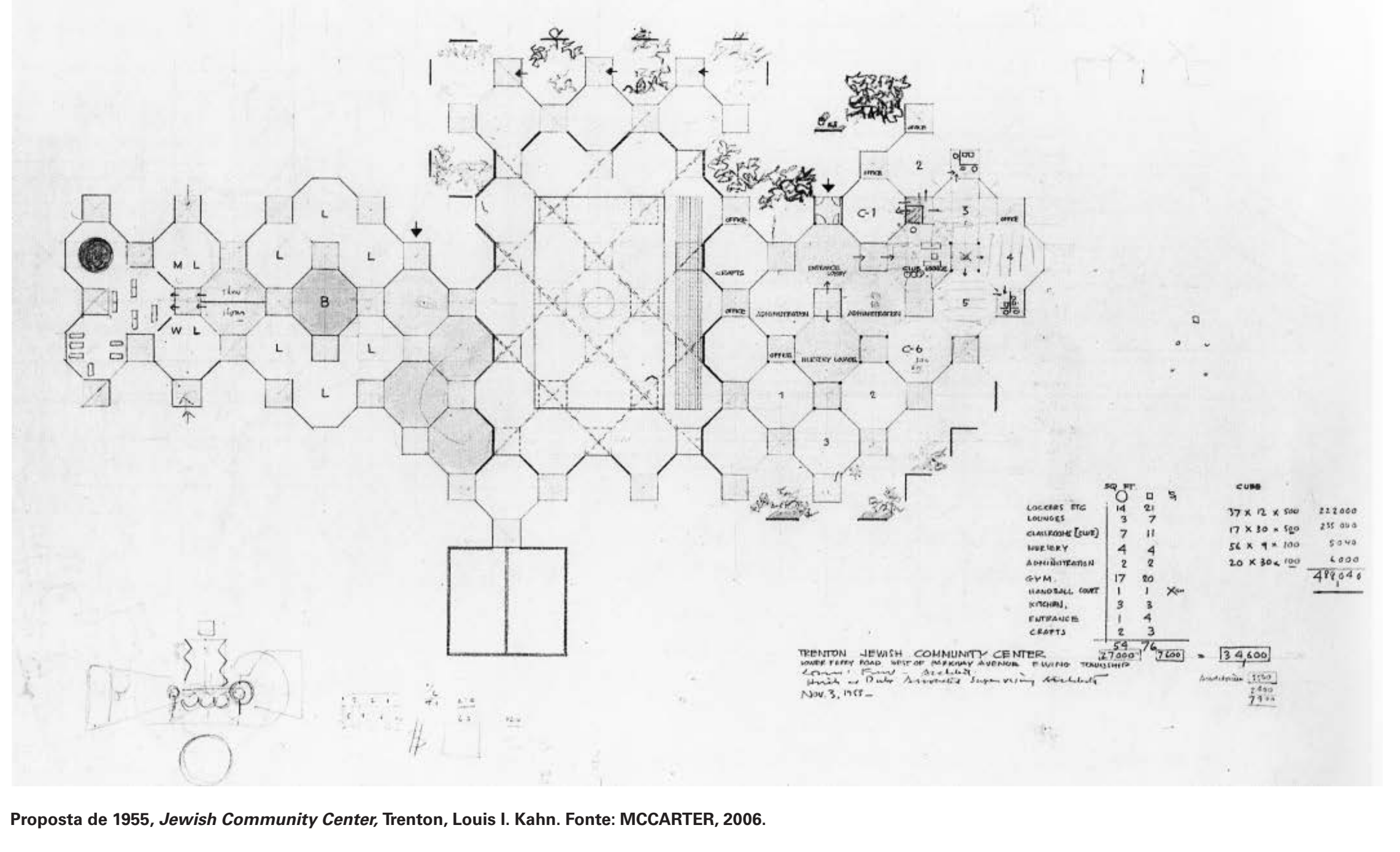

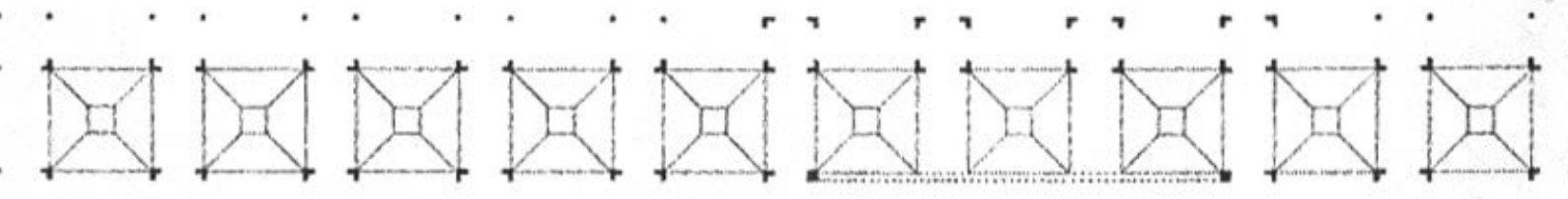

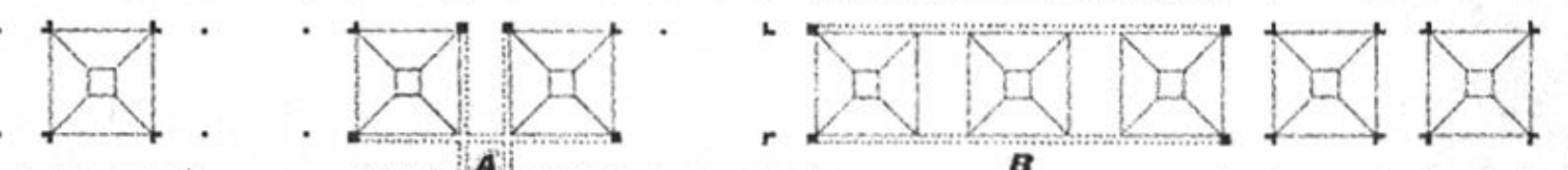

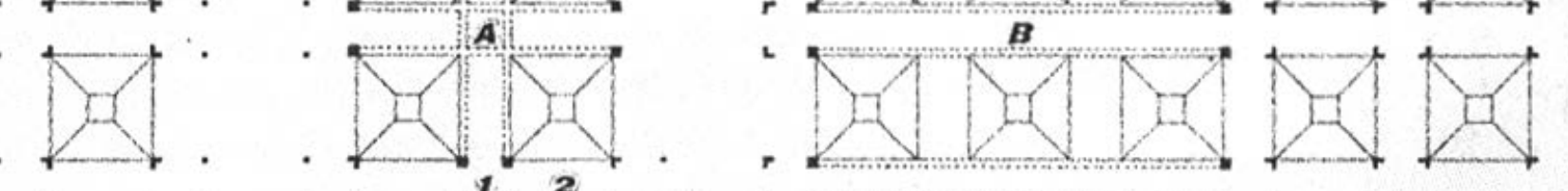

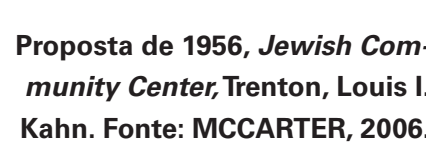

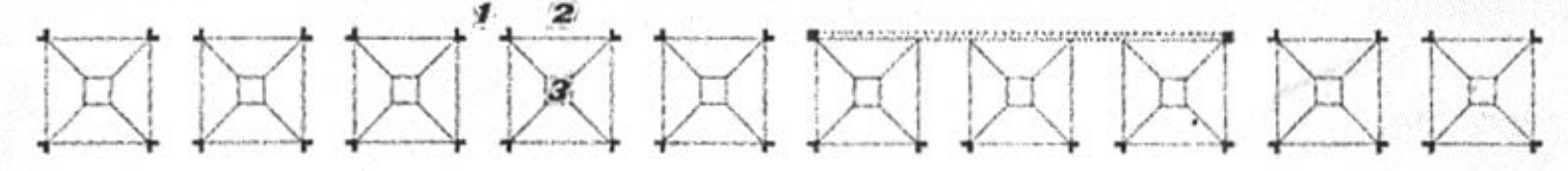

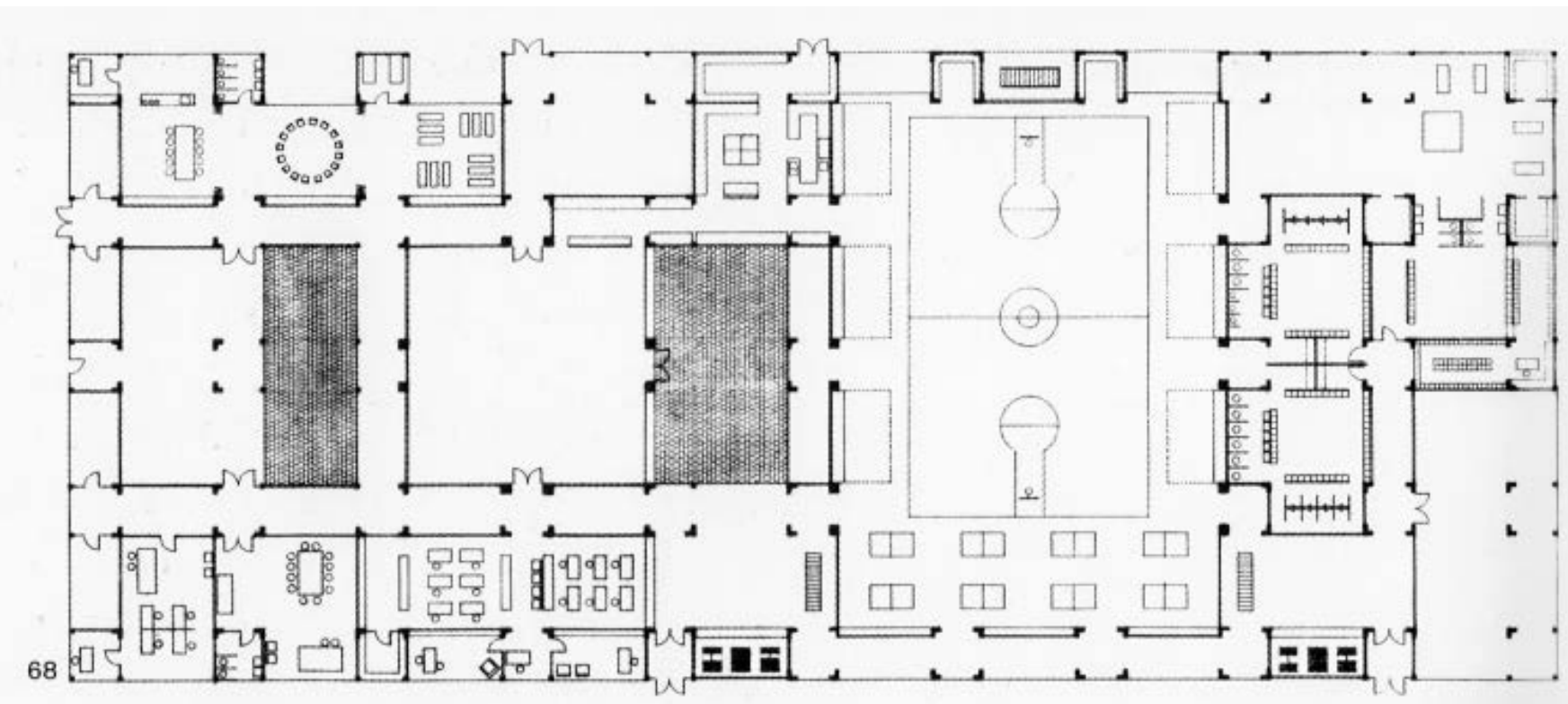


A edificação é constituída por cinco módulos quadrados de, aproximadamente, $9 \mathrm{~m}$ de lado, conforman uma cruz grega. ixas ortogona e, aproximadamente, 2,4m. 0 módulo quadrado central descoberto e os quatro módulos que formam as pontas da cruz possuem cobertura piramidal, construída em estrutura de madeira. A cumeeira superior das quatro faces da pirâmide é aberta e cria um domo zenital. 0 cruzamento das faixas ortogonais formam prismas retangulares de base quadrada, construídos em bloco de concreto aparente e cobertos por laje também em concreto aparente. Cada um dos prismas constitui uma base onde Kahn apoia as pirâmides. Mais do que "pilares", esses volumes são espaços que dâo apoio à função principal que se desenvolve sob a cobertura piramidal É importante assinalar que o vértice de ca da poio das cobertion cobertura de cada prisma, o que em planta corresponde ao centro do vazio da planta quadrada.
Ainda que, no nosso entendimento, a descrição acima demonstre certa abstração espacial desejada por Kahn

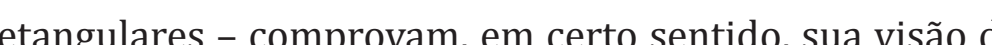
projeto como organização entre lugares intermediários ugares funcionais cuja identidade é decorrente do reconhe cimento de elementos construtivos qualificados, dentro da tradição histórica da arquitetura. Assim, podemos afirmar que, apesar do indiscutivel desempenho funcional eto, da racionalidade e da clareza como os materiais são empregados, a força da obra reside no reconhecimento da forma na maneira como ela se materializa e na diversidade espacial que sua repetição proporciona. A importância do referido reconhecimento se justifica não pelo emprego da figuração arquitetônica, não pela reproducão de estilos rquitetônicas consagrados historicamente, mas sim pela maneira como Kahn trabalha as referências formais do projeto na estruturação de espaç̧os, capacitando-os para dar sentido à construção

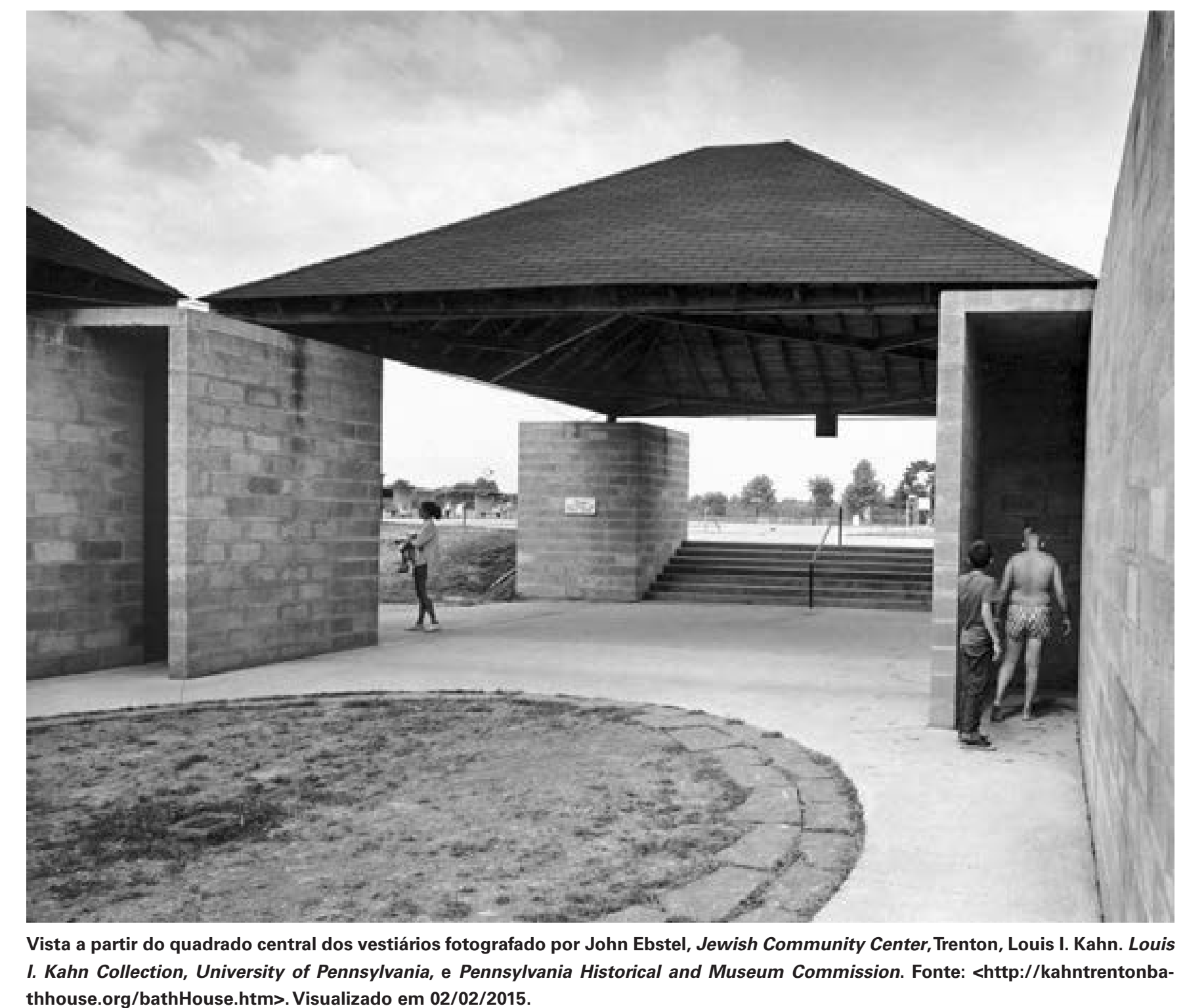


0 interesse de Louis Kahn pela relação da arqui政 seus contemporanneos, como nos lembra Jenn Lons Cons (2013:352), n reconhecidas na sua obra comprovam sua preocupação em promover a evolução da arquitetura sem, contudo, submeter sua expressão unicamente aos avanços tecnológicos da modernidade.

A visão sistêmica em relação à cidade, pensada na forma de um organismo que é gerado a partir dos seus fluxos, da sua energia, fica ainda mais clara em 1957 com o projeto de Louis Kahn para o Midtown Philadelphia. Seus conhecidos croquis e perspectivas reforçam a ideia lançada pela expressão gráfica e o raciocínio do projeto urbano é uma evolução natural da visão empregada por Kahn no Jewish Community Center em Trenton, New Jersey, como apresentamos. Os espaços funcionais - os edifícios - são envolvidos por uma malha tridimensional, uma infraestrutura que deve ser tão qualificada como os próprios edifícios funcionais. A forma arquitetônica é capaz de gerar a vitalidade da vida urbana em consonância com sua infraestrutura e partir dela. Portanto, é inapropriado considerar, como nos ensina Giulio Carlo Argan, que há na obra de Louis Kahn,

[...] uma indiferença em relação ao problema u banistico, a volta ao projeto "clássico" da form arquitetônica como entidade plástica autônoma. (ARGAN, 1993: p)

Ao contrário, Argan defende que, [a] arquitetura de Kahn possui, portanto, uma raefieto a metodologia do interprojetual) independente de modelos de racionalidade, tradur-se. assim na "especificidade semântiç" on na cocrência intrínseca de uma linguagem tipicamente arquitetônica, e apenas por extensão urbanística É uma posição talvez inconscientemente, poré inequivocamente fenomenológica, por elimin qualquer esquema espacial, funcional, estrutural a priori; todavia, o recurso a uma ideia formal originária não constitui absolutamente um arbítrio inventivo, porque nesse caso seria contrariado desmentido pela lógica do design que lhe dá desenvolvimento. É, afinal, a racionalidade que ñ̃o se justifica num postulado metafísico, mas se verifica na exequibilidade e viabilidade concreta forma. (ARGAN, 1993: 513-514: em itálico e aspas no texto original.

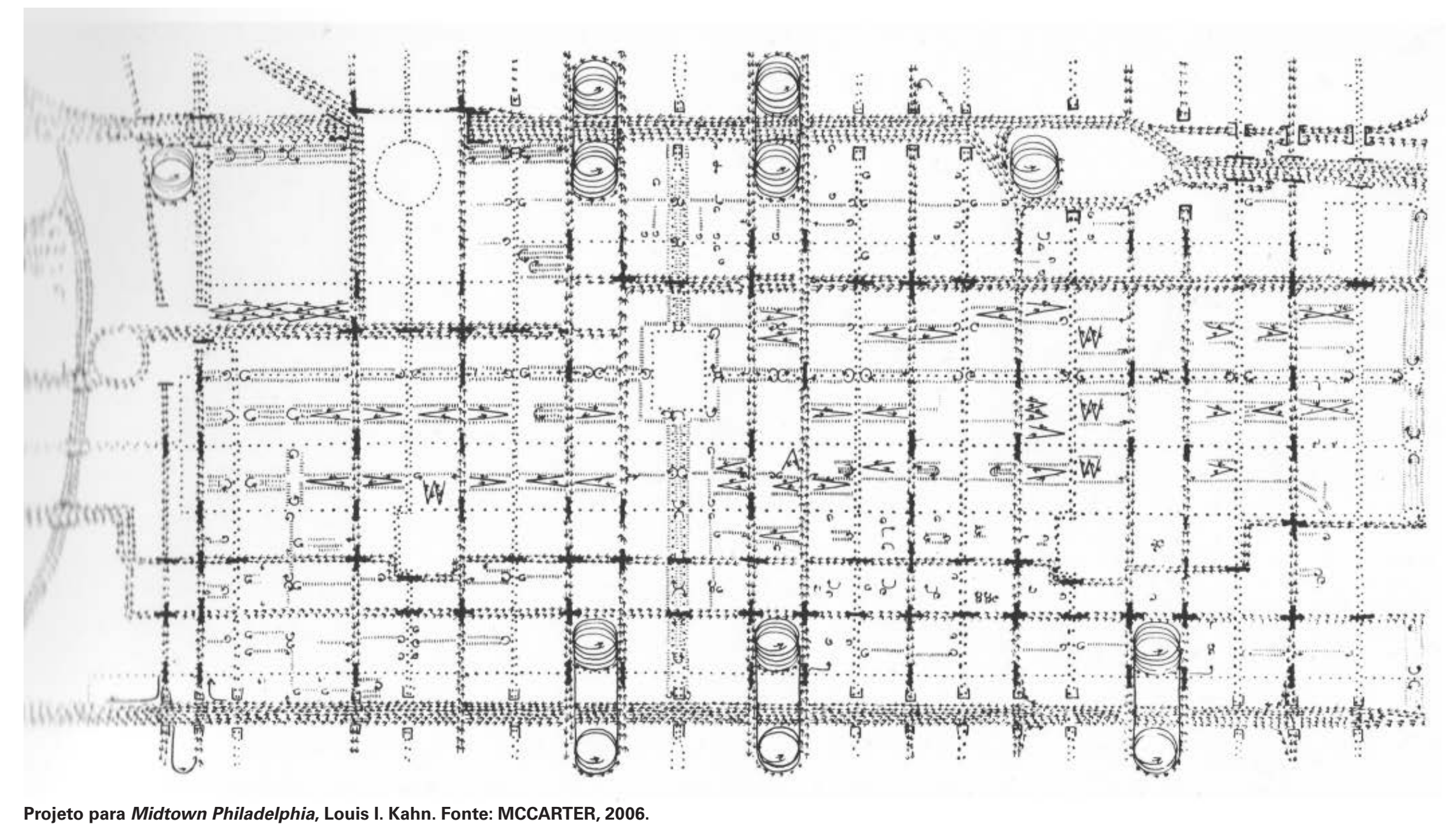

Nesse sentido, a eliminação inicial de qualquer esquema não impede seu surgimento como sistema no decorrer do seu desenvolvimento. A presença concreta da form reconhecida historicamente, "volta a ser convite e estímulo

à criatividade", como descrito por Argan (1993: 66). Ou seja, não há necessidade de um padrão inicial, pois ele surge durante o desenvolvimento do projeto como mediador do am biente construído potencializado por fluxos e conexões. 
Esse é um posicionamento que nos interessa pois auxilia a compreensão de parte significativa dos questionamentos críticos surgidos na década de 1950 em relação à arquitetura moderna, como os protagonizados pelo TEAM $\mathrm{X}^{244}$. Inicialmente por revelar com clareza e transparência o processo de projeto e a constituição de seus elementos construtivos, o que torna a obra de Kahn uma forte referência para os projetos brutalistas e, em seguida, pela organização sistêmica da arquitetura capaz de conceber um meio ambiente construído inspirador, como atestam as obras aqui estudadas e evidenciadas por Peter Smithson em sua obra Struttura Urbana (1967: 46), para quem Kahn foi único ao "criar, através da arquitetura, uma cidade reorganizada e revitalizada, sem nenhum daqueles velhos pretextos de alterar radicalmente 0 modo de vida das pesso $05^{\prime 245}$.

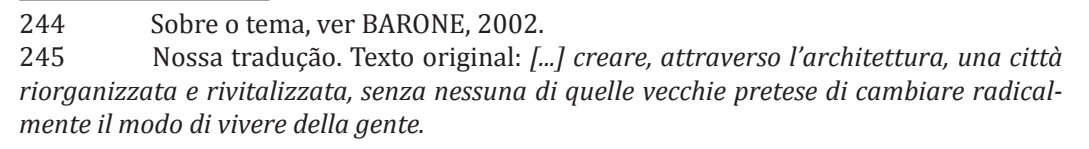

Ao discorrer sobre o processo de "discussão dos próprios projetos", promovido pelos arquitetos do TEAM X Ana Claudia Barone confirma as referências acima citadas pois, para arquitetos como Aldo van Eyck,

[...] a arquitetura precisava "reconciliar valores básicos", no sentido de superar polaridades conflituosas. Sua proposta estava no estabelecimento de uma arquitetura que desse conta dos espaços de transicăo, lugares onde as polaridades pudessem interagir. [.... A discussáo da arquitetura como configuraçao estruturada do espaço estava is Kahn em seus proitos Kapostas por Louva Kahn en seus projetos. Kahn tambem buscava uma ordenaçáo geometrica do espaço em sua arquitetura, como se intentasse gerar una nova confrutaçao para o mando a partir de estrutu-

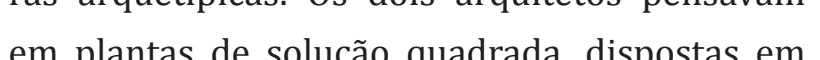

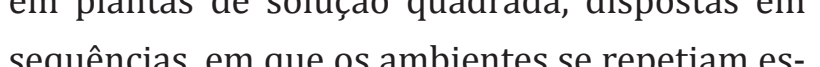
sequenclas, en que os ariam se sepetiam es-

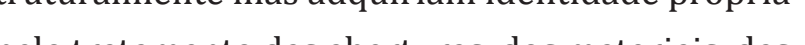
relaçōes com ambientes contíguos. (BARONE, 2002: 81-82) segundo os arquitetos do TEAM X, havia novidade na form de encadeá-los e que a "honestidade da linguagem do edifício em relação ao processo de concepção do projeto [foi] ideia emprestada de Louis Kahn". (BARONE, 2002: 134) A autora reforça em nota:

particularmente notável a influência das ideias e Kahn sobre os Smithsons [...]. O proprio Peter Smithson pensa em Kahn como um de seus mentores, como um dos precursores do brutalismo desenvolvido, nesse caso, pelo vazi de sua arquitetura, pelos materiais escolhidos. pela alusão ao sagrado e pelo mistério de sua formas. (BARONE, 2002: 134)
0 interesse dos arquitetos do TEAM $X$ pelo resgate dos fundamentos da arquitetura tornou-se um dos instrumentos para a crítica à hegemonia do espaço universal disseminado pela arquitetura moderna. Seria uma visã contemporânea do projeto, uma postura ética diante da realidade em que não haveria apriorismos, e sim diagramas específicos inventados por cada projeto, como defendido por Josep Maria Montaner, para quem

[0] interessante desses sistemas de projetos abertos e evolutivos é o fato de somarem-se à capacidade criativa das formas geométricas todas as cidade criativa das formas geometricicas todas as
contribuiçōes quantitativas e estatísticas de discontribuiçoes quantitativas e estatisticas de dis-
ciplinas que utilizam dados em série, a sociologia ciplinas que utilizam dados em serie, a sociologia
a antropologia, a história ou a ciência. Ou seja, na a antropologia, a história ou a ciência. Ou seja, na
arquitetura de diagramas a informação sobre a vida humana é vista como uma estrutura básica que vai sendo convertida em formas; as energias físicas são sintetizadas a partir das energias sociais. (MONTANER, 2017: 24) 


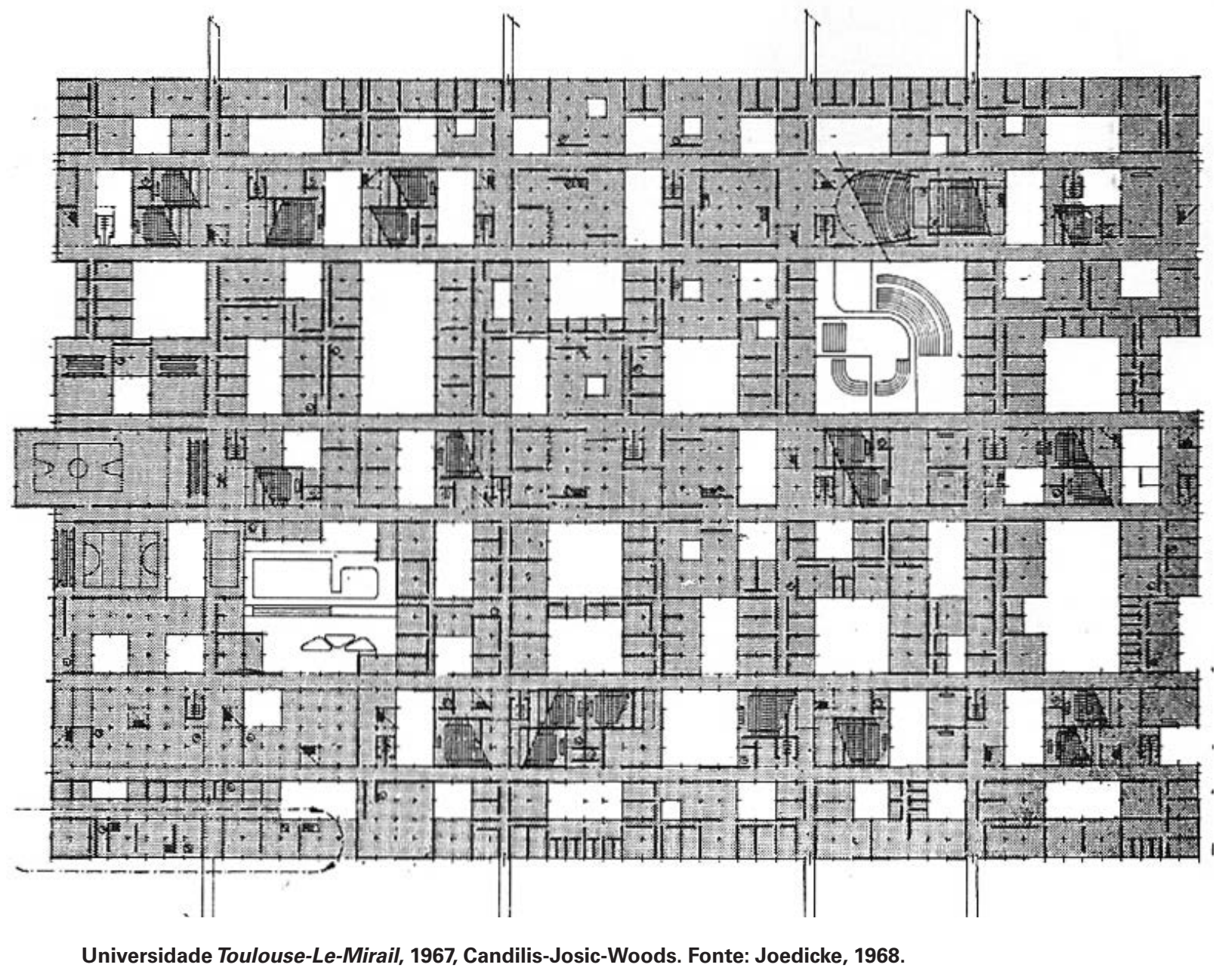

Ao chegarmos nesse ponto, encontramos o raciocínio segundo o qual as estratégias de projeto ampliam espaço para a incor na, sen contudo abandonar sua condiç̃o ordenadora. A arquitetura assume independência sem ser autônoma, ou seja, o projeto elabora sistemas baseados no conhecimento arquitetônico, como observamos na obra de Louis Kahn capazes de construir ambientes em que outras disciplinas programa definitivo. Assim, como proposto pelos arquitetos do TEAM X, as possibilidades de revisão após a ocupação da obra ou sua própria evolução em função de novas demandas podem ser introduzidas sem que os fundamentos do projeto sejam abandonados e, sim, aprimorados. 0 perpora o tempo como dimensão do programa aproximando o tempo histórico, segundo Kahn, do tempo futuro, segundo o TEAM $X$.
Antes de discutirmos com maior profundidade o projeto e a noção do tempo como dimensão do program faz-se necessário examinar o trabalho dos unsideramos introdutória do posicionamento da arquitetura do grupo perante à cidade: a Hunstanton Secondary Modern School, de Alison e Peter Smithson, projetada em 1950 para Norfolk, no Reino Unido. 


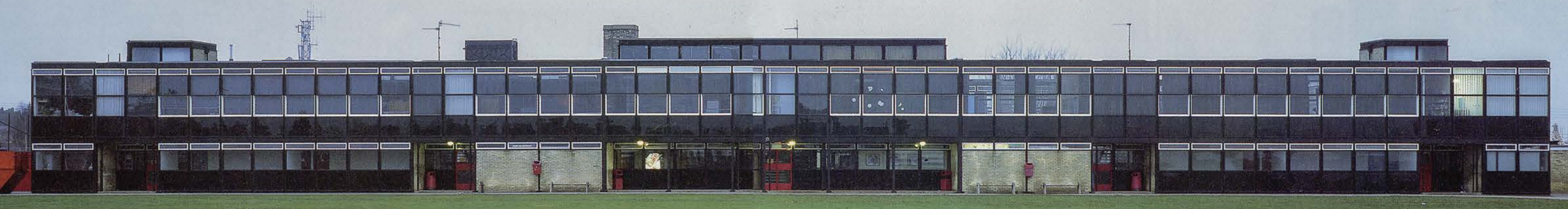


É importante perceber, no entanto, apesar do manifesto do Team X fazer oposiçáo à teoria urba acionalista do próprio Le Corbusier, seus dese nhos foram parte da inspiraçãao para o grupo. Issto foi particularmente verdadeiro em relaçào a Smithsons e a George Candilis (1913-95), Alexis losic (b.1921) e Shadrac Woods (1923-73) (que fizeram parte da equipe do projeto da Unité $d^{\prime} H-$ bitation de Marseille.[....] De acordo com os Smittsons, a infraestrutura deve mais do que facilitar a formação espontânea da comunidade - ela deve dar "coerência” à estrutura urbana: “O objetivo do urbanismo é a compreensibilidade, a clareza organização." Com isso, eles pareciam reconhece que havia uma lacuna entre a associação human espontânea e sua representação formal. Para Smithsons, no entanto, esse problema pode ser superado por meio de uma estratégia de planeja mento dualista que desenvolveu "vias e sistem de comunicaçãao como a infraestrutura urbana [usando] as possibilidiades oferecidas pela tecnlogia "descartavel" para criar um novo tipo de anbiente com diferentes ciclos de mudanç̧a para as
diferentes funções". COLQUHOUN, $2002^{246}$
Em sua conhecida obra, Modern Architecture, Alan Colquhoun percorre um interessante caminho para o enendimento do projeto baseado em megaestruturas $\mathrm{s}^{247}$. Ele demonstra que o início desse percurso parte das visões urbanas de Le Corbusier, comprovado pelo envolvimento $\mathrm{d}$ parte dos arquitetos do TEAM X com projetos fundamen-

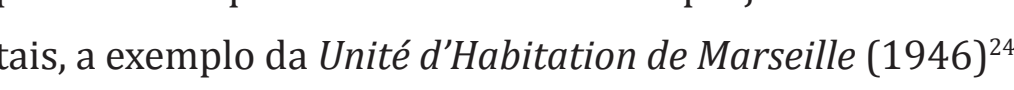
equipamento repetido como modelo, que, em certo sentido, sintetiza a visão urbana do mestre suíço, segundo Nuno Portas (1965: 31).

Como vimos até aqui, os fundamentos do projeto egundo Louis Kahn foram substancialmente decisivos na formulação da crítica à modernidade empreendida pelos arquitetos do TEAM X nas décadas de 1950 e 1960.0 exame de projetos como o Jewish Community Center en Trenton e o Midtown Philadelphia revelou a maneira pela qual o trabalho de Kahn fundamentou o discurso defendido pelos arquitetos do grupo e debatido desde então pela própria historiografia.

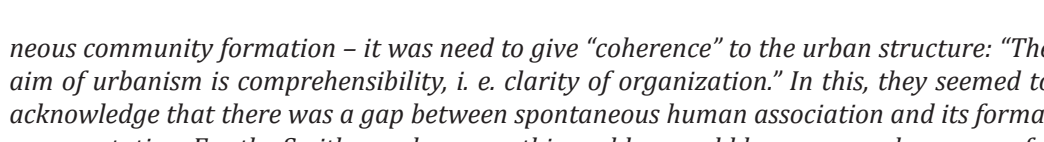

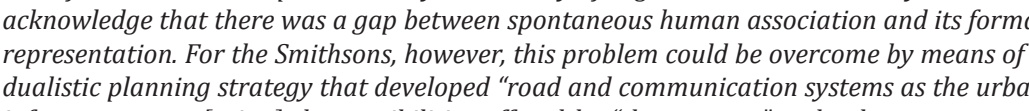

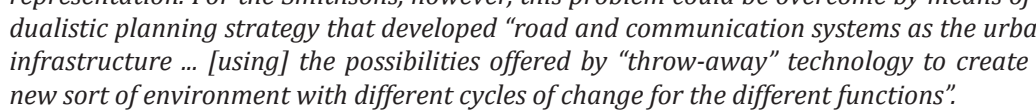
247 Ver também: Megasstructure: urban futurues of the recent past. Reyner Ba

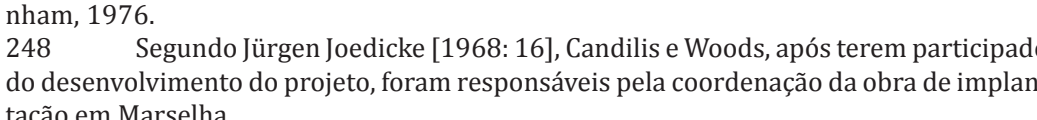

Além disso, a oposição acima citada por Coulqhoum referente à teoria urbana racionalista de Le Corbusier, re força o distanciamento crítico assumido pelo grupo, sem no entanto, romper com os fundamentos do projeto corbusiano. Assim, podemos admitir que o trabalho de parte do arquitetos do grupo, ao promover o questionamento das doutrinas racionalistas defendidas pela arquitetura moderna, aproximou visões distintas do projeto de Louis Kahn são dos elementos construtivos, baseada na aparência natural e na clareza no emprego dos materiais, os arquitetos do TEAM X apontaram para a retomada de um caminho que será amplamente reconhecido na década seguinte, o Brutalismo, agora distanciando-se dos valores estéticos dos materiais e apoinndo-se no significado ético que tal postura vem agregar ao projeto.

Uma das primeiras obras a se expressar segundo a visão do projeto como ambiente construído por elementos cuja aparência é o resultado de sua constituição natural fo a Hunstanton Secondary Modern School, de Alison e Peter Smithson, projetada em 1950 para a cidade de Norfolk, no
Reino Unido. Vencedor de concurso promovido pelo programa de reconstrução do Reino Unido após a Segunda Grande Guerra, o projeto modificou o modelo da arquitetura oficial de inspiração vitoriana ao introduzir os preceitos da modernidade para um equipamento escolar.

Como admite Keneth Frampton ${ }^{24}$, a obra não foi devidamente valorizada por ele, apesar de sua notável "poética da construção". 0 emprego da estrutura metálica aproxima a obra do trabalho desenvolvido por Mies van der Hohe para o campus do Illinois Institute of Technology (IIT- Chicago), em especial em edifícios como o Alumni Memorial Hall de $1945^{250}$. Entretanto, como lembra Frampton, a vontad obsessiva de expor a estética industrial dos elementos metálicos, das tubulaç̃oes aparentes e do tratamento bruto dos materiais "rompe radicalmente com o que Mies poderia ter imaginado".

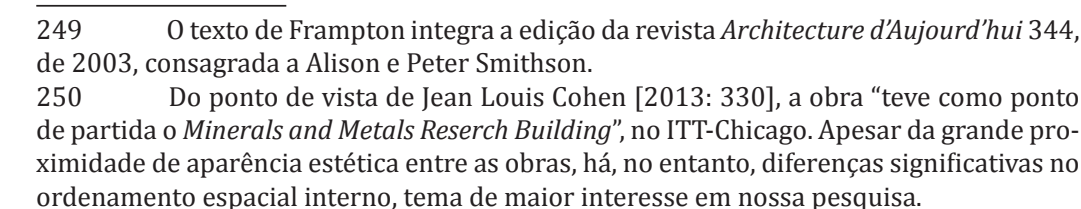




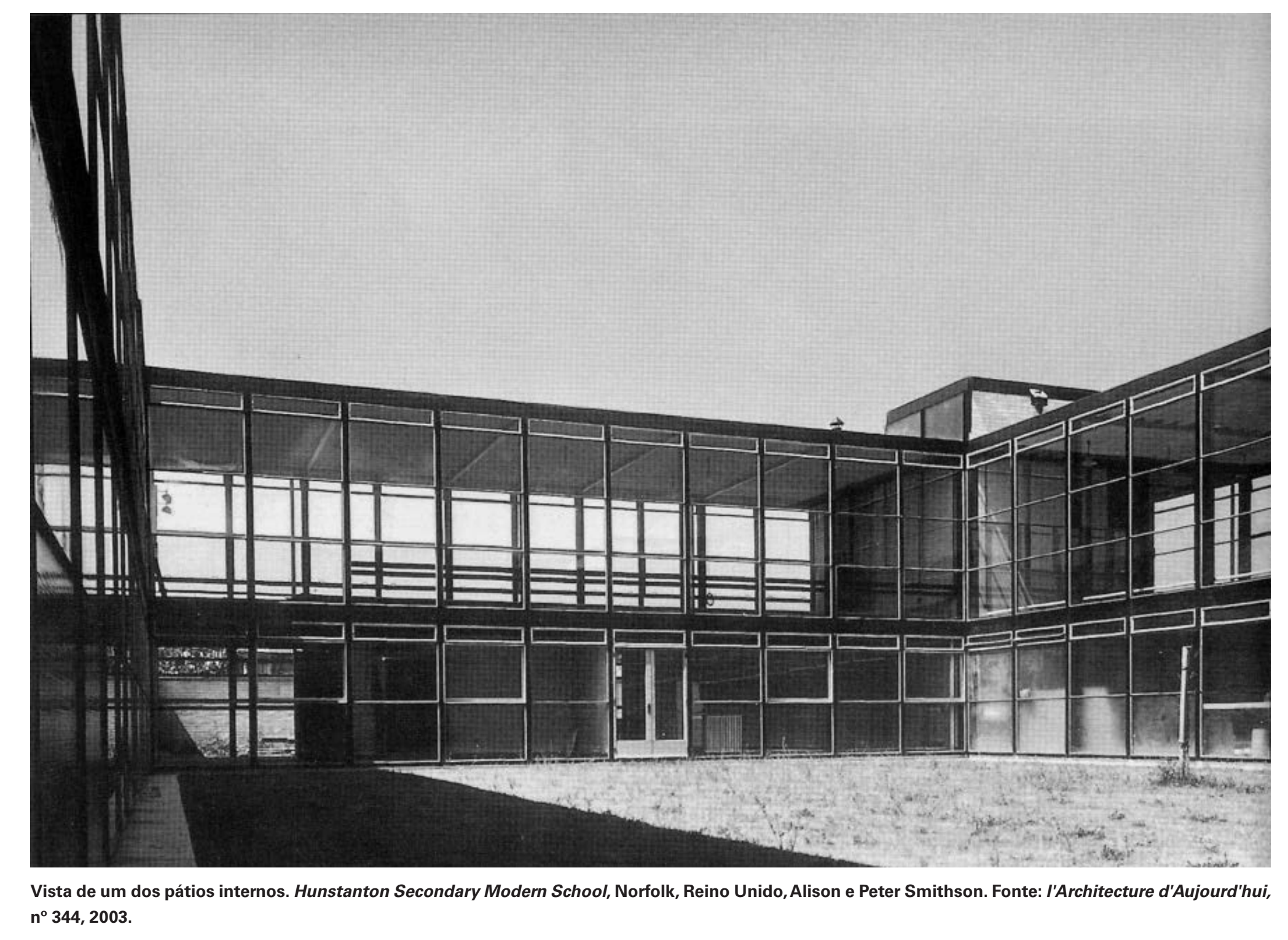

Vale destacar que, ao examinarmos os elementos construtivos da Hunstanton Secondary Modern School, encontramos grande Mies no que se le eaveris memorial Hall, e também às não construidas, como a Bblioteca e a Administração do ITT. Em relacão à primeira a referência está explíita na associação dos materiais que conformam os vol Da seeunda obra $a^{251}$, Dese imponente pátio de luz que alter

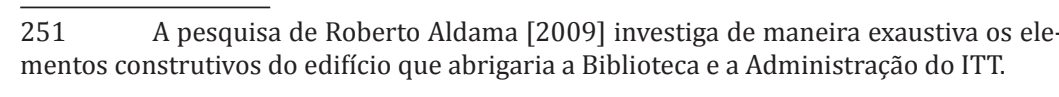

toda a lógica do espaço universal miesiano, algo que os Smithsons realizam de maneira extensiva em Hunstanton.

No nosso entendimento, o caminho para a compreensão do projeto proposto naquele momento pelos Smithsons passa obrigatoriamente pelo exame dos aspectos citados acima. Ou seja, se os Smithsons ressaltam o romp mento com o "maneirismo miesiano" 252 , o que evidenciou o estado bruto dos materiais e dos elementos construtivo como valor ético e estético da obra, a associação de espaços indeterminados com os espaços funcionais exigidos pelo programa definiu a obra como um novo padrão de equipamento, segundo os próprios arquitetos.

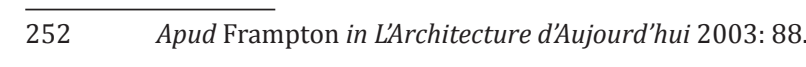



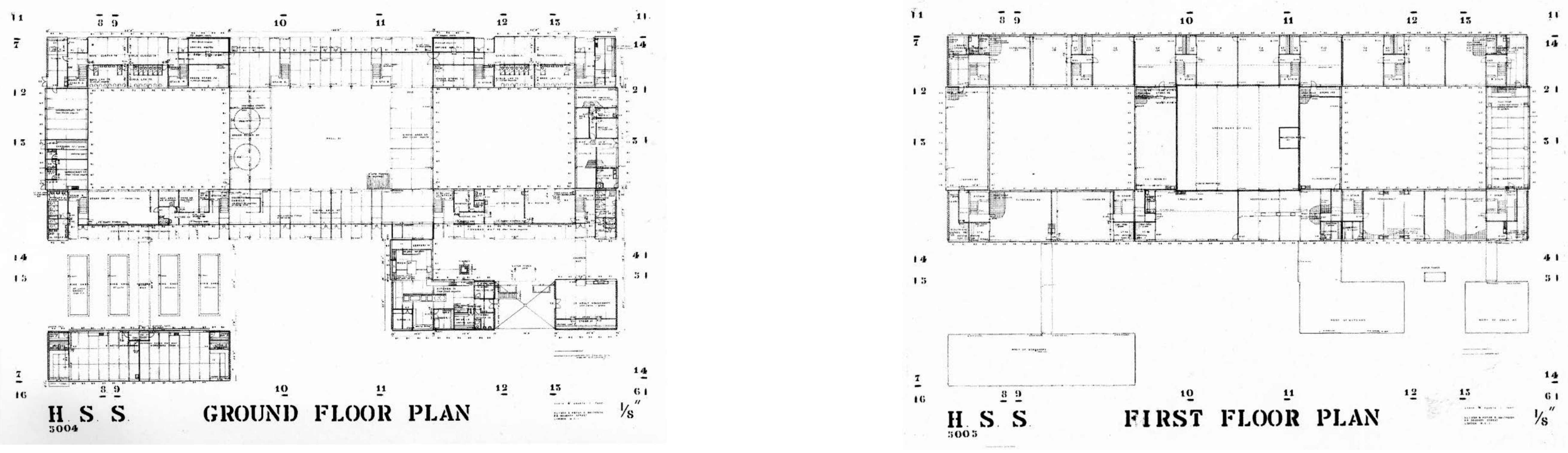

Pvimento téreo 


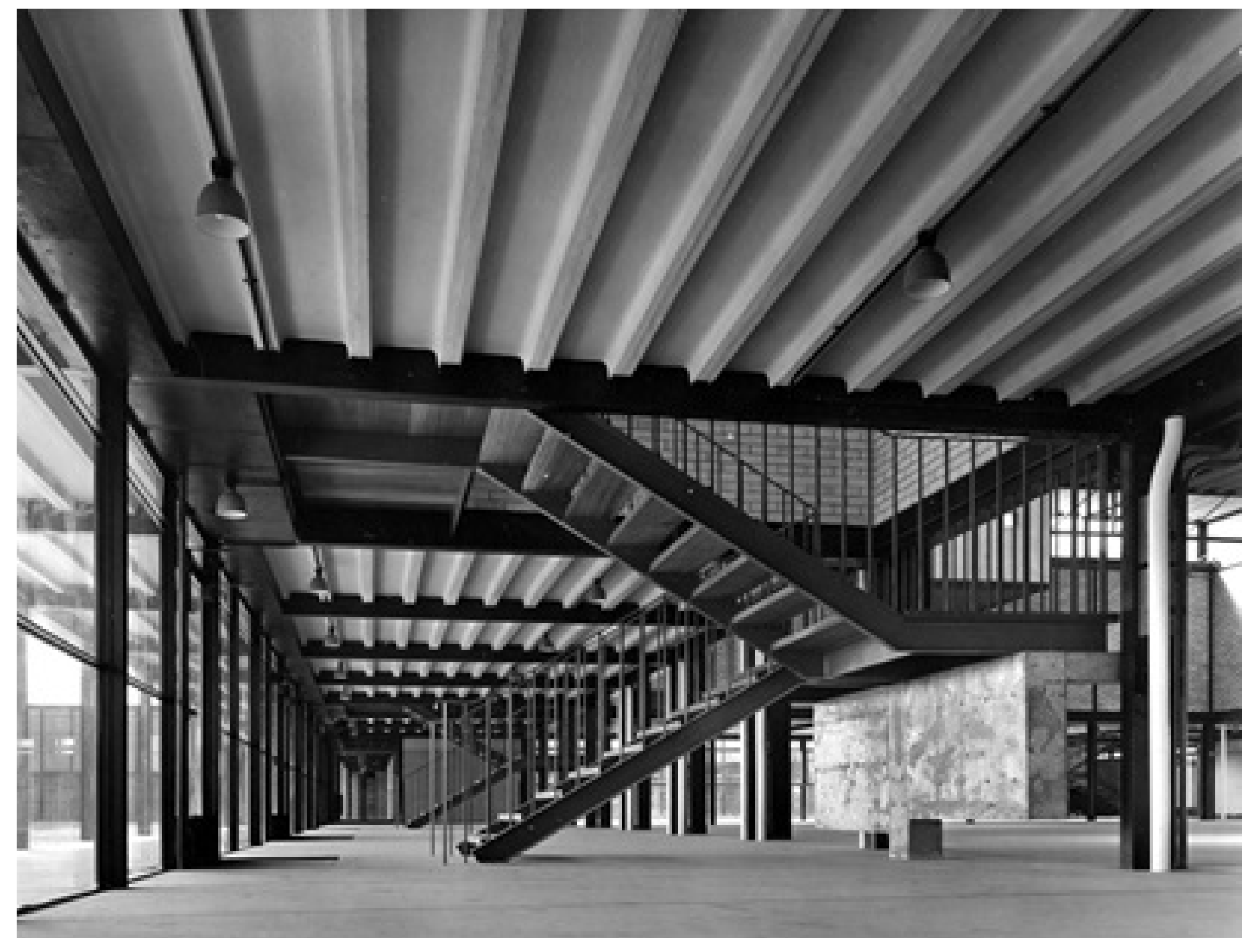

Sequência de escadas de acesso ao pavimento superior. Hunstanton Secondary Moderer School, Norfollk, Reino Uni-
A Hunstanton Secondary Modern School é definida são distribuídos os principais ambientes do programa - salas de aula e laboratórios - ocupando um retângulo de 30m de largura por $90 \mathrm{~m}$ de comprimento. Outros dois prismas retangulares vêm se acoplar à edificação principal, como satélites, onde são implantadas, no primeiro e mais próxmo, acoring do refotón mo, a cozinha do efertio, e no segundoum pouco mais distante, as oficinas de marcenaria e de serralheria. Um terceira edificação também de planta retangular abriga as atividades esportivas da escola, completando o conjunto. Todas as edificações obedecem à orientação leste-oeste.

Podemos verificar a condiç̃o acima citado ao obser-

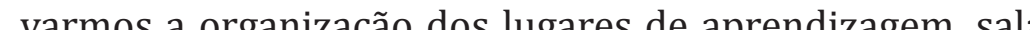

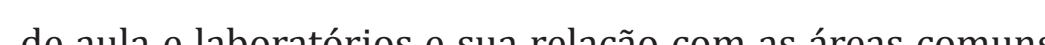
os espaços de convivência cobertos e descobertos, além dos acessos, todos distribuídos no pavimento térreo. Salas de aula e laboratórios ocupam a totalidade do pavimento su- perior, onde os arquitetos os dispuseram em conjunto de dois ambientes, servidos diretamente por uma escada, elminando corredores entre eles. Essa orgnizaço traz benefícios dos ambientes, proporcionando farta iluminação natural, o que seria extremamente importante para o ambiente de aprendizagem ${ }^{253}$. Por outro lado, a multiplicação de escadas obriga a passagem de todo o público - alunos, professores e funcionários - pelo pavimento térreo, para se servir das áreas de apoio, como sanitários, refeitório e áreas de convivência, e, principalmente, para ir de uma sala de aula até um laborațio, por exemplo Assim, o chão torna-se um plataforma em que todos obrigatoriamente estarão em algum momento da vida escolar. Ou seja, parte significativa en certo sentido, em plataforma de conexão de atividades, lugar de convergência pronto para oferecer novas possibilidades de uso.

A variação longitudinal das alturas internas livres reforça a configuração acima citada. Entre as alas que con- 

0 primeiro, onde estão os acessos no centro da edificação coberto por sheds com dupla or

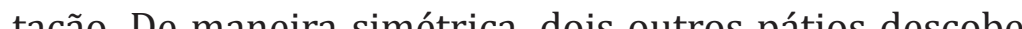

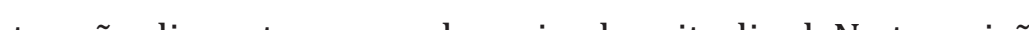
entre o coberto e o descoberto, a altura livre é reduzida conformando o que podemos chamar de varanda interna. Esse conjunto de espaços é limitado a leste e a oeste pelos apoios, completando o ground floor.

Seis escadas dividena al longtedinat note em inco conjuntos duplos de sals de aly do paunentosuper Outras quatro escadas dividem a ala longitudinal sul em três conjuntos duplos de salas maiores que podem receber laboratórios ou ateliês de artes, por exemplo. Quatro alas perpendiculares às alas norte e sul completam a implantação retangular configurando os pátios internos acima descritos. Éclaro o esfoço dos Snithsons pra Éch dos ambientes de aprendizagem do pavimento superior ao longo de um corredor de passagem, o que seria uma solução convencional. No nosso entendimento, ao vinculá-los diretamente à plataforma do térreo, o projeto desfaz o aparente isolamento dos ambientes de aprendizagem e transono chão em espaço de convergência
Assim, desfaz-se também a noção do pilotis totalmente aberto e diretamente vinculado às áreas verdes, que fundamenta sons, o chão desempen tal na medida em que consolida o sistema elaborado pelo projeto e potencializa a função primordial do ambiente escolar: promover o intercâmbio do conhecimento.

conhecida importância da obra pela exposição dos entes em seu estado bruto é sem dúvida responśível por lismo Por oulto bdo, vale destar que a noço sistenta poderia estar restrita à padronização de componentes industrializados e à coordenação modular do projeto, o que não seria suficiente, no nosso entendimento, para tornar a Hunstanton School uma obra de referência. Cabe acrescen$\operatorname{tar}$ que o p pelos a ruletos do TEAM $X$, matering por dos dos seus principais integrantes - Alison e Peter Smithson em que a construção, baseada em sistemas orgânicos e ins pirados historicamente nas cidades tradicionais, seria capaz de enfrentar a condição urbana moderna ao constituir sistemas adaptáveis e evolutivos, como veremos a seguir. 


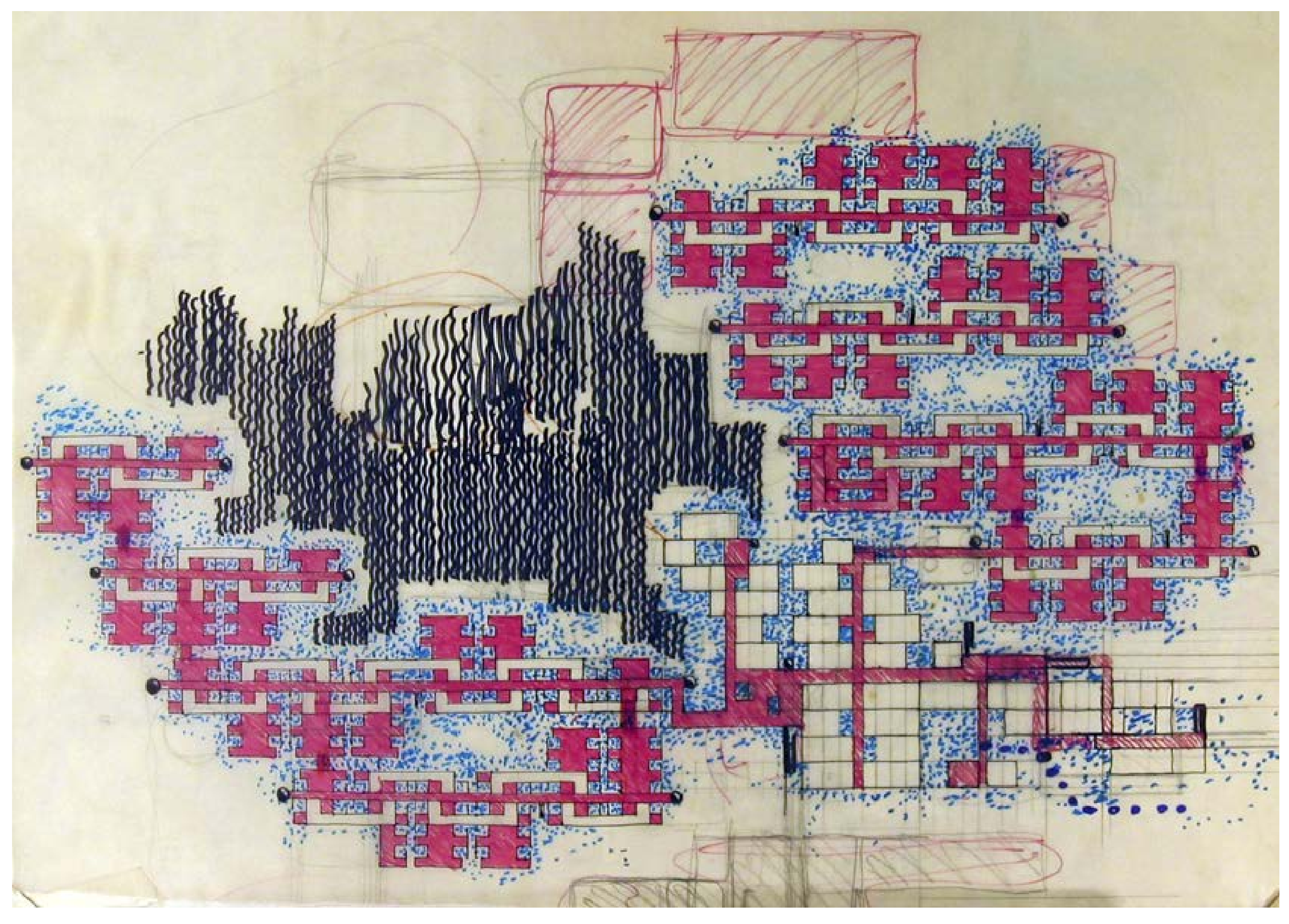

A WEB segundo Candilis - Josic - Woods

anto na arquitetura quanto nos filmes há a ideia o ponto de partida, o de chegada, e as revelaçõe não estão no final dramático, mas no percurso lirico das descobertas intermediárias. Antonion trata a imagem como protagonista, inova ao requalificar fundo e figura, forma e conteúdo, rotelro e cenário.

FURTADO, 2016

O paralelo descrito acima por Claudio Furtado en0 p nione, ilustra a visão do projeto perante a cidade, especialmente protagonizada pelo debate crítico à modernidad mpreendido pelos arquitetos do TEAM X, como vimos at 作 0 que Furtado confirma em sua análise é 0 enten mento da cidade muito mais como a construção de um meio mbiente do que a de um cenário. 0 "percurso lírico das descobertas" não encontra apenas "fundo e figura", pois no inema de Antonione, assim como na arquitetura, podemo dizer que a cidade é roteiro e personagem. Não por acaso tais cenario, roteiro e personagem referem-se a Londres de racterizaram do contras question

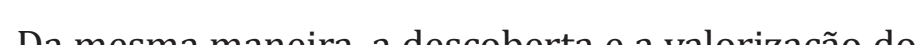

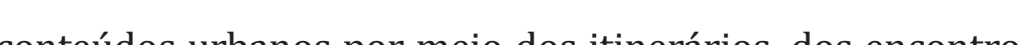
e desencontros e da energia cultural urbana, estão nas bases do projeto segundo a visão de Shadrach Woods, que teorizo parte significativa das experiências desenvolvidas e discutidas pelo TEAM X durante os diversos CIAM255 ocorridos na década de $1950^{256}$. Um de seus textos fundamentais, WEB publicado em 1962 no periódico Le Carré Bleu ${ }^{257}$, antecede a elaboração de importantes projetos de equipamentos ins titucionais em que a visão de Candilis-Josic-Woods é posta à prova ${ }^{258}$. Tais projetos são verdadeiras estruturas urbanas que, em última instância, devem gerar cidade, devem promo-

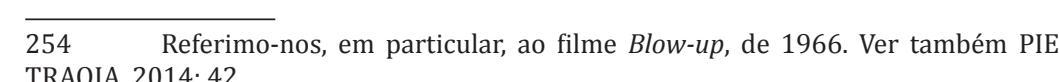

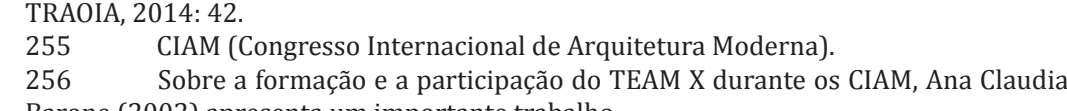

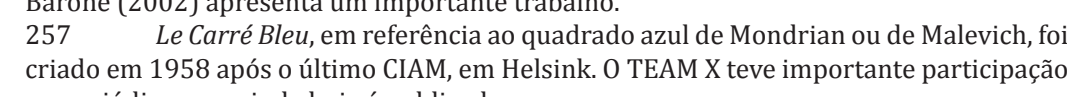

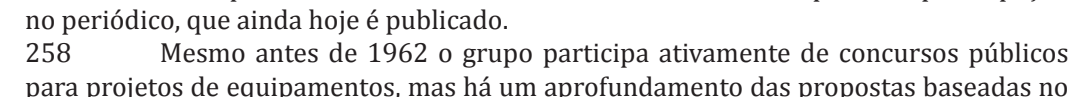

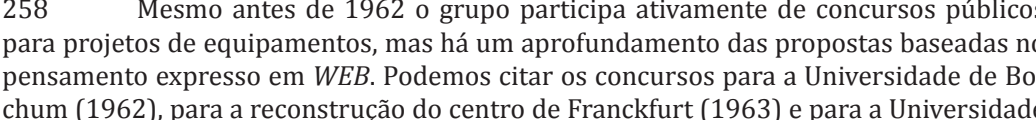

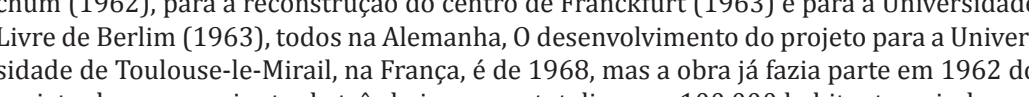

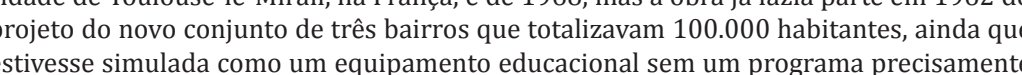


ver a aproximação de funções e de pessoas.

Na visão de Woods, a separação e a hierarquia funcionais seriam um dos fatores negativos da cidade modern funcionalista, e, portanto, deveriam ser superadas por un sistema cuja capacidade de interposição de atividades proporcionaria a verdadeira vitalidade urbana $a^{259}$. Mais do que um resgate da cidade tradicional, cuja inspiração é celebrada pelos membros do grupo, WEB propõe a construcão um novo ambien evoluir, de se adaptar e, sobretudo, de enfrentar realidades ainda desconhecidas. A analogia com a WEB no sentido de teia, que se estrutura através do entrelaçar de suas linhas, não é casual, pois o autor insiste na consistência que o sistema deve apresentar. Ao considerar o tempo como fundamento - a “quarta dimennão do projeto", segundo Woods, a arquitetura do equipamento urbano e, por consequência a arquitetura da cidade aproximam-se de uma obra aberta, sem contudo, deixar de oferecer um "urdimento $0^{260 "}$ urbano consistente, como podemos observar nas palavras do próprio Shadrach Woods:

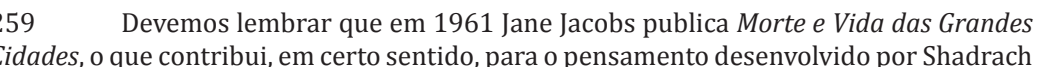

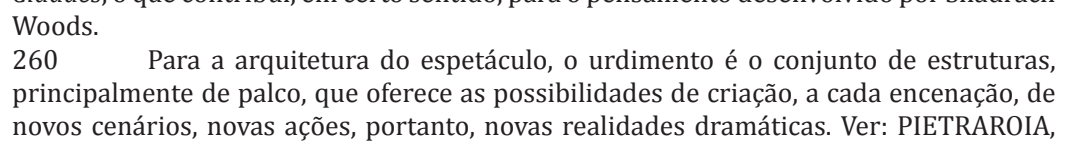

Em uma organização, a ideia de continuidade (indispensável para que nenhum de seus elementos se dissociem nem se tornem passivos ante a uma super-densificaçẵo) é essencial pał que criemos sistemas que possam ser adaptados a uma sociedade em evolução visando o universal. As redes de relações e de circulações devem ser contínuas, ććlicas e direcionadas ao hituais três dit ditemas não se limitaráa às habituais três dimensōes, eles terão igualmente . Ma din cialmente sist

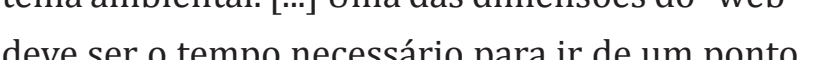
e outro "..... . . medida dr distancia eo tempo. [...]

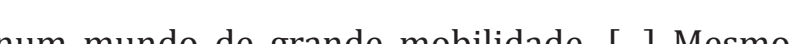
ro caso en que a prinera fise de un phos realizada, ela modficara as conderes que de-

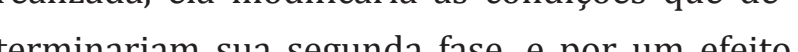

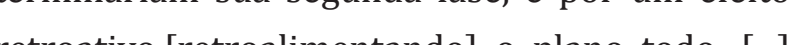

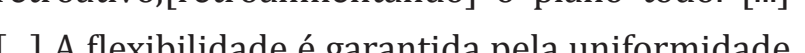

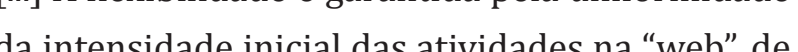

maneira que possa ser conectada a qualquer ponto, e que possa, ela mesma, interligar-se aos (Wtemas mais importantes em qualquer lugar. ${ }^{20}$ (WOODS, 1962: 2-4)

Sem dúvida, os conceitos defendidos no texto Web são fundamentais, no entanto, o que nos interessa nesse momento é entender como os questionamentos promovidos pelo TEAM X foram materializados em seus projetos ou seja, como o posicionamento crítico se refletiu na arquique compunham o grupo. Poderemos, assim, identificar projeto como enfrentamento do tempo muito mais por um independência estruturadora do que por uma suposta autonomia disciplinar, pois a única constante seria a mudança. Admitindo

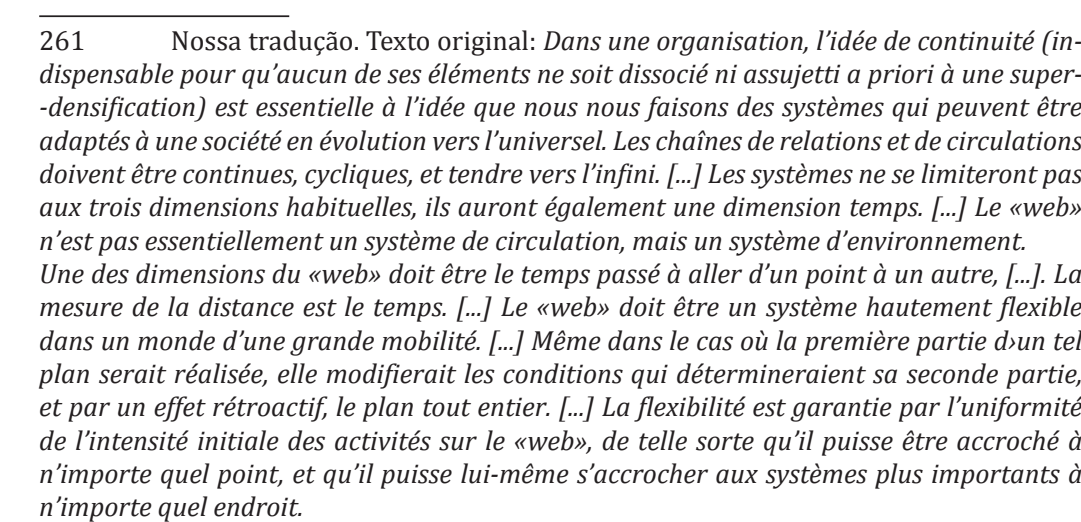


Do cluster ao stem e do stem ao web: a arquitetura do groundscraper$$
\text { como articulação }
$$

A crítica ao zoneamento funcionalista da cidade moderna foi promovida pelos arquitetos do TEAM X por meio de projetos que se apoiavam na noção de articulação como estratégia. Foi seguindo a lógica da articulação em diversos níveis que a arquitetura de dada na putict dada na publicação de Jurgen Joedicke (1968), que se fundamentou em textos descritivos e em legendas do próprio Shadrach Woods. Assim para a compreensão da obra do grupo não foi usada a organização cronológica, geográfica ou temática, como é feito convencionalmente. Os projetos foram agrupados como articulados das funç̃es (deter(inadas e não detern ninadas e não determinadas), dos limites espaciais (funcões diversas dos elementos construtivos), dos volumes (de sistemas e estruturas geométricas) e, principalmente, dos domínios públicos e privados, que seriam resultantes de sistemas e estruturas "orgânicas".
0 trabalho de Candilis-Josic-Woods não abandona a noç̃o de cluster - agrupamento - defendida pelo TEAM X. 0 agrupamento de comunidades ou de atividades com características próximas permanece fundamental para resgatar a identidade como valor do projeto. Entretanto, para que articulac̃o entre os domínios públicos e privados desses agrupamentos se concretizasse, foram propostos centros lineares de mobilidade, chamados de stem, verdadeiros troncos ou espinhas dorsais dotados de infraestrutura de comunicação e de mobilidade - mais uma ideia de forte intenção estruturadora em torno da qual os clusters podiam se conectar e se relacionar.

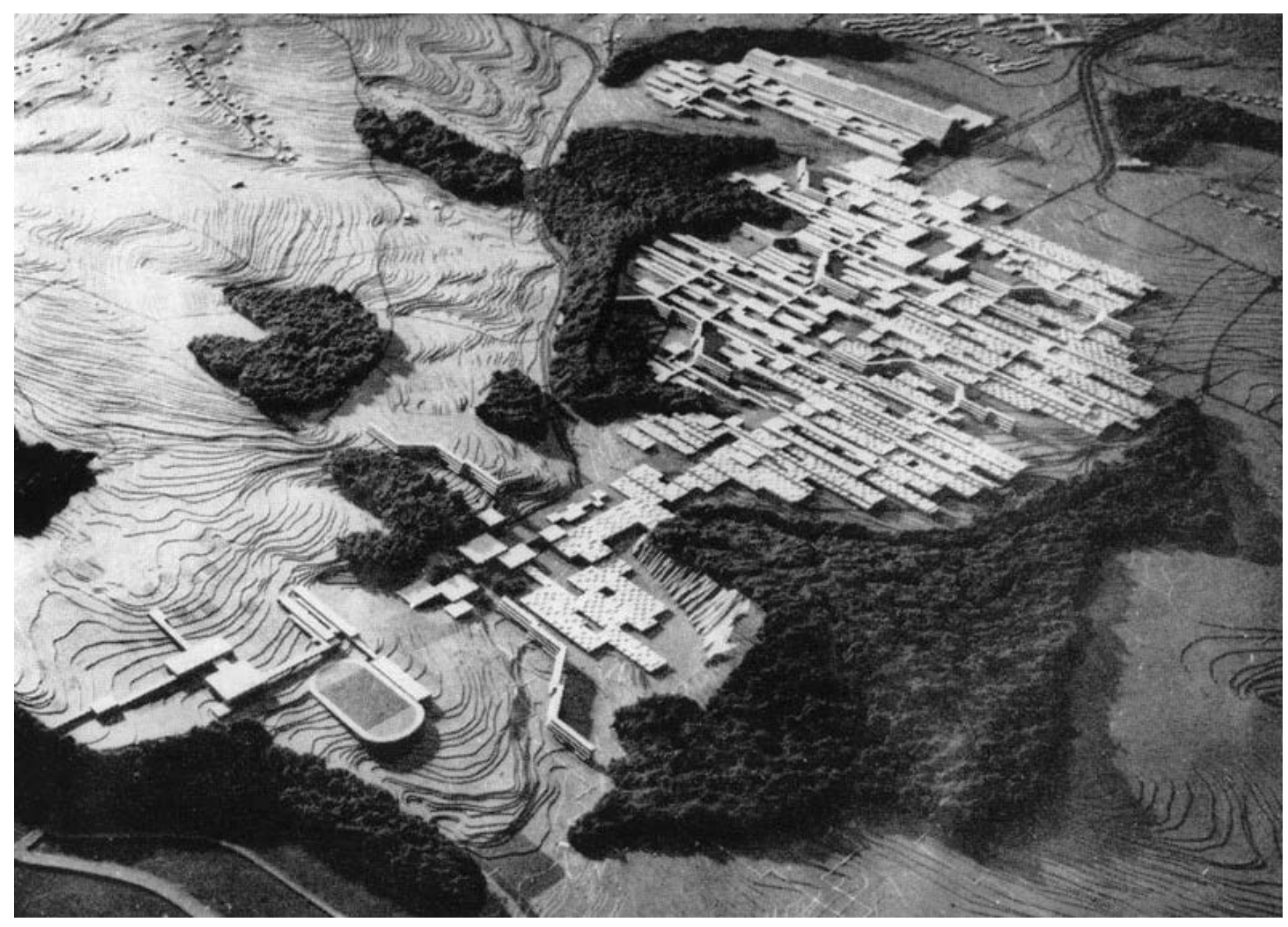

Concurso para o projeto da Universidadede de Bochum, Alemanha, Candilis-Josic-Woods, 1962. Fonte: Arquivo da Cité de IÁrchitecture \& du Patrr- 


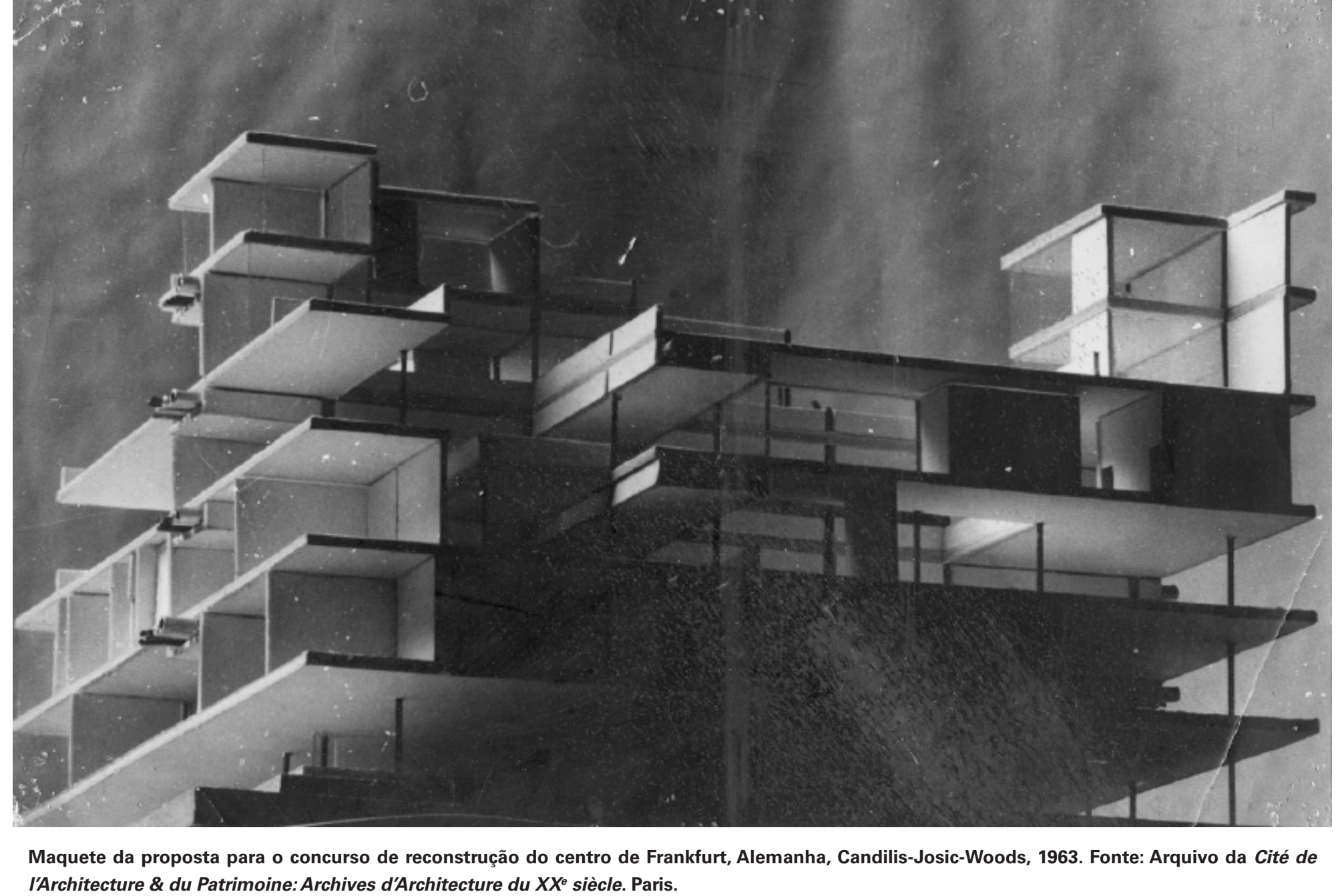

Utilizando o raciocínio do stem, os arquitetos participam do concurso para a Universidade de Bochum, na Alemanha, em 1962. Como pode ser observado na imagem da maquete, os agrupamentos que caracterizam cada unidade a dide

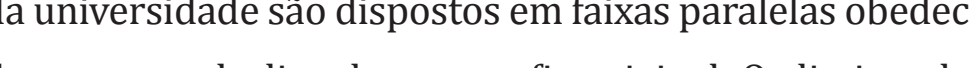
do ao suave declive da topografia original. Os limites dess paralelismo não são totalmente rígidos, permitindo diferen列 cimento independente de cada um deles. A interligação en- se desenvolve na paisagem, o que contribui para descaracterizá-lo como eixo de simetria. Entre ele e os agrupamentos estão dispostos os equ tam o programa da universidade, como sanitários, auditórios e refeitório, que são, assim, compartilhados.

pós a publicação de Web, os projetos de Candilis-Josic-Woods ampliam a noção de stem pela necessidade de responder a programas de maior complexidade. No concurso para a reconstrucão do centro de Franckfurt na Alema

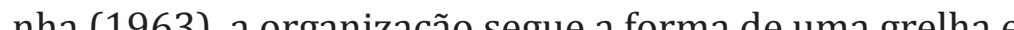
diversos ivers podndo se desevover en tés dru incorporando ainda um quarto componente, o tempo, chamado por Woods de a quarta dimensão.

Aforca do projeto reside na possibilidade de articuda Segund Gande Guerta con o que restou da cid da seguta Ga Gade com seu ambiente natural representado pelo rio Main. Vale destacar que estaria nesse sistema urbano o caminho para a materialização de um novo "urdimento", capaz de devoltre os agrupamentos é feita por um caminho transversal ao conjunto, cuja variabilidade dimensional e de escala são características que permitem a diversidade de espaços a serem apropriados pela comunidade. Esse tronco ou espinha dorsal vai se configurando como rua, praça e terraço à medida que
As plantas e maquetes demonstram como a aparente rigidez da estrutura de mobilidade e da infraestrutura ç̃os urbanas são incorporadas. Em certo sentido, a orga nização inicialmente diagramática incorpora as feições $d$ cidade histórica, ainda que os critérios racionais da modernidade sejam empregados para a materialização do concelto. Não se trata, portanto, de reproduzir o cenário histórico introduc̃ão de um modelo universal de modernidade baseado no zoneamento funcional. 0 funcionalismo é empregado muito mais como método do que como objetivo estético. A proposta não parte da ruptura mas sim do esforço de articular e de aproximar lugares consagrados historicamente com novas atividades ainda pouco definidas. 

do centro de Frankfurt em 1963, os arquitetos aplicaram a proposta sistêmica da grelha de mobilidade e infraestrutudurante a década de 1960

Dentro desse grupo de projetos em que Candilis-Josc-Woods repetiram e aperfeiçoaram o padrão chamado por eles de Web, diversos enfrentaram o tema do equipamento publico educacional, entre eles a Universidade Livre de Berlim, Alemanha (1963), a Universidade de Zurique Suíca (1965), a Universidade de Madri, Espanha (1966), a Universidade de Toulouse-le-Mirail, França (1968), a Universidade de Bruxelas, Bélgica (1969).

A equipe repete a visão sistêmica do projeto pela resença da grelha que organiza o programa através de un

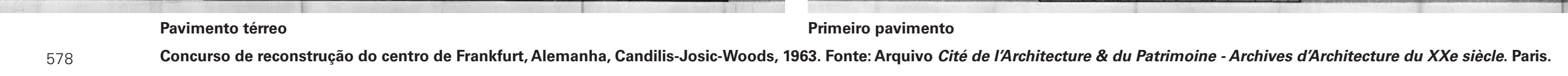



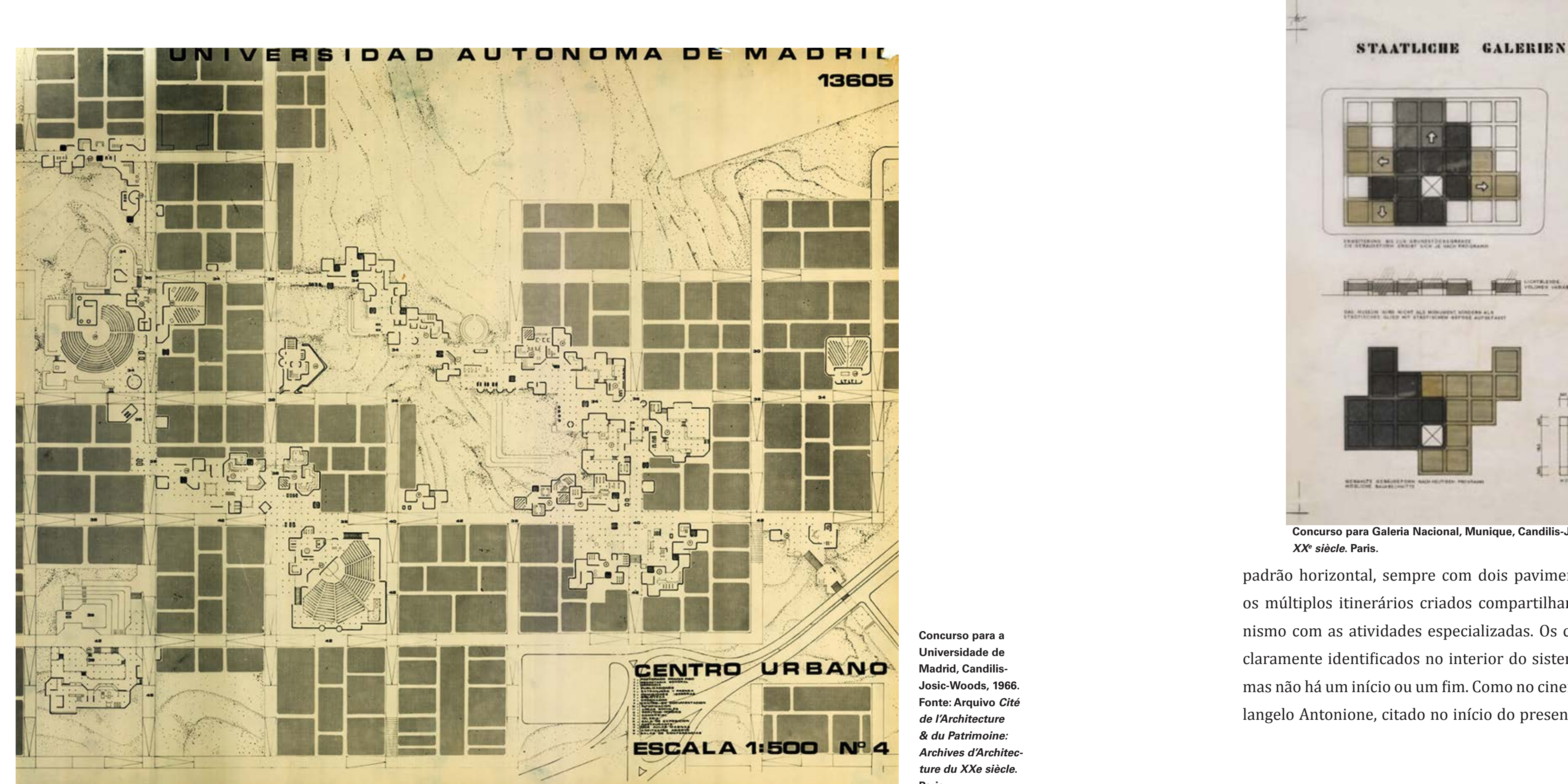

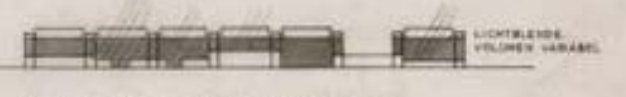
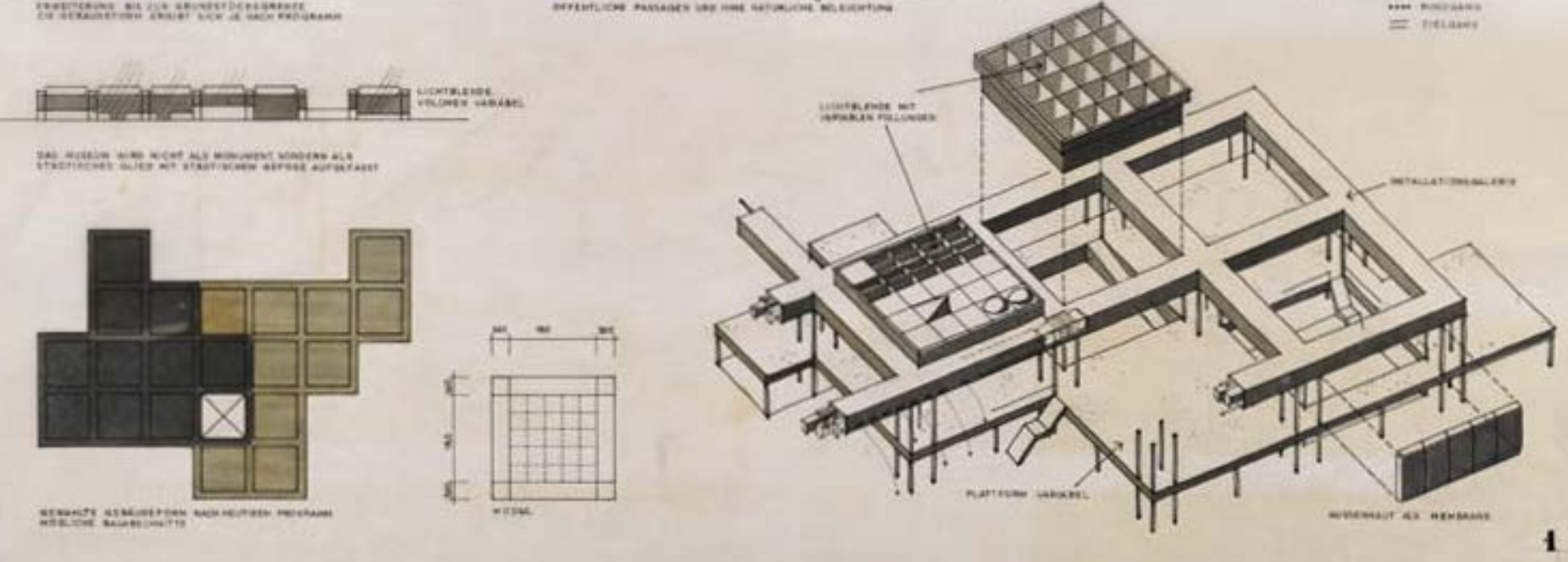
Concurso para Gale
$x x^{\circ}$ siecle. Paris.

padrão horizontal, sempre com dois pavimentos, em que os múltiplos itinerários criados compartilham o protagonismo com as atividades especializadas. Os caminhos são

claramente identificados no interior do sistema projetado

Cra

mas não háam

Em nossa pesquisa, temos um interesse especial nos projetos para Berlim e para Toulouse por serem obras realizadas e por permanecerem como importantes universidades ${ }^{262}$. 
0 texto ao lado é extraído do parecer do júriri ${ }^{264}$ que escoheu o projeto vencedor para a Universidade Livre de Berlim ${ }^{265} \mathrm{no}$ final do ano de 1963. Esse momento é especialmente significativo para Candilis-Josic-Woods, pois marca a elaboração do projeto mais conhecido do grupo, vencedor do concurso internacional promovido pelo governo da então Alemanha Ocidental, um ano após a construcão do muro que dividiu a cidade durante vinte e sete anos. 0 par des que caracterizam o projeto escolhido e sinaliza para a noção de projeto enquanto mediador, visão contida na proposta.

Para nossa pesquisa, o projeto ganha importância pois $-1=$ 
[a] Universidade Livre de Berlim é um raro exenplo de uma avançada idelia arquitetônica traduz como edificio sem modificaşes de seus principas rojetos em que Woods praticou uma arquitetura haseada na ideia do movimento como um medador físico entre a interač̃o sociale a maximizaça de escolhas. [...] Ao invés de controlar as caracteristicas espaciais estilisticas, ele associa program forma. Esse método minimo oferece um "racionalismo minimo, abastecido nesse momento regras espaciais ao invés de conceituais. Ele escohe uma organizacáă possivel dos lugares e plantas

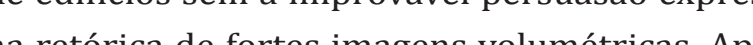
fundando questões entre conhecido e desconhecto, simples e difícil, certo e incerto, determinado ndeterminado, tratável e intratável, bem defini inexplorado, ele oferece o melhor modelo que teos atualmente para naximizar escolhas $e \mathrm{a}$ anpliar a capacidade de responder às novas ideias. (TZONIS; LEFAIVRE, 1999: 135, 139)

As palauras de Alexander Tzonis e de Liane Lefaire

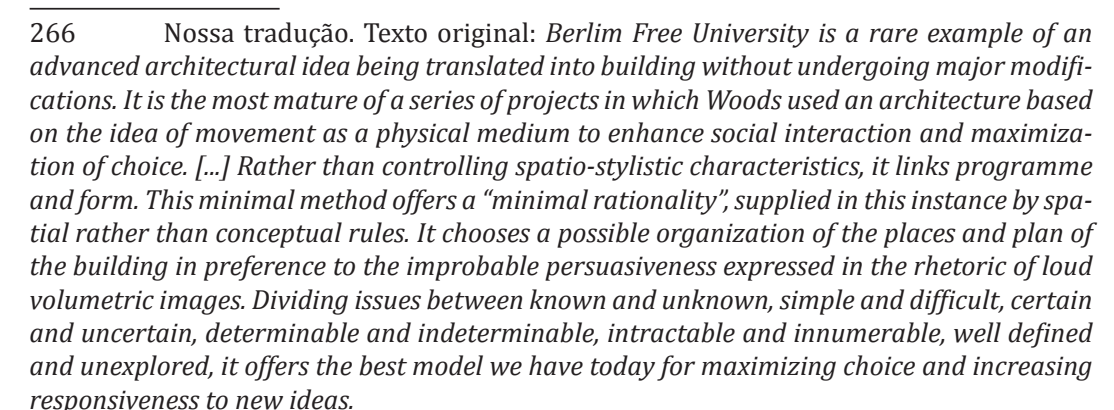

tho no final do século XX e chamavam a atençă para o predomínio de uma arquitetura em que a "persuasão é expressa pela retórica de imagens volumétricas chamativas", o que se confirmaria na primeira década do século XXI ou seja, a espetacularização da arquitetura ${ }^{267}$ que se firmara no cenário internacional.

Podemos entender com maior clareza o método utilizado por Candilis-Josic-Woods ${ }^{268}$ partindo do exame do documentos apresentados para o júri do concurso. Inicialmente, há uma série de diagramas conceituais que procuram demonstrar a necessidade de abolir a ideia dominante de atomização da universidade, ou seja, de evitar o método de organizar as áreas especializadas através de pavilhões isolados e de interligá-los por passarelas ou marquises. Ao contrário, a insistência na aproximação dos indivíduos e dos grupos que formam a universidade é justificada pela possibilidade do surgimento de novas ideias através do intercâmbio proporcionado.

Baseado nessas convicçoeses, o isolamento espacial decorrente do zoneamento funcional e da verticalização da arquitetura torna-se obstáculo para que a universida cumpra sua função na cidade e, portanto, deve ser descar-

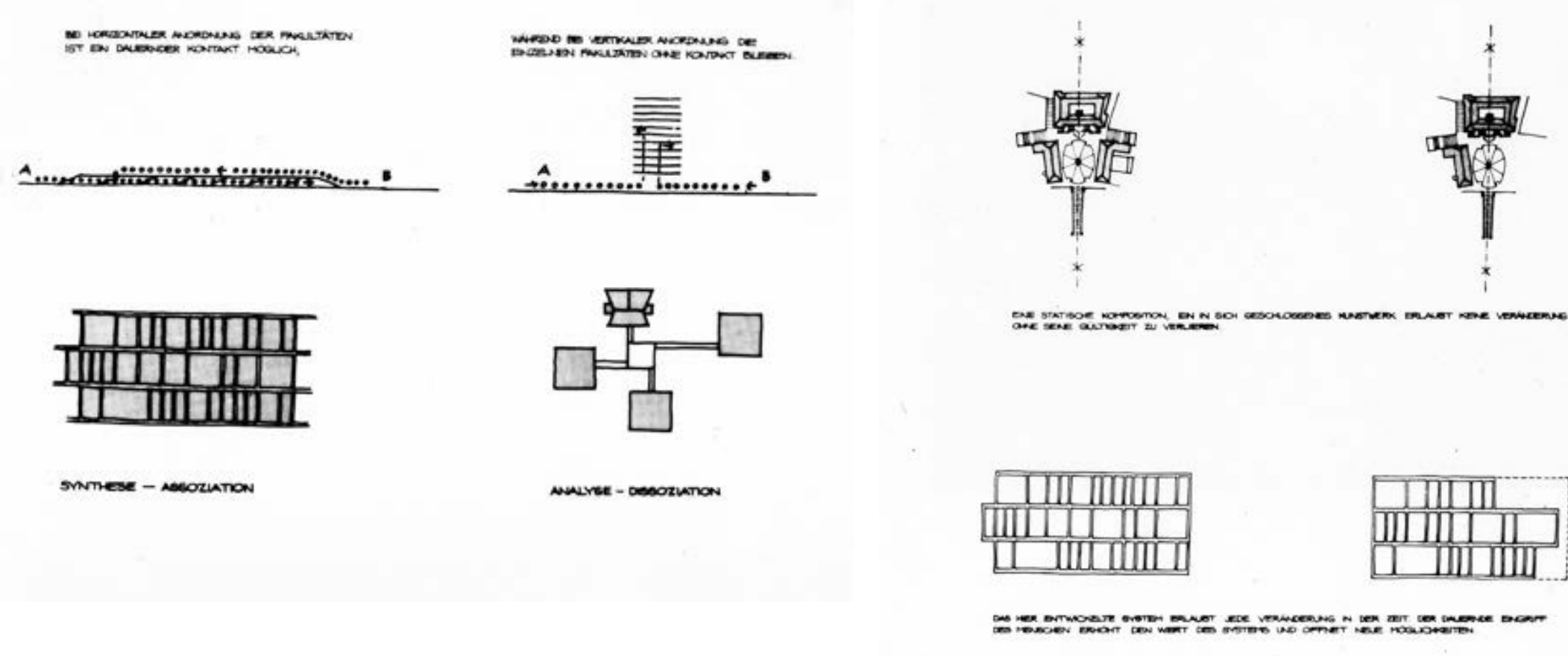

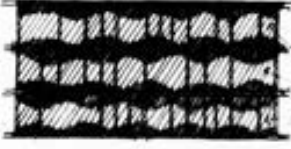

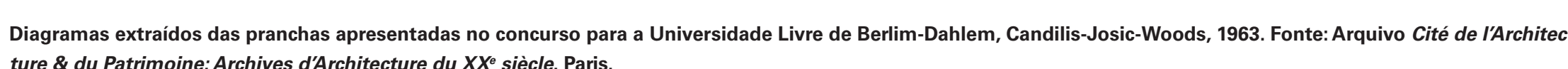


tado. Os esquemas diagramáticos são finalizados indicando como a grelha horizontal de dois pavimentos pode oferecer o máximo de relacionamento entre as diversas áreas do conhecimento que comporão a universidade, com o mínimo de estrutura e infraestrutura, ou seja, sem que se torne um entrave para as possibilidades de evolução e de mudanças futuras

Em seguida, cada unidade é definida por um retângulo proporcional à área prevista no programa do concurso e distribuída a partir de quatro eixos principais de circulação longitudinais, no sentido nordeste-sudoeste, e interceptados transversalmente por eixos secundários, no sentdo noroeste-sudeste. Cada unidade possui seus elemento fixos, como sanitários e anfiteatros, mas que podem atender toda a comunidade universitária na medida em que esão localizados nos eixos de circulação. A síntese do projeto resulta num diagrama de implantação que se assemelha à grelha da cidade norte-americana, em especial de Manhattan em Nova York, composta por avenidas de maior fluxo, longitudinalmente dispostas e interceptadas por ruas transversais de menor dimensão portanto mais tranquilas. distribuição das unidades no interior desse sistema não hierárquica pois a proximidade segue critérios de afinidade entre elas.

Ainda no diagrama de implantação é possível notar a inexistência de uma entrada ou de uma fachada principal. Assim, a multiplicação de acessos e certa homogeneidade das fachadas pretendem ampliar a integração com o contexto existente e promover seu desenvolvimento. Como um sistema aberto e contínuo, o projeto pretende atender dução do padrão proposto, podendo se aproximar dos parques existentes a sudoeste e a nordeste, como ocorreu longo de mais de cinco décadas de existência.

Ao examinarmos as plantas e os cortes do projeto possível perceber que a rigidez da trama criada pelos eixos de circulaça de cada unidade. 0 projeto mantém sua força estruturadora mas oferece inúmeros lugares para serem apropriados. A visão sequencia dos espaços é enriquecida pelo tratamento variável das unidades e por sua relaç̃o com o sistema. Para os ardit- tetos, as unidades são agrupamentos passiveis de evolução e de mudanças cuja identidade é adquirida não como uma forma identificável e sim por sua capacidade de relacionamento com outras unidades.

Os demais elementos que completam o material do concurso, como a maquete, confirmam a intenção de criar uma plataforma do conhecimento, contínua e aberta, distribuída em dois pavimentos repletos de pátios e terraços acessíveis, sem que haja um limite bem definido de seu início ou fim. A imagem resultante aproxima o projeto das imagens da cidade tradicional do norte da África, como admitem os $\operatorname{arquitetos}^{269}$.

Vale destacar ainda o predomínio da rede de espaços abertos e de circulação em relação às áreas especializadas. A valorização dos lugares de encontro extrapola os limites de um

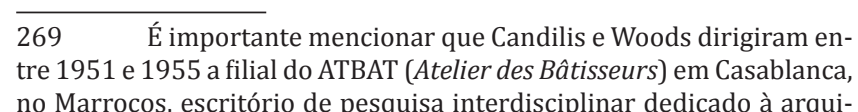

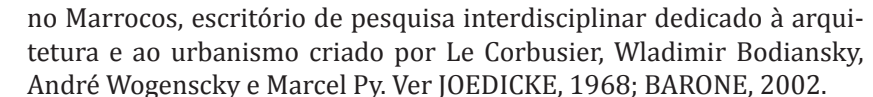

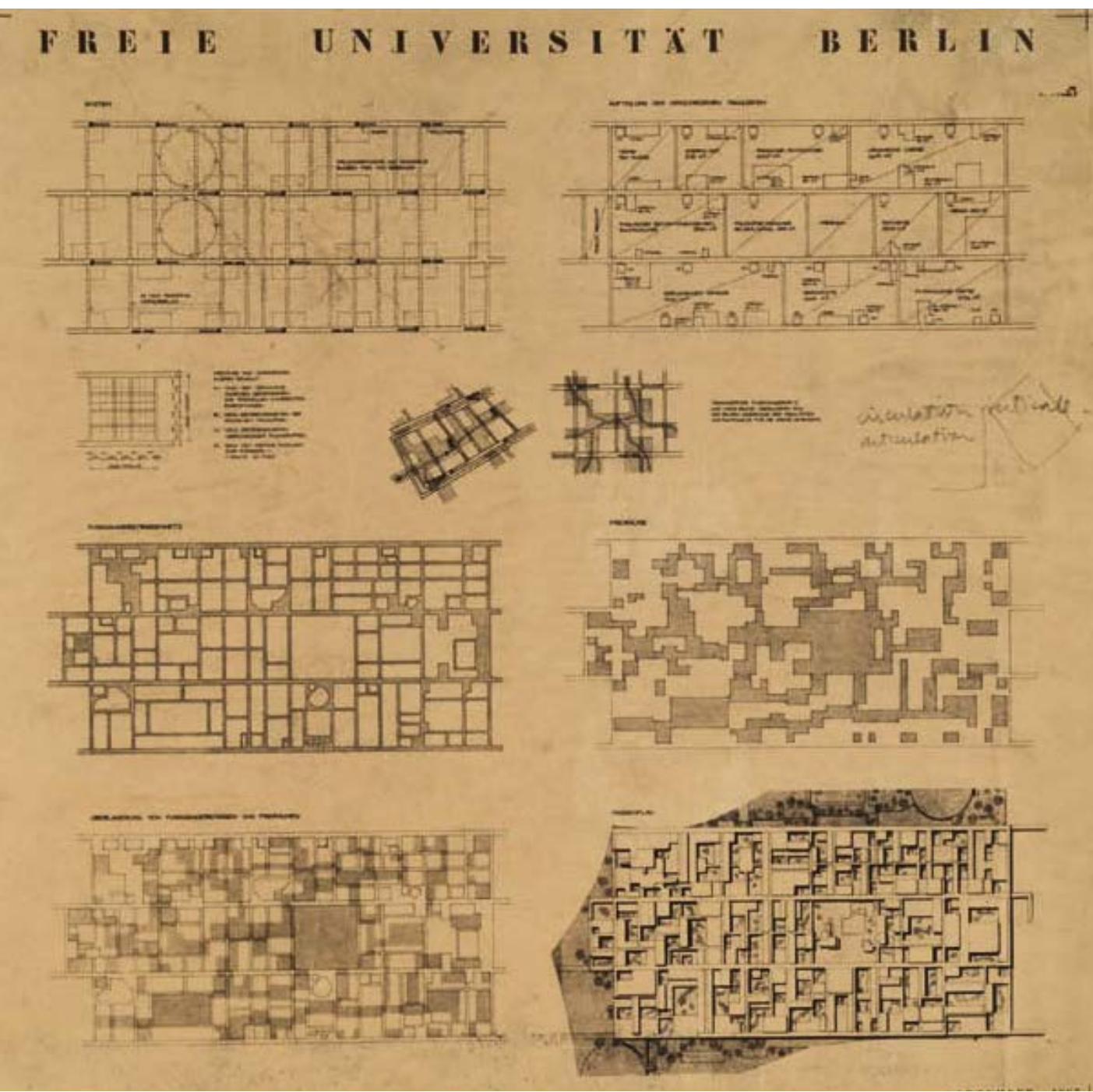

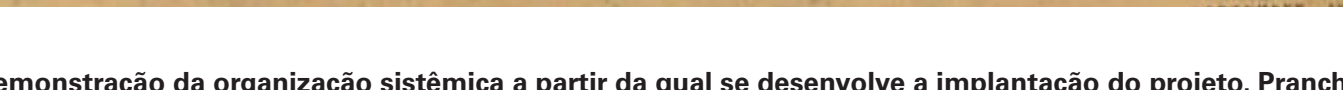

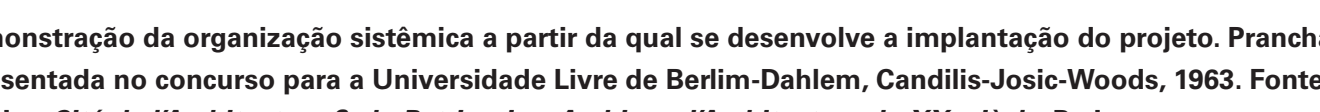




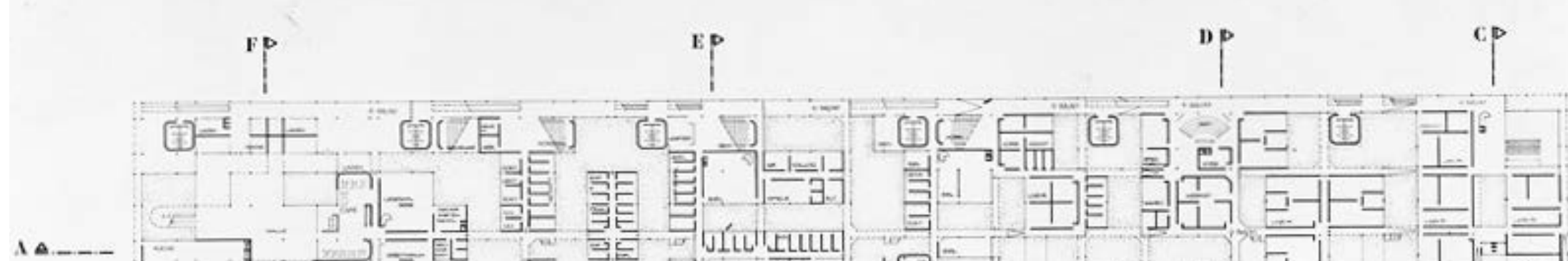
a d a

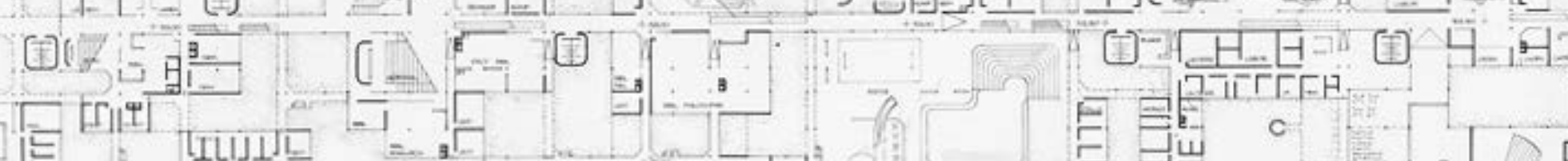
(u)

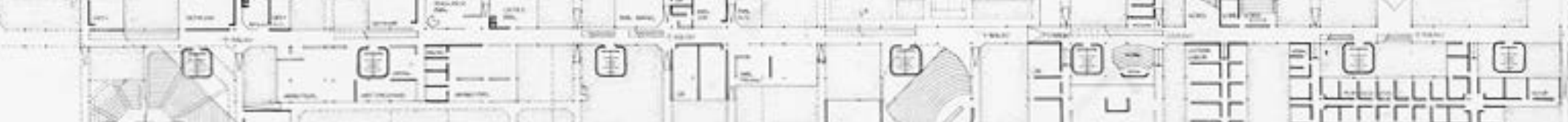

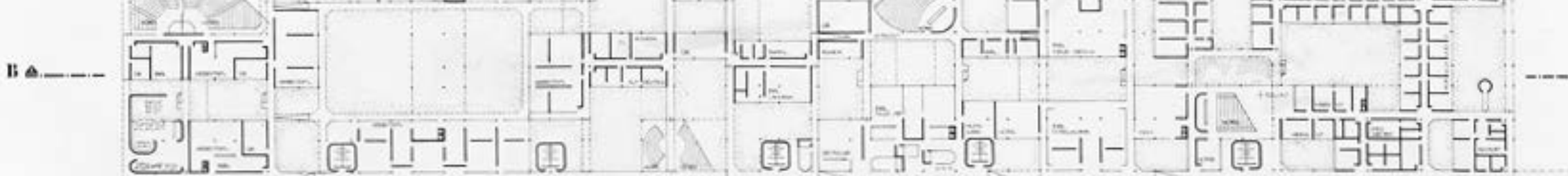

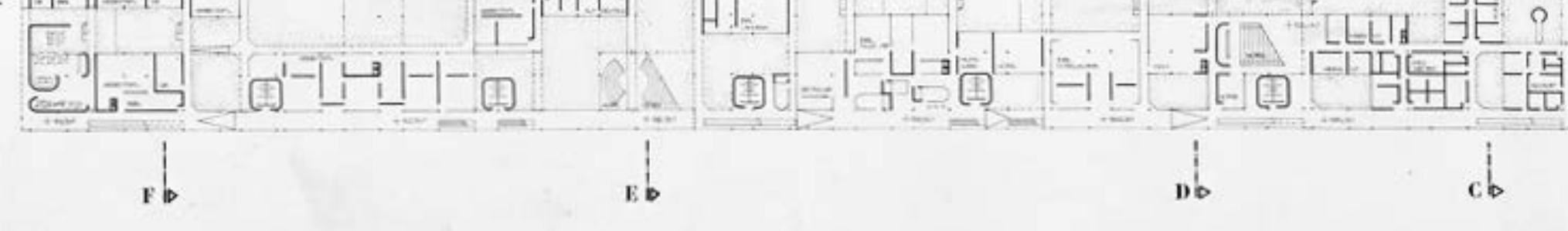

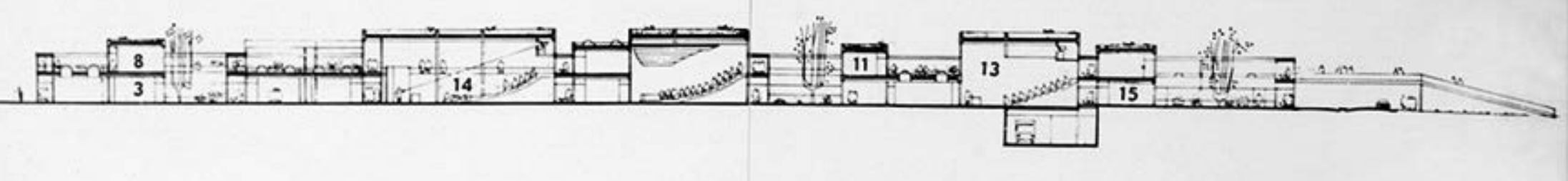

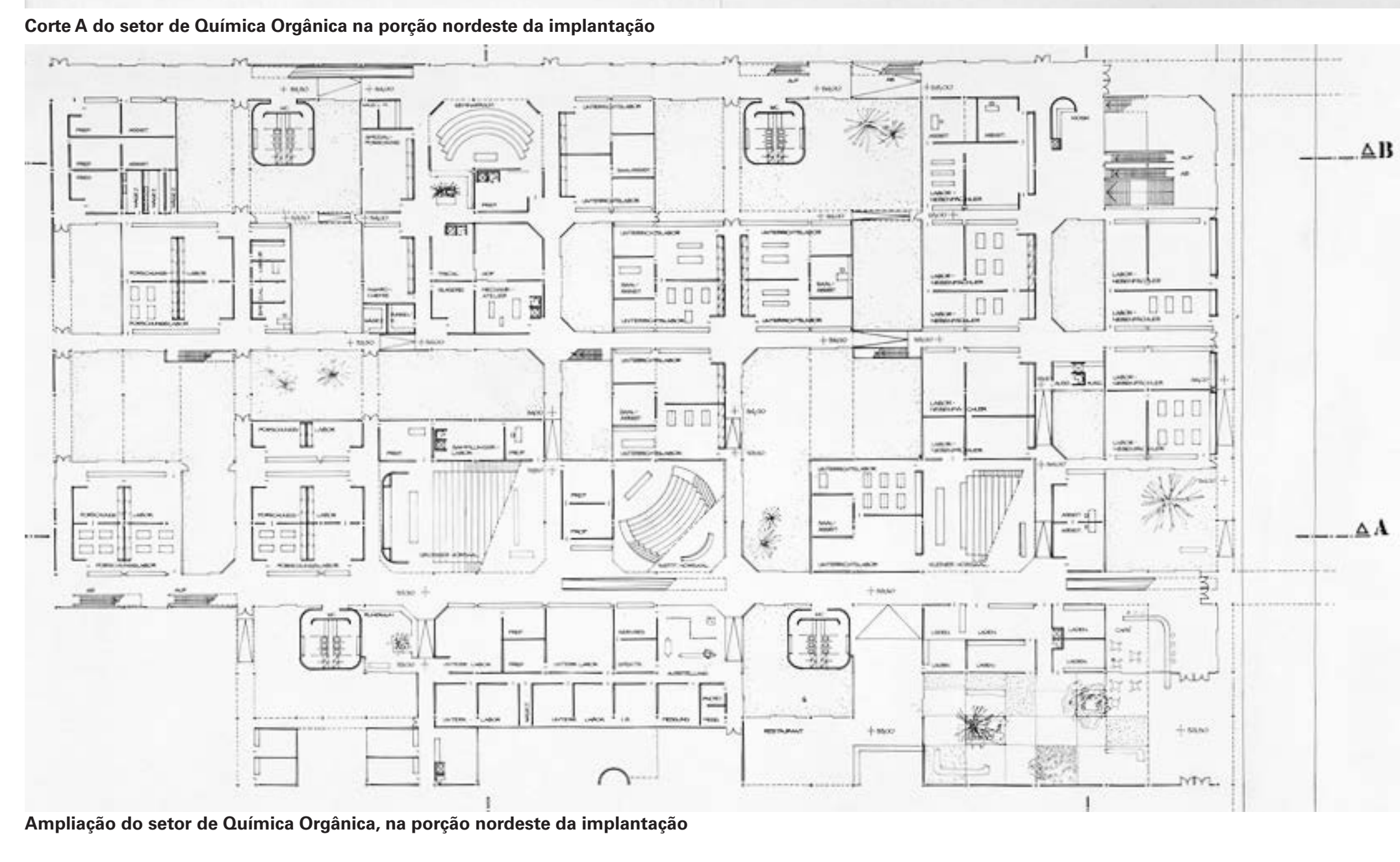

Concurso para a Universidade Live de Berlim-Dahlem, Candilis-Josic-Woods, 1963. Fonte: Arquivo da Bibliothèque Kandisky, Centre George Pompidou, Paris. 
projeto racional. Para os arquitetos, a máxima aproximação das unidades especializadas permite ao projeto se valer lugares não se torne inconveniente, isto é para que ela seja, ao contrário, um dos atributos que permita qualificar o lugar de aprendizagem:

Ser aclamado por encontrar um edifício como esse na Alemanha é estranho, pois era o lug onde uma disseminaçaao radical da linguagem rquitetura numa sociedade servida por máquinas parecia inevitável... nós estávamos esperan da Hochschule für Gestaltung em Ulm uma arq etura industrializada no mesmo nivel de perfecão que o dos equipamentos elétricos domesticos da Braun... para a Braun é uma linguagem, não uma consequência do process ${ }^{270}$. (SMITHSON 1991: 32)

A capacidade de mudança da arquitetura seria un fundamento onipresente do projeto, o principal guia "nas quatro dimensões", como recorda Peter Cachola Schmal

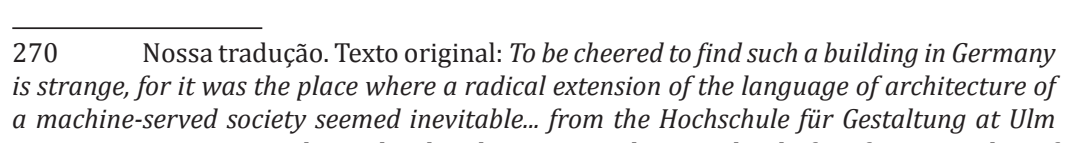

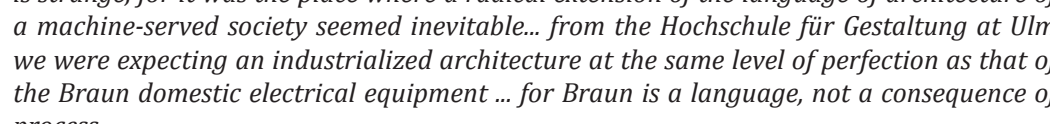

Ingeborg Flagge ${ }^{271}$. Não se trata somente da flexibilidade espacial mas da idealização da capacidade de transformaç̃o da arqui dustrializaç̃õo da obra foi um caminho natural.

$$
\text { A celebração da tecnologia, acima descrita por Pe- }
$$

ter Smithson, foi um dos argumentos mais poderosos para fundamentar os elementos construtivos da obra. Em certo sentido, contribui para a permância da obra não peta monumentalização da técnica mas sim por acreditar na tecnologia para enfrentar tanto os conflitos entre o espaço idealizado e o espaço construído como o desafio da articulação dos espaços públicos e dos espaços privados, ou seja a tecnologia transforma o projeto em mediador dentro de enso questionamento cultural e polítco. que marcou a década de 1960

Como vimos no capítulo anterior, a contribuição de Jean Prouvé para a viabilização de elementos construtivo industrializados foi fundamental para a arquitetura moderna francesa durante o século XX. Ao ser incorporado à equipe do participação no desenvolvimento e no detalhamento mostrou-se fundamental para o resultado da obra. Prouvé foi particularmente responsáve pelo das, compostos por painéis em aço patinado (aço Cor-Ten). 0 sistema foi responsável pela aparência final da obra por ter sido amplamente utilizado para a realização de sua primeira etapa.

Cabe sublinhar, no entanto, que a tecnologia tornou-se um limite à natureza não simbólica

da arquitetura proposta por Candilis-Josic-Woods em Berlim. Lembramos que a dependência e aparência totalizadora da tecnologia encontran paralelo na arquitetura do espaço teatral flexivel 272 . Esse paradoxo fica ainda mais claro por ser

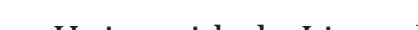
ça çôes que mais contstava o modelo de desenvolvimento tecnológico dos países industrializado como observou Bernard Huet ${ }^{273}$.

Do ponto de vista do projeto, as reflexões acima atestam a dificuldade de conciliar o ideal de flexibilidade com a estática da obra, ou seja, entre a ideia e a construção, entre conceito e estrutura.
-

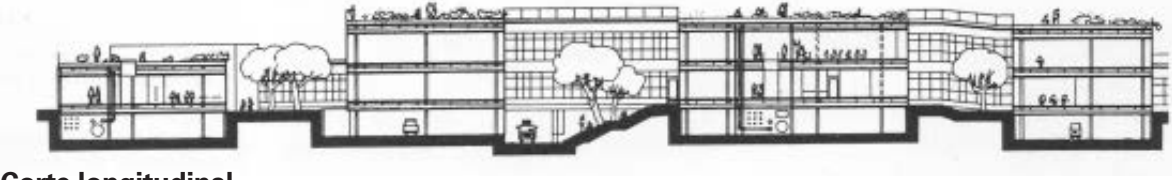

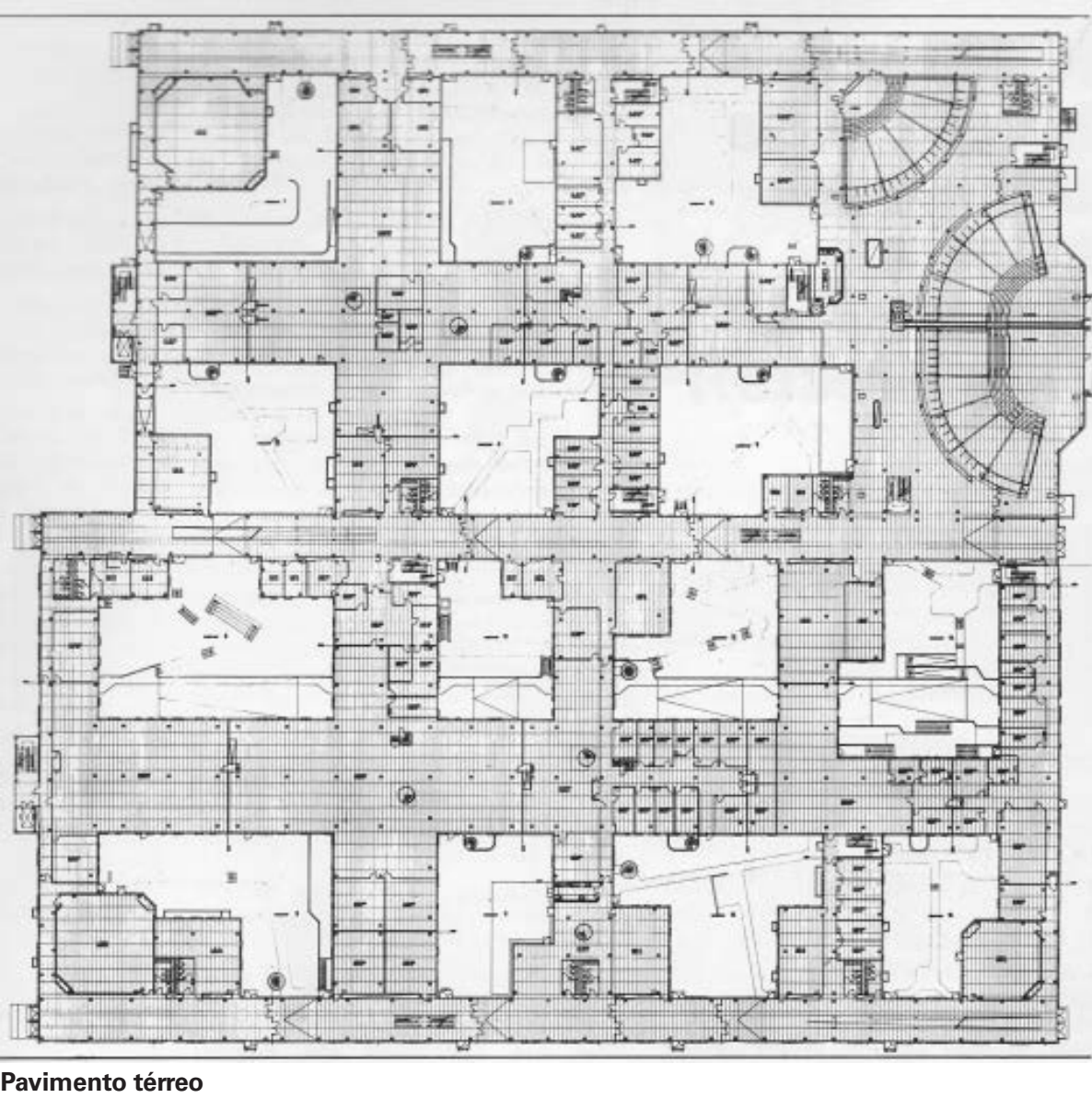

Primeira etapa, Rostlaube, do projett para a Universidade Live de Berlim-Dahlem, Candilis
Josic-Woods, 1967 Fonte- 


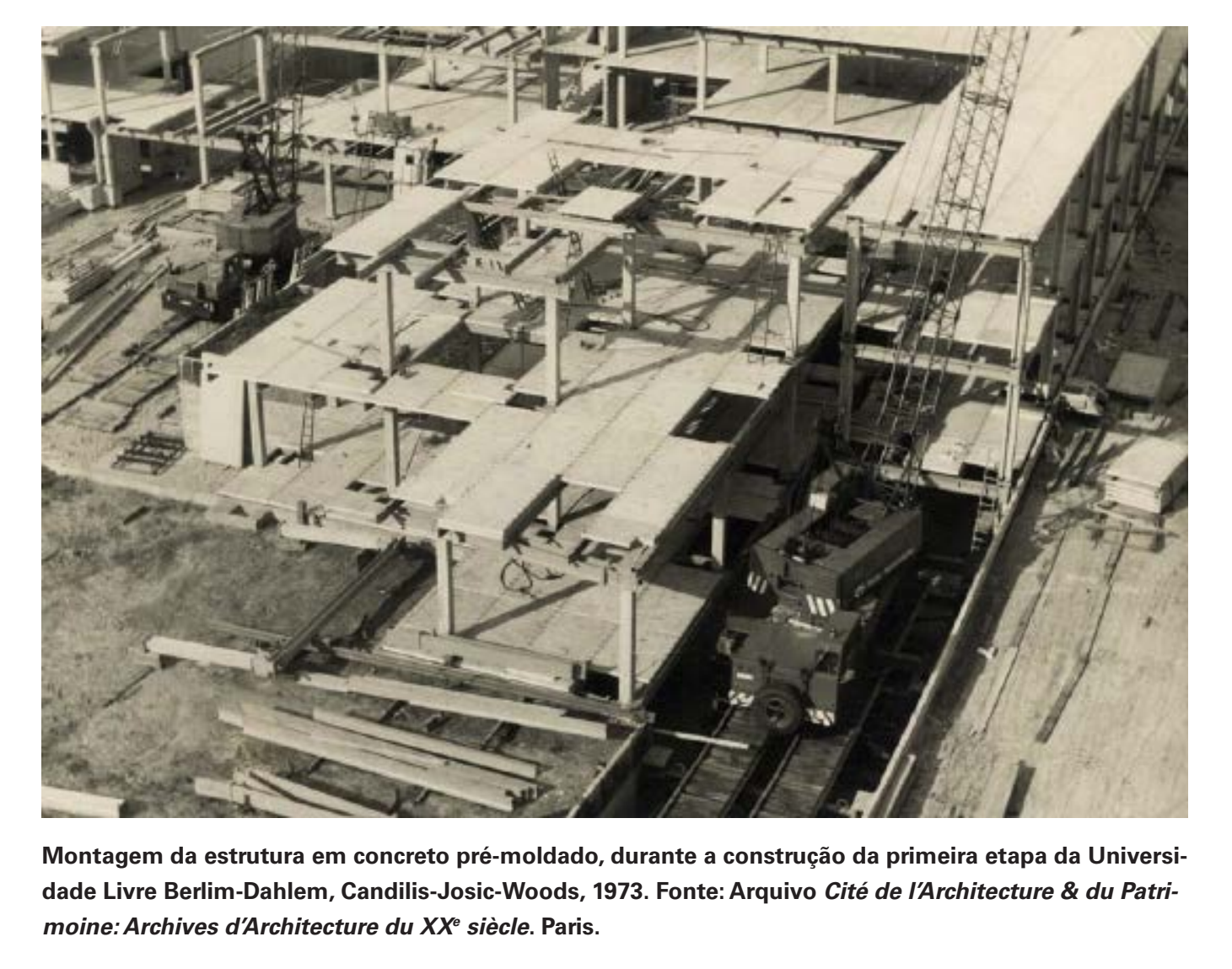

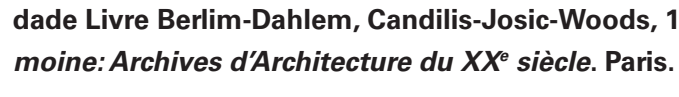

0 sistema proposto pelos arquitetos materializa os

conceitos formulados em Web e, para isso, apoia-

-se na tecnologia para viabilizar um equipamento

que se pretende

organização incorpora a experiência urbana das

cidades tradicionais do norte da África e o método

racionalista das cidades norte-americanas.

Ao observarmos sua evolução em cinco décadas de existência, podemos examinar se ela, segundo uma visão sistêmica do projeto, foi sufi-

cientemente consistente para enfrentar os novos desafios que foram colocados nesse período $0^{274}$. Não se trata de esgotar um assunto tão amplo e merecedor de uma pesquisa específica, mas de trazer a contribuicão da experiência da arquitetura proposta para a Universidade Livre de Berlim como visão sistêmica do projeto e de sua independência.

A Universidade Livre de Berlim é hoje o resultado de quatro momentos sucessivos de construção A primeira etapa, como mostra a planta da página 591, foi terminada em 1970 por Candilis-Jo-

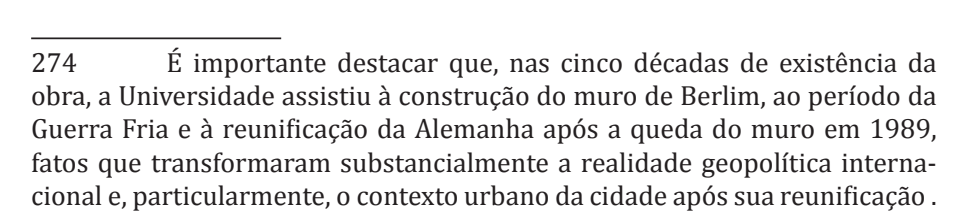

sic-Woods com a colaboração de Jean Prouvé no detaIhamento do sistema industrializado de paineis em aço patinado, e de Manfred Schiedhelm, que dirigiu a obra Por sua aparência exterior foi batizada de "Rostlaube" 27.

Na segunda etapa, também terminada em 1970, a mesma equipe empregou um sistema de painéis de fachada semelhante alterando o material para chapas de alumínio, o que lhe valeu a denominação de "Silberlaube 276".

Em 1984, a Biblioteca de Estudos Pedagógicos e o Restaurante Universitário, projetados por Manfred Schiedhelm, vieram se conectar ao sistema, ocupando sua parcela norte.

Finalmente, em 1997, a equipe de Norman Foster vence o concurso internacional para a reabilitação da primeira etapa, o que inclui o projeto de uma Biblioteca de Filosofia.

Cabe salientar que, mesmo com as dificuldades os questionamentos que a proposta recebeu, a evolução da obra seguiu as condições originais que consagraram o projeto no concurso internacional em 1963,

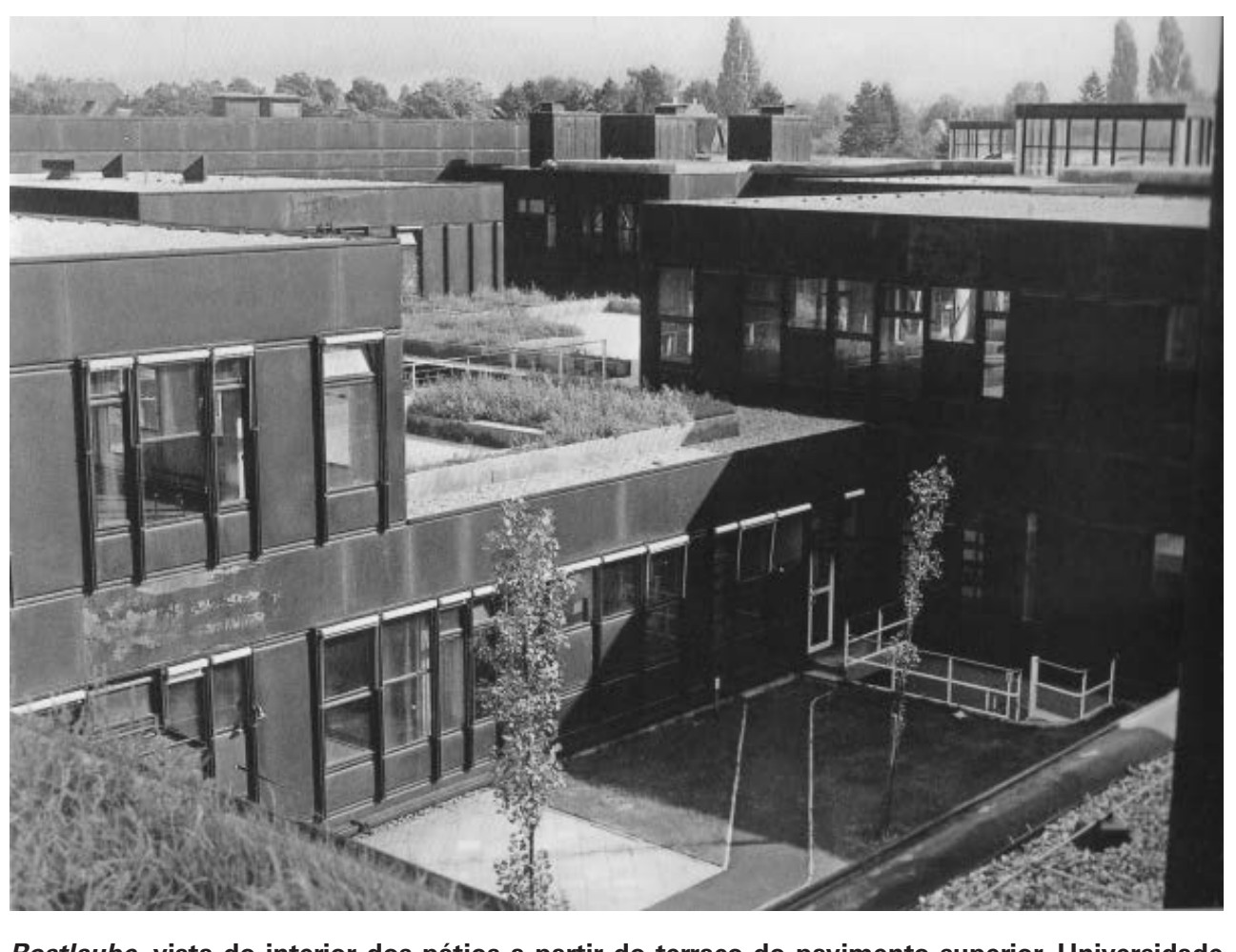

do interior dos pátios a partir do terraço do pavimento superior, Universidade
Live Berim-Dahlem, Candilis-Josic-Woods, 1973 . Fonte: VONVEGESACK, 2006. 

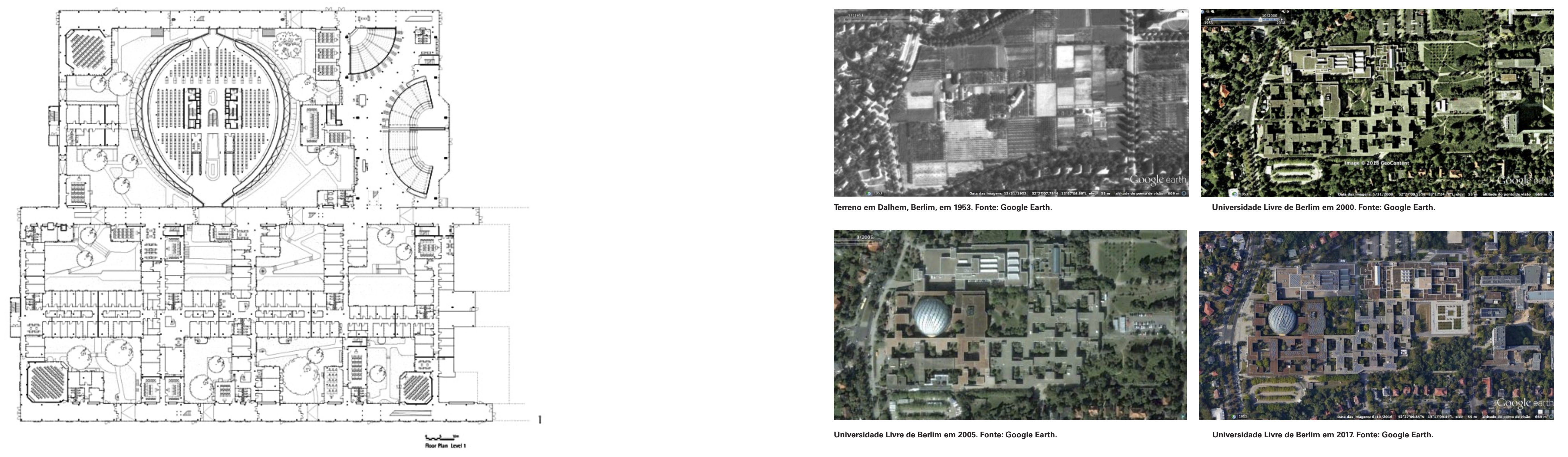

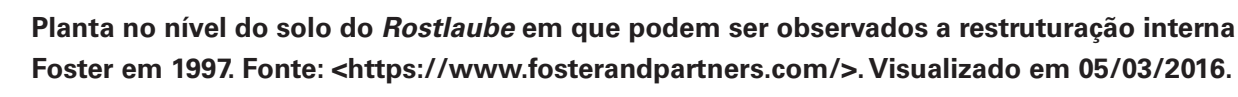

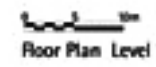


como mostram as imagens aéreas da página 595. 0 que se distanciou substancialmente do projeto inicial foram as obras do Restaurante Universitário e da Biblioteca de Estudos Pedagógicos, construídos na parcela norte do terreno, cujo programa não estava previsto inicialmente. Outro momento significativo foi o Concurso Internacional para a reabilitação da primeira etapa da obra Rostlaube, e a construção da Biblioteca de Filosofia, ocorrdo em 1997, ou seja trinta e quatro anos após o concurso inicial. Os ars de reabiltaça da edfaça form apresentad do concurso ${ }^{27}$. Baseados nas dificuldades de manutenção do edifício e, principalmente, de utilização dos espaços decorrentes das modificações que foram introduzidas ao longo do tempo, os motivos podem ser assim resumidos: - a redução da fluidez dos espaços exteriores flexíveis, que foram transformados em pátios internos quase uniformes, distorcia um dos principais fundamentos do projeto, ou seja, a rica diversidade de situaçõos espaciais,

- a multiplicaçã̃o das divisões internas, caracter-

$277 \quad$ Ver Le Carre Bleu $1 / 1999$ zadas majoritariamente por pequenas salas individuais desconsiderava o projeto original, que priorizava os espacos generosos de trabalho abertos e coletivos,

— o crescimento do programa da Universidade não

foi acompanhado pela ampliação da área construída prevista nas etapas do projeto original, o que explica em parte, as transformações acima citadas

- a falta de determinado isolamento e, em especia ausência deidentidade entrecadárece ocupada pelosins litutos, se transformaram em fatores negativos para o cotdiano da Universidade,

- e ainda, o estado de degradação dos painéis de fachada em aço patinado, cujo envelhecimento não confirmou as expectativas técnicas previstas, impedia o atendmento das normas de desempenho atuais para esse tipo edificação,

A argumentação final indica que parte das dificuldades existentes estariam diretamente relacionadas ao "car ter polivalente" do projeto, o que exigiria a intensa utilização dos espaços e a participação efetiva dos alunos, o que não se confirmou ao longo do tempo

Entretanto, o edital admitia que, apesar das mo- dificaçōes e das dificuldades apontadas, a intervenção na edificação se daria de maneira inteligente graças à excep-cionalidade da obra, encontrar um caminho que respeitasse sua herança arquitetônica, confrontando-se às questões dos tempos atuais atendendo aos parâmetros exigidos pelos promotores do concurso 278". (Le Carré Bleu, no 1, 1999: 15-20)

A equipe vencedora, liderada por Norman Fostes respondeu ao concurso resing ruas internas próximas aos pátios $3 \mathrm{e} 4$, como preconizava o edital. Ao fazê-lo, a intervenção manteve conceitualmente a proposta de Candilis-Josic-Woods mas racionalizou a mobilidade interna propondo uma hierarquia mais clara e objetiva. A partir dessa operação, foi oferecida uma propor corredores, portanto distinta da original, e introduzido um novo volume no interior do sistema (con $2.900 \mathrm{~m}^{2}$ aproximadamente) para receber a Biblioteca d Filosofia, uma figura geométrica distinta, como uma cúpula translúcida, com um pavimento suplementar, o que tam-

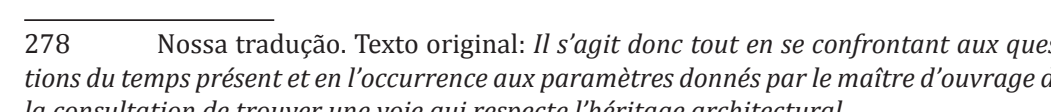

êm alterava o gabarito do sistema previsto.

o nos defrontarmos com a evolução a que a obra fo submetida e com os argumentos defendidos para a introdução de modificaçõos significativas, podemos encontrar parte da explicação nas palavras de Alexander Tzonis e Liane Lefaivre, para quem

Woods sucumbiu ao que podemos chamar "determinismo amblental, a tendêncla olmista da profissão de arquiteto em assumir que as condições ambientais podem efetivamente mudar comportamento humano e até mesmo suas conviç̧̃̃es. ${ }^{27}$ (TZONIS, LE FAIVRE, 1999:138)

No livro 280 , os autores procuram demonstrar que, tionamentos críticos por que passou a ar(a) 1960, tendo sido considerados por parte da historiografia como ingênuos e banais, utópicos e ideológicos e, portanto sem muito significado (1999:120), tais questionamento geraram projetos de extrema relevância e de atualidade do

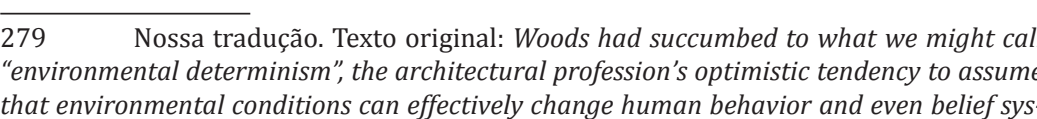
ly change human behavior and even belief sos. 
ponto de vista de suas ideias espaciais e culturais, como a Universidade Livre de Berlim. Assim como Keneth Frampton havia observado, os autores apontam que, em Berlim existência de um ambiente urbano indefinido, caracterizado pela ocupação suburbana de pequenas residências no interior de um lote, contrasta com a proposta de intenso dinamismo urbano do projeto para a Universidade de Livre, o que a distancia das condições extremamente favoráves da proposta da mesma equipe para o centro de Frankfurt, como vimos. As conclusões de Frampton são ainda mais convincentes pois justificam a perda de convicção do proje to em Berlim pela própria ausência de um microcosmos ubano e da cultura urbana que havia criado a Universidade, confirma a incapacidade de um campus autônomo produzir animada diversidade de uma verdadeira cidade.

Os estudos elaborados pela equipe durante o de- senvolvimento do projeto em 1965 e 1966 apresentam sua grande preocupação em ultrapassar o sistema teórico e abstrato vencedor do concurso para um plano a longo prazo aue do subúrbio de Dahlem. É possível identificar não apenas exercício das conexões no interior da universidade, mas também suas ligações com os antigos edifícios da universidade de 1948 a leste, com o sistema de transporte coletivo, as vias de acesso e os parques existentes nas proximidades.

No nosso entendimento, a repetição em Berlim do projeto proposto para Frankfurt não se deu pela simples reprodução do padrão. A visão sistêmica sobre a qual se apoiam os trabalhos de Candilis-Josic-Woods nesse perído oferece uma alternativa à cidade moderna que não se baseia na concentracão e na verticalização do ambiente. Materializou-se o groundscraper ${ }^{281}$, a plataforma junto chão, em oposição ao skyscraper ${ }^{282}$, a torre dominante parcularmente na arquitetura norte americana. Se em Frankfurt o sistema projeta uma estrutura ur-

$\begin{array}{ll}281 & \text { Ver KRUNCl, 2012. } \\ 282 & \text { Sobre arquiteturad }\end{array}$

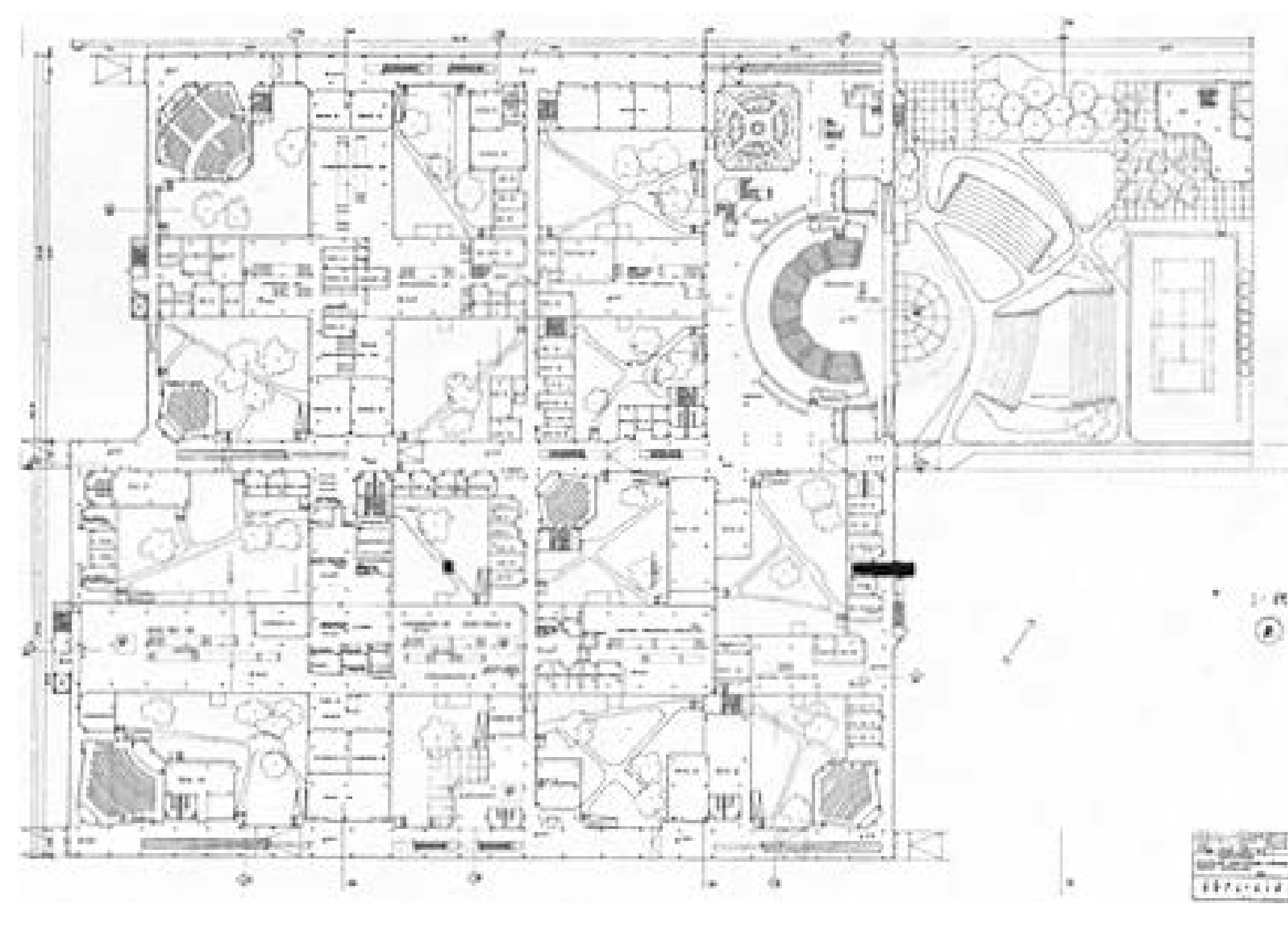

a Universidade Liver ele Berlim-Dahlem, Can
dilis-dosic-Woods, 1963. Fonte: KIEM. 2008 
bana que interliga em diversos níveis os pontos do centro histórico, "costura" áreas consolidadas mas apartadas pela destruição da guerra e materializa, assim, um caminho para uma nova vitalidade urbana, em Berlim, o sistema torna-se protagonista dentro de um quadro contextual suburbano genérico, é o núcleo a partir do qual as convergências das atividades universitárias serão capazes de gerar cidade.

Como sintetizam os diagramas apresentados pel equipe de arquitetos para vencer o concurso em Berlim ${ }^{28}$ a aproximação e a intensificação das atividades promovidas pela materialização da plataforma - o groundscraper - evi taria a típica segregação representada pela solução vertical

- o skyscraper - ainda que nesse último o pilotis corbusiano do térreo fosse a extensão natural do espaço público. Em certo sentido, a arquitetura assume a mediação entre os movimentos diagnosticados pela equipe: de um lado, as mudanças sociais no âmbito da estrutura universitária e, de outro, as transformações urbanas marcadas pela densificação da cidade.

Ela oferece ainda um modo de concepção e de desen-

283 Ver JOEDICKE, 1968: 208

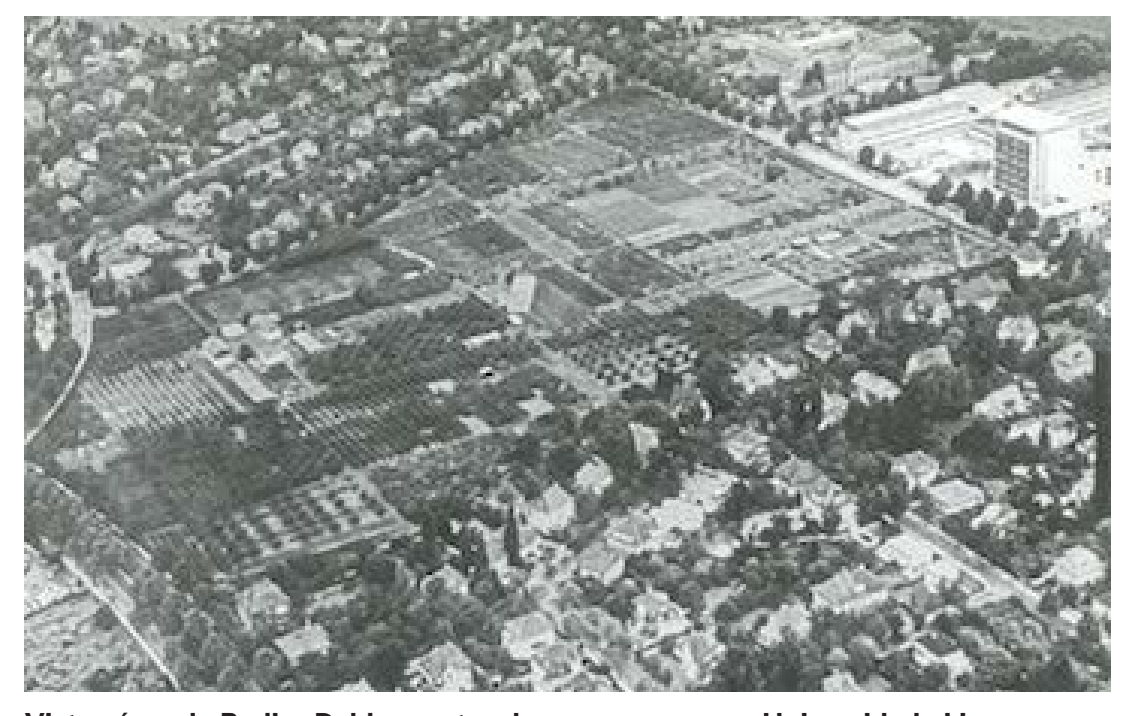

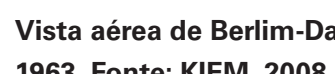

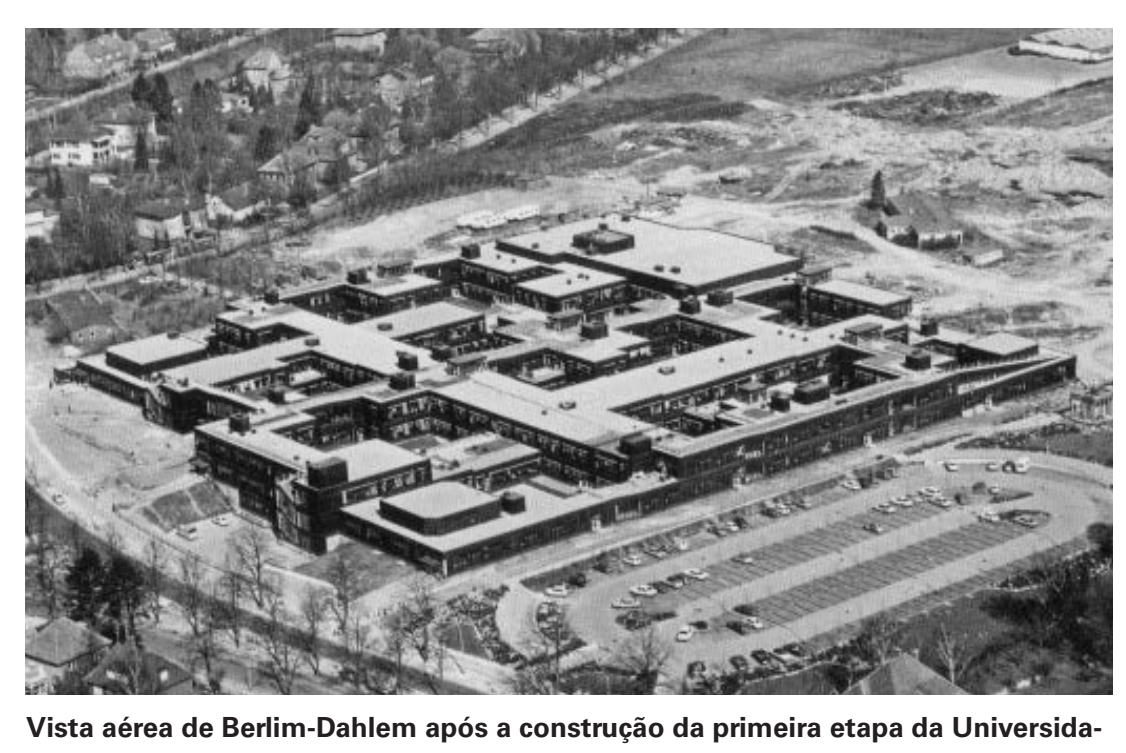

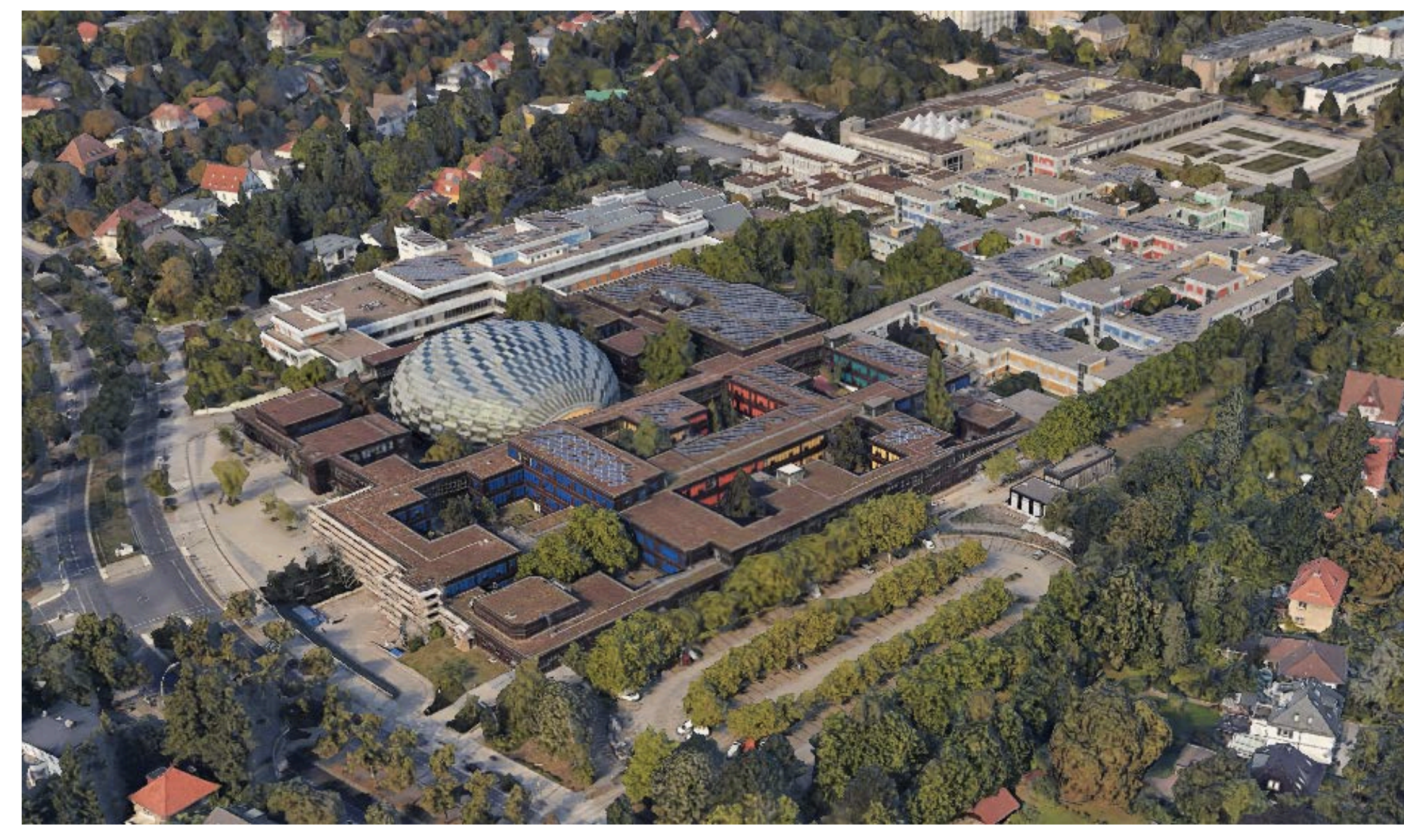

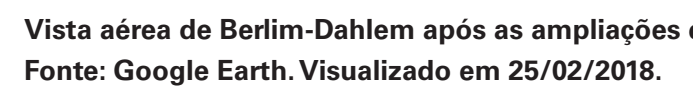


riedade de soluções dentro de um mesmo projeto, ou seja, o

sistema oferecia a possibilidade de expressão dos membros

da equipe sem que suas características primordiais fossem prejudicadas.

Mesmo após o crescimento e a reforma pelos quais passou a Universidade Livre de Berlim, sua estrutura até cero ponto divgraḿtica persiste, primeiramente ao rejeitar a oferecer plena mobilidade em diversas velocidades e frequências, através de rampas, escadas, ruas, avenidas e pátios.

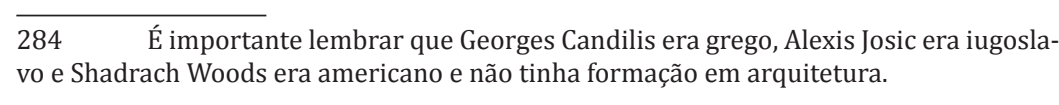

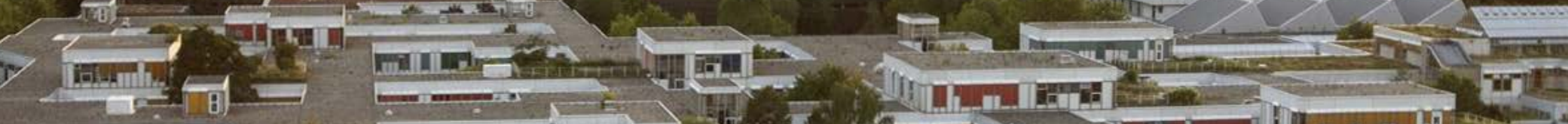

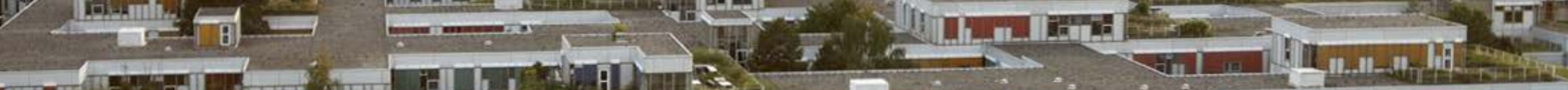
पin 
Universidade de Toulouse-le-Mirail, Toulouse, Candilis-Josic-Woods, 1967-1971

A evolução incessante, rápida, imprevisivel das necessidades tornou caducas todas as concepcões pré-determinadas de espacos de uso defindo. A única certeza sendo, na maioria das vezes o fato de que o futuro uso de um edifício perma necerá incerto e poderá mudar constantemente durante a duração de sua existência..2"

BLAKE, 1958

Em A dificil arte de ser simples, Peter Blake problematiza um dos principais desafios que a arquitetura enfrenta especialmente no final da década de 1950. Prova disso, é a estrutura mínima sobre a qual se apoiam os grounds-

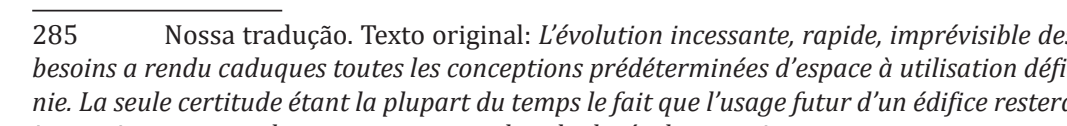

crapers de Candilis-Josic-Woods como a Universidade L vre de Berlim-Dahlem. Esse foi o principal fundamento en-

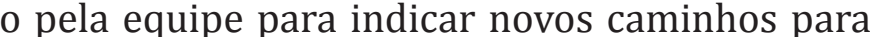
arquitetura, com o propósito de sustentar a evolução dos usos e garantir a permanência da obra. Sem que haja oposição direta ao espaço universal de Mies van der Rohe, como discutido no capítulo anterior, os arquitetos da equipe procuraram responder à demanda de Blake por uma arquiteturen (BLAKE, 1958: 25)

As dificuldades apresentadas pela implantação horizontal estendida (em Berlim o projeto previa $220 \mathrm{~m}$ por $330 \mathrm{~m}$ ) em que há o predomínio dos espaços abertos, considerados "exteriores" pelos arquitetos, confrontaram-se com as condiç̃oses climáticas do norte europeu, muito distantes do clima mediterrâneo do norte da África e cujas cidades foram sua fonte de inspiração, como vimos. Isso significa que devemos examinar com atenção o projeto para a Universidade de Toulouse no sul da França, cuja situação geográfica é mais favorável que Berlim, ainda que esteja distante do norte da África. 


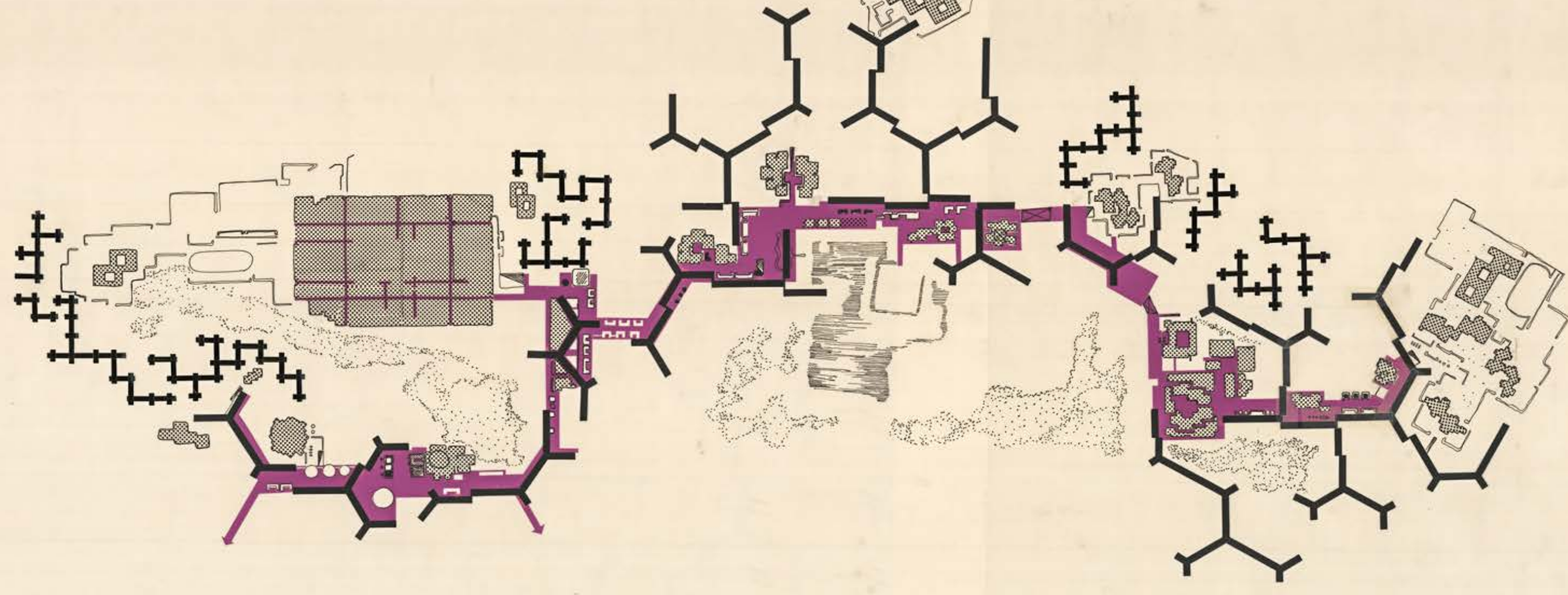

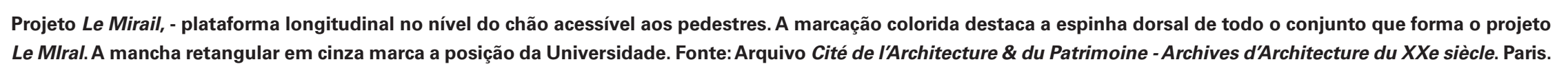

Há no chão, portanto, uma espinha dorsal de geometria não ortogonal em que se concentra toda a mobilidade do pedestre, independentemente dos veículos que estão vinculados a outro sistema de vias em níveis inferiores. $A$ implantação das habitações segue esse desenho livre justificado pelo ambiente natural - lagos, áreas verdes e colinas - em que são conectados os equipamentos à medida que a cidade evolui e as demandas surgem. É nesse ambiente que são projetados ao longo da construção e da evolução de Toulouse-le-Mirail diversos centros comunitários, creches, escolas infantis e colégios, e onde será implantada a universidade a partir de 1969 .

O que nos interessa é entender o projeto da Universidade Toulouse-le-Mirail enquanto evolução do sistema aplicado por Condilis-Josic-Woods em Franlfurt en BerUnivessictar que 1969 as duas primeinse Universidade Livre de Berlim estavam em fase final de implantação não sendo, portanto, apenas um conceito ou um promessa e sim uma realização concreta a ser novamente aplicada em Toulouse, como confirma, em diversos trechos, o depoimento do próprio Georges Candilis
Essa decisão [de incluir a universidade] impactou o plano inicial, mas nós a acolhemos, pelo fato de considerarmos que a presença de uma população univerdaria um sopro de enriqueceria a nova cidade e 1 he éa consequência lógica de nossos estudos e realiza cões precedentes, Universidades de Bochum - Berlim Oeste e Zurique Se o espírito de pesquisa perm nece o mesmo, a particularidade do sítio, do clim do programa pedagógico, da legislaç̃o e do financimento lhe dão seu caráter espećifico, sua identidade. A universidade torna-se uma parte da nova cidade à imagem de sua estrutura urbana. [-] As moradias estudantis e os equipamentos esportivos são disseminados dentro do conjunto da nova cidade para evitar o "campus-gueto universitário". [..] Os edifícios públicos por sua concepcão simples e sua localizacão funcional tornam-se verdadeiros "prolongamento do residência" e perdem seu aspecto de "pequenos monumentos modernos" ${ }^{287}$ (CANDILIS, apud JOEDICKE 1975: 97; 104; 106; 109)

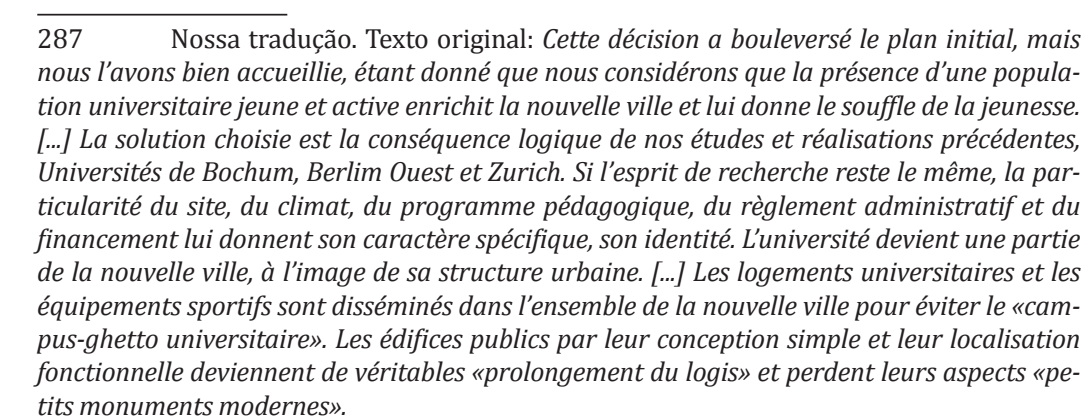


As palavras de Candilis respondem à simplicidade apontada por Peter Blake mas deixam claro que a universidade em Toulouse, assim como em Berlim, não seria ba seada no modelo do campus norte americano ocupado por "pequenos monumentos modernos", em certa medida, um referência ao trabalho de Mies no campus do ITT - Illinoi Institute of Technology em Chicago.

A proposta da criação da Universidade de Toulouse-le-Mirail foi parte do plano educacional do governo francês elaborado como resposta aos movimentos estudantis de maio de 1968 na França, que incluiu Toulouse como uma das Metrópoles de Pesquisa, responsáveis por garantir o “equlibrio" territorial dos investimentos para a descentralização do ensino superior ${ }^{288}$. Até então, as faculdades e institutos

$288 \quad$ Ver LÁrchitecture d'Aujourd'hui, 137: 4-9, ocupavam diversos imóveis, muitos deles edifícios localizados no centro histórico da cidade. A solução para a construção de um equipamento de porte em Toulouse-le-Mr - para 10.000 alunos - veio ao encontro das aspirações de uma comunidade universitária ideologicamente sensibilizada pelas ideias do projeto, baseadas em mudanças sociais e culturais em que as condições comunitárias se apoiam no diálogo entre todos que participam da construção de un novo espaço transformado pelo movimento, como defentido por Shadrach Woods. Em outras palavras, a ideia de uma arquitetura em que plasticidade, flexibilidade e mobilidade se fundamentam a partir da visão do pedestre, da rua e da cidade tradicional surgiu como oportunidade de expressão das utopias do período ${ }^{289}$.

Se o sistema desenvolvido pelos arquitetos en Frankfurt, Boch testado na Universidade Livre de Berlim com entusiasmo,

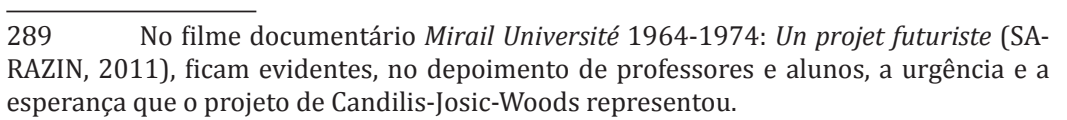

em Toulouse a urgência se apresenta como promotora da utopia universitária, como podemos observar no testem nho daqueles que particip

O programa foi sendo montado; não havia un grama; a organização era o resultado das rePeveviam a descentrilzaco peque

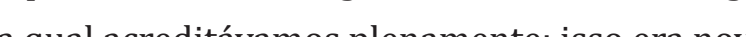
para nós: trabalhar em grupo em pequenos grupos, produzir relatórios coletivos; o espaço reflepos, s. da Universidade. (Paul Rives que seria assessor do reitor para o projeto e a conssor ấ da Universidade Toulouse-le-Mirail en 1968, SARAZIN, 2011: 19'-22')

Antes de mais nada, para haver um projeto $d$ onstrução de ử universidudé ́́ preciso ba er um projeto pedagéco de universidade, un projeto científico de universidade e nós não

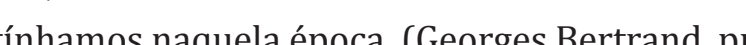
fessor de georafia in SARAZIN, 2011:37) projeto, então, transforma-se em processo, ou seja, foi necessário dar inicio à construção da universidade simultaneamente à elaboração de eais aspirações da comunidade universitária en consonância com a visão de cidade considerada humanística pela equipe de arquitetos. Na medida em que mesmo as definições programáticas de ordem pedagógica e científica iriam evoluir, a arquitetura deveria ser ainda menos definitiva que em Berlim. 0 projeto torna-se, em certa medida a "força motriz" da criaç̃o da universidade. É certo que situação favorável da obra, localizada no centro de um dos setores importantes de Toulouse-le-Mirail, que já previa en sua primeira fase de implantação vinte e dois mil habitantes, permitiu que o groundscraper proposto para a universdade estivesse muito mais artic do que a situaç̃o suburbana em que se encontrava a Universidade Livre de Berlim. Prova disso, alunos e professores afirmam ter sido naquele momento uma experiência excepcional poder morar, estudar ou trabalhar no Mirail, pois as condições do meio natural e do meio construído - vegetação, luz e ventilação naturais, espaço e amplitude - eram 

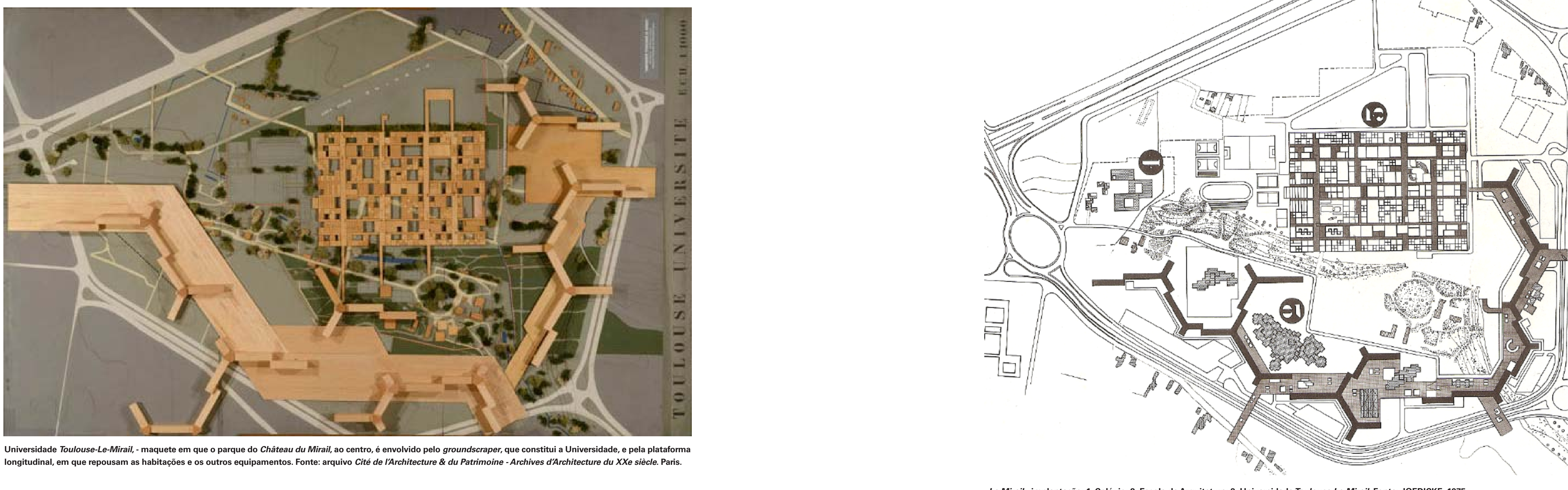

Le Mirail- - implantaçẫo: 1. Colégio; 2. Escola de Arquitetura; 3. Universidade Toulouse-Le-Mirail. Fonte: JoEDIcKE, 1975. 
extremamente mais favoráveis do que nos antigos edifícios do centro da cidade, ainda que o deslocamento trouxesse alguns inconvenientes. (SARAZIN, 2011: 27'- 29')

Vale lembrar que a referida urgência não se restrin-

gia ao caso de Toulouse pois ao apresentar um diagnóstico a situação de atraso física do ensino superior na França em 1968, Emilio Tempia reconhece que grande parte do resultado questionável das propostas arquitetônicas para as novas universidades se justificaria pela ausência de uma reflexão mais aprofundada em relação à atualizaç̃o das necessidades e do papel da universidade, pois

[o] fator decisivo, entretanto é que talvez, tenha organização capa de deses o a nuantida as necessidades a serem atendidas [...] É tão evidente que o estudo de um projeto deva ser precedido de uma análise das funções do espaço que será edificado e organizaçăo das atividades que deverão ocupá-lo, que é banal lembrar que essa análise permanece obrigatória.290 (TEMPIA, 1968: 4]
Se por um lado essa indeterminação programática inicial foi um ingrediente precioso para a aplicação dos diu, entretanto, que os elementos construtivos estivessen suficientemente ordenados. Em outras palavras, o tempo como mecanismo de projeto para a evolução da obra troux dificuldades para sua concepção, implantação e, principalmente, para sua manutenção ${ }^{2}$

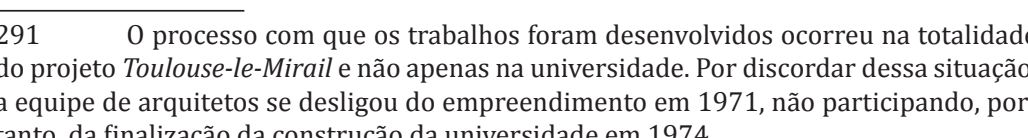
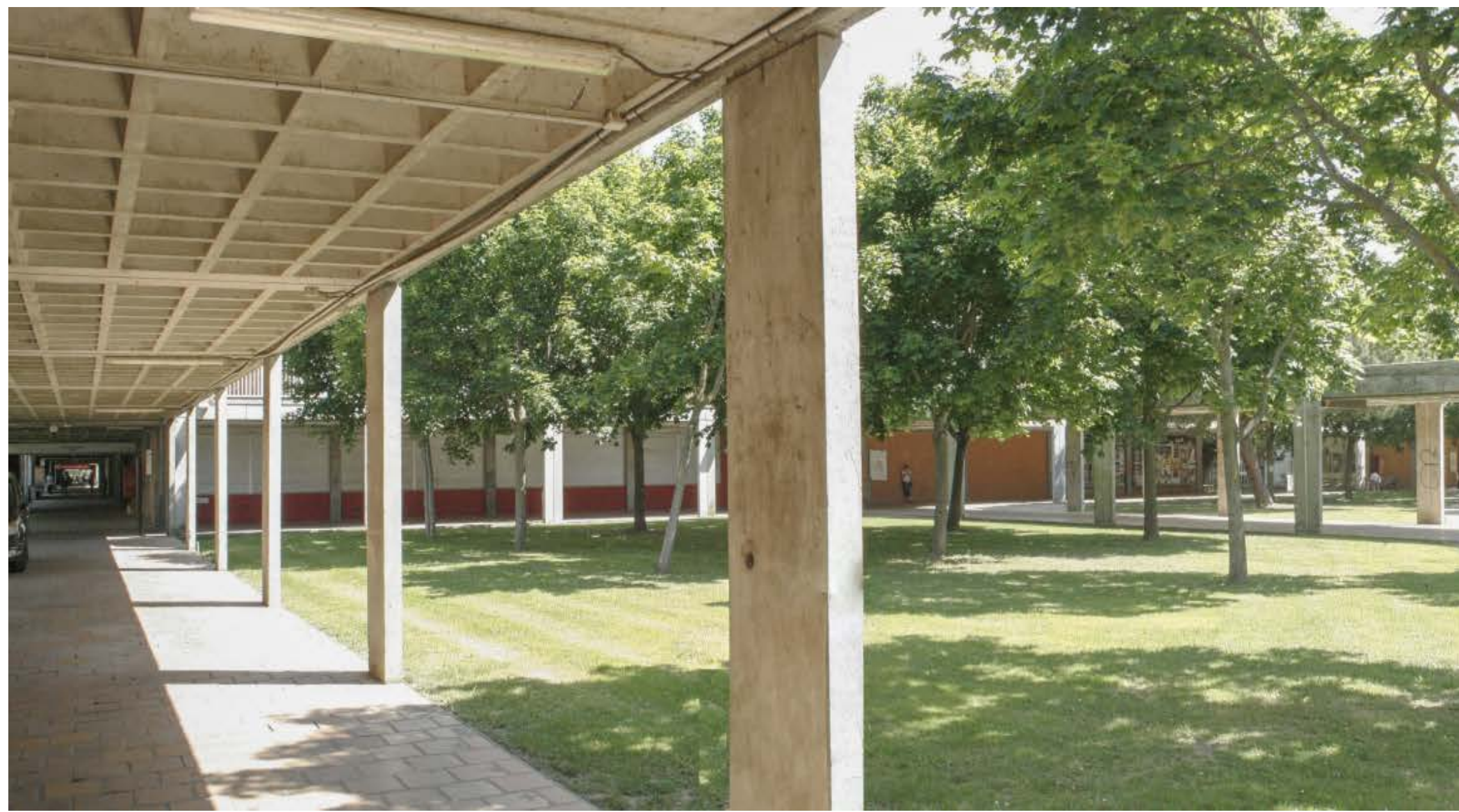

Wsta das galerias de pedestres no nivel do solo e sua relaçáa com os espaços descobertos. Foto: Valério Pietrarioia, 2012
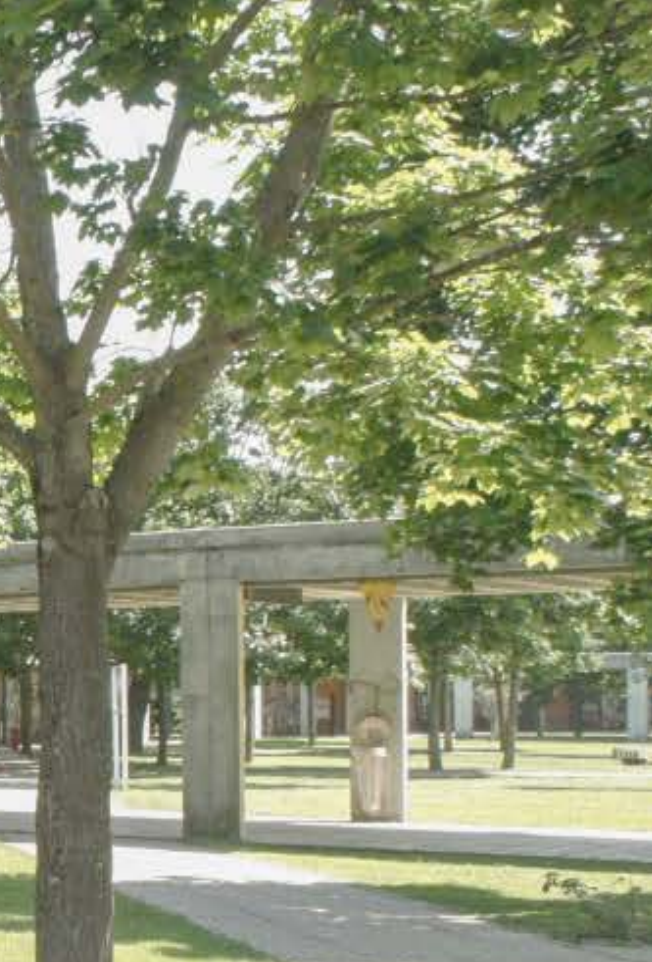
$-2$ 
Como vimos, as condições climáticas de Berlim não avoreceram a proposta do groundscraper de Candilis-josic-Woods. A aproximação entre os espaços exteriores - pá tios, praças e circulação - e as faculdades e institutos, ponto fundamental do sistema proposto, foi prejudicada pela necessidade de proteger os espaços internos das condições climáticas adversas.

Em Toulouse, ao contrário, os arquitetos puderam potencializar essa relação graças à situação climática mais favorável. Ao percorrermos as galerias longitudinais e transversais, em grande parte abertas para pátios ajardinados, é possível comprovar que o objetivo foi alcançado. Es ses espaços exteriores tornam-se fundamentais para a qualificação dos espaços funcionais interiores na medida en que oferecem 0 que o território possui de mais precioso, ou

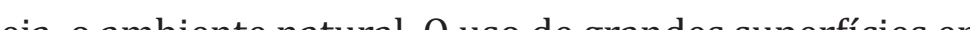
seja, o ambiente natural. O uso de grandes superfícies en draçadas no fechamento dos espaços de aprendizagem garante a qualidade superior desses ambientes, condição rara nos equipamentos de ensino superior franceses naquele momento, como assinalou Emilio Tempia ${ }^{292}$. As qualidades do projeto, no que se refere a seus elementos construtivos, foram confirmados pelos usuários que consideram ter $\mathrm{h}$ vido um grande avanço ao se oferecer espaço, luz natural contato com a natureza, aproximando uma comunidade dispersa mas não difusa e garantindo certo anonimato (SARAZIN, 2011: 25'-38').

e em Berlim a Universidade Livre pôde ser planejada e rea

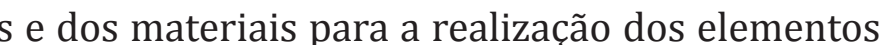
construtivos que a configuram, em Toulouse-le-Mirail o meio ambiente favorável e a urgência apontaram um caminho menor rigidez para o projeto, como veremos a seguir.

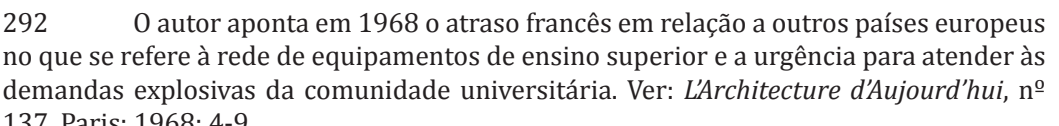

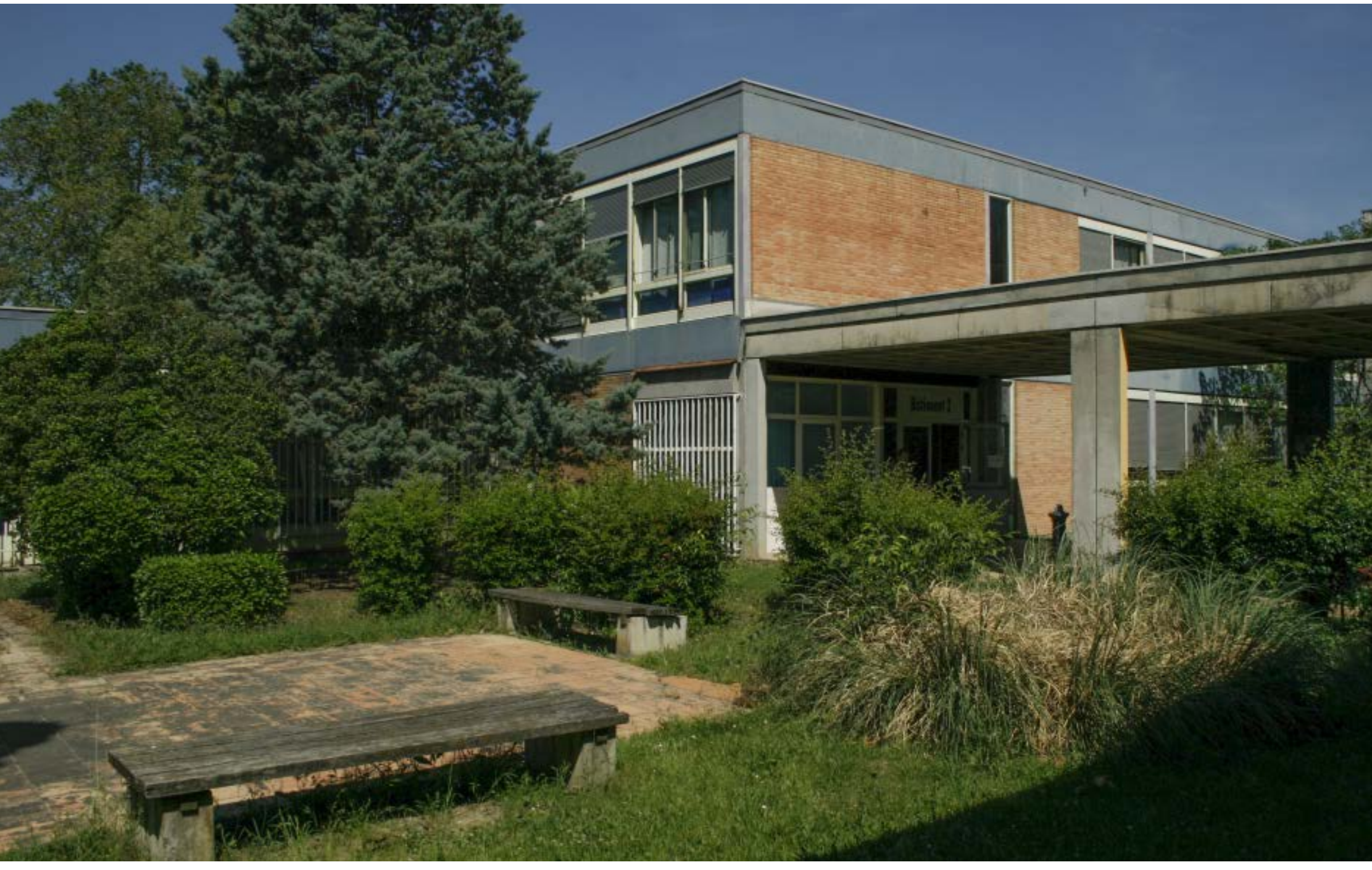

Vista dos pátios internos descobertos que promovem farta iluminaçăo e ventilaçăo naturais aos dois pavimentos da Universidade. Foto: Valério Pietraroia, 2012 


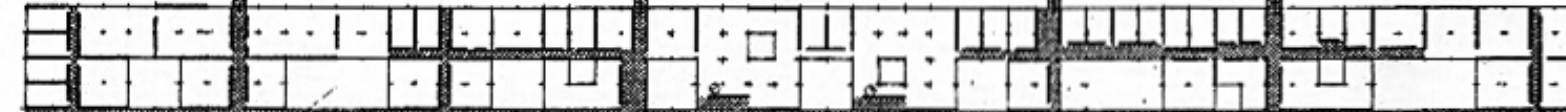 7. 4.

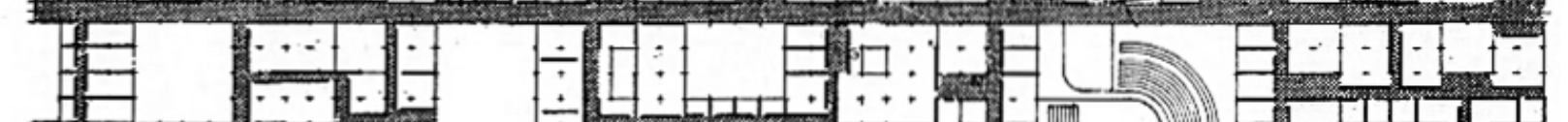

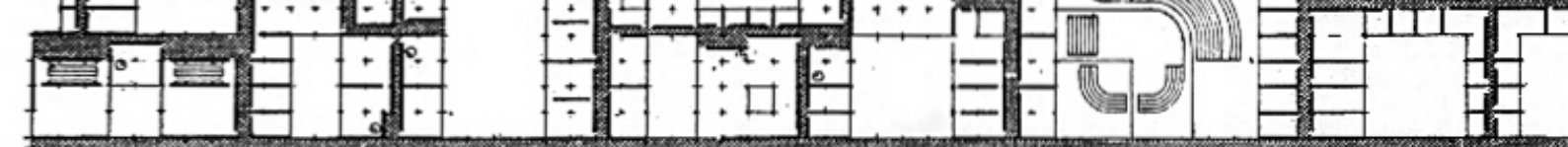

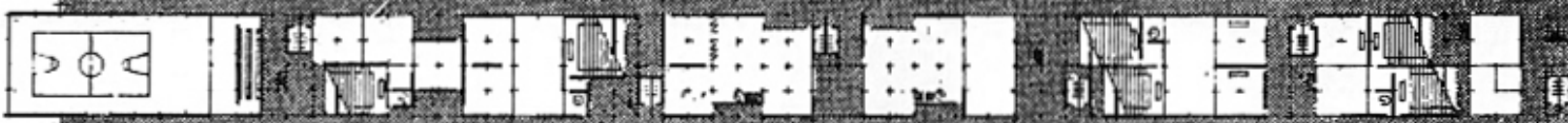 Hine 1.7.

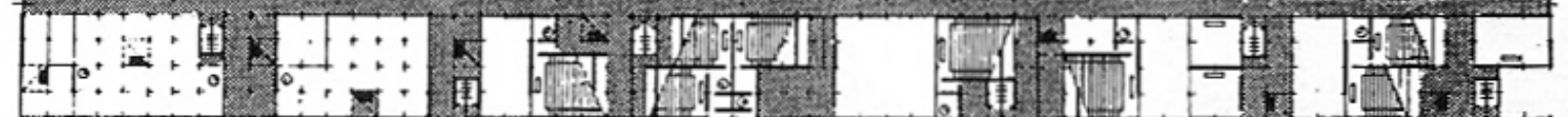

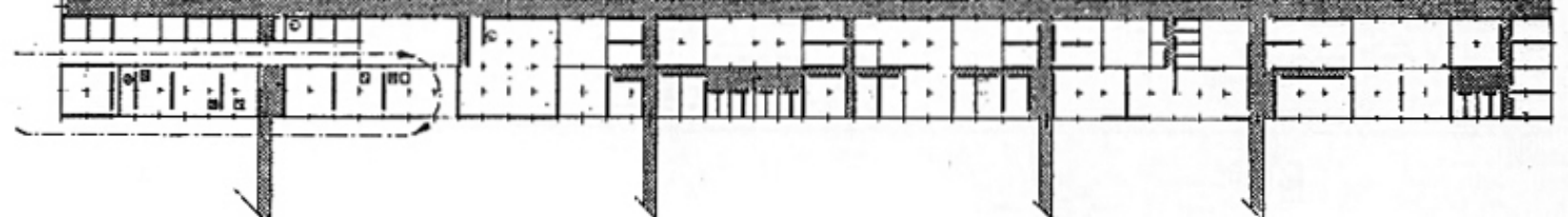

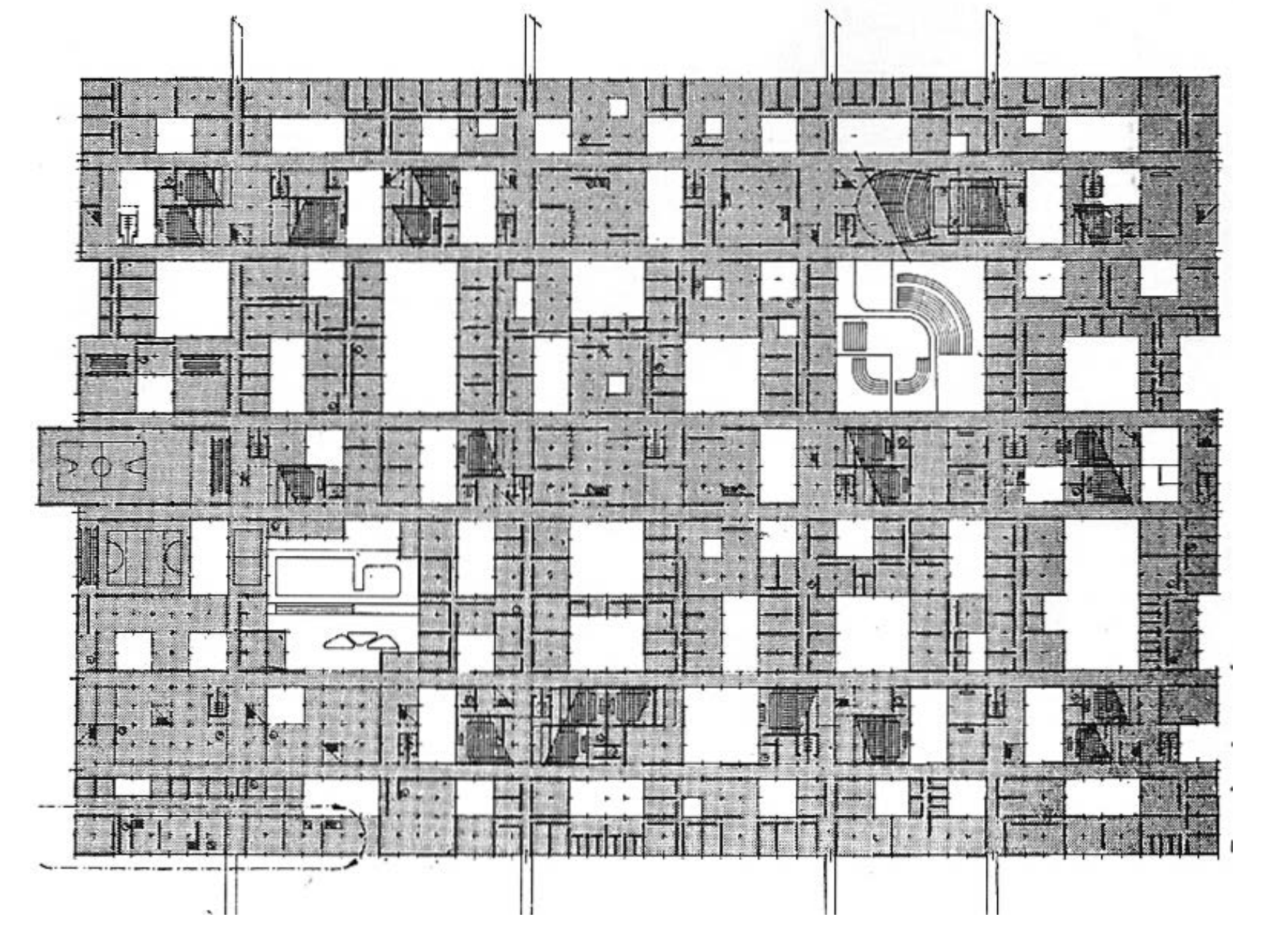



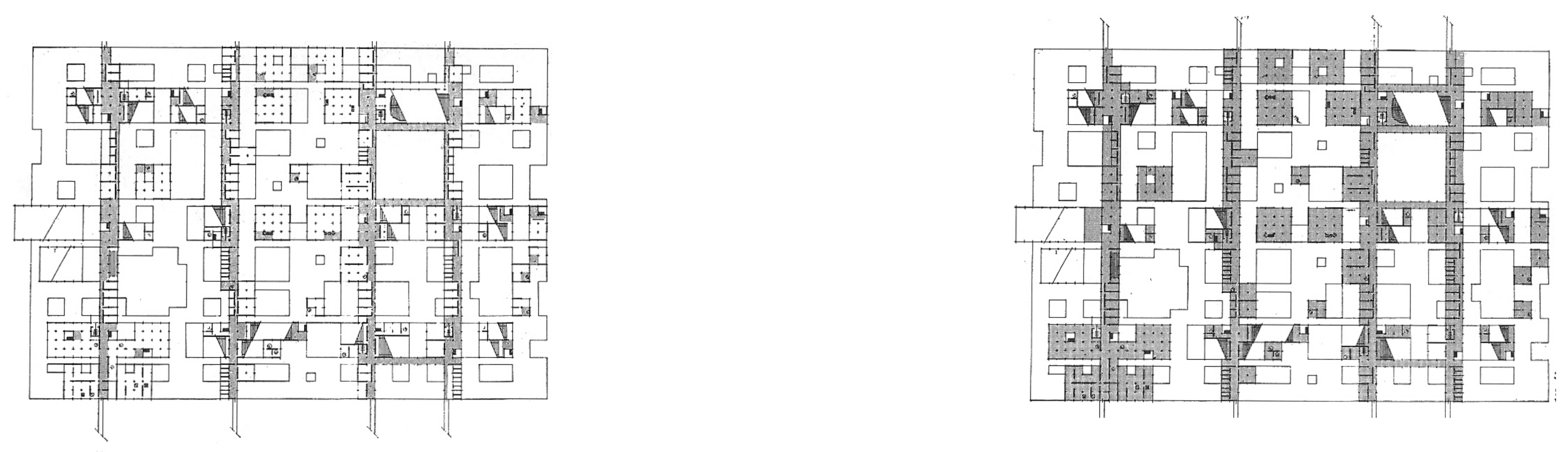

Universidade Toulouse-Le-Mirail - plantas do pavimento superior ; na primeira pla
as arreas descobertas podem ser claramente observadas. Fonte: JOEDICKE, 1975. 
reconhecer o desdobramento do projeto de Alison e Peter Smithson para a Hunstanton Secondary Modern School, em que $o$ chão ass Em Toulouse, os núcleos que ocupam o pavimento superior encontram as áreas compartilhadas de apoio e os outros núcleos ao se dirigirem para o pavimento térreo.

A partir dessas premissas iniciais, foi possível construir com certa liberdade uma malha estrutura moldado no e de lajes nervuradas, que areas conformadas pelo sistema de mobilidade. A solução ofereceu inúmeras possibilidades para fechamentos envidraçados generosos nas orientações favoráveis, contrapondo-se com painéis em laminado melamínico estrutural colorido e com planos em tijolo de barro aparente, uma forte referência à arquitetura histórica e vernacular da região. Ao percorrermos as galerias, as ruas e seus entroncamentos, podemos observar a variedade de situações que o projeto apresenta durante o percurso. Nesse sentido, a repeticãa dos elementos construtivos não oferece risco à banalizaç̃o ou à monotonia espacial.
Essa multiplicidade de situações, amparada pela oferta de condiç̧ōes ambientais e de infraestrutura favor veis, foi apo cepcional para aquele períod $0^{293}$.

Fica claro, portanto, que a menor rigidez do sistem roposto em Toulouse favoreceu a sua imediata implanta ção antes mesmo que o programa universitário estivesse totalmente definido. Vale destacar, no entanto, que a característica citada apresentou, com o tempo, dificulda de em se manter sem que houvesse interferências capazes de prejudicar seu desempenho e sua permanência, o que levou ao afastamento voluntário dos arquitetos em 1971 após construção das primeiras etapas da universidade. 0 projeto continuou a ser implantado até 1974 seguindo o sistem proposto por Candilis--osic-Woods, mas sempre se ando às demandas que foram surgindo.

A imagem aérea da obra publicada em 1975 mostra A coreza o sistema que conforma a Universidade e sua proximidade com o parque. Mostra também que a integração pretendida com o contexto não ocorreu como previsto. As dificuldades de acesso ao transporte coletiv 293 Ver SARRAZIN, 2011: 25'-27.

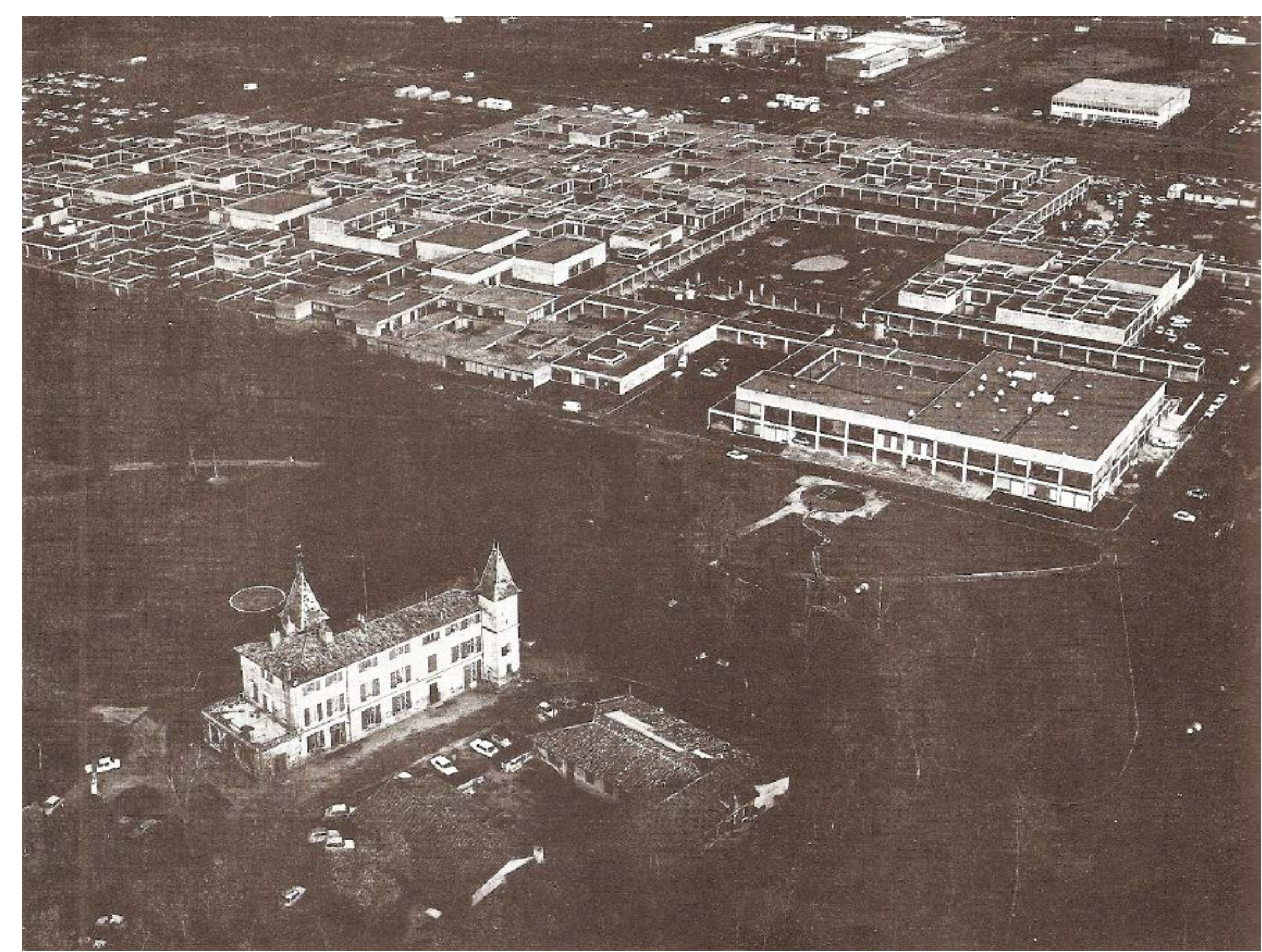

Whárea oeste da Universidade Toulouse-Le-Mirail. Em primeiro plano, o parque onde está localizado o Château du Mirail. Fonte: JOEDICKE, 1975 

dos grandes conjuntos habitacionais ocorrido nas décadas seguintes na Europa, e particularmente na França, imp diram que oprojelo prosseguisse alcançasse seus ibjetvos com plenitude.

A visita ao local demonstra certo isolamento da unversidade tanto em relação a Toulouse como ao Mirail. Ap sar desse fato, vale destacar a intensa atividade que é possvel verificar no interior das galerias e dasáreas coletivas. As cinco décadss sistência, mas não a afastaram de questionamentos, o que levou a recentes intervenções que pretenderam atualizar o "espírito Candilis" às exigências atuais. No nosso entendimento, é possível verificar entretanto, que as obras realizadas e mesmo a retirada de alguns setores não appgaram o sistema or izado Sabenos queoinpacto das nows techologis assin como o das transformações dos modos de aprendizage delas decorrentes trouxeram profundas alterações no interior da comunidade universitária, como pode ser visto, nos depoimentos dos usuários atuais ${ }^{29}$. Mesmo considerando a rigidez estrutural, apontada por Gian Carlo De Carlo no in cio do cap the geometria reconhecível e duradoura, baseada nos ensin mentos de Louis Kahan, como pudemos observar. Cabe salientar ainda que a situação acima descrita não se restringe somente à situação da Universidade em Toulouse. A universidade como tema da arquitetura, da Te aprendiza gem, permanece evoluindo de maneira intensa, o que foi possível comprovar em nossa pesquisa. Podemos considerar que esta seria uma das constantes do espaço da aprendizagem por abrigar um equipamento social sempre muito sensível à dinâmica da comunidade. Do ponto de vista rojeto, a importância do tema comprova que somente as qualidades dos elementos construtivos, apoiados nos fundamentos que a conceberam, podem garantir a permanência da obra. Esse raciocínio vem ao encontro do que Guido

$294 \quad$ Ver SARRAZIN, 2011

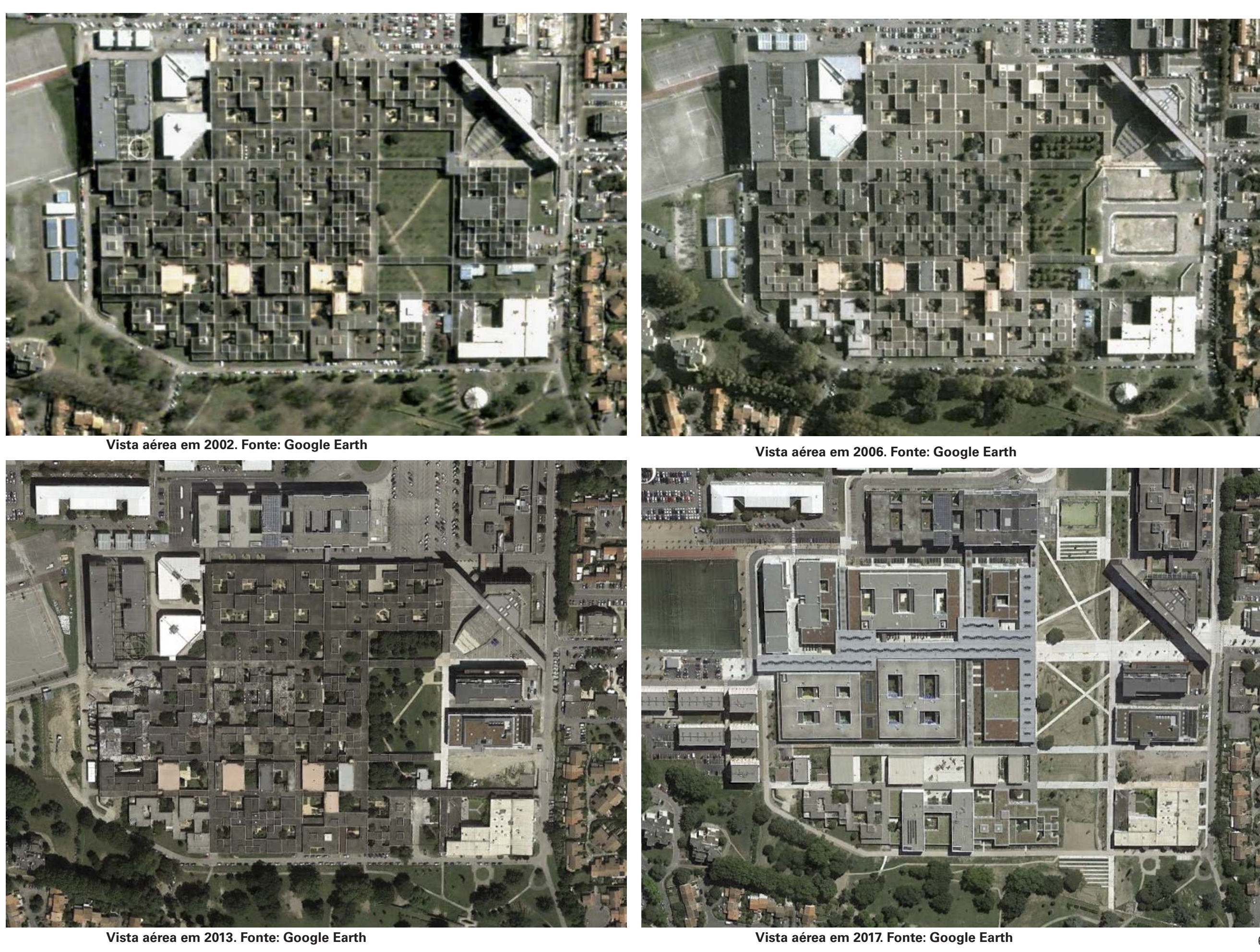


bém atuou para intermediar os conflitos, como demonstra

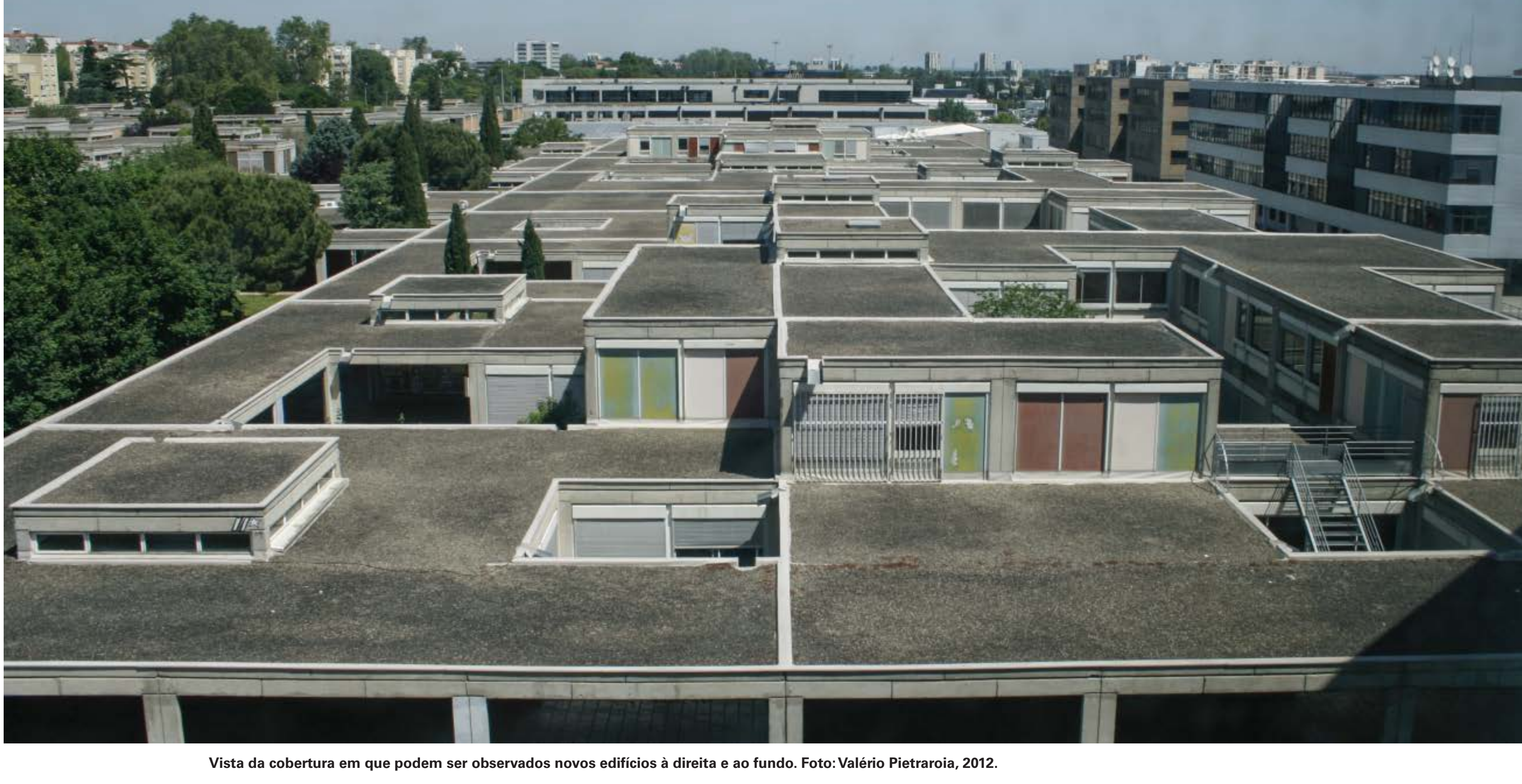

Creio que nesse contexto [abandono da históri da autonomia da forma e da funcionalidade com fundamentos do projeto] os elementos de aprecição mais construtivos são os que religam a expressão arquitetônica ao ambiente urbano ao revel rem assim caractentsicas invariavels (poderiamos falar de "codigos" utilizando a terminologia atual)

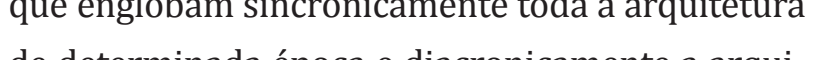
Te de

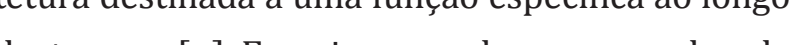
do tempo. [...] Examinemos alguns exemplos de 

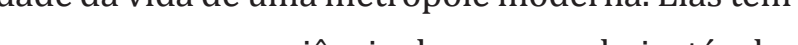
de seu papel em perpétua evolução. . $^{25}$ (CANELLA, 1968: 16-17) 


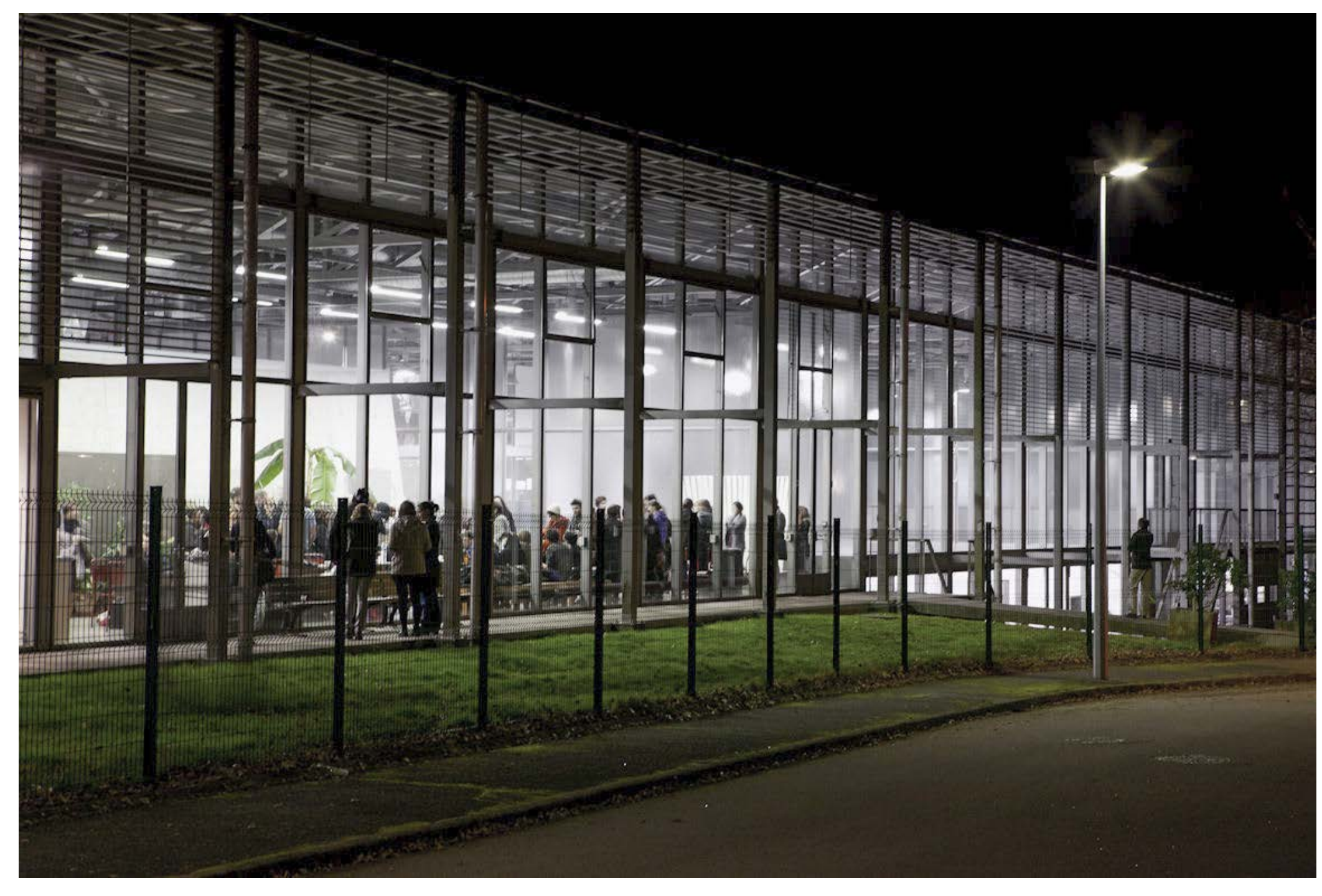

A linha de trabalho do LAB.F.AC. pode ser considerada o desdobramento de uma postura crítica à rigidez do espaço da Arquitetura Moderna, postura que, se atis às demand contemporâneas. Nesse sentido, a ENSA apresenta-se como uma oportunidade de investigação importante na medida em que a escola, com mais de vinte anos de funcionamento, enquadra-se em nosso objeto de pesquisa por ser um equidas no presente capítulo.

As propostas do grupo, expressas em seus projetos textos ${ }^{298}$, revelam estreita relação com os questionamento críticos da década de 1950, protagonizados inicialmente por Louis Kahn e pelos arquitetos do TEAM X, defensores de uma arquitetura aberta mas estruturada, em resposta

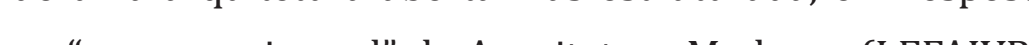
e TZONIS, 2000: 54).

$298 \quad$ vera

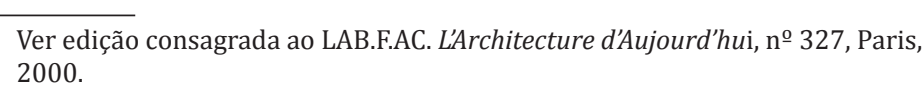

Elas demonstram também muita proximidade com as conhecidas reflexões contidas nas propostas de Italo Calvin (1991) para o novo milênio, escritas em 1985 e publicadas em 1988. É muito provável que os arquitetos tenham tido conhecimento do livro de Calvino ${ }^{299}$, pois a forma de apresentação dos projetos parece se apoiar em propostas como a da multiplicidade e a da visibilidade. Mas é nos valores de leveza e de consistência que a aproximação citada pode ser melhor percebida Ainda que o desaparecimento de Calvino cen consistenctia, que seria a sexta por ele prevista, o LAB.F.AC defende a arquitetura concebida a partir de soluções técnicas de menor complexidade, por sua capacidade de manter a leveza do conjunto, o que traria agilidade de evolução sem abandonar a consistencia original da obra Nesse sentido, o projeto se aponr de apontar novos caminhos ou pelones, de nõ inper sua natureza criativa perante os usuários.

$299 \quad$ A primeira ediçăo francesae é de 1989, Paris, Éditions Gallimard 
Em nosso trabalho de mestrado (PIETRAROIA, 2014) ficou evidente como a complexidade das estruturas responsáveis por

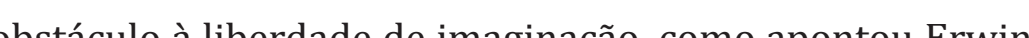
Piscator ${ }^{300} \mathrm{em}$ 1961. Assim, tanto para o encenador teatral como para o LAB.F.AC., por meio da simplicidade formal "o edifício não fica pronto após sua construção, pois ele apresenta um ponto de partida para os usuários" (KLAUSER. 2000: 83).

É importante lembrar ainda que o momento em que LAB.FAC põe em prática sua arquitetura concebida menos . ração entre diferentes elementos, é o período de sucesso da spetacularizaç̃ da arquitetura como ocorrido, por exemplo, com o Museu Guggenheim em Bilbao ${ }^{301}$, que o arquiteto Frank 0. Gehry, com sua força expressiva perturbadora, conseguiu inserir cuidadosamente no contexto local. Entretanto,

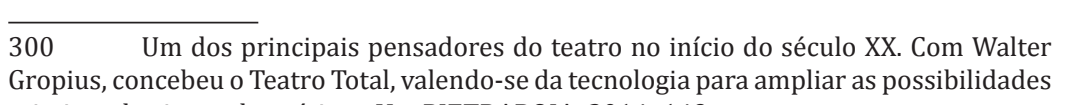

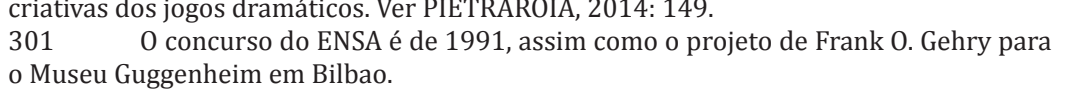

mesmo nesse caso, grande parte do museu foi concebido internamente por geometrias ortogonais e pautado em deter(2013: 451), seria uma das razões pela receptividade positiva do meio artístico local, algo que não acontecera com o Guggenheim nova-iorquino de Frank Lloyd Wright.

Outro aspecto importante do projeto para a ENSA diretamente com a mobilidade e a conectividade quec

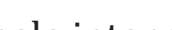
comunicação são responsáveis pelo surgimento de pontos de intensidade em que as atividades criativas podem avançar. Em outras palavras, os locais de convergência são materializados pelos dispositivos de trocas físicas e mentais 政 como a conhecemos atualmente não tenha sido consideTada no momento da concepc̃̃o do obra o projeto estaria muito próximo das propostas de espaços em rede, defenddas por Shadrach Woods (1962), ou ainda dos mat-building de Alison e Peter Smithson (SOWA, 2003a). 


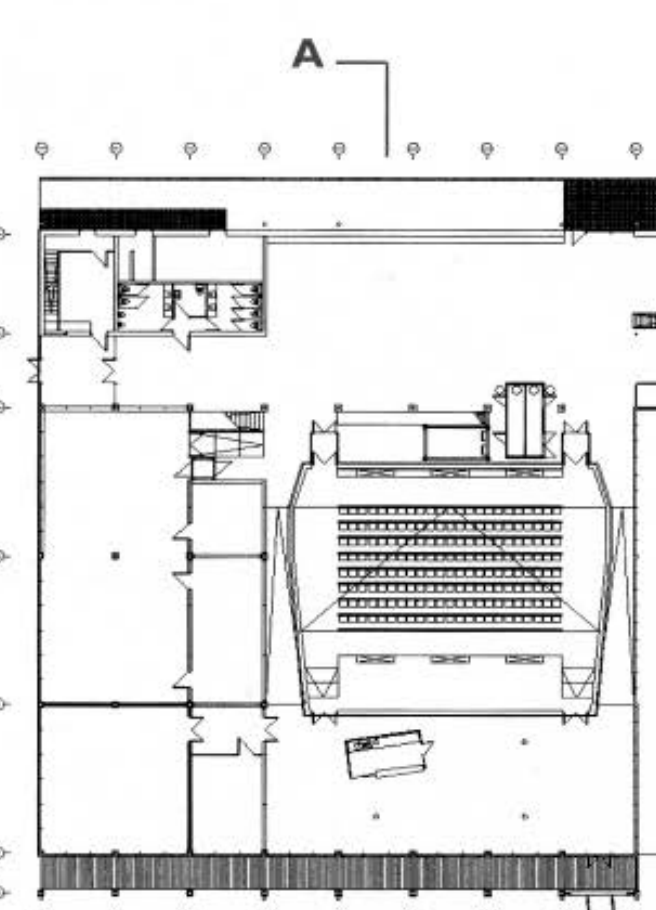

A

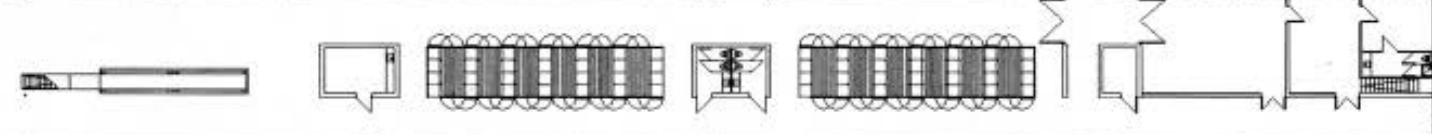

Plan du rez-de-chaussée

|WM M.M.M

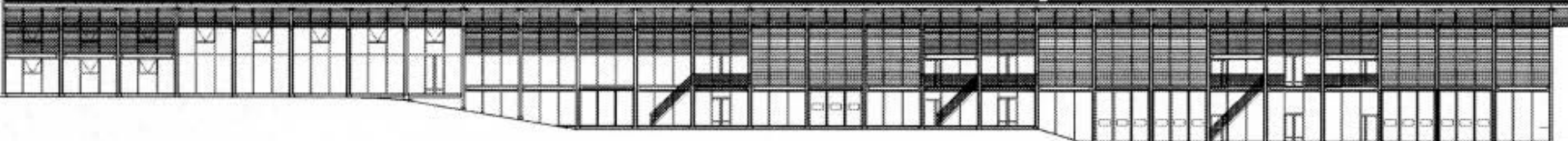
Façade ouest

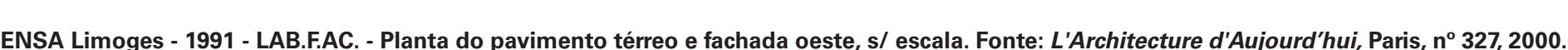

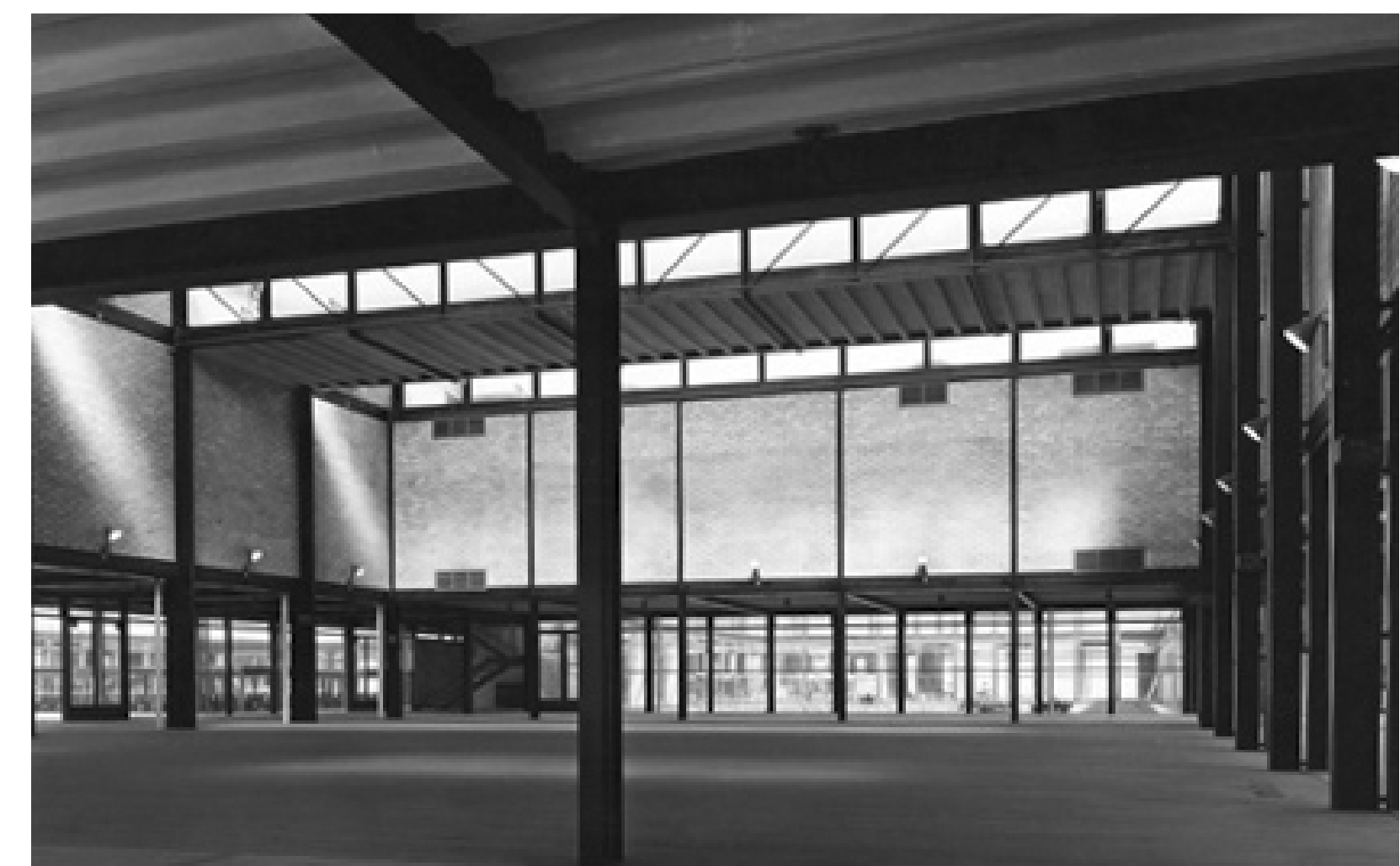

Hunstanton Secondary Moderm School- Norfolk- 1954.Alison e Peter Smithson. Fonte: RiBA carchitecture.com
Visualizado em $15 / 02 / 2018$.

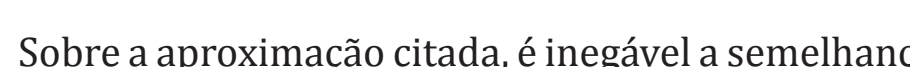

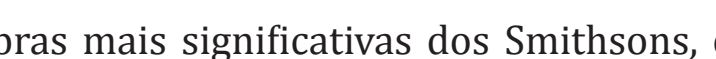
Hunstanton Secondary Modern School em Norfolk ${ }^{302}$, na Inglaterra de 1954, com a arquitetura da FNSA. Tl fato chama a atenção não apenas pela proximidade entre a solução construtiva baseada na estrutura metálica racionalmente

dén obra, mas particular pela interação espacial no interior da escola sua estreita aproximaç̃o com o exterior, garantidas pela J Iternância de escala entre os espaços ocupados eos vazios e, em grande parte, definidos por fechamentos translúcidos ou transparentes. 
Em Norfolk não há eixos de circulação que articulem a escola, como em Limoges. Todavia, em nenhum momento há distanciamento ou isolamento visual em relação aos pátios abertos ou cobertos ou mesmo em outros espaços coletivos, o que demonstra o interesse dos arquitetos do LAB. F.AC. pela obra dos Smithsons. Assim, há uma busca comum pela construção de um sistema de organização espacial que vá além da materialização estrutural.

Podemos observar que para o LAB FAC a arquiteturializam por meio de operações que promovem sua justaposição e concentração, ou seja, o projeto desfaz a noção de hierarquia e de expressão espacial sem que a obra se aproxime do genérico ou do espaço universal moderno.
Outro exemplo notável em que tais estratégias do grupo ficam evidentes é o projeto para o Métafort, consttuído substancialmente por dois elementos: una ma que suporta de maneira livre os ambientes funcionais previstos no programa e que garante infraestrutura atual e futura, e uma cobertura, cujo vão livre garante a liberdade de ocupação interna. As edificações que possam vir a se acoplar ao corpo principal atendem a programas mais definitivos, por exemplo, um silo de estacionmento ou aprtamentos de artistas resides As avidades depe culturais e sociais no interior do conjunto edificado beneficiam-se do amplo espaço de interação previsto prelimina mente e que deve evoluir em função das demandas que o Centro de Pesquisa Multimídia venha a ter, como mostram as simulações abaixo.
Apesar de uma aparente proximidade deste projeto com o Teatro Nacional de Mannheim de Mies van der Rohe, que apresen tulo 3, em particular pela criação de uma plataforma sobre a qual a infraestrutura distribuída e pelo vão livre generoso da cobertura, que oferecem liberdade total para que o programa se desenvolva as relações entre os espaços internos e sua relação com os espaços externos não se dão de maneira unitária. Isto é, dinâmica interna ocorre pela fragmentação do programa em unidades autônomas que pretendem intensificar suas trocas através dos pontos de convergência de circulação e de infraestrutura

ob esse ponto de vista, as dificuldades estarian na percepção dos espaços intermediários, os vazios com os quais a realidade é feita, embora nossos sentidos perce bam mas facilmente os objetos, conoo bam Montaner (2009). Montanor explca como as formas de articulação e intersecção a que nos referimos servem-se de sistemas lineares de natureza neoplasticista, formando dispositivos independentes ou conectados, como um sistema aberto e expansível.
Nessa mesma linha de raciocínio, Ana Claudia Castilho Barone (2002) observa também como é notável, na obra dos Smithsons, a influência dos vazios que car

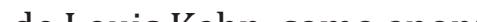
tulo anterior

Retornando ao projeto do Métafort, o concurso previa sua implantação no interior dos vestígios do Forte de Aubervilliers, cidade da região metropolitana de Paris, contexto portador de pouco significado urbano, como pode ser observado na vistron

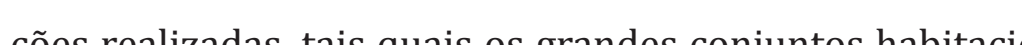
nais, o "Les Courtillières" ou a Serpentina, construído por Émile Aillaud em 1954, em primeiro plano e o estacionamento que ocupa o terreno, envolvido pela vegetação que marca a posiç̃oo original da muralha do Forte.

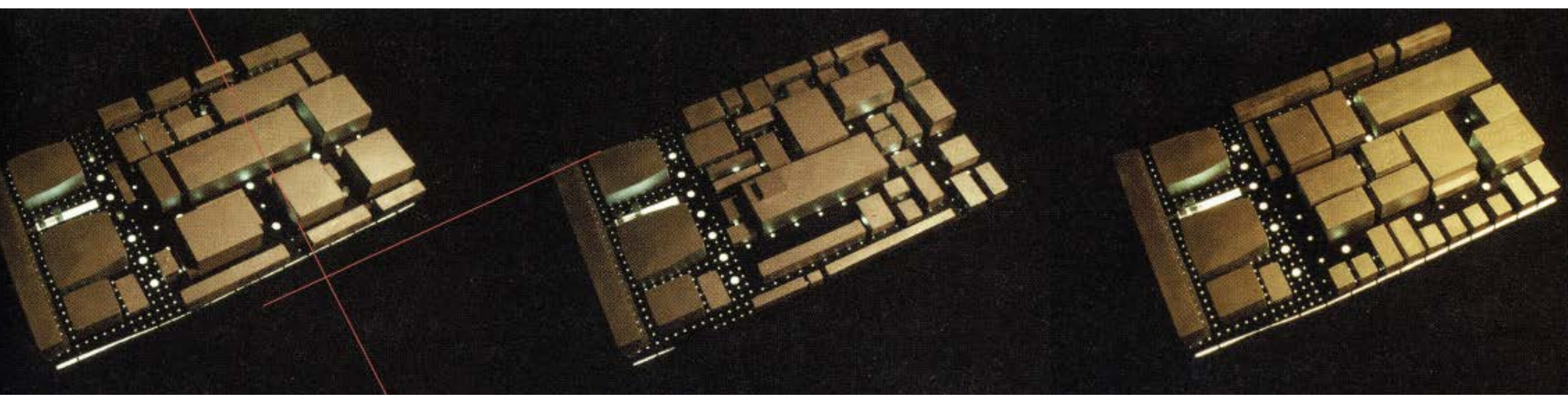


Qbi-a 0.0 는

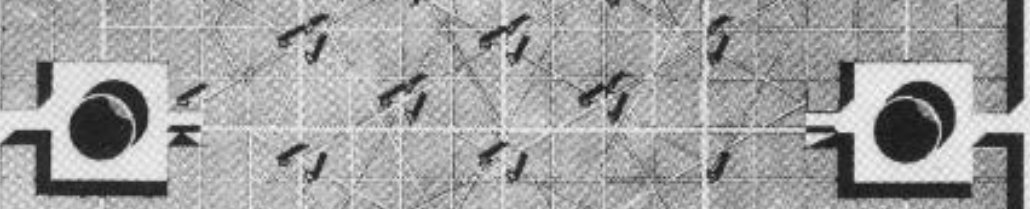
Q

Métafort Auberviliers 1997.
jourd'hui, $n^{\circ} 327$, aaris, 2000 .

Pelo que foi observado na obra do grupo LAB.F.AC podemos dizer que é possível encontrar semelhanças entre sua metodologia de projeto e as ideias nela contidas e os questionamentos protagonizados, em especial, pelo grupo TEAM X. Pode-se também aproximá-lo de algumas refle xões de Mies van der Rohe, que apresentamos no capítulo 3 para quem a forma estaria muito mais dependente da eco-

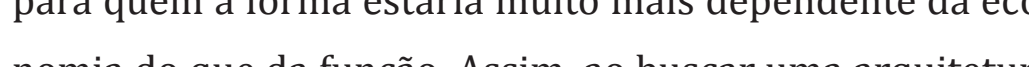
que pouco se compromete com questões de forma e estilo,

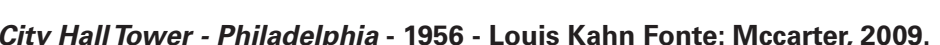

o LAB.F.AC. indica um caminho em que a realidade poderá estar cada vez mais indeterminada, e a arquitetura menos definitiva. Isso justificaria certa fragmentação dos espaços contidos no interior do conjunto, uma oposição ao espaço único, universal. Devemos lembrar, que o concurso para o projeto da ENSA foi feito apenas dois anos após a queda do Muro de Berlim (1989), momento que marca o ińcio de un mundo de maior proximidade, inaugurando o período de grande conectividade em que vivemos. 


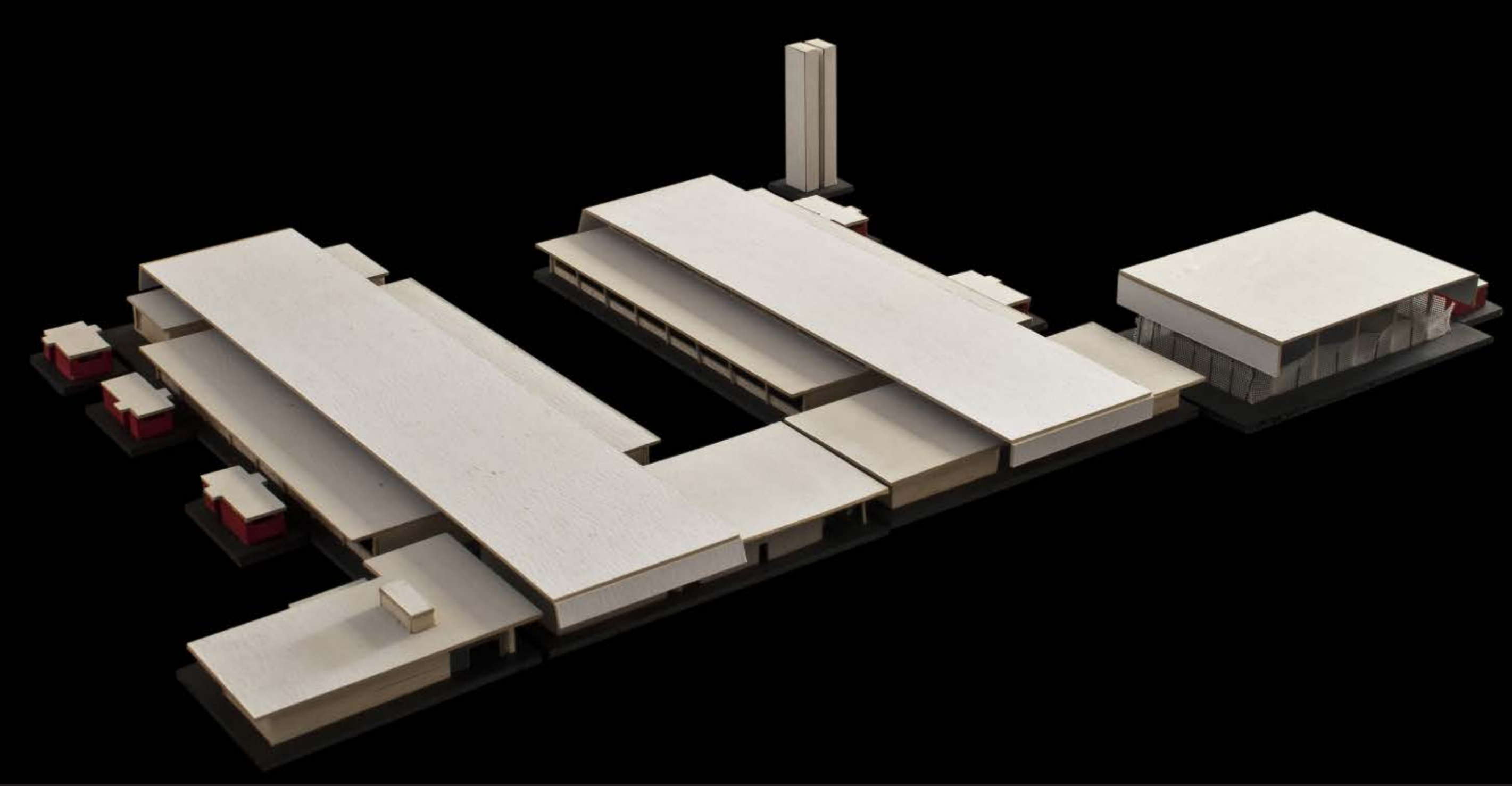

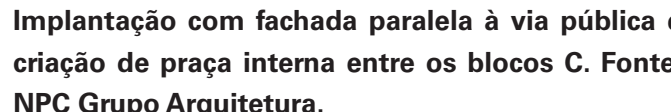

Mas não é a padronização anstancial e sem uso criativo do contento que padronização?

VENTURI, 2004

Serviço Nacional de Aprendizagem Industrial, SEAII, teve papel significativo, desde sua criação, na educação profissionalizante voltada para a atividade industrial. Sua contribuição na construção de obras significativas da arquitetura moderna brasileira, e em especial daquela praticada no estado de São Paulo, é destacada pela historiografla ntes como Hélio Duarte, Roberto Tibau, Ernesto Mange e Rino Levi, entre outros (FERRAZ, 2008). 


\section{$x-2$

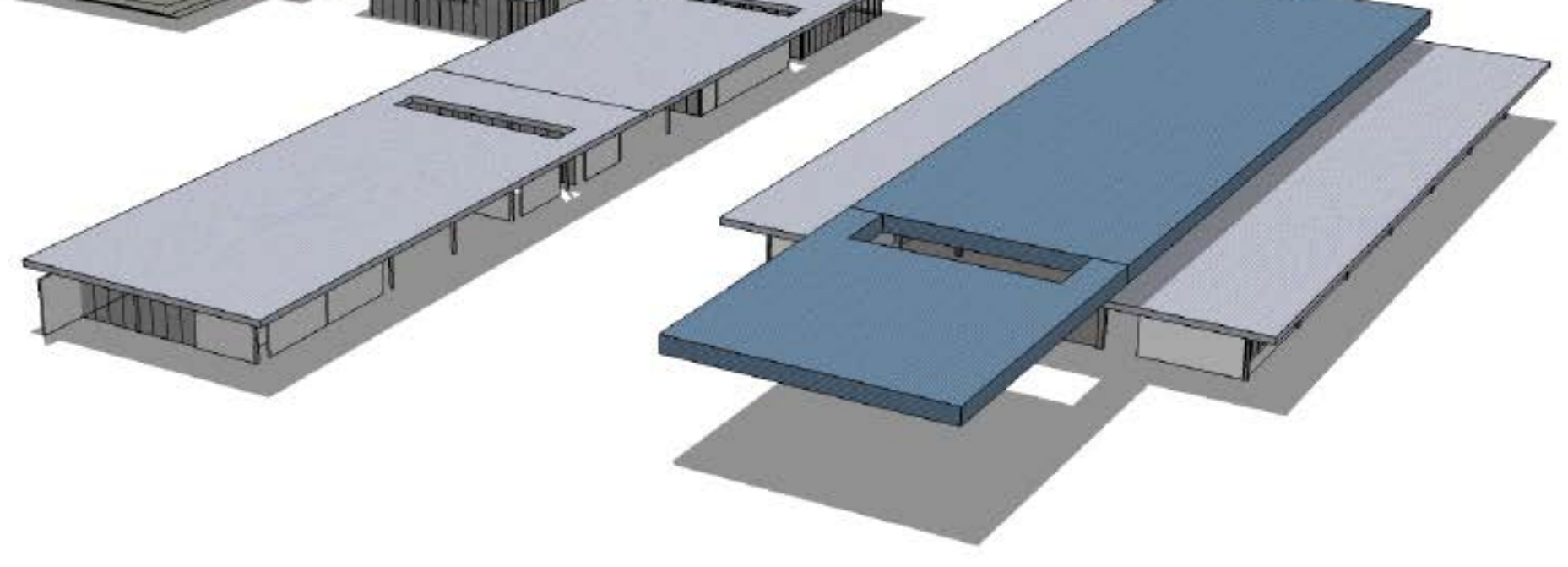

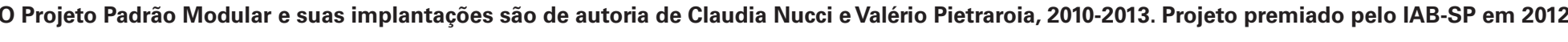

A expansão de sua rede de escolas conheceu um período de estagnação durante as décadas de 1980 e 1990. Com o objetivo de atender às urgências decorrentes das carências educacionais e do crescimento econômico recente, foi elaborado o chamado Padrão Modular, um modelo ou padrão

apaz de atender à diversidade de situações presentes nas cidades do interior do estado de São Paulo, cuja nascente vocação industrial decorre da migração das empresas que abandonaram a região metropolitana da capital, da globalização econômica e do incremento das novas tecnologias.

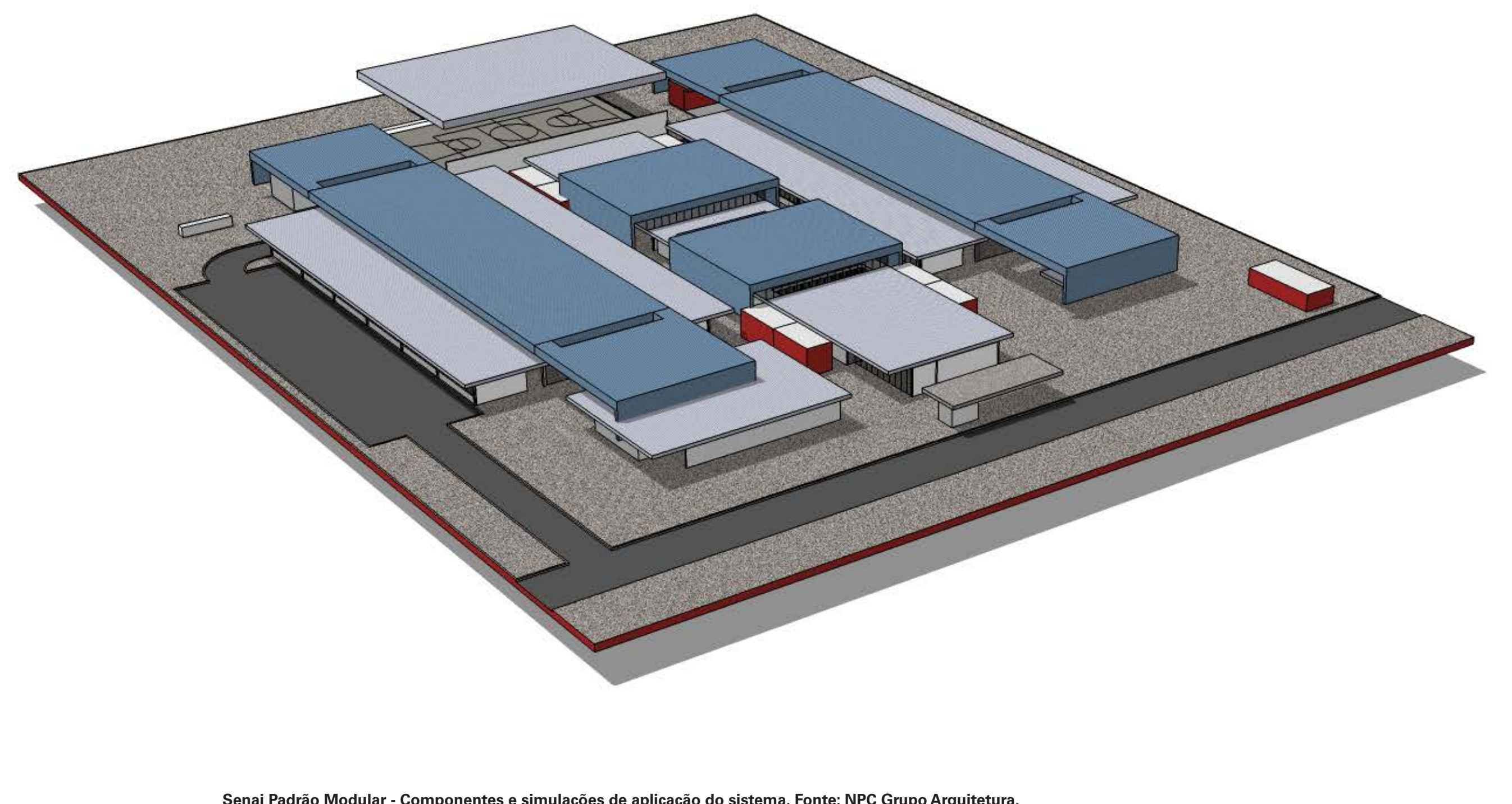

Senai Padrāo Modular - Componentes e simulacōess de aplicacāo do sistema. Fonte: NPPC Grupo Arquitetura. 


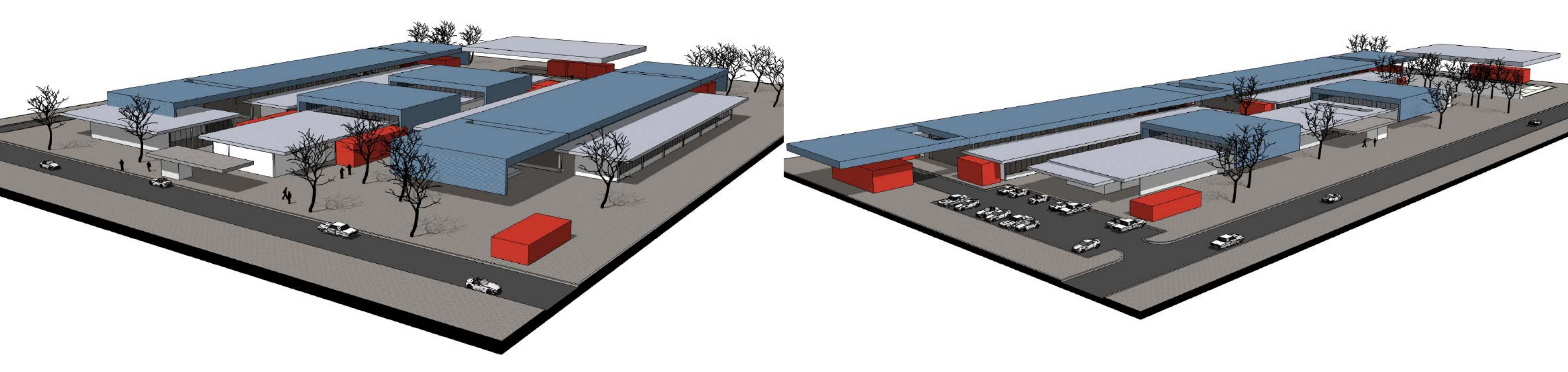


0 projeto desenvolvido ${ }^{304}$, baseado na noção de sistema, foi além da concepção do modelo, do "carimbo" a ser reproduzido. Sua implantação em quinze regiões diferentes (nove delas construídas) atendeu a programas diversficados para escolas técnico-industriais localizadas em cidades de portes distintos, como Iracemápolis com 20.000 habitantes, e Sorocaba, com 600.000 habitantes e origino obras entre $5.500 \mathrm{~m}^{2}$ e $12.500 \mathrm{~m}^{2}$ respectivamente.

$$
\text { Nesse sentido, o projeto teve que enfrentar os dois }
$$
rrama indeterigas a prom

É certo que há um conhecimento bastante consistente das condições físicas do estado de São Paulo. Sabemo também que o grau de urbanização das cidades do interior da guardam caracteríticas rurais em muitos dos teres disponiveis

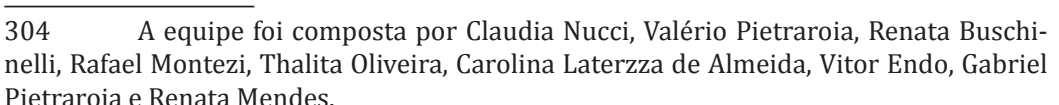

Da mesma maneira, o ensino técnico-industrial possui parâmetros e procedimentos com os quais o Senai acumulou uma longa experiência, fundamental para o projeto. Entretanto, os programas educacionais são bastante amplos em função da vocação industrial de cada cidade do estado. 0 parque industrial do interior paulista abriga indústrias automobilística, alimentícia, petroquímica e indústria moveleira, entre tantas outras, e cada uma indica uma necessidade de aprendizasem espećfica Alóm dissor o setorindustrial atravessa o quééconhecido como a quarta revolução industrial, modificando grande parte dos processos utilizados, introduzindo alterações significativas e ritmo acelerado nos procedimentos até então consagrados. Isso significa que a escola deverá refletir a mudança e a inovação permanentes abrindo possibilidades para que novos processos de produção sejam criados.

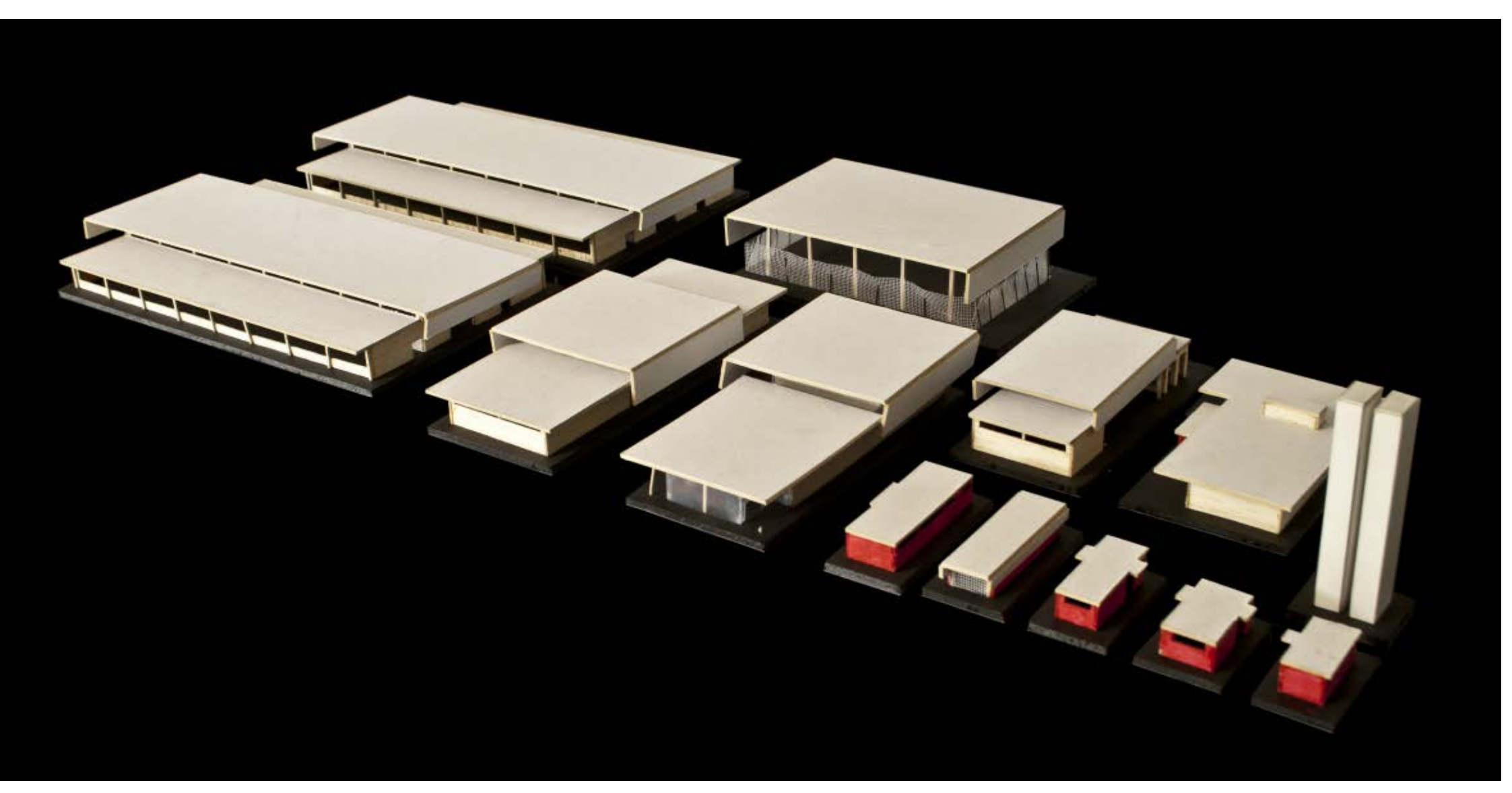

Senai Modular. Fonte: NPC Grupo Arquitetura 

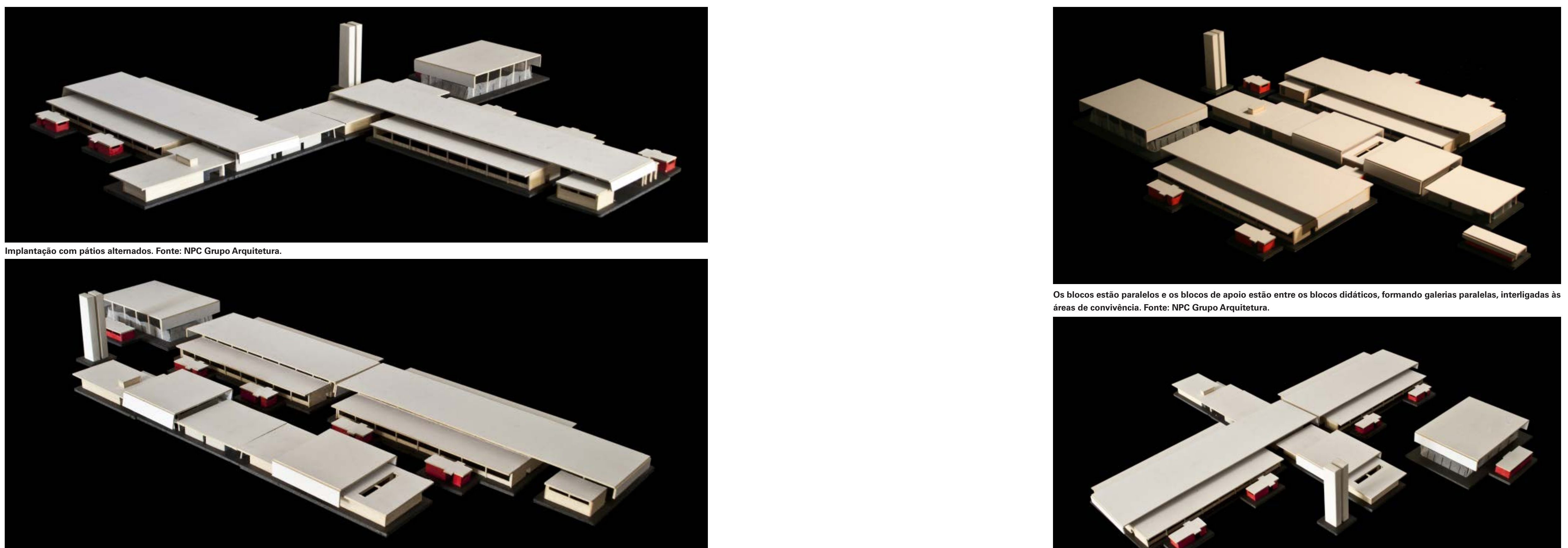

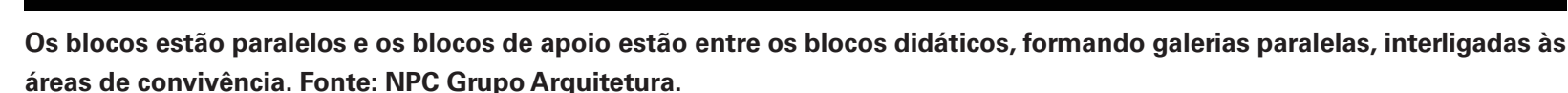

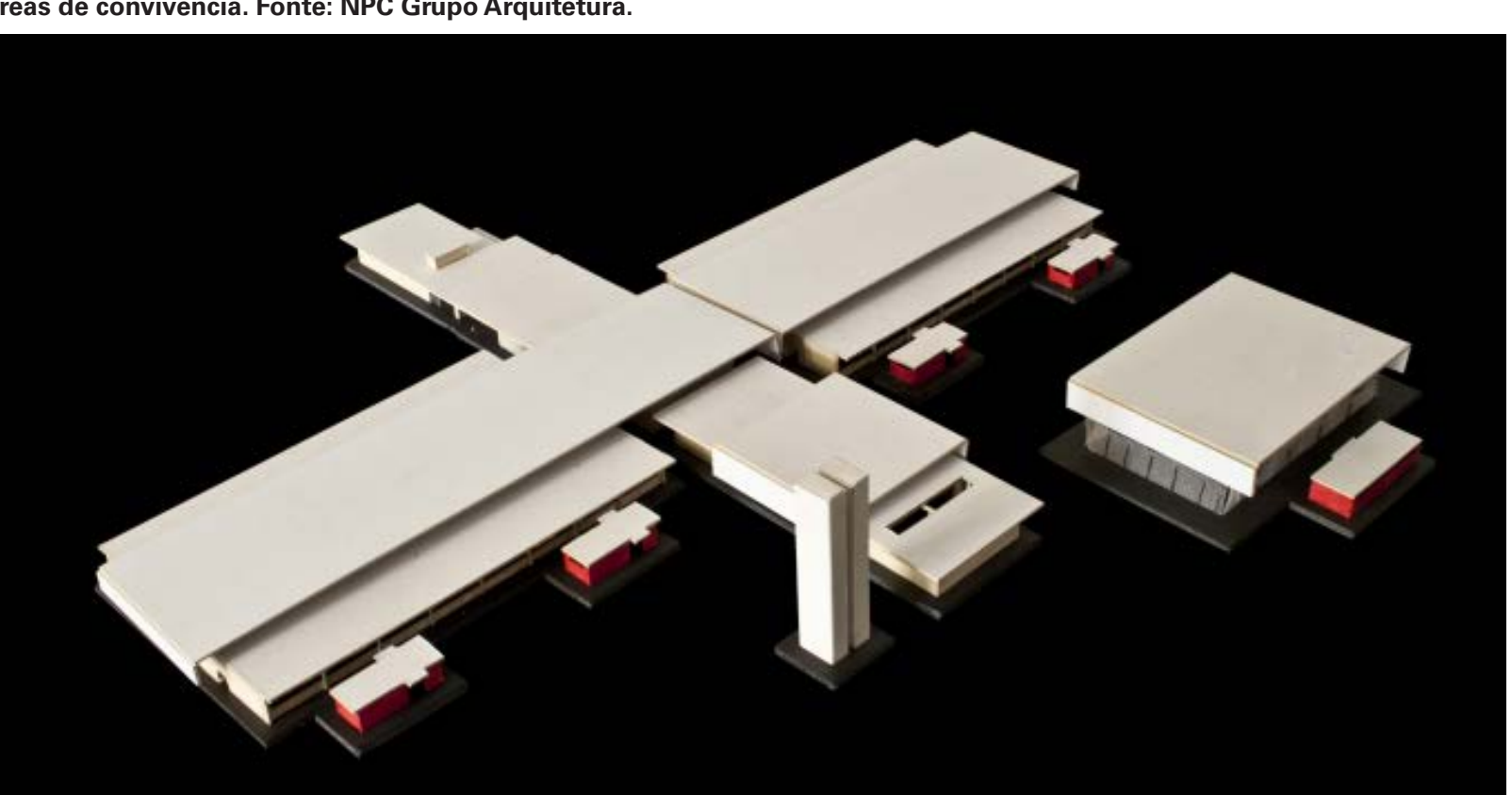




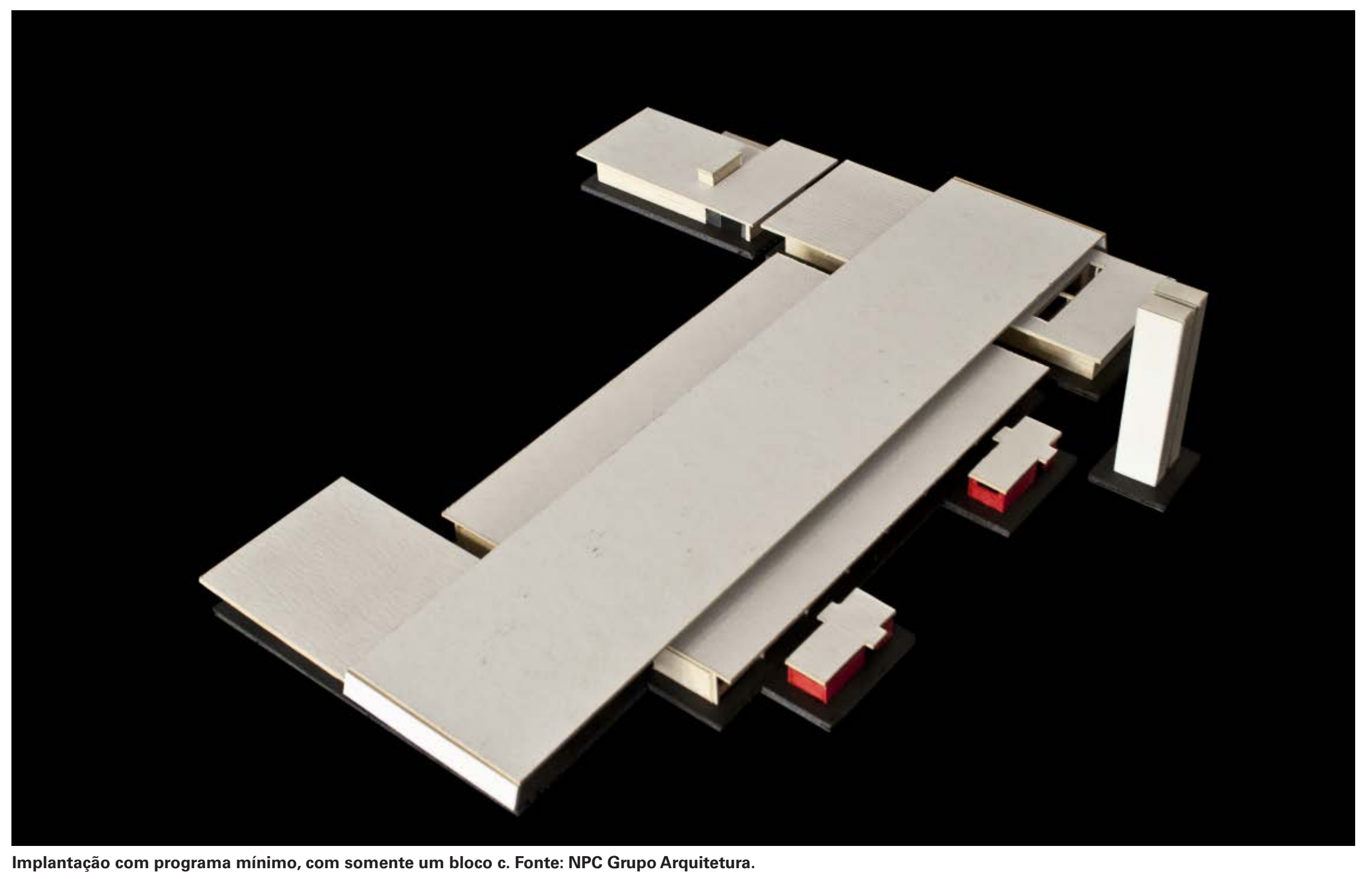

No projeto elaborado, as edificações são padronizadas, mas permitem liberdade de implantaçao, necessarria para atender ̀̀ diversidade de situações e de condiç̧oss bientais que deverão ser enfrentadas, tornando-se, assim sua principal característica.

0 programa da escola foi organizado em edifícios in dependentes, chamados aqui de Blocos, que atendem à totalidade das funções fixas e também das variáveis, adaptadas às necessidades espećficicas de cada atividade industrial para a qual a cidade tem vocação. Mesmo nesses casos, a arquitetura do Bloco está definida, deixando livre a ocupação interna, seguindo parâmetros e modulação pré-determinados

Todos os blocos, com exceção do Bloco C, possuem programa predefinido. Sua ocupação deverá respeitar o projeto de distribuição-padrão

O Bloco C, por abrigar as atividades didáticas que serão definidas em função da vocação local, não possui programa predefinido, sendo sua ocupação e distribuição determinadas em função das modulações e padrões do proje- to. Ou seja, é o bloco didático que irá nortear o projeto para a organização do conjunto, não pela disposição pavilhonar mas por uma articulação dinâmica dos volumes Os Blocos $\mathrm{P}$ funções primordiais da Escola, são edificações térreas, que seguem a mesma modulação estrutural, projetada com pilares pré-moldados em concreto e cobertura metálica. As duas alturas internas (3,5m e $6 \mathrm{~m}$ livres), os vãos necessàrios e os beirais generosos dessas coberturas são as caracos blocos, garantindo os fluxos no interior da escola, a proteção às condições ambientais, a espacialidade e a dinâmica volumétrica do conjunto.

$$
\text { Os Blocos Anexos foram projetados como "satélites", }
$$
que podem ser conectados aos Blocos Principais, em situações e quantidades variáveis, com o objetivo de atender às necessidades complementares às atividades predominantes. Quando for conveniente, poderão ser autônomos, independentes dos Blocos Principais ou, ainda, próximos 
outros Blocos Anexos. Por sua natureza diversa, predominam a estrutura em concreto moldado no local e a alvenaria Anexos possuem altura inferior aos Blocos Principais, o que confere maior número de possibilidades de conexão, permitindo a continuidade das circulações protegidas, sem a necessidade de uma cobertura complementar.

Os Blocos Principais deverão ser implantados beneficiando-se da orientação mais favorável possível, por abrigar as atividades que exigem permanência prolongad como as didáticas e administrativas.

Os Blocos A e B, onde predomina a circulação long tudinal através de galeria externa coberta, possuem abert ras transversais, voltadas para pátios internos ajardinados e protegidos. Esses eixos transversais deverão ser direcioe $\mathrm{O}$ Bloco $\mathrm{C}$, onde serão garantidas as principais ativdades de aprendizagem, foi projetado com a predominância do eixo longitudinal ao longo do qual as salas e oficinas se distribuem. As fachadas geradas por essa ocupação são protegidas por beirais generosos, mas deverão evitar as orientaçooes leste e oeste, sendo voltadas preferencialmente para norte e sul.

Os demais Blocos possuem maior liberdade de orientação, mas deverão seguir ou complementar aquela definida para os Blocos Principais.

0 afastamento minimo entre os blocos è fundamen-

tal para garantir a qualidade de iluminação e ventilação haturais do conjunto Também nesse caso, sâ os Blocos Principais que definem as condicões de recuo capazes de manter a integração e, ao mesmo tempo, impedir a interferência física entre as edificações.

A cada implantação, são preservadas as duas princpais formas de circulação no conjunto; as demais poderão ser criadas conforme novas necessidades, seguindo criterios semelhantes.

A circulação externa coberta é o eixo de convergência dos principais fluxos da escola. Sempre próxima e continuidade dos Blocos Principais, ela permite a integracão das diversas atividades, em especial as didáticas e as convivência, aproximando os usuários e, ao mesmo tempo, garantindo a proteção necessária para seu desempenho. Sua dinâmica ser Essa situaça ocorre no Bloco $\mathrm{C}$ em que duas circulações internas paralelas, ligadas às extremidades do bloco são posicionadas na transição de pé direito entre as oficinas e as salas, atendendo-as simultaneamente nas posições necessárias.

Sendo essa uma das principais características do projeto, as conexões entre os Blocos deverão ser feitas de duas maneiras:

A conexão entre os Blocos Principais será feita pel continuidade de suas coberturas, criando uma interdependência entre os volumes. Para isso, nas coberturas altas os Blocos foram projetados com módulos beirais em ba que devera ser sho tado da repetiçăo do módulo interno da edificaçã̃o (Bloco C com A, B e I).

Poderá ainda ocorrer a eliminação dos beirais transversais, propiciando a união física das cobertura baixas (Blocos A, B e E).
A conexão por proximidade resolve as situações de ligação entre os Blocos Principais e os Anexos (Blocos D, e H). Como esses também possuem beirais generosos em concreto, sua aproximação com os beirais dos Blocos Principais garante a proteção necessária.

0 encaminhamento e a distribuição da infraestrutura necessários para o funcionamento do conjunto deverão ocupar os eixos externos criados entre os blocos, procurando o melhor desempenho possível sem descaracterizar as condições do projeto.

Como os Blocos Principais organizam-se em eixos que podem ser dispostos de maneira paralela ou ortogonal, deverá ser encontrada a situação de implantação que melhor atenda às condições topográficas e ambientais do terreno, sempre garantindo o desempenho das funç̃̃es terminadas para a escola.

Quando for obrigatório implantá-los em niveis diferentes, deverá ser encontrada a forma mais adequada de sobreposição das coberturas, proporcionando a continuidade funcional e espacial do conjunto, garantindo assim sua integridade arquitetônica. 

$\Leftrightarrow$

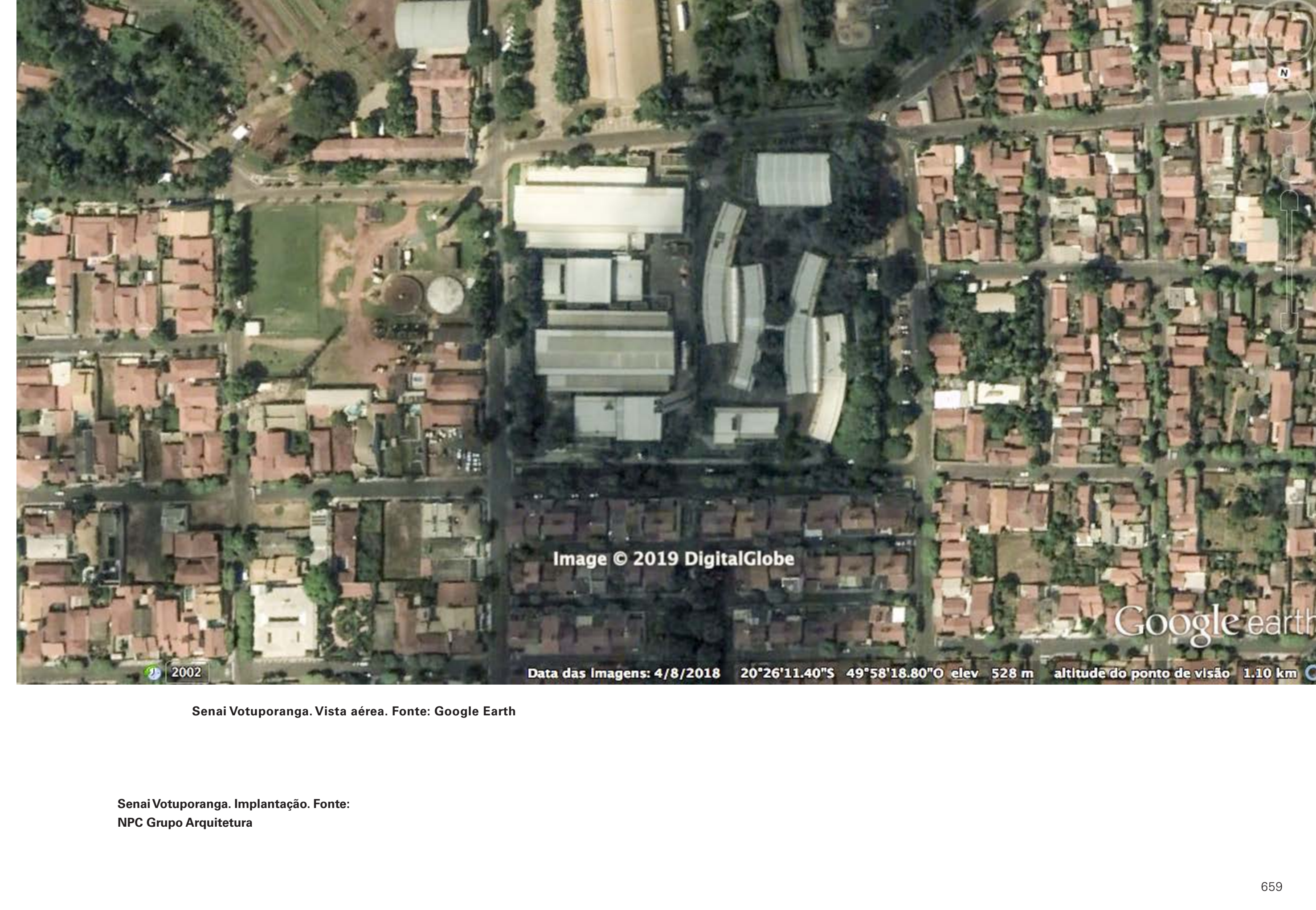




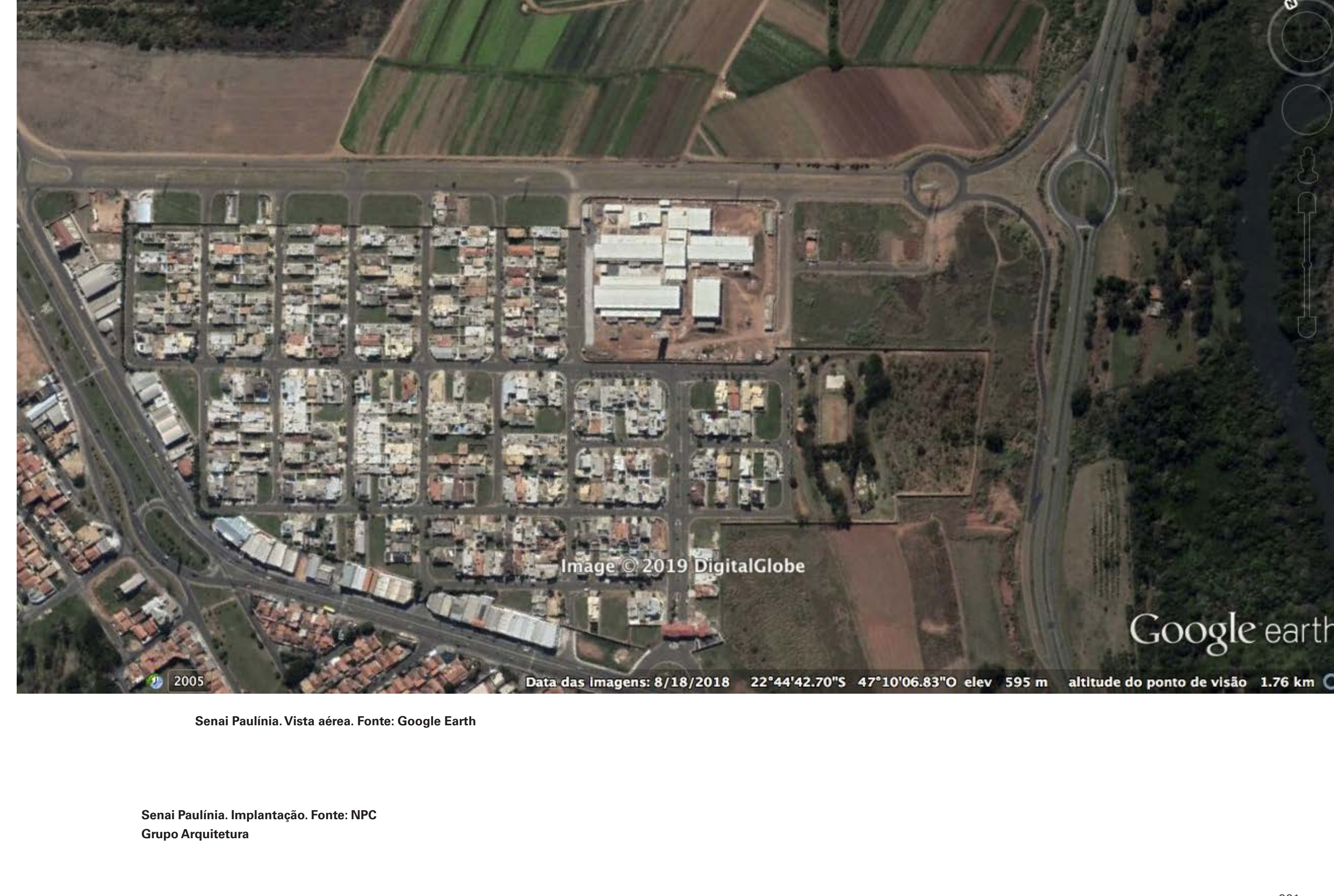


$\sqrt{12}$
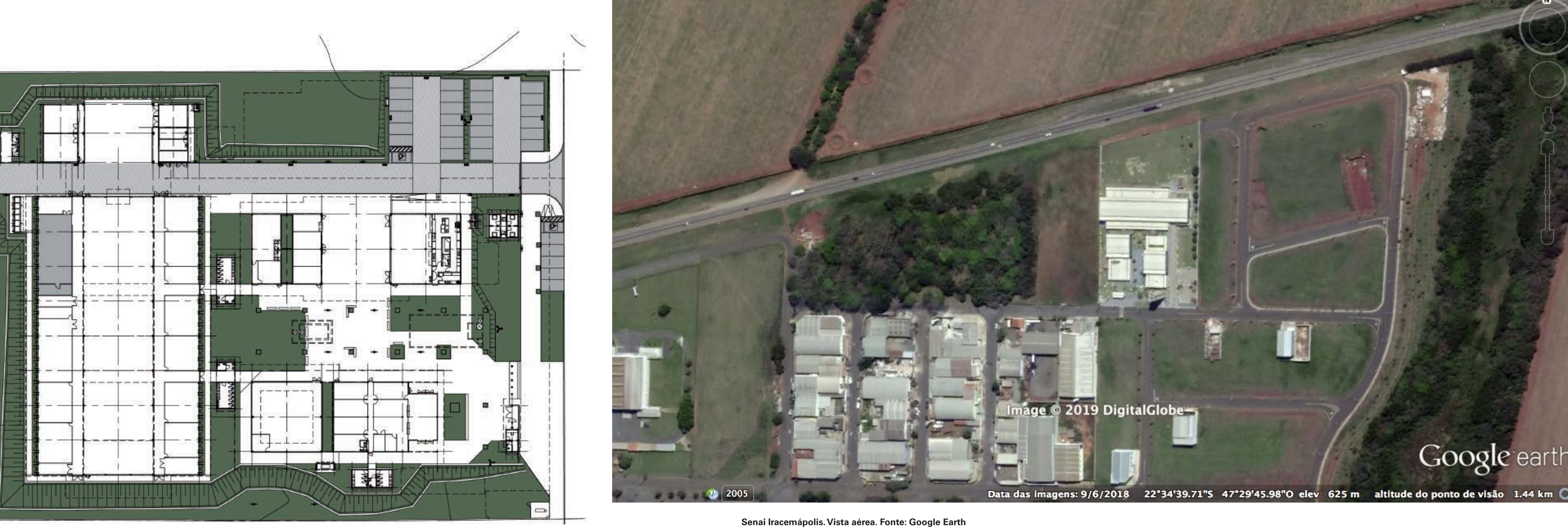

$\mathbf{N}<\begin{array}{lll}0 & 10 \quad 20\end{array}$ 

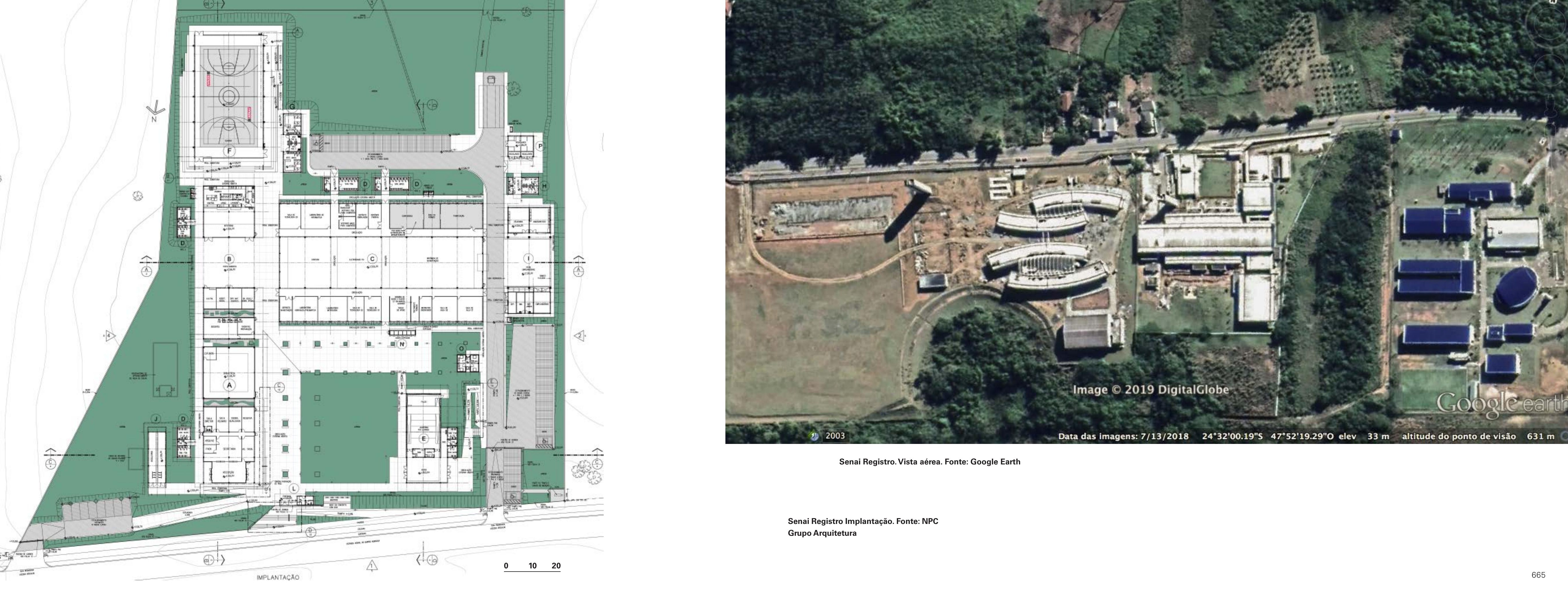

Senai Registro. Vista aerraa. Fonte: Google Earth 
Os diagramas arquitetônicos só podem evoluir se são capazes de integrar a vitalidade da experiência das atividades humanas e a diversidade dos conhecimentos e informações contemporâneas.

Para uma história e teoria da arquitetura contemporânea multidisciplinar e integrada, e para qualquer visão do futuro da arquitetura, seria portanto necessário considerar as ligacọoes e as mudanças entre os instrumentos, tecnologias, metodologias de projeto e diagramas da arquitetura. ${ }^{305}$

GARCIA, 2010

Como projeto piloto, a implantaç̃o de uma escola Se em Bragança Paulista foi a primeira de uma série que pretende atender a demandas em todo o estado de São Paulo. 


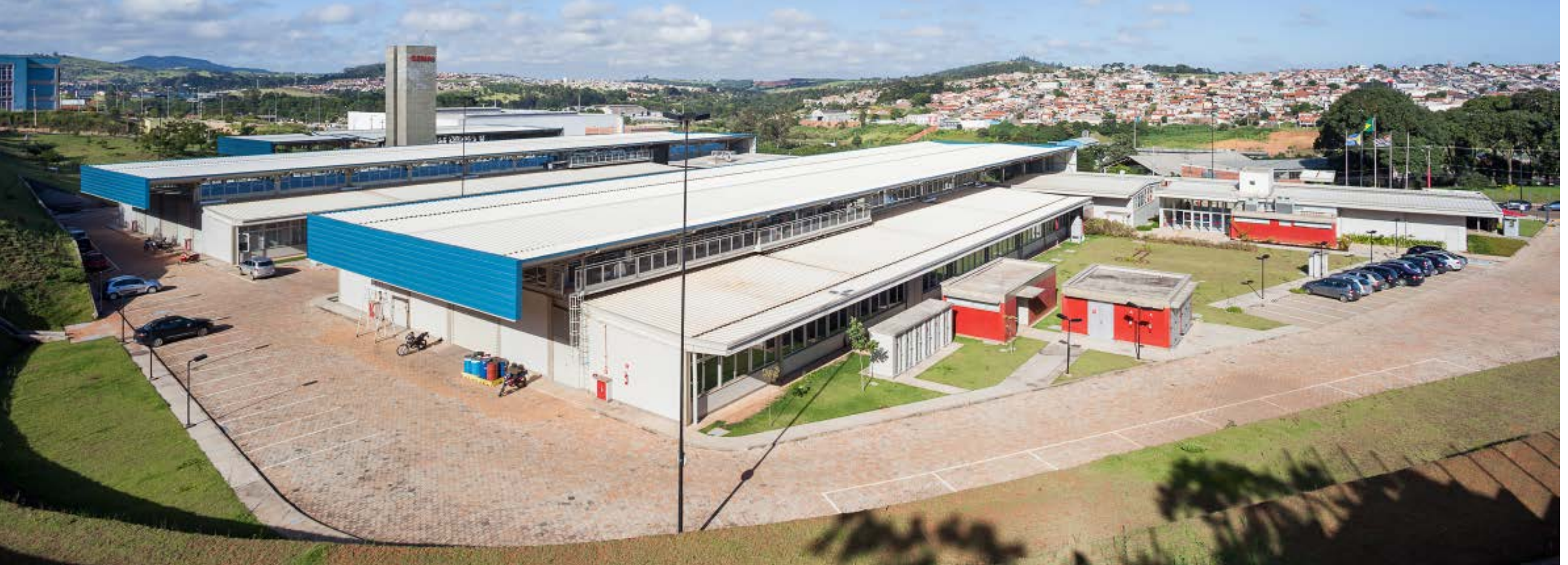

Senai Bragança Paulista. Vista leste. Fonte: Pedro Vanucchi

A partir da elaboração do projeto-padrão e de sua implantação-piloto, foram elaboradas outras 11 implanta cões (Valinhos, Araras, Sorocaba, Cotia, Paulínia, Registro, Votuporanga, Araçatuba, Mairinque, Guaratinguetá e Iracemápolis), das quais 9 foram objeto de projeto executivo (sempre através de concorrência pública) e foram construdas entre 2011 e 2018.

A proposta arquitetônica define-se dentro de uma visão de sistema e não da repetição do modelo-padrão, como previa inicialmente o contrato. Isso significa estabe lecer soluções de ordem espacial e construtiva baseadas em relações arquitetônicas e urbanas de natureza formal simbólica capazes de responder às imprevisibilidades programáticas e contextuais.

Quando falamos em sistema, estamos nos referindo cões que intera ça que compo o padra tem pouco valor ar çáo que compõe o padrão tem pouco valor arquitetônico que permite que as relaçōes citadas abram caminho para ao projeto como um sistema que constrói espaços e relaisoladamente. Sua força é decorrente do conjunto edificado,

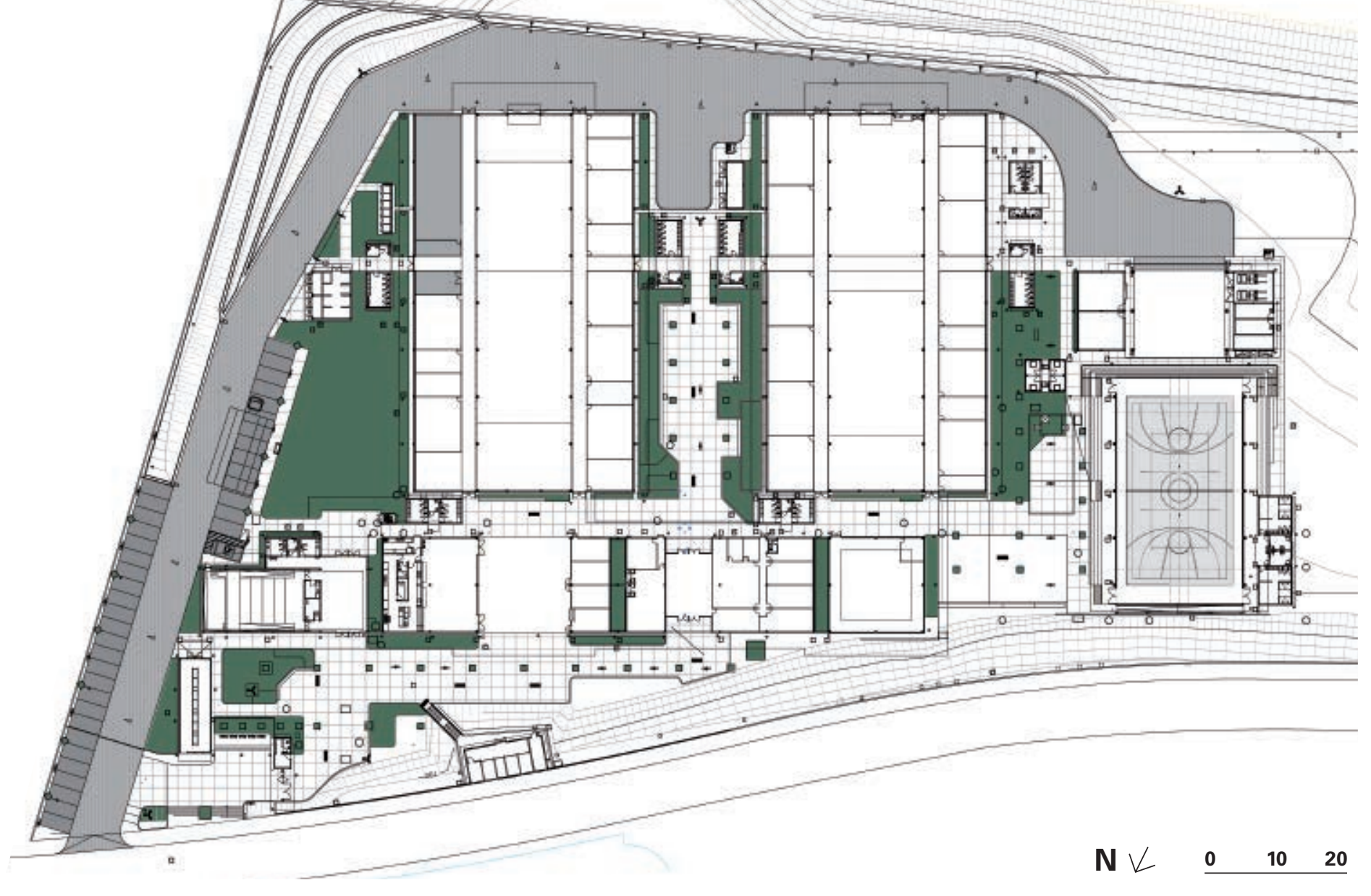

enfrentar à complexidade das atividades a serem desenvolvidas pelo equipamento e do entorno imediato. nossa realidade vem se transformando em ritmo acelerado, podemos admitir que a arquitetura para a aprendizagem deve criar não somente as possibilidades de evolucão baseadas na flexibilidade espacial mas, sobretudo, abri nhecemos, ou seja, para novas aprendizagens. Nesse caso, a arquitetura trabalha com um significativo grau de incerteza. Num primeiro momento, o contexto indeterminado leva à reflexão sobre as diversas variantes geográficas e ambientais que encontramos no amplo território escolhido, ou seja, todo o estado de São Paulo. Mas vale lembrar que a realidade a ser encarada pelo projeto não se limita às condiç̧ões naturais correspondentes. É na diversidade do ambiente urbano ou suburbano, em transos maiores desafios e aos quais deverá responder com maior objetividade. Podemos obter parâmetros bastante precisos com relação às condicionantes climáticas de deter- 


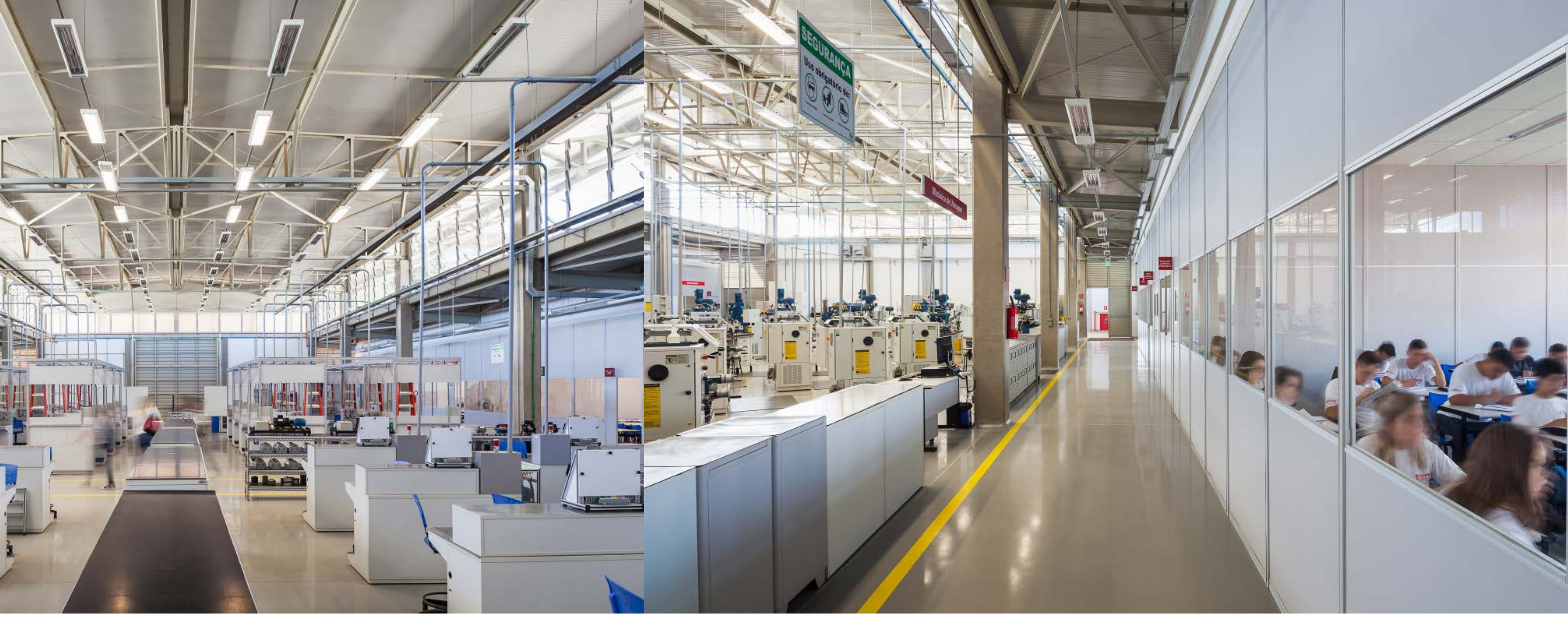


minado município do Estado. Podemos ainda entender de maneira detalhada as operações didáticas previstas para os espaços projetar o comportamento dinâmico das relações internas da obra e das mudanças do ambiente social e urbano aos quais ela responde, mesmo nos menores municípios contemplados. Para que essa situação seja enfrentada, o projeto propõe, entre outras estratégias, qualificar os lugares intermediários originados das relações de associac̃o e de proxmide entre as ed midade entre as edincaços. Os ambientes de convivência troca devem cumprir um papel primordial nas inúmeras implantações previstas, ou seja, ser um dos fundamentos, um dos elementos constitutivos do projeto, de forma a participar da desejada evolução programática e a estabelecer as necessárias interações urbanas, como avalia Aldo van Eyck:

A arquitetura deve ser concebida como uma configuração de lugares interedírios chrom defina de la tan eio de lugares intermediários definidos que à à prõo simutânea do que é signtctivo de un lado e do outro Nesse sentido, espaco intermediário fornece o terreno com onde as polridades conflitntes podem tormse de novo fenômenos sêmeos. (VAN EYCK ap VENTURI, 2004: 111)
Ainda que os programas para a aprendizagem técnco-industrial trabalhem com grande precisão, hả tambèn determinada imprevis dida em duas categorias principais.

Em primeiro lugar, a vocação industrial das cidades do estado de São Paulo são extremamente variadas, que interfere diretamente na definição das demandas de infraestrutura, insumos e recursos humanos. Tal vocação vai desde a indústria calçadista e a de confecções até a elorean tica e pela de alimentos, entre outras, cada uma com características totalmente distintas.

Em segundo lugar, sabemos que o setor industrial vive em permanente evolução, gerada pela tecnologia e pela automaç̃o. Para tanto, mais do que se adaptar às divers vocacões industriais, o projeto deve aproximar os diversos lugares da aprendizagem como maneira de oferecer camihos e oportunidades de novas práticas produtivas. E outras palavras, não se trata de bem definir isoladamente objetos arquitetônicos especializados e aproximá-los para que desempenhem sua função. Seria mais do que isso, pois Trojeto coloca os en feenente ter-relação de sua dinâmica programática e ao reservar especial atenção à materialização de situaç̃os de apren- dizagem, ou seja, trata-se de potencializar as conexões dos estres es ecom intermediários.

Do ponto de vista construtivo, foram definidas soparâmetros de racionalização modular, o que permite sua materialização em todas as regiões do estado de São Paulo. Como exemplo, a mesma estrutura metálica de cobertura em duas alturas, que define as áreas de oficina associadas às salas de aula e laboratórios se repete ma biblioteca eno pátio coberto. Essa repetição oferece a possibilidade de variar a continuidade do bloco didático, prolongando os locais de aprendizagem em direção às áreas externas e às galerias que levam à biblioteca. Nesse caso, ao trabalhar com elementos construtivos reconhecíveis da arquitetura industrial, como o "chão de fábrica" e os sheds longitudnas, a resolver as necessidades de ordem ambiental, como a iluminação e a ventilação naturais, ao mesmo tempo oferecendo diversas possibilidades de aproximação de toda a infraestrutura industrial necessária ao aprendizado, seja pelas amplas galerias internas ou pelos amplos beirais da cobertura.

O projeto, assim, constrói um padrão, como fora solicitado, porém, ao se basear na noção de sistema oferece liberdade para cada situação proposta.

Senai Braganca Paulista. Vista galerias de conexão entre bloco didáatico e biblio
teca. Fonte: Pearro Vanucchi. 
É importante lembrar, ainda, o valor simbólico que o equipamento destinado à aprendizagem industrial deve assumir. Ao repetir o projeto em cada implantação, é possivel construir uma identidade sem a necessidade de fazer o mesmo, o igual, e sim reservar grande espaço a diferente, ao imprevisto. Ao reconhecê-lo, pode-se estabelecer processos de apropriação que criam o novo, ainda que baseado na repetição, como vimos no capítulo 2. Como acontecimento, o projeto baseado no sistema reapropria as condições do ambiente sem que seja uma decorrência estrita do contexto.

Outros aspectos que não devem ser desprezados tratam dos eixos de circulação, dos fluxos, dos espaços servidos e dos que servem (os satélites), da variação de escala das transversais e longitudinais, da configurac̃o dos gares intermediários, abertos e protegidos e da expressão da cobertura, bem como a forma de expansão nas diversas direções, partindo do centro ou de uma ponta determina- da, ou em cruz, ou em pente ou ainda em z, como os mecanismos citados que colaboram na materialização de lugares intermediários que podem estreitar as relações com texto imediato

Em síntese, o projeto Senai Padrão Modular é instrumentado pelo sistema proposto e se desenvolve pelo reconhecimento do contexto físico e social em que é implantado, reservando espaço para permanente evolução. As áreas mas podem ser ampliadas ou prolongadas em direção à áreas externas protegidas e das conexões que vierem a ser ciadas. Com o projeto comportando-se dessa maneira, sistema se transforma, em certa medida, numa plataforma de trocas, distanciando-se do padrão do espaço industrial especializado e da tradição do espaço de aprendizagem ualizado. A arquitetura da escola é ider cada implantação, o que é um atributo das invariantes que a compõem. Entretanto, é na noção de plataforma de aprendizagem, como elemento construtivo, edificada com o contexto e para o contexto, que a obra exerce sua permanência.

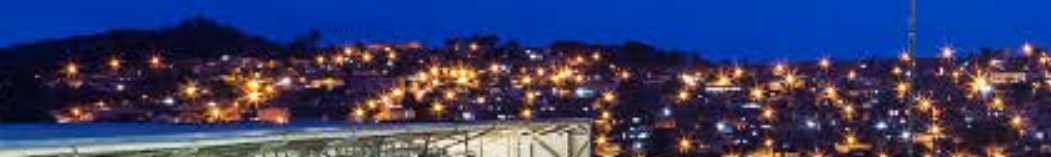

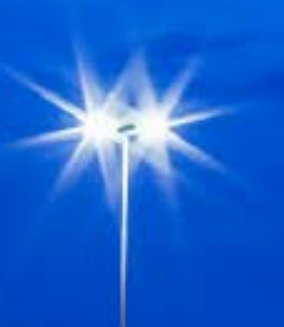

Hinstifiti

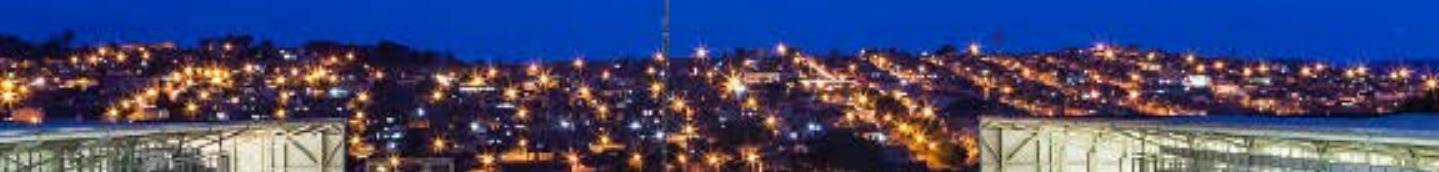

고

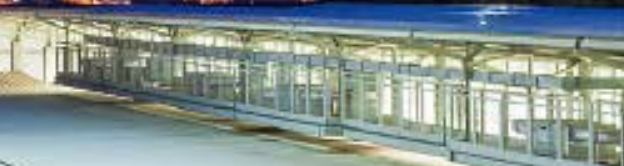

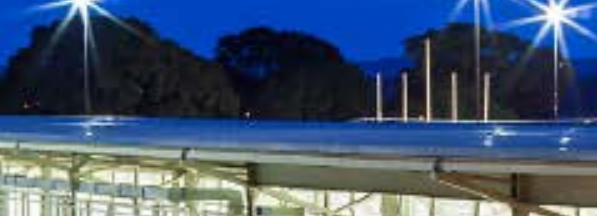
की: A10inti|| 
[...] enquanto existir na Terra um mínimo de inteligência sensitiva, haverá alguém capaz de ordenar os elementos do entorno físico, de modo que o reconhecimento da sua estrutura produza um prazer estético, independente da satisfaç̃o de quisitos funcionais.

PIÑON, 2006

a arquitetura, a investigação em projeto tem uma missão distinta da crítica. Nossa pesquisa demonstrou c ño se trata do julgamento de valores e sim da identificação, do entendimento e da apreensão dos atributos responsáveis pela construção da obra. Dessa maneira, o projeto prescinde do contexto e do programa para fazer sentido, que nos auxilia a entender e a ensinar o projeto.

Nesta tese, defendemos o "isolamento" dos elementos construtivos como elementos aqui empregado aproxima-se do sentido utilizado em pesquisas das ciências biológicas, ou seja, isola-se para exami-

Considerações finais aos seus elementos construtivos. No entanto, o tema tratado demonstrou que essa redução pode abrir um caminho fértil para que a arquitetura enfrente os desafios da contfertil para que a 0 risco de reduzir a arquitetura aos elementos construtivos como elementos de projeto vê-se certamente anpliado quando a obra é desprovida de uma realidade determinada ou de uma função social definida, ou seja, quando o contexto não the confere mais sentido ou quando o programa se esgota.

A investigaç̃o que apresentamos apontou as dificuldades que o projeto tem para enfrentar os desafios de situações que não são suficientes para justificar e para sustentar as tomadas de decisão ao longo do tempo. A fim de entender projetos de equipamentos públicos atuais, especialmente aqueles com a missão de aprendizagem e de formação, nosso trabalho percorreu um período significativo do século XX e do início do século XXI em que as intensas transformações do contexto físico e social imprimiram uma permanente evolução programática do tema. 
No âmbito da presente pesquisa, as reflexões de Hélio Piñon em epígrafe devem ser consideradas pois encontramos em seu entendimento a Teoria do Projeto como fundamento da arquitetura como experiência. Isto é, enquanto a arquitetura estiver distante dos atributos do proeto como atributos que lhe são próprios e se justificar por temas alheios a seus fundamentos, estará sujeita a um papel coadjuvante na construção de nossas cidades. Piño insiste na necessidade de se considerar a concepção como 位 vos como forma de assumir a universalidade, princípios da modernidade ainda hoje necessários.

ale destacar, no entanto, que o tema por nós exannado encontrou um caminho durável e promissor quando o projeto assumiu um comportamento sistêmico no momento sua gênese, ou seja, quando o projeto revelou potencialdades não explíitas, tanto de ordem programática como re lativas a seu entorno. Ficou claro que o projeto permaneceu independentemente dos parâmetros funcionais e contextuais. A identificação das referidas potencialidades é a principal missão que nosso trabalho apontou para o projet
Não se trata, portanto, de desprezar os valores do ugar e a dinâmica da vitalidade social como fundamentos, mas sim entender o proj to rá-lo por essas mesmas condicõos.

Foi possível, também, encontrar um meio mais adequado para o exame dos documentos de projeto, que são uma das fontes indispensáveis para a compreensão $d a$ arquitetura proposta. Em muitas situações, os trabalhos acadêmicos e as publicações de arquitetura reduzem graficamente informações valiosas contidas em cada projeto empreendido. A justificativa de que ao redesenhar, copiar ou mesmo simplificar os códigos contidos no projeto, sua compreensão é facilitada, só é valida quando se trata de uma possível vulgarização do assunto. Para um entendmento mais apurado do projeto é fundamental que a verš̃o produzida por seus autores seja a fonte primária a ser examinada. A utilização desses documentos pode nos auxilia na confrontação de obras de momentos distintos, entendendo com maior precisão as intenções de seus autores. produção editorial da arquitetura foi bastante signse inicio do século XXI.Infelizmente, com raras exceções, as publicações continuam apresentando de ra simplista os documentos de projeto, transformando-os em um esquema funcional primário e com poucas menções aos elementos construtivos que fundamentam a obra

Após introduzirmos no capítulo 1 as noções e os princípios que orientaram nossa tese, no capítulo 2 , foi possivel encontrar em importantes programas de implantaça de redes de equipamentos de aprendizasen no estado do Rio de Jario e na cidede Saro Pallo estudos resttados de certa forma distintos, decorrentes dos próprio limites dos projetos propostos - CIEP e CEU. 0 exame das realizações desses programas mostrou que a arquitetura proposta marcou de forma definitiva a capital paulista todo o estado fluminense.

No CIEP, Oscar Niemeyer manteve a expressão de suas estruturas em concreto armado apesar do uso da pré-fabricação dos componentes ${ }^{306} .0$ que destacamos foi a ca-

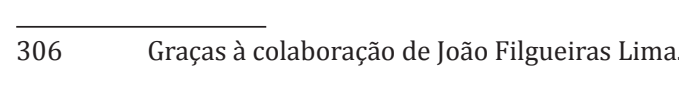

pacidade do projeto de não se alinhar às soluçốes construtvas padronizadas pelo mercado, como ocorreu em outras caminho coerenteco sua visão do equipamento de aprendizagem.

Por outro lado, tanto no CIEP como no CEU, as dificuldades encontradas não se originaram da noção de repetição, fundamental para o sucesso dos referidos programas. Certamente a repetição obrigou à padronização do projeto mas trouxe também a oportunidade de construir novas tuaç̃es, isto é, novas realidades que pudessem dar sentido à obra. Isso significa que os projetos não valorizaram corretamente a repetição como um possível fundamento, tend sido decididos apenas como uma unidade a ser repetida. $A$ obra, então, assumiu o caráter de protótipo a ser copiado como se todas as dúvidas já estivessem por ele resolvidas coubesse agora apenas viabilizar a sua reproduç̃o: encontrar terrenos, posicionar o protótipo e promover sua produção usando a pré-fabricação de seus componentes, sen dúvida, um limite imposto ao projeto.

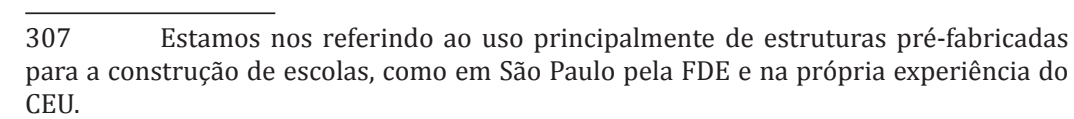


Ficou evidenciado que o projeto pode ir além se considerar a repetição como um atributo. Ao encontrarmos uma possível genealogia do equipamento público de aprendizagem em São Paulo, muitas respostas nos auxiliaram a entender o valor da repetição. A obra de Ernesto Mange, integrante da equipe do 2o Convênio Escolar, é um exemplo valioso. Mesmo concentrando os esforços na sistematizacão e na padronização da rede de equipamentos escolares empreendido pela equipe no início da década de 1950 c cuja arquitetura é perfeitamente identificável ainda hoje, Mange encontrou na repetição necessária a oportunidade para a construção de uma identidade baseada na exatidão entre contexto e programa. Os exemplos dos Grupos Escolares Domingos Sarmento (Brás), General Antônio Sampaio (Osasco) e República do Chile (Vila Nova Cachoeirinha) são um testemunho de que a aparente repetição da proposta encontrou no projeto o momento de construção de uma nova obra
Destacamos ainda como as experiências da rede de escolas-classe e escolas-parque, idealizadas durante grande parte do século XX por Anísio Teixeira no Rio em Salvad piraç̃o pra os progra estuddos. Cabe salentar entanto, que essa forte presença pouco se refletiu nos proetos realizados, o CIEP e o CEU. Mostramos como há um significativa distância entre as obras, em especial quando examinamos o meio ambiente constrú́do e sua relação con mediação concebeu obras notáveis, como a escola-parque SQS307-SQS308 em Brasília, projetada por José Reis en 1958. Traduzindo literalmente os termos do Plano de Construções Escolares de Brasília idealizado por Anísio Teixeira o conjunto encontra no projeto a oportunidade de construr uma plataforma em que atividades formadoras de natureza cultural e esportiva se confrontam com os atributos $d$ cidade-parque imaginada por Lúcio Costa. Em outras pala vras, as qualidades ambientais da capital moderna qualific fundamentalmente a obra graças aos elementos constru- dos do projeto de José Reis. A escola-parque, assim como a escola Elefante Branco, também obra de Reis examinada no nosso trabalho, antecip vas que marcaram a arquitetura paulista na década seguin$\mathrm{te}^{\mathrm{3} 8 \mathrm{8}}$. Entretanto, as dificuldades da capital paulista levaran a arquitetura a negar, em certo sentido, sua condição urbana, diferentemente das qualidades da cidade-parque no Planalto Central, que não puderam ser desprezadas.

$$
\text { Encontramos também evidências da proximidade }
$$

entre a a

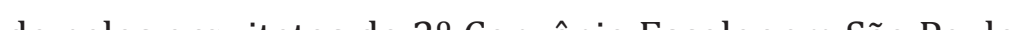
por Affonso Eduardo Reidy no Rio de Janeiro com o pensa mento construtivista e funcionalista que consolidou a noção de equipamento público, em especial no período entre as duas Grandes Guerras. 0 projeto, através dos seus elen tos construtivos, atumido como mediador e enfrentando as transformações urbanas e sociais em suas diversas escalas pôde ser identificado ao confrontarmos as obras brasileira às realizações exemplares de Hannes Meyer e Hans Wittwer em Basel, de Joannes Duiker e Bernard Bijvoet em Amster- dam, de Eugène Beaudouin e Marcel Lods em Susrennes, de André Lurçat em Villejuif, de Giuseppe Terragni em Como e de Richard Neutra, em Los Angeles. 0 legado apontado, principalmente no que diz respeito ao raciocínio científico e à sistematização do projeto, ainda hoje são fundamento que, em grande medida, orientam os projetos escolares empreendidos pela FDE no estado de São Paulo.

Vale destacar que não se trata de encontrar um meio 位 a capacidade do projeto de encarar as transformações urbanas e sociais nas suas diversas escalas. 
No capítulo 3, ao nos propormos a examinar a permanência do projeto mesmo na ausência do program encontramos, revela potencialidades não explícitas pelo problema in cialmente colocado

0 exame de obras significativas, como o Teatro de Mannheim de Mies van der Hohe, o Learning Center da EPFL em Lausanne de SANAA a a Marquise do Conjunto do Parque tou como os programas em formação ou em plena transformação não limitaram o projeto. Ao contrário, foi nessa aparente dificuldade inicial que o projeto encontrou os meio para revelar novas vocações do lugar, imprimir um caminho aberto às relações sociais que ainda não tinham sido construídas e amparar a permanência da obra em seu contexto.

Os imaginados "Edifícios para Fins Universais" descritos por Alberti encontraram nas obras estudadas sua materialização diante de contextos físicos e sociais extremamente diversos, em momentos distintos e protagoniza-

Muito além do programa
Mostramos como a visão do teatro segundo Mies, exressa na proposta para o concurso de Mannheim, leu-se dos elencto um programa aparentemente tradicional, mas extremamente preparado às novas experiências dramáticas e sua franca relação com a cidade, sem que tenha sido necessário se entregar à espetacularização a tecnologia. Como constatado por Erwin Pisicator, a sofiscacã̃o tecnológica ea flexibilidade total, como respostas à mandas das vanguardas teatrais do início do século $\mathrm{XX}$ ornaram-se muito mais uma dificuldade do que um caminho para a criatividade ${ }^{309}$

A força da obra de Niemeyer na construção do vazio do Parque do Ibirapuera é outro testemunho verdadeiro da vitalidade com que os elementos construtivos permitem a a Marquise é a prova de que a arquitetura do programa merece uma reflexão permanente. A interioridade do vazio do Parque se depara cotidianamente com as "diferenciações existentes da natu-

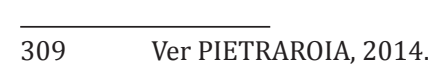

reza humana", lembradas por Alberti, com a missão de superá-las, empreitada que vem exercendo intensamente há mais de seis décadas.

Uma outra situação de destaque foi evidenciada na obra construída por SANAA no campus da École Polytechnique Fédérale de Lausanne (EPFL), o Learning Center: um equipamento de porte em que mais da metade de seus $20.000 \mathrm{~m}^{2}$ não possuem uso definido. 0 projeto encarou a construção do vazio no interior do campus destacando sua função indeterminada. Dessa forma, o projeto passa a pensar e a construir formas de relacionamento que desfazem as divisões funcionais e apoiam iniciativas de novas formas de ação e de interação. Sua extensa superfície contínua e ondulada cria uma paisagem interior em que a estrutura regular, quase imaterial, da formas a se aproximando-se da noç̃o de arquitetura como sistema distanciando-se da noção de objeto arquitetônico. 
Se admitirmos que a evolução progressiva da sociedade vem gerando atualmente demandas de variedade inimaginável, a arquitetura deverá cada vez mais promover ação entre as pessoas. Mais do que a satisfação das necessidades humanas preconizadas pela modernidade na prime ra metade do século XX, isto é, o programa, é na promoção da aproximação e da interação que o projeto deverá atuar para sua propria sobrevivência. Mais do que o respetto a a integraç̃o com os valores existentes, ou seja o contexto de fendido pelos questionamentos críticos da segunda metade do século XX, é na qualidade e na generosidade dos espaços a serem imaginados que os valores da arquitetura podem permanecer vitais.

É com esses objetivos que o capítulo 4 responde através do projeto, aos problemas colocados nos capítulos 2 e no 3, isto é, se o projeto tem dificuldades para se amparar no contexto e no programa, a arquitetura deve se vale de atributos que lhe são próprios para enfrentar uma real-

Freespace, Freeing Architecture ${ }^{310}$ dade cada vez menos determinad
S obras examinadas são muito menos obras ou projetos propriamente ditos, e sim muito mais sistemas que constroem realidades funcionais ou processos que suportam a construção de programas, como nas pesquisas empreendidas por Candilis-Josic-Woods. Mesmo destacando suas obras para a Universidade Livre de Berlim-Dahem e para a Universidade, pudemos evidenciar que a força do trabalho do grupo reside na noção de arquitetura como pesquisa, resultando em uma obra aberta, e não no objeto arquitetônico em si. 0 projeto elabora sistemas baseados no conhecimento arquitetônico que promove a ação d outras disciplinas, sem que se tornem objetos de um programa definitivo. A ocupação e a apropriação da obra, no sentido de ação entre indivíduos, promovem sua evolução e seu aprimoramento sem que o projeto seja abandonado. Este, então, incorpora o tempo como dimensão do programa, aproximando o tempo histórico, segundo Louis Kahn do tempo futuro, segundo o TEAM $X$.

o destaque está no fa do grupo ter ampliado a atuação do projeto ao incorporar profissionais de diversas áreas e origens. Apesar de sua experiência ter se limitado a pouco mais de uma década, com obras como a ENSA (École Nationale Supérieure d'Art), em Limoges, e o Métafort, em Aubervilliers, observamos como os locais de convergência podem ser materializados pelo dispositivos de trocas físicas e mentais entre os usuário graças à oferta de infraestrutura de circulação e de comunicação. 0 desenho tem uma forte posição ordenadora sem se tornar um limite ou um fim em si mesmo.

Na experiência do Senai Padrão Modular, destacamos a natureza inacabada da obra no momento anterior à sua implantação. Isto significa que o projeto considera como padrão sua própria modularidade, ou seja, não copia nem repete un padrão. Ao contrário, tem a mudança como padrão. 0 projeto de um sistema a ser edificado segundo a combinação e

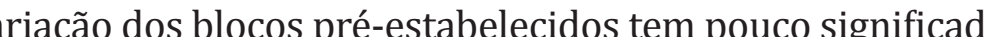
se não se relacionar com o contexto. Noções de proximidade justaposição e associação entre os blocos funcionais e os blocos variáveis indicam uma possível saída para o desafio entre a permanência e a evolução, condição que nossa tese coloca para a sobrevivência da arquitetura. 
Como demonstram esses exemplos, a repetição é encarada como a oportunidade de reencontrar uma nova obra. Se, no momento da concepcão, o contexto não h sido definido, por outro lado, no momento da implantação a obra deverá ordená-lo e ser por ele ordenada, abrind sempre possíveis caminhos para as mudanças, condiçãa fundamental para encarar contextos sociais de alto teor urbano. Em certa medida, o raciocínio antecipa a noção de território que seria posteriormente incorporada ao programa CEU na cida so trabalho.
Há, portanto, uma convergência de preocupações que valorizam a importância do território na definič̃o projeto implantado. Na experiência do Senai Modu

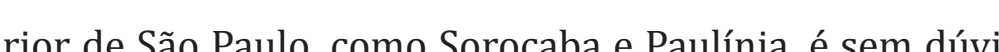
menos significativo do que do programa CEU na periferi da cidade de São Paulo. Entretanto, a possibilidade de enfrentamento de territórios tão diversos, como a pequen Iracemápolis com 20.000 habitantes, é a prova de que o projeto projeto deve ser encarado como experiência no sentido do acúmulo do conhecimento obtido, ou seja, um acervo baseado na práxis, como forma de fortalecimento do projeto não como modelo exemplar a ser copiado.
0 exame dos projetos apresentados em nossa tese destacou o caminho que defendemos, no qual a permanência do projeto como meio social urbana está fundamentalmente baseada no conhecimento dos elementos construtivos como elementos de projeto e não na referência formal como transformadora do lugar. Não se trata de negar essa referência formal, tal com。 defendida pela modernidade, e sim aprender e apreender 0 conhecimento acun como meio de instrumentar o projeto.

Sublinhamos também como a técnica permitiu que os desafios encontrados fossem transformados em atributos do projeto, condição que vem sendo deformada no programas examinados, transformando-se em limites de ordem financeira e tecnocrata. Ao considerar a prevalência das condições de ordem econômica e de desempenho em detrimento dos conhecimentos científicos que são próprios detrimento dos conhecimentos científicos que são proprios
ao projeto, baseados nos elementos construtivos, a arquitetura desses amplos programas limitou as possibilidades de sobrevivência da obra e de sua capacidade de transformação do lugar. 
Não estamos nos referindo à duração física da obra e sim à necessidade de que ela faça sentido enquanto arquitetura. A imagem da escola de Bento Rodrigues, que abre ence nosso traber ê catástrofe ambiental que devastou o território da pequena vila, mas a arquitetura perdeu seu sentido.

Ao construir um raciocínio e não uma análise das obras, nossa tese responde à hipótese colocada inicialmente. Insistimos que o projeto deve promover a permanência da arquitetura ao encontrar na realidade as condições de uma ação mais ampla. Para isso, o conhecimento acumulado pela arquitetura ganha importância na busca pela interdisciplinaridade necessária.

$$
\text { Para encerrar, podemos apontar uma contribuição }
$$

de nosso trabalho do ponto de vista do ensino de projeto em que seja possível considerar sua independência em relação ao contexto e ao programa ao identificar quais são as estruturas próprias da arquitetura capazes de permanecer mesmo quando suas justificativas contextuais e programáticas se esgotam. 
AALTO, Alvar. Humaniser de I'Architecture. In La table blanche et autres textes. Paris: Parenthèses, 2012 [1940]

ABREU, Ivanir Reis Neves. Convênio Escolar: Utopia Cons truída. 2007. 334 p. Dissertação (Mestrado) - Faculdade de Arquitetura e Urbanismo, Universidade de São Paulo, São Paulo, 2007

ACAYABA, Marcos de Azevedo. Residências em São Paulo 1947-1975. São Paulo: Projeto, 1986.

ADORNO, Theodor. Quasi una fantasia. São Paulo: Unesp 2018.

ALBERTI, Leon Batista. Da Arquitetura. Tradução e organi-

Bibliografia

ALDAMA, Roberto Rojas. 0 Edificicio da Biblioteca e Adminis tração do IIT - Processos de Projeto. Barcelona: ETSAB-UPC 2009
ALEXANDER, Christopher. Ensayo sobre la Síntesis de la For$m a$, Buenos Aires: Infinito, 1973 [1966].

; ISHIKAWA, Sara; SILVERSTEIN Murray. Un lenguaje de patrones, Barcelona: Gustavo Gili, 1980 [1977].

ALLENSPACH, Christoph. La Arquitetura en Suiza: La construccíon en los siglos XIXXXX. San Gallen: Pro Helvetia, 2001.

ANDRADE JUNIOR, Nivaldo Vieira de. Arquitetura moderna na Bahia, 1947-1951: uma história a contrapelo. Tese (Doutorado. Faculdade de Arquitetura Universidade Bahia, Salvador, 2012

ANELLI, Renato. Centri Unificati di Educazione a São Paulo Casabella. 2004, 727, 5-18.

ARANTES, Otília. 0 lugar da arquitetura depois dos modernos, São Paulo: Edusp, 1993. 
ARGAN, Gian Carlo. História da arte como história da cidad São Paulo: Martins Fontes, 1998.

_. A História na Metodologia do Projeto, Cara-

melo. 1983, 6, 155-170.

Projeto e Destino, São Paulo: Ática, 2000.

992.

Arte Moderna, São Paulo: Cia. das Letras,

Sobre a Tipologia em Arquitetura. In NESBITT, Kate. Uma nova Agenda para a Arquitetura. São Paulo Cosac \& Naify, 2006.

ARRUDA, Ângelo - O Colégio Estadual de Oscar Niemeyer em Campo Grande MS: uma análise compositiva. Arquitexos [online]. Nov. 2000. Disponível em <http://www.vitruvius. com.br/revistas/read/arquitextos/01.006/960>- Acess em 15/07/2018

ARTIGAS, Rosa (org.). Paulo Mendes da Rocha, São Paulo Cosac \& Naify, 2000

$$
\text { (org.). Paulo Mendes da Rocha: Projetos de }
$$

1999 - 2006. São Paulo: Cosac \& Naify, 2007.

AURELI, Pier Vittorio. The Possibility of an Absolute Arch tecture. Cambrige: MIT Press, 2011.

7ZEVEDO, Ricardo Marques de. Metrópole: Abstração. São Paulo: Perspectiva, 2006.

Antigos Modernos: Estudos

da Doutrinas Arquitetônicas nos séculos XVII e XVIIL. São

Paulo: FAUUSP, 2009. da Arquitetura. Pós, 2015, 37, (22).

Tipo e Caráter no Discurso

BANHAM, Reyner. Arquitectura del entorno bien climetiza do. Buenos Aires: Infinito, 1975

Megastructure : urban futures of the re-

cent past. London: Thames and Hudson, 1976.

Los Angeles: A Arquitetura de Quatro Ecologias. São Paulo: WMF Martins Fontes, 2013.

BARONE, Ana Cláudia Castilho. Team 10: arquitetura como crítica, São Paulo: Annablume/ Fapesp, 2002

Ibirapuera: parque metropolitano (1926-1954). Tese (Doutorado), Faculdade de Arquitetura e Urbanismo, Universidade de São Paulo, São Paulo, 2007.
BASTOS, Maria Alice Junqueira. A Escola Parque: ou um sonho de uma educação completa (em edifícios modernos). AU. 2009, 178, 42-45.

_ e ZEIN, Rurh Verdi. Brasil: Arqu teturas após 1950, São Paulo: Perspectiva, 2010.

BAXANDALL, Michael. Padrões de Intenção. São Paulo: Cia. das Letras, 2006.

BENÉVOLO, Leonardo. A arquitetura do Novo Milênio. São Paulo: Estação Liberdade, 2007

BENJAMIN, Walter. A Obra de Arte na época de suas técnicas de reprodução. In Os Pensadores, v.XLVIIII, São Paulo: Ed Abril, 1961.

BEZERRA, Valter Alnis. Estruturas conceituais e estratégias de investigação: modelos representacionais e instanciais analogias e correspondência. Scientiae Studia. 2011, 3, (9) 585-609. 
BIENAL INTERNACIONAL DE SÃO PAULO. Arquitetura na Bienal de São Paulo. São Paulo: Graficar, 1951.

BOUDON, Philippe. Sur lespace architectural. Paris: Dunod, 1971.

DESHAYES, Philippe; POUSIN, Frédéric

BISILLIAT, Maureen (org). Memorial da América Latina. São Paulo: Empresa das Artes, 1990.

BLAKE, Peter. L'Art difficile d'être simple. LA'Architecture d'Aujourd'hui. 1958, 79, 24-25.

BOESIGER, Willy. Richard Neutra: building and projects. Zurique: Gisberger, 1951.

BOMENEY, Helena. A Escola no Brasil de Darcy Ribeiro. Em Aberto. 2009, 80, (22), 109-120.

BONDUKI, Nabil Georges. Affonso Eduardo Reidy. São Paulo Instituto Lina Bo Bardi; Lisboa: Blau, 1999.

e KOURY, Ana Paula. Os Pioneiros da Habita cão Social. São Paulo: UNESP e SESC, 2014, v.2. SCHATZ, Françoise. Enseigner La Conception Architecturale

BRAGA, Andrea da Costa. Guia de Urbanismo, Arquitetura e Arte de Braślia. Brasília: Fundaç̃õo Athos Bulcão, 1997.

BRAGA, Milton. 0 Concurso de Brasilia: Sete Projetos para uma Capital. São Paulo: Cosac \& Naify, 2010

BROOK, Peter. O espaço vazio. Rio de Janeiro: Apicuri, 2015.

BRUAND, Yves. Arquitetura Contemporânea Brasileira. São Paulo: Perspectiva, 1981

BRUNA, Paulo Júlio Valentino. Os Primeiros Modernos: Habitação Social no Brasil 1930-1950. São Paulo: Edusp, 2010 Paris: Éditions de la Vilette, 1994 e GUERRERO, Ingrid Quintana (org). Quatro

CAMARGO, Mônica Junqueira de. Inventário dos bens culturais relativos ao Plano de Ação do Governo Carvalho Pinto

CANDILIS, George; JOSIC, Alexis; WOODS, Shadrach. Recherches d'Architecture. In LÁArchitecture d'Aujourd'hui. 1958, 115, 14-19.

SCHIEDHELM, Manfred. L'UniRomano Guerra, 2010

BUEKSCHMITT, Justus. Ernst May. Stuttgard: Alexande Koch, 1963

CALDEIRA, Mário Henrique de Castro. Arquitetura para educação: escolas públicas na cidade de São Paulo (1934-1962). Tese (Doutorado) - Faculdade de Arquitetura e Urbanismo Universidade de São Paulo, São Paulo, 2005.

CALVINO, Italo. Seis Propostas para o Próximo Milênio, São Paulo: Cia. das Letras, 1991 versité Libre de Berlin. Le Carré Bleu. 1964, 1

CARPO, Mario. L'Architecture à l'ère du pli. L'Architectur d'Aujourd'hui. 2003, 349, 98-103.

Topos, stéréotype,

d'Aujourd'hui. 202, 343, 42-51.

CARTER, Peter. Mies van der Rohe at Work. New York: Phaidon, 1974. 
CASTRO, Carlos Dunham Maciel Siaines de. O Espaço da Escola na Cidade: CIEP e Arquitetura Pública Escolar. 2009. 136 f. Dissertação (Mestrado) - Universidade de Brasíli. Brasília, 2009

CHAHIN, Samira. Cidade, Escola e Urbanismo: 0 Program Escola-Parque de Anísio Teixeira. In Seminário de História da Cidade e do Urbanismo. 14, 2016, São Carlos. São Carlos: IAU/USP, 2016. Anais [online]. Disponível em <http:// www.iau.usp.br/shcu2016/anais/wp-content/uploads/ pdfs/11.pdfs. Acesso em 07/02/2018

CHALANDJIEVA, Veneta. Pérennité d'une Utopie. Le Carré Bleu. 1999, 1.

CHOAY, Françoise. La règle et le modèle. Paris: Seuil, 1980.

CINQUALBRE, Olivier. UAM, Union des artistes moderne Une aventure moderne. Paris: Centre Pompidou, 2018.
COHEN, Jean-Louis. O Futuro da Arquitetura desde 1889, Uma História Mundial. São Paulo: Cosac-Naify, 2013.

Architectures du Front Populaire.

Mouvement Social. Jan. - Mar. 1989. Disponível em: http:// aboratoireurbanismeinsurrectionnel.blogspot.com br/2012/05/architectures-du-front-populaire.html. Acesso em: 19/11/2017

COLLINS, Peter. Los Ideales de la Arquitectura; su Evolución (1750 - 1950), Barcelona: Gustavo Gili, 1998.

COLOMBO, Luciana Fornari. O projeto de teatro de Ludwig Mies van der Rohe. Arquitextos [online]. Out. 2015. Disponível em: wwwvitruviuscom br/revistas/read/arquitextos/16.185/5782

COLQUHOUN, Alan. Modernidade e Tradição Clássica: Ensaios sobre Arquitetura. São Paulo: Cosac \& Naify, 2004.
Tipologia e Metodologia de Projeto. In ESBITT, Kate. Uma nova Agenda para a Arquitetura. São Paulo: Cosac \& Naify, 2006.

University Press, 2002

odern Architecture. Oxford: Oxford

CONESP. Manual de Dimensionamento modular e Especifcações de Ambientes para Construções Escolares de São Paulo: CONESP, 1977.

Manual de Padronização de Componentes para Construções Escolares de 1ํo Grau, São Paulo: CONESP, 1977.

CURCIO, Giovanna. La Città del Settecento, Roma: Laterza 2008

CURTIS, Willian J. R. Modern Architecture since 1900. London Phaidon, 1996.
DAZA, Ricardo. Buscando Mies. Barcelona: Actar, 2000.

DELEUZE, Gilles. Différence et Répétition. Paris: PUF, 1968

DELIJAICOV, Alexandre. Arquitetura do Lugar. Piseagrama [online], 488, 1-2. Disponível em: http://piseagrama.org/ artigo/488/arquitetura-do-lugar/. Acesso: 2011.

DELIJAICOV, Alexandre; TAKYA, André; ARIZA, Wanderley. Centros Educacionais Unificados. Jornal Arquitectos. 2004 215, 3-8.

DELPHINO, Deborah. Conceituação e Desenvolvimento da Escola Parque em Brasilia, Rio de Janeiro, Salvador e São Paulo: de 1931 a 2013. Dissertação (Mestrado) - Faculdade de Arquitetura, Universidade Presbiteriana Mackenzie, São Paulo, 2013. 
DEWEY, John. Arte como Experiência. São Paulo: Martins Fontes, 2010.

DOUTRIAUX, Emmanuel. La «libre université» désenchantée. L'Architecture d'Aujourd'hui. 2002, 343, 36-38.

DREXLER, Arthur. The architecture of Richard Neutra : from International Style to California modern. New York: The Museum of Modern Art, 1984.

DUARTE, Hélio. 0 problema escolar e a arquitetura. Habitat. 1951, 4, 4-6.

ESPALLARGAS GIMENEZ, Luis. Pedro Paulo de Melo Saraiva arquiteto. São Paulo: Romano Guerra, 2016a.

João Kon: arquiteto. São Paulo: Romano Guerra, 2016

EISENMAN, Peter. Giuseppe Terragni: Transformations, Dé compositions, Critiques, New York: Monacelli Press, 2003.
Dall'oggetto alla relazionalità: la casa del Fascio di Terragni. Casabella, 1970, 344, 38-41.

FANTL, Ernestine. Modern architecture in California. New York: Mueum of Modern Art, 1935

FERRATA, Carlos Augusto. Escolas públicas em São Paulo (1960-1972). Dissertação (Mestrado) - Faculdade de Arquitetura e Urbanismo, Universidade de São Paulo, São Paulo, 2008.

FERRAZ, Artemis Rodrigues Fontana. Arquitetura Modern das escolas "S" paulistas, 1952-1968: Projetar para a formação do trabalhador. Tese (Doutorado) - Faculdade de Arquitetura e Urbanismo, Universidade de São Paulo, São Paulo, 2008.
FERREIRA, Avany de Francisco; Corrêa, Maria Elizabeth Peirão; MELLO, Mirela Geiger (org). Arquitetura escolor paulista: restauro. São Paulo: FDE, 1998.

FOCILLON, Henri. Vie des Formes, Paris: Presses Universitaires de France, 1947

FRAMPTON, Kenneth. História Crítica da Arquitetura Moderna, São Paulo: Martins Fontes, 1997. tura Escolar paulista: estruturas pré-fabricadas. São Paulo FDE, 2006.

1960. São Paulo: FDE, 2006

rquitetura escolar paulista : anos 1950

FERREIRA, Wilson Roberto Vieira. As Imagens Seduzem e Iludem. Disponível em: http://cinegnose.blogspot.com. br/2013/09/as-imagens-seduzem-e-iludem-no-filme. html. Acesso em 18/09/2013.

FINGERMANN, Dominique. Os Paradoxos da Repetição, São Paulo: Annablume, 2014.
L'Architecture d'Aujourd'hui. 2003, 344, 88-95.

et al. Mies van der Rohe: su arquitectura sus discípulos. Madrid: Ministerio de Obras Publicas y Urbanismo, 1987.

FUJIOKA, Paulo Yassuhide. Tratados brasileiros de arquitetura moderna - Aprendendo arquitetura com quem faz. $V$ truvius,Jan. 2017, 181 (1).Disponível em: http://www.vitruvius.com.br/revistas/read/resenhasonline/17.181/6379. 
FURTADO, Claudio. A Arquitetura em Antonione. Pós. 2016, 38 (v.22), 158-170

GADANHO, Pedro. Do MOMA ao mais novo museu de Lisboa. Folha de São Paulo. 11/09/2016. Ilustrada, p. 6

GARBUGLIO, Jo'se Carlos; BOSI, Alfredo; FACIOLI, Valentim. Graciliano Ramos. São Paulo: Ática, 1987.

GARCIA, Mark. The Diagrams of Architecture, Chichester Jonh Wiley and Sons Ltda, 2010.

GARCIA, Patrícia Melasso. Pedagogias Invisíveis do Espaço Escolar. 2016. 407 f. Tese (Doutorado) - Faculdade de quitetura e Urbanismo, Universidade de Brasília, 2016.

GOLDBERGER, Paul. The Skyscraper, New York: Alfred A. Knopf, 1985.

GREGOTTI, Victorio. Território da Arquitetura, São Paulo Perspectiva, 1978

GROENENDIIK, Paul; VOLLAARD, Piet; ROOK, Piet. Guide to modern architecture in Amsterdam. Rotterdam: Rotterdam 1987.

GUATELLI, Igor. A marquise do Parque Ibirapuera e manisuporte de aç̃os. Arquitextos [online]. Mar. 2006. Disponfvel em: <http://www.vitruvius.com.br/revistas/read/arquitextos/06.070/371>. Acesso em 25/10/2017.

GUERREIRO, Isadora. CEUs: Potencialidades e Contradições. Urbania 4. 2010. Disponível em: http://urbania4. org/2011/04/17/ceus-potencialidades-e-contradicoes/ $15 / 09 / 2010$

GOMES, Candido Alberto. Darcy Ribeiro. Recife: Fundação Joaquim Nabuco/Editora Massangana, 2010.
HADLICH, Flávio. As escolas do IPESP: projetos de edifício escolares produzidos para o Instituto de Previdência do Estado de São Paulo de 1959 a 1962. Dissertação (Mestrado) Faculdade de Arquitetura e Urbanismo, Universidade de São Paulo. São Paulo, 2009.

HEAD, Robert. História da Pintura Moderna, Rio de Janeiro: Zahar, 1980

HERTZBERGER, Herman. Liç̃os de Arquitetura, São Paulo Martins Fontes, 1999

HITCHCOCK, Henry-Russel; JOHNSON, Philip. The International Style. New York: W.W. Norton, 1932

UUME David. Investigaça sobre o Entendimento Humano Os Pensadores, V. XXII. São Paulo: Abril, 1973.

ITO, Toyo. Arquitetura Diagrama. El Croquis. 1996, 77 (I).
JACOBS, Jane. Morte e Vida das Grandes Cidades. São Paulo Martins Fontes, 2000.

JOEDICKE, Jürgen. Candilis-Josic-Woods. une décennie d'a chitecture et d'urbanisme. Paris: Eyrolles, 1968.

ville nouvelle. Stuttgard: Kramer, 1975.

JOHNSON, Philip. Mies van Der Rohe, Buenos Aires: Victor Leru, 1960

JOHNSON, Philip; HITCHCOCK, Henry-Russell. Modern Ar chitecture: International Exhbition. New York: Museum of Modern Art, 1932

JOLY, Pierre e JOLY, Robert. L'Architect André Lurçat. Paris Picard, 1995.

JORGE, Luís Antônio. 0 Espaço Seco: poética e imaginário do arquitetura moderna na América Tese (Doutorado) - Faculdade de Arquitetura e Urbanismo, Universidade de São Paulo. São Paulo, 1999. 
Um parque e um país sob a marquise SP-Arte [online]. 2014, 201. Disponível em: https://www. sp-arte.com/noticias/um-parque-e-um-pais-sob-a-ma quise-por-luis-antonio-jorge/.

KAUFMANN, Emil. De Ledoux à Le Corbusier: Origine et De vellopement de LÁArchitecture Autonome. Paris: La Villette, 2002 [1933].

KHIDEKEL, Regina. Lazar Khidekel and the Suprematism Munich: Prestel, 2014.

KISHI, Waro. História e contemporaneidade na era moder-

na. El Croquis. 1996, 77 (II).

KLAUSER, Wilhelm. Labfac ou la grille cinétique. L'Architecture d'Aujourd'hui. 2000, 327, 62-103.

KIEM, Karl. The Free University Berlin (1967-73), Campus design, Team X Ideals and Tectonic Invention. Weimar: VDG, 2008.
KOPP, Anatole. Quand le moderne n'etait pas un style mais une cause. Paris: Ecole Nationale Supérieure de Beaux-Arts, 1988

Architecture en réseau et minimalis-

KRÜGER, Mário Júlio. Teorias e analogias em Arquitetura São Paulo: Projeto, 1986.

KRUNIC, Diana. The “Groundscraper”: Candilis-Josic-Woods and the Free University Building in $B$ ris. 2012, 23, 30-49.

KRUNIC, Dina. The Groundscraper: Candilis-Josic-Woods Free University Building, Berlin 1963-1973. Master's thesis University of California, Los Angeles, 2011. Disponível em: <http://dissertations.umi.com/ucla:10019>

KUHN, Thomas. A Estrutura das Revoluções Cientificas. São Paulo: Perspectiva, 1978

KÜHN, Wilfried. Mies à Bad Karlshafen: la présence réflexive du classique. L'Architecture d'Aujourd'hui, 2002, 343, 58-65. me cartésien. L'Architecture d'A

LAMBERT, Phillis (org). Mies in America, New York: H. N. Abrams, 2001

LAMPE, Angela. Chagall, Lissitzky, Malévitch, I'Avant-Garde Russe à Vitebsk. In Catalogue de l'Exposition. Paris: Centre George Pompidou, 2018.

LEFAIVRE, Liane; TZONIS, Alexander. Beyond Monuments, Beyond Zip-a-tone, Into Space/Time: Contextualizing Shadrach Woods's Berlin Free University, A Humanist Architecture. Architectural Association: Exemplary Projects. 1999, 3. 118-141.

Le Paysage Intérieur. Direção: Pierre MAILLARD. Lausanne CAB Productions, 2010. 1 DVD (83 min.).

LLOSA, Mario Vargas. A Civilização do Espetáculo, São Paulo: Objetiva, 2013.
LOUREIRO, Claudiae e AMORIM, Luiz (org.). Por uma arquitetura social: a influência de Richard Neutra em prédios 作 em: < http://www.vitruvius.com.br/revistas/read/arquitextos/02.020/813>. Acesso em: 29/12/2017.

LURAN-D-31-1. Concours: Groupe scolaire Karl-Marx, Villejuif (Val-de-Marne). Disponível em: http://archiwebture.citechaillot.fr/pdf/FRAPN02_LURAN_objet-21257.pdf. Acesso em: 15/11/2017.

LURÇAT, André. Formes, composition et lois d'harmonie. Pa ris: Vincent, Fréal \& Cie, 1953.

MACEDO, Danilo Matoso. Da Matéria à Invenção: as Obra de Oscar Niemeyer em Minas Gerais, 1938-1955. Brasília: Câmara dos Deputados, 2008.

MAHFUZ, Edson. A Pesquisa e suas Possíveis Relaç̃oes com o Projeto. In DUARTE, Cristiane Rose; RHEINGANTZ, Paulo Afonso; AZEVEDO, Giselle; BRONSTEIN, Lais, (org.). $O$ Lugar do Projeto no Ensino e na Pesquisa em Arquitetura e Urbanismo. Rio de Janeiro: Contra Capa Livraria, 2007. 
MANGE, Ernesto. Arquitetura Escolar. Acrópole. 1955, 197 (XVII), 211-213.

MARTINS, Carlos Alberto Ferreira. Construir a Escola, Construir a Cidade, Construir o Cidadão: A Ação do Convênio Escolar e a São Paulo dos anos 50. In Seminário de História da Cidade e do Urbanismo, V, 1988, Campinas. Campinas: FAUPUCCAMP, 1998. Anais.

MCCARTER, Robert. Louis Kahn, New York: Phaidon, 2006

MEDRANO, Leandro e RECAMAN Luiz. Vilanova Artigas Habitação e Cidade na Modernização Brasileira, São Pau Unicamp, 2013.

MELLO, Mirela Geiger de. Arquitetura escolar publica paulista. Fundo Estadual de Construções Escolares - FECE: 196 -1976. Dissertação (Mestrado) - Faculdade de Arquitetura e Urbanismo, Universidade de São Paulo. São Paulo, 2012
MONDRIAN, Piet. Neoplasticismo na Arte e na Arquitetura, São Paulo: Cosac \& Naify, 2008.

MONEO, Rafael. Inquietação Teórica e Estratégia Projetual São Paulo: Cosac \& Naify, 2008

Sobre la Noción de Tipo. El Croquis. 1964 20, $584-596$

MONTANER, Josep Maria. A Modernidade Superada. Barceona: Gustavo Gili, 2001

Gili, 2007. Arquitetura e Crítica. Barcelona: Gustavo
Cistemas Arquitetônicos Contemporâneos.

Barcelona: Gustavo Gili, 2009.

_. Arqueología de los Diagramas. C.P.A. 1. Bar-
Do Diagrama às Experiências, Rumo a uma Arquitetura de Ação. Barcelona: Gustavo Gili, 2017.

MONTEIRO, Adolfo Casais. Graciliano sem nordeste. Diário notícias, Rio de Janeiro, 7 Fev. 1959. Suplemento literá rio.

MONTESANO, Dario. Arquitetura e Ensino (1ํ e $2^{\circ}$ grau). Tese (Doutorado) - Faculdade de Arquitetura e Urbanismo Universidade de São Paulo. São Paulo, 1972.

MONTLIBERT, Christian de. L'Impossible Autonomie de l'Architecture, Strasbourg: Presses Universitaires, 1995.

MORIN, Edgar. Enseigner à Vivre: Manifeste pour changer l'Educacion. Arles: Actes Sud, 2014.

MOSTAFAVI, Mohsen. Arquitectura Inorgánica. El Croqui Ago. 2011, 155, 6-16
MUNARI, Luiz Américo de Souza. Diagrama, Arquitetura e Autonomia. Pós. 2013, 20, 160-180.

NELSON, George. Industrial Architecture of Albert Kahn New York: Architectural Books, 1939.

NESBITT, Kate. Uma nova Agenda para a Arquitetura. São Paulo: Cosac \& Naify, 2006.

NEUTRA, Richard. The Ring Plan School: a Project. The Architect and Engineer. 1935, 3 (123).

Quente. São Paulo: Todtmann. 1948

NICOLIN, Pierluigi. Il tao della Sejima. in Lotus 96, Milano: Elemond, 1998.

NICOLIN, Pierluigi; CHASLIN, François. Mario Botta: Construcciones y Proyetos 1961-1982. Barcelona: Gustavo Gil, 1984 
NUNES, Clarice. Centro Educacional Carneiro Ribeiro: concepção e realização de uma experiência de educação integral no Brasil. Em Aberto. 2009, 80 (22), 121-124. Disponível em: <http:www.http://emaberto.inep.gov.br/index php/emaberto/issue/view/243>. Acesso em: 20/01/2018

OLIVEIRA, Olivia de. O novo "Learning Center" para a Escola Politécnica Federal de Lausanne, EPFL, Arquitextos [online], 2005. Disponível em: <http://www.vitruvius.com br/revistas/read/arquitextos/05.059/478>. Acesso em 25/10/2017

OZENFANT, Amedée; JEANNERET, Charles Édouard. Depois do Cubismo, São Paulo: Cosac \& Naify, 2005.

PACZOWSKI, Bohdan. Instruments de la Création. LArchitecture d'Aujourd'hui. 2003, 349, 90-93.

PAPADAKI, Stamo. The Work of Oscar Niemeyer. New York: Reinhold Publishing, 1950.
PEREIRA, Alessandro Guimarães. Arquitetura Escolar: Notas Comparativas sobre Projetos em São Paulo e Brasila Dissertaç̃ão (Mestrado) - Faculdade de Arquitetura, Universidade Nacional de Brasília, Braślia, 2007.

PEREIRA, Miguel Alves; SAWAYA, Sílvio Barros. Cadernos de arquitetura FAUSP: registro do pensamento e da produção dos arquitetos da FAUSP, nos últimos 25 anos. São Paulo: Pin FUPAN, 2001.

PEVSNER, Nikolaus. Perspectiva da Arquitetura Europeia Lisboa: Ulisseia, 1943.

cas, Barcelona: Gili, 1979. Historia de las Tipologia Arquitectoni-

PFEIFFER, Helen. Hélio Piñón. Idéias e Formas, São Paulo: Ed. da Cidade, 1999

PICON, Antoine. A arquitetura e o virtual: Rumo a uma nova materialidade. In SYKES, K (org) O Campo Ampliado da Aquitetura 1993-2009, São Paulo: Cosac \& Naify 2013.
PIETRAROIA, Valério Marcos Nogueira. Arquitetura do Espetáculo em Cena. 2014. 327 p. Dissertacão (Mestrado) - Faculdade de Arquitetura e Urbanismo, Universidade de São Paulo, São Paulo, 2014

e BARONE, Claudia Nucci. A Arquitetura Paulista de Alcides Rocha Miranda. In ANTICOLI, A.M.; CRITELLI, F.; CHIARELLI, S.R.; OSSANI, T. (org.). Arquiteturas do Gestão. São Paulo: Editora Altermarket, 2017.

PIÑóN, Hélio. Teoria do Projeto, Porto Alegre: Livraria do Arquiteto, 2006.

Paulo Mendes da Rocha, São Paulo: Romano Guerra, 2002.

. El Sentido de la Arquitectura Moderna, Barcelona: UPC, 1998.

PORTAS, Nuno. A Cidade como Arquitetura. Lisboa: Horizontes, 1965
POUND, Ezra. ABC da Literatura. São Paulo: Cultrix, 2006.

PRICE, Cedric. Price talks at the AA. L'Architecture d'Aujourd'hui spring. 1990, 19, 27-34.

PROJETO DESIGN. 2006, 316, São Paulo: Arco Editorial.

PROJETO DESIGN. 2013, 405, São Paulo: Arco Editoral.

QUEIROZ, Rodrigo. O Modelo e o Original na Arte. Pós. 2016, $37(22), 8-10$.

RAGOT, Gilles. Utopies Réalisées. Paris: Somogy, 2009.

RENZI, Ricardo. Architettura del fascismo, simbolo estetico di un'era da rimuovere? Il Giornale dell'Architetura.com [online]. Out. 2017. Disponível em: http://ilgiornaledellarchitettura.com/web/2017/10/27/architettura-del-fascismo- simbolo-estetico-di-unera-da-rimuovere/. Acesso em $27 / 12 / 2017$.

RESSELADA, M. Raumplan versus Plan Libre: Adolf Loos and Le Corbusier, 1919-1930. Delft: Delft University Press. 1988 
RIBEIRO, Darcy. O livro dos Cieps. Rio de Janeiro : Bloch, 1986.

ROCHA, Bruno Massara. Novos Olhares e Desafios da Complexidade na Epistemologia Projetual. PóS. 2016, 39 (23) 102-119.

ROCHA, Ricardo de S. As propostas de ensino de Anísio Teixeira e os projetos de José de Souza Reis para a arqutetura escolar de Brasília. In Seminário Docomomo Brasil. 9, 2011, Brasília. Disponível em: < http://docomomo. org.br/wp-content/uploads/2016/01/091_M03_RM-AsPropostasDeEnsino-ART_ricardo_rocha.pdf $>$. Acesso em 08/02/2018

ROLEX Learning Center. Direção: Juliette GARCIAS. Paris Les Films d'ICi, 2012. 26 min. Disponível em: https://youtu. be/v57KDwRpJVk?t=28. Acesso em: 10/10/2017.

ROUGERON, François. L'école de plein-air de Suresnes: Aboutissement d'une réflexion sociale. 2017. 109 p. Enoncé Theórique (Master) - LTSAM.EPFL, Lausanne, 2017.
ROSSI, Aldo. A Arquitetura da Cidade. São Paulo: Martins Fontes, 2001

ROWE, Colin. Maneirismo y Arquitectura Moderna y otro Ensayos, Barcelona: Gustavo Gili, 1999 [1976].

ROTH, Alfred. La Nouvelle Architecture, Zurique: Les Editions d'Architecture, 1946 [1940]

RUBANO, Lizete Maria. O Terceiro Território: Habitação C letiva e Cidade, São Paulo: Vigliecca \& Associados, 2014

SAFLATE, Vladimir. Um Certo Tipo de Surdez. Folha de Sâo Paulo. São Paulo, 27/07/2018.

SANTOS, Samuel Dereste dos. A racionalização da construção no Brasil: experiências, conquistas e limites. Dissertação (Mestrado) - Faculdade de Arquitetura e Urbanismo, Universidade São Judas Tadeu. São Paulo, 2011.
SASSEN, Saskian. Escala e amplitude num mundo digital global. In SYKES, A. Krista. O Campo Ampliado da Arquitetura:Antologia Teórica (1993-2009). São Paulo: Cosac \& Naify 2013

SCHULZE, Franz. Mies van der Rohe: una Biografía Crítica. Madrid: Hermann Blume, 1986

SCHULZ, Christian Norberg. Rencontre avec Mies van der Hohe L'Architecture d'Aujourd'hui. 1958, 79, 41.

SCOTT, Geoffrey. The Architecture of Humanism: A Study in the History of Taste. Boston: Houghton Mifflin Company 1914

SCULLY JUNIOR, Vincent Joseph. Louis I. Kahn, New York George Braziller, 1962

Arquitetura Moderna: $\mathrm{Ar}$

quitetura da Democracia, São Paulo: Cosa
SEGAWA, Hugo. Arquiteturas no Brasil 1900 - 1990, São Paulo: Edusp, 2002

65.

Arquitetura Escolar. Projeto. 1986, 87, 64 dor. $A U .1998,80,59-64$

SERRA, Cristina, Tragédia em Mariana: a história do maior desastre ambiental do Brasil, Rio de Janeiro: Record, 2018.

SERRANO, Ramon. El Crown Hall de Mies Van der Rowe. Ar quivo de vídeo. Disponível em: www.youtube.com/watch? $v=$ jQrc5_G9N6k. Acesso em: 15/06/2013.

SERT, Josep. Centros para la Vida de la Comunidad. In ROGERS, SERT e TYRWHITT. El Corazón de la Ciudad: por uma vida más humana de la comunidad. Barcelona: Hoepli, 1955.

SHERWOOD, Roger. Modern Housing Prototypes, Barcelona Gustavo Gili, 1983 [1978]. 
SCHIMMERLING, André. Concours pour l'Université Libre de Berlin. Le Carré Bleu. 1962, 3.

SOWA, Axel. Le Futur du "classique moderne". LArchitecture dAujourd'hul. 2002, 343, 52-57.

Alison et Peter Smithson. L'Architecture $d^{\prime} A$

SMITHSON, Alison e SMITHSON Peter. Aujourd'hui, c'est les pubs que l'on collectionne. L'Architecture d'Aujourd'hu 2003, 344, 40-45

SMITHSOM, Peter. Struttura Urbana. Bologna: Calderini 1971. Rizzoli, 1991

SOLÀ-MORALES, Manuel de. De cosas urbanas, Barcelona: Gustavo Gili, 2008.

SOUZA, Ricardo de. A educação social em espaços de expertmentação pedagógica: as potencialidades dos CEUs. Dissetação (Mestrado) - Faculdade de Educação, Universidade de São Paulo, São Paulo, 2010.

jourd'hui. 2003, 344, 28-29. Editoria

_. On demande l'auteur! L'Architecture d'Au jourd'hui. 2003, 349, 94-97.

. Editorial. LA'Architecture d'Aujourd'hui. 2005, $359,46$.

SPEAKS, Michael. A Inteligência de Projeto. In SYKES, A. Krista. O Campo Ampliado da Arquitetura: Antologia Teórica (1993-2009), São Paulo: Cosac \& Naify, 2013.

SUMMERSON, Sir John. A Linguagem Clássica da Arquitetu-

SYKES, A. Krista. O Campo Ampliado da Arquitetura: Antora, São Paulo: Martins Fontes, 1982. Jogia Teórica (1993-2009). São Paulo: Cosac \& Naify 2012
SZAMBIEM, Werner. Schinkel. Paris: Hazan, 1989.

TAFURI, M. et al. Dela Vanguardia a la Metropoli: Crítica Ra dical a la Arquitetura. Barcelona: Gustavo Gili, 1982.

TRECAT, Sophie. Penseees croisées sur la ville contemporane. LArchitecture d'Aujourd'hui. 2003, 344, 46-53.

VALÉRY, Paul. Eupalinos ou o Arquiteto. São Paulo: Editora 34,2006

TAFURI, M. Esfera yel Laberinto. Vanguardias y Arquitectur de Piranesi a los anos 70. Barcelona: Gustavo Gili, 1984

TAKIYA, André. Edif 60 anos de Arquitetura Pública. 2009. 92 p. Dissetacão (Mestrado) - Faculdade de Arquitetura Urbanismo, Universidade de São Paulo. São Paulo, 2010.

TAYLOR, Brian Brace. Pierre Chareau: Designer and Architect. Colônia: Taschen, 1992.

TEDESCHI. Enrico. Teoria de la Arquitetura. Buenos Aires Nueva Vision, 1965.

TEIXEIRA, Anísio. Plano de construções escolares de Brasilia. Revista Brasileira de Estudos Pedagógicos. 1961, 81 (35) 195-199.
VÁZQUEZ, Fernando. Mies van der Rohe 1886-1969. Lisboa: Blau, 1999.

VELOSO, Pedro Luís Alves. Gesto Técnico: interferência da modelagem digital na criação arquitetônica. Dissertação (Mestrado) - Faculdade de Arquitetura e Urbanismo, Universidade de São Paulo. São Paulo, 2011.

e PRATSCHKE, Anja. Uma arqueologia $d$ Diagramas Cibernéticos. In SIGraDi, 17, 2014, Valparaíso 20-22 Nov. 2013.

VENTURI, Robert. Complexidade e Contradição em Arquitetura. São Paulo: Martins Fontes, 2004 
VIDLER, Anthony. Claude-Nicolas Ledoux 1736-1806. Milano: Electa, 1994.

Architecture Key To Schools' Function. Los Angeles: UCLA, 2000

. A Terceira Tipologia. In NESBITT, Kate. Uma nova Agenda para a Arquitetura. São Paulo: Cosac \& Naify, 2006.

Histories of the Immediate Present: Invering Architectural Modernism, 1930-1975. Delfet: Technische Universiteit Delft, 2005

0 campo ampliado da arquitetura. SYKES, K. (org) O campo ampliado da arquitetura 1993. 2009. São Paulo: Cosac \& Naify, 2013.

WAISMAN, Marina. El Interior de la História. Hitoriografia

Arquitectónica la, 1993.

WESELY, Michael. Arquivo Brasilia. São Paulo: Cosac \& Naify 2010

woODS, Shadrach. Web. Le Carré Bleu. $1962,3$.

XAVIER, Alberto (org.). Arquitetura Moderna Brasileira: D poimento de uma Geração. São Paulo: Associação Brasileira de Ensino de Arquitetura/Fundação Vilanova Artigas/Pin 1987.

ZEVI, Bruno. Omaggio a Terragni. Milão: Etas/Kompass, 1968
Números completos de revistas:

\section{Acrópole:}

Le Carré Bleu:

1953,185

Architectural Association: Exemplary Projects:

1962,3

1998, 3-4.

dhel

Arquitetura e Engenharia:

1950,14

L'Architecture d'Aujourd'hui:

2006, 127

Módulo:

1964, 112. Concours pour l'Université Libre de Berlin.

1960, 20 (4)

1968, 137. Universités.

1986, 91. CIEP

VON VEGESACK, Alexander. Jean Prouvé, The Poetics of the Technical Object. Weiam Rheim: Vitra Desugn Stifung GmbH, 2006 . 


\section{Outras fontes:}

Catálogos de exposições:

CENTRE GEORGES POMPIDOU (Paris, França). UAM - Unio des artistes moderne: Une aventure moderne. De 30/05 a $27 / 08 / 2018$

CITÉ DE L'ARCHITECTURE ET DU PATRIMOINE (Paris, França). Aalto Architecture \& Designer. De $9 / 3$ a 1/7/2018.

FONDATION CARTIER (Paris, França). Junya Ishigam Freeing Architecture. De 30/03 a 10/06/2018.

MUSÉE D'HISTOIRE ET SOCIALE (Suresnes, França). Eugè08/11 a 24/06/2018

MUSEUM D'HISTOIRE NATURELLE DE LYON (Lyon, França). Musée des Confluences. De 22/03 a 27/05/2001.
Guias:

ORDINI DEGLI ARCHITETTI, PIANIFICATORI, PAISAGGIS-

TI CONSERVATORI (Como, Itália). Itinerari nella tracce delle architecture razionaliste. $\mathrm{S} / \mathrm{d}$

Outros:

PREFEITURA DO MUNICÍPIO DE SÃO PAULO. SECRETARIA MUNICIPAL DE DESENVOLVIMETO URBANO (São Paulo, SP). Termo de Referência para Contratação de Projetos de Arquitetura e Urbanismo do Programa Territórios CEU Centros de Educação Unificada. São Paulo: SP Urbanismo 22/08/2013

PREFEITURA DO MUNICÍPIO DE SÃO PAULO. SECRETARIA MUNICIPAL DE HABITAÇ̃̃̃o. Edital. Concurso Público Nacional de Projetos de Arquitetura e Urbanismo. Concurso 001/2011.

AYMONIN, David; BISBROUCK, Marie-Françoise; JOYE, Ncolas; RITTMEYER, Mirjana. Processes of Architecture competition : Learning Center, the Lausanne example. LIB Architecture Group Seminar. Utrecht, The Nederlands, 22 a 24/03/2006.
BIBLIOTECA FAUUSP. Faculdade de Arquitetura e Urbanismo, Universidade de São Paulo (São Paulo, SP).

CENTRE D'ARCHIVES DE LIFA. Inventaire Général du Patrimoine Culturel d'lle-de-France. Disponível em: www.culture.gouv.fr/public/mistral/merimee_fr?ACTION=CHERCHER\&FIELD_98=REF\&VALUE_98=IA94000161

ARCHIVES COMMUNALES DE LA VILLE (Suresnes, França). PÔLE NATIONAL DE PRODUCTION ET PATRIMOINE AUDIOVISUELS (Paris, França).

INSTITUT NATIONAL DE L'AUDIOVISUEL (Paris, França). MUSÉE D'HISTOIRE URBAINE ET SOCIALE (Suresnes, França).

FUNDAÇ̃̃o OSCAR NIEMEYER (Rio de Janeiro, RI).
MÉDIATHEQUE DE LEPFL. Ecole Polytechnique Fédérale deLausanne (Lausanne, Suíça).

AGENCE SCHMUCKLE-MOLLARD (Paris, França).

ARCHIVIO TERRAGNI (Como, Itália).

MUSEO VIRTUALE ASTRATTISMO E ARCHITETTURA RAZIONALISTA (Como, Itália).

Cité DE LARCHITECTURE ET DU PATRIMOINE. Archives d'architecture du XXe siècle (Paris, França).

BIBLIOTHĖQUE KANDISKY. Centre George Pompidou (Paris, França)

ARQUIVO DIDÁTICO BEAUDOIN ARCHITECTS (Paris, França). Disponível em: http://www.beaudouin-architectes.fr/ category/modernite-russe/.

SERVICE PATRIMOINES ET INVENTAIRE. Région Île-de-France (Paris, França). 